Universidad Politécnica de Madrid

Escuela Técnica Superior de Arquitectura

\title{
Memoria, Aprendizaje y Experimento. La invención del paisaje en Miguel Fisac
}

Tesis Doctoral

Jaime Aparicio Fraga, Arquitecto

2016 

Departamento de Proyectos Arquitectónicos

Escuela Técnica Superior de Arquitectura

Universidad Politécnica de Madrid

\title{
Memoria, Aprendizaje y Experimento. La invención del paisaje en Miguel Fisac
}

\author{
Tesis Doctoral \\ Jaime Aparicio Fraga, Arquitecto
}

Director

Eduardo Delgado Orusco

Doctor Arquitecto

Tutor Departamento de Proyectos ETSAM

José Antonio Ramos Abengózar

Doctor Arquitecto 

Tribunal nombrado por el Mgfco. Y Excmo. Sr. Rector de la Universidad Politécnica de Madrid, el día

Presidente D.

Vocal D.

Vocal D.

Vocal D.

Secretario D.

Realizado el acto de defensa y lectura de Tesis el día

en la Escuela Técnica Superior de Arquitectura de Madrid

Calificación:

EL PRESIDENTE

LOS VOCALES

EL SECRETARIO 
Memoria, Aprendizaje y Experimento. La invención del paisaje en Miguel Fisac

A María, que nunca me deja reflejarme en los charcos.

A mis padres, hijos -Jaime, Carmen, Pablo- y a mi familia, que son la luz de mi paisaje.

A la memoria de Darío Gazapo y Luis Moreno Mansilla 
Memoria, Aprendizaje y Experimento. La invención del paisaje en Miguel Fisac

¿En qué laboratorio farmacéutico nos podrían fabricar esos comprimidos de extracto de la Naturaleza, del Cosmos, y de toda la Creación?

Miguel Fisac, 1950 
Memoria, Aprendizaje y Experimento. La invención del paisaje en Miguel Fisac

\section{INDICE}


Agradecimientos

Resumen

Nota preliminar

\section{1_INTRODUCCIÓN}

1.1_Biografía contextualizada

1.2_Objetivos, delimitación y alcance de la Tesis

1.3_Razón de estudio

1.4_Hipótesis de partida

1.5_Precisiones sobre el concepto paisaje

\section{2_MEMORIA}

2.1_Geografías de la Memoria. El niño y el hombre

2.2_ La arquitectura popular. Reflexión y metáfora del paisaje

\section{3_APRENDIZAJE}

3.1_ Viajes, cuadernos y croquis

3.2_ Otras vías

La Alhambra

Japón y la casa japonesa

3.3_ Maestros de la modernidad

Aprendiendo de los nórdicos. Asplund y Aalto

Frank Lloyd Wright

Mies van der Rohe 
Le Corbusier

Richard Neutra

3.4_ Las publicaciones de la época

3.5_Otra vez La Mancha

\section{4_EXPERIMENTO}

Gramática de un paisaje

El horizonte: miradores, umbrales, fronteras

El agua: estanques, fuentes y surtidores

Sombras, secuencias, tránsitos y límites

Jardinería y vegetación

Textura y materialidad

\section{5_ LA INVENCIÓN DEL PAISAJE EN LA ARQUITECTURA DE MIGUEL FISAC}

5.1_ Identidad y paisaje. El Instituto Laboral de Daimiel. Ciudad Real (1950-1953)

5.2_ El Objeto en el paisaje. El Tránsito de Arcas Reales a Alcobendas (1951-1955)

5.3_ El Hombre en el paisaje. El Centro de Formación del Profesorado de la Ciudad Universitaria. Madrid (1952-1957)

\section{6_CONCLUSIÓN. CONSTELACIONES EN EL PAISAJE}

\section{7_BIBLIOGRAFÍA}




\section{8_APÉNDICES}

Apéndice 1_Miguel Fisac a los estudiantes de arquitectura.

Conferencia dictada en la Escuela Técnica Superior de Arquitectura de Valencia como clausura del curso académico, el día 31 de mayo de 1995. [inédita]

Apéndice 2_Cuadernos de Viaje.

2.1_Facsímiles del Cuaderno de Viaje a Europa

2.2_Facsímiles del Cuaderno de Viaje alrededor del mundo [inédito]

2.3_Transcripciones de varios cuadernos de viaje [inédito] 


\section{Agradecimientos}

Quisiera agradecer en primer lugar a mi Director, Eduardo Delgado, sus recomendaciones y su incansable e incondicional apoyo, así como su insistencia en que esta investigación fuera avanzando. Sin su labor comprometida, -mucho más allá de lo profesional- esta tesis no hubiera llegado a buen puerto.

Asimismo sirvan estas palabras como reconocimiento a tres profesores que desde mi estancia como alumno en la Escuela Técnica Superior de Arquitectura de Madrid fueron y siguen siendo especialmente inspiradores, -ejemplos de vida y profesión-, sembrando el germen del amor por la Arquitectura, a los que siempre tengo presentes y que siempre están disponibles para lo que se necesite: José Antonio Ramos Abengózar, Alberto Campo Baeza, e Ignacio Vicens.

Agradezco a mis padres que siempre me animaran a continuar y a visualizar la meta; así como a mi gran amigo y siempre socio Iván Yllera, que siempre tuvo palabras de ánimo y certeros consejos.

También a todas las personas que han seguido de cerca el desarrollo de la tesis y me han facilitado el acceso a la información -a veces difícil- . A la Fundación Fisac, en especial a Diego Peris que dedicó varios días a facilitarme la búsqueda de la documentación más inaccesible; a Pablo Gómez Ruiz, por su tiempo; al personal del Centro de Información de Arquitectura (CIA) de la Universidad Politécnica de Valencia y en especial a su directora; al equipo del Archivo Histórico Municipal de Valencia, y al arquitecto y catedrático valenciano Francisco Gómez Lopera, cuya inestimable ayuda ha hecho posible la obtención de valiosa información para esta Tesis.

Y como pieza más importante de este viaje, agradezco a María, mi mujer, su apoyo sin límites, comprensión sin límites y paciencia sin límites que me ha permitido disfrutar del camino tanto como si ya hubiera llegado. 
Memoria, Aprendizaje y Experimento. La invención del paisaje en Miguel Fisac 


\section{Resumen}

La presente investigación propone que la construcción del paisaje -la invención del mismo- es el elemento esencial para la comprensión global de la obra de Miguel Fisac. Se rebela así ante el desprecio "por el paisaje social, humano y físico" que le atribuye a los representantes del Movimiento Moderno.

A través de tres ejes, Memoria, Aprendizaje y Experimento, se hilvana un viaje autobiográfico, con salida y regreso a La Mancha.

Memoria, que recorre sus vivencias infantiles en intenso contacto con la naturaleza; así como su embelesamiento por la esencia de la arquitectura popular, esa "que hacen el pueblo y el tiempo".

Aprendizaje, como un proceso de búsqueda con capacidad para mover los ejes referenciales en relación a su concepción de la arquitectura y a como ésta ha de dialogar con el paisaje: viajes alrededor del mundo, encuentros intelectuales con maestros indiscutibles de la modernidad, y el descubrimiento de otras culturas, materializado a través de la casa tradicional japonesa y de La Alhambra.

Y Experimento, donde se concretan los conceptos anteriores a través de una suerte de gramática que el arquitecto utiliza para activar el paisaje, modificarlo, o reinterpretarlo.

Todo ello se contrasta en ejemplos paradigmáticos de su arquitectura: el Instituto Laboral de Daimiel (1950-1953), el Centro de Formación del Profesorado de la Ciudad Universitaria de Madrid (1952-1957); y en el tránsito producido entre los conjuntos dominicos del Colegio Apostólico de Arcas Reales de Valladolid y el Teologado de Alcobendas (1951-1955). Arquitecturas en las que los citados aprendizajes tamizados en la memoria propicia que el paisaje resuene en ellas, transformando en cuerpo nuevo el alma del pasado.

Ejemplos que sustancian un mapa mediante el cual se posibilita, desde el paisaje como herramienta de análisis, una relectura transversal de la obra del maestro daimieleño y que presiente su trayectoria como un proyecto único. 


\section{Abstract}

The current research proposes that the landscape construction -its invention- is the essential element for the overall understanding of Miguel Fisac's work. So, he rebels against the thought -attributed to the Modern Movement representatives-, who despise the "social, human, and physical" landscape

He uses three aspects to develop his own life journey, which leaves and returns to La Mancha: Memory, Learning and Experimentation.

The Memory is a journey inside his childhood, when he was very much in contact with nature; and later, his captivation by the essence of the popular architecture, that one which is "made by people, and by time".

The Learning is the process which it has the capacity to move his referential axis relating his own conception of architecture and how it must dialogue with the landscape: journeys around the world, intellectual meetings with the best masters in Modernity and the discovery of other cultures, becoming real in the traditional Japanese house and La Alhambra.

And the Experimentation, where these mentioned concepts are concreted through a kind of grammar, with which the architect is able to activate the landscape, modify, or reinterpret it.

All of this is reaffirmed in some paradigmatic examples of his best architecture: the Occupational Institute of Daimiel (1950-1953), the Teacher Training Center of the Madrid's University City (1952-1957); and the way between the "Arcas Reales" Apostolic College in Valladolid and the Dominican Theologate in Alcobendas (1951-1955).

Architectures that show how the Learning, screened through Memory, promotes that the landscape resonate in them, becoming new body the soul of the past.

These examples substantiate a map which allows, from the landscape as a tool of analysis, a cross-reading of the work of this master-architect from Daimiel, and we can sense his career as a unique project. 


\section{Nota preliminar}

El interés suscitado por la obra y el pensamiento de Miguel Fisac se remonta a mi etapa como alumno de Proyectos en esta Escuela de Arquitectura, cuya arquitectura me descubrió el Catedrático Ignacio Vicens.

Posteriormente, como doctorando, a ese interés se incorporaron una serie de interpretaciones sobre el paisaje, la memoria, y su conexión íntima con la arquitectura, canalizadas a través del recordado y querido profesor Darío Gazapo.

Fruto de las investigaciones sobre la arquitectura de Miguel Fisac, en 2006 se presentó como Trabajo de Investigación Tutelado un estudio sobre sus estructuras, los llamados "huesos", bajo la tutela de los profesores Antonio Juárez y Eduardo Delgado, durante cuya etapa tomé conciencia de la profundidad de sus ideas y de la carga de pensamiento que se esconde detrás de una aparente simplicidad campechana, surgiendo una serie de inquietudes y algunas intuiciones.

Posteriormente, gracias a una serie de conversaciones con arquitectos, expertos estudiosos y cercanos -algunos, amigos- a Fisac, estas intuiciones se pudieron canalizar en la construcción de una hipótesis de partida, de forma que esos intereses, transformados ya en pasión, dan lugar a esta investigación. A ello contribuyeron el Catedrático Alberto Campo Baeza, y los profesores Francisco Arques, Eduardo Delgado y Miriam García. 
Memoria, Aprendizaje y Experimento. La invención del paisaje en Miguel Fisac 
Memoria, Aprendizaje y Experimento. La invención del paisaje en Miguel Fisac Introducción

\section{1_INTRODUCCIÓN}

\section{1_ Biografía contextualizada}

1.2_Objetivos, delimitación y alcance de la Tesis

1.3_Razón de estudio

1.4_Hipótesis de partida

1.5_Precisiones sobre el concepto paisaje 


\section{1_Biografía contextualizada}

De la gran cantidad de reseñas bibliográficas que se han escrito sobre Miguel Fisac nos gustaría en esta, además de aportar datos inéditos hasta la fecha, enfocar, tanto el meollo de su propia biografía como el contexto en el que se desarrolló su formación -y en definitiva su vida- a nuestra investigación, sin perdernos en los numerosos datos que podríamos apuntar y que podrían desenfocar nuestro objetivo.

Tras bucear en las fuentes conocidas, y otras hasta el momento no tan exploradas en el ámbito de la investigación arquitectónica, se han podido recabar datos de extraordinaria trascendencia para esta Tesis.

Nacido en Daimiel -Ciudad Real-, en 1913, poco se ha hablado de la infancia ese niño de familia de clase media acomodada que se topa con la muerte siendo muy pequeño.

En efecto, sus padres, Joaquín Fisac, farmacéutico y titular de una de las seis farmacias de Daimiel ${ }^{1}$ y Amparo Serna, ama de casa, tuvieron siete hijos, de los que tres de ellos murieron al poco de nacer, y otra de las chicas, Matilde, murió con doce años, quedando por orden de edad José, Dolores -Lola-, y el propio Miguel. Esta tragedia sorprendió a Miguel muy niño, lo que hubo de ser compensado con excursiones y otras distracciones junto a sus tíos, como paseos en bici o pesca. Daimiel era un pueblo cuya principal actividad económica era la agricultura.

La casa familiar se encontraba muy próxima a la plaza del pueblo, en la calle Comercio, número 14 -actual calle Virgen de las Cruces, en la que se encuentran las "Viviendas en línea"-. Sus padres vivieron hasta Septiembre de 1965 (Joaquín), y Diciembre de 1967 (Amparo).

\footnotetext{
${ }^{1}$ Iglesia, F. de la (1984) Esto ha sido y es Daimiel, 34. Daimiel: Ayuntamiento de Daimiel
} 

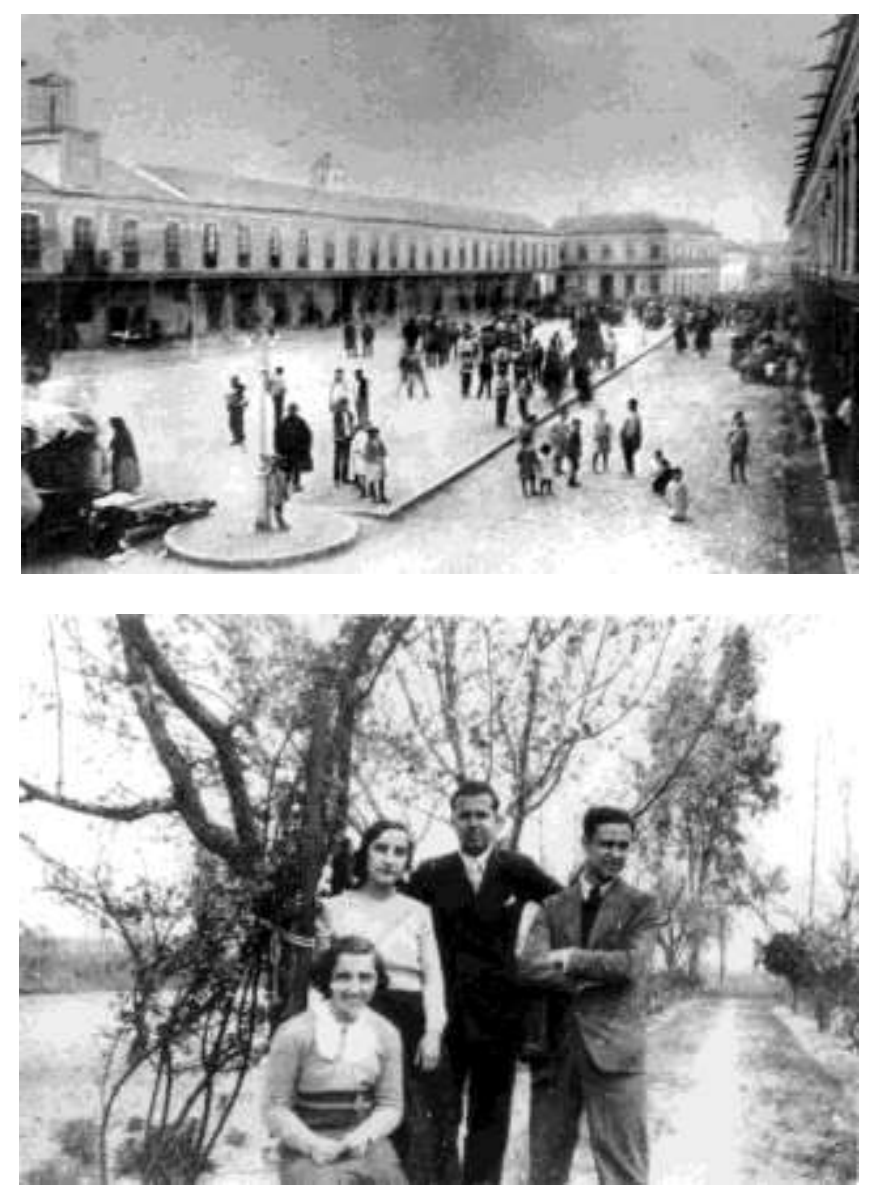

Plaza mayor de Daimiel

Fotografía de la familia Fisac-Serna. Miguel Fisac es el primero por la derecha

Sin especiales dotes personales para el dibujo, aunque mostrando gran vehemencia y pasión por mejorar en este aspecto, en 1926 decide firmemente estudiar Arquitectura; y tras realizar el Bachillerato Universitario en Badajoz, se traslada a Madrid en 1930. Entre 1932 y 1934 supera las pruebas de acceso a la Escuela de Arquitectura, accediendo únicamente 10 alumnos entre los que se encuentran Cabrero o Fernández del Amo.

Su amistad desde 1935 con Pedro Casciaro, compañero de la Escuela de Arquitectura, cambiará el curso de su vida, ya que éste le presentó a Josemaría Escrivá de Balaguer, fundador del Opus Dei, en la Academia DYA -residencia para universitarios fundada por el propio Josemaría Escrivá-2.

\footnotetext{
${ }^{2}$ Casciaro, P. (1994). Soñad y os quedaréis cortos. Madrid: Rialp
} 
Cuando en julio de 1936 estalla la Guerra Civil, Fisac se encontraba en Daimiel, de descanso estival tras haber terminado el curso. Debido a que la zona de Ciudad Real formaba parte del bando Republicano, Fisac hubo de esconderse en una minúscula buhardilla -que él mismo bautizó como "el Agujero"-, hasta finales de Octubre de 1937.

Durante este tiempo leyó a los clásicos -la Divina Comedia, el Quijote,...-, escribió cartas, y realizó múltiples dibujos a lápiz.

Desde Daimiel, los Fisac, a través de Lola, proveyeron de alimentos vía ferrocarril a una serie de miembros del Opus Dei que se encontraban recluidos en la Legación de Honduras de Madrid, incluido Josemaría Escrivá. Estos envíos eran recogidos por Isidoro Zorzano, que por su condición de ciudadano argentino tenía mayor facilidad para circular por Madrid.

En otoño de 1937, Miguel Fisac, con sólo 24 años y junto con otros miembros del Opus Dei (Escrivá de Balaguer, Jiménez Vargas, Sainz de los Terreros, Alvira, Albareda, Casciaro, y Botella), inició una arriesgado viaje para tratar de pasar a la zona nacional a través de los Pirineos. Tras una serie de carambolas y siguiendo las indicaciones de Josemaría Escrivá, uno de los que había ido a recoger a los que estaban en Valencia, Jiménez Vargas fue a recoger a Fisac a Daimiel, y junto con Botella partieron en coche de nuevo vía Valencia, llegando a Barcelona la noche del 1 de noviembre. Desde allí la expedición que debía partir de forma inmediata se retrasó hasta el 19 de noviembre, y tras cruzar los Pirineos, alcanzaron Andorra el 2 de diciembre; y el 11 de diciembre, zona nacional. Durante esa travesía estuvieron en explícito peligro de muerte en varias ocasiones, tanto por la cuestión bélica como por las climatológicas, haciendo frente a la nieve, la lluvia, y a un frío extremo. 


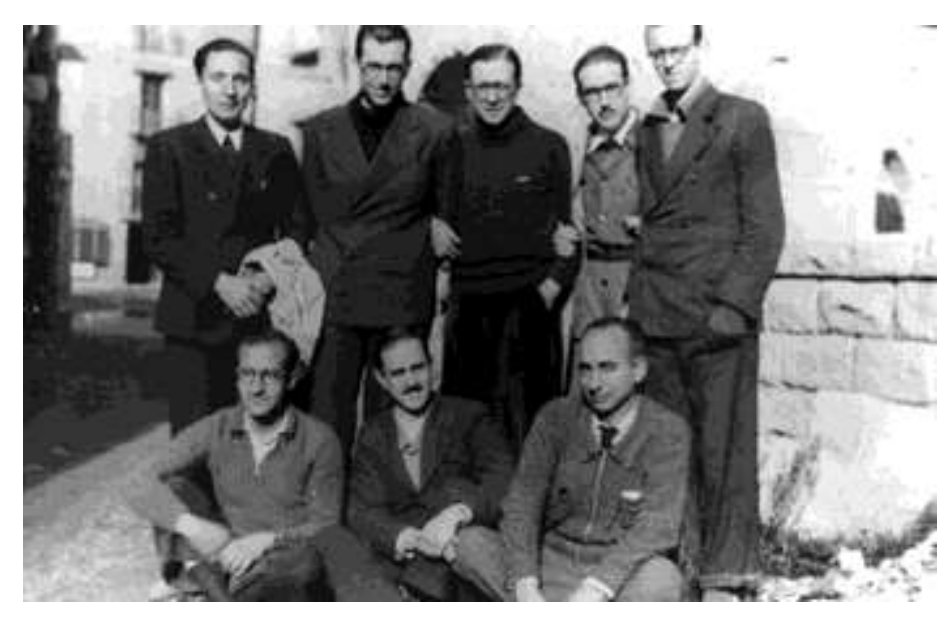

Una imagen previa al paso de los Pirineos. Abajo: Pedro Casciaro, Miguel Fisac y Paco Botella. Arriba: José María Albareda, Juan Jiménez Vargas, Josemaría Escrivá, Tomás Alvira, y Manuel Sáinz de los Terreros.

Este episodio personal, que terminó con Miguel Fisac sirviendo en el bando nacional, al mando del General Lahuerta, -donde se encontró con Alejandro de la Sota- Io consideramos de mucha importancia tanto por la huella que dejaría en su vida, como por las personas con quiénes compartió esta intensa aventura, a través de los cuales luego realizaría algunos trabajos.

Sirva como botón de muestra la relación de amistad con José María Albareda, que aunque de mayor edad que Miguel Fisac, también tuvo su primer contacto con Josemaría Escrivá en 1935. Eminente catedrático de Geología Aplicada de la Facultad de Farmacia de la Universidad Complutense de Madrid, fue el Secretario General del CSIC desde 1939 a 1966, desde donde se produjeron los primeros encargos importantes, primero en colaboración con Fernández Vallespín, y posteriormente en solitario. Asimismo, Albareda compartía con Fisac el interés por cuestiones agrícolas y relativas a la vida en el mundo rural, como también un padre farmacéutico -el padre de José María Albareda era farmacéutico en Caspe-3.

Tras el paréntesis obligado por la Guerra Civil, Fisac prosigue su formación universitaria y en 1940, todavía estudiante, comenzó a colaborar con el que fuera director de la citada Academia DYA Ricardo Fernández Vallespín -que había terminado la carrera en

\footnotetext{
3 Pérez, P. (2012). San Josemaría y José María Albareda (1935-1939). Studia et Documenta, 6, 13-66. Roma: Instituto Histórico San Josemaría Escrivá.
} 
19344-, en el madrileño estudio de Villanueva 15, relación profesional que se mantuvo hasta 1950, fecha en la cual Fernández Vallespín dejó de ejercer la profesión.

Finalizada la carrera en 1942 Miguel Fisac obtuvo el premio Fin de Carrera de la Real Academia de San Fernando.

Aunque no insistiremos en exceso en detalles ya relatados, si es preciso decir que los inicios de Fisac como Arquitecto titulado comienzan con un cliente de enorme importancia para su carrera profesional, el Consejo Superior de investigaciones Científicas ${ }^{5}$ (CSIC), y para el que, además de realizar la reconversión de la biblioteca y auditorio del Instituto-Escuela -hoy Instituto Ramiro de Maetzu- en la iglesia del Espíritu Santo, diseñó la ordenación de la parte sur de la Colina de los Chopos, así como el pabellón central del Consejo, o los institutos de Edafología ${ }^{6}$-ciencia cuyo nombre en castellano se debe precisamente a Albareda- y Óptica.

Son momentos en los que Fisac se aferra al lenguaje clásico, mientras en su interior lamente que ese camino le lleve a ningún sitio.

Superado estos balbuceantes comienzos en lo estilístico -aunque de espectacular rigor en lo constructivo-, inicia un camino en el que va descubriendo las virtudes de la esencia de las arquitecturas populares y vernáculas, además de forjar una idea de lo que no quiere que sea su Arquitectura.

A través de las Revistas de Arquitectura a las que tiene acceso, nacionales o internacionales, y sobre todo a través de viajes -de sobra conocidos, especialmente su Viaje a Europa de 1949, que trataremos con detalle más adelante-, va creándose una forma propia de concebir la Arquitectura, y de ponerla en práctica.

\footnotetext{
${ }^{4}$ San Antonio, C. y Delgado, E. (2004). Ricardo Fernández Vallespín. Los brillantes 50. 35 proyectos, $132-$ 143. Pamplona: T6 Ediciones, Escuela Técnica Superior de Arquitectura de la Universidad de Navarra y Ministerio de Fomento.

${ }^{5}$ Institución de enorme importancia en los comienzos de Fisac, surgida tras la Guerra Civil con el objetivo de estimular la investigación.

${ }^{6}$ Pérez, P.(2012). Op. cit
} 


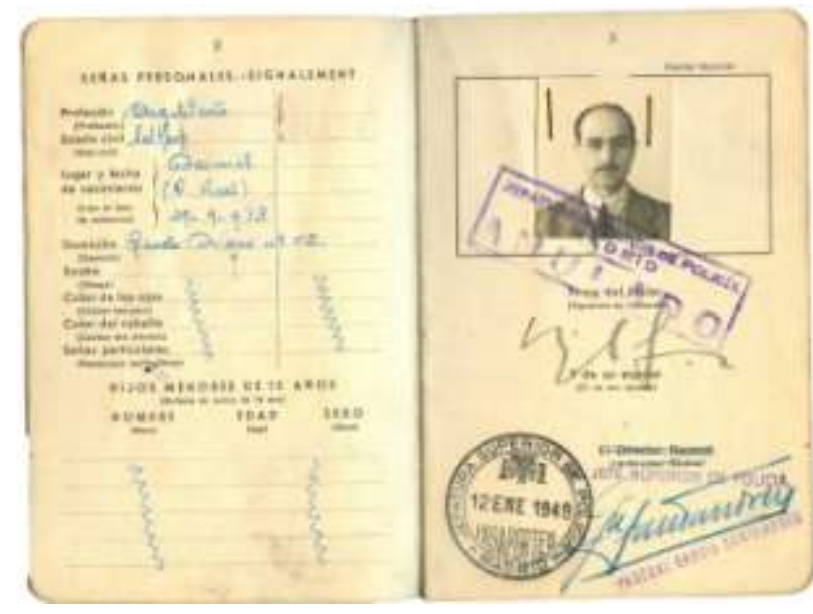

Pasaporte de Miguel Fisac en 1949. Archivo personal del arquitecto

La obra de Fisac es como un árbol conformado por múltiples ramas; aspectos diversos a los que fue prestando exhaustiva atención a lo largo de su prolífica trayectoria que abarca más de 60 años de ejercicio profesional: la materia y su expresividad -con el hormigón y sus encofrados flexibles a la cabeza-, la estructura -con las vigas hueso-, la prefabricación, el interés por la renovación espacial de las iglesias postconciliares, las propuestas para la ciudad del futuro, o la construcción del paisaje. Esta última rama es la que desarrollaremos en esta investigación.

Cuando Miguel Fisac termina la carrera, en España ya hay una serie de arquitectos que se identifican con el Movimiento Moderno, y que producen obras muy significativas; mientras otro grupo se mantiene anclado en un lenguaje clasicista.

Fisac es uno de aquellos valientes renovadores que, dentro de lo que Fullaondo llama "primera oleada" -junto con Sota, Coderch, Cabrero o Fernández del Amo-, trata de aportar soluciones renovadoras siguiendo un camino propio, y con una preparación y adquisición progresiva de conocimientos que, no sólo es equiparable a otros arquitectos europeos del momento, sino que llega a superarse.

El Movimiento Moderno según Fisac "corresponde a una vanguardia plástica, que comienza a gestarse en el siglo pasado ${ }^{7}$, paralelamente a las teorizaciones progresistas de Marx, Fourier, Proudhon, Cabet, etc. y que culmina con la creación del CIAM, Congreso Internacional de Arquitectura Moderna que en Atenas en su Tercera reunión, en el año 1933, presenta una especie de Manifiesto urbanístico conocido por "La Carta de Atenas" en la que dogmáticamente define la ciudad como lugar para habitar, trabajar,

${ }^{7}$ Se refiere al siglo XIX 
circular y recrear cuerpo y espíritu. Manifiesto que es la causa teórica y práctica, a nivel profesional, de la deshumanización de la ciudad. ${ }^{" \prime}$.

Como reacción a ello y a su desprecio por el lugar en el que se desarrollan esas arquitecturas, aún reconociendo la genialidad de varios de los representantes del Movimiento Moderno, su Arquitectura pretende enfocarse en la humanización de los espacios, interiores o exteriores, definiéndola como "un trozo de aire humanizado"9.

Seducido por los viajes profesionales como herramienta de aprendizaje -que desarrollaremos con detalle-, y reconociendo que él es "poco de libros" -aunque esta afirmación contrasta con su vasta cultura y profundidad de la misma-, descubre en la ampliación del Ayuntamiento de Gotemburgo de Asplund, una fuente en la que saciar su sed de búsqueda de referencias válidas para desarrollar su propia vía, si bien conocida al menos un par de años antes a través de otros viajes a Europa de su compañero de estudios Fernández Vallespín y publicaciones internacionales, de la que queda la exquisita biblioteca de la Fundación Goerres de 1948.

En efecto, desde 1949, realiza una ingente cantidad de viajes gracias a los que conoce, en primera persona, además de las construcciones clásicas de Grecia y Roma, o las ciudades más representativas desde los Ángeles a Bangkok, las obras más recientes de los arquitectos más en boga del momento. Él mismo afirma (Fisac, 1995) haber visitado -aunque luego mantenga una posición crítica ante su Arquitectura- "casi toda la obra de Mies van der Rohe"10.

De esta forma, poco a poco va dejando a un lado las inspiraciones más tradicionales, retándose a sí mismo en cada nuevo encargo para transitar por el camino de su propio estilo.

Como contraste a ello, es muy interesante la referencia a la reunión del TEAM $X$ en Oterloo en 1959, cuando (López-Peláez, 1983) "aún no se había producido la revisión más erudita del Movimiento Moderno"11, con una cierta nostalgia de referencias pasadas, y en la que Van Eyck afirma: "Los arquitectos modernos han estado jugueteando continuamente con aquello que es diferente en nuestro tiempo, hasta tal punto que han perdido contacto con 10 que no es diferente, sino siempre $y$

8 Fisac, M. (1985). Conferencia dictada en Noviembre, en el Primer Curso de Postgrado "Políticas y problemas ambientales de Europa en relación con España", organizado por la Dirección General del Medio Ambiente, el Ilustre Colegio Nacional de Doctores y Licenciados en Ciencias Políticas y Sociología, el Instituto Universitario de Ciencias Ambientales, la Facultad de Ciencias Políticas y Sociología, y la Oficina de la Comisión de Comunidades Europeas en Madrid

${ }^{9}$ Fisac, M. (1989). Miguel Fisac. Colección Documentos de Arquitectura, 10. Almería: Colegio Oficial de Arquitectos de Andalucía Oriental.

10 Fisac, M. (1995). Conferencia dictada en la Escuela Técnica Superior de Arquitectura de Valencia el día 31 de mayo de 1995.

11 López-Peláez, J.M. (1983). Innovación y tradición en la obra de Fisac. Arquitectura, 241, 47-50 
esencialmente lo mismo...El lenguaje que desarrollaron los arquitectos, después de que el período de los pioneros hubo pasado, sólo coincide consigo mismo, y es, por tanto, esencialmente estéril y escolar, literalmente abstracto..." ${ }^{12}$.

Los encargos recibidos le darán la oportunidad para poner en práctica con sentido crítico lo vivido en sus viajes, lo estudiado en las revistas, y lo guardado en su Memoria.

En los años en los que nos enfocaremos especialmente (1951-1971), Miguel Fisac abarca desde el Instituto Laboral de Daimiel, hasta su propio Estudio en el Cerro del Aire. Es éste un período de grandes cambios en el panorama arquitectónico, en el que el Racionalismo va dejando paso al Movimiento Moderno y no son muchos los arquitectos que trabajan por ofrecer con su arquitectura situaciones espaciales que concuerden con el lugar.

Al mirar sobre sus contemporáneos, nos encontramos con lo que se ha llamado como período "heroico", en el que un grupo de arquitectos españoles, superada la Segunda Guerra Mundial, rescatará los principios del Movimiento Moderno que consideran válidos y los trasladan a su arquitectura.

Principios que Fisac estudia pero no comparte, entre otros motivos por su total desprecio al lugar. Según él mismo la arquitectura racionalista es "seca, sin humanidad y sin paisaje", y "desprecia el paisaje social, humano y físico"13.

Como bien apunta (Campo Baeza, 1994) "Miguel Fisac es tan personal, tan genial, que cuando los mejores arquitectos en los años 50 hacían "racionalismo" él hacía otra cosa: una arquitectura espléndida de difícil etiquetación. Rebelde. Revolucionario. Libre. Y si ese período de aquellos arquitectos de posguerra que se pusieron en pie de modernidad se ha calificado, creo que con justicia, de heroico, yo me atrevería aquí a proponer que lo que Fisac hizo es algo muy propio de él: "el más difícil todavía". Ser heroico dentro del grupo de los héroes. Ser rebelde dentro del grupo de los revolucionarios. Ser libérrimo dentro del grupo de los libres.".

En los años 50 viaja a Japón en varias ocasiones, y comenzará a traducirse a sus obras el interés, tanto por la casa tradicional japonesa y la forma en que se dispone como subsidiaria de la naturaleza, como por la esencia de sus jardines.

En esta década de los 50, Fisac atraviesa intensos episodios personales, como su salida del Opus Dei en 1955, y desde ese mismo año a través de un curso de Jardinería de la Escuela de Arquitectura, su conocimiento y posterior matrimonio con Ana María

\footnotetext{
12 Idem

${ }^{13}$ Fisac, M. (1979). Lección impartida 3 de diciembre de 1979. Cátedra de Estudios Contemporáneos. Fuente: Fundación Fisac
} 
Badell, que le acompañará hasta el fin de sus días. "A la Jardinería le debo mi mujer"14, afirmará con gracia, constatando su pasión por esta disciplina.

La simple enumeración de la cantidad de proyectos realizados en estos momentos nos haría perder el enfoque de esta breve reseña contextualizada, labor que dejaremos para más adelante.

Mención especial requiere su participación en el Manifiesto de La Alhambra (1953), cuyo texto definitivo fue redactado por Chueca Goitia, si bien Fisac tiene una contribución importante en la parte IV, relativa a Jardines y Fuentes, que realizó junto con Francisco de Asís Cabrero por encargo de Carlos de Miguel.

Dicho escrito, que fue firmado por los arquitectos Aburto, Bidagor, Cabrero, Calonge, Chueca, Domínguez Salazar, Fernández Huidobro, Galmes, García Falencia, Lacasa, Larrodera, López Mateos, Magdalena, Marsá, De Miguel, Moreno López, Ontañón, Picardo, Prieto Moreno, Robles, Rodríguez Avial, Romero, Suazo, y el propio Fisac; y materializó una postura crítica y de ruptura con la etapa anterior, así como una postura entusiasta de búsqueda de una Arquitectura y lenguaje modernos.

En relación a ello, también es interesante situarnos en qué estaban haciendo otros arquitectos cercanos en mayor o menor medida a Miguel Fisac.

Es la época en la que Le Corbusier realiza el proyecto de Ronchamp (1950-1955), -que posteriormente visitará Fisac con su esposa Ana María-; y Mies van der Rohe la casa Farnsworth (1951), -que también visitaría Fisac, encontrándosela en un estado lamentable-, o el parque Laffayette junto a Hilberseimer (1965).

En esta época Alejandro de la Sota proyecta el poblado de Esquivel (1955), el Gobierno Civil de Tarragona (1956), la Residencia Infantil de Miraflores de la Sierra (1957), la fábrica de la Central Lechera CLESA (1958-1961), el Gimnasio del Colegio Maravillas (1961), ó el Colegio Mayor César Carlos (1967).

Interesa acentuar el posicionamiento de este arquitecto en referencia al paisaje, por el que también muestra interés, ya sea en forma de dominación, o bien de integración como puede suceder en la casa Guzmán, de 1971-.

Oiza, por su parte, se encontraba trabajando en -proyectos cercanos a esta investigación- la Capilla en el Camino de Santiago, junto con Oteiza (1954), el mismo año que Fisac recibía la Medalla de Oro en la Exposición Internacional de Arte Sacro de Viena por el proyecto de Arcas Reales en Valladolid. Asimismo, acomete en esta época el Santuario de Aránzazu (1950); los poblados de Fuencarral y Entrevías, en 1955 y

14 Notas para la Conferencia 22 de mayo de 1984. Dentro del ciclo de conferencias "Homenaje a la Marquesa de Casa Valdés" en el Real Jardín Botánico de Madrid. Fuente: Fundación Fisac 
1956 respectivamente; o la Casa Gómez en Durana, Álava en 1959, hasta llegar a las madrileñas Torres Blancas (1961-1968).

Mientras tanto, Coderch construía viviendas como la Casa Ugalde (1951), o la propia casa familiar (1955).

Josep Lluís Sert, por su parte, fue seguido también por Fisac, desatacando su casa familiar en Cambridge, Massachusetts, en 1958 que el propio Fisac visitó.

No podemos dejar de citar a Fernández del Amo, con los poblados de Vegaviana, Cáceres (1954-58), y Villalba de Calatrava Ciudad Real (1955-59).

Han existido varios autores, a partir de Juan Daniel Fullaondo, que han tratado de esquematizar en varias etapas la ingente producción de Fisac. A ellas nos remitimos, debido a que no realizaremos incursiones en esta investigación sobre etapas "estructuralistas", ni de "pieles", proponiendo en esta materia del paisaje un estudio transversal.

Sin embargo, es interesante vislumbrar cómo a partir de la década de los $70 \mathrm{su}$ producción merma considerablemente.

Escritor y pensador reflexivo, además de arquitectura nos ha dejado valiosa literatura, ya sea a través de sus escritos de opinión periodística, entre la que destaca sus aportaciones en $A B C$ y el dominical Blanco y Negro -con artículos sobre el Paisaje o el Urbanismo-, dirigidos por quien se convertirá en cliente suyo, Don Torcuato Luca de Tena.

En relación a sus libros, destaca La Molécula Urbana, publicado en 1969, así como Mi estética es mi ética (1982), Carta a Mis sobrinos (1982), y Arquitectura Popular Manchega (1985), en algunos de los cuales profundizaremos.

El reconocimiento a su obra le llegó tarde pero todavía con vida, a través de la Medalla de Oro de la Arquitectura, concedida por sus compañeros los arquitectos en 1994 (Consejo Superior de los Colegios de Arquitectos de España), el Premio Antonio Camuñas en 1997, y el Premio Nacional de Arquitectura en 2003. 


\section{2_Objetivos, delimitación y alcance de la Tesis}

El primer objetivo de esta investigación es buscar la claridad y la sencillez, la esencialidad de la exposición y de las cosas, aún en nuestra andadura por territorios abruptos.

Trataremos de navegar según la mirada que sobre Fisac tienen Emilio Tuñón y Luis Moreno Mansilla: "nos da envidia esa forma de afrontar la arquitectura que tiene Fisac, tan natural, tan libre, y tan poco necesitada de complejos discursos teóricos. $Y$ es que nos da envidia esa manera que tiene Fisac de contar su obra, directa, sin necesidad de complicar la exposición con referencias o citas." 15

También es objetivo de la misma poner el acento, cuestión en la actualidad no planteada por ninguno de los autores estudiosos de Fisac, sobre una cuestión fundamental para la comprensión global de su obra: su concepción del paisaje, que como no puede ser de otra manera deviene en la invención del mismo. El paisaje entendido como la expresión de un itinerario interior en la búsqueda de reelaborar el mundo que lo rodea.

En efecto, hasta la fecha, la mayor parte de los trabajos realizados sobre Miguel Fisac (Daimiel, 1913), realizan lecturas lineales de la concepción de su arquitectura ${ }^{16}$; o bien se detienen en un edificio; en aspectos concretos de su concepción estructural, en la expresividad en el uso de materiales, o en su especial interés en los recintos religiosos, etc..

Esta idea no sólo acoge su interés por las relaciones de la arquitectura con ella misma, con el hombre, o con el entorno que la circunda, ya sea natural o artificial: se trata más bien de las interpretaciones que de ello realiza, del uso que hace de la arquitectura como instrumento resonador del paisaje que quiere construir -inventar-, y de la búsqueda de su posición referencial desde la que elabora esta personal transformación del mundo.

\footnotetext{
${ }^{15}$ Cfr. Tuñón, E. y Moreno Mansilla, L. (1994). Una habitación vacía. En VV.AA. (1994). Fisac, 264. Madrid: Ministerio de Fomento

16 "resultado de la adición ordenada de una serie de partes: programa, lugar de emplazamiento, estructura más adecuada para el caso y resultado obtenido de unificar todas esas cualidades en un conjunto, que me haga bien". Cfr. Navarro, M. I.. (2003). Fisac 2003. Basa, 27, 38. Las Palmas: Colegio Oficial de Arquitectos de Gran Canaria. Texto manuscrito firmado por Miguel Fisac el 27 de junio de 2003.
} 
Al igual que su admirado San Juan de la Cruz, Fisac no se limita a tener una visión contemplativa del paisaje, no es un mero espectador. Su interpretación es dinámica y compleja, es singular, consiguiendo que los elementos involucrados en el proyecto, sean naturales 0 artificiales, se mantengan en diálogo intenso: Miguel Fisac aprecia el lugar como herramienta proyectual.

Si bien todas estas cuestiones están presentes con mayor o menor consciencia desde el inicio de su obra, no es hasta el comienzo de la década de los 50 cuando se desarrollen con interés para la investigación que se pretende realizar, tomando como punto de partida el Instituto Laboral de Daimiel (1950-1953).

Esta investigación pretende también realizar una lectura profunda y transversal sobre todos los factores que en mayor o menor medida influyen en las aproximaciones que Miguel Fisac realiza sobre los paisajes; ya sean metafísicos, arquitectónicos, etc.. para posteriormente descodificarlos sobre experiencias construidas; bien se ubiquen en un barrio periférico o el centro de una ciudad, frente al mar, o en medio de una gran extensión de terreno baldía.

Desde la Memoria, en claro contraste y aparente contradicción con lo que el propio Fisac afirma como actitud previa ante cada nuevo reto, de "mantener la mente en blanco"; en tanto que los vínculos con las vivencias de su infancia, sus orígenes en La Mancha, o su concepción trascendente de la vida humana se mantienen vivos durante toda su vida y son elementos decisorios en su quehacer proyectual.

Desde el Aprendizaje, en tanto que, fruto de sus viajes, tenacidad en el estudio, e intereses espaciales, interioriza una serie de valencias de otras culturas (hispanoárabe, japonesa, etc...), de otros arquitectos (Asplund, Wright, Aalto, Neutra, Saarinen...), o de la propia Historia; haciendo propios una serie de conceptos íntimamente ligados a la construcción del paisaje.

$Y$ desde el Experimento, como la forma en que el maestro de Daimiel reacciona ante todo ello, y de qué forma se produce la materialización de ese itinerario en su arquitectura. Todo ello se ejemplifica en una serie de proyectos seleccionados y en el estudio de una serie de conceptos que Fisac desarrolla como forma de diálogo con el paisaje que inventa: miradores, umbrales, texturas, sombras, estanques o surtidores.

De esta forma veremos cómo el Proyecto da respuesta unitaria desde la invención del lugar a la función prevista; al entorno y al clima, a la tradición y a la modernidad.

Esta cuestión es asimismo generadora de preguntas profundas y complejas sobre la existencia de un vínculo de conexión entre el creador y la persona que habita o el espectador; si la obra de este arquitecto, y su interpretación del paisaje actúa 
emocionalmente sobre las personas; asunto que no desarrollaremos por trascender el alcance de esta investigación.

Si se pretende, por el contrario, dejar suficientemente acreditada la importancia de la concepción del paisaje en la obra de Fisac y su poética, que igual que otros aspectos más conocidos de su obra como materia, forma, función o técnica es otra de las ramas del árbol que conforman la estructura de su emoción.

Quién sabe si nos encontraremos por el camino con el germen de muchos temas que hoy son de absoluta actualidad, desarrollados gracias a las herencias recibidas (temas ecológicos, sociales, políticos o paisajísticos...) en parte por el quehacer de Fisac.

Todo ello tratando de resolver, además, una serie de cuestiones como:

- Cuánto hay en la concepción del paisaje de la obra de Fisac de la interiorización de los paisajes manchegos, de su infancia, y del interés por la arquitectura tradicional.

- En qué medida influyen sus viajes y el estudio in situ de la obra de otros arquitectos que le interesan en esta actitud ante el paisaje (Asplund, Aalto, Lewerentz, Wright, Saarinen);

- Si el estudio y el conocimiento profundo de la Historia y sobre todo de ciertas culturas arcaicas o clásicas son decisivas para estas actuaciones (cultura hispanoárabe, griega, japonesa, etc.. );

- Cuáles son las consideraciones realizadas ante el posicionamiento de los edificios en su propio recinto y en el entorno.

- Si existe una cierta estrategia común en toda su obra, o cada caso es único y singular. $\mathrm{Si}$ existen parámetros esenciales y atemporales que hacen que esta arquitectura no pierda su vigencia y no deje de ser moderna.

- Qué criterios se utilizan para las decisiones proyectuales que afectan al paisaje, incluyendo los mundos interiores creados (jardines, claustros, plazas, etc..)

- Por qué y Cómo se utilizan conceptos y elementos como los reflejos, la sombra, el horizonte, los itinerarios, etc.. y en qué medida colaboran en la conexión entre el paisaje interior creado y la naturaleza exterior.

- Y por último, si todo ello deviene en una cierta mirada poética en su concepción e interpretación del paisaje, y si ello es definitivo para la concepción poética de su obra. 


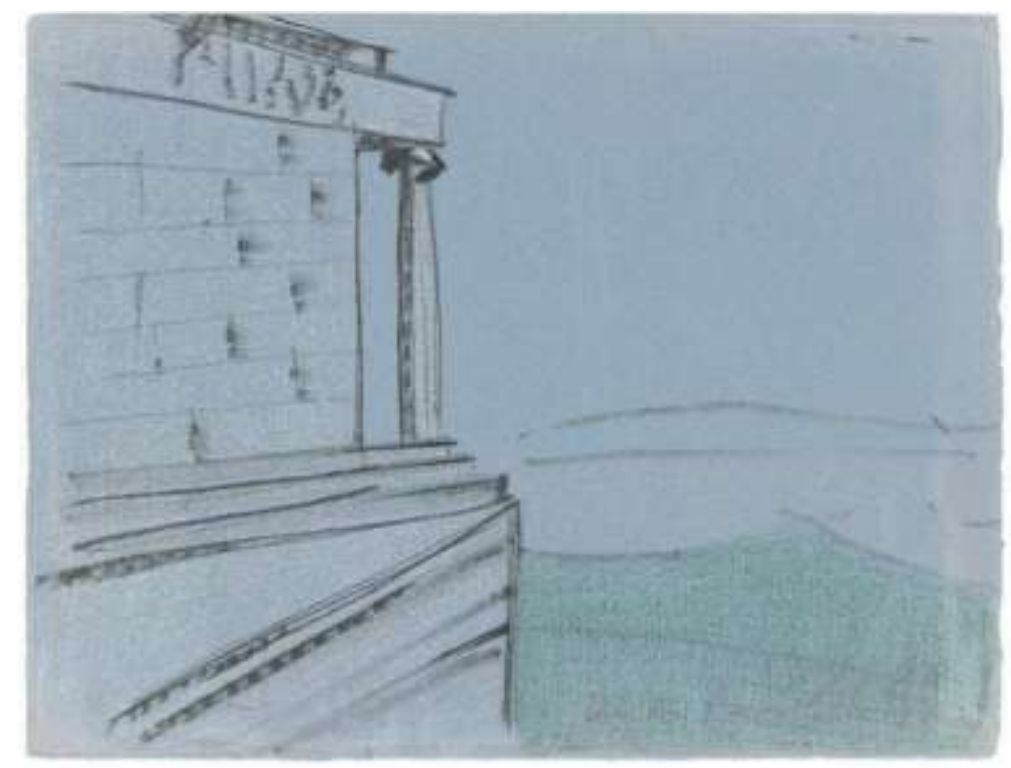

Miguel Fisac. Paisaje desde la Acrópolis de Atenas, 1955

Se busca en definitiva posibilitar que en el estudio de su obra, más vivo que nunca, pero hasta ahora sólo enfocado desde el punto de vista estructural, funcional o material, empiece a cobrar importancia la reflexión sobre el lugar, materializada en la invención del paisaje.

Algunas de estas reflexiones se pueden extraer de los planos de "Emplazamiento", u otros denominados de "Jardinería", en los que se definen estrategias ante el entorno, o se detallan actuaciones, etc.., inéditos en su mayoría. Asimismo, también se recoge información muy valiosa en las "Memorias" de los Proyectos, donde se encuentran muchas de las claves para entender ciertas actitudes ante el paisaje.

A veces, puede llevarnos a equívoco ciertos términos empleados. Son fruto del lenguaje de la época y hemos de tener en cuenta que ciertos términos no estaban desarrollados con la madurez con la que ahora los vislumbramos. Así, cuando Fisac refiere "Dios hizo al hombre para vivir en un jardín", además de la referencia al Génesis entendemos una alusión a aquello que posteriormente descubrirá en la arquitectura tradicional japonesa, que la arquitectura es subsidiaria de la Naturaleza, para ayudarla y suplirla cuando no hay más remedio, idea que, entre otras, desarrollaremos a continuación, trasladándolas a su arquitectura. 
A lo largo de la investigación se irán haciendo las correspondientes delimitaciones y aproximaciones a determinados términos complejos empleados, como paisaje, memoria 0 aprendizaje.

Como asumía el filósofo Giner de los Ríos:

"Todo el mundo sabe lo que es un paisaje, y, sin embargo, iqué concepto más complejo encierra esta palabra!"17

Por ello se le dedica un epígrafe en el que se realizan una serie de aproximaciones históricas y contemporáneas, así como se delimita la utilización del mismo. Y es que la potencia evocadora del mismo es inherente a su complejidad, a su riqueza semántica, y se encuentra en la propia naturaleza del término.

En nuestra tesis utilizaremos una doble significación, diferentes a las acepciones más comunes que nos indica la $\operatorname{RAE}^{18}$ :

- La primera, cercana a la línea de ciertas investigaciones realizadas por Darío Gazapo, como una construcción mental y no un objeto físico, algo que se elabora a partir de determinadas circunstancias Una idea que, por tanto, trasciende lo material o puramente topográfico. En esta investigación trabajaremos con la idea de que esta construcción mental nace y se desarrolla a partir de una serie de vinculaciones ${ }^{19}$ : vinculaciones en el espacio (aprendizaje a través de viajes, estudios, intereses, o influencias de otros arquitectos), y vinculaciones en el tiempo (memoria, tradición, infancia y juventud, La Mancha).

- La segunda acepción se referirá al paisaje como físico, como parte del territorio -sea urbano o rural-, pero que precisa la mirada de un hombre para su existencia. $Y$ sus relaciones con la arquitectura. Esta segunda acepción, también tiene una importante carga de profundidad que la conecta directamente con la primera.

$Y$ es que si acordamos que el paisaje es un pedazo de la realidad, agreste o civilizada, natural 0 artificial, no podemos ocultar que ello está generado por la mirada del hombre y sus circunstancias. El paisaje es diferente, por tanto, a cada persona, pues sobre cada uno se proyecta una realidad en función de determinados factores: es una interpretación de la realidad.

17 Giner de los Ríos, F. (1915). La lectura. Tomo I

${ }^{18}$ Según la RAE: 1. f. Accidente de tiempo, lugar, modo, etc., que está unido a la sustancia de algún hecho o dicho; 2. f. Calidad o requisito; 3. f. Conjunto de lo que está en torno a alguien; el mundo en cuanto mundo de alguien.

${ }^{19}$ Se toma prestado de la obra póstuma e inconclusa de Saint-Exùpery, Ciudadela, las ideas que subyacen en la filosofía del arraigo, de las raíces, que al vincular al hombre a su familia, a su oficio, y a su patria, lo protegen contra el abismo del espacio, en tanto que los ritos y las tradiciones, al permitirle ubicarse en el suceder temporal, lo protegen contra la erosión del tiempo. 
Asimismo, se concretarán los elementos Memoria y el Aprendizaje.

Delimitaremos el concepto Memoria a la memoria individual, la del propio Fisac, no abundando en la memoria colectiva, de la sociedad, ni en otras significaciones complejas como la memoria del lugar, ya que si bien pudiera considerarse que Fisac trabaja con alguna de estas valencias, se nos escapa del ámbito de la Tesis. Asimismo, trataremos la Memoria como un elemento con diferentes capas o estratos, quizás una membrana semipermeable a través de la cual se realiza una acción de ósmosis de otros elementos.

Por su parte, la utilización del término Aprendizaje, lo delimitaremos de acuerdo con la RAE, como "adquisición del conocimiento de algo", pero trascendiendo de los medios de esta adquisición a unos intereses -creados 0 descubiertos- y con unas consecuencias trascendentales:

Aprendizaje como itinerario, como conjunto de "idas y regresos" con capacidad de mover los ejes refererenciales del posicionamiento de Fisac ante la arquitectura y el paisaje, para, enlazando con la primera acepción de Paisaje descrita, crear una suerte de paisaje propio, la invención de un paisaje. Según afirmaba Oteiza:

"Hay idas y regresos en el paisaje. $Y$ son incesantes estos viajes en el proceso formativo de un tipo de hombre, de una cultura. Así va imaginando el artista el sitio entre sus manos y efectúa sus descubrimientos y construye esa morada eterna: el ser estético.".20

El desarrollo de todo ello será de especial trascendencia para el entendimiento de obras seleccionadas a la luz de la propuesta de mirada de esta Tesis, decodificando una serie de parámetros esenciales para poder mirar el paisaje desde el paisaje.

20 Oteiza, J.(1943). Interpretación estética de la estatuaria megalítica americana. Edición al cuidado de Maria Teresa Muñoz, 2007. Navarra: Fundación Museo Oteiza 


\section{3_Razón de estudio}

"Dios creó al hombre (...) para vivir en un jardín", dice Fisac citando el Génesis²1.

Detrás de esta afirmación tan rotunda no sólo hay una convicción sobre lo que debe ser la arquitectura, sino una declaración de intenciones de lo que a lo largo de toda su vida se realizará. Para Miguel Fisac, la relación íntima entre arquitectura y paisaje es definitiva en su obra.

Edificios de una gran diversidad tipológica y de escala, pero con una serie de parámetros comunes, de entre los que destacan, si bien no con la repercusión que podrían haber merecido, el valor de la implantación del objeto arquitectónico en el paisaje, de sus conexiones profundas con el lugar, y de la interpretación que del paisaje se realiza.

Este punto de partida es complementado por una serie de ideas que refuerzan la importancia de esta investigación y no sólo la justifican, sino que la hacen necesaria:

Para Miguel Fisac, "La Arquitectura, como el árbol, está plantada en el paisaje"22; es más, "La Arquitectura es un objeto de arte fijado en un paisaje"23. Ello representa una gran sensibilidad e interés por el entorno y el lugar sobre el que se trabaja.

Desde el inicio de su andadura profesional ya se le presenta la oportunidad y se muestra interés, -con mayor o menor acierto-, en estos aspectos. La plaza interior y el pórtico a la calle Serrano del $\mathrm{CSIC}^{24}$ son un claro ejemplo de ello.

Posteriormente, sobre todo a partir de 1949, las experiencias de sus viajes y conocimiento in situ de una selección personal de obras de arquitectura, además del estudio de otras culturas (tanto la árabe como la japonesa, etc..), enriquecerá enormemente su visión y su concepción del paisaje, como veremos a continuación. A partir de este momento se comenzará a conformar una actitud muy decidida ante el paisaje, y a producir espacios de una riqueza digna de mención.

21 Cita de una conferencia impartida por Fisac, recogido por Morales, Felipe. Arquitectura religiosa de Miguel Fisac (1960). pág. 5

22 VV.AA. Miguel Fisac. La madera en la iglesia de San Pedro Mártir y en el Colegio de la Asunción. UPM, 2010

${ }^{23}$ Navarro Segura, Maria Isabel. Op. Cit. Pg. 9

${ }^{24}$ Cfr. Fisac, M. (1945). Proyecto de urbanización, jardinería y cerramiento del CSIC. Madrid. 
Su carácter inconformista le obliga a entrar en los detalles asumiendo coherentemente hasta las últimas consecuencias de sus decisiones. Cada espacio, jardín o plaza; cada especie arbórea, pavimento o material, color, espacio de sombra, fuente o surtidor..son decididos sin dejar nada al azar. Todo ello en dos líneas de trabajo, hacia la ciudad y hacia el mundo interior creado.

Asimismo, en relación al paisaje urbano y el desarrollo de las ciudades, sus propuestas no sólo quedaron patentes en publicaciones como La molécula urbana, sino en su quehacer como arquitecto. En cada edificio que diseñaba, se tenía muy en cuenta su relación con la ciudad o con el espacio que lo circundaba, ya fuera urbano (como veremos en ejemplos como el edificio de viviendas en Valencia), o en un enclave natural (como veremos en sus viviendas en Mallorca o Cádiz).

Hablando de la vocación urbana de los edificios de Fisac, se pretende asimismo demostrar que las siguientes afirmaciones no sólo son matizables sino que no recogen el posicionamiento de la arquitectura de Fisac ante el paisaje. En ellas se afirma (Capitel, 1983), que después de las obras en la Colina de los Chopos y a excepción del Instituto Cajal de Biología se abandona por parte de Fisac el interés por el paisaje urbano:

"Cosa que más adelante abandonará por completo, como toda la cultura moderna ya triunfante, rompiendo con una dilatada tradición persistente más allá de coyunturas y estilos, y fundando la destrucción de la ciudad como consciente hecho formal.".

No estamos negando que entre los 450 -aproximadamente- edificios e intervenciones arquitecturas de Fisac, existan algunos que aborden este asunto con mayor o menor acierto, pero en la investigación se ha pretendido demostrar que el posicionamiento de Fisac ante el paisaje fue totalmente opuesto a lo allí afirmado; bien al contrario, una pata sustancial sobre la que se asienta la arquitectura del maestro manchego.

En este tema era un auténtico creador de opinión. No en vano escribió una enorme cantidad de artículos periodísticos para el diario ABC, para el dominical Blanco y Negro, o para el magazine La Actualidad Española, dejando opiniones profesionales sobre temas concretos de ciertas ciudades o entornos naturales, así como sobre conceptos como la belleza, el paisaje, el agua en la arquitectura, etc... De igual forma se encuentran recogidas también en la prensa sus opiniones vertidas en multitud de mesas redondas sobre estos mismos temas. Félix Rodríguez de la Fuente contó con su savoire faire en la redacción de un plan de protección para la isla de La Cabrera.

Su interés por el mundo de la jardinería y la botánica, categorías que indudablemente están incluidas en su concepción del paisaje, está fuera de toda duda, así como el dominio y el profundo conocimiento sobre el tema. Todo ello se evidencia en los más 
que interesantes y ya citados planos de Emplazamiento durante toda su carrera, algunos de los cuales estudiaremos con detalle.

Las intuiciones que nos invitan a profundizar sobre este último aspecto están más que justificadas en ejemplos de utilización de ciertas especies vegetales como instrumentos para transmitir conexiones de diversa índole, o para trasladar a un lugar una intensidad especial.

En el Pabellón de Ciudad Real de la II Feria Internacional del Campo (1953), -por ejemplo- no es baladí la existencia de la higuera junto a la noria como expresión poética del paisaje manchego y del saber popular (curiosamente Alvar Aalto también repara en esta especie, en su viaje a España en 1951); en el Teologado de Alcobendas, se realiza en el espacio claustral un jardín japonés para la meditación (con todos sus elementos agua, rocas, vegetación, topografía, perspectiva, etc.); en Málaga aparecen continuas referencias a la Alhambra, utilizando olores, brillos, reflejos o sombras potenciadas con el uso de ciertos materiales; en Valencia aparece el jardín como un remanso de paz en el ajetreo de la ciudad, con una pequeña fuente de inspiración hispano-árabe.

En este sentido, la maestría de tratar de explicar el paisaje desde el paisaje, el uso de una suerte de "metalenguaje", aporta intensidad a la poética de su arquitectura.

También surge, de la lectura de sus escritos, y del estudio de sus proyectos y obras, la necesidad de profundizar en sus intereses en La Alhambra o la casa japonesa, así como en la arquitectura de la que es deudor, la de sus maestros -reconocidos o no, como posteriormente veremos- y como esto reverbera en la relación de su arquitectura con el paisaje. 

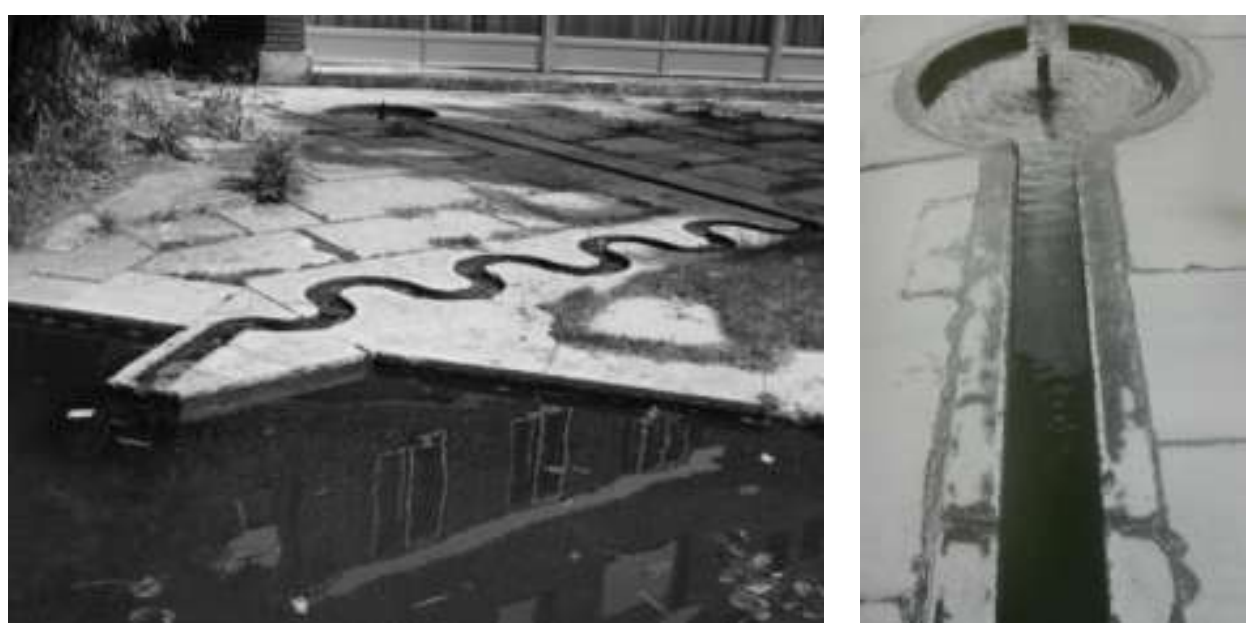

Fuente del patio del Colegio Apostólico de los Dominicos de Valladolid y Fuente del Patio de los Leones en La Alhambra

En relación a La Alhambra, esta idea tiene tal trascendencia que justifica el presente estudio, así como las posibles resonancias "de ida y vuelta" a través de otras arquitecturas como la de Richard Neutra. La invitación a recorrer de su mano estos jardines hispanoárabes podría suponer un aprendizaje en doble sentido, como a continuación trataremos de estudiar. No en vano, Neutra afirmó que "la verdadera esencia espacial de mi trabajo esta extraída de los patrimonios arquitectónicos de España, especialmente la Alhambra de Granada"25.

Otros autores, expertos en el estudio de Miguel Fisac, han tenido intuiciones que vislumbran la intensidad de la mirada del arquitecto en el paisaje y la resonancia de éste en su arquitectura, como ahora veremos.

Cualquier estudio sobre Fisac debe obligatoriamente citar el primer, temprano y preciso acercamiento a su obra que realizó en su Tesis Doctoral $M^{\text {a }}$ Cruz Morales Saro, en la Universidad de Oviedo (Historia del Arte), en 1974, posteriormente convertido en un libro editado por el Colegio de Arquitectos de Ciudad Real. Si bien se trata de un trabajo de ámbito fundamentalmente descriptivo y su temprana realización no permite la necesaria perspectiva sobre los aspectos que aquí se pretenden contemplar, si que se recogen sus influencias, se enumeran viajes y la trascendencia de los mismos, y nos pone "en la pista" de que la construcción del paisaje puede constituirse como uno de los factores determinantes de su arquitectura:

${ }^{25}$ Navarro Segura, M. I. (2001). Desde el origen: La arquitectura de Fernando Higueras. Basa, 24. Las Palmas: Colegio de Arquitectos de Gran Canaria. 
"El paisaje, los materiales locales (no floklorizados)...son otras tantas facetas positivas que abrirán horizontes al desarrollo de la arquitectura de Miguel Fisac."26

Posteriormente en 1998, ya en la Escuela Técnica Superior de Arquitectura de Madrid, realiza su Tesis Alberto Morell Sixto, con el título Forma, espacio y construcción en la arquitectura de Miguel Fisac. En ella destaca, en el encuadre pretendido en esta investigación, las aportaciones sobre las influencias que a lo largo de su trayectoria guían a Fisac, y estudia en profundidad tres obras: el Instituto de Óptica, la iglesia de la Coronación de Vitoria y el madrileño Centro de Estudios Hidrográficos.

En 2003, también en la ETSAM, y por primera vez en el Departamento de Proyectos Arquitectónicos (ya que la Tesis de Morell se realizó en el Departamento de Ideación Gráfica), lee su Tesis Doctoral el profesor Francisco Arques Soler, con el título La forma y el ornamento en la obra arquitectónica. El Centro de Estudios Hidrográficos de Miguel Fisac. Un para qué, un cómo y un no sé qué. Esta investigación se centra fundamentalmente en las estructuras postesadas conocidas como vigas-hueso y el espacio de la nave de modelos del citado Centro, así como su proceso constructivo, manifestándose el carácter inventor de la figura de Fisac. A esta Tesis le precedió, en 1996, la publicación por Arques Soler de la monografía más completa del arquitecto manchego hasta la fecha, aderezada por una serie de comentarios del propio Fisac, y de una serie de concisos análisis del profesor, en la que se citan en algunas ocasiones la importancia que la consideración del paisaje tenía para su arquitectura.

En 2009, también en la ETSAM, en el Departamento de Construcción, realiza su Tesis Fermín González Blanco, bajo el título Los huesos de Fisac. En busca de la forma ideal, que realiza un recorrido por la obra de Fisac pero exclusivamente centrado en el ámbito estructural y constructivo de la arquitectura, en las piezas huecas que el arquitecto produce y desarrolla.

Y en 2014, por segunda y última vez en el Departamento de Proyectos de la ETSAM, lee su Tesis Doctoral Nieves Cabañas Galán, con el título Convento dominico de Miguel Fisac en Madrid. El acento de los objetos. En ella, como su propio nombre indica, el análisis se centra fundamentalmente en el conjunto dominico de Alcobendas. Para la determinación del estado de la cuestión, es relevante mencionar que se hace en ella alusión al uso del agua en este edificio, así como el estudio realizado de los patios de este conjunto. También se cita, lógicamente, las influencias recibidas en los viajes realizados por el arquitecto.

En ninguna de ellas, sin embargo, se realiza una profundización sobre el alcance que tiene la construcción del paisaje en el entendimiento global de la obra de Fisac, más allá de la importancia de lo estructural y constructivo de su arquitectura.

${ }^{26}$ Morales Saro, M.C. (1979). La arquitectura de Miguel Fisac, 26. Ciudad Real: Colegio de Arquitectos. 
También en 2014, y en el Departamento de Proyectos de la ETSAM, si bien no se trata ya aquí de una investigación monográfica sobre el arquitecto, se realiza la Tesis Lo popular en la arquitectura moderna en España. Coderch, Fisac, De la Sota, Fernández del Amo, por José Ángel Vaquero Gómez. En ella se trata la incorporación de lo popular en determinadas arquitecturas de la modernidad, concretamente en algunas obras del daimieleño; sin embargo dicho acercamiento no incluye una profundización de la consideración de la arquitectura de Fisac -en su caso la de procedencia directa de una influencia de la arquitectura popular- como construcción del paisaje ni el desarrollo de ninguna obra concreta.

Por otra parte, en la bibliografía especializada y en artículos de investigación existen menciones varias a la consideración del paisaje para Fisac, pero sin desarrollos extensos, que se van enumerando a lo largo de esta investigación.

Únicamente citaremos una referencia, por ser la que más se acerca al tema en cuestión, realizada recientemente por Francisco Arques sobre el Centro de Estudios Hidrográficos:

"El edificio no sólo existe en el paisaje, sino que lo contiene, como si el sueño del arquitecto norteamericano Frank Lloyd Wright, en su famosa Casa de la cascada (Fallingwater 1935-37), se hubiera finalmente cumplido. La cubierta de la Nave de Modelos se repliega como una membrana orgánica cuya vibrante estructura hace reverberar la conciencia de la naturaleza que la habita. Y, en correspondencia, es la arquitectura la que cobija al paisaje: es la cascada la que en la casa vive."27.

Justificada esta necesidad, concluiremos con una idea importante: no es esta una investigación sobre el pasado ni sobre el presente. Con Fisac, pensamos que:

"La Arquitectura del s.XXI será una arquitectura llena de sensatez, de economía y de respeto al paisaje, si queremos que haya s. XXI.". ${ }^{28}$

Y estamos convencidos de que a eso sólo se puede llegar aprendiendo de nuestros mayores.

\footnotetext{
27 Arques, F. (2007). Estructuras óseas. Vigas-hueso. Miguel Fisac. Huesos varios, 75. Catálogo de la exposición al cuidado de Fermín González Blanco. Madrid: Fundación COAM

${ }^{28}$ Revista Pasajes de arquitectura y crítica, nº 1, 1998. Miguel Fisac. Entrevista realizada por José Ballesteros y Miguel Barahona.
} 


\section{4_Hipótesis de partida}

Del supuesto rechazo de Fisac por el Movimiento Moderno, debido al desprecio de sus representantes por el paisaje social, humano y físico ${ }^{29}$, surge enseguida la pregunta de cómo él mismo reacciona ante esto. La respuesta trataremos de buscarla en sus obras de arquitectura en relación con el paisaje, sin dejar de navegar en sus escritos, conferencias, 0 artículos de opinión.

Asimismo, es interesante preguntarse por qué Fisac no sigue la misma senda que muchos de sus coetáneos, sin plantearse a veces más cuestión que ser moderno, -que no era poco en aquellos años convulsos-. A ello trataremos de responder buscando en lo que llamaremos la Memoria y el Aprendizaje, elementos a través de los cuales Fisac tamiza su arquitectura.

Para Fisac lo más importante de su arquitectura es el hombre, más concretamente el hombre en el paisaje. Al igual que para Unamuno el hombre no es un elemento perturbador del paisaje sino parte integrante de él, y a su vez modificador de él 30 .

Esto nos lleva a pensar que quizás Fisac se adelanta a su tiempo. De hecho, aparte de las realizaciones de los Poblados de Colonización -que eran por sí mismas operaciones de ámbito urbanístico-, en la época no se suele prestar demasiada atención en España al aspecto del paisaje, o a cuestiones singulares de ciudades. Prueba de ello es que no es hasta 1962 (Alarcón, 1999, 156) cuando se comienza a hablar en las publicaciones españolas de algo similar al townscape, definido por Carlos Flores como "el arte capaz de conseguir que un grupo de edificios formen una entidad con carácter y vida propios"31.

La arquitectura de Miguel Fisac en su exterioridad, así como la relación de la misma con los paisajes que la circundan, se encuentra -más aún que sus propios edificios- llena de conexiones con sus experiencias vitales; ya procedan de vivencias de su infancia y su

${ }^{29}$ Fisac, M. (1979). Op. cit.

30 Unamuno, M.(1903). De mi país. En obras completas VI. Edición Biblioteca Castro, 1999. Madrid: Fundación José Antonio de Castro

${ }^{31}$ La palabra townscape, fue tomada prestada de una serie de artículos de Gordon Cullen publicados en Architectural Review sobre el paisaje por la revista Hogar y Arquitectura desde 1962 -fascículo 41-, donde comienzan a aparecer una serie de artículos de Carlos Flores sobre el tema, siendo el primero "El townscape o panorama urbano". Tomado de Alarcón, C. (1999). La Arquitectura en España a través de las revistas especializadas 1950-1970. El caso de Hogar y Arquitectura (tesis doctoral). Madrid: Universidad Politécnica de Madrid. 
primer entorno, o bien hayan sido aprendidas posteriormente frutos de los intereses del mismo. Se propone una nueva mirada sobre su arquitectura, entendida como herramienta para inventar paisajes.

Podríamos pensar que los paisajes que se proyectan y construyen son la reelaboración de una forma de pensar y vivir de nuevo su propia tierra, que se sirve de ellos para inventar la Mancha; que son un viaje de ida y vuelta.

El resultado promete ser más que atractivo. Paisajes que destilan juventud, atemporalidad, esencialidad. Paisajes en los que predomina lo primitivo, lo ancestral; llenos de matices y alusiones a lo vivido o estudiado.

Los paisajes que estudiaremos en primera instancia transcienden lo puramente topográfico. Son, utilizando terminología de Saint-Exùpery, vinculaciones: vinculaciones en el espacio (aprendizaje a través de viajes, estudios, intereses, 0 influencias de otros arquitectos), y vinculaciones en el tiempo (memoria, familia, infancia y juventud, La Mancha como concepto).

Posteriormente, trataremos de analizar cómo esas vinculaciones reverberan en su arquitectura, concretamente en la creación de la exterioridad. Partiremos, por tanto, de la cosmología para llegar a la cosmografía.

Unas y otras, además, se pueden considerar metáforas de su posicionamiento rebelde ante la vida, por lo que estos paisajes inventados, ante todo, tratan de ser un "sacudirse el polvo", un canto a la libertad.

Porque si hay algo que defina la arquitectura de Miguel Fisac, y esto va íntimamente enlazado con su personalidad es la Rebeldía. En su caso, la rebeldía es un primer acto de aprendizaje: la acción de oponerse a "lo dado" para redefinir su posicionamiento, su sistema referencial.

A la vez, esta rebeldía es una vuelta al sentido común, a la re-visión de aquello sobre lo que actúa desde el despojamiento de todo "lo que sobra", para reducirlo a lo sencillo, a lo esencial, a la sobriedad, a la autenticidad, y a la ausencia de artificio (que se traducirá, por ejemplo, en cómo se utilizan determinados materiales). Fisac captura lo que caracteriza y define cada paisaje con su arquitectura, eliminando lo casual.

Se trata pues, de volver sobre los pasos de Fisac en su búsqueda del sentido de la esencialidad, tratando de discernir qué es lo que realmente le interesa de aquellos patrones sobre los que cimenta su idea de arquitectura, ya sea arcaico o primitivo, ya contemporáneo. Y de cómo Fisac hace propio el pálpito del pasado lejano, tamizándolo en su propio pasado, en su insondable memoria, quizás en las experiencias de su niñez: su infancia, sus experiencias personales, son también materia con la que posteriormente se construirá su arquitectura. Nos interesaremos por aquellos paisajes, 
en palabras de Unamuno "que fueron la primera leche de nuestra alma, valles o llanuras en que se amamantó nuestro espiritu cuando aún no hablaba, todo eso nos acompaña hasta la muerte y forma como el meollo, el tuétano de los huesos del alma misma".

De esta forma iremos vertebrando sus ideas y posiciones para descubrir que el personaje se construye de forma totalmente coherente.

Asimismo, trataremos de aproximarnos a ello a través de viajes, de encuentros intelectuales con maestros, o el descubrimiento de arquitecturas que encierran la más profunda humanización de los espacios. Una serie de aprendizajes que se mueven entre una suerte de grandes placas tectónicas: Oriental, Nórdica ó Americana, que lejos de colisionar entre ellas, convergen formando una rica e interesante orogénesis.

Finalmente, abriremos la puerta al estudio de casos concretos, de obras de arquitectura que encierran esos principios, decodificando una serie de parámetros esenciales para poder mirar el paisaje desde el paisaje. En este punto debemos advertir que hemos tratado de introducir arquitecturas menos conocidas de la enorme producción de Fisac, de forma que, por un lado se ponga a disposición de la comunidad investigadora nueva documentación inédita, y por otro, dotar a esta investigación de un carácter diferenciador con otras realizadas sobre la obra del maestro daimieleño.

Como si de un prensado de uva se tratara, contrastaremos si el jugo último de las esencias de La Mancha, madurado en ancestrales barricas, pero con notas nórdicas, japonesas, o hispanoárabes pudiera mostrarnos un sabor novedoso y actualizado, sin perder la presencia de la tierra donde se cultivó.

Una conexión con el paisaje que, más que física, es íntima -trascendental-, reelaborando así una forma de entender el mundo, un posicionamiento ante el paisaje usando la arquitectura como herramienta, que quizás se adelanta a su tiempo. 


\section{5_Precisiones sobre el concepto paisaje}

Ante un término complejo y polisémico como el de paisaje, parece necesario plantear una serie de aproximaciones que, sin dar por supuesto su significado, capturen la esencia y la estratificación que del mismo se pretende desarrollar en esta investigación, y que permitan enfocar de forma certera y aprehensible nuestra mirada acerca de la construcción e invención del mismo aquí propuestas.

Con este fin, realizaremos en primer lugar un breve acercamiento histórico, desde la óptica de distintas disciplinas, para tratar de entender los orígenes del concepto. A continuación, el desarrollo de lo anterior nos permitirá explicar la aparición de una sensibilidad paisajística moderna; para posteriormente centrar nuestra mirada en el papel del paisaje en la arquitectura del siglo veinte y concretamente en los maestros de la modernidad, para lo que nos ayudaremos de ciertas delimitaciones realizadas por Kenneth Frampton ${ }^{32}$.

Como punto de partida, tomaremos provisionalmente la definición realizada por el Consejo de Europa en el Convenio Europeo del Paisaje del año 2000, que entiende el paisaje como "cualquier parte del territorio tal y como la perciben las poblaciones, cuyo carácter resulta de la acción y la interacción de factores naturales y humanos"33.

Si bien esta definición necesita matizarse desde varios ángulos para acercarse más a lo que aquí se pretende desarrollar, nos brinda un primer acercamiento a un aspecto clave: el factor humano y su interacción en el medio -natural o urbano-.

La lectura que la presente Tesis realiza sobre el concepto de paisaje, además de incidir especialmente en este factor humano, se pretende enmarcar en una categoría superior, perteneciente al ámbito de una construcción mental, -más allá del objeto físico, de la realidad natural-. Por ello, en esta investigación, el paisaje no estará definido "por el hecho de que toda suerte de cosas estén extendidas unas junto a otras sobre un trozo de la corteza terrestre y sean contempladas inmediatamente"34; sino que es precisamente la visión emocional del hombre -con las interferencias que puedan crear aspectos de la memoria o el aprendizaje- la que unifica y define el carácter del mismo.

\footnotetext{
32 Frampton, K. (1990). En busca del Paisaje Moderno. Arquitectura, 285, 52-73

${ }^{33}$ Convenio Europeo del Paisaje, hecho en Florencia el 20 de octubre de 2000 y ratificado por el Estado Español en 2008 http://ipce.mcu.es/pdfs/convencion-florencia.pdf

${ }^{34}$ Simmel, G. Filosofía del paisaje. El individuo y la libertad. Edición 1986. Ensayos de crítica de la cultura, 175-186. Barcelona: Península.
} 
Debemos diferenciar entre la consideración del concepto paisaje por parte de la sociedad, -con su idiosincrasia, historia, cultura y climatología propias-; y de otro lado la gestación individualidad del mismo, fruto de una mirada que le es transmitida culturalmente a una persona, las interferencias de su memoria, y de un aprendizaje buscado o encontrado, una suerte de amalgama que deriva en una relación simbólica del hombre con el medio que lo rodea. Esta última será la que nos interesa, pues tratamos de aproximarnos a cómo un arquitecto, a través de sus intervenciones, construye, inventa, crea el paisaje.

Para Alvar Aalto, "el paisaje ofrecido por la naturaleza primitiva con todos sus encantos y sortilegios no sabría reemplazar una perspectiva donde la mano del hombre ha dejado rastros visibles, desde el instante en que esta "impronta humana" la completa armoniosamente y la pone en valor"35

Podemos aproximarnos al concepto de paisaje como un lugar o realidad física sobre la que se detenga una mirada. De acuerdo con el geógrafo Humboldt, es la visión emocional del hombre la que unifica y define el carácter del paisaje:

"El contorno de las montañas que coronan el horizonte en una lejanía nebulosa, el tinte sombrío de los bosques de abetos, el torrente que se precipita tumultuosamente a través de rocas abruptas, en fin todo lo que forma el carácter de un paisaje se une, por un antiguo lazo misterioso, a la vida sentimental del hombre."

La idea de paisaje está tan ligada al hombre, que deja traslucir ciertas obsesiones. A Dimitris Pikionis, -responsable de la ordenación de las colinas de la Acrópolis-, en íntima unión a lo largo de toda su trayectoria con Atenas y su paisaje mítico, una sola piedra le evocaba intensas conexiones cosmológicas con la Acrópolis.

"You are the landscape. You are the Temple that is to crown the precipitous rocks of your own Acropolis" 36

Una aproximación al concepto de paisaje que nos sirve como referente es la sostenida por Oteiza: "El Paisaje es como un cuerpo múltiple y sensible, cargado de misteriosas energías y que rueda fatalmente sobre nosotros con la clave de nuestro propio destino.

${ }^{35}$ Aalto, A. La arquitectura en el paisaje de Finlandia Central. En VV.AA. Alvar Aalto. Escritos 1921-1966, 16-18. Departamento de Proyectos Arquitectónicos, 1993. Sevilla: Escuela Técnica Superior de Arquitectura.

36 "Eres el paisaje. Eres el Templo que va a coronar las escarpadas rocas de tu propia Acrópolis". Pikionis, D. (1935). A sentimental topography. En VV.AA. Dimitris Pikionis, Architect 1887-1968, 68. Edición 1989. Londres: Architectural Association. 
A formas distintas de hombre corresponden distintas interpretaciones del paisaje." ${ }^{37}$. En el capítulo "El paisaje y el hombre" de su libro Interpretación estética de la estatuaria megalítica americana, establece Oteiza que el paisaje se conforma de tres categorías: la primera, la estabilidad del soporte natural (el árbol, la montaña, el río), aquello que es percibido como invariable; la segunda, que acoge todo aquello que cambia y que hace a una persona ser consciente del transcurrir del tiempo, del crecimiento, y de la muerte; y la tercera se refiere al aporte del habitante, que es capaz de superar tanto a lo natural como al tiempo, aquello que perdura incluso después de la muerte. Ejemplo de esta tercera categoría sería el yacimiento de San Agustín (Colombia), con sus esculturas monolíticas que además de definir el paisaje hacen que sus desaparecidos creadores sobrevivan a la muerte, y venzan a la naturaleza y al tiempo transmitiendo su cultura.

Por último, en cuanto a la construcción del paisaje, conviene precisar, apoyándonos en Heidegger ${ }^{38}$, que construir un objeto arquitectónico no es una condición esencial para la construcción del paisaje. Construir significa originariamente habitar, abrigar, cuidar cultivar una viña, por ejemplo-, por lo que construir el paisaje sólo requiere una referencia humana que suponga una visión del mundo.

\section{Una aproximación histórica}

"Antes de transformar un soporte en una columna, un tejado en un tímpano, antes de colocar piedra sobre piedra, el hombre colocó la piedra sobre la tierra para reconocer un emplazamiento en medio de un universo: para tenerlo en cuenta y modificarlo"39

Si bien el desarrollo del concepto paisaje es relativamente moderno, surge la necesidad de encontrar sus orígenes y estudiar su desarrollo hasta la actualidad de forma que podamos entender más claramente el posicionamiento de ciertos arquitectos ante él.

Sobre el origen del concepto de paisaje, de acuerdo con la cita anterior de Vittorio Gregotti, podemos encontrar expresiones del mismo en las manifestaciones megalíticas que se sucedieron desde el Neolítico hasta la Edad de Bronce, desde el 5000 a.C. aproximadamente.

\footnotetext{
37 Oteiza, J. (1943). Interpretación estética de la estatuaria megalítica americana. Edición al cuidado de María Teresa Muñoz, 2007. Navarra: Fundación Museo Oteiza.

38 Heidegger, M. (1951). Construir, habitar, pensar. En Conferencias y artículos. Martin Heidegger, 127-142. Edición 2014. Barcelona: El Serbal

39 Gregotti, V. (1982). Conferencia en la liga arquitectónica de Nueva York. Recogido en Frampton, K. (1990). En busca del paisaje moderno. Arquitectura, 285, 52-73
} 
En un momento determinado, el hombre toma consciencia del paisaje y lo traslada a una serie de disciplinas de expresión artística, que a lo largo del tiempo acogerán la pintura o la arquitectura, la fotografía, la literatura o la geografía.

Aceptando que el primer arte en apropiarse de la representación del paisaje fue la pintura, surge El Saltador de Paestum ${ }^{40}$ como la primera manifestación encontrada en Occidente (480 a.C.) en la que se sintetiza la simbiosis entre Naturaleza -árboles, horizonte...-, Arquitectura -edificio-trampolín- y Hombre -en su esencia, en su desnudez.

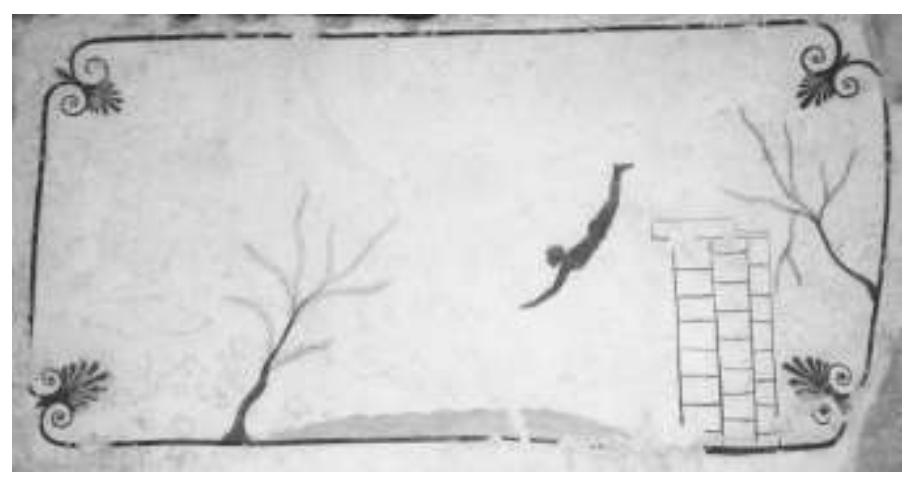

El saltador de Paestum (480 a.C.) Museo Arqueológico Nacional, Paestum.

Si bien se trata de una representación, que además no tenía vocación de ser contemplada por los hombres puesto que era la cara interior de una tumba, los elementos existentes en ella nos sugieren conceptos que se pueden considerar ancestros de las ideas que se pretenden desarrollar, como la conjunción del hombre y el objeto ante el paisaje, la profundidad, el horizonte, etc.., sintetizados en los tres elementos citados y representados con la máxima sencillez.

El concepto de paisaje no está presente en todas las culturas ni civilizaciones ${ }^{41}$. En el siglo XIV sin embargo, se descubre en Occidente la contemplación de la naturaleza como placer estético, a través de la conocida experiencia de Petrarca en la subida al Mont Ventoux.

40 El Saltador es un ejemplo de pintura helénica, encontrada en 1969 en la ciudad italiana de Paestum (Magna Grecia). Se trata de uno de las losas de un enterramiento y data del año 480 a.C. Museo Arqueológico Nacional, Paestum.

${ }^{41}$ Aceptando las propuestas del geógrafo francés Augustín Berque en Paysage, Milieu, Historie, según el cual se precisan cuatro condiciones para que se valide la existencia del concepto de paisaje en una cultura: una literatura que describa lugares -naturales o artificiales-, la existencia de representaciones pictóricas, la existencia de espacios ajardinados para el puro placer, y la existencia de un término que nomine el concepto paisaje. 
"El día 26 de abril de 1336 el poeta Francisco Petrarca, que vivía en Aviñón, junto a la corte papal hizo realidad el insólito deseo de subir a la cumbre del Monte Ventoux, el más alto de la región. Tan descabellada idea, la de realizar el enorme esfuerzo de ascender a un monte sin que mediara ninguna necesidad, sin el propósito de obtener algún beneficio concreto, supuso una 'extravagancia'. [que] condujo al poeta a escribir una carta a Dionigi da Borgo San Sepulcro, a la sazón obispo de Cavallón, explicándole las dificultades por las que atravesó y lo que aconteció cuando llegó a la cima. [...] Lo que la carta narra no [son] tanto las penalidades de la escalada, que poco le importarían al obispo que era confesor de Petrarca, como las dificultades y las flaquezas por las que todo buen cristiano atraviesa para conseguir ascender a la cima de la virtud. Pero, con independencia de la verdadera razón por la que [el poeta] escribió la citada carta en un latín exquisito, la escena que en ella cuenta sobre lo que ve desde el monte Ventoux ha tenido una enorme trascendencia, [y muchos son los historiadores que mencionan esta carta como el origen de la sensibilidad hacia el paisaje en Occidente] El poeta quedó asombrado y conmovido por el vasto panorama que se extendía a sus pies, los montes de la provincia de Lyon, el mar de Marsella, el Ródano". Turbado ante la contemplación de la belleza del mundo abrió el libro de las Confesiones de San Agustín para leer en ellas: "Y los hombres van a admirar las cumbres de las montañas, las olas enormes del mar, el dilatado curso de los ríos, las playas sinuosas de los océanos, las revoluciones de los astros, et relinquunt se ipsos nec mirantur (y se olvidan de mirarse a sí mismos)"."42

Esta experiencia hace a Petrarca renunciar al disfrute -experiencia sensual-, de la contemplación del paisaje, por lo que habrá que esperar al Renacimiento para que el paisaje se haga realmente presente en la pintura, a través de Giotto o Piero della Francesca.

${ }^{42}$ Cfr. Maderuelo, J. (2007). Paisaje y arte, 5-10. Madrid: Abada Editores 


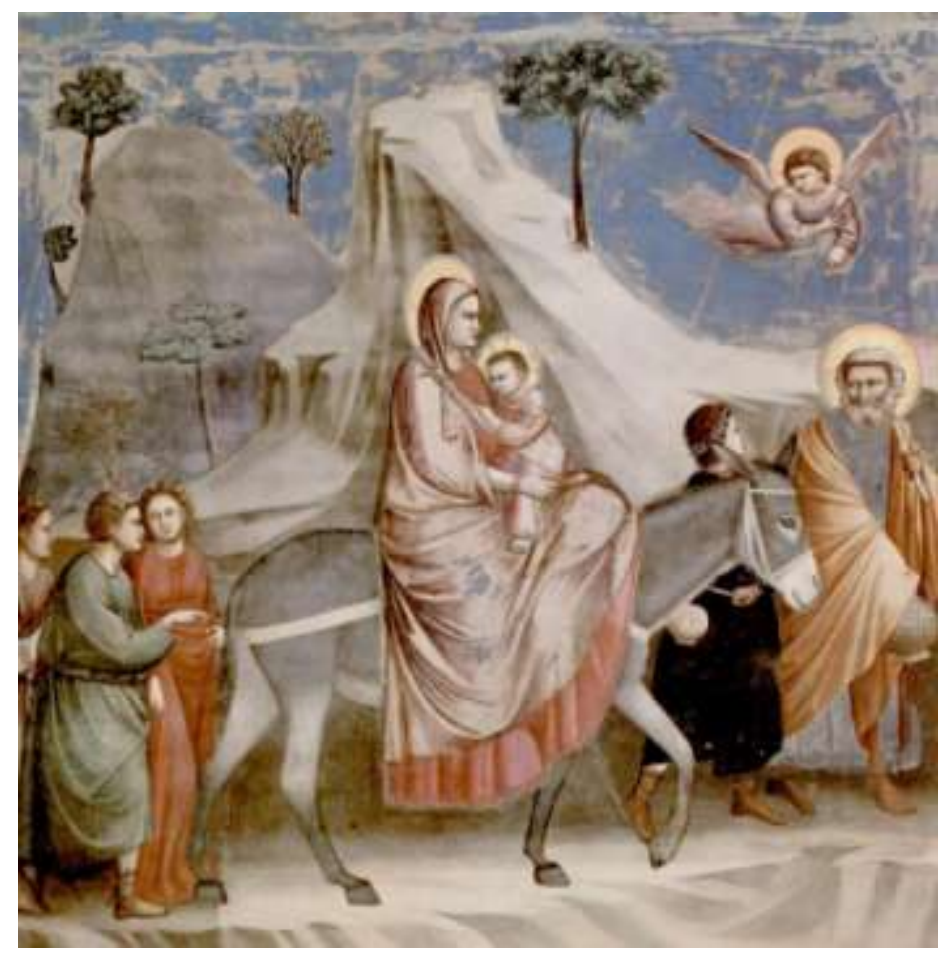

Giotto di Bondone. Huida a Egipto. 1304-1306. Padua

Durante los siglos $\mathrm{XV}$ y $\mathrm{XVI}$, época de los grandes viajes por parte de los Descubridores, se desarrolla espectacularmente la geografía y como consecuencia de ello la cartografía. Se representan los "países", y se toma conciencia de las diferentes territorialidades y entidades nacionales. En este sentido, la demanda de dibujos complementarios a los mapas aumenta enormemente, para poder comprender los territorios sin conocimientos técnicos: cordilleras, ciudades o costas son representadas con el objetivo de poder ser entendidas por un mayor número de personas. Sin embargo, no nos desviaremos por este camino, ya que se tratan de representaciones de "necesidad", y no realizadas en la búsqueda de la contemplación o del placer estético.

En el siglo XVII, según Javier Maderuelo, es cuando se produce el primer paisaje occidental: se trata de la pintura de Hendrik Goltzius "Paisaje de dunas cerca de Haarlem", que data de 1603. Este hecho se explica por ser el primer dibujo de paisaje que no es "fondo" de algo, ni es una herramienta cartográfica o geográfica; sino que es paisaje en sí mismo. Se reafirman aquí, según Maderuelo, los conceptos iniciados en el Renacimiento. 


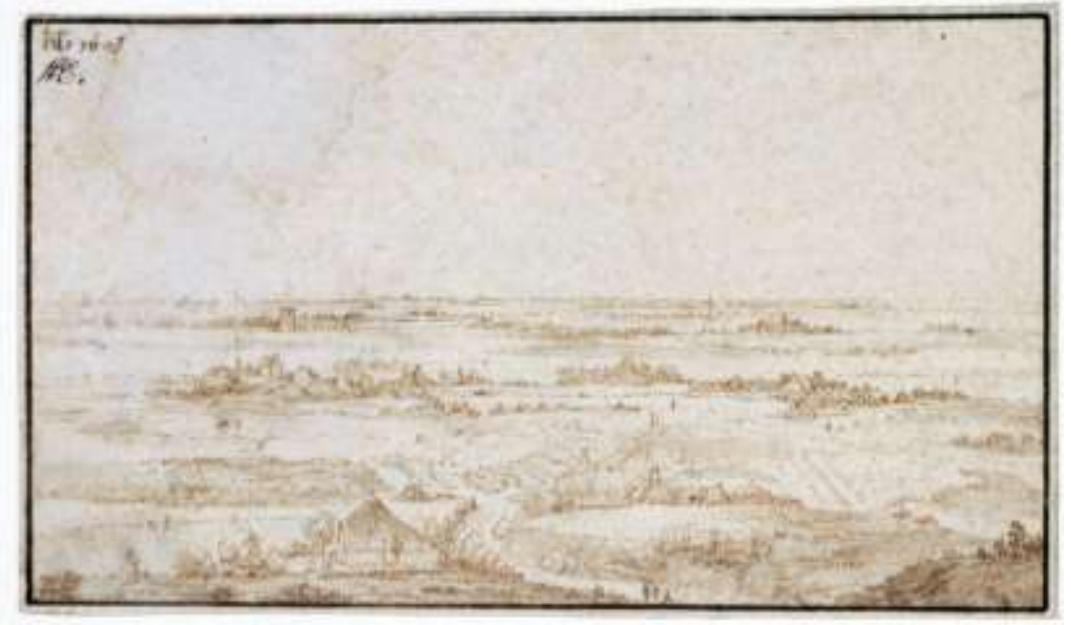

Paisaje dunar cerca de Haarlem. Hendrick Goltzius, 1603

En las últimas décadas del siglo XVIII y principios del siglo XIX encontramos otro hito importante en la construcción del término paisaje. Ello es debido a que el Romanticismo rompe con las concepciones mecanicistas impuestas por la Revolución Industrial, reaccionando ante ello a través de una visión organicista de la naturaleza ${ }^{43}$, e introduciendo la experiencia estética como herramienta para conocer el mundo.

En este sentido juega un papel importante el filósofo Immanuel Kant (1724-1804), conectando la exterioridad, con la intimidad de la persona, apareciendo así un nuevo concepto, la "naturaleza-paisaje", "entendido el paisaje como naturaleza estéticamente presente, que se muestra al ser que la contempla con sentimiento. La mirada, por así decirlo, se carga de teoría y la contemplación teórica se convierte en espectáculo estético."44. Es por tanto el hombre el que convierte un determinado espacio en paisaje.

En esta misma línea, el geógrafo Humboldt afirma que "el mundo exterior físico se refleja como en un espejo sobre el mundo interior moral"

Esa vinculación entre el mundo exterior y el mundo íntimo de la persona, es la que permite la aparición del paisaje; para que una biblioteca exista, dice el geógrafo Georg

\footnotetext{
43 El término organicista es usado en el sentido de entender la naturaleza como un todo vivo y organizado, del que forman parte los seres humanos, y totalmente conectada entre sí.

${ }^{44}$ Cfr. Gómez Mendoza, J. La mirada geográfica del paisaje. Aula Humanismo y Cultura. Córdoba 31 de enero 2012.
} 
Simmel (1858-1918)45, no basta con disponer una serie de libros unos al lado de los otros, sino que tiene que haber conciencia de totalidad:

"Innumerables veces caminamos a través de la naturaleza salvaje y percibimos, con los más diversos grados de la atención árboles y aguas, praderas y campos de trigo, colinas y casas y los miles de cambios de la luz y las nubes; pero por el hecho de que prestemos atención a esto en particular o de que también veamos conjuntamente esto y aquello, aún no somos conscientes de ver un "paisaje". Antes bien, precisamente tal contenido aislado del campo visual ya no puede encadenar nuestro sentido.

Nuestra consciencia debe tener un nuevo todo, unitario, por encima de los elementos, no ligado a su significación aislada y no compuesto mecánicamente a partir de ellos: esto es el paisaje. Si no me equivoco, raramente se ha puesto en claro que el paisaje aún no está dado por el hecho de que toda suerte de cosas estén extendidas unas junto a otras sobre un trozo la corteza terrestre y sean contempladas inmediatamente".

\section{$\underline{\text { Visiones del paisaje moderno }}$}

Centrados en la arquitectura del siglo veinte, tomaremos como punto de partida válido los tres conceptos propuestos por Kenneth Frampton ${ }^{46}$ en la evolución del paisaje moderno. Se trata de tres direcciones diferentes, posicionamientos en relación a la arquitectura y la naturaleza, tomados por maestros indiscutibles de la modernidad.

- El primer concepto es de origen griego, y considera "la estructura del edificio como la de un asiento temenos frente a la inmensidad del espacio y del tiempo". Le Corbusier o Mies van de Rohe son valedores de esta idea.

- El segundo concepto es de inspiración japonesa, y se origina como un jardín íntimo y reflexivo, resguardado del exterior. Wright, Schindler, o Richard Neutra son representantes de este concepto.

- Y el tercero está vinculado al jardín paradisiaco islámico, a la traslación de un trozo del Paraíso en la Tierra. Esta idea aparece también en ciertos trabajos de Wright, Hans Poelzig, y sobre todo en la obra del arquitecto mejicano Luis Barragán.

Una vez enunciados estos conceptos, no se nos oculta que el Movimiento Moderno en sus orígenes, como bien expone Frampton, "no cultivaría tanto la naturaleza como más

${ }^{45}$ Cfr. Simmel, G. (1913). El individuo y la libertad. Ensayos de crítica de la cultura, 175-186. Edición 1986. Barcelona: Península.

${ }^{46}$ Frampton, K. (1990). En busca del paisaje moderno. Arquitectura, 285, 52-73 
bien acomodaría sus construcciones dentro de ésta", un posicionamiento que se mantendrá durante los años veinte.

Sin embargo, a partir de finales de los años veinte y principios de los treinta, se observa un giro de timón en la relación de la arquitectura con el emplazamiento. Un buen ejemplo de ello es el proyecto de la Trades Union School en Bernau de Hannes Meyer (1930). El edificio comienza a ser sensible a un conglomerado de características resumidas en el citado término "emplazamiento", pero que recoge acceso, orientación, terreno, capa freática, viento dominante, imperativos ecológicos; todo ello sin referencias a un pintoresquismo ya superado, en palabras de Frampton, la evolución hacia un "paisaje orgánico".

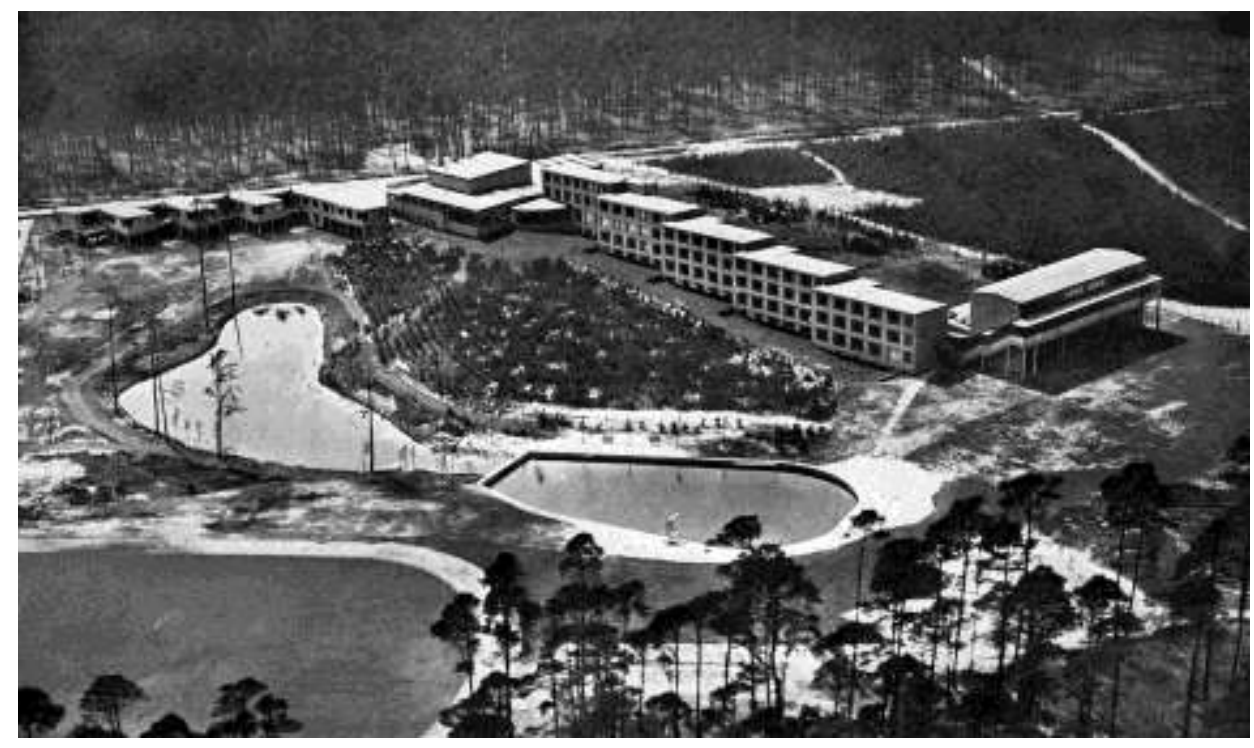

Vista exterior Trades Union School en Bernau. Hannes Meyer. 1930. Imagen de Kieren, M. (1990) Hannes Meyer: Dokumente zur Frühzeit Architektur und Gestaltungsversuche 1919-1927. Heiden: A. Niggli.

Aceptando esto, interesará en la presente investigación poder evolucionar del término emplazamiento al término paisaje mediante la sensibilización de la arquitectura a otros conceptos como son la memoria, el aprendizaje, la reverberación del lugar en la materia de la misma, la permeabilidad en la penetración de la naturaleza, la idiosincrasia o cultura de una determinada sociedad, la tradición arquitectónica popular, etc... que nos acercarán de forma más completa a la manera en que la arquitectura construye, o mejor dicho, activa el lugar, como si creara un polo magnético o un campo de energía que polariza los elementos que la rodean y hace comprender el nuevo todo desde otra óptica, constituyendo una nueva manera de leer el entorno en su totalidad, al que llamaremos paisaje. 
Sin tratar de hacer una revisión -que puede pecar de simplista- de la visión del paisaje que tienen los maestros anteriormente citados, es interesante observar las distintas corrientes citadas por Frampton, para después poder confrontarlas con las ideas vertidas por Fisac.

La relación de Le Corbusier con el paisaje es amplia, compleja, y cambiante a lo largo de su trayectoria -recorriendo ésta varias fases-. Introducirnos de lleno en ella nos alejaría de los objetivos de esta investigación, por lo que destacaremos las características entendidas como más relevantes.

En este sentido destaca en Le Corbusier un posicionamiento, como hemos dicho griego de origen, con un carácter de dominación sobre la naturaleza y que paralelamente absorbe con gran sensibilidad el poder evocativo del paisaje.

Una actitud de dominación que no significa ser impasible ni impide tener afecto al paisaje; de acuerdo con Vicent Scully "el templo griego no es indiferente al paisaje en el que se ubica; el paisaje posee, en cada caso, las cualidades apropiadas al carácter del dios al que se ha de servir; el valle, la llanura, la montaña de perfiles agudos o la suave lomada, todo eso ha de significar que el sitio es propicio o no para rendir culto a Apolo o Zeus"47

Las interpretaciones de Le Corbusier sobre la Acrópolis le llevaron a desarrollar en ciertos proyectos una suerte de polarización magnética del espacio, de modo que la forma de la arquitectura, como la del templo griego, atrae el paisaje hacia su campo de energía.

En la Villa Saboya (1929) es el estrato elevado a modo de palafito primitivo el que propone un nuevo posicionamiento del hombre ante la naturaleza, como recuperación de los "placeres esenciales" 48 , la reinterpretación de la vida en torno al sol, al aire, al campo y al horizonte:

"La casa es una caja en el aire, agujereada a su alrededor, sin interrupción, por una ventana en longitud. (...) La caja está en medio de unos prados, que dominan el vergel." 49

En esta casa, además, se enmarca la naturaleza circundante a través de huecos que la atrapan, desarrollando una serie de secuencias desde lo cercano a lo lejano, que

\footnotetext{
47 Scully, V. (1965). The Earth, the Temple, and the Gods: Greek sacred architecture. Edición 2014. San Antonio: Trinity University Press

${ }^{48}$ Le Corbusier. La casa del hombre, 99. Edición 1999. Barcelona: Apóstrofe

49 Le Corbusier (1929). Conferencia 11 octubre 1929, recogida en: Precisiones. Respecto a un estado actual de la arquitectura y el urbanismo, 158. Edición 1999. Barcelona: Apóstrofe
} 
potencia una buscada profundidad espacial: la naturaleza constituye el fondo del cuadro.

Si fijamos nuestra mirada en la Capilla de Ronchamp (1951-1954), que será estudiado y visitado por Fisac, encontramos en el itinerario de aproximación, en el camino de llegada, un proceso en el que la arquitectura se va desvelando desde la frondosidad de la naturaleza circundante, para finalmente convertirse en elemento que corona el promontorio a modo de atalaya.

Hablando de la experiencia espacial del entorno de esta Capilla, Luis Martínez SantaMaría explica: "Durante la lenta ascensión por la falda de la montaña, debido a que el camino está ligeramente atrincherado, no es posible llegar a ver la figura del templo por entero"50, y continúa posteriormente que las visiones del edificio son "siempre fragmentos o esquirlas de un conjunto cuya unidad queda oculta, ya que la estructura anular del recorrido sólo admite percepciones limitadas en arcos de círculo. la visión de la figura completa se hace imposible, pues conforme se gira, la aparición de un nuevo episodio al frente lleva aparejada la desaparición de alguna otra cosa a la espalda del caminante." 51

Encontramos asimismo otra serie de elementos que colaboran en la construcción y activación del paisaje; algunos exentos -como el estanque, el cuerpo de campanas, o la cruz-, y otros pertenecientes propiamente al edificio -la gárgola, o la propia cubierta-, que junto con ciertos espacios que la circundan, como el espacio exterior para celebrar Misa, o la formalización del propio objeto arquitectónico potencian ese magnetismo del que hablábamos anteriormente.

El concepto del estrato elevado es también una singularidad desarrollada por Mies van der Rohe en su arquitectura. Sin embargo, una de las características más destacables en relación con su posicionamiento ante el paisaje es la apropiación de la naturaleza, su atrapamiento entre dos planos horizontales, uno superior y otro inferior.

Asimismo es destacable la búsqueda de contrastes entre las visiones lejanas de la naturaleza salvaje -enmarcada, hecha propia- con la visión de otra naturaleza creada en sus atrios -artificial-, en los que se suceden elementos arquitectónicos que dialogan con ella, bien sean una serie de reflejos en un muro de ónice, de mármol verde, en un

\footnotetext{
50 Martínez Santa-María, L. (2004). El árbol, el camino, el estanque, ante la casa, 185. Colección Arquithesis, 15. Barcelona: Fundación Caja de Arquitectos.

51 Idem
} 
estanque $^{52}$; o la continuidad espacial propiciada por las transparencias de un paño de vidrio.

Cuando Mies proyecta la casa Farnsworth (1950) en Plano, Illinois, en palabras de Frampton, "enmarca la vegetación en la que está situada; el follaje, bien se refleja oblicuamente en el vidrio o, enmarcado por las ventanas ofrece el aspecto de una especie de papel pintado. La casa viene a ser como un mirador que muestra una intensidad perceptual sobre sus alrededores."53

Mies entendía, actuando así, que la naturaleza era parte de su proyecto: "También la naturaleza debería vivir su propia vida. Deberíamos evitar perturbarla con el colorido de nuestras casas y del mobiliario. De todas maneras, deberíamos esforzarnos por conseguir establecer una mayor armonía entre naturaleza, vivienda y hombre. Cuando se observa la naturaleza a través de los muros de vidrio de la casa Farnsworth, ésta adquiere un significado más profundo del que tiene cuando se está fuera, al aire libre. La naturaleza se realza, ya que pasa a formar parte de un conjunto más amplio."54

Por otra parte, no es menos importante hacer referencia al uso del material y cómo éste participa en la creación del paisaje, en el diálogo de la arquitectura con la naturaleza, siendo esto de especial relevancia en la obra de Mies. Además de la confluencia de reflejos, transparencias o vegetación fosilizada generados por los grandes muros de mármol de Grecia o de Ónice Dorado del Atlas con su exquisita tersura, o los pilares de acero cromado, existen otro tipo de materiales cuya textura dialoga y contrasta con la de los anteriores, como la aspereza de los muros de fábrica de ladrillo, cubiertos a veces de hiedras.

El caso de Frank Lloyd Wright es especialmente singular, y también evolutivo a lo largo de su obra. Varios son los aspectos que convierten la obra de este arquitecto en una arquitectura especialmente ligada con la naturaleza: su infancia transcurrida en conexión íntima con el mundo rural, su fascinación por la cultura japonesa, su encuentro con los paisajes del sur de California, o su descubrimiento del desierto del suroeste americano. Todo ello posibilita, de una forma consustancial, el desarrollo de ciertas arquitecturas que activan el paisaje donde se ubica.

Absolutamente fascinado por la cultura japonesa desde su contacto con la misma a través del Pabellón Ho-o-den en la Exposición Colombina del parque Jackson de

\footnotetext{
${ }^{52}$ En el citado artículo de Kenneth Frampton se refiere a estos elementos como vegetación fosilizada.

53 Frampton, K. (1990). Op cit.

${ }^{54}$ Norberg-Schulz, C. (1958). Una conversación con Mies van der Rohe. Baukunst und Werkform, 11. Reproducido en Neumeyer, F. (1986). Mies van der Rohe, la palabra sin artificio: reflexiones sobre arquitectura, 1922-1968, 516-517. Edición 1995. Madrid: El Croquis Editorial
} 
Chicago en 1893 -que más adelante desarrollaremos con más detalle- y de su viaje a Japón en 1905, que se prolongará por seis meses, sus influencias se materializan no exclusivamente en el realce de la naturaleza, o en el destacado contraste entre una arquitectura ordenada dentro de un entorno salvaje -como podemos ver en la casa de Avery Coonley (1908)-.
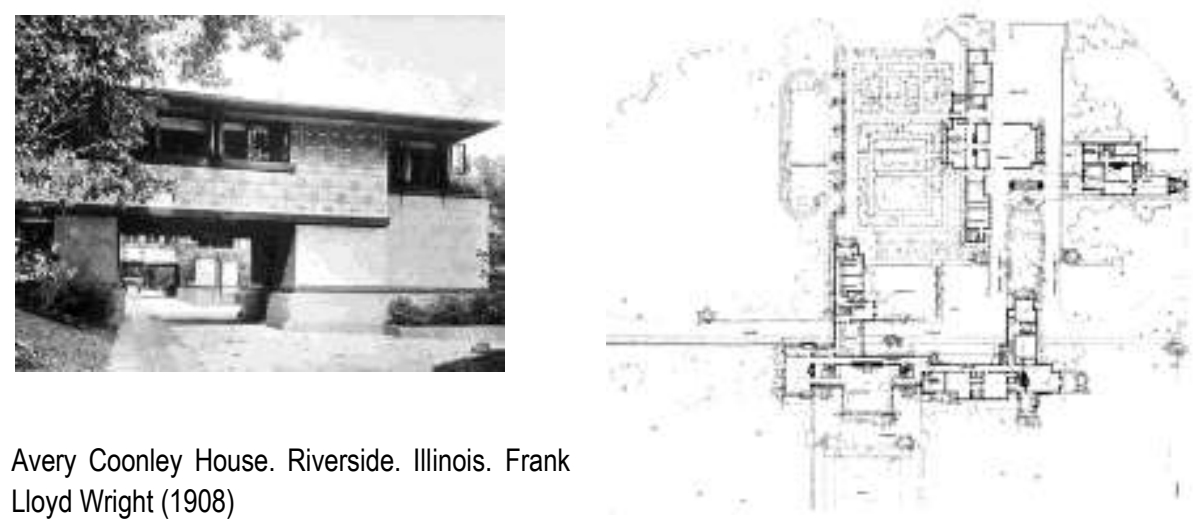

Lloyd Wright (1908)

Más allá de esto, que realmente potencia la espacialidad de la arquitectura, Wright trabaja con herramientas proyectuales que activan el paisaje, como la búsqueda de la continuidad espacial y la disolución de los límites interior-exterior; el subrayado del horizonte y la delimitación de las visiones de la naturaleza, aportando mayor intensidad a la experiencia del paisaje; la utilización de corredores exteriores que recuerdan ciertas construcciones tradicionales japonesas; la utilización expresiva de materiales desnudos; o la búsqueda de una arquitectura orgánica, marcadamente horizontal, que surge con el entorno y responde a su enclave, a lo que ayudan una serie de muros bajos que afianzan la casa en su emplazamiento.

Y no menos importante es el diseño de los elementos de vegetación, que van evolucionando a lo largo de su obra, desde disposiciones formalistas a diseños más libremente organizados, sin los cuales no se podrían entender una parte importante de la arquitectura de Wright.

Su experiencia de encuentro con el desierto marcará un hito fundamental en su actitud ante el territorio, destacando e incluso potenciando las características del contexto.

A ello contribuyeron la esencialización de determinados elementos de sus arquitecturas, el marcado carácter horizontal de la mismas, y su estudiada ubicación en función de la topografía. Asimismo, la inspiración en la vegetación autóctona, fundamentalmente en 
los saguaros de Arizona, la búsqueda de conexiones ancestrales con antiguos asentamientos o la elección del material, también contribuyeron especialmente a ello.

Ocatillo Camp en Chandler, Arizona en 1929; la vivienda de H.D. Price en Phoenix en 1954, o su propia casa, estudio, y escuela de arquitectura de Taliesin West (1937) son tres ejemplos de ello.

"La llamada genius loci tenía una importancia suma para Wright. Por ello, cuando construyó en Taliesin West de Arizona, a principios de los años 30, eligió una prominencia concreta y dispuso en estratos sus masas constructivas dentro del emplazamiento de forma que sugiriera un asentamiento antiguo. Wright acentuó este sentido de la continuidad histórica, casi mística utilizando petroglifos encontrados en el emplazamiento o cerca de éste." 55 .

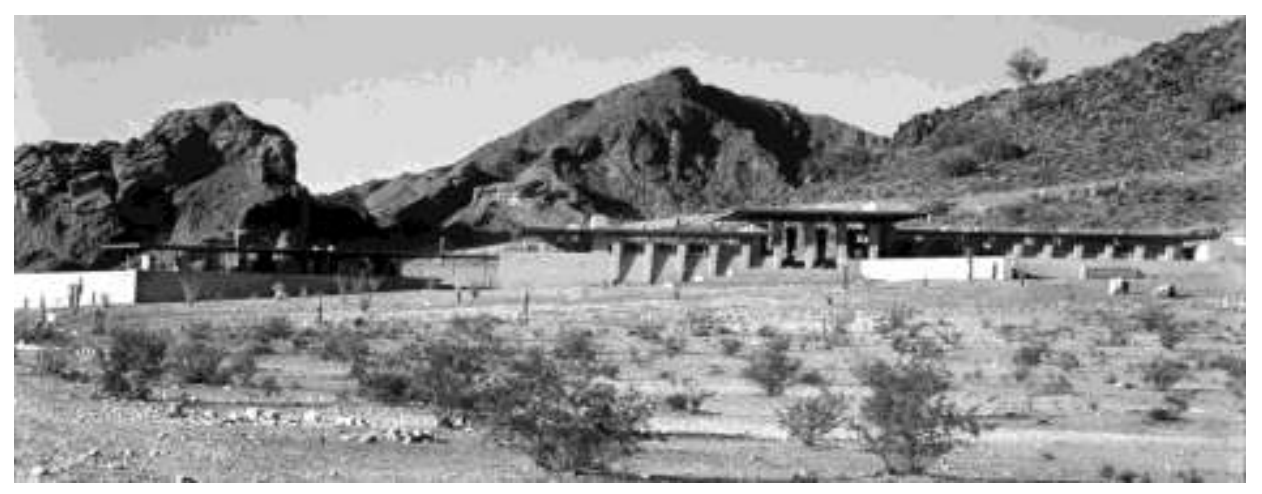

Harold Price, Sr. House. Tatum Paradise Valley. Arizona. Frank Lloyd Wright (1954)

Richard Neutra heredó de Wright la sensibilidad en la conexión de la arquitectura con el entorno, y con ello una serie de herramientas de activación del paisaje.

A lo largo de su carrera, Neutra desarrolló importantes habilidades sobre diseño de jardines y cultivos hortícolas, aprendidas de Gustav Ammann, destacado jardinero suizo, que puso en práctica en ciertas obras de Schindler (como en la casa Howe de Los Ángeles, de 1925), Mendelsohn, y otros.

También en una serie de casas de cuño propio, comenzando por la casa Lovell (1929), y especialmente las realizadas entre 1935 y 1947, la vinculación de la arquitectura con el jardín que las rodea se erige como cuestión fundamental para la comprensión del conjunto, actuando en cierto modo como filtro entre la arquitectura y la naturaleza y facilitando el entendimiento de la continuidad espacial.

${ }^{55}$ Frampton, K. (1990). Op. cit. 
Si bien nos centraremos en otros aspectos de la construcción del paisaje, es importante citar estos orígenes como tierra fértil posteriormente abonada por una serie de conceptos orientales en la relación arquitectura-naturaleza.

En efecto, un viaje a Extremo Oriente a principio de la década de los 30 produce en Neutra un embelesamiento por la arquitectura japonesa, y la asunción de conceptos de la misma en su conexión con la naturaleza, como la delimitación de las visiones exteriores a través de planos horizontales y verticales, la textura del material, o la íntima relación entre espacios interiores y exteriores.

A partir de aquí, se insiste en una especial relación con el horizonte, capturándolo a través de techos planos y voladizos de hormigón. La Naturaleza, -las montañas, el horizonte- pasa a convertirse en límite del espacio interno, extendiéndolo hasta el infinito.

"Ya que el salón está sólo separado de la naturaleza por medio de unas puertas correderas de cristal de gran altura y finos marcos, el espacio habitable avanza y se extiende a lo lejos hasta cerrarse ante la montaña. La montaña es, en realidad, el muro de la parte trasera de este magnífico salón" 56 .

Todo ello reafirma la interpretación que hace Neutra del lugar, y su entendimiento de cómo debe relacionarse el hombre y la Naturaleza; la Arquitectura debe capturar y extraer las más íntimas cualidades del mismo. En la obra de Neutra, la Arquitectura construye el paisaje permitiendo que la totalidad de su espíritu y plenitud penetre en ella para transformarla. Esta idea fue bien sintetizada por Alejandro de la Sota:

"Hablaba hace poco Richard Neutra en Madrid de cómo el paisaje se extiende desde el horizonte hasta nosotros mismos, nos incorpora a él: el paisaje es el aire que respiramos. En las casas de Neutra, el paisaje, siguiendo su camino, penetra en ellas. ¿Cómo podría deternerse? (...): hay que ver el paisaje, es necesario dejarlo penetrar. Amando el paisaje como Neutra lo ama, ¿qué otras casas podría proyectar? Son simple consecuencia de este amor." ${ }^{57}$.

A mediados de los años 50, Neutra visita España, y conoce de primera mano La Alhambra. Tal es el impacto que el conjunto nazarí causó en él, que posteriormente llegaría a firmar que "la verdadera esencia espacial de mi trabajo esta extraída de los patrimonios arquitectónicos de España, especialmente la Alhambra de Granada"58.

\footnotetext{
56 Neutra, R. (1951). Mystery and Realities of the Site, 24. Scarsdale: Morgan \& morgan

57 Sota, A. de la (1954). Algo sobre paisajes y jardines. Publicado en Puente, M. (Ed.) (2012). Alejandro de la Sota: escritos, conversaciones, conferencias. Barcelona: Gustavo Gili

${ }^{58}$ Navarro Segura, M. I. (2001). Desde el origen: La arquitectura de Fernando Higueras. Basa, 24. Las Palmas: Colegio de Arquitectos de Gran Canaria.
} 
Si hay un arquitecto que interpreta en clave moderna las ideas de la arquitectura hispano-árabe, ese es Luis Barragán. Y fue precisamente Neutra uno de sus primeros referentes en relación a la construcción del paisaje, si bien con el tiempo llegó a criticar su posicionamiento demasiado expuesto ante el paisaje ${ }^{59}$.

Sin embargo, Barragán también bebe de las ideas del paisajista francés Ferdinand Bac, de quién descubrirá el interés de la comunión del hombre con la Naturaleza, en este caso a través del estudio de sus jardines.

Esta idea es de tal intensidad en la obra de Barragán que trasciende lo puramente terrenal para encaramarse en el terreno de lo espiritual, como si pareciera que su obra precede a la naturaleza, de manera que fuera ésta la que imita.

El jardín eleva la vida del hombre, puesto que crea un espacio y un tiempo para la contemplación, para el reposo; es la apropiación de un trozo de paisaje que nos invita a sentarnos y utilizarlos como si de una estancia más de la arquitectura se tratara, a ser un lugar de encuentro entre personas, etc.

"Me pregunto a qué hora del día el hombre moderno que vive esta clase de vida puede meditar y permitir a su imaginación el desarrollo de ideas creativas y espirituales; $y$ también me pregunto si esa forma de vida nos permite encontrar la paz y serenidad necesaria que cada hombre debe tener cada día, y especialmente en los tiempos presentes." 60

Barragán entiende los jardines en clave de la materialización de la idea hispanoárabe de un trozo de Paraíso en la Tierra. Es por ello que los jardines de La Alhambra y el Generalife son referencias fundamentales para él; jardines que contienen "lo que debe contener un jardín bien logrado: nada menos que el universo entero."61.

Destaca asimismo Barragán un valioso ingrediente en la concepción de un jardín que pretenda huir de la vulgaridad: el elemento "misterio", proveer al jardín de la invitación a ser recorrido, que el visitante vaya desvelando, a través de recovecos y esquinas, su totalidad. Lo misterioso y lo poético se deberán aunar con la serenidad y la alegría para conseguir un jardín bien logrado.

59 Barragán, amigo de Richard Neutra y a quién consideraba "un arquitecto de primera", afirmaba que la apertura total de sus casas al entorno a través de cerramientos de vidrio, mal entendidas por sus seguidores, habían sido "muy peligrosas en la historia de la arquitectura". Cfr. Entrevista a Luis Barragán por Elena Poniatowska realizada en 1976. En Riggen, A. (2000). Luis Barragán. Escritos y conversaciones, 114-115. El Escorial: El Croquis editorial.

60 Barragán, L. (1951). Gardens for enviorement. Jardines de El Pedregal. Conferencia dictada ante el California Council of Architects y la Sierra Nevada Regional Conference en Coronado, California. En Riggen, A. (2000). Op. Cit., 37.

${ }^{61}$ Barragán, L. (1980). Discurso de aceptación del premio. The Hyatt Foundation. The Pritzker Architecture Prize. En Riggen, A. (2000). Op. Cit, 58 
Es precisamente la búsqueda de aquel elemento "misterio" el que empuja a Barragán a huir de las vistas panorámicas, pues "un paisaje aumenta en belleza cuando se enmarca y delimita propiamente." ${ }^{.2}$.

Más allá de los jardines, las propuestas de Barragán en relación al paisaje se dirigen a que la arquitectura realce el paisaje, de forma que "no debe existir la casa; que la casa sea paisaje, que los paisajes sean casas: no una casa que se traga al paisaje y que sobresale de forma casi insultante."63.

En las propuestas citadas al inicio de este epígrafe, Frampton no contempla un concepto que a nuestro entender es decisivo en la evolución del paisaje moderno: la revitalización y la renovación del paisaje tradicional, a través de la conexión con una suerte de vínculos ancestrales.

Este concepto encuentra sus representantes en la arquitectura nórdica, y aparece en trabajos de Erick Gunnar Asplund, Sigurd Lewerentz, o Alvar Aalto.

En efecto, estos arquitectos, lejos de romper con el pasado, lo releen, insuflándole una nueva energía y dotando a su paisaje de una dimensión espiritual.

Un claro ejemplo del afecto hacia el paisaje de los arquitectos nórdicos lo encontramos en el Cementerio del Bosque de Estocolmo, concurso ganado por Asplund y Lewerentz en 1915, y cuyos valores son clave para entender que Suecia se movía en aquellos momentos por unos derroteros distintos al resto de Europa.

En su propuesta destaca la apropiación del salvaje bosque nórdico existente como materia del proyecto, realizando una delicada operación de senderos mínimos que lo atraviesan libremente y ordenan las tumbas distribuidas de forma informal en su interior; o la decisión de ubicar la capilla en el corazón del mismo, que encuentra en su presencia escondida la conexión con el lugar. Las terrazas y colinas se realizan de tal modo que la nueva topografía conecta con imágenes ancestrales del paisaje.

Toda una suma de sencillas operaciones que sugieren una maravillosa evocación de imágenes primitivas, cuyo resultado es un paisaje eterno y atemporal, fruto de la fusión del paisaje nórdico con el simbolismo arquitectónico.

En este sentido, el intercambio de los motivos tradicionales existentes en los cementerios por la fuerza evocadora de dualidades del lugar, refuerza la idea de dimensión espiritual del paisaje: bosque-claridad, cielo-tierra, muerte-resurrección. El único elemento que encontramos, que surge rotundo al final de la ascensión, y que crea

62Barragán, L. (1951). Op. Cit., 40.

${ }^{63}$ Cfr. Entrevista a Luis Barragán por Elena Poniatowska realizada en 1976. En Riggen, A. (2000). Op. Cit., 115. 
un especial contraste con el horizonte, es la gran cruz de granito. Esta cruz infiere al paisaje un potente carácter simbólico.

El estanque, la pradera, la escalinata de piedra, la topografía, el muro bajo o la vegetación son elementos de una gramática que de forma intensa nos evocan al paisaje nórdico, a la dualidad vida-muerte; y que además se fusionan con elementos mediterráneos, de la Antigüedad clásica, o de arquitectura vernácula, cuyo valor emocional es clave para entender este proyecto y el mensaje de estos arquitectos.

Son varios los referentes de Asplund y Lewerentz ante este proyecto y su visión del paisaje nórdico que les lleva a redefinirlo.

El primero lo encontramos en la tradición romántica y pintoresca del jardín inglés, cuyo germen en Suecia es Frederik Magnus Piper (1746-1824), que realizó los jardines ingleses de Drottningholm. Allí evocó imágenes de notable primitivismo en la conocida como colina monumental, si bien al encontrarse en el corazón de un jardín inglés, resultaba un elemento algo artificial y pintoresco.

El referente más importante la encontramos en el pintor alemán Caspar David Friedrich (1774-1840), que pintó paisajes nórdicos inspirados en poemas del poeta sueco y Nobel de Literatura Verner von Heidenstam (1859-1940), abducido por el contenido emocional del mismo. Su pintura utiliza ciertos arquetipos de la imagen del paisaje nórdico: espesos bosques con tumbas perdidas en sus profundidades, una colina coronada por robles, o una cruz.

Estas imágenes, que tienen una importante carga simbólica y trascendente, son tomadas como referentes en el proyecto del concurso de Asplund y Lewerentz, interpretadas en clave moderna y suavizando el tono romántico de las mismas.

En la Capilla del Bosque (1918-1920), edificio y paisaje son concebidos como un todo. Ubicada en el corazón de una arboleda, la capilla pertenece al paisaje como el paisaje pertenece a la capilla, de forma que no pueden separarse la una del otro.

Los soportes evocan troncos de árboles, y la cubrición, piramidal, las copas de los robles, en un intenso diálogo de la arquitectura con la naturaleza.

Se produce aquí la unión entre lo vernáculo y lo primitivo; entre una construcción rural rodeada de árboles y una pieza de morfología elemental como la pirámide, levantada sobre columnas toscanas, que dota a esta arquitectura de un carácter eterno.

Los elementos que conforman el paisaje de este Cementerio conforman una gramática estructural, son partes de una composición musical cuya sinfonía resonará en la mirada moderna sobre la construcción del paisaje. 
En el dibujo que Asplund realiza en 1932 desde la entrada del cementerio, nuestra mirada se deja llevar por el itinerario que indica el muro que acompaña el camino a la Capilla, junto al cual se extiende un espacio despejado de árboles. Aparece la Colina de la Meditación, coronada con un bosquecillo de abedules, el Crematorio, el Pórtico. El paisaje se convierte así en un espacio que se encuentra polarizado por varias piezas, activándose el diálogo entre todas ellas y estableciendo el entendimiento de la totalidad. El suelo y el cielo se convierten en una suerte de tablero en el que los arquitectos disponen sus piezas. Arquitectura y Naturaleza se fusionan sin dejar de representar la dualidad básica que su oposición simboliza.

El simbolismo es intrínseco a los elementos y al conjunto, como la Colina de la Meditación, revisión del túmulo nórdico, que nos recuerda que en el vientre de la tierra se produce la muerte y la resurrección.

El Cementerio, en fin, es una referencia válida que explica ciertos posicionamientos implícitos en la concepción del paisaje de los maestros nórdicos de la modernidad: combinación certera de memoria, tradición y simbolismo, alejada de romanticismos ya superados.

En la obra de Alvar Aalto encontramos cómo el paisaje puede convertirse en material de proyecto.

No sólo por su lugar de procedencia; sus viajes, los contactos con ciertos maestros que le influyeron notablemente, o el descubrimiento de la cultura oriental fueron decisivos en la configuración de su relación con la Naturaleza.

En una de sus obras más representativas, la Maison Carré encontramos un buen ejemplo de ello; la casa tiene voluntad de formar parte del paisaje, de construirlo. El cuidadoso estudio de implantación de la casa en un entorno rural muy tradicional y abierto64, llevó a Aalto a implantar de forma expresiva las curvas de nivel como referentes de la articulación de la casa en su búsqueda por integrar la arquitectura en el terreno.

Tradición, historia, contexto y paisaje son categorías definitorias de la esencia de la arquitectura nórdica, y específicamente la aaltiana. La proximidad a la Naturaleza de esta arquitectura emana en gran medida de la utilización de materiales autóctonos, que,

${ }^{64}$ Laaksonen, E. y Ólafddóttir, A. (2008). The house as part of the landscape; Man's mark on the landscape. En Alvar Aalto architect: Maison Louis Carré, 1956-63, 16. Helsinki: Alvar Aalto Akatemia. 
de acuerdo con Norberg-Schulz permite "una estrecha relación con la Naturaleza de alrededor, de la cual tienden a visualizar el genius loci”65.

En el caso de Aalto además, la forma en la que se utiliza el material produce en su arquitectura una especial intensidad poética. Esta intensidad emana del entendimiento del material natural autóctono como trasposición de la materia Naturaleza a la arquitectura, filtrada a través de una abstracción formal y conceptual. De esta forma, Alvar Aalto dirige a la abstracción moderna a dialogar con el paisaje; y consigue así un profundo sentido de pertenencia a él.

Una exquisita materialización de lo anteriormente expuesto, el encuentro entre naturaleza y artificio, la comunión entre el edificio y el lugar que ocupa, la encontramos en la Villa Mairea (1938-1939). Pero es sobre todo en la casa experimental de Muuratsalo (1953), que se abre para recoger una visión del lago junto al que se erige, donde hace Aalto una declaración de intenciones, en la que destaca la especial intención de trabajar con la dimensión humana del espacio como aspecto fundamental en el entendimiento de su propuesta de construcción del paisaje.

Si recorremos por etapas -en mayor medida aceptadas por la crítica más autorizada- la obra de Aalto, no existe período en el que no encontremos con una decisiva intención de integrar la arquitectura en el paisaje66.

En el Sanatorio de Paimio (1929-1933), que será duramente criticado con posterioridad por Fisac, es precisamente la visión curativa del paisaje para los pacientes -que se encuentran en posición horizontal o postrada- la esencia del proyecto, y todos sus elementos se configuran en torno a esta idea: la dimensión humana, la orientación, la luz, la captura del horizonte, etc.

El Ayuntamiento de Säynätsalo (1948-1952), es una de las obras en la que Aalto culmina su diálogo con la Naturaleza, y para Fisac supone "una intención decidida hacia la humanización y la arquitectura en el paisaje con evidente sabor popular" . Sobre una plataforma generada sobre la cota existente, dispone los diferentes pabellones administrativos, suscitando una interesante articulación del conjunto con la topografía. Asimismo, la contundencia de los volúmenes, la elección del ladrillo como material -que contrasta con la vegetación circundante creando un hermoso diálogo-, y la ausencia de huecos, confiere a la arquitectura un cierto grado de abstracción. Es una arquitectura que nace del suelo y al mismo tiempo construye nuevas jerarquías: desde el patio el

\footnotetext{
${ }^{65}$ Norberg-Schulz, C. (1985). Passato, presente e futuro: un analisi dell'architettura norvegese. Domus, 658. Milán

66 Alvar Aalto utilizaba la palabra paisaje para referirse a la "Naturaleza ofrecida a nuestra vista", subrayando también el factor humano del concepto. Cfr. La arquitectura en el paisaje de Finlandia Central. 1925. En Schildt, G. (2009). Alvar Aalto. De palabra y por escrito. El Escorial: El Croquis editorial.
} 
hombre se siente en un lugar recogido de carácter urbano pero al mismo tiempo inmerso en la naturaleza, de la que siente su presencia a través de la arquitectura.

Estas visiones del paisaje a través de la historia y de una serie de maestros de la modernidad, nos han ayudado a aproximarnos y a delimitar la noción de paisaje sobre la que deseamos reposar esta singular mirada sobre la arquitectura de Miguel Fisac.

Para finalizar estas precisiones, conviene decir que no sólo hablaremos de objetos construidos. De acuerdo con Heidegger ${ }^{67}$, construir un objeto arquitectónico no es una condición esencial para la construcción del paisaje. Construir significa originariamente habitar, abrigar, cuidar -cultivar una viña, por ejemplo-, por lo que construir el paisaje sólo requiere una referencia humana que suponga una visión del mundo.

Una línea de pensamiento bien cercana a Fisac, para quien el paisaje forma parte esencial de su definición de arquitectura, como vemos aquí y como iremos desarrollando a lo largo de esta investigación. En dicha definición el arquitecto integra dos aproximaciones al término: el paisaje físico y el paisaje psicológico, que en esencia nos refieren a la conexión profunda del lugar en el que se erige la arquitectura con el hombre.

"Defino la arquitectura como "un trozo de aire humanizado". Para mí, la técnica estructural y hasta estética no son más que medios para conseguir esa humanización del espacio y que responde a la concepción que hace muchos siglos nos dió Lao-Tsé de la arquitectura.

Esta esencial humanización del espacio arquitectónico lleva incluidas la adecuación de la arquitectura al paisaje. Al paisaje físico en el que está ubicada; con su clima, su aspecto y sus demás circunstancias ambientales y también al paisaje psicológico de las gentes que lo han de usar; con su peculiar idiosincrasia, costumbres, etc.

En el mundo actual, con tan potentes medios de comunicación, con tan rápidos transportes, con una movilidad tan grande de las gentes; gracias a estos medios, se suele caer en la equivocación de suponer que a la arquitectura le afecta esta movilidad y que tiene o debe tener el desarraigo del automóvil o del avión; que van de un lugar a otro cambiando continuamente de paisaje.

Y esa radical equivocación hace a las arquitecturas iguales, e igualmente deshumanizadas, en muchas latitudes del mundo y para muchas gentes; y que vienen a ser residuos de los secos criterios racionalistas de la próxima pasada arquitectura.

${ }^{67}$ Heidegger, M. (1951). Construir, habitar, pensar. En Conferencias y artículos. Martin Heidegger, 127-142. Edición 2014. Barcelona: El Serbal 
Creo que para conseguir esa esencial humanización del espacio a más de esa adecuación al entorno y a las gentes que la han de usar, es preciso que el proceso de creación del diseño siga un cierto rigor jerárquico. Que sea el programa humano propuesto, el que configure las primeras ideas espaciales y volumétricas de la futura arquitectura, y sus medidas estén engendradas por el volumen que la persona y $\underline{s u}$ propia territorialidad psicológica definen, que a continuación, sea la técnica la que acuda en auxilio de esa creación espacial, para hacerla posible y que, por último, la sensibilidad de artista del arquitecto realice los pequeños ajustes finales para que aquello que cumple las necesidades materiales que se le han impuesto por el programa y son realizables de la forma más económica y conveniente por la técnica, llegue también a contener una trascendencia estética que proporcione al hombre esa dimensión bella que su espíritu necesita. (...)"68

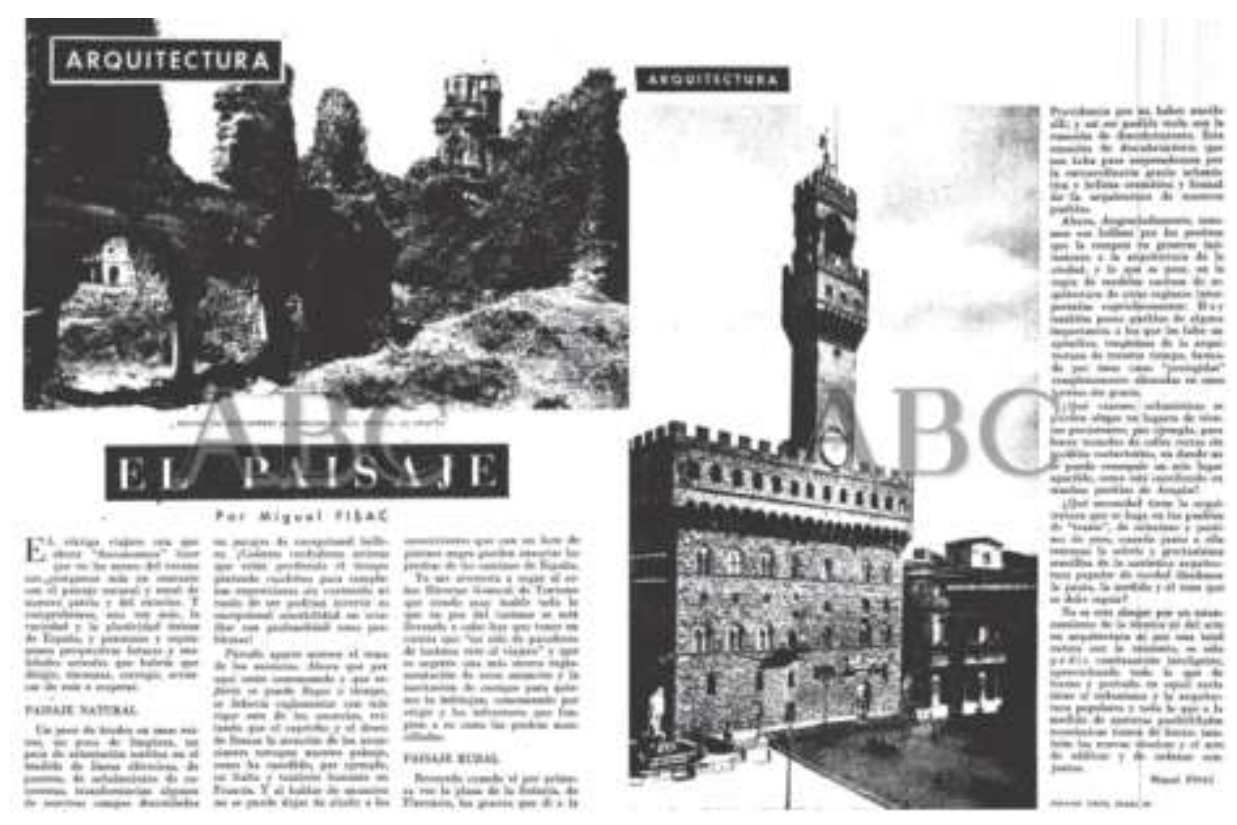

Artículo El paisaje. Publicado por Miguel Fisac en el dominical Blanco y Negro del diario ABC. 26 de octubre de 1957. Fuente: Hemeroteca ABC

Ese habitar el paisaje al que nos referíamos anteriormente, supone un posicionamiento previo ante el mismo; una actitud desde la cual se pueda alcanzar posteriormente una condición que permita ser propositivo, o dicho de otra forma, poder tomar el paisaje como herramienta de proyecto.

${ }^{68}$ Fisac, M. (1972). Un texto de Miguel Fisac sobre arquitectura. En Fullaondo, J.D.(1972). Miguel Fisac, 5153. Madrid: Ministerio de Educación y Ciencia. Subdirección General de Información y Publicaciones. El texto en negrita es de Fisac, el subrayado es del autor de la Tesis. 
De acuerdo con el catedrático de la Universidad de Sevilla Florencio Zoido69, estas actitudes previas ante el paisaje, en general, son las siguientes:

- Conciencia de la dimensión espacial, ser y estar en el mundo;

- Asombro ante él;

- Contemplación y sublimación de la naturaleza;

- Voluntad de describir, representar, comprender y explicar el mundo exterior;

- Propósito de darle forma conveniente u ordenarlo;

- Búsqueda de un paradigma de respeto e integración.

Y si bien a partir de las mismas se podría establecer un amplio debate sobre las que faltan o sobran, éstas recogen ampliamente la esencia de la idea que queremos transmitir en esta investigación. A continuación iremos desgranando cómo la actitud de Fisac ante el paisaje, que contiene todas las premisas anteriores, es dinámica, y oscila entre el Aprendizaje y el Experimento, jugando la Memoria un importante papel de tamiz de esos conceptos. Este posicionamiento deviene necesariamente en una reelaboración del mismo, una invención, de forma que el nuevo paisaje brilla con mayor luz.

69 Zoido, F. (2012). El paisaje un concepto útil para relacionar estética, ética y política. Scripta Nova. Revista Electrónica de Geografía y Ciencias Sociales. [En línea]. Barcelona: Universidad de Barcelona, 10 de julio de 2012, vol. XVI, nº 407. <http://www.ub.es/geocrit/sn/sn-407.htm 
Memoria, Aprendizaje y Experimento. La invención del paisaje en Miguel Fisac Introducción. Precisiones sobre el concepto paisaje 
Memoria, Aprendizaje y Experimento. La invención del paisaje en Miguel Fisac Memoria

\section{2_MEMORIA}

2.1_ Geografías de la Memoria. El niño y el hombre

2.2_ La arquitectura popular. Reflexión y metáfora del paisaje 


\title{
2.1_Geografías de la Memoria. El niño y el hombre
}

\author{
La imaginación está hecha de convenciones de la memoria. Si yo no \\ tuviera memoria no podría imaginar. Borges \\ La originalidad consiste en volver al origen; así pues, original es \\ aquello que vuelve a la simplicidad de las primeras soluciones. Gaudí
}

No se nos oculta la dificultad que conlleva tratar de realizar una aproximación a un término tan complejo como la memoria, para explicar en qué medida está presente ésta en la obra de Miguel Fisac y en concreto en esta investigación. Un concepto aquí aplicado para el que no encontramos suficientemente cercanas ninguna de las acepciones prescritas en el Diccionario de la Real Academia Española ${ }^{70}$, ya que trascienden a las mismas. Un término profundamente desarrollado por intelectuales tan estudiados por Fisac como San Agustín, San Juan de la Cruz, o Miguel de Unamuno.

En esta Tesis, sirva como delimitación a la definición de la misma la hipótesis que pretendemos demostrar con la invocación a este término: para Miguel Fisac, la Memoria es un instrumento de trabajo; una herramienta proyectual, que en principio pudiera parecer que choca frontalmente con el inicio del itinerario mental que propone el propio Fisac de intentar "dejar la mente en blanco" en cada proyecto.

Un elemento más, si bien decisivo, que completa el conocido itinerario mental por él planteado: para qué, dónde, cómo, no sé qué. ${ }^{71}$

Este quinto elemento no trata exclusivamente del recuerdo del pasado. Más bien, es el tamiz por el que se filtran sus intereses y aprendizajes. Una suerte de cordón umbilical

\footnotetext{
70 Únicamente podría considerarse como aproximación la segunda acepción: "En la filosofía escolástica, una de las potencias del alma". Sin embargo, esto nos llevaría a una discusión filosófica que se escapa absolutamente de lo buscado en esta Tesis.

${ }^{71}$ El itinerario mental no es absolutamente fijo a lo largo de toda su vida. En los primeros planteamientos realizados por Fisac aparecen cuatro variables: programa, técnica, estética y paisaje; que posteriormente se convertirán en res: para qué, cómo, no sé qué; para, por último, añadir el dónde.
} 
que lo une a la tierra, a su tierra; una forma de tener siempre presente el carácter humanizado de su arquitectura, que con tanto ahínco defendió.

Un concepto únicamente penetrable desde la perspectiva del estudio global de su obra. Un elemento que, lógicamente Fisac no podía expresar con palabras, siendo obligación del estudio posterior el abordaje de este cometido, pues genera altas expectativas, según queda patente en sus escritos, producción arquitectónica, o en su propia vida.

Una de las características principales de ello es que no es un concepto aplicable de forma lineal, como si fuera una etapa que se supera por otra. Se trata de un elemento que nos conducirá necesariamente a visualizar la obra de Fisac de forma transversal, encontrando referencias a la misma en obras tempranas como el Instituto Laboral de Daimiel (1951-1953), o en otras más tardías como su casa familiar en Almagro (1978).

II

Soy de mi infancia como de un país. (Saint-Exùpery).

Si anteriormente tratábamos de dibujar su perfil biográfico, en el que destaca la pasión por la naturaleza, el campo o la pesca -trasladada principalmente por su tío como distracción, vía de escape y celebración de la vida ante la muerte de una de sus hermanas-, no podemos dejar pasar que todo ello fue forjando un espíritu curioso e inquieto, que le hacia preguntarse la razón última de casi todo, lo que pasaba ante sus ojos....y lo que no ${ }^{72}$.

Criado en una llanura infinita, desnuda, en la que sólo existe el horizonte, la luz, la tierra, el cielo y el aire; donde los pueblos no sólo se confunden con la tierra, sino que son la tierra misma, el paisaje manchego fue uno de los grandes maestros de Miguel Fisac durante su infancia: algo más que un elemento físico.

En ese paraje ascético de principios de siglo, y con esas premisas, seguramente aprendería Fisac a contemplar, tanto lo material como lo espiritual.

Pero Daimiel posee una singularidad. Y es que el humedal de las Tablas de Daimiel frecuentado por Fisac, (a escasos 10 kilómetros de su núcleo) es un oasis dentro de La Mancha, un elemento tan diferente que es lo contrario al resto del paisaje que lo circunda.

\footnotetext{
72 Un relato detallado de la intensidad de su contacto infantil con la naturaleza descrito en primera persona se puede encontrar en Lamfus, P. (2007). Op. cit.
} 

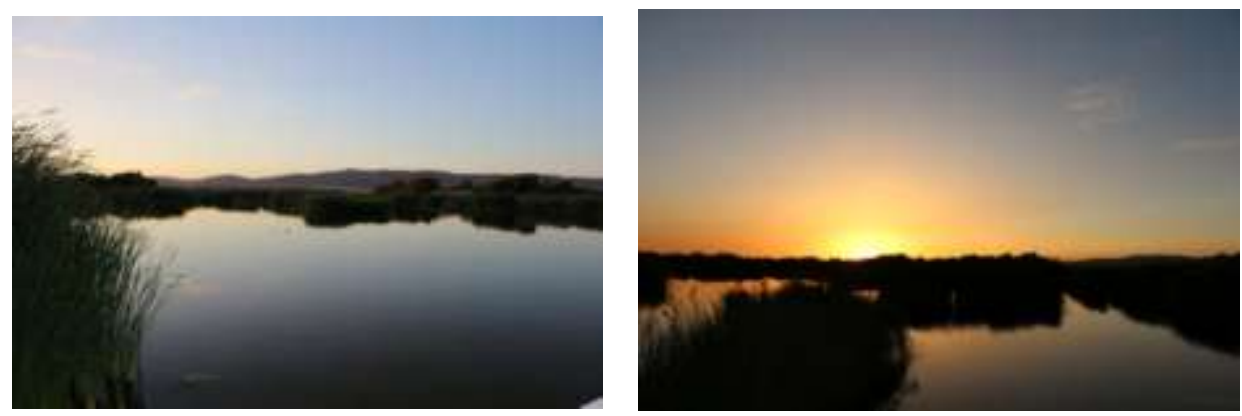

Tablas de Daimiel. Fotografías del autor de la Tesis.

Paisaje evocador de otros paisajes, la tabla fluvial genera un espacio equívoco y ambiguo -pues no se puede pisar esa gran extensión de terreno-.

Este espacio, vergel húmedo en el que recala el Guadiana, espejo de cielo y verdor, en el que los reflejos y el agua son protagonistas, dejará una huella imborrable en Fisac que le acompañaría toda su vida e influirá definitivamente en su imaginario.

Sus excursiones por estos humedales y por "la Arboleda" le enseñaron que La Mancha es árida sólo para el que no la conoce; que es caldo de cultivo para soñar, para dejarse fascinar por la horizontalidad, por la tierra, por la potente luminosidad de mediodía, o por la sabiduría ancestral. Que La Mancha en sí misma le confiere un determinado posicionamiento ante la vida y el paisaje, una manera concreta de ver las cosas.

Miguel Fisac vivió una infancia llena de reflejos, de caminos de tierra flanqueados por grandes plátanos que dejan filtrar la luz en cada recodo, de contacto directo con la naturaleza y con los animales. $Y$ forjó en estos momentos un espíritu crítico. $Y$ es esto lo que mantiene vivo hasta el fin de sus días: las experiencias sobrias, ancestrales, son las que nunca dejará de mencionar: son el fundamento de su Memoria.

Al pensar en la infancia de Fisac, no podemos evitar pensar en Daniel, el Mochuelo, personaje de Miguel Delibes en El Camino, y en su comunión con el paisaje que le rodeaba:

"El valle... Aquel valle significaba mucho para Daniel, el Mochuelo. Bien mirado, significaba todo para él. En el valle había nacido y, en once años, jamás franqueó la cadena de altas montañas que lo circuían. Ni experimentó la necesidad de hacerlo siquiera. 
A veces, Daniel, el Mochuelo, pensaba que su padre, y el cura, y el maestro, tenían razón, que su valle era como una gran olla independiente, absolutamente aislada del exterior. Y, sin embargo, no era así; el valle tenía su cordón umbilical, un doble cordón umbilical, mejor dicho, que lo vitalizaba al mismo tiempo que lo maleaba: la vía férrea y la carretera. Ambas vía atravesaban el valle de sur a norte, provenían de la parda y reseca llanura de Castilla y buscaban la llanura azul del mar. Constituian, pues, el enlace de dos inmensos mundos contrapuestos. (...)

Le gustaba al mochuelo sentir sobre si la quietud serena y reposada del valle, contemplar el conglomerado de los prados, divididos en parcelas y salpicados de caseríos dispersos. $Y$, de vez en cuando, las manchas oscuras y espesas de los bosques de castaños o la tonalidad clara y mate de las aglomeraciones de eucaliptos. $A$ lo lejos, por todas partes, las montañas, que, según la estación y el clima, alteraban su contextura, pasando de una extraña ingravidez vegetal a una solidez densa, mineral y plomiza en los días oscuros"73

$Y$ es que nada más pertinente que este fragmento del ilustre académico de la Lengua para meternos de lleno en esa inocencia infantil sobre la que sedimentarán la tradición, las raíces, y la sabiduría natural -de las que la Memoria es depositaria-, y que se contraponen al posterior saber aprendido.

Todo ello ejerce una influencia que se siente en dibujos o arquitecturas. La naturaleza, para Fisac, también es fuente de inspiración y maestra, ya sea en formas, materiales 0 maneras de trabajarlos. Fisac se asoció a la naturaleza porque era el único elemento que le podía ofrecer libertad total a un carácter como el suyo.

En concreto, es muy llamativa la constante presencia del agua en su vida. No sólo en sus dibujos sobre arquitectura tradicional manchega, en los que son frecuentes juncos, reflejos o láminas de agua. También en su intervención en el Manifiesto de La Alhambra se encargará del tema del agua, y quedará prendado de la vida fluvial de Bangkok, y diseñará fuentes y surtidores, etc...

${ }^{73}$ Delibes, M. (1950). El camino. pg. 20-21. $1^{\text {a }}$ Edición de la colección Austral, 2010. Barcelona: Ediciones Destino, S.L. 


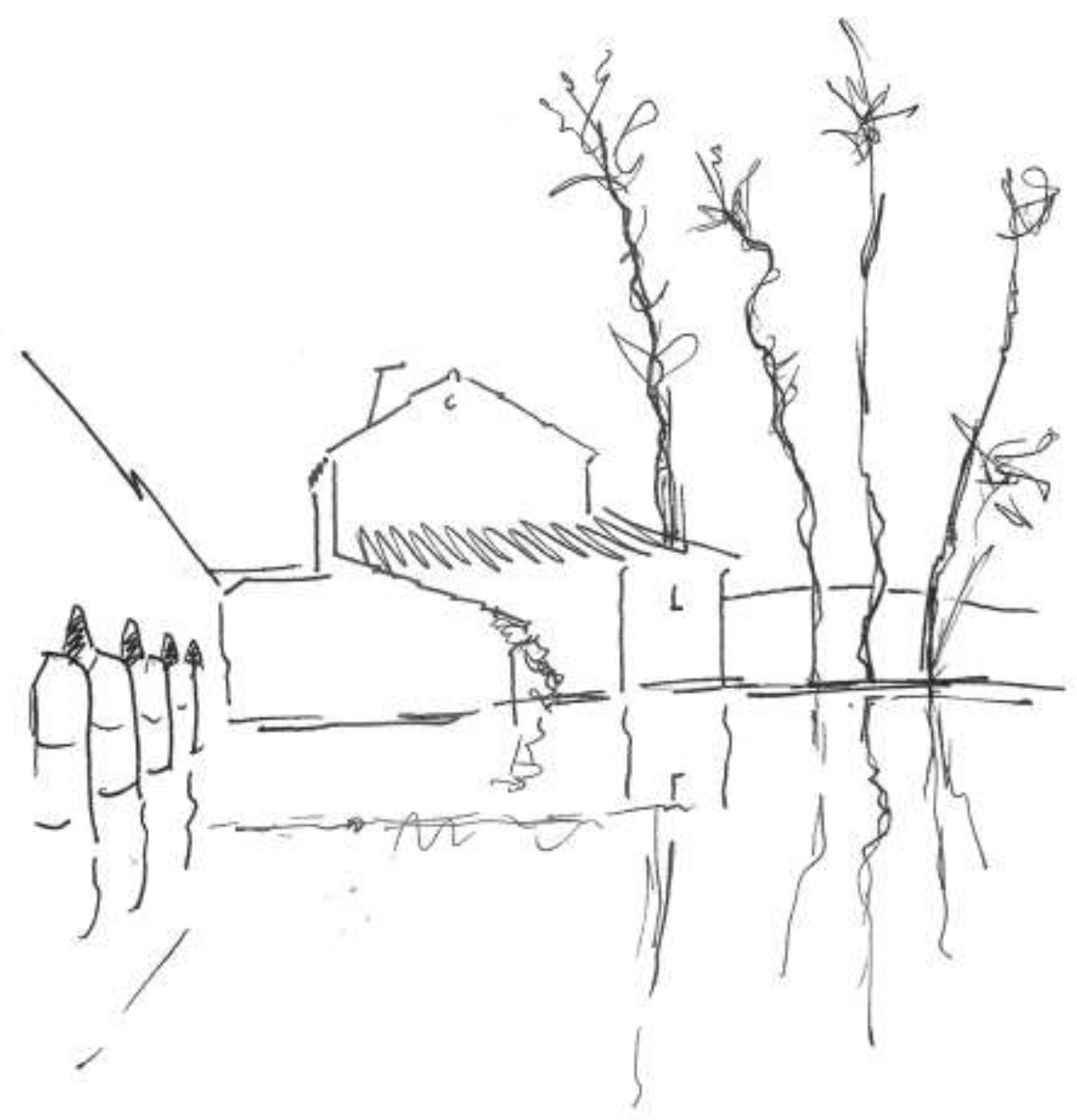

Arquitectura popular manchega. Dibujo de Miguel Fisac ${ }^{74}$

Evidentemente el sentimiento estético de la naturaleza no sólo se le despierta ante la contemplación del paisaje agrario o una casilla manchega, también ante una ruina, una ciudad, o ante ciertas arquitecturas -como La Alhambra-, de las que hablaremos posteriormente.

Sus experiencias de sabiduría manchega necesitarán ser ratificadas en su vida de juventud. El resto de su vida, desde que se traslada a Madrid, será una continua búsqueda de esta reafirmación, y su obra es el vivo reflejo de ello.

Y el hombre. Protagonista de ese paisaje y protagonista de la arquitectura de Fisac cribada a través de la Memoria.

74 Tinta china sobre papel, numerado. Dibujo de 1984. En Fisac, M. (2005). Op. cit. 
Memoria, Aprendizaje y Experimento. La invención del paisaje en Miguel Fisac

Geografías de la Memoria. El niño y el hombre

Si algo le interesó a Fisac siempre fueron las personas que iban a habitar su arquitectura. También la crítica que realiza -veremos posteriormente- a las arquitecturas que estudiaba y visitaba, en sus escritos, conferencias o anotaciones de viaje tuvieron como centro al hombre. De su definición más conocida de arquitectura la palabra más importante es "humanizada".

El hombre que forma parte de un paisaje, de un emplazamiento físico y social por el que ciertas arquitecturas, en sus propias palabras tienen un "olímpico desprecio"75.
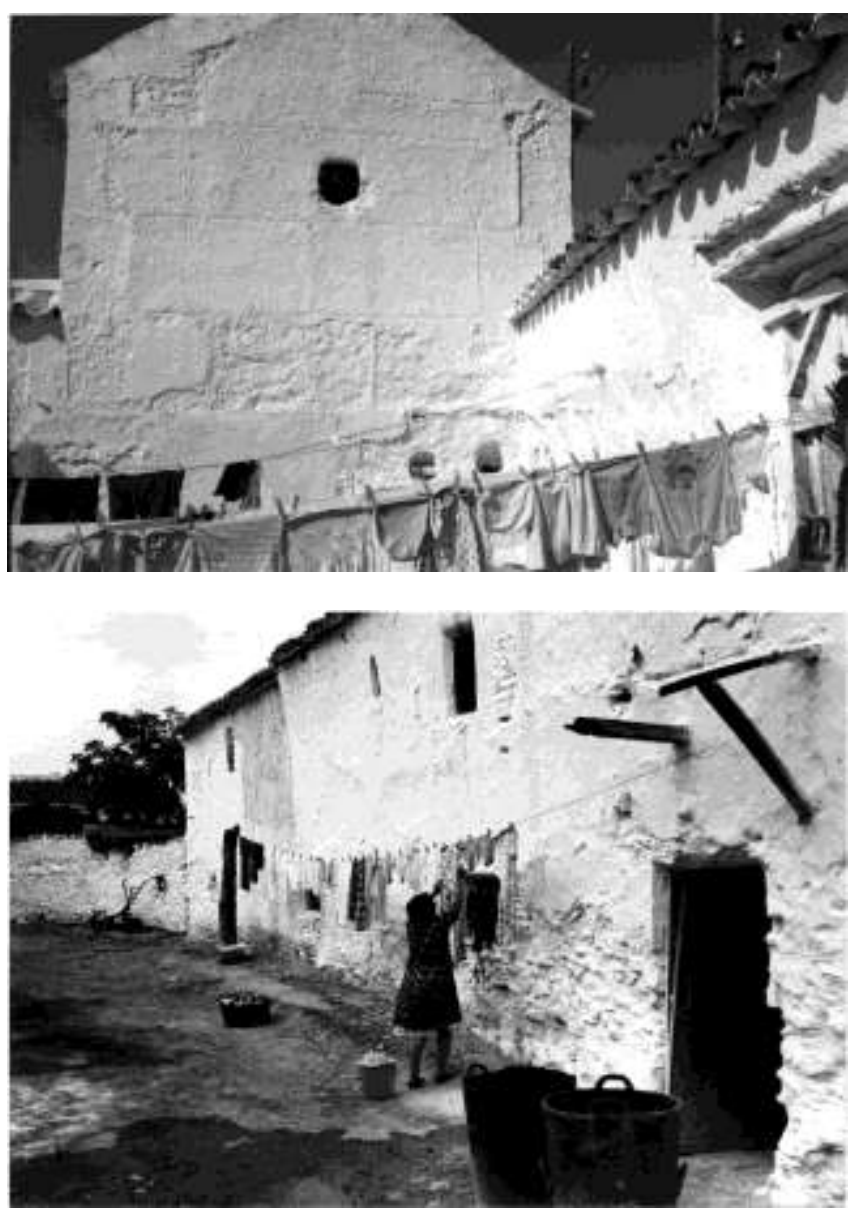

Fotografías tomadas por Miguel Fisac. Fundación Miguel Fisac

75 Fisac, M. (1994). Lo que he aprendido en La Alhambra. Miguel Fisac. Medalla de Oro de la Arquitectura, 10-11. Arquitectos, 135. Madrid: Consejo Superior de los Colegios de Arquitectos de España. 
Como si de un viaje de ida y vuelta se tratara, realizado una y mil veces, será materia utilizada por Fisac para construir su propia identidad y reelaborar el mundo que le rodea a través de su arquitectura. Materia que busca y se alimenta de la esencia de esa Memoria, dejando a un lado lo accesorio, lo circunstancial.

No es la Memoria un lastre, un saco de piedras del pasado. La Memoria utilizada por Fisac -al igual que en San Agustín- es futuro, es esperanza.

No en vano, resulta especialmente interesante, por los paralelismos que podemos encontrar en la arquitectura de Fisac, aproximarnos a ella a través de las palabras del Santo de Hipona, cuyo libro Décimo de sus Confesiones se ocupa de profundizar precisamente en ella -la Memoria-, entendiéndola como trampolín para el futuro, no como regreso a un aparente tiempo muerto.

"Alli -en la memoria- se me ofrecen al punto el cielo y la tierra y el mar con todas las cosas que he percibido sensiblemente en ellos, a excepción de las que tengo ya olvidadas. Alli me encuentro con mí mismo y me acuerdo de mí y de lo que hice, y en qué tiempo y en qué lugar, y de qué modo y cómo estaba afectado cuando lo hacía. Allí están todas las cosas que yo recuerdo haber experimentado o creído. De este mismo tesoro salen las semejanzas tan diversas unas de otras, bien experimentadas, bien creídas en virtud de las experimentadas, las cuales, cotejándolas con las pasadas, infiero de ellas acciones futuras, acontecimientos y esperanzas, todo lo cual lo pienso como presente."76

Se trata por tanto, de traer al presente y proyectar al futuro la esencia de lo vivido en aplicación a su arquitectura.

De esta forma, podemos acordar que Fisac nos entrega un mapa, en el que la Memoria es uno de los puntos de referencia que debemos buscar si pretendemos profundizar en su itinerario mental, y además brújula de lo que debería ser la arquitectura del futuro, esa a la que ya hemos llegado sin demasiado éxito.

Es el cimiento de ese ansiado cambio de rumbo buscado, que posteriormente se materializará en el encuentro con Asplund, y que paradójicamente se trata de descubrir aquello que no cambia, aquello que permanece y tiene cualidades de esencia. Un manifiesto a una arquitectura "eterna" -si se permite la expresión-, desligada de modas o de los ídolos del momento.

${ }^{76}$ San Agustín. Confesiones. Libro X. Capítulo 8, 14 


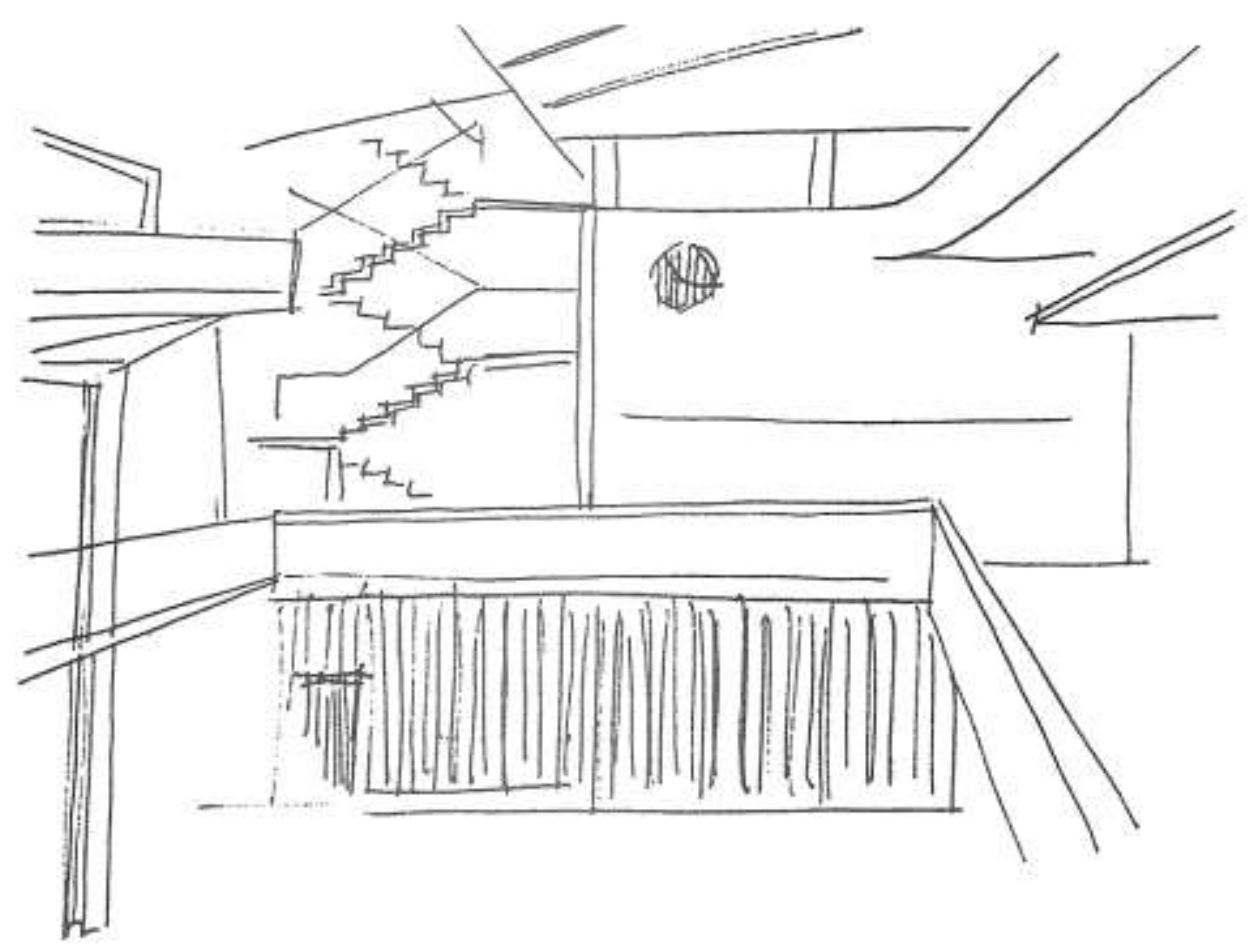

Asplund. Ampliación del Ayuntamiento de Gotemburgo. Dibujo de Miguel Fisac ${ }^{77}$

En estos "anchurosos palacios de la memoria" definidos por San Agustín, encontramos una cercanía a aquello que intuimos que seduce a Fisac.

"Mucha admiración me causa esto y me llena de estupor. Viajan los hombres por admirar las alturas de los montes, y las ingentes olas del mar, y las anchurosas corrientes de los ríos, y la inmensidad del océano, y el giro de los astros, y se olvidan de sí mismos, ni se admiran de que todas estas cosas, que al nombrarlas no las veo con los ojos, no podría nombrarlas si interiormente no viese en mi memoria los montes, y las olas, y los ríos, y los astros, percibidos ocularmente, y el océano, sólo creído; con dimensiones tan grandes como si las viese fuera. $Y$, sin embargo, no es que haya absorbido tales cosas al verlas con los ojos del cuerpo, ni que ellas se hallen dentro de mí, sino sus imágenes. Lo único que sé es por qué sentido del cuerpo he recibido la impresión de cada una de ellas. ${ }^{178}$

77 Dibujo de 1982 publicado en el libro Carta a mis sobrinos (estudiantes de arquitectura)

${ }^{78}$ San Agustín. Op. cit. Capítulo 8, 15 
Porque, como veremos más adelante, si los viajes de Fisac son una fuente de Aprendizaje, la Memoria es aquella energía gracias a la cual puede tener una mirada crítica sobre las ciudades que conoce, o las arquitecturas que visita y estudia.

Esta idea guarda de alguna manera relación con las obsesiones personales. A Pikionis, -responsable de la ordenación de las colinas de la Acrópolis-, en íntima unión a lo largo de toda su trayectoria con Atenas y su paisaje mítico, una sola piedra le evocaba intensas conexiones cosmológicas con la Acrópolis. De igual forma la obra de Fisac siempre se encuentra en conexión con La Mancha.

Quién diera varias veces la vuelta al mundo -algo poco usual en aquellos años 40 y 50 -, quién conociera remotas culturas, quién debatiera con los grandes arquitectos del siglo XX y visitara las obras más interesantes, a la hora de enfrentarse a un proyecto nuevo, siempre, sus potencias se vuelven hacia La Mancha. Aunque a veces sea de reojo, siempre vuelve.

A través de su arquitectura, de sus escritos, de su obra plástica, Fisac contribuye a que ese lugar trascienda de lo físico para constituirse en construcción mental, y por lo tanto, -según hemos desarrollado en epígrafes anteriores- en un paisaje propio.

La Mancha impregna totalmente Fisac. Su profunda conexión de Fisac con la esencia de sus orígenes, hace que cualquier idea que circunde su alma de artista - con mayor 0 menor consciencia de ello-, se vea impregnada de su perfume.

Fisac "da la vuelta" a la hosquedad del páramo manchego. Por su afán de colocar al hombre en el centro de su arquitectura, de "humanizar el aire", ese terreno yermo y desabrigado, helado en invierno y ardiente en verano, le otorga en su arquitectura una atmósfera humana; se apropia así del territorio para convertirlo en paisaje.

Contribuye así Fisac con su arquitectura a acrecentar el mito quijotesco de este paisaje, una arquitectura que pretende sobrevivir en la aspereza de un territorio. Con su posicionamiento ante el paisaje se nos muestran cosas ante nuestros ojos que de otra forma no seríamos capaces de contemplar, actualiza referentes a un lenguaje moderno, los intensifica, y hace partícipe de ello al espectador.

Siempre al ascetismo del paisaje infinito, a la fuerza de lo ancestral.

Lo que en principio pudiera parecer contrario a la búsqueda de un camino hacia algo nuevo, se torna como una forma de avance: la reafirmación de sí mismo.

Una de las conquistas de la arquitectura de Fisac es devolverle a La Mancha parte de una identidad diluida, pero liberada de anodinos costumbrismos, un canto épico contra la desaparición de una cultura ancestral. 
Su personal visión de La Mancha, en una cierta lucha contra el costumbrismo ordinario y mal entendido, produce en Fisac una chispa que conecta con su inquietud de hacer una arquitectura renovada.

Además de ello, nos atreveríamos a decir que Fisac eleva ese territorio a la categoría de imaginario. Superponiéndose en cierto modo al papel de Cervantes, La Mancha podría constituirse como un emblema -poético si se quiere- de su arquitectura. Una arquitectura sencilla y esencial, atemporal, ligada al lugar, que reafirma al hombre ante el horizonte.

Con determinación quijotesca, convierte este territorio en el ideal sobre el que comenzar a desarrollar su nueva visión de arquitectura; como si quisiera resarcir su lugar de origen de la ironía cervantina.

"Posiblemente rebuscando en su memoria no encontró don Miguel paisaje y arquitectura -de los muchos que había conocido- que fueran para él más anodinos, más antipoéticos, menos proclives a la idealización, que las resecas llanuras manchegas, los caminos polvorientos, las simplicísimas ventas y los fantasmales molinos de viento. $Y$ acertó. Acertó, sin proponérselo, traspasando el realismo más duro, presentándolo de la forma más cruelmente burlesca, hasta llegar a las cotas más altas del más sublime idealismo."79.

A ello contribuyen elementos físicos, determinados actos, o referencias poéticas.

Los elementos físicos lo constituyen materiales o estructuras como los muros de tapial con su particular forma de construcción, las estructuras triangulares de madera, o las cubiertas de rollizo -definido por Fisac como un material específico de la zona y altamente aislante-.

Los referidos actos están fundados en una serie de rituales de resonancias prehistóricas traídos a la actualidad, muchas veces relacionados con la forma de construcción y ejecución de la arquitectura. Ejemplo de ello es el hecho de repasar con los operarios del Instituto Laboral de Daimiel la forma de tirar la cal, "con un cacillo o sartenilla atados a la punta de una caña de tortasol (girasol) para conseguir la estética original de la quintería manchega, o las reflexiones que le llevan a realizar en una obra por primera vez un encofrado con plásticos, que posteriormente originaría los encofrados flexibles. Ello genera una arquitectura que no es de "arista viva" sino redondeada, tomando como origen las sucesivas capas de cal que espesan los muros de tapial, dibujada por el sol. Una arquitectura de contornos imprecisos, de sugerentes rugosidades y preciosas texturas, que le confieren un aspecto de un tiempo lejano, una cualidad haber existido siempre.

${ }^{79}$ Fisac, M. (1985). Op. cit., 23-24 
Y las referencias poéticas se establecen a partir de la concepción sensual de determinados elementos del paisaje -que constatará y reafirmará en el descubrimiento de La Alhambra-, generando una secuencia de atmósferas que encuentran su origen en La Mancha: la fragancia de la higuera, el rumor de los chopos, el cántaro como elemento evocador de lo artesanal, el reflejo y el murmullo del agua, etc. Todo ello será utilizado en multitud de ocasiones a lo largo de su extensa trayectoria, materializando en ellos la Memoria con especial intensidad poética.

A través de la construcción del paisaje, podemos ver como Fisac realiza con su arquitectura una operación -si se permite la comparación- similar a la de Aureliano Buendía en la obra de García-Márquez Cien años de soledad.

En dicha obra, se narra la llegada de una chica huérfana, Rebeca, a Macondo, trayendo consigo una epidemia de insomnio, cuyo efecto no era propiamente la imposibilidad de dormir, sino la pérdida gradual de memoria, el olvido de los nombres de los objetos y su utilidad:

"cuando el enfermo se acostumbraba a su estado de vigilia, empezaban a borrarse de su memoria los recuerdos de la infancia, luego el nombre y la noción de las cosas, y por último la identidad de las personas y aun la conciencia del propio ser, hasta hundirse en una especie de idiotez sin pasado."

Aureliano, con gran audacia, trata de poner remedio a la epidemia: al no recordar un día, el nombre de un material con el que trabajaba en el laboratorio, comenzó a marcar todo por su nombre: mesa, flor, vaca... así como una explicación de uso: "Esta es una vaca; hay que ordeñarla todas las mañanas para obtener leche, y luego la leche, una vez hervida se agrega al café y se tiene café con leche".

Otros habitantes inventaron un sistema para leer en pasado en los naipes, y contrarrestar así de otra forma los efectos de la enfermedad. Finalmente, Buendía inventa una máquina de la memoria para registrar cada mañana los hechos de su vida pasada. De esta forma se podía poner en cualquier momento la máquina a funcionar y recordar día a día toda la vida pasada.

En la aparente simpleza de la reconstrucción del pasado desde lo elemental que recoge esta historia, emerge la importancia de la Memoria y su salvaguarda.

Con ese acto no se termina con la enfermedad, que precisa de un antídoto mucho más profundo, pero se aplaca. En la obra de Fisac, la Memoria se hace materia en cada proyecto huyendo de la desaparición de la misma.

Es por todo ello que podemos decir que en la obra de Fisac la Memoria está hecha de tierra de su propia tierra; y por consiguiente que La Mancha de Fisac, -su entendimiento 
Memoria, Aprendizaje y Experimento. La invención del paisaje en Miguel Fisac

Geografías de la Memoria. El niño y el hombre

físico y social por un lado, y arquitectónico y paisajístico por otro-, se derrama en su arquitectura para llenarla de esperanza.
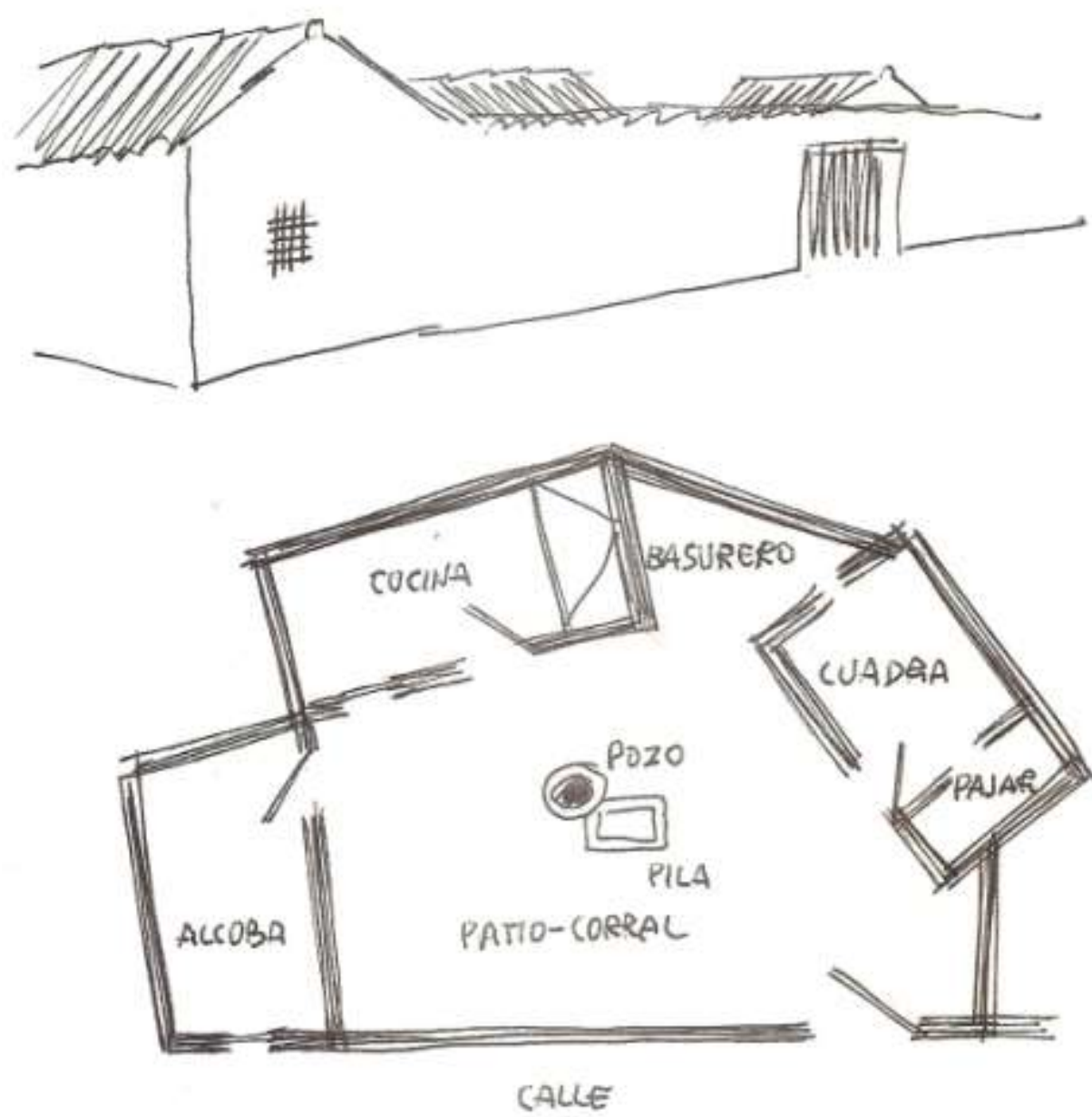

Arquitectura popular manchega. Dibujo de Miguel Fisac ${ }^{80}$

80 Tinta china sobre papel, numerado. Dibujo de 1984. En Fisac, M. (2005). Op. cit. 


\section{2_ La arquitectura popular. Reflexión y metáfora del paisaje.}

Según Miguel Fisac la arquitectura popular "es la arquitectura que hacen el pueblo y el tiempo"81; es el resultado de la "decantación sosegada" de una serie de espacios y elementos constructivos validados por muchas generaciones, en un lugar determinado y con una idiosincrasia común.

Son las formas tradicionales de habitar un lugar, realizadas con artesanal sabiduría a lo largo del tiempo, respetando los recursos naturales y culturales, y potenciando el ingenio desde el sentido común. Y habitar un lugar, según Heidegger ${ }^{82}$, es una forma de construirlo; ya que construir, en su origen etimológico es habitar, abrigar, cuidar.

Construir un paisaje, por tanto, supone necesariamente apreciar las formas de habitar propias del lugar; y es por ello que podemos entender que las manifestaciones de arquitectura popular son propiamente el paisaje.

La arquitectura popular podría definirse como "la implantación a lo largo del tiempo de una comunidad con sus símbolos, tradiciones, ritmos temporales, modalidades del habitar y cultivar, sus ansias de cuidar y embellecer, de transmitir...La belleza de un paisaje es consecuencia no tanto de la expresión de determinados valores estéticos sino expresión de una serie de valores éticos y morales en los que se refleja la propia sociedad."83.

Para Fisac la arquitectura popular es un elemento que resuena, cuya esencia se hace presente a través de su Memoria en el paisaje que pretende inventar. Porque él quería tomar de la arquitectura popular la esencia, no el modelo.

El hombre es protagonista de ese paisaje, que trasciende a la arquitectura pero que sin ella no se comprende.

"...creo que lo más interesante, para nosotros, de la arquitectura popular es su esencia humana. De todos los tipos de arquitectura, la arquitectura popular, por la manera de crearse y por su íntima razón de ser, tiene una humanidad efectiva que es, precisamente, la que es necesario recoger, no para integrarla en lo que hoy llamamos

81 Fisac, M. (1985). Arquitectura popular manchega,11. Discurso de ingreso en el instituto de Estudios Manchegos. Edición 2005. Ciudad Real: Colegio de Arquitectos

82 Heidegger, M. (1951). Op. Cit.

${ }^{83}$ Quesada, S. (2007). La memoria del paisaje. Aldaba, 22, 97-107. Martos: Ayuntamiento de Martos (Jaén). 
arquitectura moderna, sino para esa otra arquitectura que venga después, que tenga una raíz humana, que es lo que no tiene la actual." ${ }^{\text {". }}$.

En su discurso "Arquitectura Popular Manchega" dedica Fisac una explicación detallada a los porqués de los emplazamientos de los refugios en función de lo que un ganadero podía caminar una jornada. Asimismo, explica cómo se distribuía un refugio según las necesidades del hombre que lo iba a habitar, sin ningún lujo ni adorno.

Es esta una manera de humanizar el paisaje, de inventar el mismo en función de unas necesidades tan ancestrales como el refugio del ganadero. Como explicaba Unamuno:

"Poco a poco ha ido el hombre convirtiendo a la naturaleza en habitación suya haciéndola más humana, humanizándola. Y a la par su trato con ella, el continuo roce, ha ido acercándolo a ella más y más, enseñándole a mirarla con amor, naturalizándole en fin.

Así es como concurren a concuerdo el hombre humanizando con su labor a la naturaleza y ésta naturalizando de rechazo y como en pago al hombre, y así es cómo nos hacen vislumbrar el ideal de un hombre enteramente natural en comunión íntima con una naturaleza a la que podamos llamar ya humana..." 85 .

Existe una descompensación entre la intensidad que el propio Fisac, tanto consciente como inconscientemente, infundió sobre la arquitectura popular, y la escasez de los estudios que sobre ello se han realizado.

El único libro que escribió sobre un tema puramente arquitectónico, que bien podría ser considerado como testigo de sus orígenes, de su Memoria, es una plataforma de despegue para la creación de un Universo conceptual propio desde el respeto y la admiración "a sus mayores". Lejos de anclarse en lo provinciano, se realizan reflexiones sobre La Mancha que trascienden lo puramente objetual. Finalmente, la propia contemplación o reflexión sobre el paisaje manchego, es reactivo de la propia emoción.

Sin embargo, al hablar de arquitectura popular en relación con Fisac, en seguida podemos cometer la simplificación de pensar exclusivamente en la arquitectura popular manchega. Pero no sería justo obviar que sus intereses, si bien con epicentro en La Mancha, van más allá de aquella región. Porque a Fisac le interesaba, fuera de donde fuera, la arquitectura popular: la esencia, no el modelo.

84 Fisac, M. (1953). Valor actual de las arquitecturas populares. Aplicación particular a la arquitectura popular de los tipos mediterráneos. Sesiones de Crítica de Arquitectura. Revista Nacional de Arquitectura, 35-44. Año XIII, n. 137. Mayo 1953. Madrid: Consejo Superior de los Colegios de Arquitectos de España. Participación de Miguel Fisac.

85 Unamuno, M. de (1966). Paisajes, 29-30. Edición a cargo de Manuel Alvar. Madrid. Ediciones Alcalá. Tomado de López Ontiveros, A. (2009). Valor, significado e identidad del campo y de los paisajes rurales españoles según Unamuno. Boletín de la Asociación de Geógrafos Españoles.51, 127-152 
En la entrevista realizada por Eduardo Delgado el 13 de enero de 1998, se observa el interés de Fisac en la arquitectura popular que se realiza en cada lugar:

"Una revista que traía arquitectura que se hacía en la Alemania de aquellos años y de unos años antes también, que era muy inspirada en la arquitectura popular alemana, pero era buena y con unos visos, unos ciertos visos románticos, una sencillez romántica. Es lógico ver una influencia muy grande y yo creo., . ¿cómo se llamaba?. No me acuerdo- era una revista muy conocida. Bien, y eran cosas simpáticas, populares y tal, pero...eso tuvo mucha influencia." 86 .

Es éste un interés ampliamente demostrado a lo largo de su vida, con obras concretas. Porque no se pueden entender los posicionamientos ante el paisaje de las casas de Costa de los Pinos, muchas de ellas realizadas a principios de los años sesenta, sin haberse dejado seducir por los puros volúmenes de la arquitectura popular ibicenca. 0 el refugio familiar de Canfranc (1959) y la iglesia del mismo lugar (1965) sin la elementalidad pétrea de las casetas de falsa cúpula de la arquitectura popular oscense. O las viviendas de los hermanos Larragueta en Ortigosa del Monte (1955), sin la arquitectura propia de los Berruecos.

Son unos pocos ejemplos que pueden darnos una visión global de lo que significaba para Fisac seguir "la esencia, no el modelo" de la arquitectura popular, una idea con aroma de atemporalidad, y con la capacidad de definir una arquitectura no sólo acorde con la modernidad, sino en cierto modo adelantada a su tiempo.

Por tanto nuestra reflexión sobre la Memoria en Miguel Fisac, va más allá de lo popular, más interesada en los valores "absolutos" que de ahí se extraen: la ligazón a la tierra; la modestia y la humildad, la sensibilidad especial al entorno y a los elementos de la naturaleza, que se traducen en una sensibilidad ante el material; la sencillez de las soluciones; o el aplastante sentido común.

No es que no sea importante la mirada del objeto en el lugar. La contemplación juega un papel importante, sobre todo cuando es evocadora de ciertas energías poéticas que también construyen paisaje: largos muros de piedra a hueso, corrales, palomares, bombos, albercas, y patios; $u$ otros no construidos, pero al fin, actuaciones del hombre en el paisaje, del habitar que diría Heidegger como paseos, 0 azudes.

${ }^{86}$ Parece que se refiere a la revista Moderne Bauformen. Delgado, E. (1998). Conversaciones sobre Arte Sacro e Iglesia del siglo XX, 44 


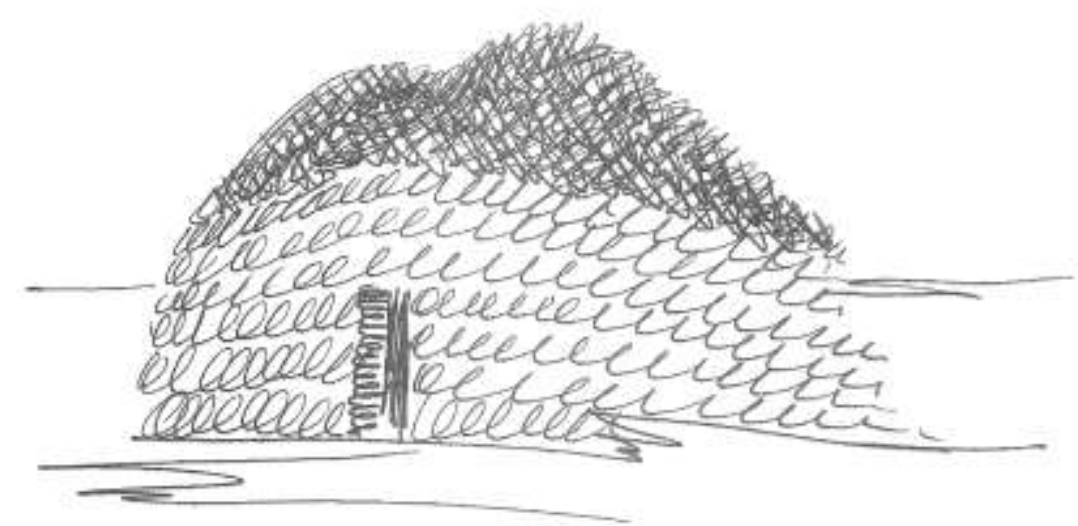

Bombo manchego. Dibujo de Miguel Fisac ${ }^{87}$

La emoción generada en Fisac por la arquitectura popular manchega, lógicamente el caso más íntimamente ligado a Fisac, viene acentuado por las evocaciones de la planicie manchega, su desnudez y esencialidad, el horizonte, la luz, y la nítida unión entre la tierra parda y el cielo azul.

Por otra parte, a partir de tener la oportunidad de realizar una serie de proyectos en la mallorquina Costa de los Pinos -proyectos singulares en la arquitectura de Fisac-, estudiará y realizará una interpretación de la arquitectura vernácula y popular balear sobre todo ibicenca-, de la que tuvo conocimiento a través de la participación en una Sesión Crítica de Arquitectura en la que fue ponente Gabriel Alomar. ${ }^{88}$

La arquitectura mallorquina se integra de modo sinfónico con el paisaje, "...modestas y olvidadas construcciones que asoman, sin empaque, del verdor gris de los olivos o de los almendros floridos completamente asimilados al paisaje, como si hubieran nacido espontáneamente entre las rocas o entre los campos de rastrojos, como nace un pino 0 una amapola." ${ }^{89}$.

En la misma línea de modestia y sencillez, pero como contrapunto a la misma, la arquitectura popular ibicenca alcanza su armonía con el paisaje por contraste.

87 Tinta china sobre papel, numerado. Dibujo de 1984. En Arquitectura popular manchega. Edición 2005. Ciudad Real: Colegio de Arquitectos

${ }^{88}$ Alomar, G. (1953). Valor actual de las arquitecturas populares. Aplicación particular a la arquitectura popular de los tipos mediterráneos. Sesiones de Crítica de Arquitectura. Revista Nacional de Arquitectura, 35-44. Año XIII, n. 137. Mayo 1953. Madrid: Consejo Superior de los Colegios de Arquitectos de España. En dicha sesión participó Miguel Fisac.

$89 \mathrm{Idem}$ 
Procedente, a través de Cartago y Fenicia, de los antiguos pueblos de Oriente Medio, esta será la base sobre la que Fisac desarrollará su concepto arquitectónico y relación con el paisaje en la Costa de los Pinos: muros de mampostería siempre encalados, con cubiertas planas, "en forma de azotea". Y totalmente desnudas de ornamentación:

"Contraste de líneas, que se mueven en las tres direcciones cartesianas; contraste de claroscuro; contraste de luz y sombra; contraste, en fin, de blanco inmaculado sobre el azul absoluto del cielo.

(...)

Las casas ibicencas no tienen ornamentación de ninguna clase. Su valor estético reside en su misma simplicidad y en el juego de volúmenes simples y abstractos."."90

En las citadas intervenciones de Miguel Fisac en las Pitiusas, el juego de volúmenes, la luz y la sombra en contraste con la vegetación, el mar y el cielo, nos traslada a una arquitectura de formas elementales, eterna y primitiva a la vez, que nos sugiere haber estado allí antes de que se conformara el propio paisaje.

90 Ibidem 
Memoria, Aprendizaje y Experimento. La invención del paisaje en Miguel Fisac

La arquitectura popular. Reflexión y metáfora del paisaje

El propio Fisac lo adelanta en los textos de las memorias de sus proyectos, insistiendo en un gran número de ellos sobre la misma idea:

"... la simple expresión de volúmenes, crean un conjunto armónico de neta filiación mediterránea, que entona perfectamente con el paisaje y con el color intenso del cielo y del mar." 91

El material también colabora a esa vocación de pertenencia: la estructura de la casa está basada en muros de carga de piedra de "marés". También frente a la casa encontramos zonas de la parcela reforzadas con muretes bajos de la misma piedra, esta vez a hueso y sin encalar.

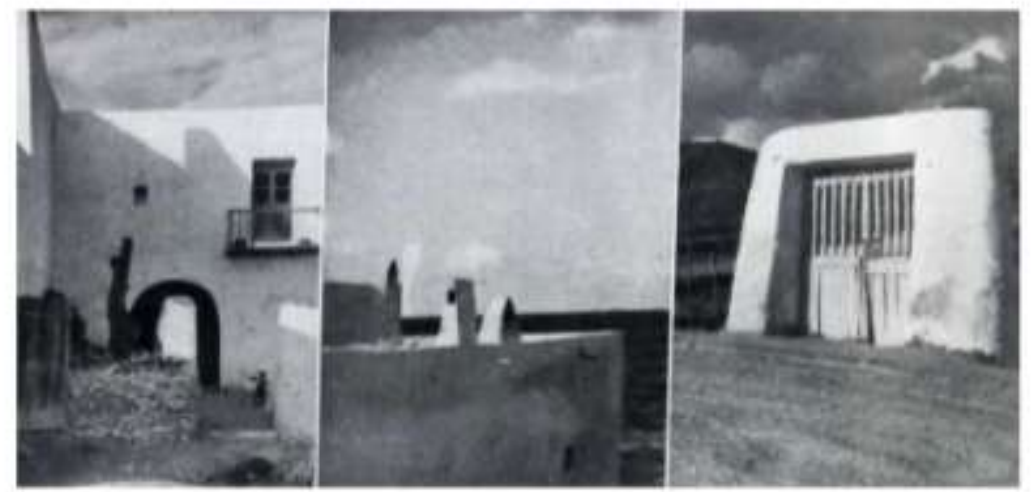

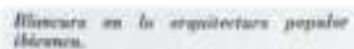
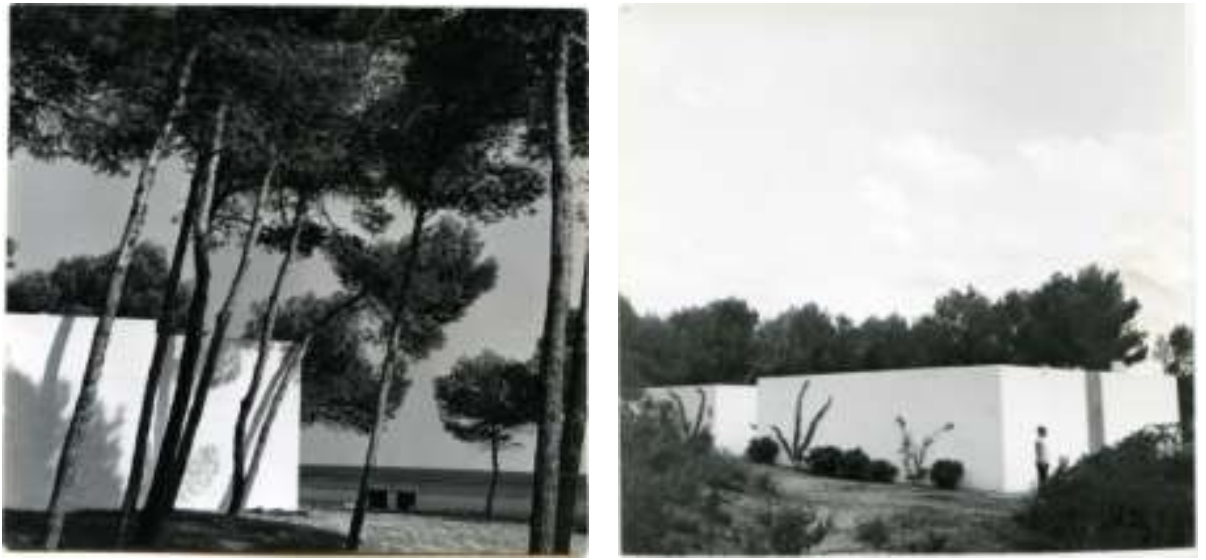

Arquitectura popular ibicenca

Casas de Miguel Fisac para D. Pablo Magaz en Costa de los Pinos.

91 Fisac, M. (1961). Proyecto de hotel en "Costa de los Pinos" (Mallorca) para D. Torcuato Luca de Tena. Memoria. 
Memoria, Aprendizaje y Experimento. La invención del paisaje en Miguel Fisac La arquitectura popular. Reflexión y metáfora del paisaje
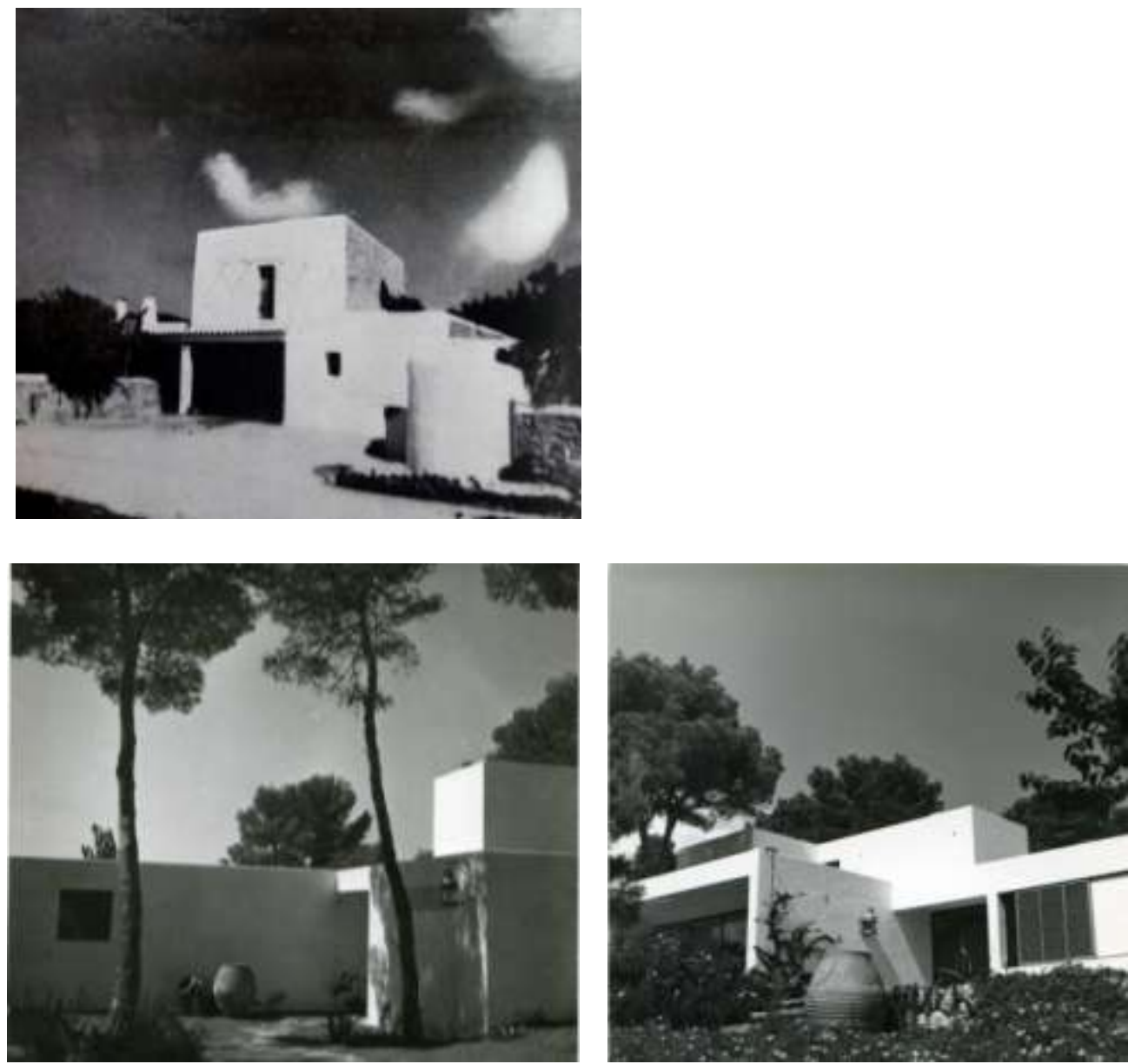

Arquitectura popular ibicenca (arriba) y vistas de la vivienda de Torcuato Luca de Tena (abajo). Fundación Fisac. 
Fisac también conocía bien la arquitectura tradicional de Huesca, la tierra de su mujer; y como no las casetas que poblaban las laderas de Los Arañones -en Canfranc-, llamadas "de bóveda" ó "de falsa cúpula"92, que tanto en común tienen con los ancestrales "bombos manchegos" vistos en su infancia, utilizadas por pastores y labradores como refugio. También los refugios realizados durante la Guerra Civil -él cruzó los Pirineos durante la contienda, como hemos comentado-, y que se funden con el paisaje, como el de la Rioseta que él mismo fotografió junto con su entorno, como objeto que forma parte del paisaje.

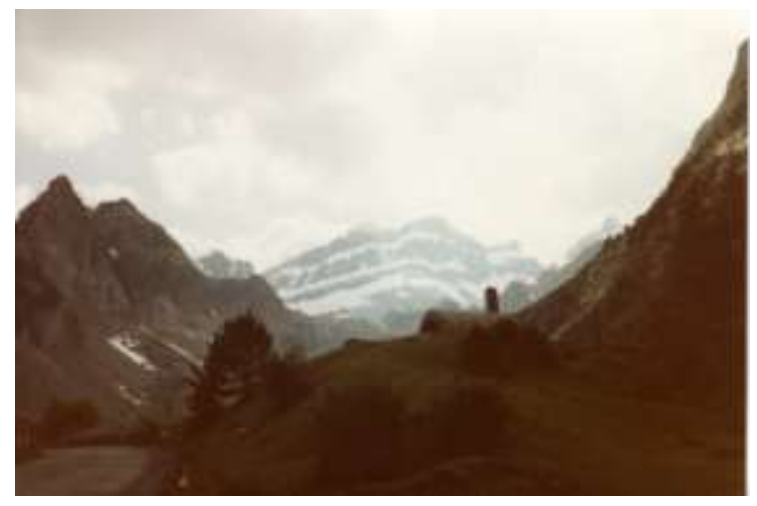

Refugio de Rioseta en el paisaje de Canfranc, en la conocida como Línea P.

Fotografía de Miguel Fisac

Los citados bombos eran definidos por Fisac como una construcción, "de planta circular, o más propiamente cuadrada o rectangular, con las aristas ampliamente redondeadas, construida con lajas de piedra, generalmente caliza, de mediano tamaño y aparejadas a matajunta en seco, sin mortero, creando una falsa cúpula por avance horizontal de unas piedras sobre otras, lo que hace suponer que las primitivas tuvieron una antigüedad de varios miles de años, ya que esta manera de construir es anterior a la invención del arco, de la bóveda y la cúpula, y por tanto podría remontarse a la Edad de Bronce.

\section{(...)}

\footnotetext{
92 Las casetas de "falsa cúpula" son una manifestación de la arquitectura popular construida con piedra en seco y con unas bóvedas muy interesantes.

Se utilizaban de refugio por pastores o labradores (existían plantaciones y campos de labor en las laderas de Los Arañones y muchos otros lugares de Huesca), para protegerse de la lluvia o el calor del verano. Su construcción es de gran sencillez, y disponen de un pequeño hueco de acceso. La "cúpula" se construía mediante la colocación de losas ligeramente inclinadas que "volaban" cada vez más hacia el interior, hasta culminar en una losa horizontal de gran tamaño que podía ponerse o quitarse como salida de humos. El exterior se cubría con tasca (cuadrados de hierba con tierra) para evitar la entrada de agua. Al igual que los "bombos manchegos" tienen un enorme interés etnológico y forman parte del paisaje.
} 
El mimetismo de los bombos resulta casi perfecto en el paisaje manchego, especialmente en el tiempo de invierno, ya que no es que tengan el color del terreno, sino que propiamente son terreno.". ${ }^{93}$
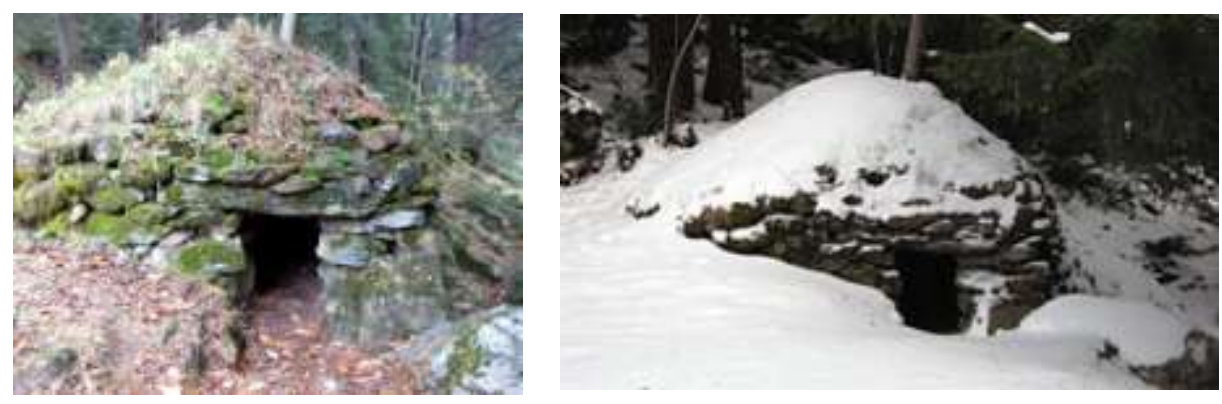

Casetas de falsa cúpula. Canfranc ${ }^{94}$

Los proyectos que realiza Fisac en Canfranc (Huesca), como objetos aparentemente cerrados que se relacionan con el paisaje, aprenden en cierto modo de este afán de mímesis de las casetas de falsa cúpula oscenses; una arquitectura que no quiere ser nueva, sino que aspira a formar parte de un nuevo todo.

Nos muestra aquí Fisac otra forma de disponernos en el entorno, sin necesidad de aperturas, secuencias, grandes huecos o transparencias; un objeto que también construye el paisaje desde la conexión con lo primitivo y con los valores etnológicos del lugar. La construcción del paisaje desde la comunión con la tierra, con el lugar, y con el valor de lo ancestral.
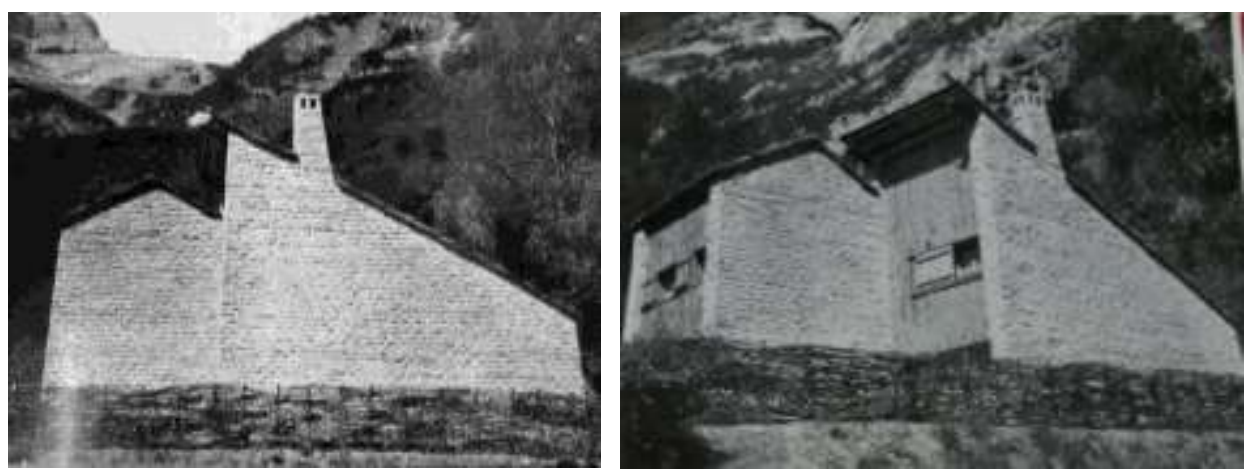

Refugio familiar en Canfranc. Miguel Fisac. 1959

${ }^{93}$ Fisac, M. (1985). Arquitectura popular manchega, 24. Edición 2005. Ciudad Real. Colegio de Arquitectos 94 Procedencia de las imagenes: http://depaseoporcanfranc.blogspot.com.es/2014/11/el-arboretum-decanfranc.html 
Memoria, Aprendizaje y Experimento. La invención del paisaje en Miguel Fisac

La arquitectura popular. Reflexión y metáfora del paisaje

Fruto de estas intenciones se muestran una serie de acuarelas, si bien posteriores a la construcción de la casa, en el año 1986, como si quisieran dejar testimonio de la intención de participar y de mimetizarse con este paisaje.
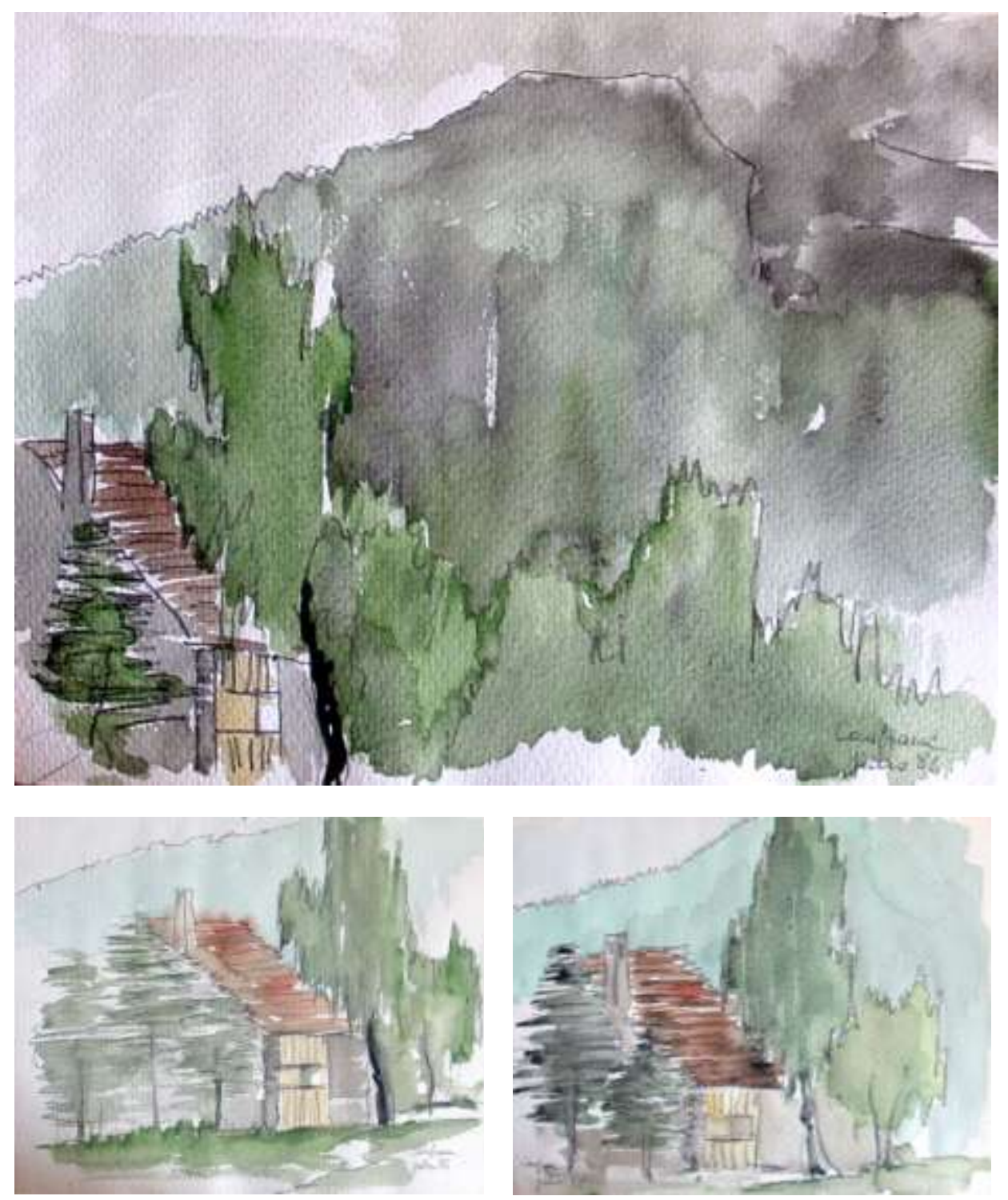

Acuarelas firmadas en Julio de 1986. Archivo personal de Miguel Fisac. Imágenes del archivo personal de Eduardo Delgado Orusco (2003). 
La casa se intuye, no se muestra en su total volumetría, y la arquitectura se funde con los árboles, con la niebla, con las montañas. Como si deseara que fuera el paisaje el que hubiera imitado a la arquitectura: las ramas de los árboles tienen la misma inclinación que la cubierta, y el trazo horizontal de sus ramas quieren tener continuidad con las hiladas de la teja. Hay un intercambio de valencias entre arquitectura y paisaje, y de esta forma fluyen, la una hacia la otra y la otra hacia la una.

Parece que se hacen realidad aquí las palabras de Camilo José Cela que tanto gustaban a Oiza:

"Fruto del amor del hombre con la Tierra, nace la casa, tierra ordenada en la que el hombre se guarece, cuando la tierra tiembla -cuando pintan bastos- para seguir amándola"

La fábrica de piedra, su utilización natural y desnuda a modo de mampostería, en sus muros longitudinales; y la madera en los cerramientos transversales -utilizada en listones verticales para reafirmar la vocación de verticalidad de la pieza-, el contraste de sus texturas, acercan el objeto al paisaje, lo hacen pertenecer a él, potencian su carácter estereotómico. La sencillez constructiva y estructural también es decisiva para su entendimiento como refugio, ligado a la celebración del concepto de "lo primitivo", tan ligado a la arquitectura popular.

De igual modo su forma, la inclinación de su cubierta y el pequeño tamaño de los huecos visibles desde fuera de la propiedad, lo conducen a un diálogo con las cadenas montañosas que circundan Canfranc de forma sincera, natural y espontánea, integrando la construcción en el paisaje. 
En definitiva, Fisac se dejará embelesar por la emoción estética de lo primitivo, asumiendo una serie de categorías que llegan a aquel que experimenta uno de estos paisajes ancestrales. Texturas, sonidos, o atmósferas de eternos parajes, de labradores curtidos al sol bajo la mansa cúpula del cielo que lo conectarán con la intrahistoria.

Al igual que en sus cuadros Fisac fusiona el paisaje con la arquitectura en una suerte de "síntesis del paisaje", utilizando la propia tierra como material de los mismos, la arquitectura popular vincula la arquitectura con la propia tierra.

Podríamos decir que uno de los torrentes de fuerza de la arquitectura de Fisac procede de una reflexión metafórica del paisaje manchego tamizada por la Memoria. Al igual que le sucede a las obras literarias de Unamuno, en las que la contemplación de lo material produce una la reflexión espiritual que evoca la trascendencia del hombre a través de la resonancia de los paisajes de la niñez.

Visiones interiores de paisajes, que como decíamos trascienden de lo topográfico. Se trata de la emoción producida por la naturaleza marcada por las huellas del hombre.

La permeabilidad y filtraciones de lo popular en la arquitectura de Fisac es definitiva, es fuente continua de creatividad y de frescura. La verdadera poesía nace del pueblo, sostenía Machado: "Deseoso de escribir para el pueblo, aprendí de él cuanto pude, mucho menos, claro está de lo que él sabe. Siempre que advirtáis un tono seguro en mis palabras, pensad que os estoy enseñando algo aprendido del pueblo"95.

En el epílogo de su libro Arquitectura Popular Manchega, tras certificar la desaparición de la misma lanza Fisac una sentencia no exenta de amargura: "sólo podrá resucitar en la mente de los artistas o de los poetas". Y él la resucita, la reactiva, y la utiliza como herramienta para inventar un nuevo paisaje en el que la tradición y la memoria son ingredientes fundamentales, haciendo realidad la sentencia de Dimitris Pikionis:

"La Arquitectura sólo lo será en tanto que sea carne de la carne de la tierra y, por lo tanto, de sus habitantes".

${ }^{95}$ Machado, A. (1937). Hora de España, I. Valencia 
Memoria, Aprendizaje y Experimento. La invención del paisaje en Miguel Fisac La arquitectura popular. Reflexión y metáfora del paisaje 
Memoria, Aprendizaje y Experimento. La invención del paisaje en Miguel Fisac Aprendizaje

\section{3_APRENDIZAJE}

3.1_ Viajes, cuadernos y croquis

\section{2_ Otras vías}

La Alhambra

Japón y la casa japonesa

3.3_ Maestros de la modernidad

Aprendiendo de los nórdicos. Asplund y Aalto

Frank Lloyd Wright

Mies van der Rohe

Le Corbusier

Richard Neutra

3.4_Las publicaciones de la época

3.5_ Otra vez La Mancha 
Siguiendo el itinerario marcado por Fisac en sus escritos, y ampliado en otros aspectos que consideramos destacables, profundizaremos en aquellos elementos que despertaron en él la emoción que trasladará a ciertas arquitecturas.

De esta forma, consideraremos los Viajes, La Alhambra, la Casa tradicional japonesa, Asplund, Frank Lloyd Wright, Alvar Aalto, Mies van der Rohe, Le Corbusier y Richard Neutra.

Podría decirse, paradójicamente, que su Aprendizaje fue un viaje de búsqueda, en el que recaló en puertos que llenaron sus arcas de sabiduría. Al igual que en el poema de Kavafis, en su viaje hacia Ítaca, el propio camino fue el tesoro:

"Ten siempre a Ítaca presente en el espíritu.

Tu meta es llegar a ella, pero no acortes el viaje: más vale que dure largos años y que abordes al fin tu isla en los días de tu vejez, rico de cuanto ganaste en el camino, sin esperar que Ítaca te enriquezca. " ${ }^{196}$

Viajes realizados con la intención de "ver arquitectura", de analizarla sin ninguna interferencia, para sacar conclusiones propias.

A la vista de ello, se podría decir que dejamos en el tintero una de las grandes maestras de Miguel Fisac: la arquitectura popular. Sin embargo, se ha considerado conveniente, en virtud de una mejor comprensión de esta investigación, vincularla más al concepto de Memoria que al de Aprendizaje, si bien podría -honestamente- situarse a caballo entre las dos.

96 Kavafis, K. Viaje a Ítaca. Tomado de Wiegand Petzet, H. (1983). Encuentros y diálogos con Martin Heidegger 1929-1976. Edición española, 2007. Buenos Aires: Katz editores 


\section{1_Viajes, cuadernos y croquis}

La primera noticia que tenemos de la intensa vida viajera de Fisac es su visita a Lisboa con catorce años, mientras realizaba el Bachillerato en Badajoz. Posteriormente volverá en su viaje de fin de carrera en 1942, gracias a la cual (Roda Lamfus, 2007) se hace "consciente de su actitud de viajero curioso, con un objetivo claro: el conocimiento de la arquitectura en otros países, un interés que le acompañará toda su vida"97.

Si bien no se trata de una actividad exclusiva de Miguel Fisac como arquitecto español, destaca la cantidad; sorprende la prontitud con la que ya había recorrido una parte importante del mundo; e impresiona la intensidad con la que es utilizado lo aprendido en sus viajes para el desarrollo de su arquitectura -aún para tomar el camino contrario a lo experimentado-.
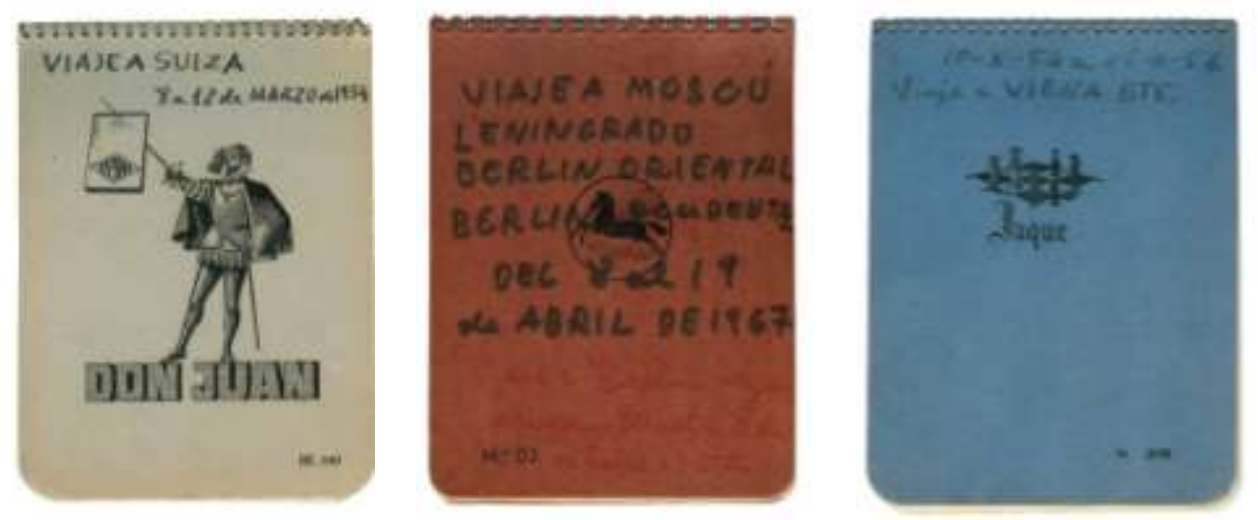

Miguel Fisac. Cuadernos de Viaje.

Y es que si la práctica del Viaje era un instrumento de descubrimiento, de encuentro con uno mismo, o de búsqueda, en ese paso ambiguo entre la juventud y la madurez, es porque realmente nutría a quién se aventuraba de una apertura mental y de la vivencia de unas experiencias imposibles de asimilar de otra forma.

${ }^{97}$ Roda Lamfus, P. de (2007). Miguel Fisac apuntes y viajes. Madrid: Scriptum. 
Así, son conocidos viajes de intelectuales españoles como Julián Marías, que posteriormente daría lugar a su libro "Juventud en el mundo antiguo", cuyo primer capítulo "Notas de un Viaje a Oriente" publicaría en el Diario El Sol el 27 de agosto de $1933^{98}$, debido a que era obligatoria la redacción de una bitácora.

Como arquitectos, abrieron la brecha los García Mercadal, Luis Lacasa, Sánchez Arcas o Bergamín ${ }^{99}$, (San Antonio, C. de, 2010), cuya estela fue seguida, tras los períodos de guerra por Coderch, Cabrero, el propio Fisac, Cano-Lasso, Sáenz de Oiza o Vázquez Molezún.

Los destinos fueron muy heterogéneos, si bien destaca una corriente de conexión entre Cataluña e Italia a comienzos de la década de los 50 , no produciéndose una intensa conexión de viajes para conocer la arquitectura nórdica -Finlandia incluida-hasta la década de los 60 -sobre todo por parte de arquitectos de la escuela de Madrid, si bien los primeros se organizaron desde Cataluña-, con notables influencias como la de Fernández Alba, y llamando la atención la sensibilización ante el paisaje y la naturaleza, que en Fisac se había producido muy anteriormente:

"Se iniciaron estos viajes hacia 1960, con un dilatado itinerario por la Europa aún en fase de reconstrucción, llegando hasta los tupidos y nevados bosques de Säynätsalo en Finlandia. (...)

El respeto a la naturaleza, la presencia industrial implicada en todas las memorias populares, el encuentro con una arquitectura mediadora entre las posibilidades tecnológicas y los sentimientos, la elegancia y frescura en el tratamiento de los detalles arquitectónicos, y la coherencia del espacio construido eran lecciones directas donde esclarecer la política del espacio." 100

$Y$ en la arquitectura internacional, sin abundar en territorios que excederían esta investigación, son conocidos los viajes de contemporáneos como Wright, Aalto, Asplund o Lewerentz, por citar algunos.

98 Crucero por el Mediterráneo en el que participarían más de 200 estudiantes, profesores y catedráticos, entre los que destacan Fernando Chueca Goitia o Gregorio Marañón. Fuente: Hemeroteca digital Biblioteca Nacional.

99 López Otero, Sánchez Arcas, de los Santos y Bergamín realizaron un viaje en 1928 por Estados Unidos, previo a la construcción de la Ciudad Universitaria. Al año siguiente, Lacasa y Sánchez Arcas realizaron un viaje por Francia, Suiza, Alemania, Dinamarca e Inglaterra antes de construir el edificio Rockefeller, en la colina de los Chopos. En San Antonio, C. de (2010). El viaje desconocido de un arquitecto olvidado. Revista De Arquitectura, 12, 25-36.

100 Fernández Alba, A. (1997). Esplendor y fragmento. Escritos sobre la ciudad y la arquitectura europea 1945-1995. Madrid: Biblioteca Nueva 
En el caso de Fisac, el viaje es entendido como un complemento a su formación, y es la mejor manera que entiende de ver y estudiar la arquitectura del momento y de buscar referencias válidas.

A buen seguro Fisac estaría de acuerdo con Siza cuando dice "Aprender a ver es fundamental, 0 al menos 10 es para un arquitecto, existiendo un bagaje de conocimientos a los que inevitablemente recurrimos, de tal modo que nada de cuanto hagamos podría ser completamente nuevo"101.

Sin embargo, sobre el terreno y según se desprende tanto de sus Cuadernos de Viaje como de los artículos que posteriormente escribiría, no es el objeto arquitectónico lo que en exclusiva interesa a Fisac. Más cerca estaría de su interés, el paisaje -humano y físico; el objeto en el paisaje y las circunstancias naturales que lo rodean; así como la ciudad y sus coyunturas: reunión, habitabilidad y circulación.

Como antecedentes cercanos a los viajes de Fisac, es de considerable importancia el realizado en 1947 por su compañero del estudio de la calle Villanueva, Fernández Vallespín. Y es que, en la línea de las investigaciones realizadas (San Antonio, C. de, 2010) el viaje de éste a Suiza, Holanda, Dinamarca, Suecia e Inglaterra, del que se conservan más de 60 diapositivas y anotaciones, así como las cartas enviadas a Miguel Fisac -entre otros-, confirman la influencia de ello en los preparativos del conocido viaje a Europa de 1949.

Viajes de estudios anteriores únicamente se conoce el de Cabrero a Italia en 1941 -por sugerencia de Coderch, al que llamaba maestro a pesar de ser únicamente un año mayor que él-, y contemporáneos el de Oiza a Estados Unidos en 1948.

El viaje de Vallespín, encargo del CSIC y cuyo objetivo era conocer edificios similares para el diseño y construcción del Patronato Juan de la Cierva, le llevó a visitar edificios tan representativos como la Biblioteca de Estocolmo, lo cual indica ya un acercamiento a la obra de Asplund; así como la ciudad de Gotemburgo, en cuyas anotaciones sorprendentemente no se menciona que visite la ampliación del Ayuntamiento, aunque sí otros edificios de colaboradores de Asplund. Una imagen de la citada biblioteca se encontraba entre los apuntes tomados por Muguruza en su viaje a Estocolmo en 1946 como representante de la Dirección General de Arquitectura para asistir a la inauguración de la Exposición iberoamericana de Arquitectura-, publicados por la Revista Nacional de Arquitectura, aunque sin referencias escritas a la obra de Asplund ${ }^{102}$.

\footnotetext{
101 Siza, A. (2003). Imaginar la evidencia

102 Muguruza, P.(1946) Notas de una visita a Estocolmo.Revista nacional de Arquitectura, 52-53, abrilmayo, 76-104, citado por San Antonio, C. de (2010), op. cit.
} 


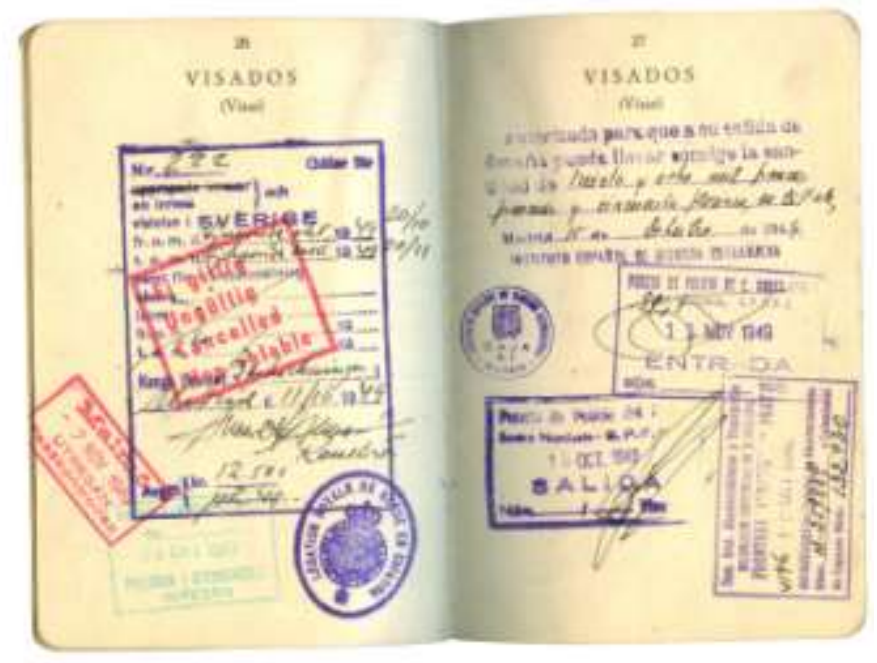

Pasaporte de Miguel Fisac. Visado de entrada a Suecia. 1949

Los motivos de la ausencia de anotaciones sobre los trabajos de Asplund en el Ayuntamiento de Gotemburgo pueden ser variados, sin embargo, no nos resistimos a pensar en pérdidas, extravíos 0 incluso algún despiste antes que la no realización de esta visita. Máxime cuando Fisac llevaba anotada exclusivamente esta parada en el Rathaus, además de otras, realizadas antes por Vallespín, como la sala de conciertos de Nils Einar Eriksson (1935), antiguo colaborador de Asplund:

"En Goteborg hemos visto muchas más cosas interesantes de las que esperábamos. La sala de conciertos es realmente buenísima toda forrada de madera de abedul y con una acústica perfecta"103

En efecto, el viaje que realizaría Fisac a Suiza, Francia, Suecia, Dinamarca y Holanda, en octubre y noviembre de 1949 partió de una serie de anotaciones previas, que además de tomadas de revistas extranjeras de la época, necesariamente tomó del anterior viaje de su compañero Vallespín, ya que tanto Asplund como Alvar Aalto no fueron publicados en la revista Arquitectura con anterioridad al viaje a Europa de Fisac.

${ }^{103}$ Fisac, M. (1949) Cuaderno de Viaje a Suiza, Francia, Suecia, Dinamarca, Holanda. Octubre-Noviembre 1949, pg. 27 


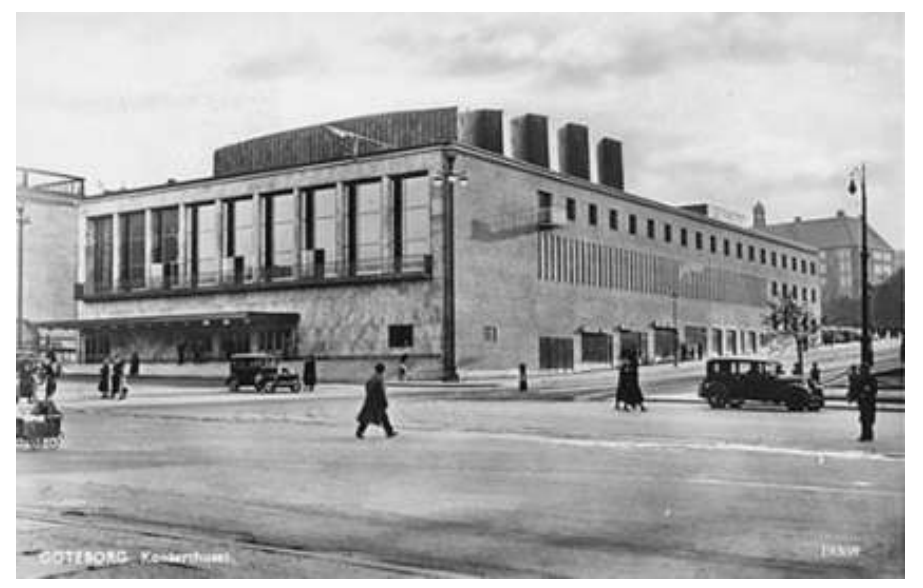

Sala de Conciertos de Eriksson (Gotemburgo, 1935). Nótese el mirador de la fachada longitudinal, que posteriormente referiremos.

Su periplo se desarrolló por Ginebra, Berna, Zurich, Basilea, París, Estocolmo, Uppsala, Gotemburgo, Mälmo, Copenhague, Amsterdam, La Haya y Bruselas. A la vista del recorrido, se observa una carencia sorprendente: Finlandia. El motivo es político ya que en aquellas fechas, Finlandia estaba padeciendo las consecuencias de varias guerras, (Guerra de Invierno, Guerra de Continuación, Segunda Guerra mundial, en la que fueron aliados de los alemanes...), en las que perdió parte de su territorio -anexionado a la Unión Soviética-, y que por tanto era de difícil entrada.

El motivo del mismo, profesional. Según él mismo cuenta (Fisac, 1989, 13):

"Un viaje por Europa (octubre-noviembre 1949) para documentarme en la estabulación de animales de experimentación: ratas, ratones, cobayas, etc., en un proyecto para el Instituto Cajal de Microbiología, me permitió conocer la arquitectura empírica que realizaban los países nórdicos.

Con 20 ó 30 grados bajo cero, y una sociedad muy progresista, no se puede jugar a elucubraciones fáciles, y los arquitectos suecos hacian una arquitectura técnicamente seria". ${ }^{104}$

No fue éste el primer viaje de Fisac por Europa. Según vemos en su pasaporte, en Enero, Mayo y Junio de 1949 realiza varios viajes a Italia, de los que prácticamente no

${ }^{104}$ Fisac, M. (1989). Miguel Fisac. Colección Documentos de arquitectura, 10, 13. Almería: Delegación de Almería del Colegio Oficial de Arquitectos de Andalucía Oriental. 
se tienen datos, pero que coinciden cronológicamente con el inicio de las obras de Villa Tevere en Roma, la que posteriormente será la sede central del Opus Dei. A pesar de la previsible intensa agenda de trabajo de Fisac en esos viajes, no es extraño que aprovechara para ver algunas piezas de su interés, además de las obligadas visitas romanas.

Volviendo al viaje a Europa, del mismo destacan tres aspectos:

En primer lugar, el conocido encuentro con la ampliación del Ayuntamiento de Gotemburgo, de Asplund, gracias al que surgirá un intenso interés por el neo-empirismo sueco y la obra de este arquitecto. De las experiencias de este viaje, inmortalizadas en unas breves notas, surgirá posteriormente el reconocimiento continuo en escritos ${ }^{105} \mathrm{y}$ conferencias, en los que siempre saldrá citado el arquitecto sueco como uno de los responsables primeros de su aprendizaje arquitectónico.

"Asplund está rehabilitado. Todo lo que me decepcionó el Instituto de Biología de Stockholm me ha gustado la ampliación del Rathaus (supongo que será la palabra sueca para ayuntamiento o tribunal) de Göteborg. Es sencillamente la solución de un problema bien planteado. No estoy de acuerdo en despreciar de esa forma tan absoluta las fachadas exteriores." 106

En segundo lugar, la constatación de la sensibilidad hacia el aspecto paisajístico de la arquitectura, climatológico y humano. Sus anotaciones denotan el interés y la reflexión sobre el espacio no ocupado -mirada que se desarrollará en posteriores viajes- :

"un barrio nuevo de las afueras con casas de tres plantas en alineación irregular contrapeando unas rocas y en el centro un gran espacio verde con las escuelas a un lado y un Kindergarten en el centro"107

En este sentido, se detiene en soluciones arquitectónicas para mejorar la continuidad espacial interior-exterior, como una luna con contrapeso para un enlace cuarto de estarjardín o la forma en la que se accede a los edificios;

"Una característica muy importante de la arquitectura que hemos visto es la falta de rigidez o mejor la flexibilidad. El acto de entrar en un edificio es romper con el exterior

\footnotetext{
105 Fisac, M. (1981). Asplund en el recuerdo. Quaderns de arquitectura i urbanisme, 147, 32-33.

106 Fisac, M. (1949) Op. cit., pg. 26. Se muestra su decepción tras la visita de los Laboratorios Bacteriológicos del Estado, diseñados por Asplund en 1933. Asimismo, reafirma su falta de interés por la solución de la fachada del Ayuntamiento dada por Asplund, que posteriormente confirmará en varias ocasiones.

${ }^{107}$ Fisac, M. (1949). Op. cit., pg.28.
} 
pasar a otros orden de cosas, pues bien, aquí no. El clima es muy duro, la diferencia de temperaturas es mayor y sin embargo esta tajante separación no existe."108

y visita la Escuela Elemental Bruderholz en Basilea (1935-1939), obra de Hermann Baur -al que conoció personalmente en ese viaje, y que a buen seguro mantuvo posteriores contactos con él, ya que la mayor parte de su producción arquitectónica posterior está relacionada con iglesias y capillas-, cuya disposición de aulas y vistas en continuidad con la naturaleza -así como acceso directo desde el exterior-, así como la posibilidad de impartir clases al aire libre a buen seguro interesaron a Fisac.

"Vemos las escuelas hechas por el arquitecto Baur y (...) quedamos en visitarlo por la tarde"109

$Y$ en tercer lugar el desarrollo de una capacidad crítica sincera y sin paliativos. Esta franqueza, tan espontánea como brutal, será muy útil para discernir lo que le interesa de lo que no. En este caso, no tiene reparos en calificar de "lamentable" el campus Miséricorde de la Universidad de Friburgo, de Honegger y Dumas, que hicieran en 1939 utilizando hormigón armado.

"En el viaje he visto de refilón la universidad de Friburg: es tan lamentable como me la figuraba el hormigón visto es horrible. La orientación general de las cosas que he visto en hormigón son siguiendo a Perret."110

O de "porquería" una obra que visita de Le Corbusier:

"Lamentable fuera de toda ponderación el pabellón suizo de la ciudad universitaria de Le Corbusier. Tiene todos los latiguillos plásticos de la peor arquitectura cubista. No cabe una mayor falta de sentido común en las soluciones constructivas y funcionales. Las calidades no pueden ser peores. En resumen: una porquería."111

A continuación, en torno a 1950, realiza varios viajes de los que se conservan una serie de bocetos. Según sus propias palabras, (Roda Lamfus, 2007) decidió hacer un estudio crítico intenso: "voy a irme yo sólo por ahí a ver la arquitectura llamada moderna que no he visto directamente..."

Aprovechando un viaje a París, visitó la Unidad de Habitación de Marsella de Le Corbusier, "y unas cuantas cosas suyas del principio".

Asimismo, por la fecha de sus dibujos, realizó un viaje a Estados Unidos en torno a 1950, del que tenemos pocos datos, al parecer actuó aquí como suministrador de

\footnotetext{
108 Fisac, M. (1949). Op. cit., pg.32.

${ }^{109}$ Fisac, M. (1949) Op. cit., pgs. 12-13.

110 Fisac, M. (1949). Op. cit., pg.4.

111 Fisac, M. (1949). Op. cit., pg.17.
} 
materiales de la orden de los Dominicos. Al menos visitó Chicago y Nueva York, donde realiza croquis de las torres de apartamentos Lake Shore Drive de Mies van der Rohe de 1949-, y de la Lever House de Skidmore, Owings y Merril (SOM) ${ }^{112}$, respectivamente. También visitó Centro Técnico de la General Motors de Saarinen, en Warren, Michigan, -comenzado en 1949 y terminado en 1956- que había contado con la colaboración del paisajista Thomas Church.

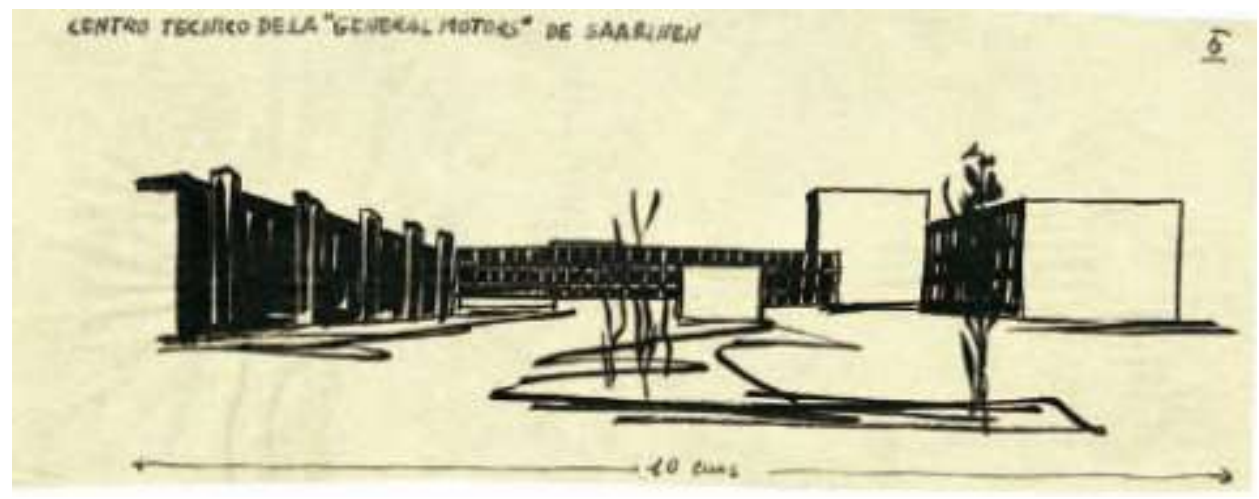

Croquis Centro Técnico General Motors de Eero Saarinen (1949), realizado por Miguel Fisac.

Sorprende cómo Fisac se deja seducir por la Lever House, que considera el único edificio que "se salva" de Nueva York, y su "desprecio" en forma de silencio del edificio que Mies levantaba justo enfrente, el edificio Seagram ${ }^{113}$.

En 1953 viaja a Extremo Oriente. Conocemos la existencia de un cuaderno de viaje a través de un texto suyo, en el que se vuelve a dejar patente su sensibilidad por la exterioridad de la arquitectura y la trascendencia para él de la misma: "cada piedra, cada monte, cada poblado, tantas veces impersonal, está aquí cargado de una trascendencia religiosa e histórica, desde luego inigualables"114.

En este viaje marca un antes y un después en cuanto al desarrollo de una experiencia sensorial que se despierta aquí, y que encaja perfectamente con sus reflexiones sobre la materia, el paisaje, los elementos esenciales o la forma de construcción.

\footnotetext{
112 El edificio Lever House se contruyó entre 1951 y 1952, por lo que su visita no pudo ser anterior a esa fecha, si bien se expuso una maqueta del mismo en el MOMA, en 1950.

113 Fisac, M. (1956a). La Actualidad Española. Viaje alrededor del mundo parando en nueve ciudades: Nueva York. Año V. No: 219, 15 de marzo. Fuente: Fundación Fisac.

114 Fisac, M. (1953). Cuaderno de viaje a Extremo Oriente, 64. Extraido de Roda Lamfus, P. (2007). Op. cit.
} 
"Todo en Japón tiene su tensión. Una piedra aquí y otra piedra allí... En fin, todo. En jardinería se ve muchísima tensión. Queda muy bello un paisaje, en un jardín tomando el té...

En todo jardín japonés hay unas piedras que se llaman del atardecer, pues es sencillamente donde hay que sentarse cuando se pone el sol. ¿Por qué? Pues porque este árbol, este agua, este tal...van formando y creando una belleza. Hay un sitio que es el más tranquilo, pues en ese lugar ponen unas piedras desde donde el jardín tiene un aspecto de más sosiego."115

Entre el 8 y el 12 de marzo de 1954 viaja a Suiza, en el que destaca las visitas a los apartamentos Doldertal, de Breuer y Roth en Zurich.

Entre el 10 y el 26 de octubre de 1954 viaja a Viena, a la exposición de Arte Sacro en la que le concedieron la Medalla de Oro por el conjunto de las Arcas Reales de Valladolid. En ese viaje visita Milán, Venecia y Verona.

Entre el 17 de agosto y el 28 de septiembre de 1955 se produce su uno de los viajes más importantes que realiza en cuanto a su significado e influencias: el Viaje alrededor del mundo. A pesar de no ser el viaje que más interés produjo en Fisac, si fue éste sobre el que más reflexionó, cuyas ideas fueron trasladadas desde su cuaderno de viaje a una serie de artículos periodísticos publicados en La Actualidad Española en 1956. El periplo lo llevó por Atenas, Beyrouth, Jesusalén, Bangkok, Manila, Tokio, y Estados Unidos -Alaska, Seattle, San Francisco, Fresno, Los Ángeles, Chicago, Madison, Nueva York, y Boston-

Podemos diferenciar en dos categorías las influencias de este viaje: por un lado, las obras de arquitectura por las que se interesó, y por otro, las impresiones recogidas sobre las ciudades visitadas.

115 Idem 


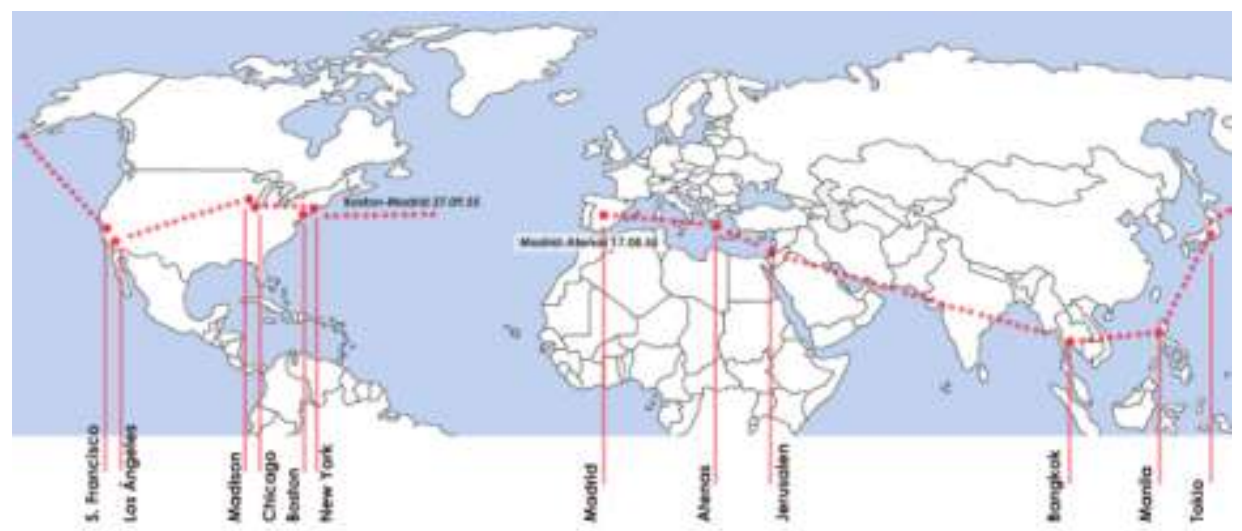

Esquema del Viaje alrededor del mundo de Miguel Fisac (1951), a partir del itinerario indicado en su libreta de viaje (inédita). Realizado por el autor de la Tesis. Véase Apéndice 2.

Es en este viaje en el que se encuentra con la obra de Wright (visita la casa y el taller de Wright en Spring Green, así como la fábrica de Racine y la Johnson Wax). También visita la Farnsworth de Mies van der Rohe, y en Boston algunas obras de Breuer y Gropius, cuyas visitas han pasado bastante desapercibidas y que guardan una estrecha relación con la idea de arquitectura de Fisac.

"En Boston también vi obras de Gropius y de Breuer, más de Breuer..." (Alarcón, 1999, 423)

Gropius quiso que su casa de Lincoln (Massachusetts, cerca de Boston), construida en 1938, fuera un ejemplo para sus alumnos de Harvard. Además, la evolución de su arquitectura en lo relativo al interés por lo orgánico y la integración de su arquitectura en el paisaje de Nueva Inglaterra seguro que debió llamar la atención de Fisac: los muros de piedra circundando los humedales -tan conocidos por Fisac-, el huerto de manzanos, el jardín de la parte sur, o la disposición de los porches para acentuar la relación entre la casa y el lugar.

Asimismo, también le debió interesar el intenso trabajo realizado en la jardinería, con la cuidada selección de árboles maduros -pinos blancos o silvestres, olmos, robles y hayas americanas-, realizado junto a Ise Frank -su segunda esposa-, que intervino como paisajista. La inclusión de rocas, celosías de madera con trepadoras o vides, fueron también responsables de la integración de la casa con el paisaje. Todo ello evolucionó tras un viaje a Japón de la familia Gropius en los años 50 , que ayudó a incluir plantas de suelo o zonas de grava gris, así como un gran arce japonés -momento en que Fisac conoció la casa-. 
El propio Gropius evidencia la mirada al paisaje del lugar, cercano a ciertas posiciones de Fisac:

"This fusion of the regional spirit with a contemporary approach to design produced a house that I would never have built in Europe with its entirely different climatic, technical and psychological background"116

Probablemente Fisac encontró en las casas de Breuer ${ }^{117}$, invitado por Gropius como profesor en Harvard en 1937, la humanización que había echado en falta en las casas del Movimiento Moderno. Y es que junto con Gropius, investigaron sobre las relaciones de la arquitectura con el paisaje y sobre la materialidad de las mismas, a través de la fusión de los métodos tradicionales de construcción y una concepción abstracta de la arquitectura.

Estas visitas por tanto, fueron clave para que la concepción de las relaciones entre arquitectura y paisaje se estrecharan en el universo creativo de Fisac.

Paralelamente, en el mismo viaje, se encontrará con la potencia de la Acrópolis, lo que le produce una gran intensidad de emociones, a pesar de que tenía pocas esperanzas en ello, como se desprende de sus notas manuscritas.

Y es que en su encuentro con la civilización griega le hace reflexionar sobre dos temas importantes para él: la humanización de la arquitectura -aquí a través de un correcto uso de la escala-, y la disposición de los elementos en el espacio, así como el aire que queda entre ellos.

"Este montón de bloques de mármol (...) tiene aún muchas lecciones que dar. La primera la del urbanismo. Urbanismo que es en primer lugar topografía de situación. La colina rocosa de la Acrópolis dejando siempre el cielo como telón de fondo es el más bello contraste que se puede imaginar y después la disposición de los edificios es de una audaz lógica maravillosa."118

\footnotetext{
116 Gropius, W. (1956). Scope of Total Architecture. "Esta fusión del espíritu regional con un acercamiento contemporáneo en el diseño, da como resultado una casa que nunca hubiera construido en Europa, con un fondo totalmente distinto en lo climatológico, técnico y psicológico"

117 Varias obras de Breuer fueron publicadas en España en fechas previas al Viaje alrededor del mundo de Fisac. Asimismo fue seleccionado, entre otros, junto a Fisac y Richard Neutra, para responder un cuestionario en 1955 para opinar sobre una serie de conceptos de arquitectura y su relación con el hombre y el entorno. Esteban Maluenda, A. (2008). El papel de Informes de la Construcción en la difusión de la arquitectura moderna extranjera (1948-1968). Actas de las II Jornadas de investigación en construcción. Madrid: Instituto Ciencias de la Construcción Eduardo Torroja

118 Fisac, M. (1955). Cuaderno de Viaje alrededor del mundo, 4-5. Inédito.
} 
En su reflexiones en Bangkok, y otras ciudades como Los Ángeles o Chicago se comienza a gestar su idea de lo que debe ser la ciudad y el urbanismo, así como su idea de convivencia como centro de la creación de nuevas ciudades. Reunión, habitabilidad, y circulación, son las tres características que considera básicas para que una ciudad sea completa, "proporcionadamente desarrollados en la relación justa que exige la idiosincrasia de sus habitantes.".

En Bangkok porque encuentra una diferencia esencial con la ciudad de Occidente, la ausencia de un núcleo central, de un "corazón", como "la plaza de Chinchón".

"Bangkok es una ciudad que no tiene corazón. Entendiendo por corazón, claro está, lo que así se llama en urbanismo, o creo, centros de convivencia ciudadana, o religiosa, o comercial etc, etc., Este núcleo netamente occidental que es la polis griega o el foro romano y que es en nuestros núcleos la plaza, no existe o queda sedimentariamente expresado en las ciudades de oriente. Este corazón es el que preclaramente no existe en Bangkok. Y es curioso pero entonces una ciudad ha perdido su más noble expresión: la convivencia, para transformarse en un simple lugar de viviendas aisladas." 119

$Y$ en los Ángeles o Chicago, porque encuentra algo contra lo que reaccionar: la ciudad hecha a medida del automóvil. De esta forma, se adelanta a lo que años después encontraremos en España:

"Un tema que es indispensable abordar con cierta extensión al hablar de Norteamérica es el del automóvil, en todas sus variadas facetas; tanto las que se refieren a impactos físicos y psicológicos en el hombre, como otras que corresponden al campo de la geografía, del paisaje y, sobre todo, del urbanismo." ${ }^{120}$.

Y en San Francisco porque "sólo con una urbanización amplia y soleada se consigue un conjunto agradable"121.

En Tokio, la experiencia estética y paisajística sublima la arquitectura:

"Lo que más se parece a un paisaje japonés es la pintura japonesa de paisaje japonés. Los "kakemonos" -etimológicamente "cosa que se cuelga"- son esos cuadros alargados sin marco, con sólo dos cañas o dos maderitas arriba y abajo que tienen pintados unos paisajes retorcidos de montañas, de ríos con puentes, de árboles y de flores. Cuando los hemos visto por primera vez nos hemos figurado que eran la interpretación subjetiva que los artistas japoneses hacían de paisajes poco más o menos como los nuestros. Pero cuando llega uno a Japón se da cuenta de que el subjetivismo pictórico es allí muy

119 Fisac, M. (1955). Op. cit., 17-18.

120 Fisac, M. (1956b). La Actualidad Española. Viaje alrededor del mundo parando en nueve ciudades: Chicago. Año V. No: 217, 1 de marzo. Fuente: Fundación Fisac.

${ }^{121}$ Fisac, M. (1955). Op. cit., 32. 
relativo. Que las montañas, y los ríos, y los árboles, están allí retorcidos realmente, y tienen un decorativismo salvaje y extraño, como el que nos reflejan los "kakemonos"."122

Posteriormente realiza otros viajes. Entre el 8 y el 19 de abril de 1967 viaja a Moscú, Leningrado, Berlín Oriental y Berlín Occidental. En la libreta aparece una anotación inferior que indica Viaje a Berlín y Praga 30 de septiembre a 8 de octubre 1967. Asimismo, existen otros muchos realizados con su familia o no recogidos en cuadernos de viaje, que exceden el alcance de esta investigación.

En esta línea, sin embargo, es interesante la fotografía que junto con su mujer, Ana María, tomó en la capilla de Ronchamp, en torno a 1958.

Asimismo, por otras investigaciones tenemos constancia de un viaje a Alemania con Ortiz-Echagüe en 1949 -en aquel entonces estudiante de segundo curso de Arquitectura- :

"Yo tuve la suerte de hacer dos viajes fuera de España durante esos años, ambos en 1949: uno a Roma, en el que aparte de conocer la arquitectura del pasado, pude ver ya algunas obras de Gio Ponti; hice también un viaje a Alemania, acompañando a Fisac, pero sólo vimos ruinas $y$, eso sí, grandes proyectos para la reconstrucción de las ciudades. En ambos viajes pude comprar algunas revistas." ${ }^{123}$.

\footnotetext{
122 Fisac, M. (1956c). La Actualidad Española. Viaje alrededor del mundo parando en nueve ciudades: Tokio. Año V. No: 213, 2 de febrero. Fuente: Fundación Fisac.

${ }^{123}$ Alarcón, C. (1999). Fragmento de un texto de César Ortiz-Echagüe de fecha 6 de noviembre de 1998. Parte II, Anexo E, 22. La Arquitectura en España a través de las revistas especializadas 1950-1970. El caso de Hogar y Arquitectura (tesis doctoral). Madrid: Universidad Politécnica de Madrid
} 

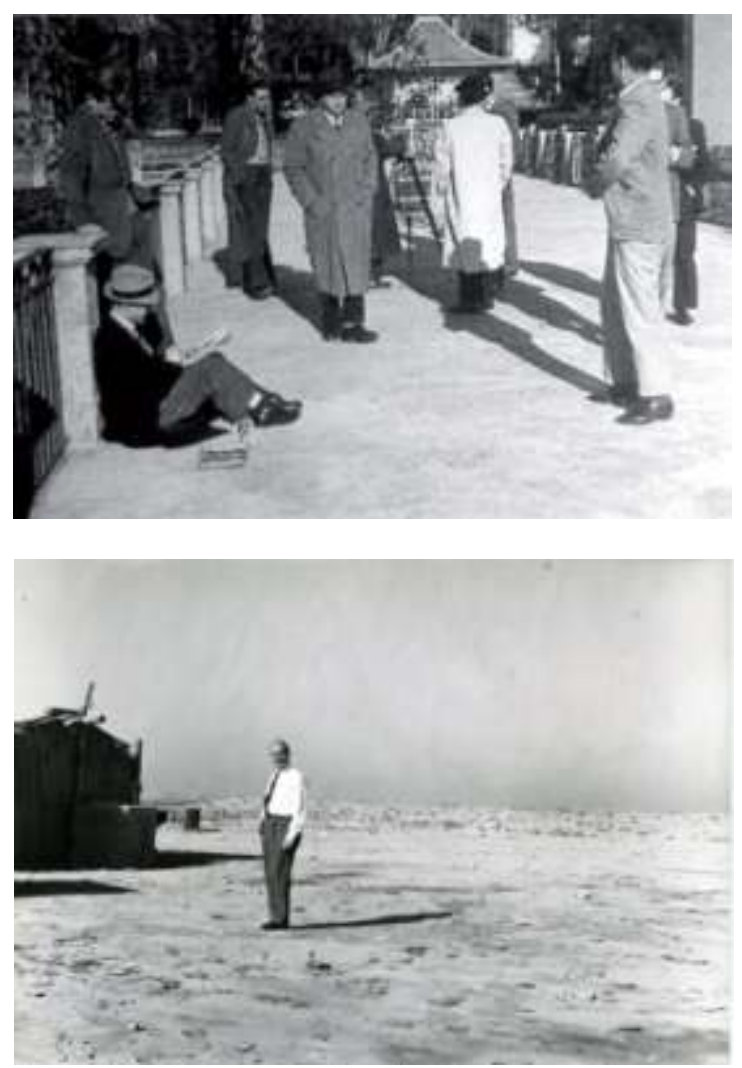

Miguel Fisac dibujando en la calle en uno de sus viajes. Fundación Miguel Fisac Miguel Fisac en el Golfo Pérsico, 1971. Fundación Miguel Fisac

En definitiva, la forma de aprendizaje preferida por Fisac (Alarcón, 1999, 422):

"La única forma de entender la arquitectura es viajando y viendo la obra; ni he preguntado, ni he leído bibliografias. Me han llegado a echar de los edificios..." 124

${ }^{124}$ Alarcón, C. (1999). Op. cit. Fragmento de una conversación mantenida con el arquitecto Miguel Fisac en su casa-estudio del Cerro del Aire. 28 de septiembre de 1998. Parte II, Anexo E, 14. 


\section{2_ Otras vías}

\section{La Alhambra}

La Alhambra siempre estará presente en la vida y en la obra de Fisac; sirviéndose de ella para explicar cómo se hace patente la materialización de su cambio de rumbo y el desarrollo de una nueva sensibilidad arquitectónica y paisajística.

Y es que como él mismo explica, si en los primeros años de su vida profesional sus inclinaciones se dirigen hacia el Palacio de Carlos V, tras el comienzo de su madurez, que podemos situar al comienzo de la década de los 50 , tras el viaje a Europa- se sentirá arrebatado por el conjunto nazarí.

De hecho, cuenta el propio Fisac que en una de sus primeras visitas a Granada en la década de los 40, llamado para la restauración de la casa del Chapiz, le preguntaron que qué le había parecido La Alhambra, a lo que él respondió: "pero La Alhambra, ¿es arquitectura?"125 , frase de la que reconoce que se arrepintió años después.

En 1952 fue invitado junto a un grupo de arquitectos a La Alhambra, donde se organizó una sesión crítica a instancias de Prieto Moreno, entonces Director General de Arquitectura -además del responsable de su restauración-, que desembocaría en el Manifiesto de La Alhambra, una suerte de escrito de conclusiones. Para ello, se constituyeron con carácter previo cuatro grupos de trabajo, encargándose Fisac de debatir sobre la Parte IV (Jardines), junto con Fernando Chueca, Fernando Lacasa y Francisco Prieto-Moreno, al que se uniría Francisco de Asís Cabrero; tema sobre el que Fisac trabajará posteriormente con intensidad, y que se traducirá en su obra.

En dicha sesión se desarrollan asimismo, tomando como punto de referencia La Alhambra, otros temas fundamentales como Formas, Construcciones, Decoración, desarrollados por otros arquitectos.

También la visita nocturna organizada en esos días fue asimismo revulsivo para la nueva consideración del conjunto por parte de Fisac. Según la crónica:

"Una escogida noche de luna llena en la que el grupo fue llevado a medianoche, habiéndose dado la orden de apagar todas las luces del recinto y de los barrios

${ }^{125}$ Fisac, M. (1982a). Carta a mis sobrinos, 21. Edición 2007. Ciudad Real: Fundación Miguel Fisac. 
próximos. El recorrido realizado en silencio bajo la luz de la luna permitió experimentar esa arquitectura como estímulo a los cinco sentidos."126 (Navarro, M.I., 2004)

Y precisamente la toma de consciencia de esos cinco sentidos creará en Fisac la necesidad de realizar una arquitectura que se encuentre con ellos.

En el grupo de debate sobre los jardines se profundizó, tomando como referencia La Alhambra, sobre una serie de conceptos que posteriormente tendrán una influencia notable: los elementos intermedios entre arquitectura y jardín, la ambivalencia de "la casa es jardín y el jardín, casa", la posible equiparación que en jardinería correspondería a un paisaje como el español, la geometrización de los espacios no construidos, etc...

Se trata de un texto de intensas sugerencias proyectuales del que emana una sensualidad que se podría aproximar a la experiencia espacial del jardín de La Alhambra, y que a buen seguro encontramos en su obra posterior.

Si la máxima aspiración del arquitecto al proyectar un jardín es evocar un trozo de cielo en la tierra, no es menos atractivo vislumbrar una casa "que se desparrama en el jardín", con miradores y pabellones que flotan en la naturaleza, "entre verdura y aguas limpias y frescas"

Fisac interviene en dos ocasiones, desvelando aspectos claves de su actitud ante la arquitectura y el paisaje:

"Me interesaría que se resolviera la posibilidad de que la arquitectura entrara en colaboración con el entorno agrícola por analogía o por contraste, tomando el jardín precisamente como elemento de unión."127.

Una idea profunda sobre la contemplación del paisaje exterior dado desde el paisaje interior -creado por el hombre-, así como la búsqueda de la continuidad espacial mediante la fusión de la naturaleza y el jardín que posteriormente veremos, -como en la casa de Sotogrande -Cádiz-, en su propia vivienda del Cerro del Aire; o la posición de dominación -como en el mirador de la Ciudad Universitaria-. Es una reflexión sobre el "dónde", que en algunos casos requerirá la colaboración "por analogía" y en otros casos "por contraste", y que él desarrolla en las dos direcciones, ya que lo esencial es la

\footnotetext{
126 Navarro, M.I. (2004). La crítica italiana y la arquitectura española de los años 50. Pasajes de la arquitectura española en la segunda modernidad. Actas del Congreso Internacional Modelos alemanes e italianos para España en los años de la postguerra, 99. Pamplona: Universidad de Navarra.

127 Fisac, M. (1953). Intervención en el grupo de trabajo sobre Jardines. Manifiesto de la Alhambra. Dirección General de Arquitectura. Ministerio de Gobernación. Edición Fundación Rodríguez Acosta, 1993. Granada: Delegación en Granada del Colegio Oficial de Arquitectos de Andalucía Oriental
} 
reflexión que se hace sobre el paisaje, profundizando en él y extrayendo del mismo los datos necesarios para moverse en una dirección u otra.

Asimismo, esto tendrá una importante repercusión en su posterior estudio para la ciudad del futuro: La Molécula Urbana.

"Yo veo en La Alhambra, como elemento arquitectónico esencial, el aire, el aire quieto. Después, el agua; agua en movimiento, como expresión de vida. Las superficies que limitan este aire quieto son las que dan lugar a las formas espaciales. La vegetación se incorpora a todo este conjunto.

El dar el principal papel en arquitectura al aire, al agua, a la naturaleza, exige del arquitecto una posición de humildad amorosa. Los arquitectos de La Alhambra nos dan un gran ejemplo. Han obrado humildemente."128

Y es que realmente La Alhambra es la esencia de la definición de arquitectura de Fisac, que luego entrará en comunión con la arquitectura japonesa cuando descubra allí la prevalencia de la naturaleza sobre la arquitectura: para el arquitecto, humanizar el aire es tomar un posicionamiento de humildad ante la naturaleza, no en cuanto a sumisión, sino en el obrar virtuoso de acuerdo con sus limitaciones.

El conjunto nazarí emana una serie de lecciones cuya esencia recogerá Fisac para llevarlas a su arquitectura.

Una de las lecciones es utilizar los materiales que se encuentran a pie de obra. De esa manera el paisaje acogerá mejor a la arquitectura, porque de hecho forma parte de él. La siguiente lección es la de la sinceridad: en su estructura, en su composición y en su acabado. Los materiales se muestran tal como son y nos hablan de su naturaleza. Además, ninguno de ellos aparece disfrazado, ni el yeso, ni la madera, ni el mármol.

"La Alhambra es rabiosamente sincera: esqueleto de muro de tapial; músculo de mármol y madera; traje de yeso. Mármol, para los suelos que han de pisar los pies desnudos y en las columnas; barro vidriado, donde hay roce; en los techos, madera fibrosa que soporta la flexión; y, por adorno, yeso"129

Miguel Fisac recoge en 1994, en las notas de una conferencia impartida en el Colegio de Arquitectos de Granada de 21 de abril de 1994, su aprendizaje de La Alhambra, ya

\footnotetext{
${ }^{128}$ Fisac, M. (1953). Op. cit.

129 García Gómez, E. (1953). El manifiesto de La Alhambra por 24 arquitectos españoles. Al-Andalus, XVIII, 261-269.
} 
conocido por su publicación en el monográfico que realizó el CSCAE con ocasión de la concesión de la Medalla de Oro de la Arquitectura, pero que merece la pena revisitar ${ }^{130}$.

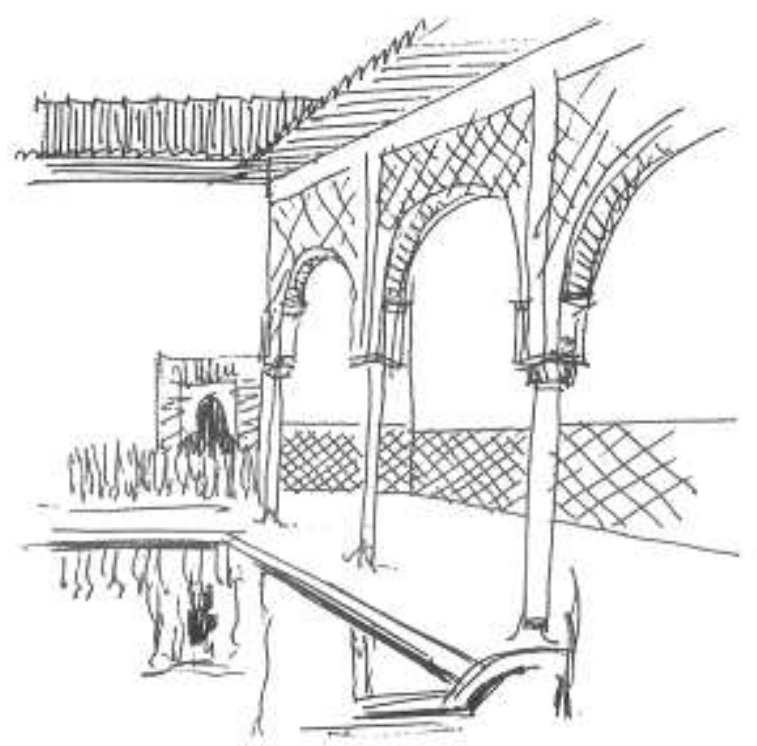

Patio de los Arrayanes en La Alhambra. Dibujo de Miguel Fisac

Allí nos habla de cómo al repasar, de los edificios que conocía, aquellos en los que desatacara un marcado carácter espacial, el primero en el que pensó fue La Alhambra. $Y$ de esta forma saca varias enseñanzas que se pueden aplicar a lo que bajo su entendimiento debe ser la buena arquitectura:

- Que la arquitectura es espacio, no volumen

- Que el espacio puede humanizarse limitándolo geométricamente

- Que tiene grandísima importancia el tratamiento que se dé a las superficies limitantes de ese espacio

- Que La Alhambra nos recuerda que tenemos cinco sentidos

- Que tiene una importancia capital la forma de articular los diferentes espacios de un edificio

- Que la vertebración de todo el conjunto responde a una concepción trascendente de la vida humana

130 Fisac, M. (1994). Lo que he aprendido en La Alhambra. Miguel Fisac. Medalla de Oro de la Arquitectura, 10-11. Arquitectos, 135. Madrid: Consejo Superior de los Colegios de Arquitectos de España 
Una gran parte de estas enseñanzas las veremos posteriormente reflejadas en lo que hemos denominado gramática del paisaje; instrumentos de los que se sirve Fisac para configurar una serie de relaciones entre la arquitectura y el lugar, para activar el paisaje.

Se constata así que de la arquitectura hispanoárabe en general y de este conjunto nazarí en particular surge el embelesamiento por estos elementos que son verdaderos configuradores del paisaje.

Así, veremos cómo acoge el arquitecto la importancia de la delimitación de los espacios y la captura del horizonte, así como la contemplación de la Naturaleza. Huecos y miradores (como los de las casas de Mallorca o el de la Ciudad Universitaria), en los que, haciendo una asimilación de ideas con las realizadas por el profesor Jesús Aparicio sobre la Torre de Comares, se introduce la emoción, e "incorpora el exterior como una forma de hacer cercano lo que es lejano, de hacer particular lo que es universal, de hacer privado lo que es público."131

En este sentido, también constata a través del estudio de La Alhambra la consideración por el material con el que compone su arquitectura, sus cualidades internas y su textura. Una acción que permite por un lado que la arquitectura encaje con lo sustancial del paisaje formado a lo largo de la historia, y por otro que genere diversas emociones a través del trabajo del mismo.

Siguiendo esta línea argumental también se introduce aquí un importante encuentro con el agua, con el placer estético de contemplación, o como reflejo de la obra de la naturaleza y la obra del hombre, en sus tres momentos de surgir, de conducirse 0 de estancarse. Y también con el sonido y rumor de la misma, que genera también la consideración de los cinco sentidos y por tanto la arquitectura como humanizadora.

No podemos olvidar una de las más importantes herencias que Fisac recibe de esta arquitectura: el interés por la jardinería y la vegetación. Los jardines -como posteriormente veremos- tienen para Fisac la importancia de relacionar la obra del hombre con la de la naturaleza, el interior o el exterior, el acá con el allá, y contienen, como decía Ferdinand Bac parafraseando a Barragán, "nada menos que el Universo entero".

De todo el aprendizaje que extrae el arquitecto de este conjunto nazarí, podemos destacar como enseñanza más importantes que la arquitectura no es sólo el espacio cubierto y cerrado: también las galerías, terrazas y patios son arquitectura. De hecho estos elementos aportan intensidad y ayudan al hombre a encontrarse con la belleza y la espiritualidad.

${ }^{131}$ Aparicio, J. (2000). La Alhambra. desvanecimiento y presencia. El muro, 37. Universidad de Palermo. 
"Son arquitectura no sólo los espacios cerrados, sino que tan arquitectura son también los espacios semiabiertos de [las] galerías y hasta los abiertos en su plano superior, de los patios, en los que uno de los lados de esos paralelepípedos espaciales son el aire, la vegetación y en otros casos el cielo y el agua al menos en parte."132.

En este sentido la sombra es tomada como sustancia activa en varios de los proyectos, ya sea a través de pórticos que hilvanan distintos pabellones, marcando un acceso, o tensando un jardín. Fisac sumerge en la luz los espacios, los materiales, las texturas, los colores, las superficies y las formas: atrapa la luz del paisaje y la refleja, la filtra, la atenúa o la rebaja, para que aparezca en su intensidad certera.

El espacio humanizado que es la arquitectura, por tanto, no depende de la limitación física superior o lateral, entrando en juego posibilidades tan interesantes de delimitación -lateral, superior, inferior- como la vegetación, el cielo, el agua o el aire.

Se reafirma así la idea de que el espacio no construido, los vacíos, umbrales, terrazas, patios y jardines serán tomados por Fisac para formar parte de un paisaje inventado.

132 Fisac, M. (1994). Lo que he aprendido en La Alhambra. En Cánovas, A. (ed.) (1997). Miguel Fisac. Medalla de Oro de la Arquitectura, 10-11. Arquitectos, 135. Madrid: Consejo Superior de los Colegios de Arquitectos de España 


\section{Japón y la casa japonesa}

Fisac tuvo gran interés por la influencia cultural e intelectual que producía Japón en los arquitectos. Y ello se materializó tanto en su estudio sobre la casa tradicional japonesa y su relación con la naturaleza, así como otros aspectos de esta cultura; como posteriormente en la integración de algunas de estas valencias a su arquitectura.

El interés se remonta a su época universitaria; y si bien no se especifica si la chispa surgió a través de una obra o un arquitecto en concreto, sí que hay mención especial para quien trajo el japonesismo a Occidente con mayor influencia: Frank Lloyd Wright.

En este sentido, iremos afianzando con datos concretos la idea de que los arquitectos por los que se interesó Fisac, tuvieron con Japón una vinculación intelectual.

"Me empezó a interesar Oriente en la época de cuando estaba estudiando: yo creía que Japón tenía cosas. Y además veía que la gente que hacía la arquitectura entonces se inspiraba mucho en lo japonés. Excepto Frank Lloyd Wright que llegó allí a Japón a hacer su hotel, el Imperial, que lo han terminado tirando y haciendo otro. Yo lo vi todavía funcionando."

Por otra parte, es interesante la mención que se hace a Wright en el Manifiesto de La Alhambra comparando esta "importación" de lo japonés a Estados Unidos como si de algo artificial se tratara, y defendiendo como contraste lo hispanoárabe en España como perteneciente a lo más íntimo y auténtico de nuestro país, con el objeto de reinterpretar en clave contemporánea ciertos conceptos allí contenidos que marcaran en cierto modo el camino a seguir por los arquitectos del momento para revitalizar una arquitectura nacional que se encontraba en vía muerta.

En su caso, Fisac, que celebró la reconsideración de La Alhambra en aras de una nueva arquitectura, también "se sacudió el polvo" de los complejos y estudió en profundidad esta cultura oriental reavivada y filtrada por Wright, más a fondo a partir de su viaje de 1953 a Extremo Oriente. Con el encuentro, que como hemos visto ya estaba latente desde los años universitarios, de la arquitectura japonesa, Fisac se sintió interpelado para tomarla como uno de los puntos referenciales en su investigación del espacio moderno.

En ese año, metido de lleno en la obra del conjunto de los padres Dominicos de Valladolid, fruto de su buena relación con el Provincial de esta orden en la Provincia del Santo Rosario, fue invitado para impartir una serie de conferencias sobre arquitectura religiosa a Manila. 
La acción misional dominicana en el Lejano Oriente, estaba en Manila, en donde residía el Provincial, que asignaba misioneros a Vietnam, Japón, China y Formosa -Taiwán-. Fue él quien encargó los sucesivos trabajos a Miguel Fisac -Teologado de San Pedro Mártir en Alcobendas, Conjunto de Arcas Reales en Valladolid, y el proyecto para iglesia en Taiwán en 1966133., y por tanto el responsable de que Fisac visitara Extremo Oriente desde esa fecha.

Posteriormente, volvió a Japón en 1955, en su Viaje alrededor del mundo.
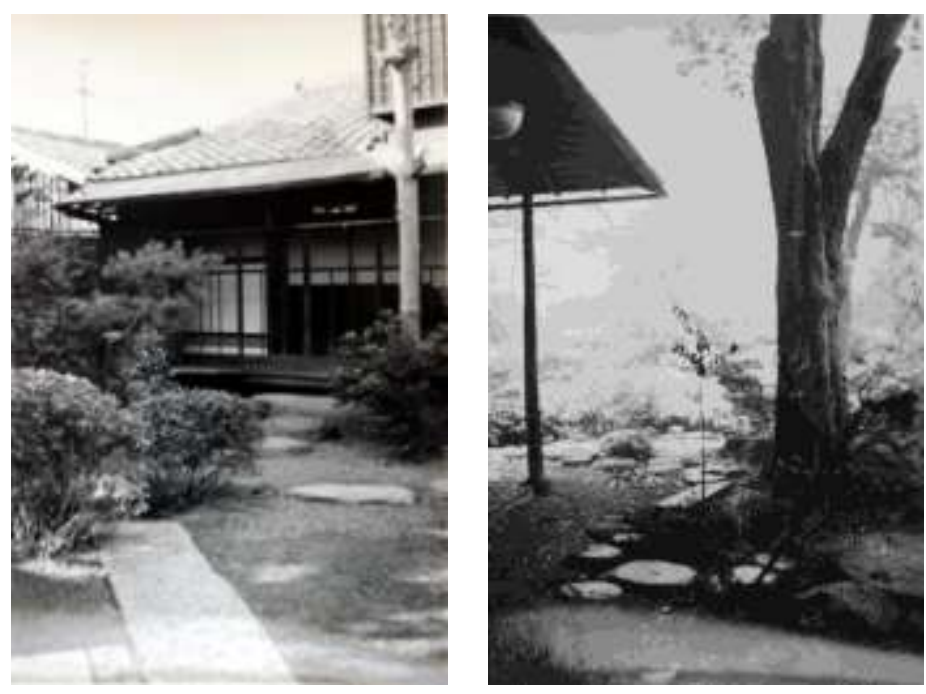

Fotografías de jardín de casa japonesa realizadas por Fisac

No parece pues que se trate, como se ha dicho en multitud de ocasiones, del encuentro de una referencia más en su búsqueda de elementos que le ayudaran a encontrar un nuevo camino para su arquitectura: el interés es anterior, si bien reavivado al tener nuevos contactos a través de los viajes.

Como antecedentes próximos, no podemos dejar de citar que fueron muchos los arquitectos, maestros del siglo XX, que se acercaron a Japón, a su filosofía y su cultura, y se dejaron seducir por ella a través del estudio o la fascinación por la obra y la vida de Frank Lloyd Wright. De esta forma en los casos de maestros como Sainz de Oiza, Jorn Utzon, Fernando Távora, u otros muy cercanos a Fisac como Richard Neutra así parece que sucedió; aunque el posterior desarrollo intelectual individual de esos fundamentos japoneses siguieran líneas totalmente divergentes.

133 Tras el crecimiento exponencial de católicos en la isla en la década de los 50, se vió la necesidad de una nueva iglesia, que proyectó Fisac. Para una información más completa sobre los Dominicos en Extremo Oriente, Borao, J.E. Dominicos españoles en Taiwan (1859-1960): primer siglo de historia de la Iglesia católica en la isla, 1 
Sin embargo, en el caso de los arquitectos escandinavos, -entre los que podemos destacar a Aalto, Asplund, o Lewerentz- en los que también se dio esta especial seducción por Japón, existieron otras vías de conocimiento de la tradición japonesa, como la construcción, iniciada en 1935 en Estocolmo, de la casa de té Zui-ki-tei, por impulso de la japanóloga Ida Trotzig' ${ }^{134}$. Por esos años, Aalto se desplazó a Estocolmo en varias ocasiones para encontrarse con Asplund, por lo que es lógico que fuera a visitar la casa de té -suposición ampliamente aceptada por los estudiosos de Aalto, incluido Juhani Pallasmaa-.

En el mismo año 1935, Aalto dicta una conferencia en la Swedish Carft Society de Nueva York:

"...There is a civilization that, even in its traditional phase, its handcraft era, shaved enormous sensitivity and tact towards the individual in this regard. I mean parts of the Japanese culture, which, with its limited range of raw materials and forms, inculcated a virtuoso skill in creating variations and almost daily recombinations. Its great predilection for flowers, plants, and natural objects is a unique example. The contact with nature and its constantly observable change is a way of life that has difficulty getting along with concepts that are too formalistic..." 135.

Asimismo, también en 1935, Tetsuro Yoshida publicó el libro La Casa Japonesa, que también resultó muy influyente para Aalto, especialmente para el diseño del jardín de invierno de Villa Mairea (1939).

\footnotetext{
${ }^{134}$ Fotógrafa, etnóloga y japanóloga sueca, que vivió más de 30 años en Japón, inspiradora del primer pabellón de té en el Museo etnográfico de Estocolmo.

135 Aalto, A. (1935). From Rationalism and Man. Conferencia dictada en el encuentro anual de la Swedish Craft Society de New York el día 9 de mayo. "...Existe una civilización que, incluso en su fase tradicional, en su era artesanal, mostró una enorme sensibilidad y tacto hacia el individuo en este sentido. Me refiero a ciertas partes de la cultura japonesa, que, con su limitada gama de materiales y formas, inclucaron una virtuosa habilidad en la creación de variaciones y recombinaciones. Su gran predilección por las flores, las plantas y los objetos naturales son ejemplos únicos. El contacto con la naturaleza y la contemplación de su constante cambio es una forma de vida que tiene la dificultad de llevarse bien con ciertos conceptos que son demasiado formalistas..." Posteriormente, en 1937, Aalto leyó el libro de las casas de Bruno Taut a través de Hugo Valvanne, agregado cultural de Finlandia en Japón, si bien se desconoce el alcance del interés sobre ello para Aalto.
} 


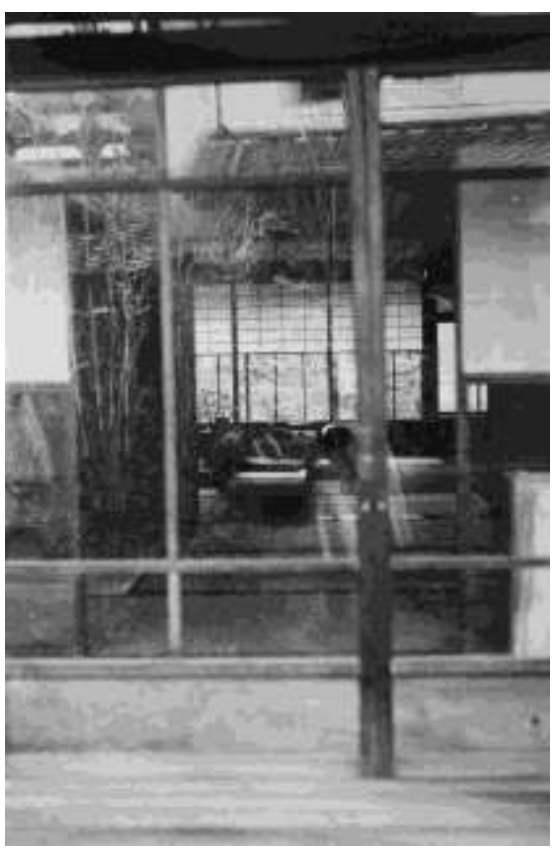

Fotografías de interior de casa japonesa realizada por Miguel Fisac

Habida cuenta que los encuentros entre Alvar Aalto y Wright no se produjeron hasta 1939, cuatro años después de la conferencia, podemos concluir que, al menos para Aalto, -aunque intuimos que para el grupo de arquitectos escandinavos-, la influencia japonesa no llegó en primera instancia a través de Wright. De cualquier forma, aunque no fuera la vía primera de conocimiento, es indudable que las referencias japonesas de la obra de Wright influyeron de forma importante en el posterior desarrollo de la arquitectura de Aalto.

Posteriormente, en la visita que realiza Alvar Aalto a España en 1951, no deja de ser sorprendente que no aparezca recogida ninguna mención a Japón en el tiempo que dedicó a visitar las calles de Barcelona, Madrid o la tan famosa visita a El Escorial136, en la que Fisac fue uno de los acompañantes, y que posteriormente fue recogida en el Boletín de la Dirección General de Arquitectura de 1951.

El caso de Wright merece señalarse especialmente, como precursor de un gran número de influencias procedentes de Japón.

136 Una crónica detallada de la visita de Alvar Aalto a El Escorial puede encontrarse en Delgado Orusco, E. (2002). Alvar Aalto en El Escorial. Actas del Simposium El monasterio del Escorial y la arquitectura, 8/11-92002, 437-460. San Lorenzo de El Escorial: Real Centro Universitario Escorial-Maria Cristina. 
La primera visita de Wright a Japón se produjo en 1905, con una estancia de seis meses en la que recorrió el país. A lo largo de su vida, en la que se suceden largas estancias y una importante cantidad de obras de toda índole en tierras japonesas, se irán cristalizando ciertas ideas subyacentes a la arquitectura japonesa en su obra.

Pero la única vía de conocimiento de Japón no fue únicamente a través del pensamiento estético de Fenollosa ${ }^{137}$, sino a través de Silsbez -primero-; y Sullivan después-, del que fuera estrecho colaborador, y del cual heredó, entre otras cosas, su pasión por el arte tradicional japonés -no en vano Wright llegó a disponer de una colección de más de 6000 objetos, cuadros, grabados, etc...-

Posteriormente, Wright tuvo contacto con Kakuzo Okakura ${ }^{138}$, quien comisarió la exposición del pabellón japonés de la Exposición Colombina del parque Jackson de Chicago, en 1893 -que Wright negó visitar nunca-, que reproducía el Pabellón del Fénix (Ho-o-den Pavillion) cerca de Tokio, y que tuvo una importante repercusión sobre la ciudad. Okakura fue quien escribió "El libro del té" en 1906, con el que obsequió a Wright el embajador de EEUU en Japón, y es allí donde aparece la frase de Lao-Tsé que será referente tanto para Wright como posteriormente para Fisac a lo largo de sus vidas.

"The reality of the building does not consist in the roof and walls but in the space within to be lived in"139

Esta frase tuvo una gran repercusión en la vida y la obra de Wright. De hecho, ordenó colocar la sentencia esculpida en Taliesin, y refiriéndose a su obra, diría a sus alumnos "Lao-Tsé lo dijo, pero yo lo construí".

Asimismo, según los estudios de Kevin Nute ${ }^{140}$, los trabajos realizados por el etnólogo Edward S. Morse sobre la arquitectura doméstica de clase media japonesa puso tener

\footnotetext{
137 Wright asistió a varias conferencias dictadas por Fenollosa, importante orientalista estadounidense, y a partir de entonces tuvieron mucha relación, unidos por la pasión que tenían ambos por el arte y la filosofía japonesa.

138 Okakura fue un filósofo, escritor, historiador y crítico de arte japonés, Director de la Escuela de Bellas Artes de Tokio, y discípulo de Ernest Fenollosa, a quién sucedió en el cargo de comisario en el Museo de Bellas Artes de Boston.

139 La traducción libre que de esta frase de Lao-Tsé hace Miguel Fisac es: "cuatro paredes y un techo no son arquitectura, sino el aire que queda dentro" que derivará en su definición de arquitectura como un trozo de aire humanizado y bellamente delimitado. Véase Apéndice 1. Conferencia en la Escuela Técnica Superior de Arquitectura de Valencia, 1995.

140 Nute, K. Frank Lloyd Wright and Japan. En este libro se describe de forma detallada los orígenes y el desarrollo de la relación intelectual y arquitectónica de Wright con Japón. El libro de Edward Morse (18381925) referido es Japanese Homes and their Surrounding (1886), que tuvo gran difusión e importancia en la época, sobre todo por la novedad de los conceptos arquitectónicos estudiados y la inclusión de sugerentes imágenes.
} 
también cierto impacto en Wright, sobre todo en los diseños de las Prairie Houses, mediante la eliminación de varias características típicas de las viviendas de Estados Unidos, sobre todo en lo que a la continuidad espacial se refiere.

Fundamentalmente, las enseñanzas extraídas de Japón por Wright, sin ánimo de realizar un listado exhaustivo, fueron las siguientes:

- Aleros profundos, porches abiertos, y largos muros que amplifican la extensión del espacio, y a su vez delimitan el paisaje y subrayan el horizonte.

- Grandes huecos, que hacen patente la búsqueda de la continuidad espacial, y fusionan interior y exterior en un sólo espacio.

- Continuidad espacial interior-exterior. Utilización de recursos para negar la frontera, creando la continuidad espacial entre el objeto y el observador.

- La consideración de la vivienda como un "templo" de la vida familiar, un matrimonio entre lo religioso y lo doméstico, en torno a un altar, una suerte de corazón central comunitario, que trae múltiples e interesantes posibilidades espaciales. Esto se refuerza con la idea, ya vista en el Ho-o-den Pavillion, del hogar como una gran habitación; una estructura abierta que se aleja de la noción occidental de la arquitectura como una caja portante.

- El realce de la naturaleza, que potencia la espacialidad de la arquitectura.

- La adopción de mecanismos de doble circulación, utilizando corredores exteriores.

- La utilización expresiva de los materiales desnudos, y su trabajo mediante técnicas tradicionales. El Kōshi (entramado de madera, perteneciente a la fachada, que proporciona texturas especiales) es especialmente evocador de texturas.

- La estandarización de determinados elementos, -concepto que no tiene nada que ver con industrialización ni producción en serie-. Por ejemplo, la estandarización de los interiores de las viviendas en tatamis (de 1,91 x 0,955 $\mathrm{m})$.

- La búsqueda de la horizontalidad en el diseño, para integrar la arquitectura y la naturaleza. En este aspecto, es reseñable la respuesta arquitectónica al paisaje de determinadas obras de Wright, buscando dar una respuesta "japonesa", de conexión, respeto y subrayado de la naturaleza; la búsqueda de una arquitectura orgánica, que surge con el entorno y responde a su enclave en el paisaje. 


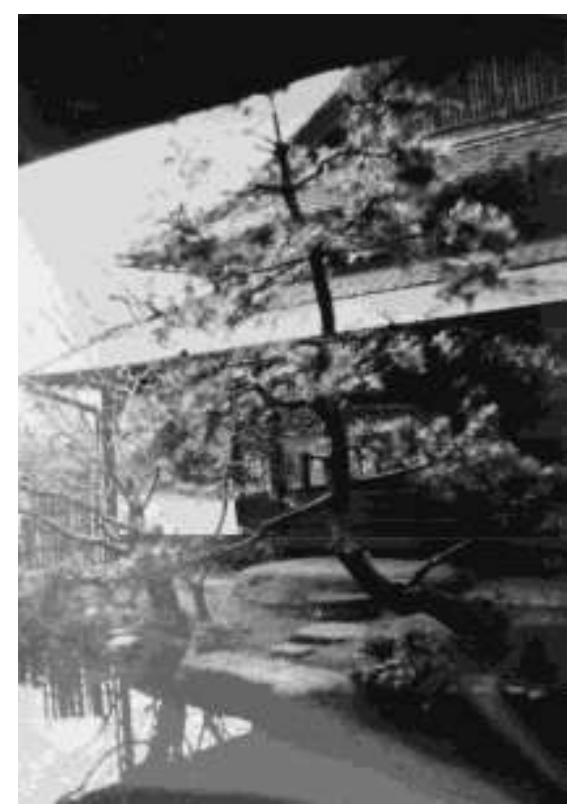

Fotografía de jardín de templo japonés realizada por Miguel Fisac

El caso de Fisac y su relación con Japón tiene un itinerario parecido al de Alvar Aalto: existe una diferenciación entre una primera vía de interés por Japón, y otra segunda de conocimiento y profundización posterior.

En este caso el primer conocimiento sí que se produjo a través de Frank Lloyd Wright, como el propio Fisac manifestó, pero la profundización en los fundamentos del japonesismo se filtra a través de otras vías.

Y esto es importante porque entrará en juego una figura destacada del desarrollo artístico español de aquella época: Jorge Oteiza.

Oteiza y Fisac fueron conocidos y colaboradores, cuya amistad se prolongó más allá de la relación profesional en el conjunto de Arcas Reales de Valladolid ${ }^{141}$. Así, compartieron relación epistolar, mesa de conferencia en varias ocasiones ${ }^{142}$, o debate sobre el arte y la arquitectura...y qué duda cabe de que cuando comenzó su

141 Sirva como ejemplo esta relación de bocetos no exhaustiva: Aparición de la Virgen a Santo Domingo; Elías en su carro de fuego; Un reloj de sol con la figura de Jesús resucitando a Lázaro, Escuadrilla de Ángeles; Savonarola en su fuero interno; o la imagen de Santo Domingo, esta sí colocada en lo alto del exterior del ábside.

142 Como por ejemplo el debate celebrado en el Ateneo Mercantil de Valencia en 1958 "La ciudad como obra de arte", en el que además de Fisac y Oteiza, participaron Chueca Goitia, Carvajal y el grupo Parpalló. Cfr. Martínez Gorriarán, C. Jorge Oteiza. Hacedor de vacios 
colaboración en 1953, en pleno auge del interés de ambos por lo japonés, intercambiaron ideas e impresiones sobre el tema, y compartieron el descubrimiento.

Fue Sáenz de Oiza quién descubrió a Oteiza las posibilidades de lo japonés a partir de su colaboración en Aránzazu desde 1950, influencia procedente, como se ha dicho, del interés del primero por la obra de Wright ${ }^{143}$. Sin embargo, no es hasta después de la colaboración con Fisac cuando comienza a desarrollar en su obra estas ideas.

No cabe duda que la tradición oriental fue uno de los fundamentos de la obra de Oteiza, en concreto en dos cuestiones, como veremos. En primer lugar su encuentro con el vacio. $Y$ en segundo lugar su reflexión sobre un concepto también originario de la cultura oriental, unos espacios que podemos llamar "intermedios", semi-públicos, con una aplicación cercana al paisaje urbano.

Una reflexión muy profunda y desarrollada sobre ello la encontramos en la Tesis Doctoral de María Jesús Muñoz ${ }^{144}$, en la que se nos demuestra que las investigaciones oteizianas sobre el vacio, tienen su origen en Japón. Y no sólo eso, sino que ese vacío puede tener un desarrollo interesantísimo desde el punto de vista del urbanismo, -que tiene relación con las ideas que Fisac desarrolla posteriormente en los llamados "espacios de convivencia" de La Molécula Urbana-, de la que hablaremos posteriormente.

"Esta observación oteizesca sobre el vacío, el área de silencio y desocupación, esta suerte de Cero espacial y expresivo, signo neutralizado y vacío, tiene relación con un concepto en apariencia diverso, originalmente oriental, que Kurokawa define como EnSpace o Espacio-Medio.

\section{(...)}

Según los pensadores japoneses, este posible espacio crómlech de Oteiza se proyecta hacia una dimensión urbanística, social, concebido como un espacio intermedio, un conector urbano o sistema de conexión, que intenta enlazar el espacio vivido (espacio privado) con el espacio social (espacio público). Este enlace serviría asimismo para, de hecho, transmitir información, una suerte de camino de amplificación, generando un nuevo sentimiento de "estar unidos" para los Ciudadanos.

Esta realidad, dentro de la filosofía japonesa se vincula al complicado concepto de lo que llaman Espacio Ma, en lo que vendría a ser una zona de amortiguación, tercer

\footnotetext{
143 Pelay, M. (1978). Oteiza. Su vida, su obra, su pensamiento, su palabra. Bilbao: La Gran Enciclopedia vasca.

144 Muñoz, M. J. (1988). El Minimalismo en Arquitectura. El precedente de Jorge Oteiza (tesis doctoral). Madrid: Universidad Politécnica de Madrid.
} 
factor, una suerte de área o espacio "gris", que no fuera ni interior ni exterior, que no encarnará "ninguna de las ideas opuestas". Los intérpretes japoneses, indican la necesidad de proyectar espacios Ma para intercambiar cultura dentro de la zona urbana, en una función similar a las del pozo antiguo donde las personas iban a charlar.

Espacio semi público o "intermedio", en definitiva.

Posteriormente, áreas urbanas japonesas menos precisas, como las situadas por ejemplo, bajo los aleros de los edificios, se consideran desde esta luz, el equivalente de la plaza o el square de las ciudades europeas."
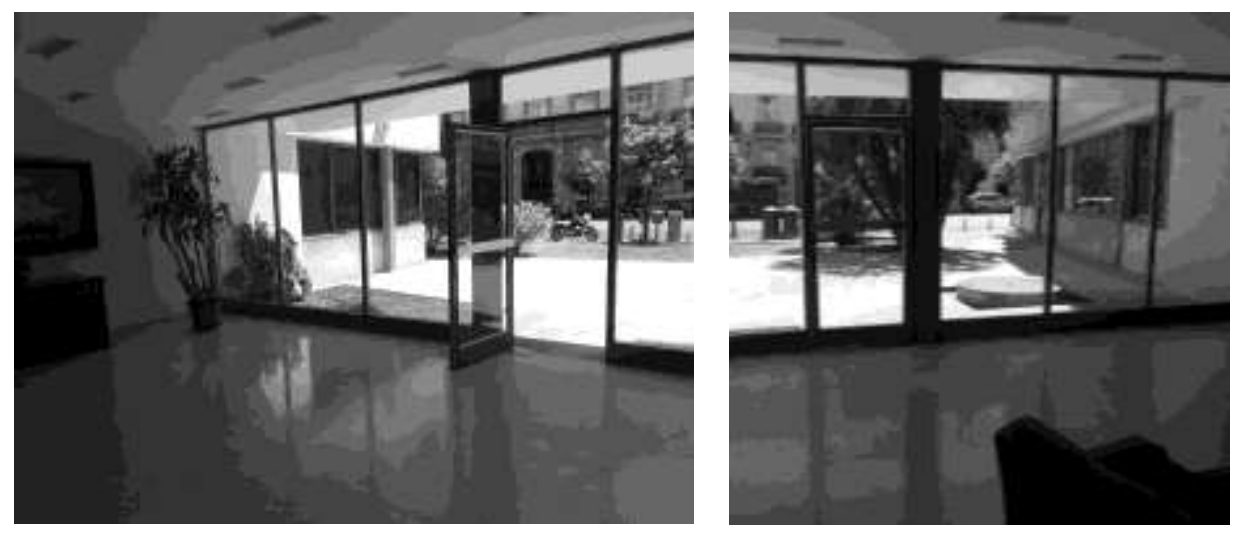

Edificio de viviendas en Valencia. Arquitecto, Miguel Fisac (1962). El acceso dispone de un umbral con una fuente en la zona derecha y un parterre en la parte izquierda, cuya geometría singular en el proyecto -no construido-se incorporaba al interior atravesando el paño de vidrio.

En 1957 conocerá personalmente a Kenzo Tange (era jurado de la Bienal de Sao Paulo en la que participó), realizando al año siguiente, 1958, una serie de esculturas denominadas "Homenaje a Kenzo Tange", en la que la investigación sobre el vacío es protagonista.

Desde su infancia, la soledad, además de conducirle a la contemplación de la naturaleza, "le llevó a inventar dos juegos que luego reconoció como el fundamento inconsciente de su concepción esencial del arte: buscar el vacio, abrir huecos y protegerse del mundo hostil contemplándolo a través de ellos"145.

${ }^{145}$ Martínez Gorriarán, C. Op. cit. 
Estudió ciertos recintos sagrados japoneses, como los jardines-templos de Kyoto y los contempló intelectualmente en paralelo a los crómlech vascos, interesándose por la dualidad espacio lleno-espacio vacío -ausencia-. De esta forma nace su expresión triunfalista : "Hemos encontrado nada"146. El vacío es lo positivo de su investigación.

Y esto se traslada también a la trascendencia del lugar en el que se encuentra la arquitectura. En su libro Quosque Tandem...! (1963), junto a la fotografía de un templo cercano a Kyoto explica su idea de la trascendencia del espacio vacío:

"En su sentido físico, la idea de espacio vacío aparece en este ejemplo como marco que destaca el lugar pero también como marco receptivo de fenómenos espirituales"147.

Por tanto, la importancia del espacio vacío en el templo japonés también reside en la creación de un recinto en el que a través de un cercado se distingue entre interior y exterior, que caracteriza de forma distinta la consideración tradicional del "dentro" y el "fuera", idea a la que también será sensible Miguel Fisac.

Fullaondo establece una relación causa-efecto en la Ley de los Cambios de Oteiza, aplicada al concepto de ocupación del lugar. "Utilizando la primera ley de los cambios, podemos deducir que el hombre encuentra un espacio y tiende a ocuparlo, dejando marcada su huella sobre el lugar. Según la segunda ley, una vez ocupado, lleno el espacio, se tenderá a vaciarlo hasta encontrar una visión serena de espacio despojado de toda expresión".

Todo ello puede encontrar su origen en las reflexiones de Okakura sobre la relevancia del vacío especialmente en el Sukiya -el pabellón del té, o también conocido precisamente como Casa del Vacío-.

"Es sólo en el vacío, donde se halla lo que es verdaderamente esencial. Una habitación existe por el espacio vacío comprendido entre las paredes y el techo, no por el techo y las paredes mismas. La utilidad de una jarra de agua consiste en el espacio vacío en que se puede poner el agua, no en la forma o en la materia de la jarra. El vacío es omnipotente, porque puede contenerlo todo. Sólo en el vacío es posible el movimiento.

Quién pueda hacer de sí mismo un vacío en el que los demás puedan penetrar libremente, será el dueño de todas las situaciones; el todo puede siempre dominar la parte." 148

\footnotetext{
146 Muñoa, P. La vida como experimento

147 Espuelas, F. (1999). El claro en el bosque. Reflexiones sobre el vacío en la arquitectura. Colección Arquithesis, n. 5. Barcelona: Fundación Caja de Arquitectos

${ }^{148}$ Okakura, K. (1906). Libro del té. Cuarta edición, 2005. Barcelona: Kairos
} 
Asimismo, como se ha dicho, en su traslación a una dimensión urbanística, el espacio crómlech tendrá también relación con el concepto de En-Pace o Espacio Medio. Este espacio es traducido por Oteiza como un espacio intermedio, un conector urbano 0 sistema de conexión, que intenta enlazar el espacio vivido con el espacio social.

Centrémonos en cómo influye en Fisac la arquitectura japonesa.

"La casa japonesa es punto y aparte. Confieso paladinamente que ni la arquitectura clásica y renacentista, ni los grandes maestros contemporáneos me han enseñado más que ella. En la casa japonesa la arquitectura está en su sitio: como subsidiaria de la Naturaleza. Para ayudarla y suplirla cuando no hay más remedio. Plantea la vida humana lo más cerca posible a la meta ideal: el Paraíso. Adán y Eva no tuvieron allí casa, porque no sentían frío ni calor, les molestaba el sol, ni les resultaba desagradable la lluvia. Y la casa japonesa casi consigue otro tanto: pasar inadvertida en el jardín, crear un trozo de aire simple y bellamente limitado. ¿Cómo alcanza esto? Con una estructura de madera de ciprés o cedro, sosteniendo un techo y unos bastidores ligerísimos que enmarcan una superficie de cristal, de papel, o de madera, con los que se aísla del exterior, se tamiza la luz, o se oscurecen totalmente los recintos interiores.

\section{(...)}

La casa japonesa tiene un amplio alero de más de un metro de vuelo, que protege un corredor abierto a todo alrededor de ella, lo que hace casi imposible que sus paredes correderas puedan mojarse con la lluvia o la nieve. Entre los pies derechos de la estructura se colocan -ya lo he dicho- unos bastidores con vidrio uno, con papel otro y un tercero de madera."149

La emoción generada por la casa japonesa, podríamos entenderla como basada en la delicadeza con que se posa en la tierra, en la sutileza que de alguna manera genera su exquisita arquitectura. Ello contrasta, a priori, con otros conceptos con los que se se identifica a Fisac.

Sin embargo, al reflexionar sobre ello nos damos cuenta que se trata de cuestiones complementarias. No es incompatible la potencia de lo estereotómico que puede caracterizar una parte de la obra de Fisac, con la ligereza tectónica de un pabellón de té. La fuerza que los conexiona es la humildad en ocasiones invocada por Fisac; la belleza de la materialidad mostrada de forma desnuda, o cuanto menos sincera, la energía desprendida de una meditación profunda sobre la esencia de las cosas, donde, como se dice en el citado Libro del Té "cualquier detalle ha sido preparado con un

149 Fisac, M. (1956c). Op. cit. 
cuidado aún más exquisito que el necesario para construir un palacio o el templo más fastuoso." 150

Fisac será sensible a los conceptos y al tratamiento japonés del paisaje, que transforma o inventa el entorno, que crea un nuevo paisaje en búsqueda de una nueva belleza, que pareciera que se adelanta a la naturaleza.

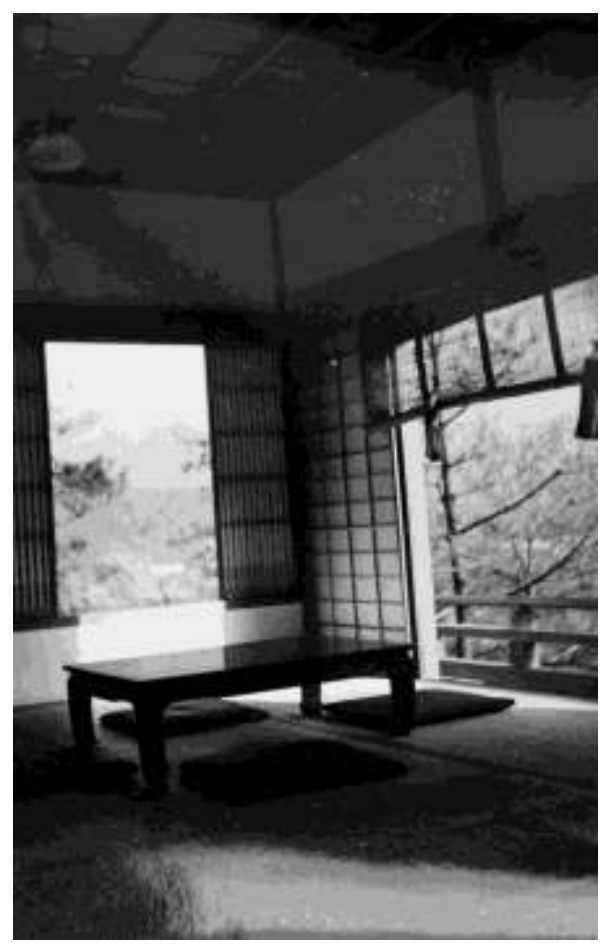

Fotografías del interior de una casa japonesa realizada por Miguel Fisac en su Viaje Alrededor del Mundo (1955).

"He comparado en alguna ocasión el jardín japonés con las fieras enjauladas, que son más salvajes aún que cuando están en libertad. El jardín francés con plantas recortadas haciendo dibujitos cursis de bordados de mantelería de principios de siglo, viene a ser como domesticar a la fiera: convertir al león en un perro san Bernardo. Por el contrario, en los jardines japoneses, se enrabisca a la fiera enjaulándola, para conseguir, erizando su piel, una soberbia belleza. Y para que esta imagen de la fiera enjaulada sea más auténtica, hasta existen los barrotes de la jaula: son los palos o los alambres con que amarran las ramas de los árboles, a fin de retorcerlas y forzarlas a seguir direcciones violentas, hacia abajo. (...)

${ }^{150}$ Kakuzo Okakura. op. cit 
Ante el paisaje japonés se plantea la duda de si ha sido antes el paisaje natural o su interpretación pictórica, y esta duda no tiene una contestación tan clara como a primera vista pudiera parecer, porque toda esa rara belleza que flota en todo lo japonés procede de una refinadísima cultura estética a la que nunca se ha llegado en Occidente. Tiene uno la impresión de que aquel pueblo es muy capaz de haber obligado a la naturaleza a encajar en los moldes de sus conceptos estéticos de esa idea de la belleza que, sabiendo del marco estrecho de las artes plásticas, irrumpe en la vida toda." 151

El encuentro entre arquitectura y paisaje también se facilita a través de otros mecanismos, como la disposición de plataformas sobre la naturaleza -posada sobre ella con delicadas patas de madera, a medio metro del suelo-, simplemente para sentarse a meditar o en compañía de otros; la estratégica ubicación de puertas y cercados delimitando jardines o la singularidad de una exterioridad; o la disgregación de pabellones unidos por galerías, que ocupan y acotan el espacio, y se posicionan en la naturaleza, conquistándola o dejándose conquistar por ella.

Esto lo veremos en ciertas obras de Fisac: pero sirva como cita la disposición en el paisaje de su Teologado de Alcobendas, la forma de acotar la exterioridad en el corazón del conjunto, y las conexiones a través de umbrales, pasillos y galerías abiertas 0 cerradas, que buscan la compenetración con la naturaleza y aportan una singular intensidad al vacío -Oteiza-, reafirmando que éste no es el espacio sobrante de la parte construida, lo cual puede considerarse, a la luz del pensamiento de Lao-Tsé, y por tanto profundamente japonés. Y la jardinería del claustro, totalmente ligada a la inspiración japonesa, en la que todos los elementos nos conexionan con la esencia de la meditación oriental: los elementos de rocalla, el estanque de agua, las plantaciones, las diferencias de cota que aportan profundidad al espacio, las texturas y materiales, el estudiado plano del suelo, las zonas de sombra, la escalera que se posa delicadamente, etc...

Por otra parte, dado el interés que mostró Fisac por la jardinería durante toda su vida, así como los conocimientos desplegados en su obra, también se dejó seducir por la ikebana, el arte de colocar flores. Un arte efímero, "fugaz y fluyente", que contribuye a la experiencia estética de una forma muy importante.

"No hay arte sin tensión ni belleza sin equilibrio. Semejante axioma, sin duda, me lo ha inspirado la manera de colocar las flores en el Japón. Tiene allí el arte de colocar flores un antiquísimo y religioso origen, y una explicación filosófica como programa: el bien es esa parte de nuestro ser que sube derecho hacia arriba; el mal, esa otra que baja, rastrera y retorcida y nuestra voluntad, en forma de horquilla, duda atraída hacia uno u otro deseo. Tal duda es la que crea la tensión estética, mientras el equilibrio logra que la belleza en las infinitas soluciones posibles de la colocación de flores, en las que

151 Fisac, M. (1956c). Op. cit. 
Memoria, Aprendizaje y Experimento. La invención del paisaje en Miguel Fisac

Aprendizaje. Otras vías

consiguen unir la sabiduría, la armonía y la gracia que pudiera tener una joya de pintura o escultura, unida a la humilde ligereza de lo que se hace para solo unos días. No es la aspiración de ellos un "arte en conserva" como el nuestro, sino la constante creación de formas estéticas, fugaces y fluyentes como la vida misma." 152

Todo ello se manifestará en su obra. No podemos dejar de citar la casa familiar del Cerro del Aire (1956) así como las sucesivas ampliaciones que no hacen sino incrementar esta influencia japonesa en el conjunto. Destaca su espacialidad interior en torno a un patio cuya naturaleza trata de invadir el espacio de estar, donde no faltan elementos esenciales del paisaje japonés como las piedras -cuidadosamente colocadas-, o el agua, a través de un pequeño estanque. 
Memoria, Aprendizaje y Experimento. La invención del paisaje en Miguel Fisac Aprendizaje. Otras vías

Y su comunión con el paisaje. El ritual de subida a la parte más elevada de la parcela, a través de un camino sinuoso, la existencia de un espacio previo al acceso, una suerte de terraza desde donde se domina una visión lejana de esa zona de Madrid, imbuido en una naturaleza creada, de apariencia salvaje pero cuidadosamente seleccionada, el sobrio despojamiento de sus muros, la marcada horizontalidad, o los inmensos huecos son relaciones que conectan íntimamente la casa con el paisaje.
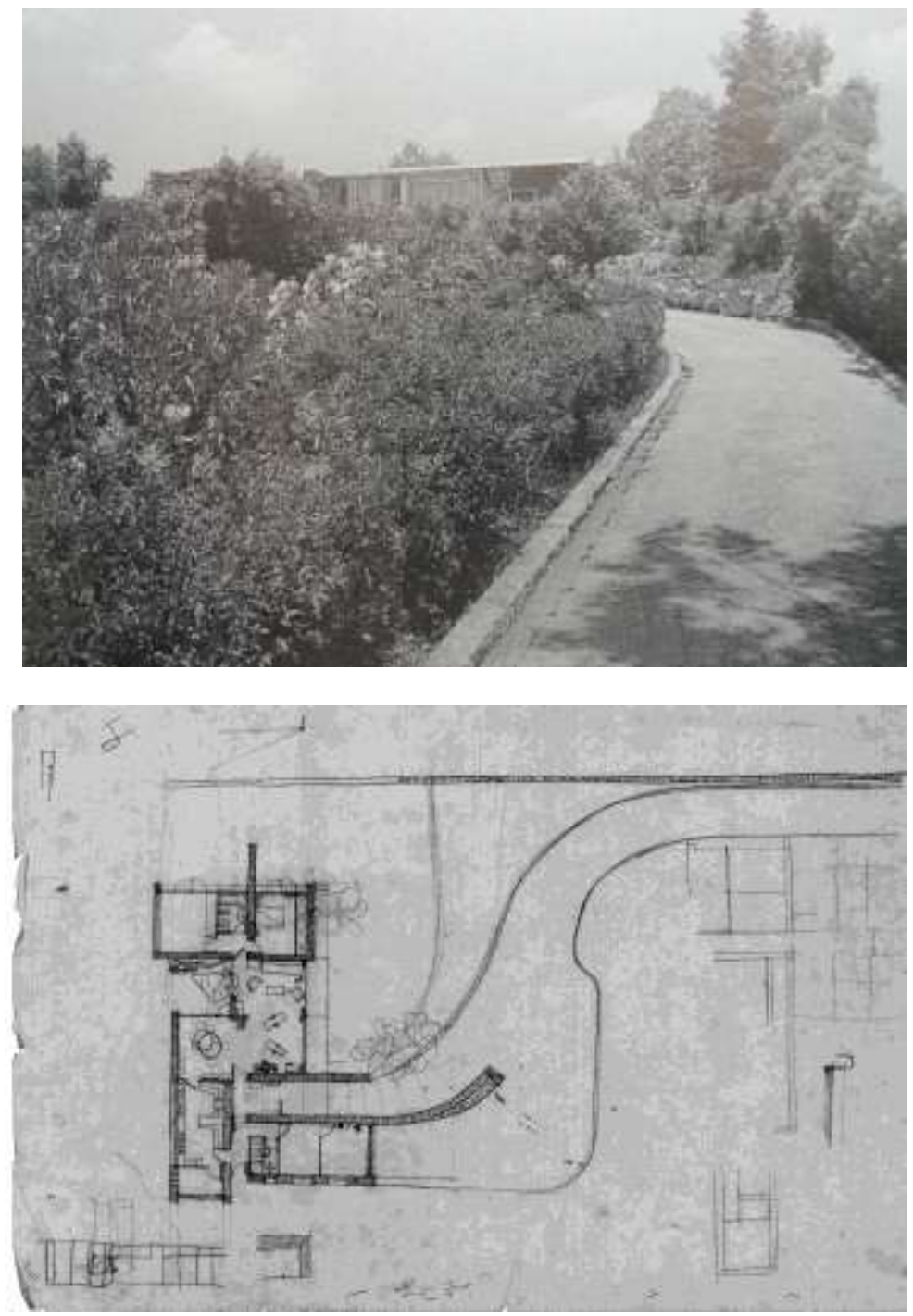

Miguel Fisac. Casa familiar en el Cerro del Aire (1956). Camino de subida a la casa y croquis del mismo. Fundación Fisac. 
Una conexión especial la encontramos en la propia definición de sukiya como casa del vacío y casa de la asimetría, existiendo también paralelismos con la casa del Cerro del Aire. Y es que tanto la sobriedad, como la apariencia de haber dejado voluntariamente algo inacabado -a fin de que la imaginación pueda acabarlo a su gusto, como leemos en el Libro del té-, hacen a la casa merecedora de esos calificativos. Y es que la casa, con sus sucesivas ampliaciones, parece estar siempre en espera de la próxima intervención.

Un elemento más hace de esta casa un homenaje al sukiya, -pabellón del té- el acceso o roji.

$Y$ es que Fisac utiliza la escalera que conduce a la casa de una forma muy japonesa, introduciendo la naturaleza para dar la bienvenida al visitante en un espacio similar al roji típico de esas arquitecturas, y que juega un papel fundamental, ya que simboliza el primer estado de la meditación, un espacio que tiene como misión romper con el mundo exterior y preparar al visitante para la experiencia estética que vivirá en el pabellón del té.

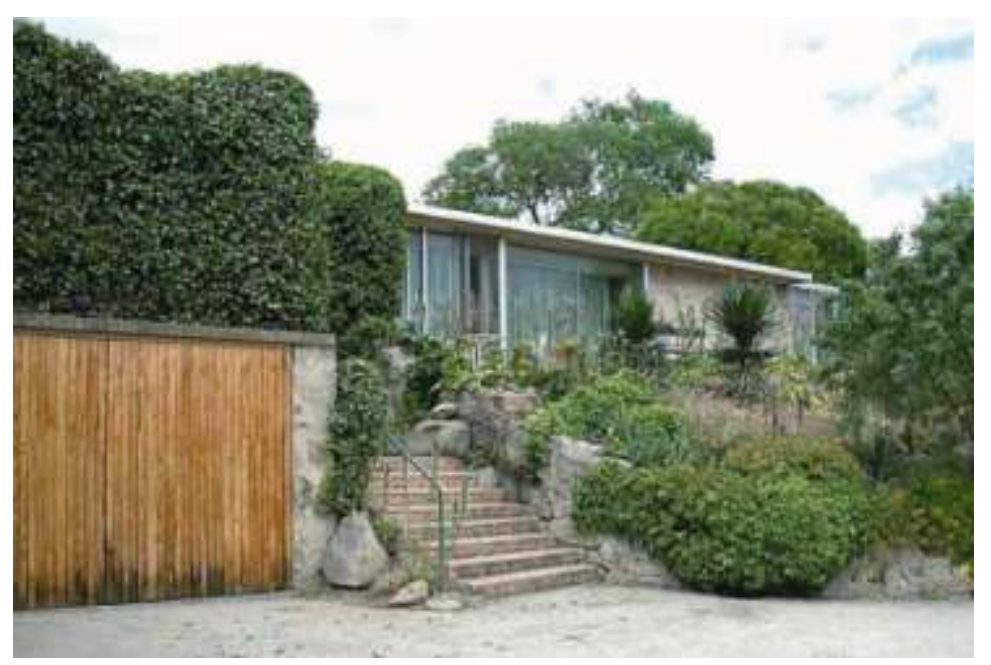

Miguel Fisac. Casa en el Cerro del Aire (1956). Fundación Fisac

"Quién ha hollado una vez el suelo del "roji", no puede olvidar jamás cuánto su espiritu se elevaba por encima de los pensamientos vulgares, mientras caminaba en la penumbra crepuscular de los árboles eternamente verdes, sobre las regulares irregularidades de los guijarros frescamente humedecidos, sobre los que se extiende un 
ligero colchón de agujas de pino secas, y mientras pasaba cerca de las linternas de granito recubiertas de musgo."153

Esta misma idea también se desarrollará en otras obras, como la iglesia de Canfranc, en la que una escalera conceptualmente a caballo entre arquitectura y naturaleza, nos hace penetrar en un espacio de sombra, un hueco profundo que nos prepara para la experiencia espiritual que nos espera en el interior.
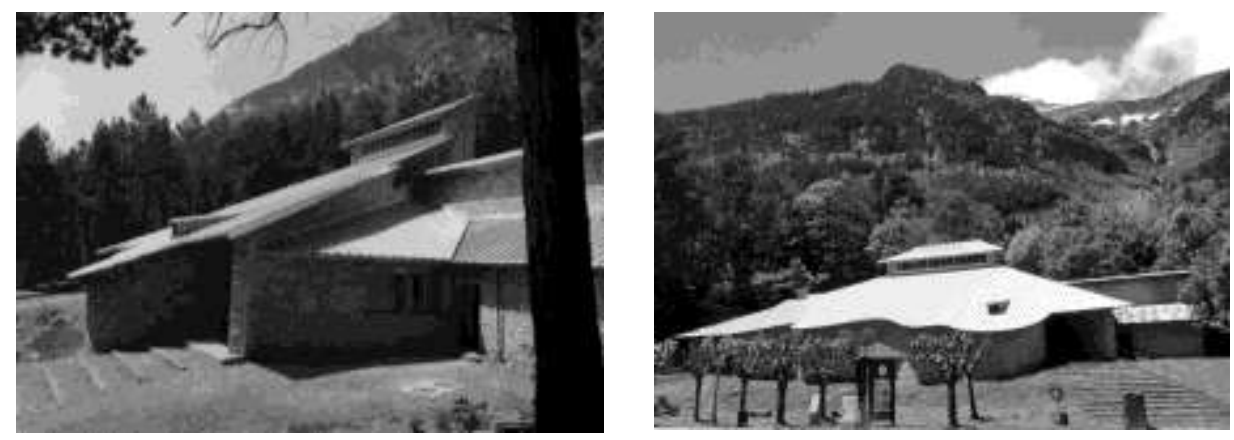

Miguel Fisac. iglesia parroquial de Canfranc, Huesca y escalera de acceso, cuyas huellas son invadidas por la hierba(1963). Fundación Fisac

En los paisajes creados tanto en el Cerro del Aire como en Canfranc, encontramos otro paralelismo con los sukiya, y es que el encuentro con la belleza reside en su materialidad, en el contraste entre el aspecto humilde y a la vez de máximo refinamiento; de su "emerger" de la naturaleza misma, de su materialidad -bambú y madera en el caso japonés, piedra, fábrica y madera en los fisacquianos- y del estudio exquisito de sus texturas mostradas en su desnudez.

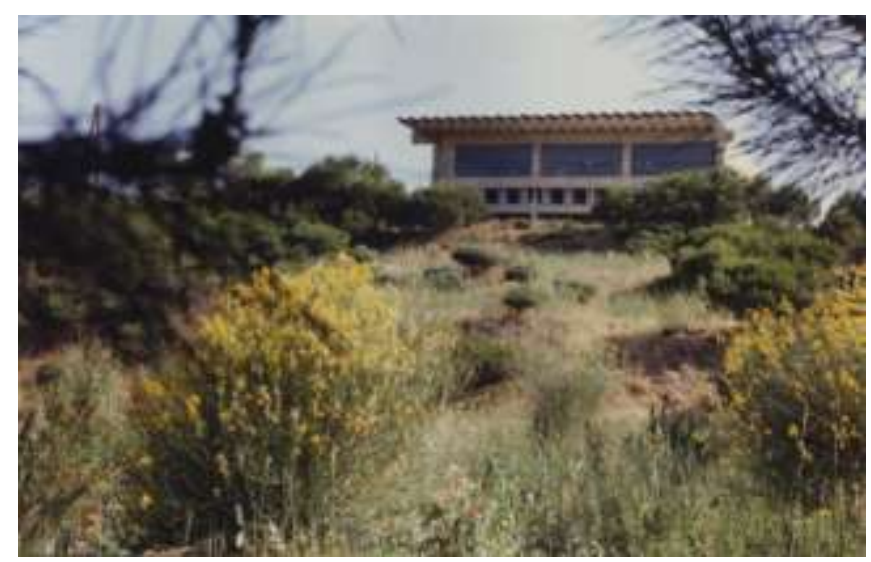

Miguel Fisac. Estudio en el Cerro del Aire (1971). Fundación Fisac

153 Kakuzo, O. (1906). Op. cit 
En definitiva, Fisac adopta una serie de conceptos esenciales tomados de la esencia de la arquitectura japonesa -tradicional y doméstica- que desarrolla en varias de sus obras, destacando para nuestra investigación la capacidad de comunicación con el entorno; la honestidad y sobriedad en el uso de los materiales, que ayuda a la integración en el entorno -en el sentido de generar la ambigüedad de quién fue primero-, y la intensa espiritualidad que desprende la sencilla expresión popular de la arquitectura, referencia no exclusiva de la cultura japonesa.

La aplicación de la esencia de los principios inherentes a la arquitectura japonesa no se producen en exclusiva en estas obras, si bien se han tomado como ejemplo gráfico de las mismas.

Por otra parte resulta sorprendente, por la fecha de proyecto y construcción del conjunto, la cantidad de características particulares de la arquitectura tradicional japonesa que aparecen en el Colegio Apostólico de Arcas Reales. Si bien el desarrollo de estas ideas trascienden el alcance de esta investigación, no podíamos dejar de citarlo.
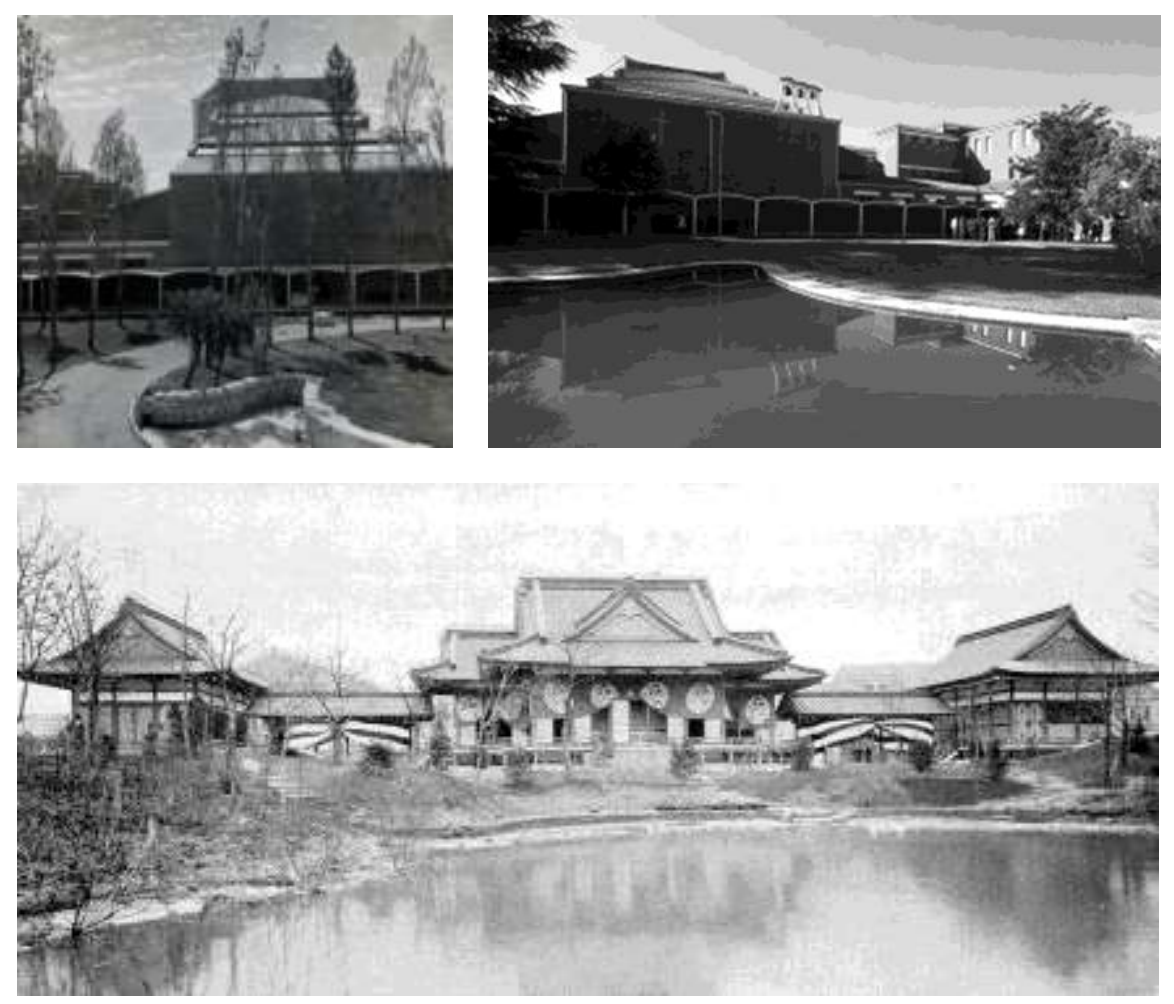

Colegio Apostólico de los PP. Dominicos en Valladolid y pabellón Ho-o-den en la exposición de Chicago en 1893. 
Memoria, Aprendizaje y Experimento. La invención del paisaje en Miguel Fisac

Aprendizaje. Otras vías

Este interés por Japón no fue para Fisac "flor de un día". Desde que conociera de primera mano su cultura, no dejará de notarse su influjo de forma continua, en su arquitectura, en sus escritos, en sus conferencias o en sus conversaciones. Personas que lo trataron en aquella época así lo atestiguan: José Antonio Moroder, hijo del promotor del edificio de viviendas de la plaza Tetuán de Valencia, que tuvo contacto continuado con Fisac desde principio de la década de los 60 , refiere una intensa admiración por Japón, que se traducía en sus conversaciones ${ }^{154}$.

En Fisac y su relación con Japón se materializan las palabras del gran poeta de Haiku Matsuo Bashō (1644-1694): "uno nunca debe imitar lo que ha heredado de sus antepasados, pero debe esforzarse por aquello por lo que sus antepasados se esforzaron"155 (Yoshida, 1969, 193), utilizando sabiamente los conceptos esenciales de su arquitectura como plataforma para construir un paisaje de su tiempo, que en el caso de Fisac se adelanta a su tiempo.

154 Conversación con José Antonio Moroder, 3 de junio de 2012.

155 Yoshida, T. (1969). The Japanese House and garden, 193. Londres: Pall Mall. Traducción JAF 


\section{3_ Maestros de la modernidad}

El encuentro de Fisac con la obra de una serie de maestros indiscutibles de la modernidad forma parte del citado aprendizaje: edificios que selecciona y estudia a través de las publicaciones, y que posteriormente visita y dibuja in situ con insistencia.

Este ejercicio autodidacta no busca copiar o seguir ideas "a pies juntillas". Se trata de realizar una mirada crítica, de investigar -dibujando- con las manos, de construir un espejo en el que reflejar y contrastar sus investigaciones. Porque en palabras de Fisac "sigo mi camino y veo pasar los trenes. Precisamente cuando yo estaba metido en todo esto de lo espacial, pasaba el tren de Kahn por delante de la puerta de mi casa y ya antes había visto pasar muchos otros.

El de Mies hay que reconocer que fue un tren de lujo, el de Kahn en ciertos aspectos podría considerarse un tren expreso, y el de Aalto de viajeros, por otra vía. Después le sucedieron los demás, como el de Rudolph, que más bien era un tren de mercancías." 156

Y después de esto, trazar un camino propio y personalísimo, desde la libertad y la independencia, alejado de modas y comprometido con el tiempo y el lugar en el que vive, "sin papanatismo por todo lo extranjero"157.

\section{Aprendiendo de los nórdicos. Asplund y Aalto}

Fisac solía llamar neo-empirismo nórdico a una arquitectura cuyo principal valedor consideraba a Erik Gunnar Asplund (1885-1940), con quien tuvo a lo largo de su vida varios reconocimientos públicos, resumidos en el artículo publicado en Quaderns ${ }^{158}$. En él se recoge fundamentalmente la trascendencia de su visita al Ayuntamiento de Gotemburgo en el viaje auspiciado por el CSIC previo a la construcción del Instituto Cajal, del que hemos dado buena cuenta.

156 Fisac, M. (1982a). Carta a mis sobrinos (estudiantes de arquitectura, 35. Edición 2007. Ciudad Real: Fundación Miguel Fisac y Lampreave y Millán editorial.

157 Idem

158 Fisac, M. (1981). Asplund en el recuerdo. Quaderns de arquitectura i urbanisme, 147, $32-33$ 
Pero no es el único reconocimiento. Ya desde 1949, Fisac estaba convencido de que en Suecia había una serie de realizaciones que merecían toda la atención: " los arquitectos suecos... hacen sencillamente la arquitectura que hay que hacer"159

Si bien queda claro que lo que más le interesó de la ampliación de la Rathaus era el espacio interior, el aire que quedaba dentro, "... aunque su fachada no me interesó ni la entiendo, su interior es muy bueno" (Alarcón, 1999, 423) no creemos que prescindiera de visitar otras obras del maestro nórdico ni que se le pasara por alto una de las grandezas de éste: la construcción de los lugares y la carga poética que era capaz de insuflar a los mismos, así como la belleza de los materiales a la luz de su propia naturaleza, en toda su veracidad.

Este encuentro, que desató el descubrimiento de un campo enorme de posibilidades para Fisac, así como la eliminación de antiguas ataduras, no sería más que el comienzo del descubrimiento de otros fundamentos o parámetros sobre los que se construye su obra.

Citar estos parámetros, y en qué medida pudieron despertar interés en Fisac, es tan difícil como arriesgado, sobre todo porque todo ello puede quedar reducido a una simple lista que no es en absoluto objeto de este estudio. Sin embargo, parece necesario detectar al menos las ideas esenciales que pudo encontrar Fisac en el quehacer de Asplund, 0 incluso aquellas categorías arquitectónicas en las que podrían coincidir procedentes de fuentes distintas, y explicar cómo se concretan en sus experiencias arquitectónicas.

Una cuestión relevante, que si bien se da en otros casos aquí cobra especial fuerza, es que el itinerario vital seguido por Asplund coincide en ciertos aspectos con el de Fisac.

El descubrimiento por Asplund, a través de sus viajes, de la arquitectura arcaica y su relación con el paisaje, su interés por la casa japonesa, la resonancia del paisaje en su arquitectura, o la profunda unión a sus raíces podrían definir intensos paralelismos entre ambos arquitectos, que a buen seguro facilitó que la identificación de Fisac por su arquitectura fuera tan intensa.

Ello nos hace preguntarnos ¿la arquitectura de Asplund, o una serie de ideas esenciales que él defendía y ponía en práctica, resuena en la obra de Fisac; es parte del Aprendizaje de nuestro arquitecto, o bien se trata de caminos paralelos y los intereses de ambos facilitan la identificación de Fisac con el maestro nórdico?

159 Sambricio, C. (1999). En torno a 1949: Gardella, del Msa y la reconstrucción, a la moderna arquitectura. En: Ignazio Gardella, [1905-1999]. Arquitectura a través de un siglo, 13-14. Madrid, Ministerio de Fomento. 


\section{$\underline{\text { La importancia de las raíces }}$}

Quizás, por el espacio cronológico que ocupa en Asplund destaca, además de la integración de lo vernáculo, la consideración y el estudio de lo clásico ${ }^{160}$, que en Fisac se diluye tras la intervención en el CSIC.

Suficientemente explicada la vinculación de Fisac con la arquitectura popular manchega y su sabiduría constructiva, ocurre algo similar con los valores tradicionales suecos en la arquitectura de Asplund.

Es curiosa la coincidencia de que en ambos casos existe cierta "ruptura" con la educación artística recibida en sendas Escuelas, tanto en el caso de Asplund en la Escuela Klara, con arquitectos más cercanos al romanticismo nacional sueco como Bergsten, Westman, Tengborn, y Östberg; como en el caso de Fisac en la Escuela de Madrid más cercana a los valores nacionales del Ministerio del Aire, ruptura certificada por Fullaondo en sus primeras incursiones en la obra del manchego.

\section{Los viajes: El interés por la arquitectura arcaica, primitiva}

Al igual que muchos otros arquitectos, y como posteriormente haría Fisac, Asplund realizó, según recogen Hakon Ahlberg ${ }^{161}$ y otros autores, un gran viaje de estudios que determinó su forma de entender la arquitectura.

En dicho viaje visitó Italia: estudió su historia, sintió emoción ante sus ruinas, analizó sus ancestros...y como también haría Fisac, recogió en una serie de Cuadernos de Viaje una serie de notas, apuntes y bocetos: pequeñas ideas que recogen la sensibilidad de su mirada, ante una ruina 0 ante una ciudad, y que encierran importantes pistas sobre los temas que le interesan.

Así, en el caso de Asplund podemos ver continuas referencias a la emoción transmitida por la arquitectura en su paisaje, por el jardín en continuidad del mismo, por el objeto en la naturaleza.

"Subimos y vi la delicia del mundo entero: la ciudad descendiendo gradualmente hacia el sur, los mil almendros en flor, los templos griegos y el profundo mar azul..."162

"Vivíamos en un pabellón de jardín, una habitación con bóveda cruzada, en medio de un jardín lleno de flores, eucaliptus, naranjos y ruiseñores, iy el paisaje!"163

160 En Asplund existe un interés especial por una serie de edificios renacentistas y barrocos, recogidos en acuarelas y apuntes de viaje

161 Gunnar Asplund, Arquitecto. 1885-1940. Murcia, 1982.

${ }^{162}$ Anotaciones 14 Febrero 1913. Sur de Agrigento (Italia). 
Posteriormente visitó Túnez. Son siempre interesantes las referencias a elementos básicos de la naturaleza utilizados como cordón umbilical con la Tierra, con el Cosmos, y como puntos de conexión con lo más profundo de su carácter, aspecto que también vemos en Fisac.

"Tenía permanentemente la impresión del cielo como una bóveda, una gran cúpula pintada de azul"164.

En ciertos apuntes ha querido ver una parte de la Crítica especializada ciertas traslaciones directas con obras concretas de arquitectura, que aquí evitaremos. En este caso, por ejemplo, se han estudiado las relaciones que pudieran existir con la bóveda del cine Skandia.

Lewerentz también emprende viajes en busca de respuestas. Las investigaciones de Luis Moreno Mansilla sobre su viaje a Italia nos da idea de cómo Lewerentz, a través de enigmáticos encuadres fotográficos, es sensible a la materialidad de las cosas. El muro del Palacio Pitti, o el pavimento de la vía de los Sepulcros en Pompeya, nos sugieren cercanía al interés por las texturas -verticales u horizontales-, íntimamente ligadas a la honestidad en el trato del material y a su diálogo con el paisaje de las arquitecturas de Fisac, más allá de los encofrados flexibles y del ladrillo del Instituto Cajal.

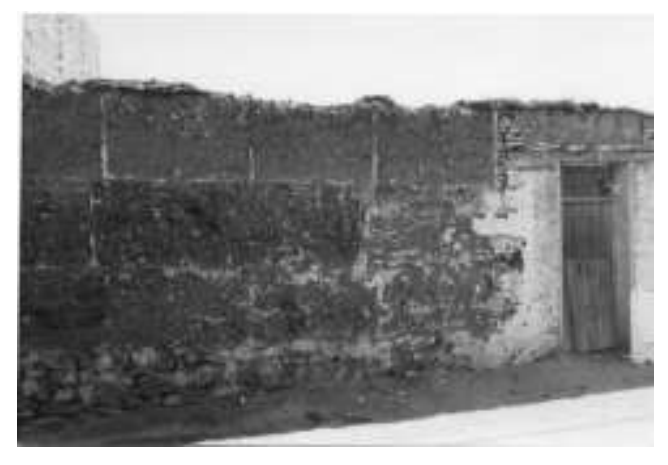

Miguel Fisac. Fotografía de un muro de tapial de La Mancha y su estructura constructiva. Fundación Fisac.

Sigurd Lewerentz. Fotografía del muro del Palacio Pitti

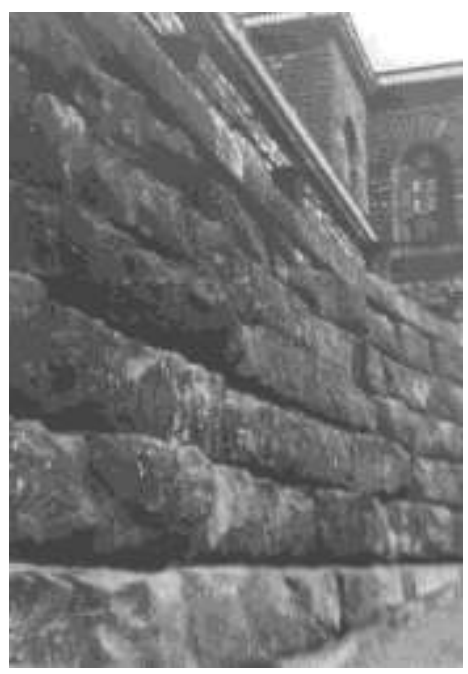

${ }^{163}$ Anotaciones 12 Marzo 1913. Albergo del Sole (Pompeya, Italia).

${ }^{164}$ Cuaderno de viaje 4 marzo 1914 


\section{La humanización de la arquitectura}

No cabe duda que la lección de Asplund de conectar emocionalmente a través de la arquitectura con las personas que van a habitarla es compartida por Fisac.

Esto es definido por Bruno Zevi como la "voluntad de lo humano", que acoge tanto lo relativo a la escala y al uso como al posicionamiento de la arquitectura ante el paisaje.

Este elemento emocional, coincidente en ambos arquitectos puede proceder de la misma fuente: la oriental, pero es definitivamente una de las características que ayuda a Fisac a conectar con su obra.

$Y$ es que en sendos casos la humanización de la arquitectura tiene tanta fuerza que se materializa, acercándose a las posturas filosóficas orientales, en las que el hombre es un concepto filosófico intermedio entre el Cielo y la Tierra.

Fisac define la arquitectura como un trozo de aire humanizado, revisitando la frase de Lao-Tsé en el libro escrito por Fullaondo ${ }^{165}$, para lo cual es preciso una relación profunda entre la arquitectura y el paisaje -físico y social-.

"Esta esencial humanización del espacio arquitectónico lleva incluidas la adecuación de la arquitectura al paisaje. Al paisaje físico en el que está ubicada; con su clima, su aspecto y sus demás circunstancias ambientales y también al paisaje psicológico de las gentes que lo han de usar; con su peculiar idiosincrasia, costumbres, etc."

Este concepto, que ayuda a la identificación de Fisac con la arquitectura de Asplund en su visita a Gotemburgo, más que proceder de una enseñanza del maestro nórdico, es la constatación de una certeza.

\section{La búsqueda de la esencia sobre todas las cosas}

Toda la arquitectura de Asplund rebosa el convencimiento de que en lo esencial, en lo más básico, subyacen las respuestas a los problemas más complejos. No se trata de simplificar sino de esencializar.

Esto se puede constatar a la luz de la clara espacialidad de su arquitectura, así como a la vista del encuentro con la autenticidad de los materiales: madera, piedra o fábrica todos ellos son tratados de forma sobria, con rigor y respeto, mostrando su propio alma y destilando su propia belleza en pro de todo el conjunto.

165 Fullaondo, J.D.(1972). Miguel Fisac. Madrid: Ministerio de Educación y Ciencia. Subdirección General de Información y Publicaciones. 
A ello se le une la meticulosidad técnica, que acaba de delimitar el camino hacia una bella esencialidad:

"Con 20 ó 30 grados bajo cero, y una sociedad muy progresista, no se puede jugar a elucubraciones fáciles, y los arquitectos suecos hacían una arquitectura técnicamente seria".

Fisac hará lo propio, sus profundas investigaciones sobre el material le llevarán a un dominio constructivo con el que reinventar sistemas, fabricaciones o texturas. El edificio se relaciona con su entorno de forma pedagógica, mostrándose como la conquista de un territorio hasta el momento inexplorado a través del hormigón in situ, el prefabricado, la fábrica caravista, etc...

\section{$\underline{\text { La resonancia del paisaje en la arquitectura. El itinerario }}$}

Las obras más emblemáticas de Asplund no sólo están unidas íntimamente al paisaje, sino al hombre en el paisaje. Esta es una de las claves de su arquitectura, y territorio común con la arquitectura de Fisac, aprendido de la arquitectura nórdica.

Si bien es cierto que esta característica no es exclusiva de la arquitectura nórdica quizás fue aprendida por ambos en la Acrópolis-, el propio Fisac se refiere en multitud de ocasiones a su aprendizaje del neo-empirismo ${ }^{166}$ nórdico, concepto que de por sí se refiere, sobre todo, a la resonancia del lugar en la arquitectura, así como al organicismo, humanismo, el equilibrio entre modernidad y tradición en el uso de los materiales y el orgullo de su raíz vernácula.

Esta constatación marcará de forma decisiva el quehacer de Miguel Fisac, en cuya obra se tendrá en cuenta, como parte del itinerario proyectual, la relación de la arquitectura en el paisaje y del paisaje en la arquitectura.

Al igual que para Asplund, "es más importante seguir el estilo del lugar que el del tiempo"167. Fisac preferirá "ver pasar los trenes" de la moda y afianzarse en el estilo del lugar, esto es, en la humanización de la arquitectura.

En el caso de Fisac, la relevancia de esta categoría es tal, que se desarrollará en mayor o menor medida en toda su obra. Esto se puede observar con claridad en obras tan distantes como el conjunto del Centro de Formación del profesorado de la Ciudad Universitaria o la capilla del Cementerio del Bosque, donde las relaciones con los

166 Bautizada así por la revista Architectural Review en 1947, una nueva arquitectura organicista y humanista, de raíz vernácula que se estaba desarrollando en Suecia después de la Segunda Guerra mundial.

${ }^{167}$ Asplund, G. (1916). Cit. por López-Peláez. 
elementos del emplazamiento, la búsqueda de alianzas con los mismos, son decisivas para potenciar esta vinculación con el entorno.

El posicionamiento ante el paisaje a veces consistirá en contemplar, otras veces en crear un paisaje nuevo, priorizar un elemento sobre otro, etc... pero siempre se defenderá el papel protagonista del "Dónde": un bosque, una plaza, un canal, una calle...

Dice López-Peláez: "el lugar, para Asplund, no era un aspecto más del problema que tenía que resolver, sino que lo entendía como fuente de inspiración necesaria para su trabajo".

De hecho, en 1931 Asplund firmará el manifiesto "Acceptera", mediante el cual adquiere el compromiso de "crear un enlace orgánico entre cultura y naturaleza, y de cualificar la arquitectura funcional en el sentido de prever su integración en la naturaleza y en la historia".

La lección de Asplund no es la única considerada por Fisac procedente de la arquitectura nórdica. Si bien el caso de Aalto merece un epígrafe aparte, también se interesó y visitó la obra de otros arquitectos, como Jacobsen o Saarinen.

De ese interés en la obra de Jacobsen procede la anécdota del Hotel Royal:

"Fui a ver a Jacobsen a Dinamarca...estaba en el Hotel Royal que acababa de ser inaugurado, me alojé incluso en él. Jacobsen estaba en los pisos superiores muy atareado ultimando detalles...pedí verle y como tarjeta de visita le presenté un fascículo de la revista Arkitehti Arkitecten en la que se había publicado una de mis obras...no me recibió, dijo que estaba muy ocupado.. "168

Una vez en Dinamarca, y aunque no hay constancia escrita de ello, dado el interés en este arquitecto, a buen seguro que visitaría, como hicieron posteriormente otros arquitectos españoles, el Ayuntamiento de Aarhus (1939); el Ayuntamiento de Rodovre (1954-1956), las Escuelas de Genofte (1951-1958) o las viviendas Bellevue (1930-1935)

Y con Saarinen, además de interesarse por el edificio de la General Motors en Detroit, tiene una deuda de gratitud, ya que la iglesia del Teologado de los Dominicos en Alcobendas es heredera de la capilla Kresge del MIT, visitada por Fisac en la década de $\operatorname{los} 50$.

${ }^{168}$ Alarcón, C. (1999). Op. cit. Fragmento de una conversación mantenida con el arquitecto Miguel Fisac en su casa-estudio del Cerro del Aire. 28 de septiembre de 1998. Parte II, Anexo E, 16. 


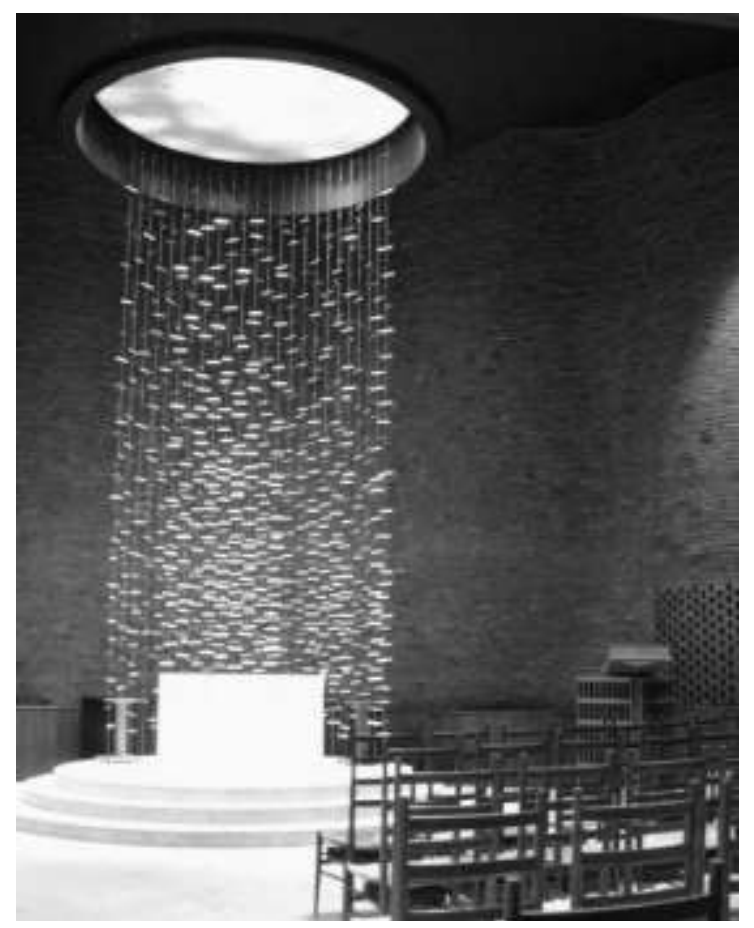

Eero Saarinen. Capilla Kresge del MIT. (1950-1955). Cambridge, Massachusetts

En la relación de aprendizaje que pudiera existir entre Fisac y Aalto no existe posibilidad de unificar un criterio, pues según el testimonio que se consulte existe por Fisac aceptación o rechazo de plano. De lo manifestado por Fisac se concluye -de hecho- una negación de cualquier aprendizaje extraído de la obra del finlandés.

Una ambigüedad que es alimentada por el propio Fisac, que unas veces afirma "conocía por fotos Villa Mairea de Aalto...pero poco más..."169 ; y sin embargo aparece en otras ocasiones entre sus influencias principales en unas notas para impartir una conferencia.

${ }^{169}$ Alarcón, C. (1999). Op. cit. Parte II, Anexo E, 15. 

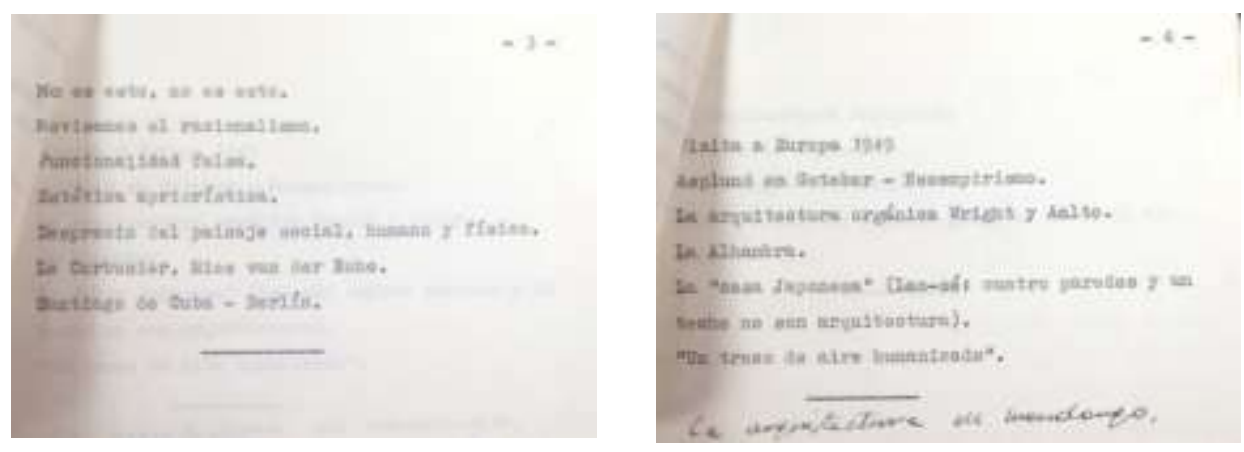

Extracto de notas para la Conferencia dictada por Miguel Fisac en la Cátedra de Estudios Contemporáneos. 3 de diciembre de 1979. Obsérvese la página 4, en la que aparece Wright y Aalto junto con las referencias más conocidas de Fisac, como Asplund, La Alhambra o la casa japonesa. Inédito. Fundación Fisac.

Lo que es innegable es que el conocimiento de la obra de Aalto por parte de Fisac se redujo a las publicaciones -no pudo visitar Finlandia por lo ya explicado-, y por tanto no pudo tener la experiencia directa de su espacialidad, lo cual, quizás, hubiera cambiado su manera de percibir y entender la obra del finlandés ${ }^{170}$.

Sin embargo, no son pocas las coincidencias materiales, formales, conceptuales y de posicionamiento ante el paisaje que existen entre la obra de ambos maestros.

No sólo aparentes referencias formales como la Librería de la Fundación Goerres (1948), la cafetería del Instituto Nacional de Óptica Daza Valdés (1947), y el salón de actos del Instituto Laboral de Daimiel; o los parecidos razonables de las escaleras de la iglesia de Canfranc (1963) con las de la Maison Carrée (1957-1960) o las del Ayuntamiento de Säynätsalo (1949-1952), sino paralelismos más intensos en su concepción organicista como la de varios de los Institutos Laborales con el Sanatorio de Paimio, o las investigaciones estructurales que dan lugar a situaciones espaciales verdaderamente cercanas.

170 El sanatorio de Paimio, por poner un ejemplo, debió estar al alcance de Fisac a través de alguna publicación de las que frecuentaba, ya que se publicó en: Architecture Française (1946), Septiembre, 21-36 ; Casabella (1935) vol. 8, n. 90, 12-21; Architects' Journal (1933), n. 5, 420-423; Architectural Review (1933), Septiembre, 85-90, etc. 
Memoria, Aprendizaje y Experimento. La invención del paisaje en Miguel Fisac Aprendizaje. Maestros de la modernidad

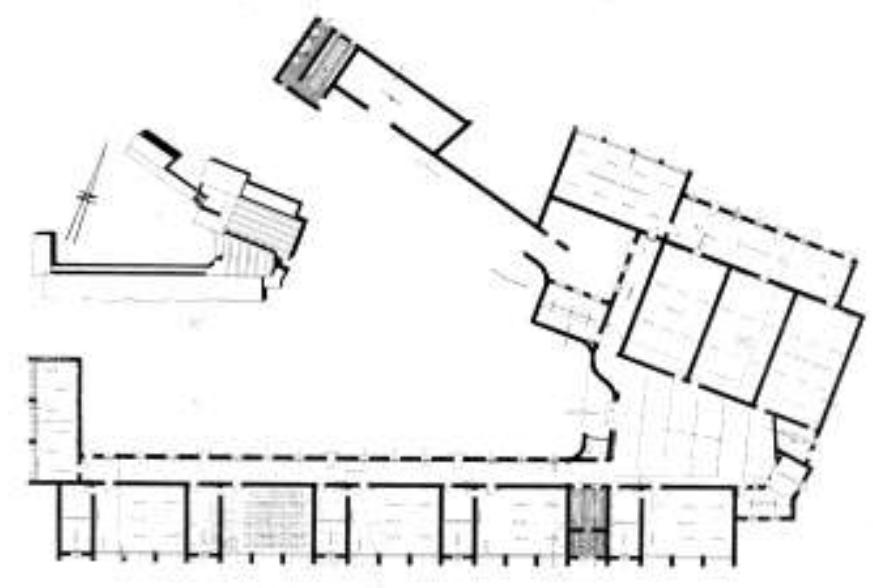

Instituto Laboral Daimiel. Miguel Fisac (1951) "Planta del conjunto del edificio en la que se aprecia la agrupación de los elementos atendiendo a su orientación y a la disposición jerárquica que cada una de ellas ha de ocupar"

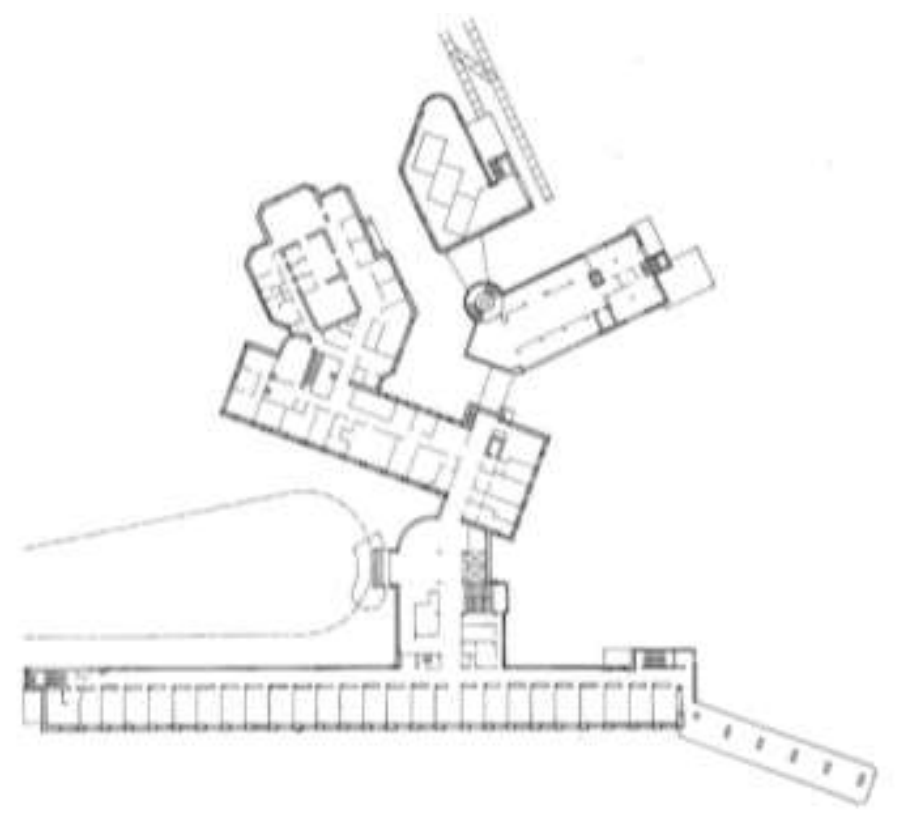

Sanatorio antituberculoso de Paimio. Alvar Aalto (1928-1932). Planta 
Memoria, Aprendizaje y Experimento. La invención del paisaje en Miguel Fisac Aprendizaje. Maestros de la modernidad
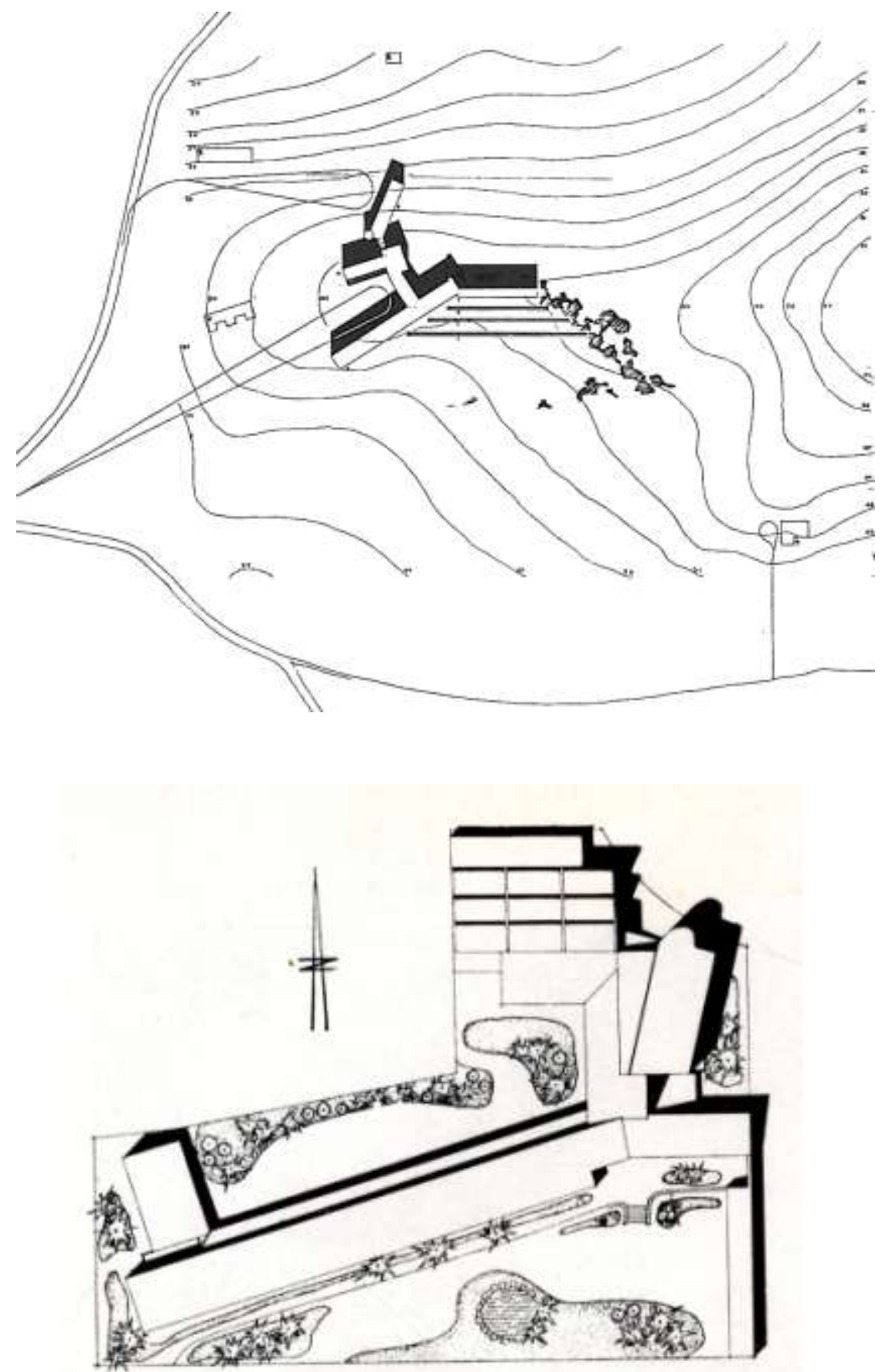

Sanatorio antituberculoso de Paimio e Instituto Laboral de Hellín. Planos de Emplazamiento 
Fisac y Aalto coincidieron personalmente en 1951, durante la estancia del arquitecto finlandés en Madrid; encontrándose precisamente Fisac entre el grupo de arquitectos que acompañó a Aalto a la anecdótica visita a El Escorial.

De esta experiencia, le quedó a Fisac en el recuerdo "un hombre natural, sencillo, cordial, que en ningún momento presentaba una posición estudiada de personaje mitológico", que en su juicio sobre el trabajo de los demás "no había ni crítica ni desprecio. Había, si, algo desconcertante, y es su falta de sentido de la curiosidad y del juicio sobre obras arquitectónicas que no están en su línea estética, ya sean buenas o malas, nuevas o antiguas", destacando, de su faceta profesional "sus intenciones de captación de algunos detalles que puedan servir a su temática plástica: la observación de los efectos abstractos de los rayos del sol sobre unos visillos, o el entusiasmo ante un muro encalado sobre un paisaje rocoso desnudo"171.

En relación a la posible conexión entre ambos arquitectos, podemos acordar que existen una serie de situaciones que resuenan en los itinerarios vitales de ambos:

Por una lado, se pueden dibujar paralelismos incluso entre vivencias infantiles tan dispares como las de intensa conexión con el mundo rural de Fisac y la de Aalto en un centro intelectual como la ciudad de Jyväskylä. Este entorno, al tratarse en ese momento de un foco de debate sobre identidad y cultura finlandesa, ayudó a Aalto a reelaborar la tradición y reinterpretar la arquitectura local. Se trata de posiciones que desde distinto origen se dirigen a una mutua preocupación por las estructuras orgánicas y por la naturaleza.

Existe en ambos casos una importante relación de ambos con la tradición popular o el interés por la arquitectura vernácula del lugar de origen como germen de sus arquitecturas, y cuya presencia es constante a lo largo de sus vidas.

Asimismo, existe en ambos arquitectos la experiencia y el embelesamiento por otras culturas y civilizaciones a través de los viajes realizados -como la japonesa o la griega-.

También cabe destacar la intensa reflexión y aprecio sobre el material, que les llevará a la investigación sobre las cualidades expresivas de los mismos -como la fábrica o la madera en Aalto, o el hormigón en Fisac, por ejemplo- en el sentido sensorial y táctil.

En relación al uso sensual de determinados materiales, una categoría que Pallasmaa denomina hapticidad, puede aplicarse a ambos, y están en lo más profundo de sendas arquitecturas. Paradójicamente, la combinación de lo innovador y lo tradicional, de lo moderno y lo vernáculo, que recorre en ambos desde el concepto espacial hasta la materia que lo delimita y su relación con el contexto que la rodea, conecta sendas experiencias arquitectónicas.

171 Delgado Orusco, E. (2002). Op. cit, 455 
Memoria, Aprendizaje y Experimento. La invención del paisaje en Miguel Fisac Aprendizaje. Maestros de la modernidad
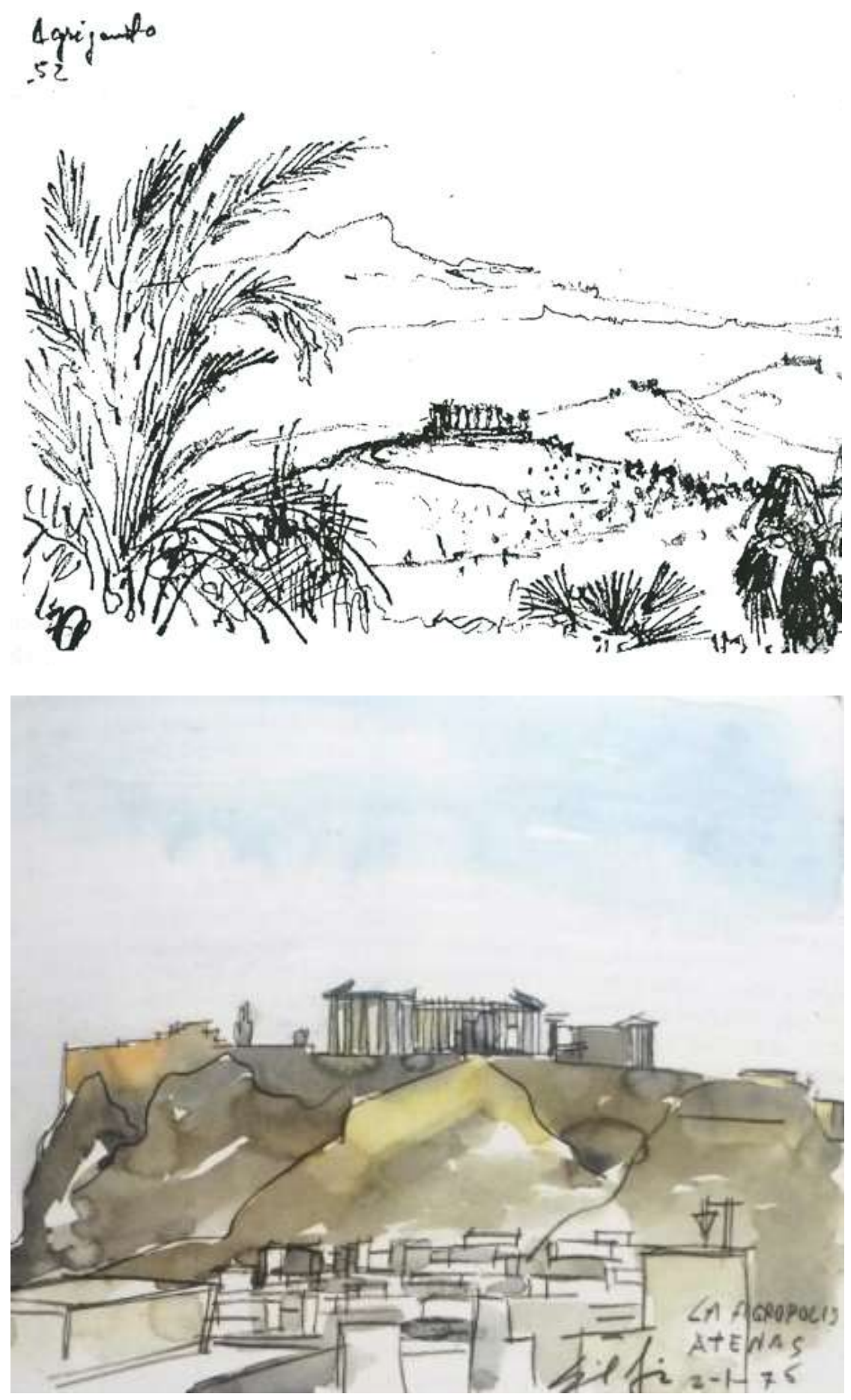

Alvar Aalto. Agrigento, 1952 Miguel Fisac, La Acrópolis, 1975 
También en ambos se potencia la percepción y la comprensión de nuestra condición existencial a través del contraste: poner la obra de la naturaleza junto a la obra del hombre hace que se estimule al espectador y pueda éste extraer mucho más de ambas.

Estas semejanzas culminan en la convergencia arquitectura-hombre-naturaleza en la que concluye cualquier discurso que busque el entendimiento de la obra de Aalto o de Fisac. $Y$ en una serie de propuestas arquitectónicas que podríamos encuadrar de modo amplio en el concepto de organicismo, cuyo máximo exponente es Frank Lloyd Wright, como ahora veremos-.

Sendas concepciones arquitectónicas, -de Aalto y Fisac-, se salen del traje que es la concepción ortodoxa de modernidad para incrementar el interés en el sentido fenomenológico de lugar, naturaleza y hombre, y sirven en sus propios contextos (Finlandia o España) como una crítica a los movimientos arquitectónicos del momento a través de sus obras.

Sin embargo, en otro orden de cosas, no deja de ser sorprendente que ante todos estos paralelismos aparezca un cierto antagonismo en el itinerario proyectual de ambos arquitectos: Aalto se entrega al subconsciente ${ }^{172}$, mientras Fisac es mucho más metódico y racional con su "para qué", "dónde", "cómo" y "no sé qué".

"Cuando tengo que solucionar un problema arquitectónico me encuentro generalmente, casi sin excepción, ante un obstáculo difícil de superar, una especie de "courage de trois heures du matin". La causa de ese fenómeno parece radicar en la complicada tarea originada por el hecho de que el proyecto arquitectónico moviliza innumerables elementos que a menudo están en mutuo conflicto. Exigencias sociales, humanas, económicas y técnicas junto con las cuestiones psicológicas que afectan tanto a los individuos como a los grupos combinadas con los movimientos de las masas y los individuos con sus fricciones internas, forman un complejo entramado imposible de desenredar de una manera racional o mecánica.

\section{(...)}

El inmenso numero de exigencias y problemas parciales forma una barrera tras la cual la idea básica arquitectónica emerge muy difícilmente.

En esa situación, aunque no de modo consciente, hago lo siguiente: olvido durante un tiempo el conjunto de los problemas hasta que todas las exigencias diversas y la atmósfera que la envuelve se sumerjan en mi subconsciente. Entonces paso por una fase semejante al proceso del arte abstracto. Dibujo guiado solamente por el instinto; no hago síntesis arquitectónicas, sino, a veces, algo parecido a composiciones infantiles, $y$,

172 De hecho, una de las máximas más celebres de Aalto es "prefiero cinco minutos del corazón que toda una vida del cerebro" 
de este modo, sobre una base abstracta, gradualmente, va tomando forma la idea principal, un tipo de sustancia general, a través de la cual es posible armonizar los múltiples problemas parciales en conflicto."173

En febrero de 1960, tras una exposición de arquitectura finlandesa celebrada en Madrid, Miguel Fisac escribe un artículo en el diario $A B C$, en el que nos aporta varias claves de su relación con la arquitectura nórdica en general y con Aalto en particular.

En primer lugar, establece una diferencia importante entre Asplund y Aalto, al afirmar que la arquitectura del primero supone una evolución de las propuestas de la Bauhaus y de Le Corbusier; realizando el finlandés una asimilación "de golpe" en Viipuri y Paimio.

En efecto, en dicho artículo se puede decir que da Fisac "una de cal y otra de arena", ya que ante el Sanatorio de Paimio afirma que se trata de una arquitectura "deshumanizada y desarraigada del paisaje"174, a pesar de los esfuerzos de Aalto por explicar lo contrario en los textos explicativos de este proyecto175; y sin embargo en otras partes del texto defiende precisamente el carácter humanizado de su arquitectura. En concreto, al hablar sobre el Ayuntamiento de Säynätsalo, afirma: "En este grupo de edificios hay una intención decidida hacia la humanización y la incorporación de la arquitectura en el paisaje con evidente sabor popular. Pero hay que advertir -dato importantísimo- que esto no es echar marcha atrás del racionalismo, sino su consecuencia natural, su continuación y su perfeccionamiento."176

En este texto se hace también una interesante reflexión sobre cómo el entendimiento que tiene Fisac de la humanización de la arquitectura está directamente vinculado al paisaje:

"Para un sueco o un finlandés la humanización es meter un poco el bosque dentro de la ciudad y dentro de la casa. El paisaje nórdico tiene unos elementos esenciales de bosque y de hielos entre los que se desarrolla de una forma tenue, casi inadvertida, una sociedad humana llena de vida y de interés. El problema es indudablemente mucho más sencillo que el nuestro, pero es, de todas formas, un ejemplo aleccionador e importante.

\footnotetext{
${ }^{173}$ Aalto, A. (1947). La trucha y el torrente de la montaña, tomado de Arno Ruusuvunori, A. (1978). Alvar Aalto 1898-1976. Helsinki: Museum of Finnish Architecture. Traducción Antonio Cortina. Publicado originalmente en la revista Domus

174 Cfr. Fisac, M. (1960) Enseñanzas de una exposición de arquitectura finlandesa.. Blanco y Negro, 2495, 50-53. 27 de Febrero

${ }^{175}$ Aalto insiste en su explicación sobre el proyecto en que es precisamente la visión curativa del paisaje para los pacientes -que se encuentran en posición horizontal o postrada- la esencia del proyecto, y todos sus elementos se configuran en torno a esta idea: la dimensión humana, la orientación, la luz, la captura del horizonte, etc.

176 Fisac, M. (1960). Op. cit.
} 
Sobre similares circunstancias plásticas y técnicas, nosotros hemos de hacer nuestra arquitectura, nuestra humanización. Mucho más complicada y rica en matices sicológicos, no cabe duda. Nuestro campo no es el simple campo del paisaje natural, con su sol, sus tierras y sus árboles. Quedaríamos muy mutilados de prescindir de nuestro paisaje histórico y sicológico, lleno de complicadísimos matices espirituales y materiales. No podemos prescindir tampoco de un sustrato arquitectónico que nos liga al pasado. Pero no podemos con todos estos elementos atarnos en ramplón historicismo que nos impida mirar hacia delante y hacer nuestra arquitectura: la que hoy necesitan las gentes de nuestro país para ser felices. "177

Esta ligazón entre ambas ideas no aporta una pista muy importante para nuestra investigación, más allá de la consideración particular que estamos realizando en este momento: la humanización está indisolublemente ligada al paisaje en el sentido más amplio que define Fisac: el lugar físico, el sustrato arquitectónico del pasado -que es contenido por su Memoria-, y el elemento psicológico -que incluye el factor espiritual-. Y ello es, si no aprendido a través de los nórdicos, si constatado o reafirmado gracias al conocimiento de las diferentes obras.

No menos importantes son las referencias a sendos grupos de viviendas de Toivo Korhonen en Matinkylä (1959) o Bertel Gripenberg en Helsinki (1957), reivindicando del primero un elemento tan español como el patio como herramienta de humanización de la arquitectura; o en el segundo caso la incorporación de la naturaleza a la arquitectura.

A la vista de las ideas que aparecen en este artículo, no queda otra que lamentarse de que no se publicara en alguna revista especializada, ya que existen reflexiones de importante calado sobre las que la crítica general parece no tener noticia, habiéndose centrado la mayor parte de los trabajos de Fisac que tratan su relación con la arquitectura nórdica en Asplund y en la visita de Fisac a la ampliación del Ayuntamiento de Gotemburgo.

En cualquier caso, en ambos arquitectos trasluce un objetivo común: la humanización de la arquitectura, un ejemplo de lo que Pallasmaa entiende por la arquitectura que debe existir hoy y en el futuro: menos preocupada de imágenes visuales y más apegada a consideraciones sociales y contextuales -al paisaje, que diría Fisac-

Las fuentes comunes de las que beben y la analogía de sus objetivos dan lugar a una relación intensa entre ambas arquitecturas, pudiéndose concluir que, más que aprendizaje, las intuiciones de Fisac, el dialogo establecido entre arquitectura y paisaje con el hombre como centro, se consolidan y reafirman al ver que maestros como Alvar Aalto validan ese itinerario.

177 Idem 
Memoria, Aprendizaje y Experimento. La invención del paisaje en Miguel Fisac Aprendizaje. Maestros de la modernidad

\section{ENSEN̂ANZAS DE UNA EXPOSICION DE ARQUITECTURA FINLANDESA}
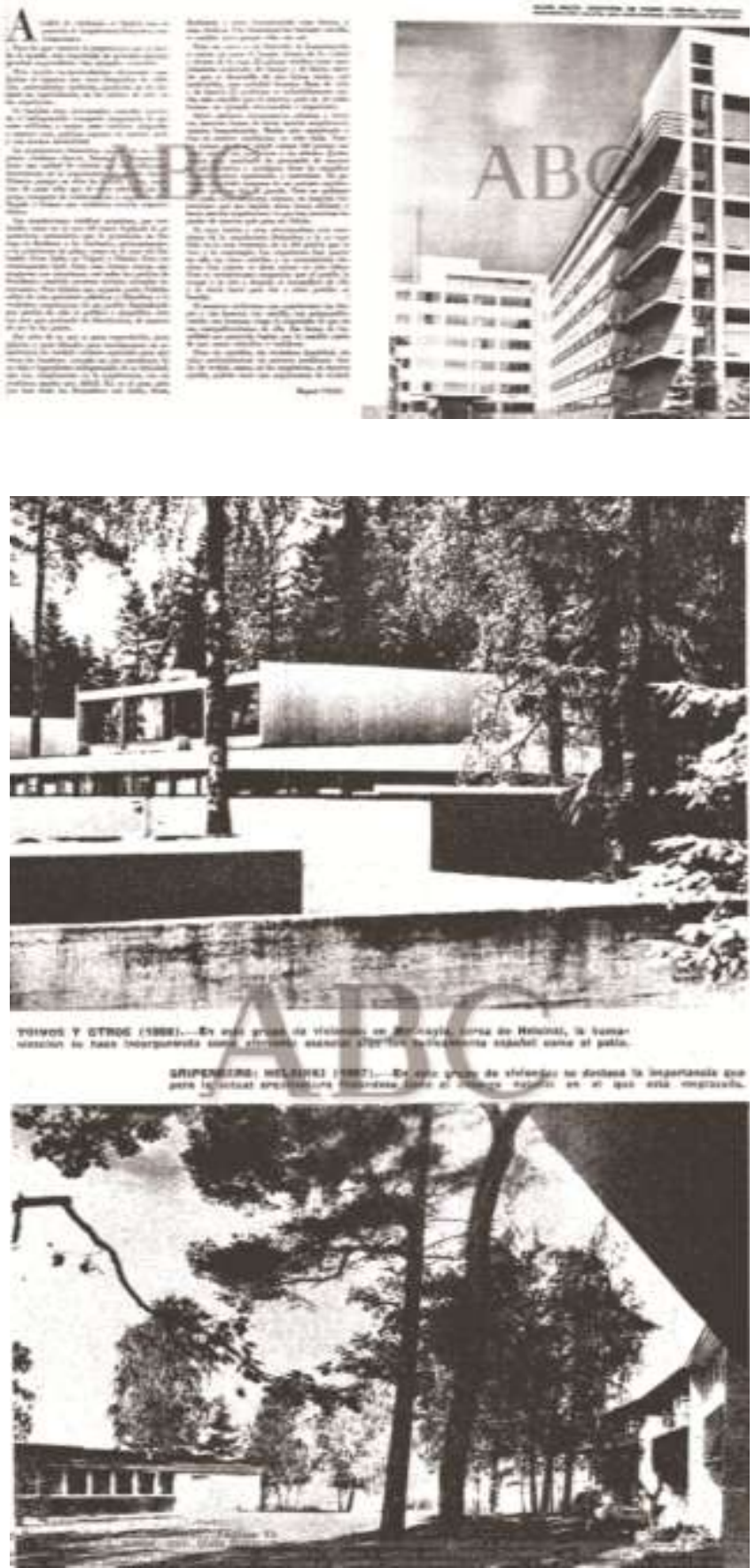

Fragmentos del citado artículo Enseñanzas de una exposición de arquitectura finlandesa.. Blanco y Negro, 2495, 50-53. 27 de Febrero de 1960. Arriba, Sanatorio de Paimio de Aalto . Abajo, imágenes de las citadas viviendas de Toivo Korhonen y Bertel Gripenberg 


\section{Frank Lloyd Wright}

"Los grandes arquitectos de lo que hoy llamamos Movimiento Moderno (Mies, Corbu, Gropius) eran en realidad hombres en muchos aspectos como lo fueron los del Renacimiento. Fuertes individualidades, con el convencimiento de que él -cada uno de ellos- tenía la clave secreta de la modernidad. Algunos profesionales serios no se dejaron seducir por sus cantos de sirena y algún genio suelto (Wright) hizo la guerra por su cuenta."

El posicionamiento de Fisac con respecto a la arquitectura de Wright podríamos llamarlo de respeto crítico.

Partiendo de su consideración como arquitecto destacado y de la aceptación de su magisterio, fiel a su transparencia de opinión y sinceridad, cuando estudia algún concepto que le interesa de la obra del maestro de Wisconsin, lo elogia; y cuando no está de acuerdo, realiza una crítica argumentada.

Encontramos referencias de elogio sobre la Johnson Wax: "la Johnson de Wright (en Racine, Illinois), es uno de los edificios que más me ha fascinado; es precioso de día y de noche..." (Alarcón, 1999, 422), y visita con interés varios edificios suyos como el estudio de Taliesin en Madison, etc...

Sin embargo, en otras ocasiones se mostrará en desacuerdo con sus ideas. De hecho, Fisac no comparte la concepción de Wright en sus propuestas de ciudad para el futuro, más cercana al individuo en Broadacre -según Wright- y por el contrario más próxima al espíritu de convivencia o a la socialización de las personas -según Fisac, en La molécula urbana-.

Al igual que hemos estudiado en otros maestros que le interesaron a Fisac, hay una serie de coincidencias en las vidas de ambos, que merece la pena reseñar, ya que pueden conducirnos a conclusiones relevantes.

Un primer gran paralelismo en la vida de ambos procede de una infancia vivida en intenso contacto con el medio rural, destacando en ambos casos la existencia de una gran planicie (La Mancha y la Pradera), y sobre todo, el mantenimiento en el tiempo de la comunión con la naturaleza a lo largo de toda su vida con una mirada ante ella de inocencia casi infantil -como subraya Ralph Waldo Emerson que le ocurre a quienes aman la naturaleza-, y que sucede en uno y otro caso . 
"The sun illuminates only the eye of the man, but shines into the eye and the heart of the child. The lover of nature is he whose inward and outward senses are still truly adjusted to each other; who has retained the spirit of infancy even into the era of manhood."178

Asimismo, este desarrollo de una sensibilidad por la belleza natural durante la infancia es -como en otros casos-, preparación necesaria para acoger las ideas orientales de una forma tan intensa, que luego llegarán a la vida de ambos.

Tanto en Fisac como en Wright se interesarán por el arte pictórico japonés, como metáfora de los paisajes orientales.

Si podemos pensar que en Wright la visión de los Ukiyo-e, (grabados japoneses con imágenes de temas variopintos, fundamentalmente paisajísticos) en los que los campesinos se muestran en entornos naturales idílicos, lo retrotrae a su infancia rural ${ }^{179}$; en el caso de Fisac podríamos realizar un paralelismo para deducir que la experiencia estética de los "kakemonos", lo ayudó a descubrir una nueva energía transformadora del entorno, que le permitió así inventar un paisaje que acentúa la belleza del entorno, en arquitectura como en la pintura o el grabado.

El impacto que produce en Fisac el paisaje japonés es determinante, y lo conecta espiritualmente con una infancia en comunión con la naturaleza: "las montañas, y los ríos, y los árboles, están allí retorcidos realmente, y tienen un decorativismo salvaje y extraño"180

En efecto, fue a través de un libro sobre Wright, como el propio Fisac cuenta, como llegó al famoso pensamiento de Lao-Tsé que posteriormente derivaría en su definición de arquitectura como "un trozo de aire humanizado".

178 El sol sólo ilumina el ojo del hombre, pero brilla en el ojo y el corazón del niño. El amante de la naturaleza es aquel cuyo interior y sentidos externos se mantienen verdaderamente ajustados entre sí; quien ha conservado el espíritu de la infancia, incluso en la era de la madurez. Traducción del autor de la tesis. Tomado de Emerson, R. W. (1849). Nature; Addresses and Lectures. http://www.emersoncentral.com/natureand.html

179 Kevin Nute sugiere que el trabajo de Wright tiene más que ver con el arte pictórico tradicional japonés que con la arquitectura -a excepción de la búsqueda de la continuidad espacial-. Las representaciones realizadas en estas estampas recogen la esencia del paisaje japonés, en el que puede aparecer la arquitectura como parte de él: galerías y umbrales con esbeltos pilares, que generan interesantes espacios de transición entre el interior y el exterior, elementos que enmarcan el horizonte y por tanto el paisaje, etc..., así como el tratamiento de las texturas y de los diferentes materiales que componen la arquitectura. Asimismo, en muchos casos aparece la naturaleza en relación con lo próximo -la arquitectura y la naturaleza creada- estableciendo un interesante diálogo con voluntad de unir los dos aspectos en uno sólo. En todo ello destaca sobre todo la obra pictórica de Utagawa Hiroshige (1797-1898).

180 Fisac, M. (1956). Op. cit. 
En cuanto a su relación intelectual con Japón, existe un posicionamiento similar en ambos casos: ninguno busca ser formalmente japonés, sino incorporar ciertos principios esenciales de su arquitectura, incluso despertar inquietudes que estaban ya previamente en la memoria de ambos. Ambos tienen deudas filosóficas con Japón, aspecto mucho más interesante que el descubrimiento de lecturas directas entre varias arquitecturas.

Asimismo, y sobre todo en relación a nuestros intereses en esta investigación, existen paralelismos en su posicionamiento con respecto al paisaje.

Ciertos proyectos de Fisac comparten algunas ideas con las desarrolladas por Wright en las casas usonianas ${ }^{181}$. "¿Dónde termina el jardín y comienza la casa? Donde comienza el jardín y termina la casa", dirá Wright defendiendo que casa y jardín forman un todo indisoluble en el paisaje.

"En toda su obra residencial, Wright se sirvió del espacio del jardín con fines muy diferentes; sin embargo, una única intención prima por encima de todas: la de crear un paisaje entre dos "arquitecturas", la artificial de la casa y la natural del paisaje. Esta sabia elocuencia formal aparece siempre que la situación de la casa lo permite. De esta manera, los jardines de Wright no son únicamente espacios de recreo y disfrute, sino un imprescindible mecanismo para proyectar el edificio que contextualiza la composición y que da presencia a la casa en el paisaje"182

Y se identifican ambos con lo primitivo, con los ancestrales principios que rigen la vida de agricultores o ganaderos. Si Fisac estudia las quinterías, los gañanes, la labranza 0 las yuntas de mulas, Wright se inspira en las ideas de Ralph Waldo Emerson sobre agricultura183.

Wright defiende a través de su Broadacre City la importancia de la relación del hombre con su medio, así como una concepción orgánica de la belleza como parte de la auténtica cultura humana. Y, aunque criticada en parte por Fisac en su libro "La molécula urbana" por la falta de espacios para la convivencia, las dos propuestas tienen un valioso objetivo común, la humanización de la ciudad -si bien no entendida la humanización exactamente en los mismos términos- .

\footnotetext{
${ }^{181}$ El concepto de casa usoniana nació en 1936 y se concretó en 1954 en el libro The Natural House (Wright, F. Ll. The Natural house. New York: Horizon Press) . Se trata de viviendas unifamiliares con terreno propio a precios moderados.

182 Álvarez, D. (2007). El jardín en la arquitectura del siglo XX, 203. Barcelona: Reverté, S.A.

183 Wright propone en 1934, y presenta en los CIAM (1935) su proyecto Broadacre City, cuyo concepto se basa una ciudad de baja densidad y autogestionada para 1400 familias, con $4000 \mathrm{~m} 2$ de terreno para cada una (1 acre), de forma que se vuelva al contacto con la naturaleza propio de los pioneros americanos, lo que supone una ruptura con muchos de los principios del urbanismo que defienden sus contemporáneos. Cfr. Wright, F. LI. (1961). La ciudad viviente. Traducción Anibal Leal. Edición 1961. Buenos Aires: Compañía General Fabril Editora, S.A.
} 
Encontramos, más allá de los posibles paralelismos formales, una valiosa herencia en Fisac a través de Wright, cuya esencia se puede sintetizar a través del ejemplo de la construcción de Taliesin, que el propio Fisac visitó.

El lugar, en primer término, es fuente de energía inspiradora para la arquitectura. En Wright esto es esencial, y la transmisión de esto es uno de los tesoros que guardan arquitectos tan ligados a la naturaleza y al lugar como Jorn Utzon ${ }^{184}$

También es importante destacar la idea de continuidad espacial, en este caso a través de la búsqueda de esa conexión entre arquitectura y naturaleza, que la certera disposición de un jardín permite.

El ritual no es menos importante. En este sentido entra en juego elementos como el camino; un camino que, en la casa familiar del Cerro del Aire por ejemplo, nos permite ver fragmentos de arquitectura y paisaje, paisaje filtrado a través de un jardín circundado.

También el posicionamiento de la arquitectura ante el paisaje, sus aperturas a través de un jardín; un jardín que a su vez potencia la belleza de la arquitectura.

Y la materialidad de la arquitectura. La intensidad constructiva, -pedagógica-, y la honestidad en el uso de los materiales, extrayendo su expresividad y sus características más íntimas: textura, gravedad, capacidad de reflexión, etc.

En otros elementos formales que no entraremos a desarrollar encontramos aprendizajes, como en los umbrales o loggias.

La obra de Fisac, al igual que la de Wright, tiene la capacidad de evocar recuerdos de las civilizaciones que nos precedieron, de reconocer y recoger la esencia del paisaje, de despertar emociones y generar un espíritu renovador y transformador de la arquitectura y del hombre.

En definitiva, Fisac recogió la esencia del discurso wrightiano -como le ocurrió con otros maestros-, lo entendió, e interpretó la partitura de su música de forma magistral.

${ }^{184}$ Cfr. Puente, M. (ed.) (2010). Jorn Utzon. Conversaciones y otros escritos. Barcelona: Gustavo Gili 
Memoria, Aprendizaje y Experimento. La invención del paisaje en Miguel Fisac Aprendizaje. Maestros de la modernidad
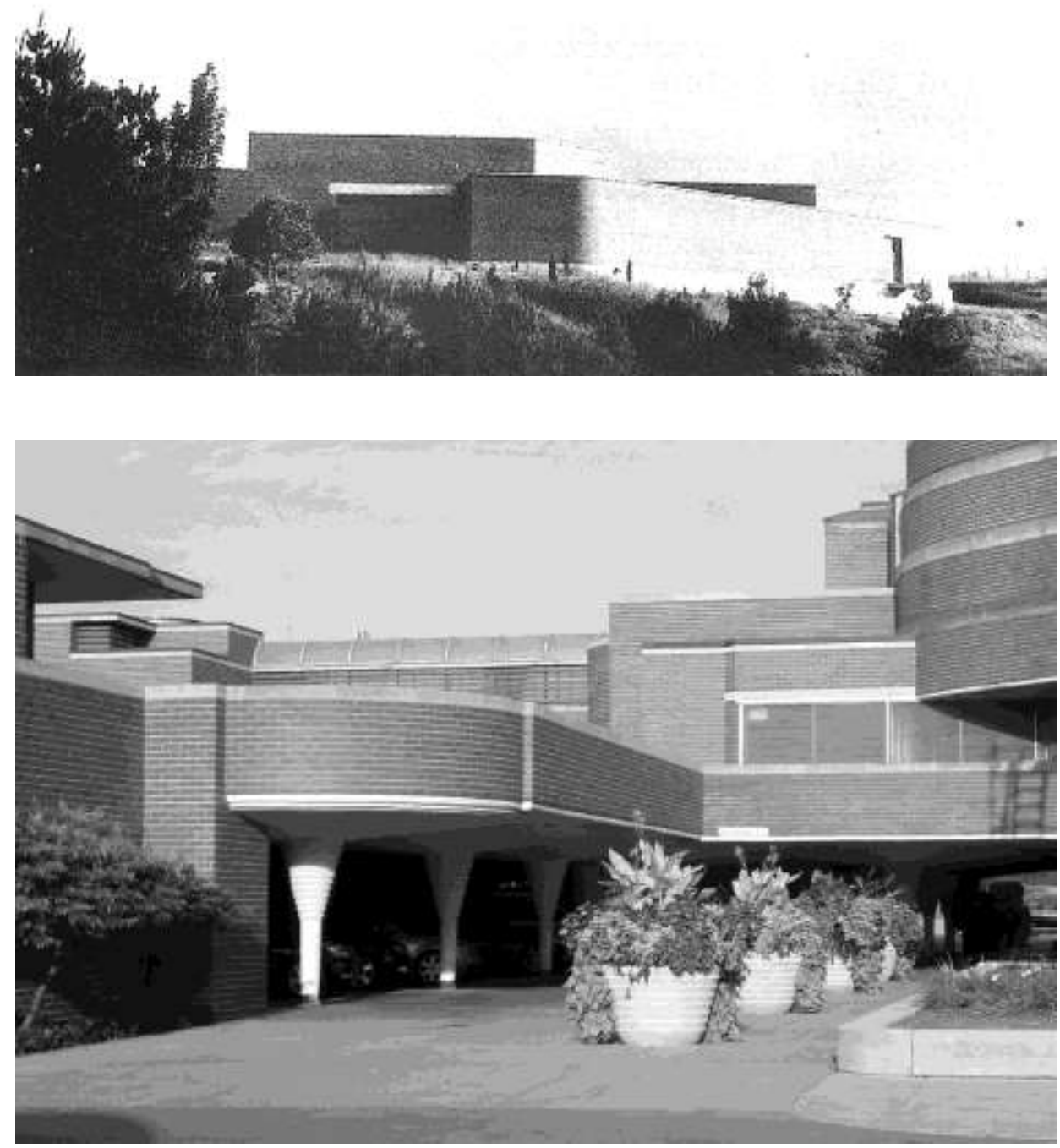

Miguel Fisac. Centro de Formación del Profesorado. Ciudad Universitaria, Madrid. Frank Lloyd Wright. Johnson Wax. [Imagen Flickr; Oomni] 


\section{Mies van der Rohe}

Verdaderamente, si alguno de los arquitectos contemporáneos a Fisac no salió bien parado en sus críticas, fue Mies Van der Rohe (1886-1969), quizás influenciado por la lectura de Venturi 185 .

A pesar de mostrar su máximo respeto, reconocer su espíritu renovador, y de visitar "casi toda su obra", Fisac nunca llegó a perdonarle a Mies su "total desprecio por el paisaje" basado en, pensaba él, haber construido el mismo edificio en Berlín y en Santiago de Cuba. Pero es desprecio por el paisaje puede tener matizaciones, como ahora veremos.

De forma muy gráfica lo explica él mismo en Valencia: "Yo me encontré con que un arquitecto por el que tengo un gran respeto y que he visto casi toda su obra, incluso algunas a medio hacer, como es la Escuela de Arquitectura de Chicago o el Museo de Arte Contemporáneo de Berlín, y resulta que en unas oficinas que le encargan en Santiago de Cuba, tiene la misma forma y las mismas características que el Museo de Arte Contemporáneo de Berlín. Es un poco fuerte... Ni el paisaje de Cuba, ni la sociedad, ni los cubanos, ni el Berlín, ni la sociedad berlinesa tienen nada que ver. ¿Cómo puede ser que esto resulte ser un cubo con 8 columnas? ¿Qué es esto? A mí me descolocó totalmente. Todos los respetos para Mies van der Rohe, pero desde luego seguirlo, "ni atao", así de claro."186.

En efecto, cuando Fisac critica, tanto en sus escritos como en sus conferencias, al Movimiento Moderno, personaliza sus reproches en Mies y la repetición insistente de modelos en uno $u$ otro lugar.

"iLa arquitectura se diferencia de todas las otras bellas artes en que no se puede mover!

O sea, es como un árbol: se planta aquí y tiene unos alrededores, mejores o peores, más bellos o menos bellos, más a tener en cuenta o menos a tener en cuenta, pero están en una calle en una ciudad, están en un sitio, o sea... jel dónde es importantísimo!

(...) Algo que aprendí del Movimiento Moderno fue que, como en todos los movimientos clásicos, habían prescindido de tener en cuenta, en absoluto, el lugar en el que estaban

${ }^{185}$ Contaba Fisac que uno de los aspectos que más le interesaba del libro Complejidad y Contradicción, el más interesante de todos los que había leído relativos a la Arquitectura, era la afilada crítica que se hacía de Mies Van der Rohe, probablemente refiriéndose a "less is bored" -menos es aburrido- en respuesta a la máxima miesiana "less is more" -menos es más-.

${ }^{186}$ Miguel Fisac a los estudiantes de arquitectura. Conferencia dictada en la Escuela Técnica Superior de Arquitectura de Valencia como clausura del curso académico, el día 31 de mayo de 1995. [inédita]. Véase Apéndice 1. 
ubicados los edificios. Una de las cosas más sorprendentes que yo veía era que jellos iban con su edificio organizado en la cabeza y lo plantaban en donde fuera!

Es decir, que una de las cosas que vi enseguida como aspecto principal del Movimiento Moderno era el desprecio por lo que había alrededor.

¡Y la arquitectura está como un árbol clavado en un paisaje! No se puede prescindir de lo que forma su entorno." (Roda, 2007)

Una crítica que puede considerarse cercana al desprecio si comprobamos que el artículo que escribió en el magazine La Actualidad Española sobre su visita a Nueva York en 1955, y en el que únicamente da por bueno como rascacielos The Lever House, ni tan siquiera cita el edificio que justo enfrente se estaba levantando en esos momentos: el edificio Seagram (1954-1958).

Hay un aspecto -sin embargo- que si le reconoció Fisac a Mies como acierto: haber conseguido dotar de expresividad un material como el acero.

De cualquier forma, la actitud de visitar sus obras puede considerarse como la aceptación de ciertas lecciones, habida cuenta de que es complicadísimo encontrar un elogio total de Fisac por algún contemporáneo suyo -lo que sí ocurre con Hilberseimer-, aunque tache a Mies de "fotogénico".

"En Plano (Illinois) visité la casa Farnsworth (entré en la finca a pesar de los carteles de advertencia). Me encontré con un espectáculo desolador: la casa estaba en muy mal estado, cubierta de telas antimosquitos metálicas, totalmente abandonada $y$, sin embargo, en las fotos que hice salió muy bien, es curioso, hay arquitecturas que son muy fotogénicas..." (Alarcón, 1999, 423)

Profundizando en lo que entendemos como lecciones aceptadas por Fisac, podemos destacar tres:

Una de ellas es la consideración de la capacidad expresiva del material -no sólo el acero, también el vidrio y el propio ladrillo-, así como la honestidad constructiva, lo cual es una forma de posicionarse ante el paisaje. $Y$ la esencialidad en su utilización: la esencialidad de un cuerpo, que como en el caso de Fisac, está compuesta por unos huesos -estructura- $y$ una piel -cerramiento-.

Existe, en este sentido, una conexión entre el proyecto para el Alumni Memorial Hall del IIT de Chicago y el pabellón de las aulas del Centro de Formación del profesorado, más allá de parecidos en su formalización. Es curioso que la fecha del dibujo de Fisac, realizado en su Viaje alrededor del mundo en 1955, es sólo cinco meses posterior al diseño de los alzados del Centro de Formación del profesorado, por lo que el conjunto miesiano lo conocería a través de alguna publicación especializada. 
Memoria, Aprendizaje y Experimento. La invención del paisaje en Miguel Fisac Aprendizaje. Maestros de la modernidad
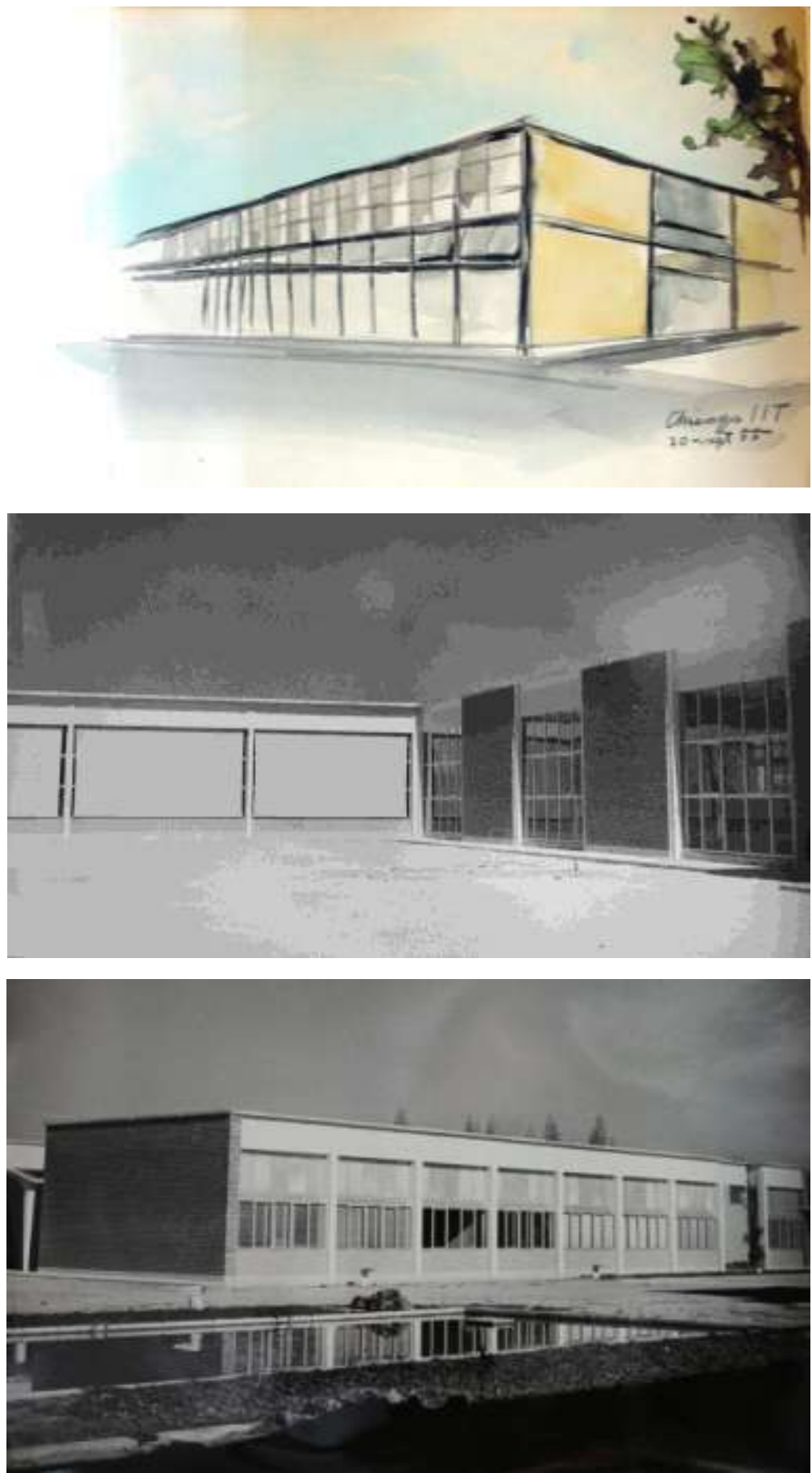

Miguel Fisac. Dibujo del Alumni Memorial Hall del IIT de Chicago (Septiembre de 1955). Fotografías del pabellón de administración y aulas del Centro de Formación de Profesorado de la Ciudad Universitaria (los alzados del Proyecto tienen fecha de abril de 1955). 
La segunda es la búsqueda de la continuidad espacial, introduciendo el paisaje dentro de la arquitectura, si bien no fue entendido esto por Fisac como una manera de responder al emplazamiento y al lugar ${ }^{187}$.

En su relación con el paisaje urbano es curioso observar como un edificio que, como hemos dicho no le interesó en absoluto, como el Seagram, puede llegar a ser inspirador de algunas intervenciones de Fisac, como el edificio no construido para la inmobiliaria Cóndor, S.A. en la plaza del Ayuntamiento de Valencia, o incluso el edificio de viviendas de la plaza de Tetuán, también en Valencia, en los que la búsqueda de la continuidad espacial interior-exterior es uno de los temas trabajados, delimitando las visiones de la ciudad que desde el interior se tienen.

En el citado edificio Cóndor, el acceso queda protegido por una pieza de hormigón visto de altura similar a su profundidad entre la línea de fachada y un acceso completamente realizado de vidrio, siendo sendas magnitudes aproximadamente 6 metros, por lo que se consigue la buscada continuidad. En esta misma línea se sitúa la utilización de perfiles metálicos, cuestión prácticamente inédita en la obra de Fisac.

187 Otras intervenciones, como las casas Farnsworth o Tugendhat, en las que hay una intención de introducir la naturaleza en la arquitectura no son consideradas por Fisac como una respuesta al "dónde". 


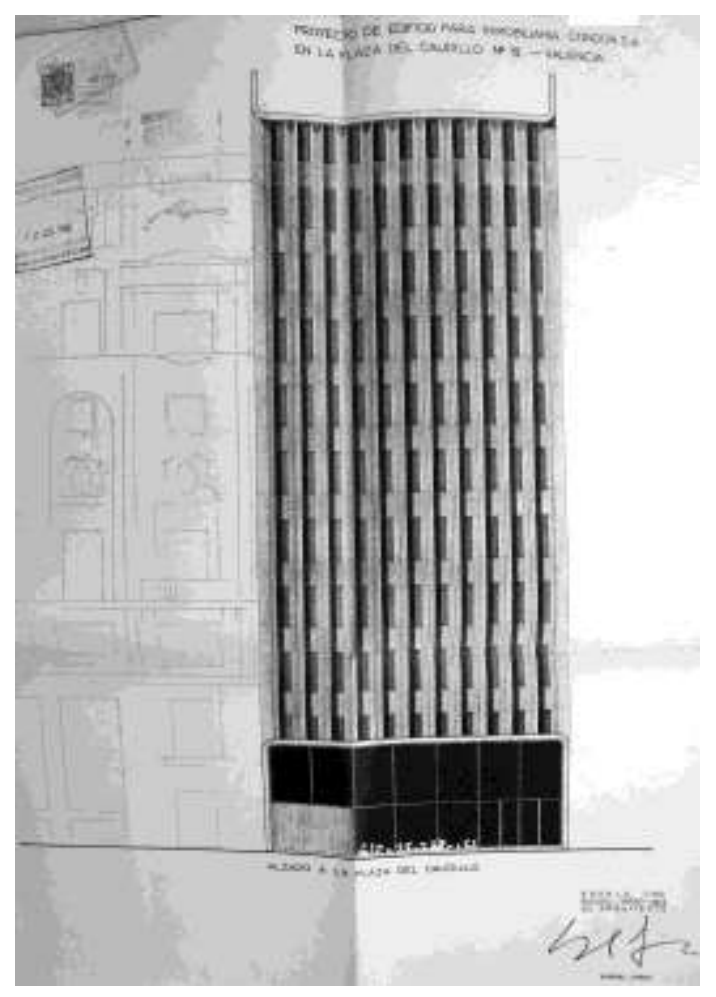

Miguel Fisac. Proyecto de edificio en la plaza del Ayuntamiento de Valencia (plaza del Caudillo, 18). Mayo 1963. Inédito

Para quien si tuvo Fisac palabras de elogio, y es obligado citarlo aquí, es para Hilberseimer, colaborador de Mies, y responsable, sobre todo de las propuestas relacionadas con el paisaje urbano.

En La Molécula Urbana podemos leer:

"Este grupo que en Europa y en los años de entre-guerras sólo consiguió crear un cierto ambiente propicio para recibir las nuevas teorías, reanuda casi íntegro sus tareas en Estados Unidos después de la segunda contienda y presenta unas soluciones que aunque no llegan a alcanzar, en ningún caso, a la totalidad de una ciudad, se llevan a la práctica en barrios de alguna importancia, como la colonia Lafayette en Detroit, en la que el gran teórico del urbanismo del grupo, Ludwig Hilberseimer, antiguo profesor de la Bauhaus, en colaboración con Mies, consigue la realización de un trozo de ciudad de una pureza inigualada, tanto teórica como formal, y que deja al desnudo la esencial concepción sociológica materialista, que un Le Corbusier en Chandigarh o Costa y Niemeyer en Brasilia, tal vez inconscientemente, superan con sensibilidad de artistas." 
Figura menos conocida en España que otros de sus contemporáneos, quizás por estar a la sombra de Mies van de Rohe, o por haberse centrado más en el desarrollo de sus ideas urbanísticas que de las edificatorias, esta reflexión pone de manifiesto la profundidad de la información que manejaba Fisac ${ }^{188}$.

Para Fisac existen dos claves importantes en la creación de ciudad: convivencia y estructura social, por una parte; $y$ la introducción de un paisaje natural por otro.

Hilberseimer consiguió conectar con Fisac precisamente a través de la incorporación del paisaje en la ciudad como herramienta que la humaniza, creándose así un vínculo de aprendizaje.

De acuerdo con el análisis de Xavier Llobet: "A partir de la experiencia de la Weissenhof, Hilberseimer empezó a considerar la incorporación del paisaje fundamentalmente en relación con las necesidades humanas. (...) la metrópoli como ciudad jardín ya contiene todas las variables espaciales y funcionales para asentar una comunidad bien relacionada con el paisaje y que toda la población pueda tener una vida saludable y completa. Es una ciudad ecológica, planificada como un organismo vivo, cuyos principios básicos son simplemente sus necesidades vitales.". 189

El lugar para reuniones sociales, la mejora de la vida en comunidad, la relación con el paisaje rural, o la desaparición de los límites entre ciudad y parque son objeto de estudio de ambos arquitectos.

Y también en relación a ello, Hilberseimer estudió intensamente como la vivienda, la industria, el lugar de trabajo o el medio natural podrían integrarse en un todo orgánico, ideas bastante cercanas a las teorías que Fisac propone en La Molécula Urbana.

De esta forma, Hilberseimer propone una serie de edificios aislados que están en el paisaje y son penetrados por él, de forma que se consigue un conjunto integrado en el territorio.

Se trata de las mismas ideas esenciales sobre las que se construye las propuestas de Fisac para la ciudad del futuro, aunque tengan formalizaciones distintas. De igual forma se proponen añadir unidades de asentamiento para las necesidades de crecimiento,

\footnotetext{
188 Fisac visitó Chicago y alrededores entre el 16 y el 21 de septiembre de 1955, según recoge en su cuaderno de "Viaje alrededor del Mundo". El parque Lafayette, en Detroit (a $400 \mathrm{~km}$ de Chicago), estaba en fase de proyecto, y no se comenzaría a construir hasta 1960. No sabemos si en ese viaje se tuvo conocimiento directo de ese proyecto, realizado por Mies y Hilberseimer, o bien fue a través de alguna publicación especializada posteriormente, si bien sorprende la referencia tan directa en su libro La Molécula Urbana, publicado en 1969.

189 Cfr. Llobet, X. (2007). Hilberseimer y Mies. La metrópoli como ciudad jardín. Colección Arquithesis, 24. Barcelona: Fundación Caja de Arquitectos.
} 
respetando las correspondientes franjas de parque a su alrededor con el objetivo de desarrollar una vida completa en contacto con la naturaleza.

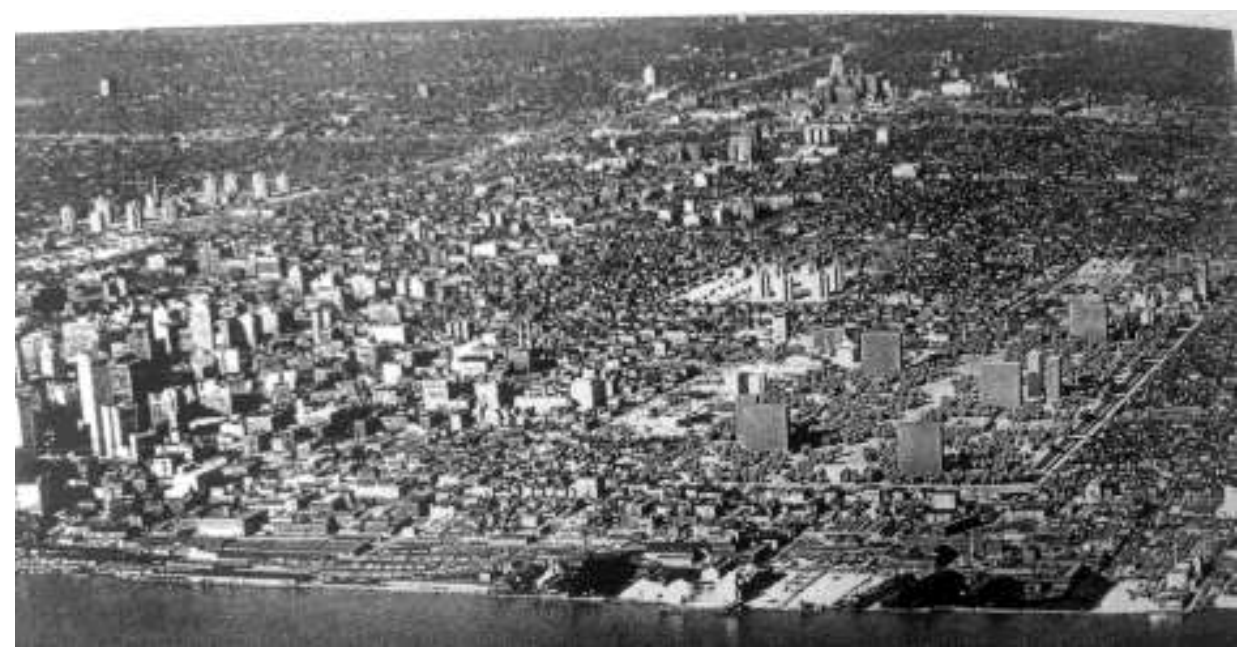

Hedrich Blessing. Fotomontaje de la maqueta de Hilberseimer y Mies sobre el solar desocupado de Lafayette Park, 1956. Tomada de Llobet, X. (2007). Hilberseimer y Mies. La metrópoli como ciudad jardín.

A la vista de lo anterior podríamos concluir que si bien Fisac realiza duras críticas sobre Mies van der Rohe a lo largo de toda su trayectoria, existe a la vez una cercana observación con capacidad para recoger los aspectos que de su obra le interesan.

\section{Le Corbusier}

No cabe duda de que la obra de Le Corbusier causó un importante impacto en la visión que Miguel Fisac tenía sobre la arquitectura.

Como se ha indicado anteriormente, en varios de sus viajes procuró Fisac visitar y analizar la obra de Le Corbusier: el citado Pabellón Suizo (1931), el 25 de octubre de 1949; la Unidad de Habitación de Marsella (1947-1952), el 14 de enero de 1958; Ronchamp (1950-1955) en un viaje familiar en torno a 1957; y "varias cosas del principio". Son, por tanto, varias las menciones que realiza a visitas de sus obras.

Sin embargo, no hay muestras de que Fisac, conscientemente, acepte su maestría: siempre se decepciona ante la visita a sus edificios, tanto a nivel proyectual como de resolución constructiva de los mismos. $Y$ siempre es blanco de sus críticas más 
intensas: "porquería"190, refiriéndose al Pabellón Suizo de la Ciudad Universitaria de París, o "tendencia al funcionalismo a la manera de Le Corbusier, osea, a lo malo"191, reflexionando sobre arquitectura danesa.

Dicho esto, también es cierto que la relación de la arquitectura de Fisac con el paisaje tiene ciertas deudas con las enseñanzas de Le Corbusier. Más que deudas, podríamos convenir que el estudio de la arquitectura de Le Corbusier por parte de Fisac es un generador de ideas, es decir, que dicho estudio y análisis le produce ciertas preguntas que él intenta resolver por su cuenta, con mayor o menor cercanía al maestro suizo.

Uno de los aspectos más importantes es el levantamiento sobre pilotes de los edificios, de cuya idea beberán edificios como el Teologado de los Dominicos de Alcobendas y otros -como el Instituto de Enseñanza Media de Málaga, o el Instituto Benlliure de Valencia-.

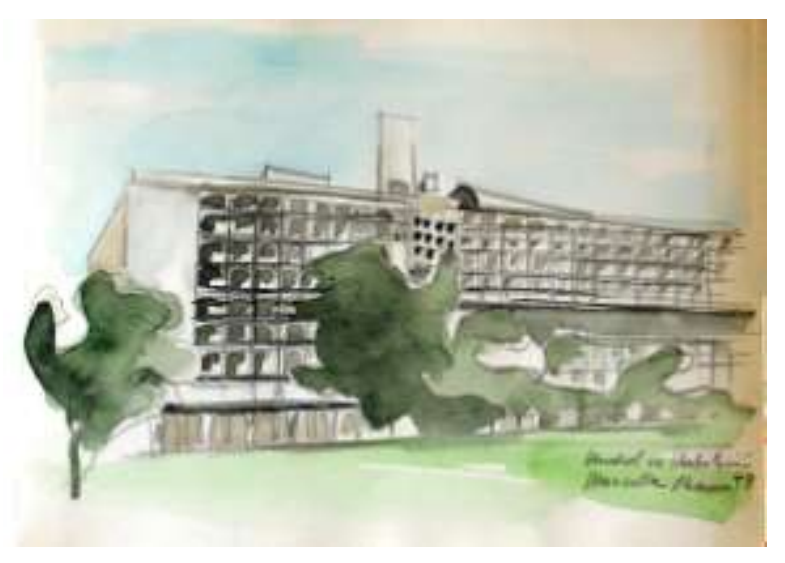

Unidad de Habitación de Marsella. Dibujo de Miguel Fisac 1958.

También el tratamiento del material, sobre todo del hormigón armado, extrayendo del mismo una nueva expresividad.

\footnotetext{
190 En el Cuaderno de Viaje a Europa, Fisac escribe: "Lamentable fuera de toda ponderación el pabellón suizo de la ciudad universitaria de Le Corbusier. Tiene todos los latiguillos plásticos de la peor arquitectura cubista. No cabe una mayor falta de sentido común en las soluciones constructivas y funcionales. Las calidades no pueden ser peores. En resumen: una porquería". Cfr. Fisac, M. (1949). Op. cit., 17

191 En el mismo Cuaderno de Viaje citado, escribe Fisac: "Dinamarca es una nación menos exótica que Suecia para nosotros. Tiene más arquitectura antigua y popular que Suecia y una arquitectura moderna menos definida. Hay alguna tendencia al funcionalismo a la manera de Le Corbusier o sea a lo malo, (...)".Cfr. Fisac, M. (1949). Op. cit., 34
} 
Siempre quedará la duda de si visitó, siquiera desde el exterior o desde una orilla del lago Leman, la Petit Maison (1923-1924), que se podrían incluir en esas "varias cosas del principio". Si bien no existen anotaciones de ello en su Cuaderno de Viaje a Europa, bien es cierto que realizó el recorrido de Ginebra a Berna pasando por Lausanne, es decir, bordeando el lago, por lo que no sería descabellado aceptar esta hipótesis.

Aunque esta visión no mereciera unas notas en el citado Cuaderno, vale la pena citar la intensa vinculación de esta casa con el paisaje, -en contraste de las consideraciones de Fisac sobre la arquitectura de Le Corbusier-, y a pesar de que Le Corbusier presumiera de diseñar la casa antes de encontrar un lugar concreto en la que construirla. Estas conexiones no sólo se realizan a través de la cubierta-jardín o del inmenso hueco horizontal, sino sobre todo, mediante el hueco que enmarca el lago desde el jardín y que delimita bellamente la naturaleza circundante, haciendo formar parte del jardín el paisaje. Un hueco-mirador, que tensiona el muro del lago, como el hueco que tensiona el muro del edificio de la madrileña Ciudad Universitaria de Fisac y que enmarca la sierra de Guadarrama. Un hueco en la piedra que realiza una conexión metafísica con el lugar, que hace cercano lo lejano -las montañas, el lago-, y que genera una habitación abierta al cielo que forma parte de la casa, ideas que posteriormente utilizará Fisac.

Una habitación exterior como en Ronchamp o como en el Centro de formación del Profesorado, que atrapa y atrae hacia sí de forma magnética el paisaje, las montañas, la tierra o las nubes, y que evoca las interpretaciones del propio Le Corbusier sobre la polarización del espacio que existe en el templo griego.

Existe, por tanto, esa generación de ideas que Fisac recoge del estudio de la obra de Le Corbusier. 
Memoria, Aprendizaje y Experimento. La invención del paisaje en Miguel Fisac Aprendizaje. Maestros de la modernidad
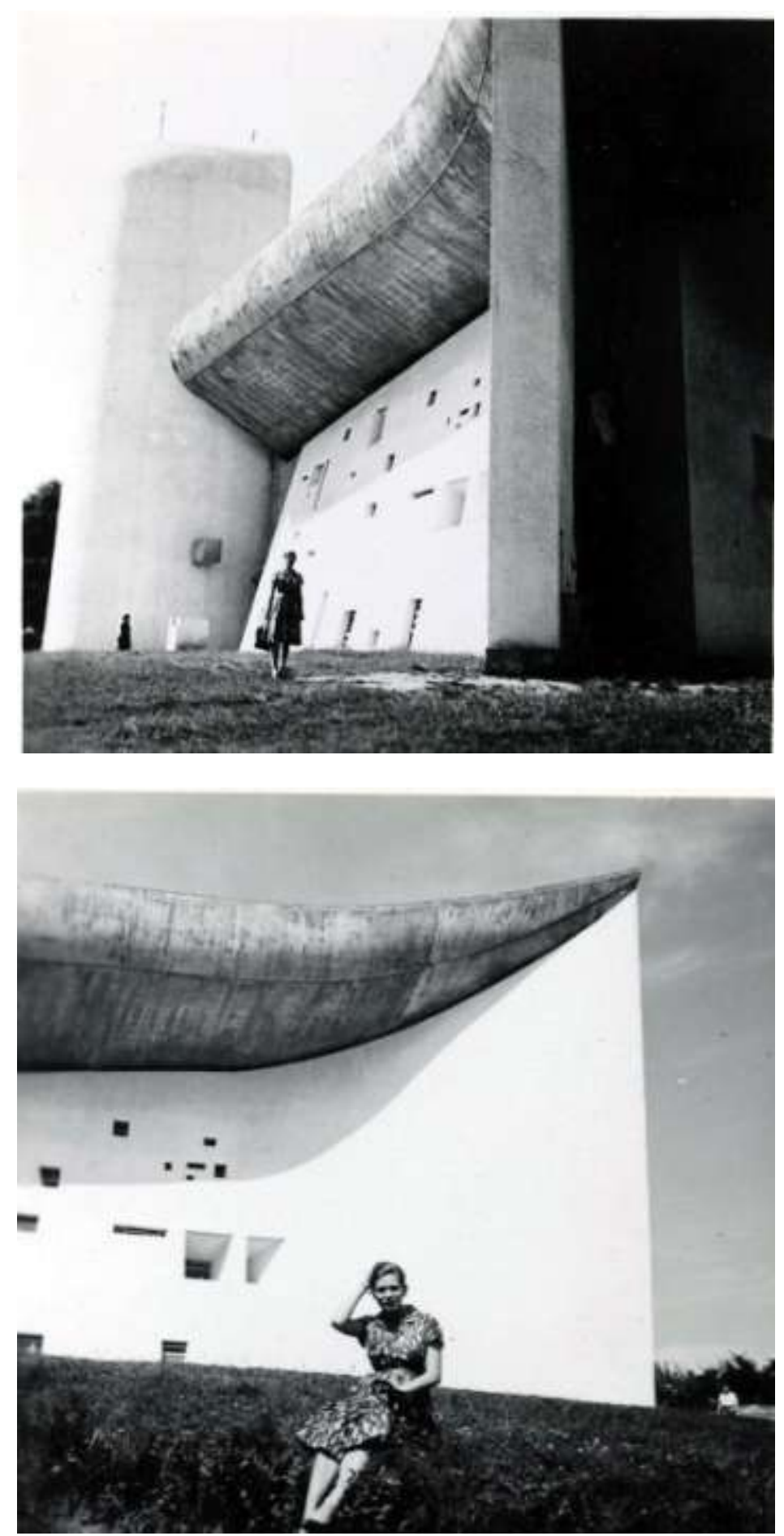

Ana María Badell -esposa de Miguel Fisac- en el muro sur de la capilla de Ronchamp. Fotografía tomada por Miguel Fisac hacia 1957-58. Fundación Miguel Fisac. Inédita 


\section{Richard Neutra}

En 1951 se publican en España dos casas de Richard Neutra construidas en 1948, en las que se destaca la "perfecta identificación con el paisaje" de ellas, así como, a través de unas breves líneas del propio Neutra, la importancia del emplazamiento, "expresión de los principios que han presidido los anteriores proyectos", defendiendo una arquitectura "adaptada al medio ambiente"192.

En el artículo se incide en la importancia de factores como el clima, la topografía y el aspecto del terreno en la concepción de la arquitectura, y se realiza la defensa de una arquitectura moderna que demuestra interés y capacidad de adaptación al ambiente natural.

Las palabras de Neutra son absolutamente esclarecedoras, y en la misma línea de los razonamientos de Fisac (Neutra, 1950): "Desde la edad de piedra a los poblados indígenas de nuestros días, podrían citarse innumerables ejemplos que demuestran la existencia de un talento especial en el hombre para aprovechar estéticamente la cualidades de un emplazamiento cualquiera. Si algunos excelentes arquitectos no han considerado nunca este punto, se debe fundamentalmente a una preocupación exagerada por conseguir un objetivo muy particular y concreto, considerándolo además totalmente disociado del ambiente del que tiene que ser parte integrante."193

La identificación con una serie de principios básicos en la concepción de la arquitectura en el paisaje intensificará la amistad entre Fisac y Neutra, presentados por Casinello, que en varias ocasiones, según testimonio del propio Fisac, visitará España junto con su familia -además de visitar Fisac varias de sus casas en Los Ángeles en 1955-.

Prueba de ello es que durante la estancia en España de Neutra en 1954, Fisac lo acompaña en su visita por el país, llegando incluso a visitar juntos La Alhambra. OrtizEchagüe, uno de los arquitectos que acompaña también a Neutra, junto a Fisac, dejará constancia de la visita a través de unas reflexiones: "Neutra construye para el hombre, con todas sus circunstancias y su trascendencia, es el centro de su atención"194

\footnotetext{
192 Informes de la Construcción, 35, noviembre de 1951; tomadas de la revista francesa L'Architecture D'Aujourd'Hui, 30, julio de 1950.

193 Neutra, R. (1950). Dos viviendas proyectadas por R.J. Neutra. Informes de la Construcción, 35, noviembre de 1951; tomadas de la revista francesa L'Architecture D'Aujourd'Hui, 30, julio de 1950. Se trata de la vivienda para el Dr. Stuart G. Bailey en Santa Mónica.

194 Ortiz-Echagüe, C. (1954). Con Neutra por tierras de Castilla. Boletín de Información de la Dirección General de Arquitectura, $8.4^{\circ}$ Trimestre.
} 
También Alejandro de la Sota nos confirma la concepción del paisaje que Neutra tenía, y de la que como hemos dicho, produjo una serie de evocaciones en Fisac.

"Hablaba hace poco Richard Neutra en Madrid de cómo el paisaje se extiende desde el horizonte hasta nosotros mismos, nos incorpora a él: el paisaje es el aire que respiramos. En las casas de Neutra, el paisaje, siguiendo su camino, penetra en ellas. ¿Cómo podría deternerse? (...): hay que ver el paisaje, es necesario dejarlo penetrar. Amando el paisaje como Neutra lo ama, ¿qué otras casas podría proyectar? Son simple consecuencia de este amor."195.

El aprendizaje de la obra de Neutra es una suerte de intercambio, un flujo de ideas "de ida y vuelta". De igual forma que Fisac le muestra a Neutra La Alhambra y extrae de ella ciertas potencias que trasvasa a su arquitectura, así Neutra transfiere la actualización de esas valencias a la arquitectura de su tiempo, de las que de alguna manera bebe Fisac.

De hecho, Neutra llega a afirmar que "la verdadera esencia espacial de mi trabajo esta extraída de los patrimonios arquitectónicos de España, especialmente la Alhambra de Granada"196.

Y de vuelta, podemos acordar que en la arquitectura de Miguel Fisac se permite que el paisaje, la totalidad de su espiritu y su plenitud, penetre en ella.

195 Sota, A. de la (1954). Algo sobre paisajes y jardines. Publicado en Puente, M. (Ed.) (2012). Alejandro de la Sota: escritos, conversaciones, conferencias. Barcelona: Gustavo Gili

196 Navarro, M.I. (2001). Desde el origen: La arquitectura de Fernando Higueras. Basa, 24 . La Palmas: Colegio Oficial de Arquitectos de Gran Canaria. 


\section{4_Las publicaciones de la época}

Existen ya importantes estudios ${ }^{197}$ sobre cómo la generación de arquitectos de la balbuciente modernidad española a la que pertenecía Fisac, la generación "huérfana", en palabras del daimieleño- utilizaron "el conocimiento de lo foráneo como medio para acceder a la realidad y transformarla, (...) una de las que utilizaron para descubrir y consolidar la modernidad en el espacio social (...)" 198, por lo que en aras a no desviar la atención de la presente investigación nos limitaremos aquí simplemente a enunciar la intensa relación de Fisac con las publicaciones extranjeras, habiéndose ya desarrollado en profundidad su prolífica actividad viajera.

Todos los testimonios coinciden en señalar las dificultades para conseguir con cierta fluidez publicaciones extranjeras -libros y revistas- en los años de la postguerra, como consecuencia del aislamiento decretado internacionalmente para el régimen de Franco. Las bibliotecas de la Escuela de Arquitectura o del Colegio de Arquitectos de Madrid, eran prácticamente los medios con los que contaban los arquitectos para bucear en los trabajos que se realizaban fuera de nuestras fronteras (sin contar los viajes que cada uno tuviera oportunidad de realizar, así como las exposiciones que sobre arquitectura extranjera se realizaron).

Sin embargo Fisac, procuró recorrer diferentes caminos para paliar dicho aislamiento; $y$ además de visitar -como hemos explicado- en primera persona una serie de arquitecturas seleccionadas en sus numerosos viajes, también fue un empedernido adquiriente y estudioso de publicaciones especializadas.

En su archivo consta una enorme cantidad de revistas, tanto nacionales como internacionales, en la que destaca la colección casi completa de la revista The Architectural Review.

El estudio de las revistas es, para el arquitecto manchego, y según manifestó en multitud de ocasiones, un importante medio de conocimiento. Si bien es cierto que sus contemporáneos también lo hacian, sobre todo las de tirada nacional, puesto que las

197 Para un estudio completo sobre este particular, consúltese Esteban Maluenda, A. (2007). La modernidad importada. Madrid 1949-1968: cauces de difusión de la arquitectura extranjera (tesis doctoral). Madrid: Universidad Politécnica de Madrid.

${ }^{198}$ Esteban Maluenda, A. La modernidad importada. Historia de una investigación. Cuaderno de notas, 12, 11. 
internacionales no llegaban con la fluidez que hubieran debido, para Fisac es especialmente importante por cuanto luego le sirve para forjarse opinión -muchas veces escritas en otras publicaciones españolas, convirtiéndose en un arquitecto con opinión influyente- $y$ trasladar unas $u$ otras ideas a su universo conceptual.

Es muy interesante, como botón de muestra de su control y estudio del panorama de las publicaciones especializadas, la carta enviada a Carlos de Miguel, por aquel entonces director de la Revista Nacional de Arquitectura, y que fue publicada en el número 185 , en mayo de 1957 (pg. 40):

"Las revistas actuales de Arquitectura creo que se pueden dividir en dos grandes grupos: revistas bonitas y revistas útiles. Claro que hay también un tercer grupo, que no es ni una cosa ni otra

\section{(...)}

Las revistas bonitas tales como L'Architecture D'Aujourd'hui, Domus, etc., tienen como tema fundamental eso: ser una publicación bonita, por lo que sacrifican todo para conseguir ese fin. Como da la coincidencia de que existe también una arquitectura para hacer de ella unas fotos bonitas (...) sacan unos números de revista admirables, que le dejan a uno epatado al ojearlas, pero que al final, con tanta "monótona originalidad", llegan a aburrir terriblemente.

Hay por el contrario, algunas revistas como The Architectural Review, la danesa Arkitekten, la finlandesa Arkitehti Arkitekten, etc., que tienden, fundamentalmente a dar criterio al publicar proyectos y realizaciones, sin perder, claro está, el cuidado por la presentación con buenas fotografías, pero sin olvidar que buenas fotografías de arquitectura no es lo mismo que buena arquitectura para hacer fotografías... "

Las revistas extranjeras eran adquiridas por Fisac en Inchausti, calle Alcalá 63 de Madrid ${ }^{199}$, omitiendo quizás Fisac la adquisición de otras durante sus numerosos viajes como hacían otros arquitectos-, ya que las posibilidades en Madrid, según las investigaciones existentes eran bastante limitadas.

"Entre los de mi promoción no se manejaban apenas revistas...de las alemanas, yo consultaba Moderne Bauformen que era una revista con un tipo de arquitectura popular muy interesante; de las francesas L'Architecture, y Domus, de las italianas (la que dirigía Gio Ponti)...bueno, también Architetti que nos puso en contacto con la arquitectura romana de la exposición de 1942 (exposición de arquitectos de Musolini en

\footnotetext{
${ }^{199}$ Alarcón, C. Op. cit. Parte II. Anexo E, pg. 14. Entrevista a Fisac . La librería Inchausti fue un importante foco de importación de publicaciones, además de haber ideado un sistema de cuotas que facilitaba su adquisición.
} 
Memoria, Aprendizaje y Experimento. La invención del paisaje en Miguel Fisac

Aprendizaje. Las publicaciones de la época

la que había obras de Moretti, Albi, Libera y otros. Arquitectos importantes que luego hicieron obra de gran calidad), mis primeros edificios los hice yo con esta inspiración..

He estado suscrito, y aún lo estoy a la inglesa Architectural Review; he consultado las norteamericanas Architectural Record y, sobre todo, Architectural Forum.L'Architecture D'Aujourd'Hui con lo del Posmodernismo, se convirtió en algo que no me interesaba. Por falta de espacio tuve que deshacerme de las colecciones completas de Werky, Casabella...etc"

De todo ello se colige que Fisac que estaba absolutamente informado de todo lo que se publicaba fuera. 
Memoria, Aprendizaje y Experimento. La invención del paisaje en Miguel Fisac

Aprendizaje. Otra vez La Mancha

\section{5_Otra vez La Mancha}

$Y$ de todo este conocimiento, de todo este aprendizaje que comienza en sus intuiciones, continúa en sus viajes y en el descubrimiento de otras culturas, y que alcanza su cénit en La Alhambra y en la Casa Japonesa, cabría preguntarse, ¿con qué se queda Fisac? ¿cómo podríamos sintetizar todo este aprendizaje?

En ello, hay un aspecto que debemos destacar. $Y$ es que considerando el itinerario de su vida y su obra, parece éste un viaje circular, con salida y regreso a La Mancha, su obsesión. La humanización y universalidad buscada siempre regresa a los conceptos y profundidades del paisaje manchego.

¿Se tratará pues de una arquitectura que funciona por ósmosis, en la que a través de una suerte de membrana semipermeable, que es su Memoria, se tamiza su Aprendizaje?.

Nos disponemos, pues, a dar respuesta a ello a través de sus Experimentos. 
Memoria, Aprendizaje y Experimento. La invención del paisaje en Miguel Fisac Aprendizaje. Otra vez La Mancha 
Memoria, Aprendizaje y Experimento. La invención del paisaje en Miguel Fisac Experimento

\section{4_EXPERIMENTO}

\section{Gramática de un paisaje}

El horizonte: miradores, umbrales, fronteras

El agua: estanques, fuentes y surtidores

Sombras, secuencias, tránsitos y límites

Jardinería y vegetación

Textura y materialidad 


\section{Gramática de un paisaje}

Si nos aproximamos desde el punto de vista fenomenológico al paisaje concebido por Fisac, podemos observar una serie de elementos, una suerte de gramática, que el arquitecto utiliza para activarlo, modificarlo, transformarlo, o reinterpretarlo. Elementos a través de los cuales se habita el paisaje, y por lo tanto, de acuerdo con Heidegger, se construye.

No tratan estos elementos de contribuir a una adaptación romántica de la arquitectura al lugar; bien al contrario, trata de reafirmar el diálogo entre ambos, desde el carácter, la identidad y la atmósfera del paisaje.

Este sistema de variables produce que sus arquitecturas se alcen como si hubieran surgido propiamente de la tierra. Toman fuerza de lo ancestral, de la memoria, de las energías que subyacen en el lugar, de forma que el paisaje resuena en ellas.

En efecto, al igual que las grandes piezas arquitectónicas que se enclavan en el borde de los riscos, como un castillo o una iglesia, no hacen sino celebrar el paisaje en el que se encuentran y parecen siempre pequeños ante la grandeza del mismo; así Fisac experimenta para contrastar que sus arquitecturas no lo minoran ni lo eclipsan, bien al contrario, hacen más visible la grandeza del mismo, que brille con una nueva luz.

Este diálogo se produce desde la memoria y desde un posicionamiento de consideración idiosincrática ${ }^{200}$, que le permite desplegar estas herramientas filtradas de una determinada manera para llevar a término sus intuiciones y comprobar que el paisaje acepta el edificio.

Amar el paisaje, mirarlo desde lo más profundo del ser, es condición sine qua non para llevar a buen término este diálogo. Precisamente un punto de partida interiorizado por Fisac desde sus paseos infantiles por La Arboleda de Daimiel, donde el aliento cercano de la muerte le condujo precisamente a celebrar la vida a través de la naturaleza.

Fisac ama el suelo del que surge su arquitectura. $Y$ ama las irregularidades de la topografía o las rocas que allí subyacen. Porque es a través de ese amor mediante el que parece que la arquitectura siempre ha estado allí. Como lo amaron los arquitectos de la Acrópolis o los hombres que levantaron las piezas de arquitectura popular de cualquier lugar en el que debe intervenir.

200 Fisac lo denomina territorialidad psicológica 
Ama el material con el que compone su arquitectura, y por ello estudia sus cualidades internas y su textura. Para que encaje con lo sustancial del paisaje formado a lo largo de la historia. La sustancia, la naturaleza de lo construido debe armonizar con la naturaleza del entorno; y por eso busca una unión íntima lugar-material-construcción. En muchas ocasiones el material procede directamente del lugar, de forma que el paisaje acepte la nueva arquitectura porque la arquitectura está hecha de un trozo de paisaje.

Ama el agua. Desde el descubrimiento de Las Tablas de Daimiel, desde que fuera invitado a escribir sobre las fuentes del conjunto nazarí en el Manifiesto de La Alhambra. Y la ama como generadora de vida, como regante de los campos, como placer estético de contemplación, o como reflejo de la obra de la naturaleza y la obra del hombre.

Ama el horizonte, la unión de cielo y tierra, tan límpida en La Mancha de su infancia. Intenta atraparlo, trata de delimitarlo bellamente con huecos profundos en sus casas de Mallorca, de contemplarlo a través de los miradores, incluso de realizar una conexión cuasi-metafísica con el mismo. Y también trata de realzarlo, en la contraposición al mismo de las torres de sus iglesias.

Ama la sombra, porque ama la luz. Y aprende de la arquitectura de la casa japonesa a secuenciar y hacer fluido el espacio, el interior con el exterior, a dotar de continuidad 0 separar. La sombra es tomada como sustancia activa en varios de los proyectos, ya sea a través de pórticos que hilvanan distintos pabellones, marcando un acceso, o tensando un jardín. Fisac sumerge en la luz los espacios, los materiales, las texturas, los colores, las superficies y las formas: atrapa la luz del paisaje y la refleja, la filtra, la atenúa o la rebaja, para que aparezca en su intensidad certera.

Y al fin, ama la jardinería y la vegetación. Jardines de herencia hispanoárabe 0 japonesa que relacionan la obra del hombre con la de la naturaleza, el acá con el allá. Jardines que contienen, como decía Ferdinand Bac parafraseando a Barragán, "nada menos que el Universo entero".

Un sistema, quizás inconsciente, de variables que se repiten como si de un léxico se tratara y que como hemos dicho actúan como elementos activadores del paisaje. Un conjunto que podríamos desarrollar mucho más ampliamente, pero del que se ha seleccionado un número determinado de elementos para no perder el espíritu clarificador invocado al inicio de esta investigación. 


\section{El horizonte: Miradores y umbrales}

Vamos a tratar de explicar cómo Fisac introduce en su arquitectura la captura del horizonte como herramienta de conexión con el paisaje. Este ejercicio, que realiza de forma continua, se materializa en miradores, huecos profundos, pórticos o umbrales.

En los escritos de Fisac destacan la sensibilidad ante experiencias estéticas tan evocadora como la contemplación del horizonte, y ello es tomado como una de las herramienta para humanizar sus espacios, para elevar la vida, para huir de la vulgaridad cotidiana.

"Cuando un día cualquiera, sin saber por qué, se nos ocurre mirar tranquilamente una puesta de sol, que es lo más bello que podemos ver, pero de la que nadie nos hace la propaganda, porque no es un negocio, se nos ensancha el alma y nos invade una placidez bendita, que nos llena de sorpresa, porque hemos llegado a olvidar lo que es la belleza verdadera, inmersos, como estamos, en esta sórdida vida cotidiana que nos hemos fabricado." 201

Esta manera de mirar y delimitar el horizonte fue aprendida a través de sus viajes. Si observamos los croquis realizados en la Acrópolis en su Viaje alrededor del mundo de 1955, observamos como con insistencia se coloca en la posición en la que el peristilo del templo atrapa el horizonte y lo hace suyo.
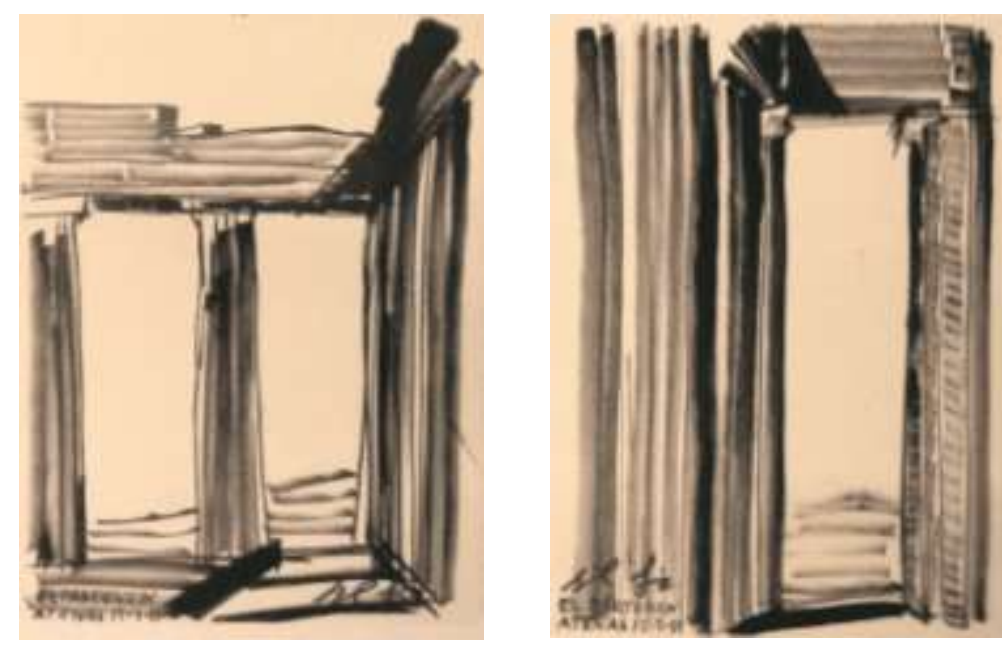

El Partenón. Apuntes de Miguel Fisac. 18 de agosto de 1955

${ }^{201}$ Fisac, M. (1969). La molécula urbana, 82. Madrid: Epesa. 
La mejor forma de explicar estos conceptos es su confrontación con una serie de obras representativas de ello.

La idea de delimitar el horizonte la realiza Fisac con enorme sencillez y belleza en la casa de Torcuato Luca de Tena en Mallorca (1961). De acuerdo con Barragán, que defiende que "uno no debe pasarse con el tema de las vistas panorámicas circulares, pues un paisaje aumenta en belleza cuando se enmarca y delimita propiamente."202

Se trata de una casa de veraneo: para contemplar el horizonte y las puestas de sol, para leer mirando al mar, o para descansar entre el rumor de los pinos que recubren toda ese paraje mallorquín. Una casa, como diría Fisac para que se nos "ensanche el alma"; una de las 6 viviendas que construye en el término de Son Cervera, en un paraje conocido como la Costa de los Pinos, y que incluye una casa para su propia familia.

Todas ellas tienen ciertas características comunes con respecto a su posicionamiento ante el paisaje, como si se tratara de un único proyecto, y es que, como hemos dicho se pretende capturar el horizonte, y poder contemplar la unión entre el mar y el cielo, delimitándolo de forma exquisita.

Así, el mar se introduce en la casa; el hueco profundo lo enmarca y desde ese momento pertenece a ella, logrando así que el paisaje se humanice a la vez que el espacio de la casa se expande.

Esta arquitectura esencial incorpora así el paisaje a la arquitectura, -el horizonte enmarcado- se apropia del exterior y lo incorpora al interior, como posteriormente hará Jorn Utzon en su tan celebrada Can Lis en la vecina Porto Petro. O Fisac en su vivienda familiar de Mazarrón y en la casa del Vizconde Ednam en Cádiz mediante un porche en voladizo compuesto por vigas-hueso, etc. De esta forma el horizonte se atrapa para que forme parte de la arquitectura.

${ }^{202}$ Barragán, L. (1951). Gardens for enviorement. Jardines de El Pedregal. Conferencia dictada ante el California Council of Architects y la Sierra Nevada Regional Conference en Coronado, California. En Riggen, A. (2000). Op. Cit., 40. 

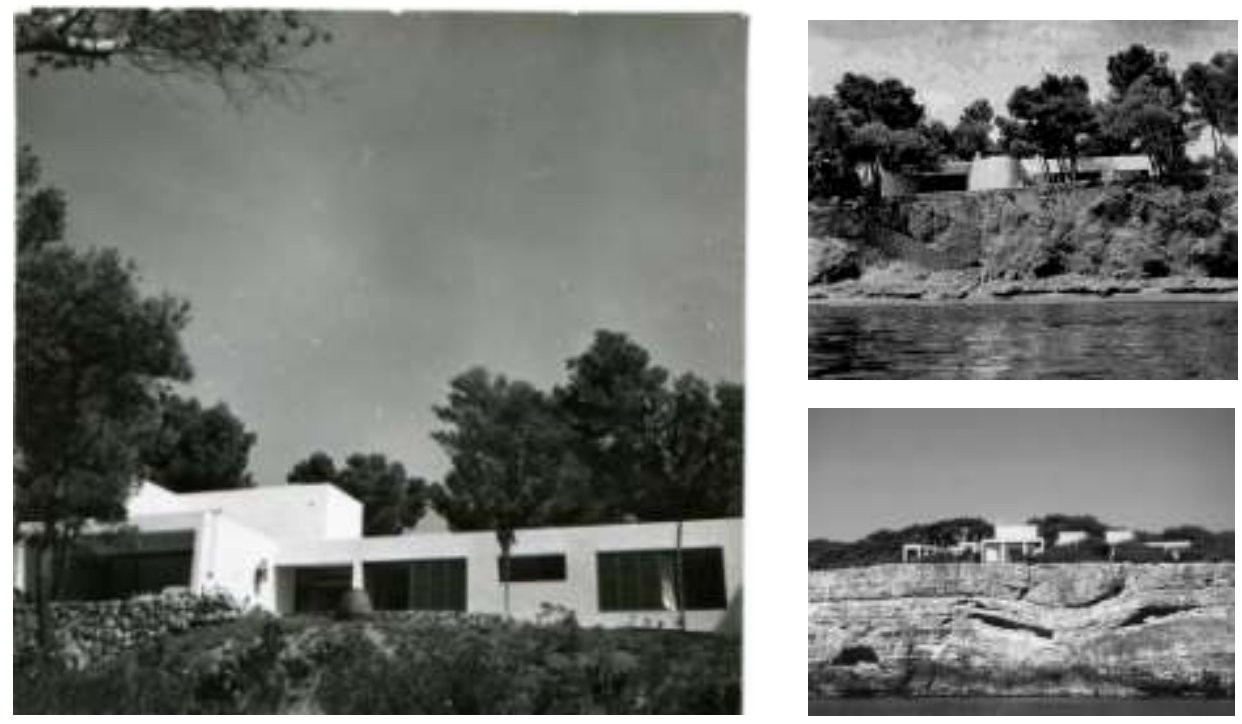

En primer plano, Casa Torcuato Luca de Tena en Costa de los Pinos (1961). A la derecha, Casa Fisac, ubicada en el mismo paraje, en Costa de los Pinos (Fisac, 1961) y Can Lis en Porto Petro (Utzon, 1972)

La pieza de mayor intensidad de la vivienda, auténtico enlace con el horizonte, es el la zona de estar. Un hueco profundo que permite la visión enmarcada a la vez que se permanece en una agradable penumbra, espacio perfecto para el descanso.

La casa Luca de Tena cuenta además con una particularidad: dispone de un estudio en planta alta, con una azotea-mirador privado. Un estudio en el que nos podemos imaginar a un escritor enfrascado en su Pepa Niebla (1970) o en Los Renglones torcidos de Dios (1979).

El juego de volúmenes, la luz y la sombra en contraste con la vegetación, el mar y el cielo, nos traslada a una arquitectura de formas elementales, eterna y primitiva a la vez, que nos sugiere haber estado allí antes de que se conformara el propio paisaje.

El texto de la memoria del propio proyecto es directa en relación con la intención de atrapar el horizonte

"El replanteo se hará respetando en todo lo posible el arbolado existente, que proporciona una gran belleza al conjunto, sombra, sonoridad al viento, y primeros términos en la contemplación del paisaje desde el interior."203.

203 Fisac, M. (1961). Proyecto de hotel en "Costa de los Pinos" (Mallorca) para D. Torcuato Luca de Tena. Memoria. 
Memoria, Aprendizaje y Experimento. La invención del paisaje en Miguel Fisac

Experimento. Gramática de un paisaje

El estudio profundo del terreno y su topografía, así como la concreta localización de los árboles nos muestran una declaración de intenciones: construir una arquitectura ligada al lugar. En este sentido el posicionamiento de la casa de forma paralela al mar, además de facilitar ese atrapamiento del horizonte ya comentado, justificado por la orientación sur y los vientos dominantes, convierte al conjunto en una arquitectura con vocación de pertenencia a su entorno, que se integra y que ayuda al hombre a disfrutar de ese paisaje ${ }^{204}$.

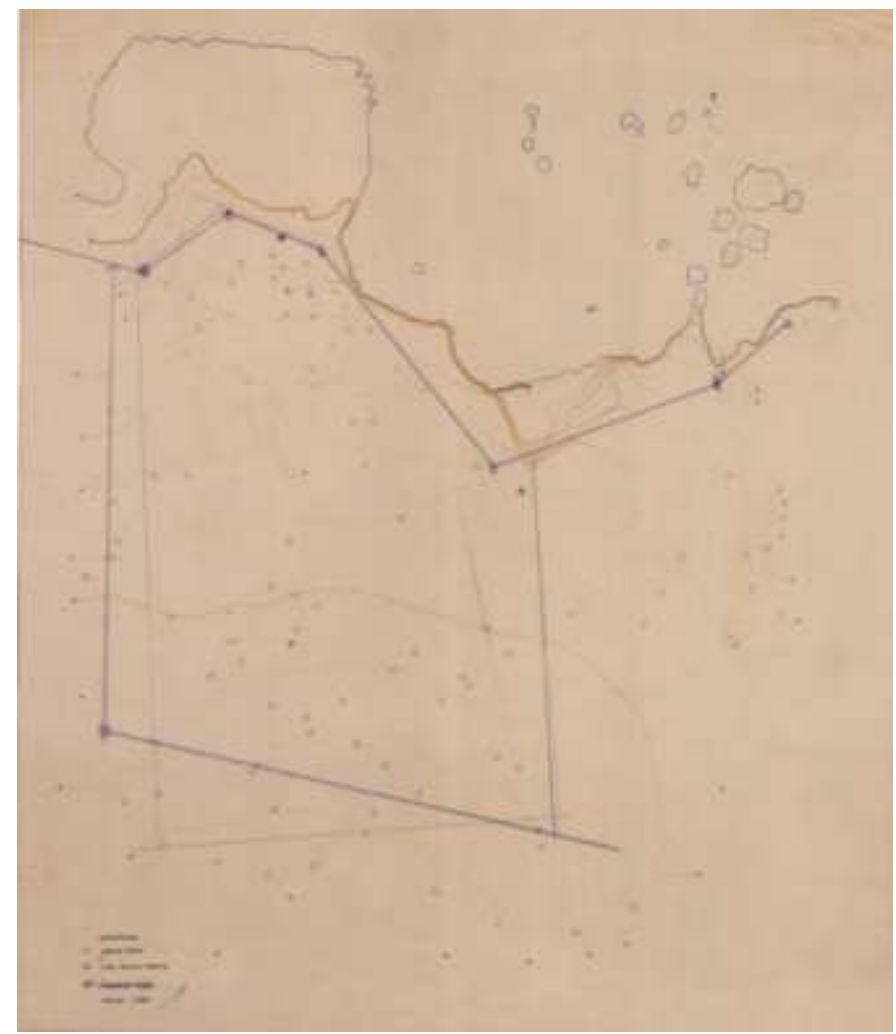

Casa Luca de Tena. Plano topográfico (1961)

204 El texto de la memoria del proyecto es muy expresiva en este sentido, denotando una interiorización total del paisaje por parte de Fisac de forma previa. 


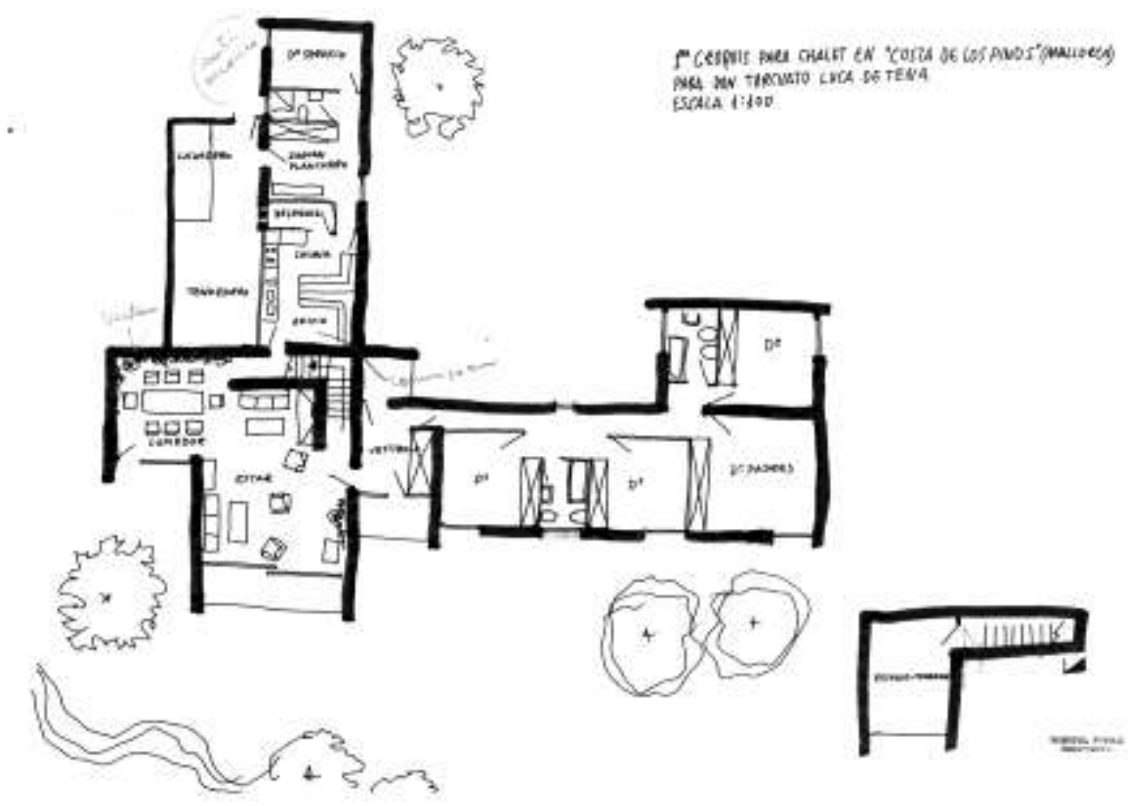

Miguel Fisac. Vivienda de Torcuato Luca de Tena en Costa de los Pinos. Croquis previo, en el que se observa la profundidad del hueco que delimita el mar y el horizonte. Fundación Miguel Fisac.

Un elemento característico de la relación de la obra de Fisac con el paisaje son los balcones-miradores. Balcones que se utilizan con doble intención: por una parte para mirar, pero por otra como elemento que conforma el "no sé que" fisacquiano para crear belleza mediante la incorporación de un elemento de tensión. De esta forma, tanto en el Centro de Investigaciones Biológicas como en el Centro de formación del Profesorado, sendos balcones consiguen focalizar la atención, ya sea en una fachada con una composición de huecos, 0 en otra fachada tersa.

Balcones similares, que recuerdan la sala de conciertos de Gotemburgo, obra de Nils Einar Eriksson que tanto gustó a Fisac en su viaje a Europa y que le había recomendado visitar Fernández-Vallespín.

"Este balcón -para tranquilidad de los curiosos, entre ellos el director de esta Revistatiene, a más de esta función estabilizadora de la euritmia general del conjunto, una función: es el único punto en la azotea de la torre desde el que se puede contemplar el maravilloso paisaje madrileño del Guadarrama, ya que el resto del pretil de esta terraza está ocupado por chimeneas de evacuación de gases y aire viciado de los recintos de animales de experimentación." 205.

205 Fisac, M. (1983). Centro de Investigaciones Biológicas de los Patronatos Cajal y Ferrán, del Consejo Superior de Investigaciones Científicas. Arquitectura, 241, 43 

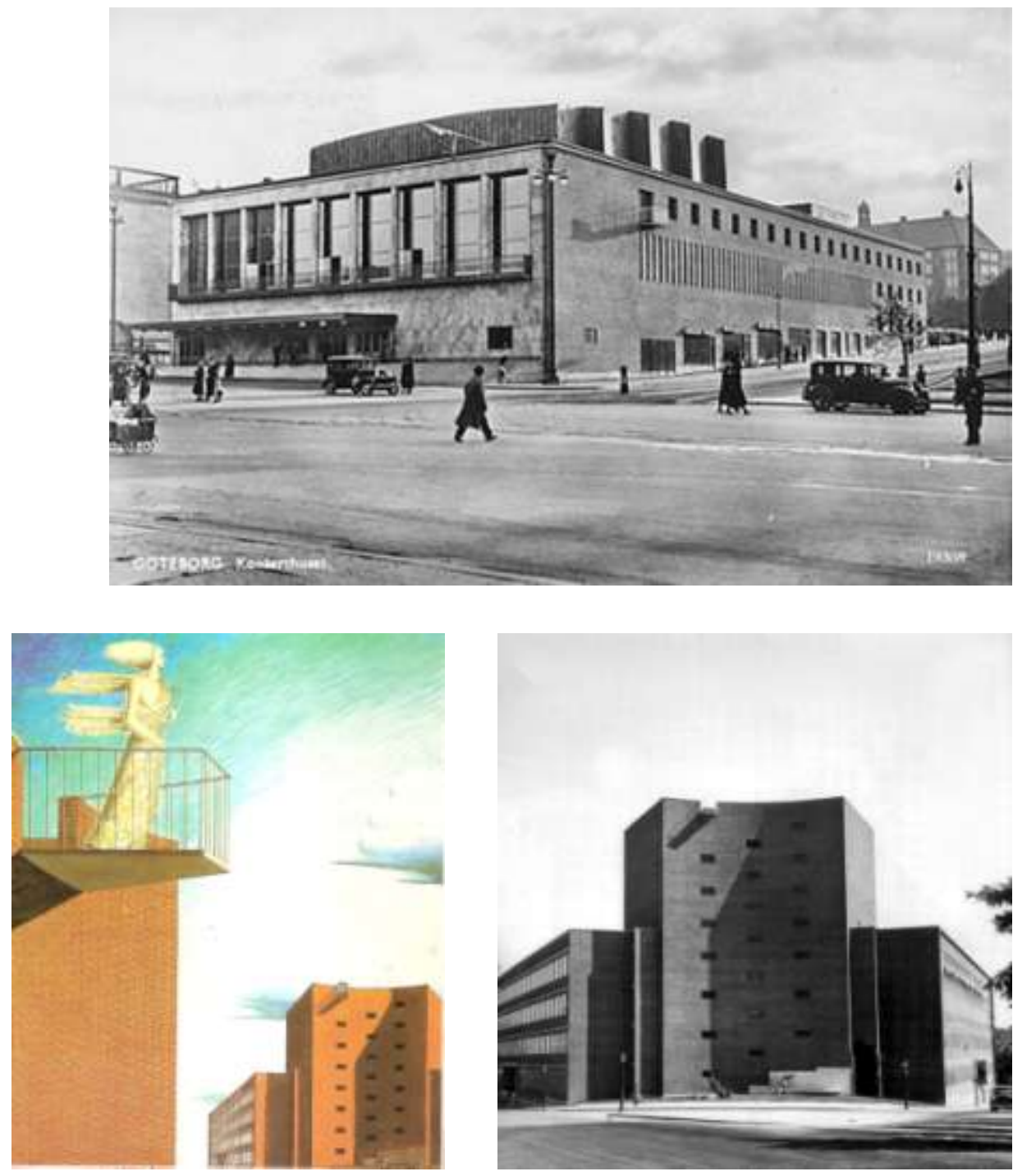

Balcón-Mirador de la Sala de Conciertos de Eriksson, y balcón del Instituto Cajal. El dibujo es de Emilio Tuñón, para la portada de la revista Arquitectura nº 241

Se trata una firme declaración de intenciones, que va mucho más allá del hecho formal. Aún en el centro de Madrid, se quiere conectar definitivamente la arquitectura con ese trozo de Naturaleza, del Cosmos, de la Creación, para lo que no hace falta subir al balcón: la contemplación del mismo nos traslada la visión cuasi metafísica de la Sierra de Guadarrama. 


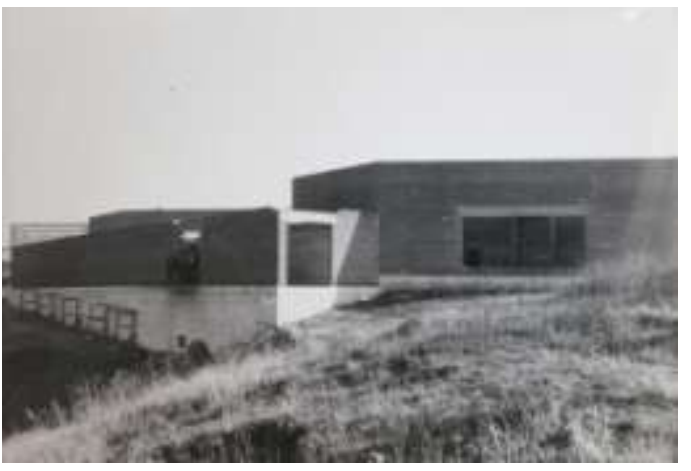

Mirador a la Sierra de Guadarrama. Único hueco en el lado Norte del Centro de Formación del Profesorado de la Ciudad Universitaria-

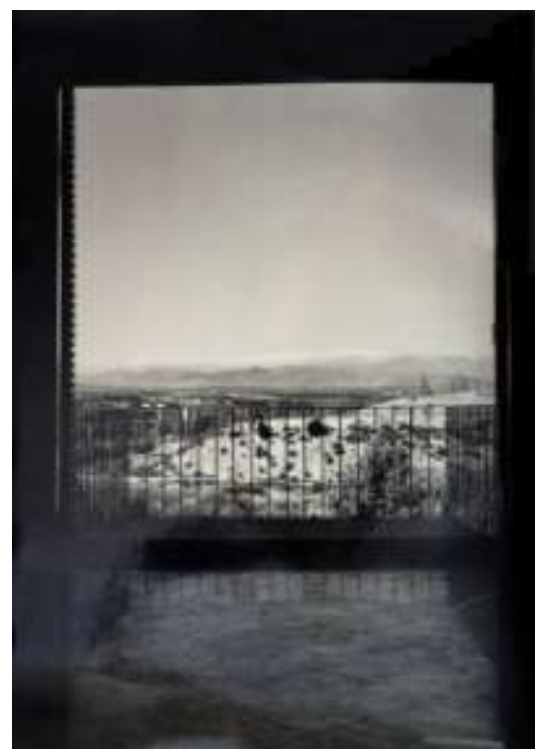

En la obra arquitectónica de Fisac la mirada, -como en La Alhambra-, no tiene un único sentido: se mira hacia fuera, pero también hacia dentro.

Porque el mirador no es sólo una apertura en un muro con unas vistas enfrente, es un instrumento de contemplación. Contemplación de la Naturaleza, de la Creación, pero también contemplación de la propia arquitectura y de otra naturaleza creada a través del jardín.

"Lo más refinado del escenario son estos miradores para la vida quiescente; por ellos el jardín se embebe en la casa, o la casa se desparrama en el jardín."206

Por otra parte, fruto de su concepción de los jardines como una estancia más de los edificios, también éstos necesitarán de lugares frescos y resguardados, marquesinas, pórticos o galerías, umbrales en definitiva, en los que intercambiar, charlar, meditar, o según el caso desarrollar valores espirituales o relativos a la contemplación de la belleza. Con esta vocación existen también los umbrales del Centro de Formación del Profesorado, los espacios porticados del Teologado de Alcobendas o del Instituto de Enseñanza Media de Málaga, o el umbral de acceso del edificio de viviendas de Valencia.

${ }^{206}$ Manifiesto de La Alhambra (1952). Parte IV. Jardines 


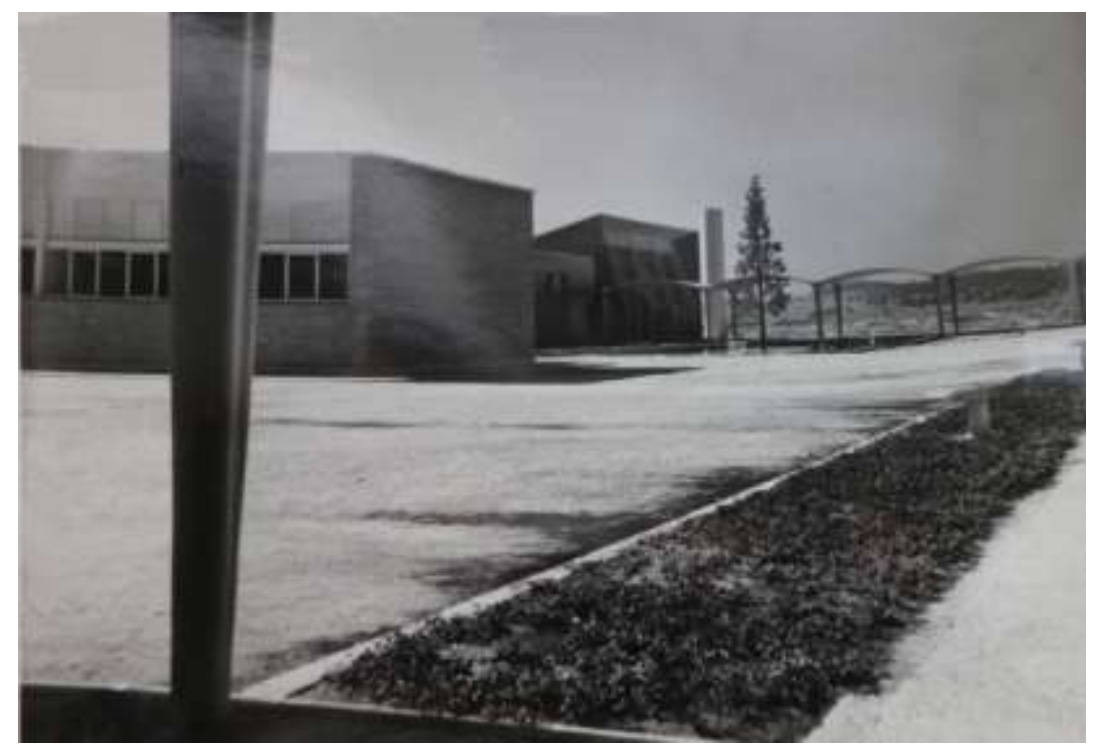

Umbrales que proporcionan sombra y delimitan el horizonte y la mirada a la Sierra de Guadarrama en el Centro de Formación del profesorado de la Ciudad Universitaria. Madrid. 1952-1957

Umbrales que nacen de los jardines hispanoárabes, pero también de la sabiduría popular, de las plazas mayores manchegas, para posteriormente ser desarrollados y adaptados a su universo arquitectónico. Umbrales que encuentran su primera formalización en el Instituto Laboral de Daimiel, -con sus pies derechos y carreras de madera-, y que posteriormente evolucionarán.

Y trata de hacerlo a través de mecanismos que unifican la tradición con la tecnología; uniendo un concepto tan aparentemente intrascendente como las "lonas al viento" con la intensa investigación sobre el hormigón armado. Y así lo materializa en la Ciudad Universitaria de Madrid. Pero siempre con una geometría esencial, abstracta. 
Esa misma formalización de galerías que también utilizará en el Colegio Apostólico de las Arcas Reales, afirmando su intención de conectar Naturaleza y jardín mediante la contemplación del paisaje interior desde la arquitectura.

Decía Luis Barragán "un paisaje aumenta en belleza cuando se enmarca y delimita apropiadamente"207. De esta forma, trata Fisac de encuadrar el horizonte cuando tiene oportunidad, de apropiarse así del paisaje exterior, y de hacerlo formar parte del paisaje interior creado en continuidad con el primero así como hacerlo partícipe de la arquitectura.

207 Barragán, L. (1951). Conferencia dictada el 6 de Octubre ante el California Council of Architects y la Sierra Nevada Regional Conference en Coronado, California. En Riggen, A. (2000). Luis Barragán. Escritos y Conversaciones, 36. El Escorial. El Croquis editorial 


\section{El agua: estanques, fuentes y surtidores}

Como hemos analizado en el epígrafe relativo a la Memoria, la infancia de Fisac estuvo muy ligada al agua, a los reflejos, fruto de sus vivencias en Daimiel, y en el entorno de sus tablas fluviales; que recogerá en sus dibujos de arquitectura tradicional manchega, llenos de reflejos a través del agua y que continuará a lo largo de su vida como si de una obsesión se tratara.
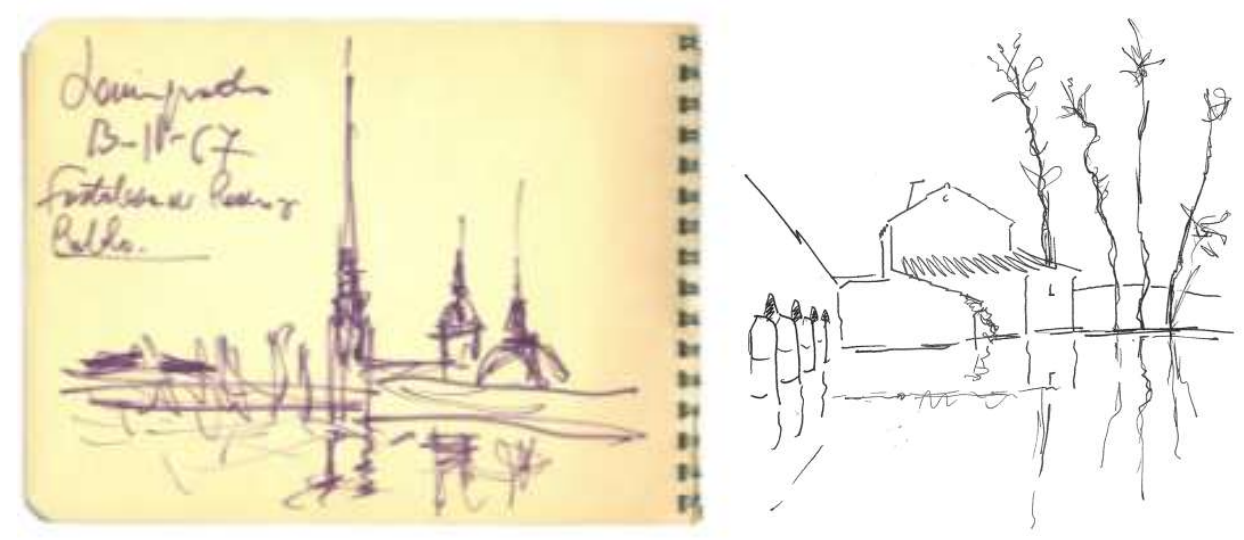

Dibujo del reflejo de la Fortaleza de San Pedro y San Pablo (ciudadela original de San Petersburgo), sobre el río Nevá, realizado por Miguel Fisac en su viaje a Leningrado en 1967 -inédita-.

Dibujo de arquitectura popular manchega. Tinta china sobre papel. Realizado por Miguel Fisac en 1984. Forma parte de los 21 dibujos que se recogen en el libro Arquitectura Popular Manchega.

"Daimiel es un oasis en la estepa de La Mancha (...) Es el milagro del agua. Es el tesoro soterrado y sacado a la superficie en una labor de años, de lustros, quizá de siglos. Milagros de Daimiel, maravilla de transformación de secano en regadío, que se repite en otras zonas manchegas, aunque en menor intensidad, porque la fertilidad de la estepa está condicionada a la existencia de agua."208

208 Pérez, F. (1958). Daimiel. Geografía de un pueblecito manchego, 7. Ciudad Real: Publicaciones del Instituto de Estudios Manchegos 
A ello contribuyen también las evocaciones de los molinos de agua, que el propio Fisac describe: "Tiene (...) esta arquitectura, eso sí, un entorno bellísimo y gratísimo de verdor y rumor de agua, en duro contraste con los resecos y polvorientos barbechos de los alrededores, muy especialmente en verano. Su impacto, plástico en el paisaje de la Mancha húmeda, era enorme y de fácil captación"209

El agua se convierte en un tema recurrente en la obra de Fisac, a través de la Memoria y a través del Aprendizaje. Adelantado su interés por su utilización tanto en el Instituto Laboral de Daimiel como en el Pabellón de la Feria del Campo, como si de una reminiscencia infantil se tratara pero con gran intuición, es sobre todo a raíz de su participación en los estudios previos al Manifiesto de La Alhambra, en 1952, cuándo comenzará a incorporarla con frecuencia y diferentes intencionalidades.

"El jardín granadino parece una enorme alquitara para lograr el líquido que no tiene semejante en belleza por su blancura y transparencia"210

Así, si en La Alhambra el agua existe en sus tres momentos: el de surgir o manantial, el de fluir, y el de estancarse, también existirán estos en las obras de Fisac, si bien la formalización de estanques, fuentes y surtidores será realizada con mayor flexibilidad.

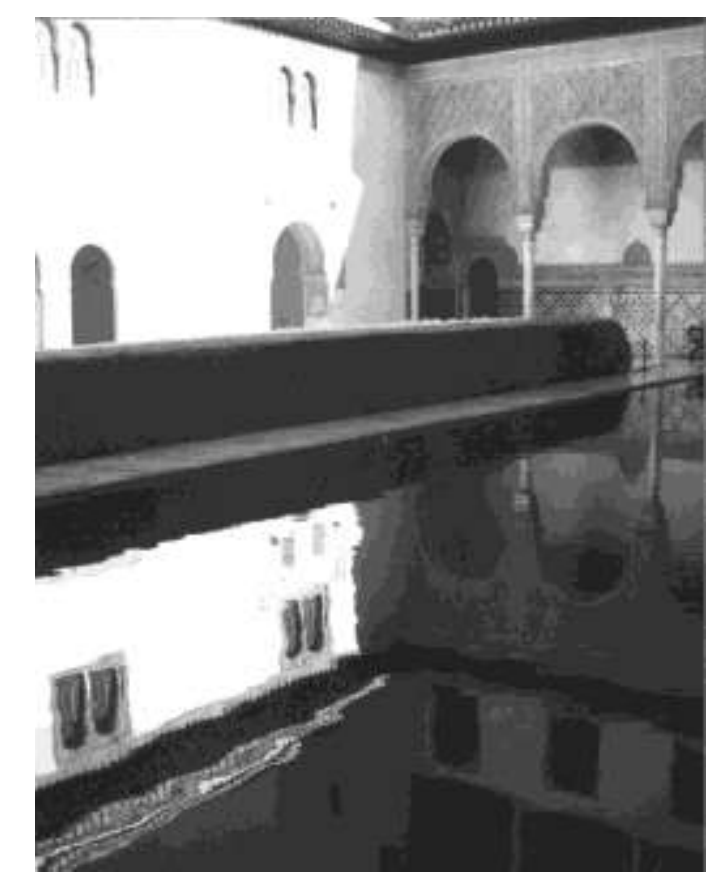

La Alhambra. Patio de los arrayanes

209 Fisac, M. (2005). Op. cit., 25

210 Manifiesto de La Alhambra (1952). Parte IV. Jardines 
Si bien su prolífica producción hace complicada alguna clasificación o el juicio sobre sus objetivos, si podemos afirmar que en todos los casos el uso del agua nos traslada a una conexión directa con el paisaje: paisaje que circunda los edificios, paisaje interior creado, o la fusión y el diálogo entre ambos. Esto es, el agua como activador en la invención del paisaje.

Citaremos algunos casos representativos del uso del agua y sus resultados, sin tratar de hacer un listado exhaustivo.

El estanque, entendido como un lugar en el que el agua permanece en reposo, formará parte de una suerte de tabla fluvial en el Instituto de Daimiel; será reflejo del cielo, la tierra y la arquitectura -como en La Alhambra- en el Centro de Formación del Profesorado de la Ciudad Universitaria; será lugar de meditación y contemplación en el Teologado de Alcobendas o en el Colegio Apostólico de Valladolid; y será balsa en Ortigosa del Monte y Cádiz. Evitaremos, no por desconocimiento sino por estar fuera del alcance de esta tesis, fundamentar intenciones sobre el estanque de la ordenación del CSIC, fruto de criterios arquitectónicos diferentes.

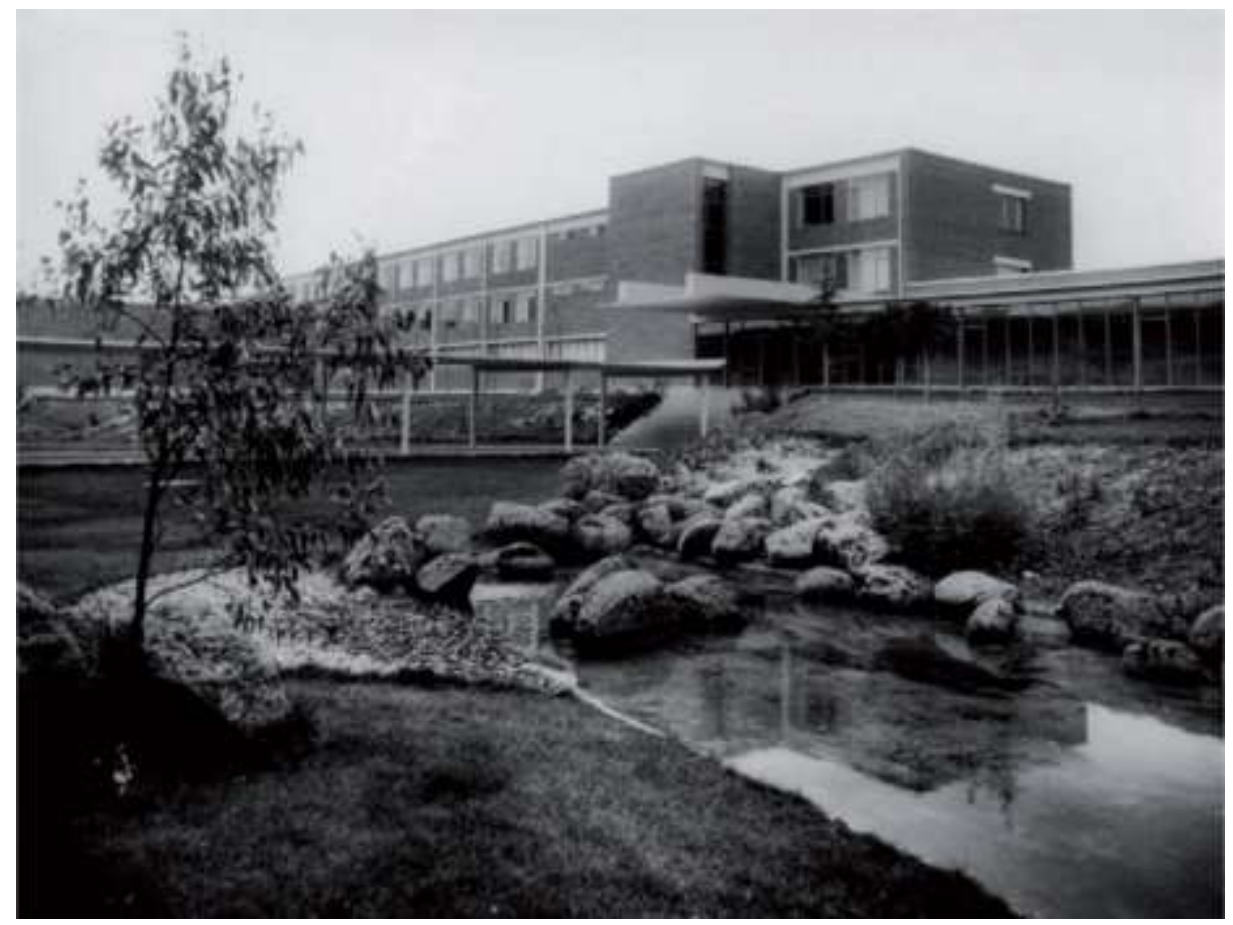

Estanque del claustro del Teologado de San Pedro Mártir. Alcobendas.

La fuente envolverá con el sonido del surtidor espacios para el reposo y esparcimiento Daimiel-; para la introspección -Valladolid-; será como un pozo, - lugar tradicional de 
reunión- en el edificio de viviendas de Valencia; tendrá vocación de aportar frescor a los patios de la casa de Sotogrande; o será un elemento de tensión compositiva como la del Instituto Cajal en el encuentro entre las Joaquín Costa y Serrano, con la escultura de Carlos Ferreira.

Y la acequia, por su parte, será un río en Ortigosa o será "lingote de hielo o plata"211, en Sotogrande, que oscila entre los patios, los refresca, afirma la gravedad y la topografía del terreno y desemboca en una gran balsa abierta al paisaje.

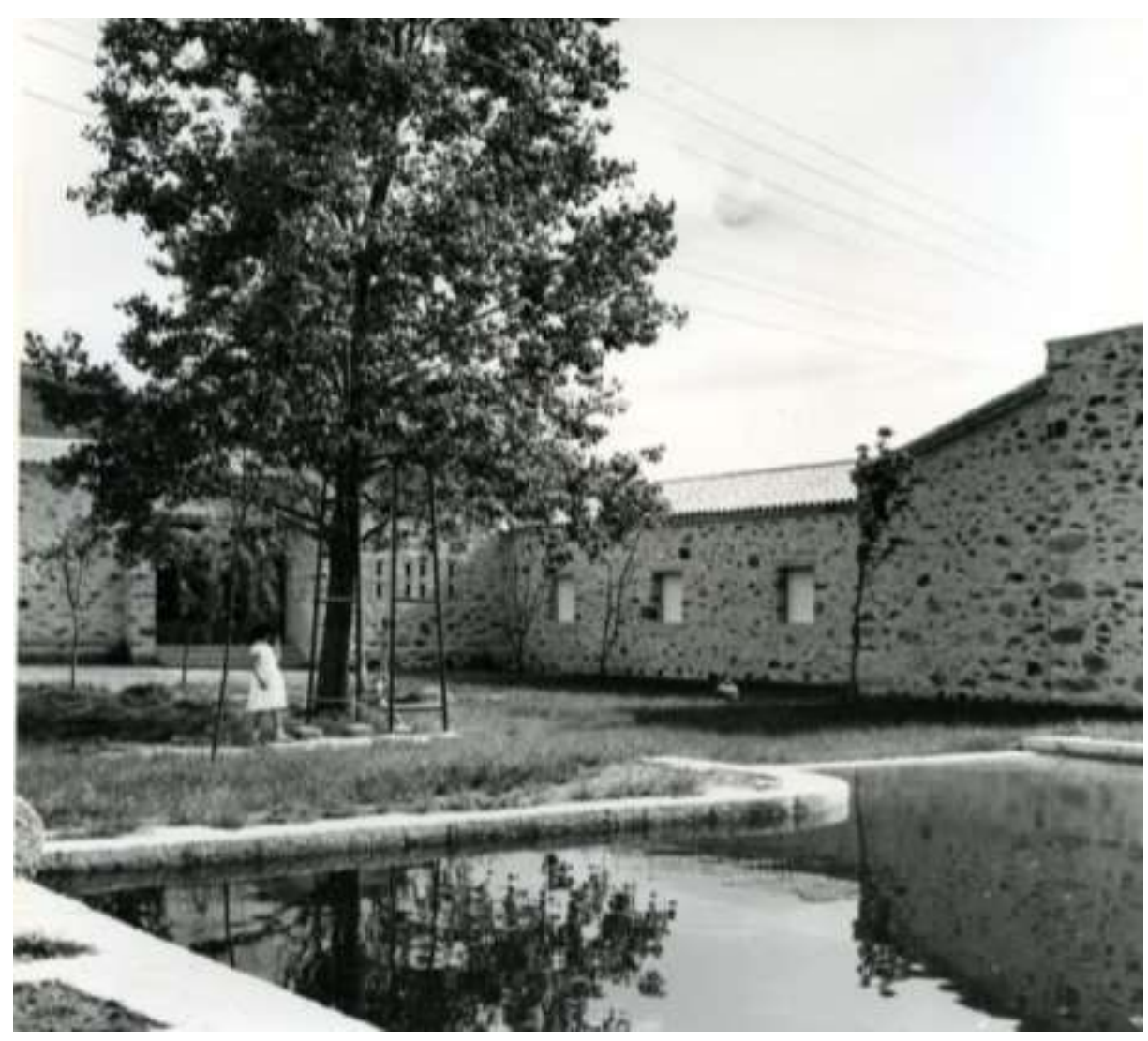

Espacio exterior común a dos viviendas gemelas para los hermanos Larragueta en Ortigosa del Monte (1953). La estrecha acequia, cuyo final se observa entre los apoyos del columpio, divide en dos la parcela

En el Instituto Laboral de Daimiel (1950-1953), el estanque permite que el paisaje manchego entre hasta lo más profundo del edificio. Las praderas de formas sinuosas, como islas que recuerdan a las existentes en las tablas fluviales que allí existen,

${ }^{211}$ Idem 
invaden el patio cóncavo y lo enlazan con el exterior, dilatando el espacio; y con el paisaje en toda su magnitud -cultural, social y climatológico-. El agua aquí, que huye de formalizaciones que no sean las de la propia naturaleza, no sólo refleja el cielo y la arquitectura, hace que reverbere el paisaje manchego en el patio.

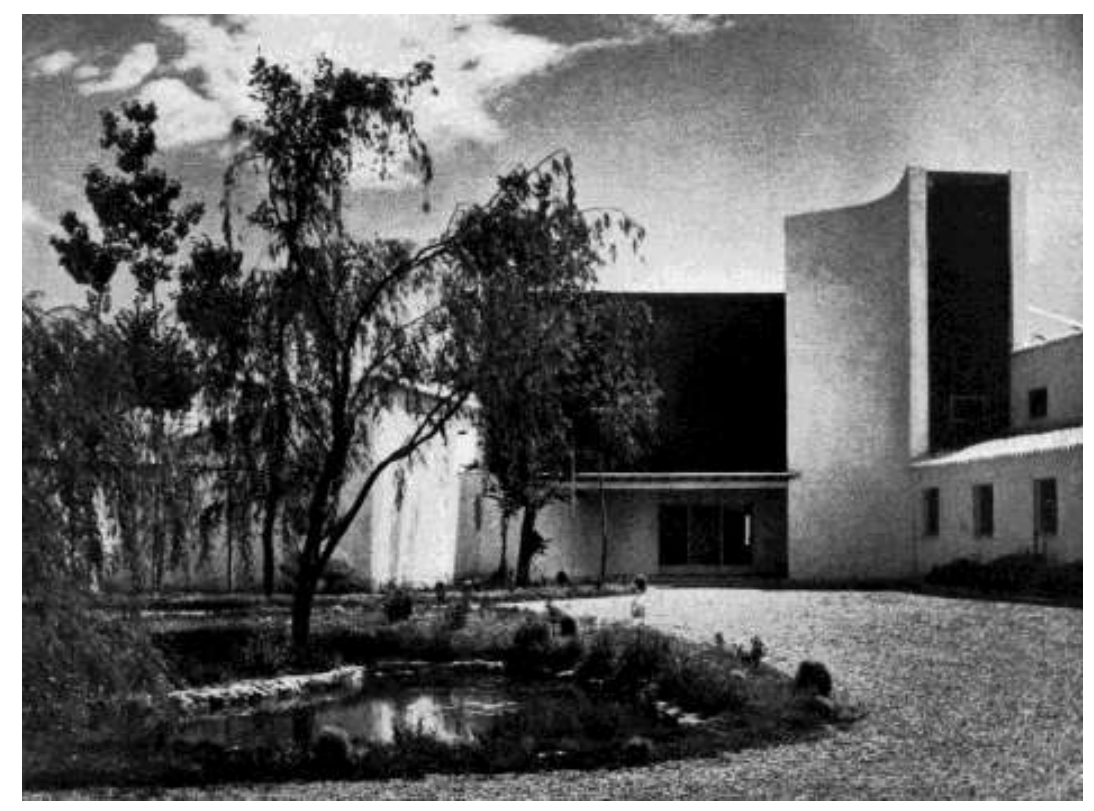

Estanque del Instituto Laboral de Daimiel

En el Centro de Formación del Profesorado (1952-1957), encontramos dos estanques que quieren conectar conceptualmente con La Alhambra.

De nuevo aquí, el reflejo del paisaje lejano, la Sierra de Guadarrama -como si de Sierra Nevada se tratara-, pero también del cielo y de la arquitectura. El estanque aquí, pone en contacto el paisaje con el Paraíso interior creado.

Fisac da un paso más. Su aprendizaje no es exclusivo de La Alhambra, y también bebe su obra de otras arquitecturas, encontrándonos aquí con referencias a la arquitectura sueca, y con la belleza de los estanques de Asplund o Lewerentz, cuyo desarrollo nos desviaría del foco de la investigación.

Si observamos el estanque, su lecho no es homogéneo, tiene varias texturas que provocan diferentes limitaciones de sus bordes y aumenta la profundidad del mismo aunque se trate de una delgada lámina de agua-. El canto de rio expande la profundidad del mismo, y el canto rodado blanco del borde permite por contraste alcanzar la sensación de profundidad: el fondo del estanque, con esta operación, se hace profundo. 
Memoria, Aprendizaje y Experimento. La invención del paisaje en Miguel Fisac

Experimento. Gramática de un paisaje

En el Teologado de Alcobendas encontramos un estanque de clara inspiración japonesa. Una superficie adaptada a la topografía, desdibujada, invadida por rocas cuidadosamente situadas.

La Naturaleza resuena en su forma, limitada por grava, roca, y un pequeño bordillo en uno de sus lados, nos hace pensar en una pre-existencia que se hubiera mantenido alli antes de levantar el edificio, y que se hubiera materializado en torno a ella. Es una porción de paisaje.

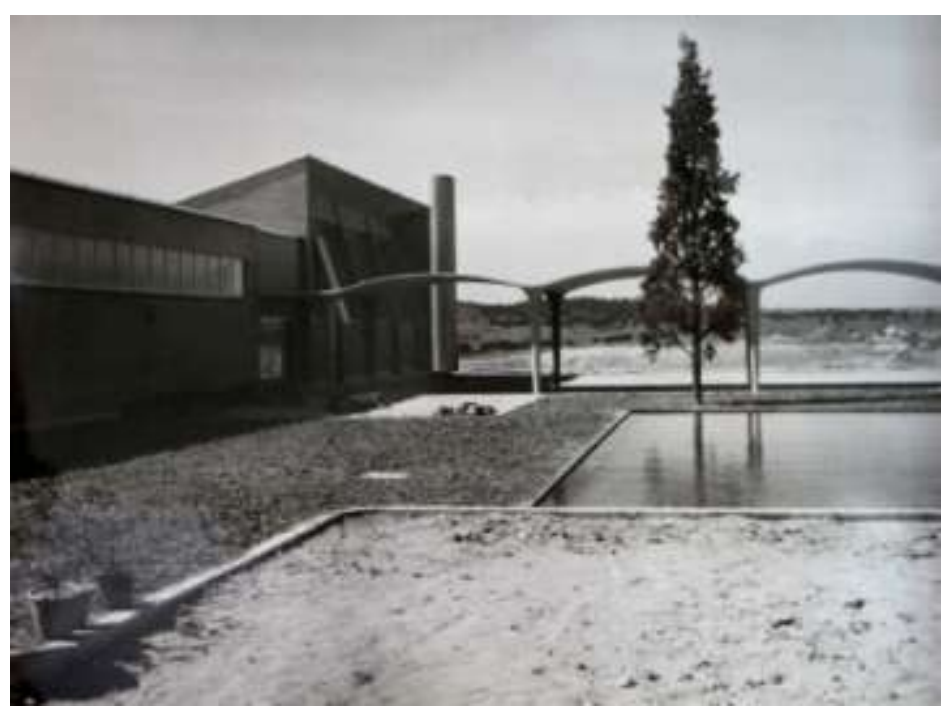

\section{Estanque Oeste del Centro de Formación del Profesorado.}

Estanque del claustro del Teologado San Pedro Mártir de los PP. Dominicos.

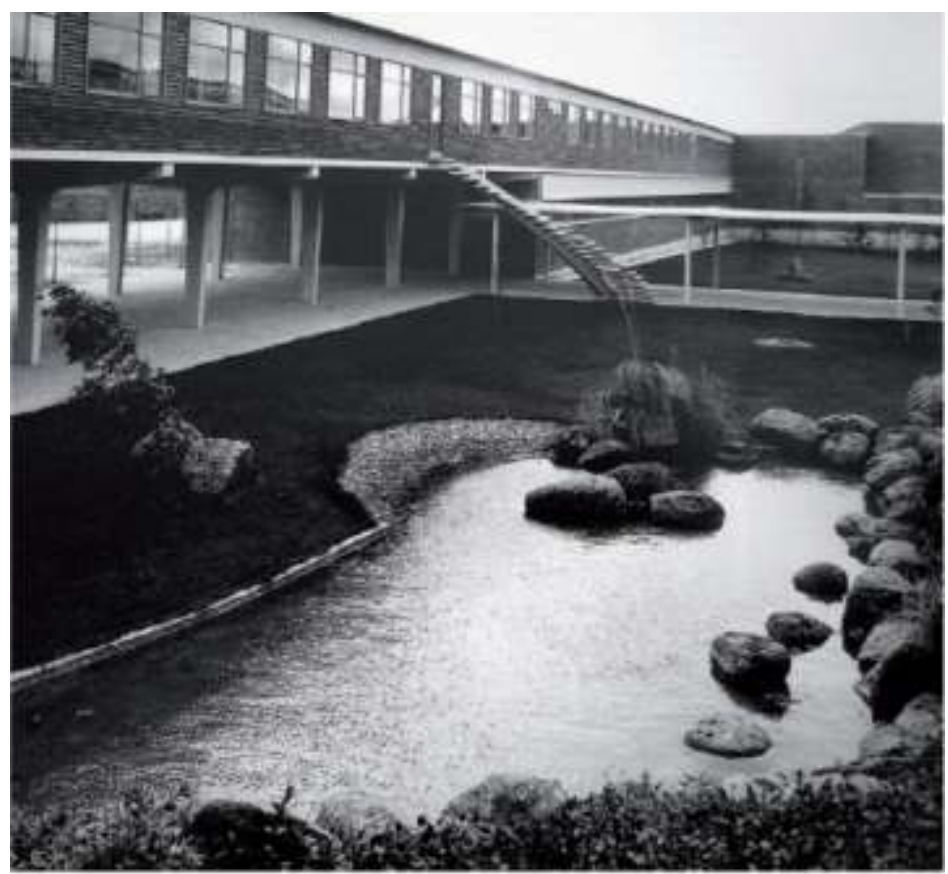


Pero al igual que en el conjunto de la Ciudad Universitaria, hay algo más allá que la lectura japonesa: podemos encontrar importantes conexiones entre este estanque y el del Cementerio Sur de Estocolmo de Gunnar Asplund.

No sólo el aspecto formal, o a su cota rehundida con respecto a la edificación. Se trata de la afirmación de una Naturaleza agreste, -que a falta de tener continuidad con la existente en este caso se crea- para que el hombre se pueda detener ante ella, a contemplarla y de esta forma entrar en contacto consigo mismo. Se convierte así en un centro, en un polo que articula una serie de elementos arquitectónicos en torno a él.

En el conjunto de Arcas Reales el estanque recoge el agua de un surtidor de forma circular, con una clara reminiscencia a La Alhambra, que se traslada a través de un estrecho canalillo con pequeños meandros y llega a un estanque. En el patio de los Padres, que es donde se ubica, se busca la belleza a través del sonido, y se conecta con la naturaleza a través de las formas. El camino pasa por encima del dibujo perimetral completo del estanque, de nuevo afirmando que el paisaje creado a través de la jardinería quiere fusionarse con la Naturaleza, tiene vocación de haber existido antes que la edificación. 
Memoria, Aprendizaje y Experimento. La invención del paisaje en Miguel Fisac

Experimento. Gramática de un paisaje
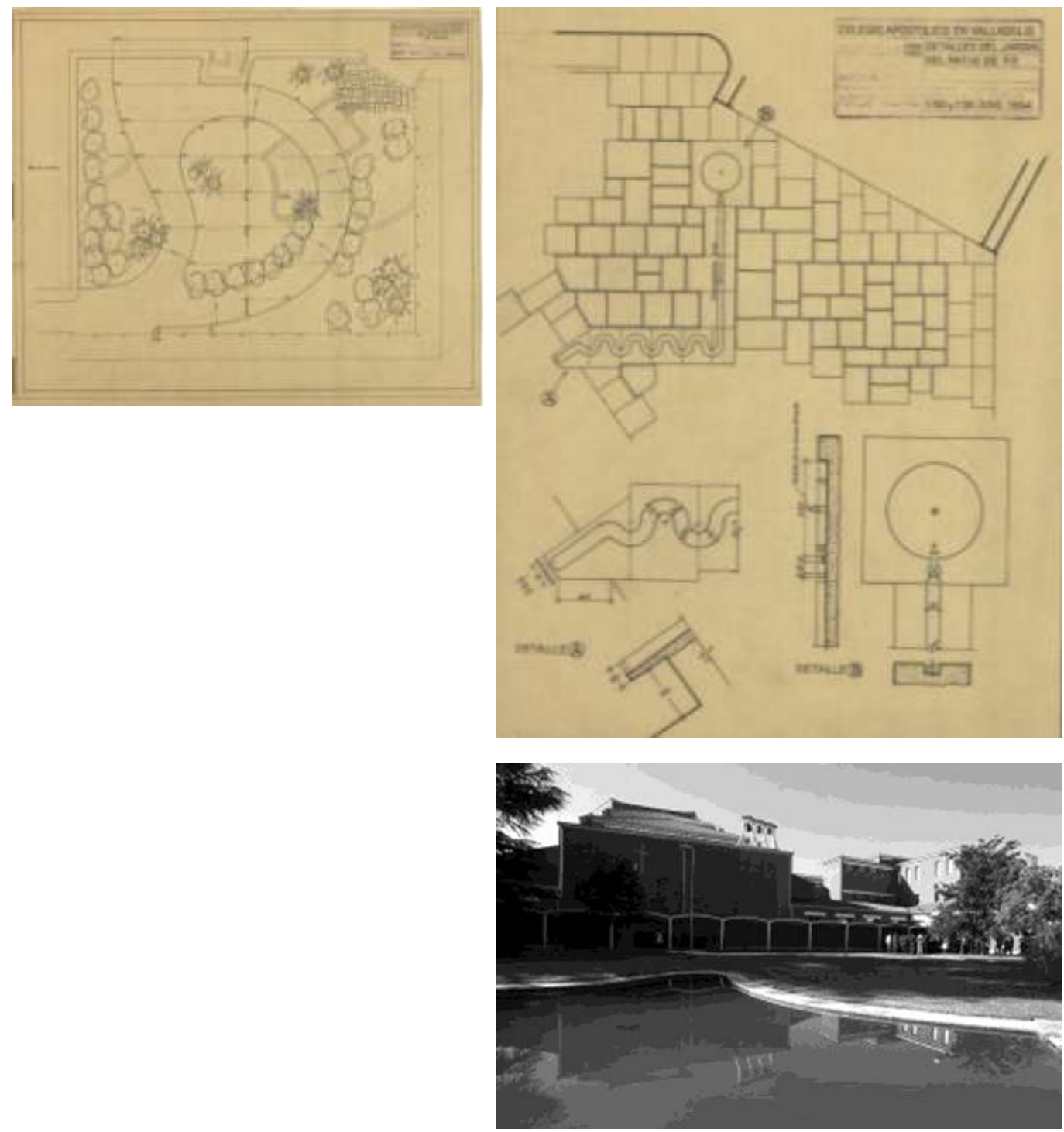

Colegio Apostólico de los PP. Dominicos de Valladolid. Estanque del patio, surtidor y acequia sinuosa. Planos de detalle y fotografías

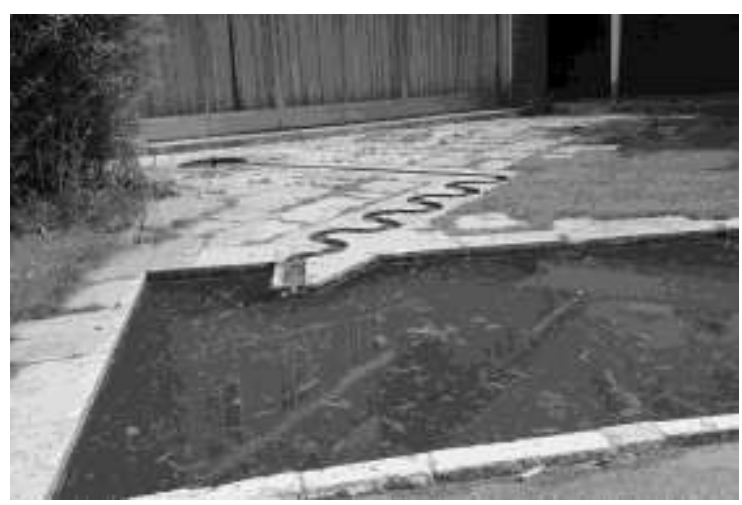


Memoria, Aprendizaje y Experimento. La invención del paisaje en Miguel Fisac

Experimento. Gramática de un paisaje

En las casas para los hermanos Germán y Dionisio Larragueta, en Ortigosa del Monte, encontramos el agua en dos de sus estados: el momento de fluir y el momento de estancarse.

Con certera intención, en un pequeño pueblo de Segovia cercano a Madrid, en el que dos hermanos encargan sendas casas gemelas con un jardín común, Fisac utiliza una suerte de acequia para dividir el jardín, evitando construir una tapia y haciendo posible la contemplación del espacio de forma unitaria.

Una acequia estrecha, que acaba en un exiguo estanque. Pequeño de tamaño, pero grande de propósito; como si hubiera querido que el río Milanillos, a escasos 100 metros de la propiedad, lo alimentara.

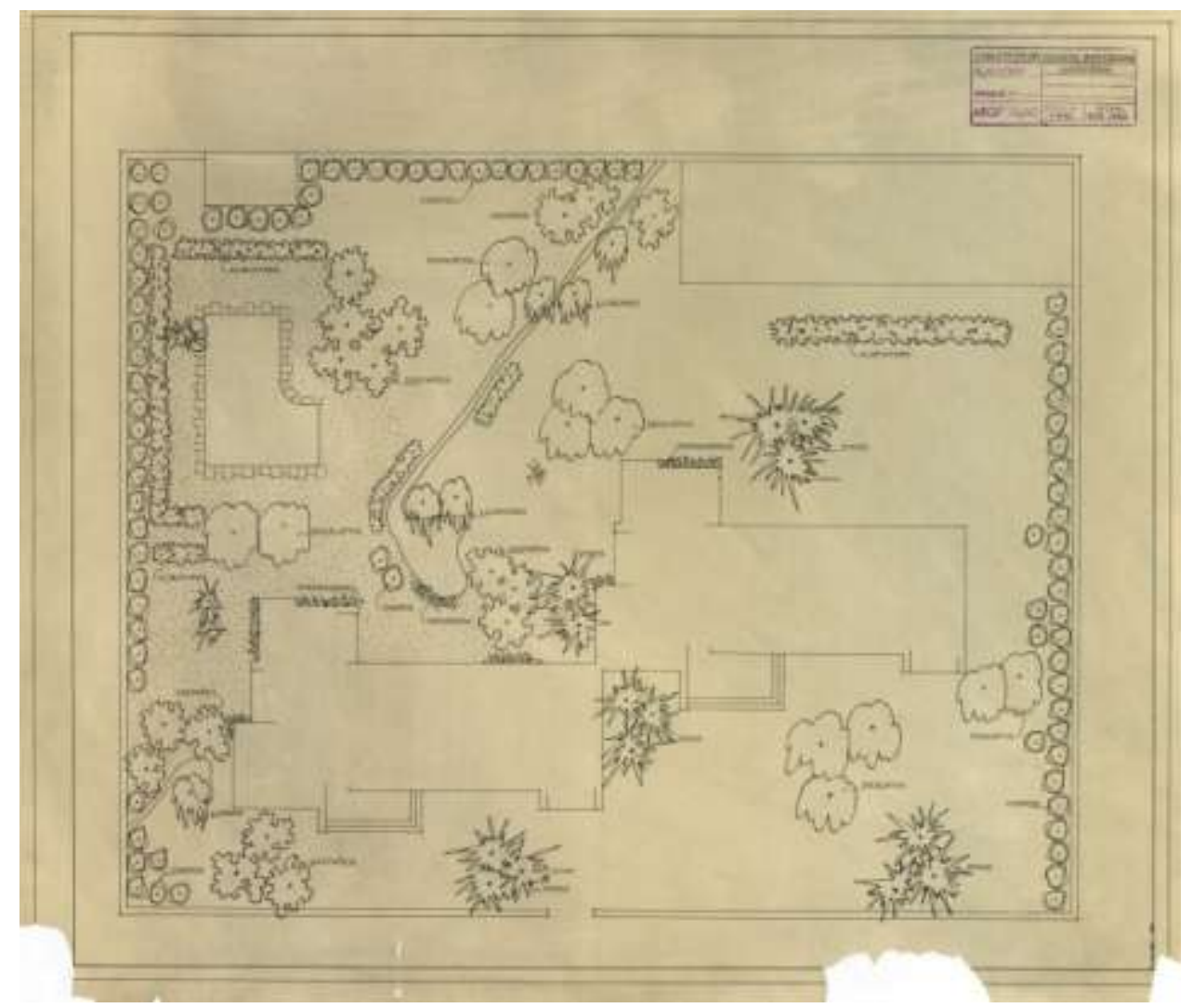

Planta de jardinería de dos viviendas gemelas para los hermanos Larragueta en Ortigosa del Monte (1953) 
No se trata de una acequia en el sentido hispano-árabe, quiere ser un elemento natural que invade el jardín, el borde de un río, con árboles de gran porte -eucaliptos y sauces llorones- y plantaciones arbustivas lineales de aligustres que reafirman su trazado.

En el mismo proyecto, encontramos una piscina que quiere no ser piscina: arquitectónicamente es un estanque, es un elemento que forma parte del paisaje, y del que nos hemos adueñado, a través de los reflejos del cielo, el entorno y la arquitectura.

La formalización de su perímetro ayuda de nuevo a hacerlo formar parte del paisaje, con uno de sus bordes rebajados -rebosante de agua-, y curvándose para dejar espacio a un grupo de castaños que quisieran haber estado allí desde siempre. También con esta intención se ubica un grupo de rocas en otro borde, invadiendo la piedra trabajada que conforma el perímetro, haciendo más agreste el conjunto.
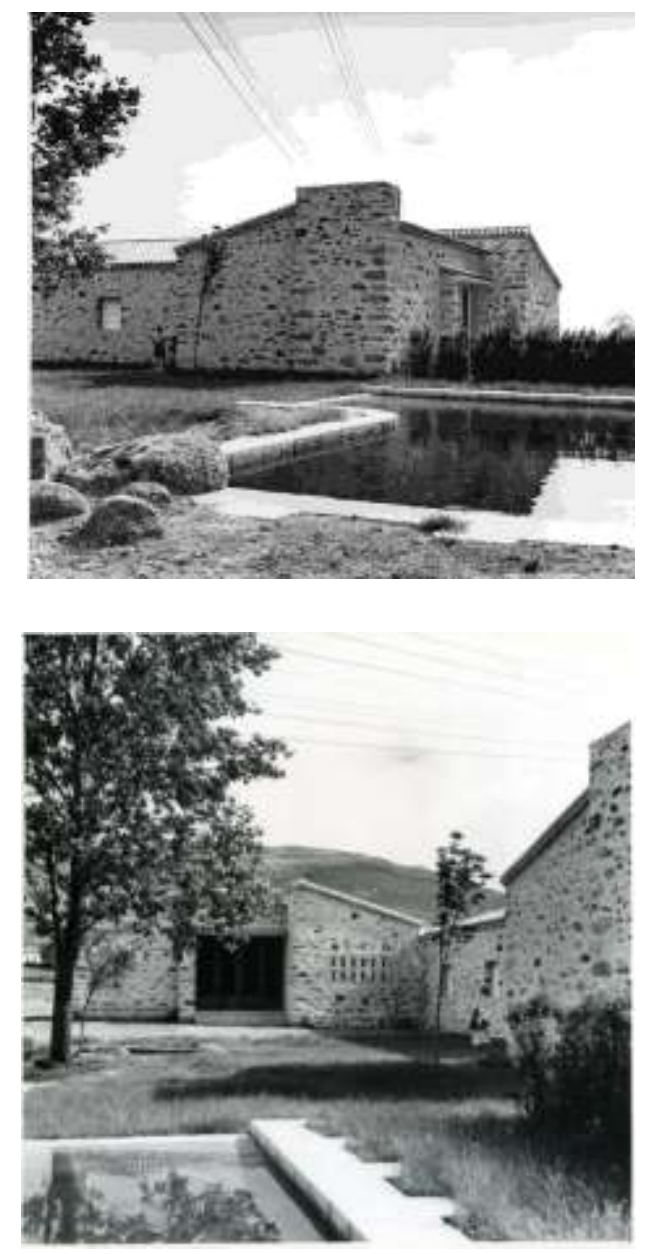

Espacio exterior común a dos viviendas gemelas para los hermanos Larragueta en Ortigosa del Monte (1953). 
En la casa de Cádiz, en Sotogrande, el agua hilvana y aporta coherencia a toda el conjunto. De los patios emana el agua a través de surtidores de forma circular; que se desplaza por gravedad a través de estrechas acequias hasta llegar al estanque principal, que vuelve a ser piscina sin serlo.

La materialización de los elementos del agua conectan totalmente con La Alhambra, el conjunto quiere ser la Alhambra: el manantial circular, el movimiento rectilíneo, el estancamiento rectangular. En este caso sucede un hecho singular: parte de la balsa está bajo el porche, reforzando aún más -si cabe- su intención de unión metafísica a La Alhambra.

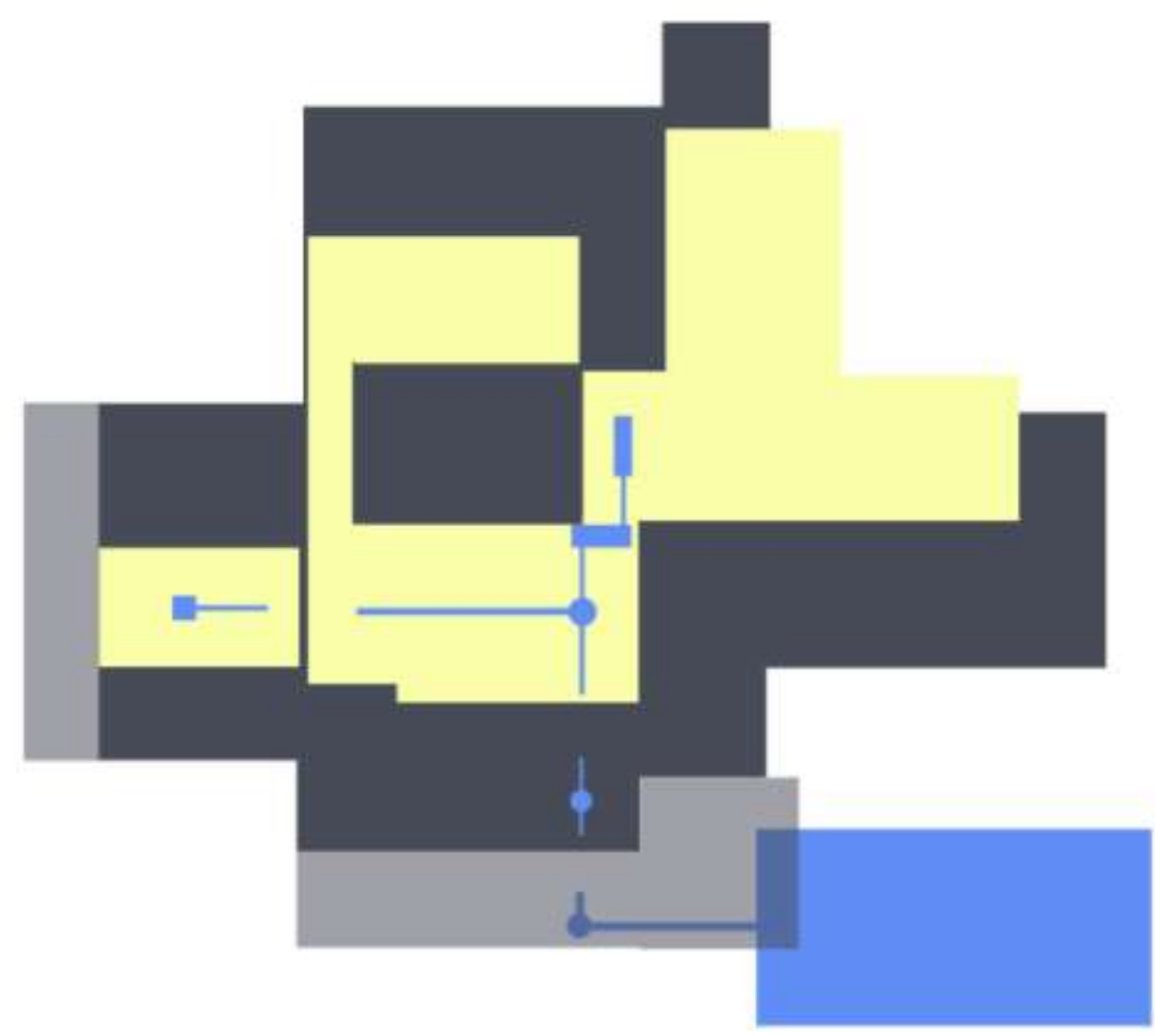

Estudio de fuentes, acequias y estanques en la vivienda para el Vizconde Ednam. Cádiz. Se señala la superficie construida en gris oscuro, los porches en gris claro, los patios en amarillo, y el agua en azul. Realizado por el autor. 


\section{Sombras, secuencias, tránsitos y límites}

La sombra es un elemento de proyecto en la relación de la arquitectura de Fisac con el paisaje.

Ésta es utilizada, no únicamente para aportar frescor o penumbra en determinadas zonas de un espacio: nos interesa ahora poner el acento en la sombra como elemento que hilvana la arquitectura con el paisaje, diferenciándola o integrándola.

Un ejemplo paradigmático de la idea que pretendemos exponer es la iglesia de Canfranc, proyectada en 1965. El dibujo en acuarela que dibuja el propio Fisac a la terminación de la iglesia la propia sombra nos invita a reflexionar, ¿dónde empieza la arquitectura y termina la naturaleza?

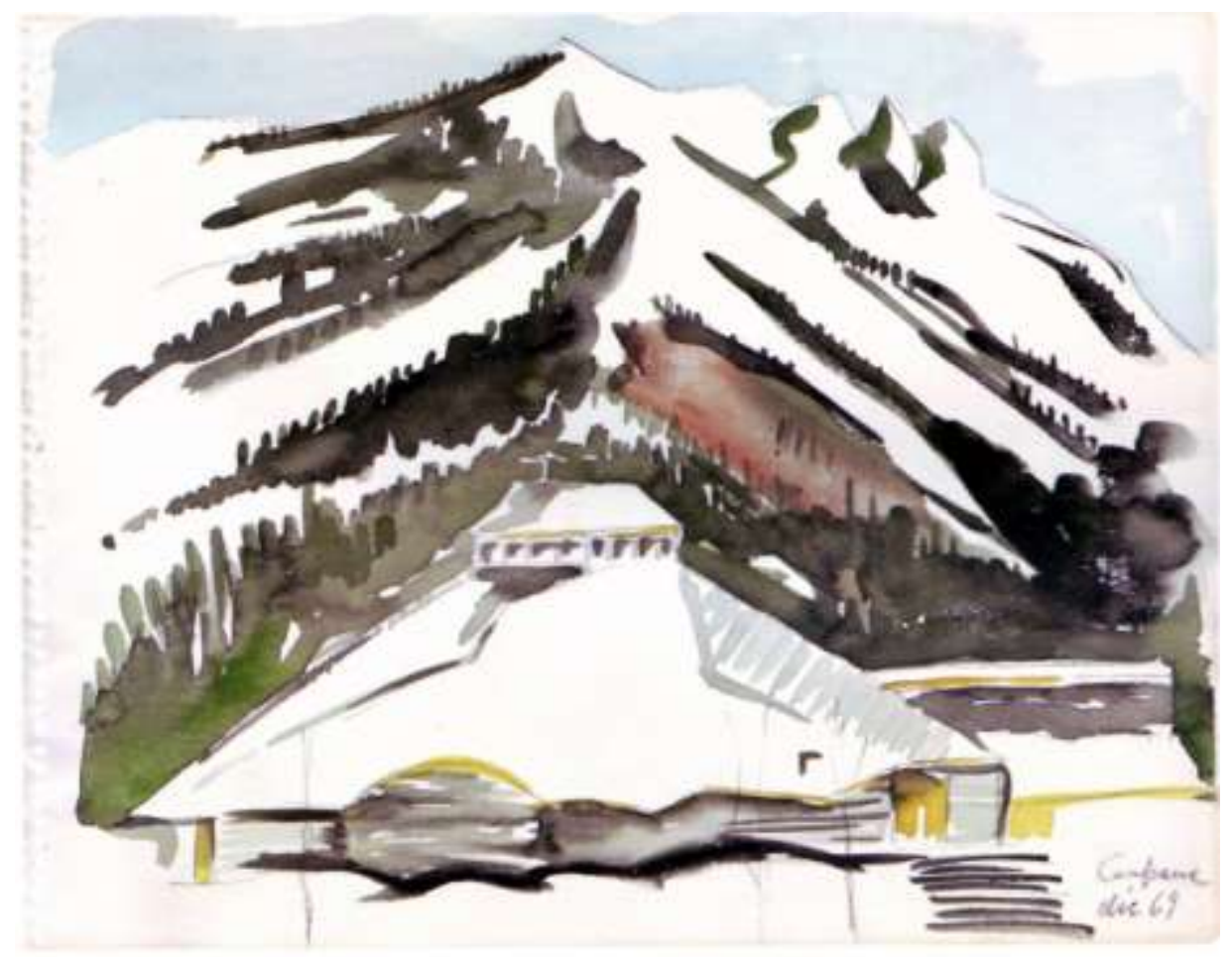

Dibujo en acuarela de la iglesia de Canfranc realizado por Miguel Fisac en diciembre de 1969 
En esta ladera rocosa muy pronunciada y en este lugar de complicada climatología, Fisac da respuesta al paisaje mediante un proyecto de dos componentes: un muro que pertenece a la tierra, y una cubierta ligera, que flota sobre ella.

En la Memoria del Proyecto se hace una declaración de intenciones: "(...) se ha procurado crear un tipo de edificio de carácter alpino que entone perfectamente con los bosques circundantes, armonizando en analogía los muros de mampostería de piedra del país y el contraste de la gran cubierta de aluminio, totalmente adecuada a la situación montañosa del lugar."212

La sombra es el elemento protagonista del proyecto y el enlace más importante entre la cubierta y la montaña, por un lado; y entre el muro y la tierra por otro.

En el largo muro ondulante que se presenta ante nosotros, cuyas formas son enfatizadas por la sinuosidad del borde de la cubierta, la sombra continua diferencia dicha cubierta de lo que no lo es; la cubierta flota sobre el terreno. Ayuda la sombra de una forma fundamental a que los muros formen parte de la tierra, que nazcan de ella y pertenezcan a ella, intensificando su estereotomía. Así, por contraste, aunque en los dibujos Fisac nos muestra una clara intención de no diferenciación - ¿qué es montaña y qué es iglesia?-, la gran cubierta de aluminio flota y se aligera, reflejando sus bordes laterales, como espejos, la naturaleza a la que se enfrentan.

Una gran discontinuidad del mismo en sombra invita a entrar como si cambiáramos de un claro en el bosque a un lugar con más espesura. Una enorme sombra geometrizada que sugiere la mano del hombre sobre unas formas mucho más sensuales y cercanas a la Naturaleza. Una sombra que transforma la puerta en hueco, y la hace participar de la escala del paisaje.

Esta ambigüedad materializada es algo sobre lo que Fisac reflexiona en varias ocasiones, y así lo muestra. No sólo por los anteriormente citados bombos manchegos que se mimetizan con el terreno, "que propiamente son terreno". Es notable la relación de dibujos en los que -por una parte- la arquitectura se disuelve en la tierra, o la tierra en la arquitectura; y otros en los que la propia naturaleza querría ser arquitectura. La traslación de este concepto al proyecto se materializa en esta iglesia de Canfranc: la interpretación de esta idea contiene la fuerza de lo ancestral, y una enorme potencia poética.

212 Fisac, M. (1965). Proyecto de iglesia parroquial en Canfranc. Inédito. 

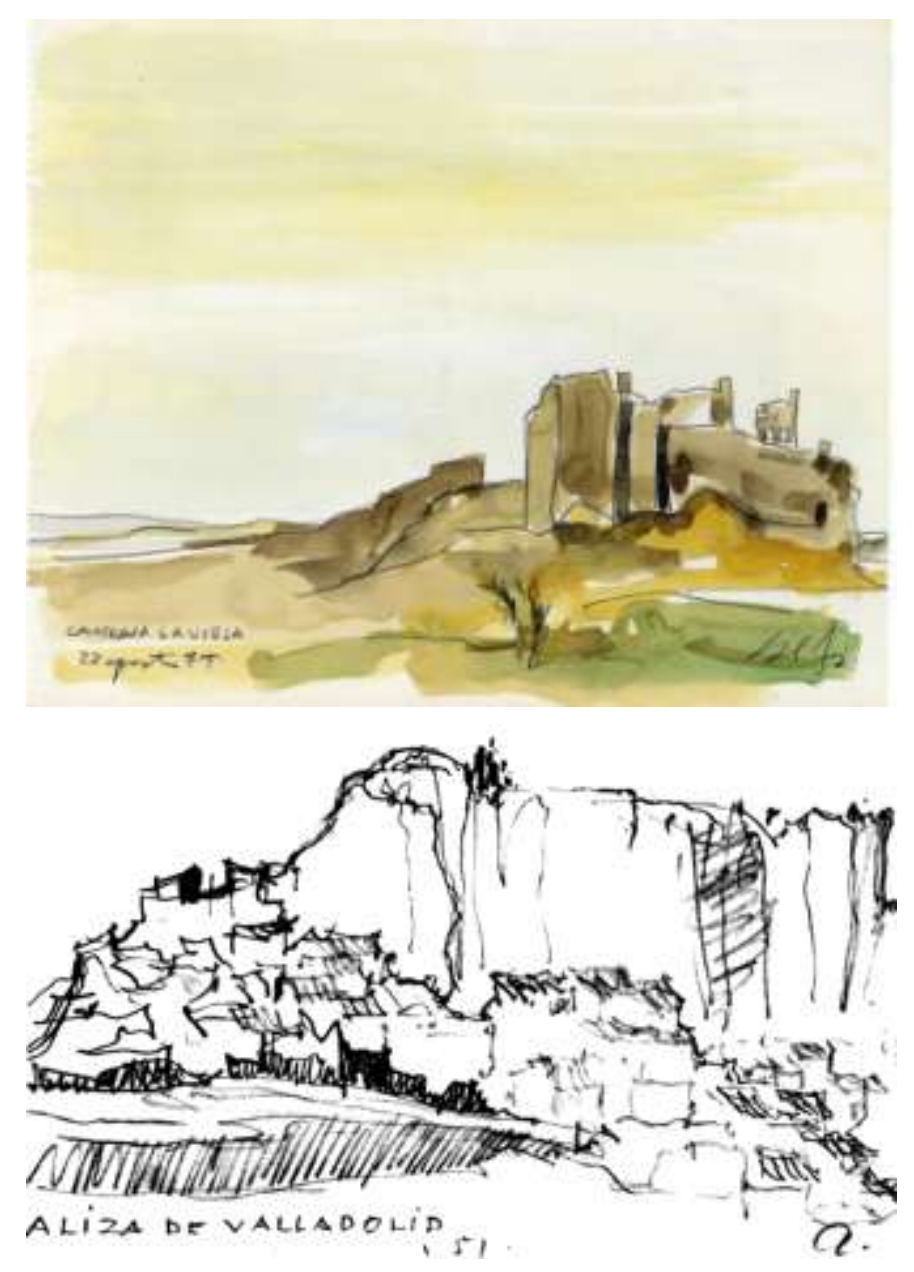

Castillo de Calatrava La Vieja. Carrión de Calatrava (Ciudad Real). Dibujo de Miguel Fisac, 1979. Ariza (Zaragoza). Dibujo de Alvar Aalto, 1951. En el dibujo aparece escrito "Aliza de Valladolid" debido a que el dibujo fue realizado desde el tren en el trayecto Barcelona-Madrid que lo condujo por su periplo español, deteniéndose éste junto en la citada estación junto a un cartel que anunciaba una ruta ferroviaria bien conocida en aquellos años: Ariza-Valladolid.

Una sensibilidad coincidente con la mostrada por Alvar Aalto, que en su visita a España, -como vemos en su dibujo de Ariza-, también resalta como protagonista la ambigüedad entre tierra y arquitectura y el paisaje que resuena en la textura de la arquitectura.

El concepto de arquitectura en la ladera interesó a Aalto desde que descubrió las ciudades italianas que se encaraman en las colinas, como materialización de un hermoso y armónico pacto entre hombre y naturaleza, adaptándose la arquitectura a la topografía y conformando una suerte de simbiosis en el paisaje. 
Memoria, Aprendizaje y Experimento. La invención del paisaje en Miguel Fisac

Experimento. Gramática de un paisaje
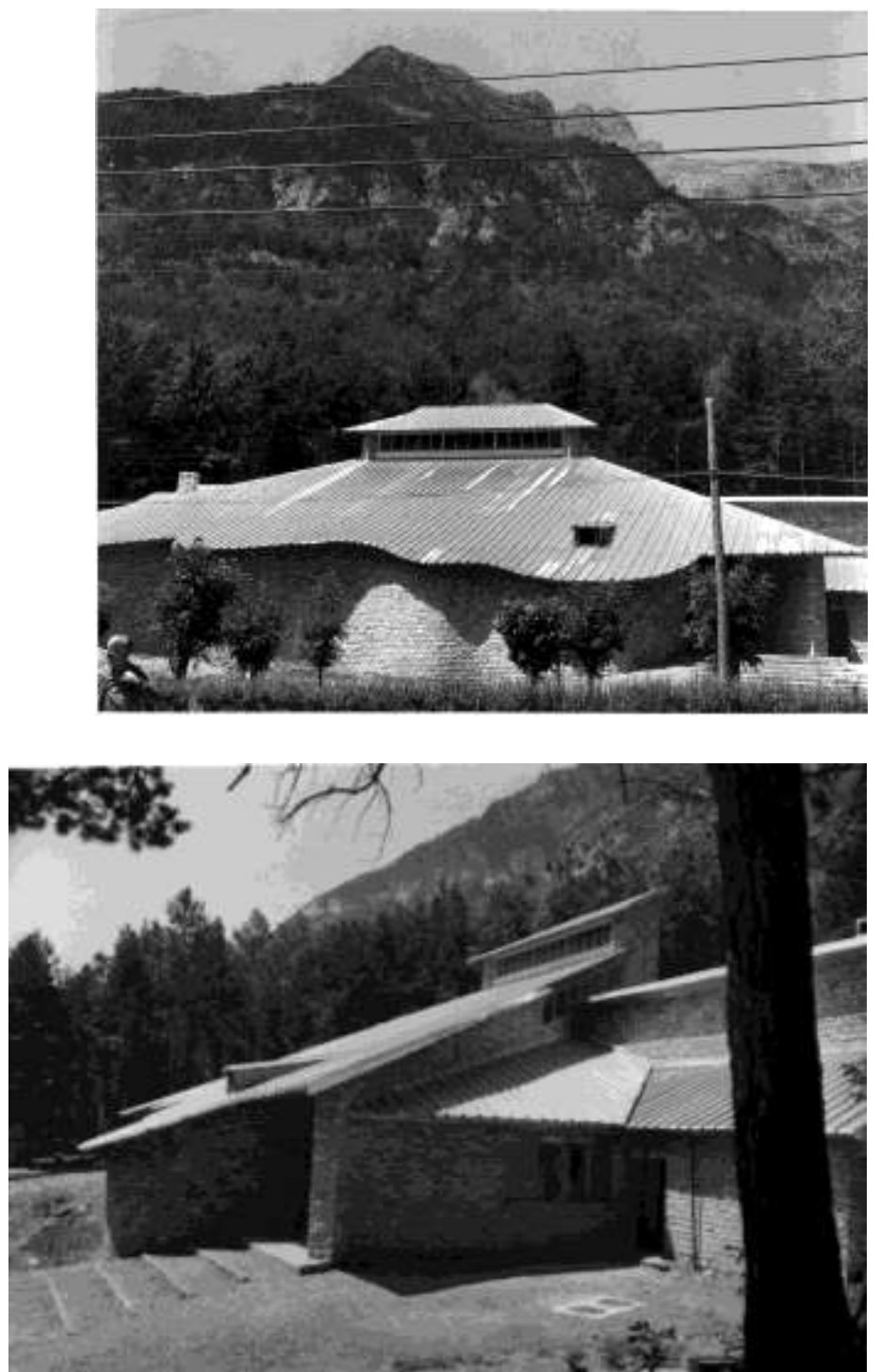

Este posicionamiento ante el paisaje, que profundiza sobre el entorno y lo protege, que lo ama en definitiva, permite una conexión profunda con él, no exenta de misticismo, y que se completará con el espacio interior.

Desde el interior también se conecta con el paisaje en esta iglesia. El acto de penetrar una gruta que forma parte del entorno montañoso cuyo acceso está en penumbra sublima la relación de pertenencia a la tierra, y una vez dentro, el espacio tensado por la luz cenital encierra un trozo del Cosmos, "humaniza" un trozo de la propia Naturaleza. 
Por otra parte, es importante destacar la secuencialidad de los espacios. Estas sucesiones ordenadas son propuestas por Fisac como herramienta que vincula determinadas piezas de un conjunto entre sí, y su unidad con el lugar.

Un mecanismo de articulación desarrollado a partir de la visión de la casa tradicional japonesa, en la que los shoji -paneles corredizos de papel de arroz- permiten la libre circulación del aire por el interior de la casa y con el jardín circundante.

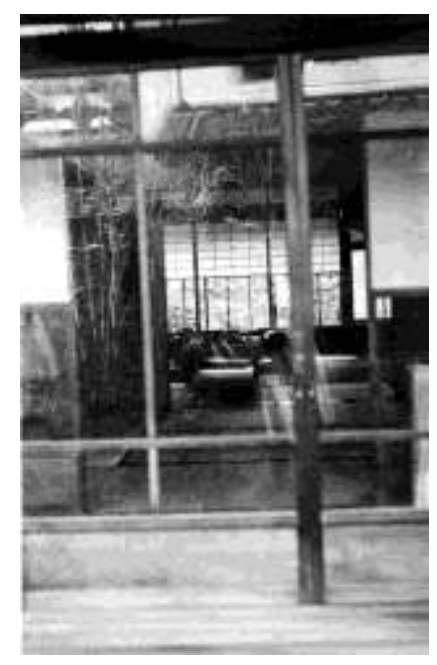

Secuencialidad espacial. Fotografía tomada por Miguel Fisac en su Viaje alrededor del mundo. 1955

Se crean así una serie de sucesiones armónicas que permite que el espacio se expansione más allá de la continuidad entre el interior y el exterior. Es una progresión armónica que proporciona un haz de visiones distintas y de profundidades, como si se tratara de una serie de estratos superpuestos.

Esta secuencialidad asimismo, permite una conexión muy interesante con el entorno de las arquitecturas, y permite la apropiación de la naturaleza para la misma. la sierra, los árboles 0 el cielo. 
Memoria, Aprendizaje y Experimento. La invención del paisaje en Miguel Fisac

Experimento. Gramática de un paisaje

Asimismo, mediante esta suerte de progresión espacial, debido a que los elementos que están en los estratos más profundos no se ven con nitidez, simplemente se intuyen, se invita al recorrido de los diferentes conjuntos. aporta pues esta secuencialidad un ingrediente de misterio, un elemento emocional que reivindicó siempre Luis Barragán para sus jardines:

"Hay que desconfiar de los jardines abiertos que se descubre a primera vista. La contemplación de los muertos e insípidos"open-gardens" que cubren la ciudad de Washington -los cuales no invitan a ser visitados- me hacen volver los ojos hacia los jardines del Generalife de Granada. Pienso con amor en los bellos jardines orientales cruzados por arcadas y murallas de verdura, las cuales forman recintos encantadores, dando valor a los espacios y convirtiendo la naturaleza en un verdadero HOME"213

${ }^{213}$ Barragán, L. (1931). Apuntes de Nueva York. Ideas sobre jardines, En Riggen, A. (2000). Op. cit, 15. El término home, utilizado repetidamente por Barragán, se refiere a la idea de hogar. 
Memoria, Aprendizaje y Experimento. La invención del paisaje en Miguel Fisac

Experimento. Gramática de un paisaje
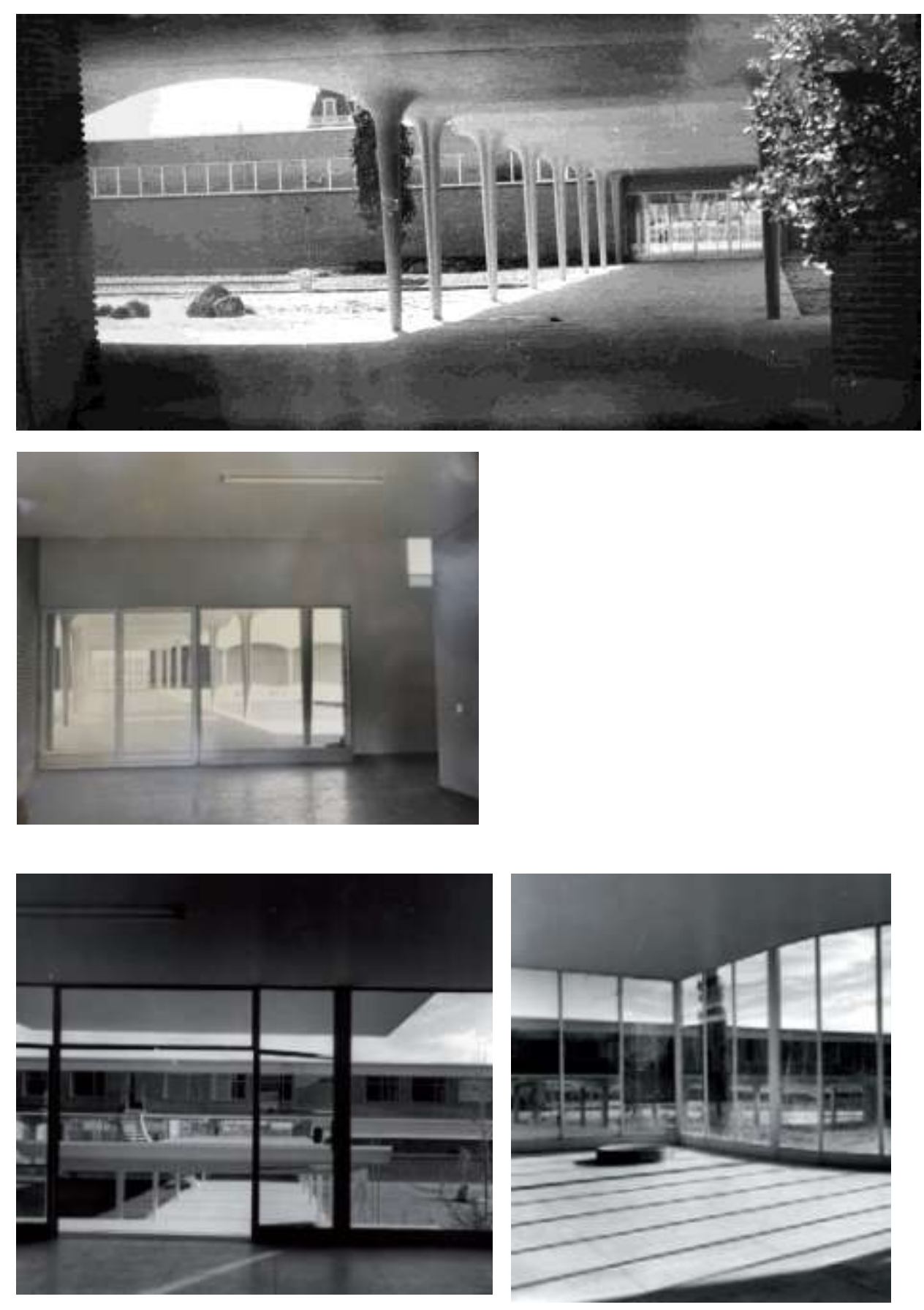

Espacios secuenciales en el Centro de Formación del Profesorado de la Ciudad Universitaria y en el Teologado de Alcobendas. En este último caso, la liberación de la planta baja del pabellón de los PP. jóvenes y la intención de un espacio exterior continuo y fluido, permite que la naturaleza circundante penetre el conjunto. Fotografías Fundación Miguel Fisac. 
Los tránsitos también son de enorme importancia para la formación del espacio en determinados proyectos. Tránsitos rápidos o lentos, con vistas directas o en escorzo; tránsitos que precisan del tiempo para recorrer las diferentes secuencias y conformar el espacio.

Si bien podríamos explicar esta idea a través de los conjuntos anteriormente citados, un ejemplo paradigmático de ello es el proyecto que realizó Fisac para el Vizconde Ednam²14 en Cádiz.

Dicha casa se define por la secuencia de paso de una sala a otra, de un pabellón a otro, y a través de las relaciones que éstas establecen con el horizonte y el paisaje.

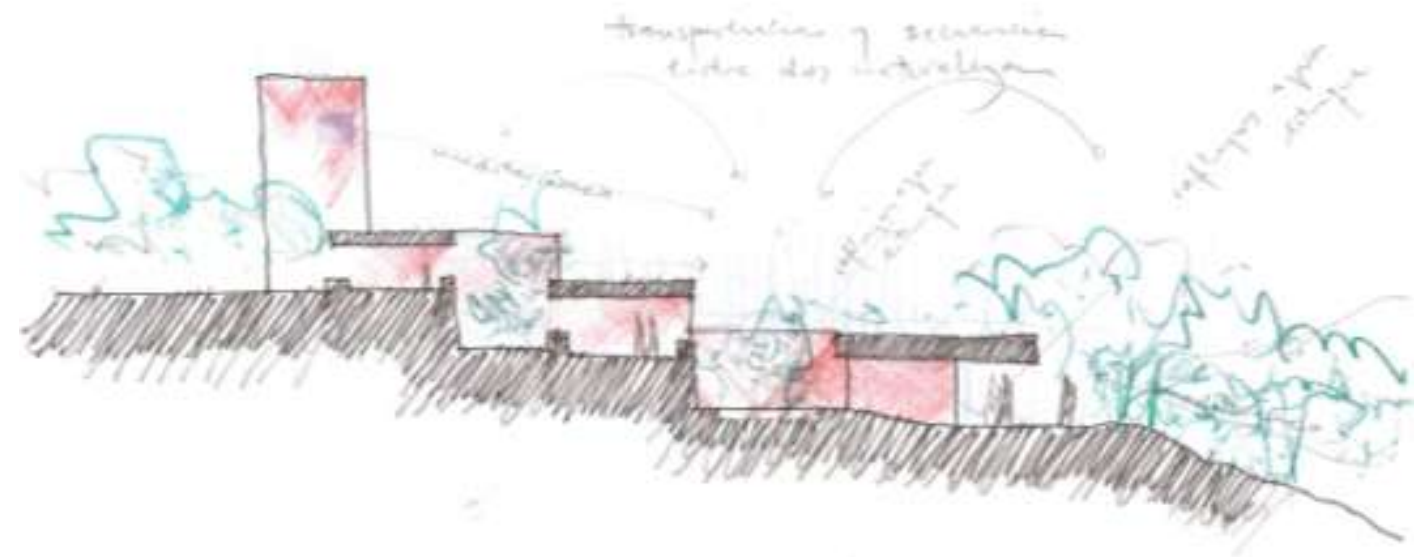

Croquis sección proyecto de palacete para el Vizconde Ednam en Cádiz. Realizado por el autor.

214 En diciembre de 1968, le llega a Fisac el encargo de una vivienda para el Vizconde de Ednam, en la algecireña urbanización de Sotogrande. El vizconde Ednam, William Humble David Ward (1920-2013), recaló en la gaditana urbanización de Sotogrande, cuna del golf y el polo en España, probablemente fruto de su matrimonio con la argentina Stella Cárcano, hija del embajador de Argentina en Reino Unido -un país Argentina, en el que el polo es el deporte más popular, después del fútbol-.Educado en la Universidad de Oxford, y casado en segundas nupcias con Maureen Swanson en 1961, el matrimonio tuvo siete hijos -ya tenía tres hijos más de su anterior matrimonio con Lady Cárcano, por lo que en la vivienda, como veremos, juega un notable papel la dotación de dormitorios para sus vástagos. 
Distintas salas que son interiores o exteriores, ya que aquí los patios son auténticas habitaciones, con nombres llenos de sugerencias y que invitan a ser recorridos: patio de las celosías, patio de la escalera, jardín de los niños, patio frío; pareciera que pretenden evocar la sensualidad de un jardín hispanoárabe. Y se hilvanan entre ellos mediante espacios cubiertos pero abiertos, así como escaleras que suben de unos a otros. A veces permite el recorrido físico entre ellos, y a veces exclusivamente el visual, utilizando el agua como barrera.

En dicho proyecto marcó Fisac dos objetivos: por un lado, aprovechar la situación de promontorio para posicionarse en el paisaje: para contemplar desde el paisaje domesticado la naturaleza que se "cuela" hasta el fondo a través de las transparencias buscadas y de la posición relativa de los pabellones y patios aprovechando el desnivel. $Y$ acentuó esto mediante un mirador para contemplar el paisaje.

Por otra parte, realizó un juego interior, con el agua y los patios como protagonistas, en los que el sonido del agua en movimiento, a través de fuentes y surtidores, finalizan su recorrido en la piscina, una suerte de estanque de agua calma.

El agua existe allí de igual manera que existe en La Alhambra, y en sus tres formas: como manantial en el momento de surgir, representada por el círculo; como acequia en movimiento, cuya morfología es la línea recta; y estancada en su quietud, a través del rectángulo. También realiza un juego de pequeñas acequias que rebosan, entrando y saliendo de la casa, entre patios, salón y terraza.

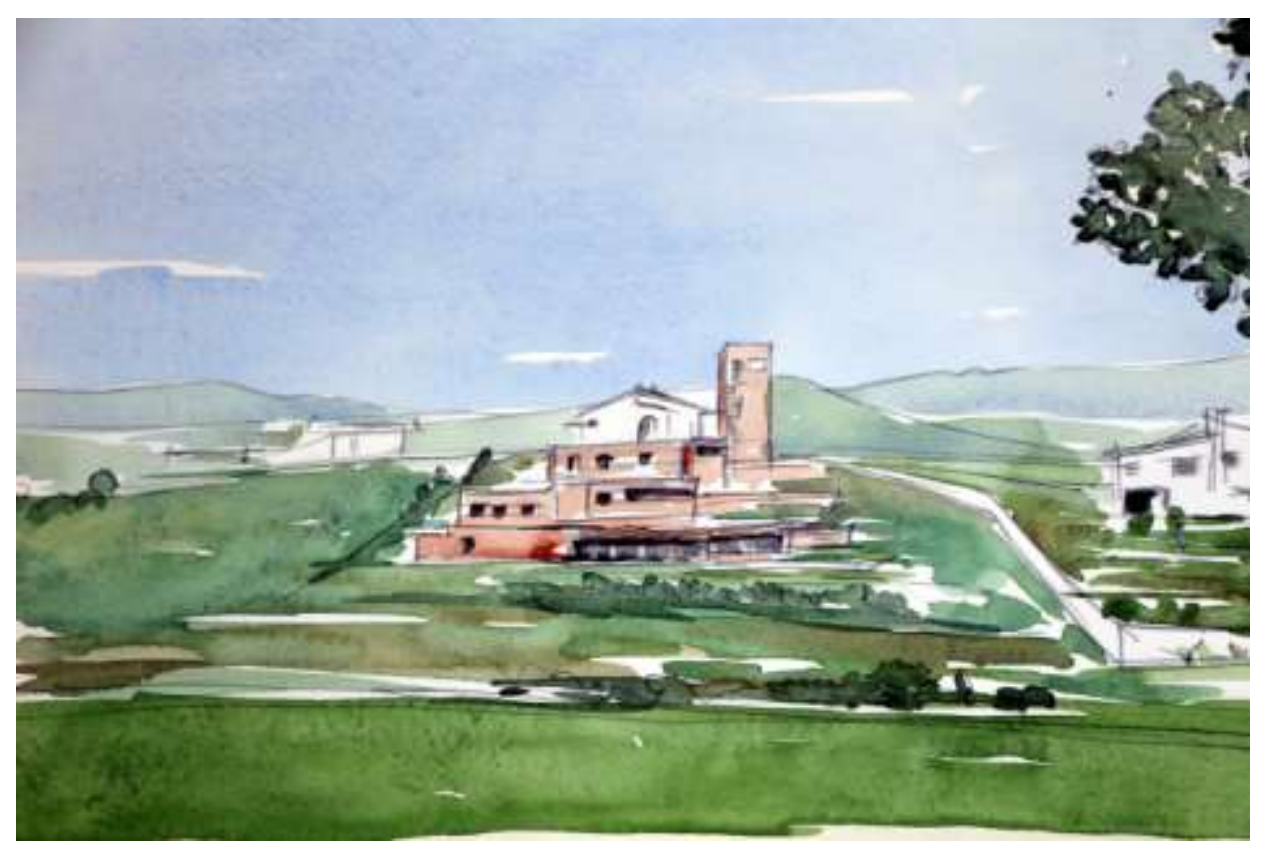

Acuarela del proyecto de palacete para el Vizconde Ednam en Cádiz. Inédito 
Todo ello hace interior y exterior se fundan en un único espacio, y que el paso de uno a otro se realice con enorme fluidez, apropiándose asimismo cada espacio de las visiones que se proporcionan a través de los huecos practicados. La etapa final de ese recorrido, sin embargo, es una bella delimitación del paisaje a través de un gran umbral en voladizo, por la que se cuelan los olores, los colores o los murmullos del aire; previa negación del mismo en el vestíbulo, que toma luz del patio frío, como si se pretendiera guardar el tesoro de la contemplación únicamente para el que tiene permiso para acceder al corazón de la casa.

El conjunto se articula como si se tratara de una serie de pabellones "que flotan entre verdura y aguas limpias y frescas"215.

Y en él se reflejan las enseñanzas referidas por Fisac que adquirió del conjunto nazarí. Fundamentalmente destaca la fluidez espacial. Si, como señala Fisac, nos detenemos en el negativo de la vivienda, vemos como un conjunto de patios envuelven el espacio construido, intensificando la fluidez espacial y la continuidad entre la naturaleza dada y el jardín o naturaleza creada.

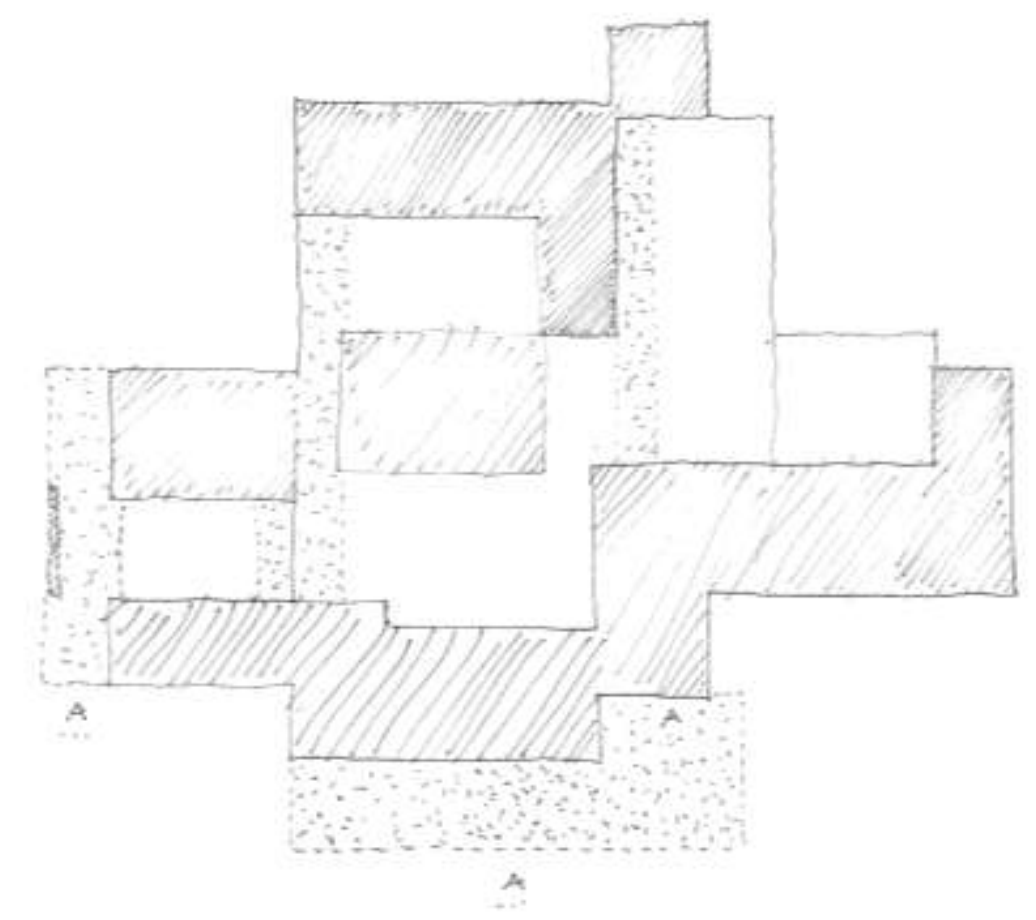

Croquis de estudio pabellón/patio/umbral en base al proyecto de palacete para el Vizconde Ednam en Cádiz. Destaca la continuidad de los patios. Realizado por el autor de la Tesis.

215 Manifiesto de La Alhambra. Parte IV. Jardines 


\section{Jardinería y vegetación}

La sensibilidad que Fisac muestra ante los elementos vegetales y la jardinería desde sus primeras intervenciones es muy destacable, fundamentalmente a partir del citado viaje a Europa y el descubrimiento de la misma como herramienta para potenciar el diálogo entre la arquitectura y el paisaje.

No en vano, en la primera de las Sesiones Críticas de Arquitectura celebradas en La Alhambra en octubre de 1952, Fisac interviene en este sentido.

"Me interesaría que se resolviera la posibilidad de que la arquitectura entrara en colaboración con el entorno agrícola por analogía o por contraste, tomando el jardín precisamente como elemento de unión." ${ }^{16}$

El propio Fisac formará parte del grupo de trabajo al que se le asignan los Jardines ${ }^{217}$ de La Alhambra. Un texto que toma el jardín hispanomusulmán como representación del Paraíso en la Tierra, conectándolo con una consideración trascendente del mismo: el arquitecto puede evocar la divinidad a los hombres a través de un jardín.

En La Alhambra "la casa se desparrama en el jardín y el jardín se embebe en la casa". Esta consideración, reforzada posteriormente con el descubrimiento de la casa tradicional japonesa, en la que "la arquitectura es subsidiaria de la naturaleza, para ayudarla y suplirla cuando no hay más remedio", serán especialmente inspiradores en el quehacer proyectual del arquitecto.

Asimismo, Fisac fue conferenciante habitual en temas de jardinería. No en vano, fue requerido por Francisco Prieto-Moreno para participar en el curso que se impartió en la ETSAM en el curso 1955-56218, en el que precisamente conoció a su mujer, Ana María, comentando posteriormente que "a la jardinería le debo mi mujer"219.

\footnotetext{
${ }^{216}$ Cfr. VV.AA. (1993). Manifiesto de la Alhambra, 121

${ }^{217}$ Se distribuyeron los participantes en cuatro grupos de trabajo para reflexionar sobre el conjunto nazarí: Formas, Construcciones, Jardines y Decoración. Miguel Fisac formó parte del grupo que debía estudiar sobre los jardines, junto con Fernando Chueca, Fernando Lacasa y Francisco Prieto-Moreno, a los que se unieron Francisco de Asis Cabrero y Ricardo Magdalena para la sesión crítica. Cfr. VV.AA. (1993). Op. Cit., 111.

218 El "Curso especial de Jardinería y paisaje" fue impartido en la ETSAM en el curso académico 1955-1956 bajo la dirección de Francisco Prieto-Moreno, a la sazón Director General de Arquitectura. En Dicho curso, que constaba de tres partes: "paisaje", "jardinería", y "arquitectura y jardinería" participó Fisac junto con Alejandro de la Sota, Luis Ceballos -ingeniero de Montes- y el propio Prieto-Moreno.

219 Conferencia Homenaje a la Marquesa de Casa-Valdés, el 22 de mayo de 1984. Jardín botánico de Madrid.
} 
Vistos los referentes históricos que Fisac utiliza, el oriental y el árabe, también es cierto que se apoya en la sabiduría popular, sensibilidad que procede de sus orígenes manchegos, para la realización de los estudios sobre jardinería realizados en sus proyectos.

Desde esta óptica Fisac trabaja lo diseñado desde lo existente. La intención general de sus emplazamientos trata de generar armonía entre las dos partes, lo que definitivamente producirá un diálogo intenso entre el jardín y la naturaleza que circunda la arquitectura.

Fisac pone especial acento en el respeto a lo existente. El sencillo gesto de mantener la vegetación circundante 0 de respetar la capa vegetal de la tierra y que la arquitectura dialogue con ella, le insufla una energía tal que parece que la arquitectura hubiera estado allí desde siempre.

Ya en los textos de las memorias de determinados proyectos se establece una sensibilidad en el actuar.

"El solar (...) está en ladera rocosa y muy pronunciada, que se aprovecha para poner el edificio en completa armonía con esa pendiente, evitando de esta forma trabajos fuertes de desmonte y la desaparición del terreno natural con todo su arbolado circundante. De esta forma, el edificio quedará protegido de la carretera con una banda de coníferas de unos 15 metros de longitud y en la parte posterior continuará un espeso bosque, aprovechándose también la colocación de este complejo precisamente en una calvera del terreno."220

Para Fisac es importante que el jardín tenga un programa ${ }^{221}$. Al igual que en los jardines orientales, en el que existen las piedras del atardecer y las piedras del Té, los jardines diseñados han de tener esos "recovecos y esquinas" -usando la terminología de Barragán- para intensificar determinados momentos y situaciones, para crear cierto grado de misterio, y que en definitiva nos conduzcan a experiencias estéticas que nos hagan trascender y por tanto disfrutar de una vida más humana.

Asimismo, para Fisac el jardín debe ser acorde con el "clima y la geografía física y racial"222. Esto está acorde con el citado texto sobre Jardines del Manifiesto de La Alhambra, que establece diferencias entre el jardín del riego y el jardín de la lluvia, y que el maestro manchego puso en práctica en sus diversas realizaciones por la geografía nacional, desde Segovia hasta Mallorca.

220 Fisac, M. (1965). Proyecto de iglesia parroquial en Canfranc. Inédito.

${ }^{221}$ Conferencia Homenaje a la Marquesa de Casa-Valdés, el 22 de mayo de 1984. Jardín botánico de

Madrid.

222 Idem 
Una de las preocupaciones de Fisac es la forma en que el jardín penetra en la ciudad, ya que entiende que esa conexión, mal realizada, puede dañarla. En este sentido difiere de las teorías de Ciudad-Jardín de Howard puesto que la propuesta de éste supone que la ciudad se sumerja informalmente en la naturaleza. Fisac sin embargo se acerca más a la posición de respetar la forma y peculiaridades propias de la ciudad y de cada una de sus partes, de forma que la naturaleza produzca una suerte de conexión orgánica entre ellas, que una o separe según el caso.

En general, la jardinería es utilizada por Fisac como una herramienta para potenciar el diálogo de su arquitectura con el paisaje, y al igual que elige el material que existe "a pie de obra" y que trata de realizar conexiones intensas con la arquitectura popular, su jardinería goza de una enorme coherencia en su forma de actuar, y hace pertenecer su arquitectura aún más al paisaje.

Ya en el Instituto Laboral de Daimiel se hace una declaración de intenciones, utilizando especies arbóreas de aquella zona manchega, así como especies arbustivas yuxtapuestas a los paramentos del edificio y parras, que evoquen un cierto surgimiento de la arquitectura desde el lugar.

Un emparrado que cubre con sombra fresca un cierto espacio durante los meses de calor y deja pasar el sol en invierno, una serie de árboles que aportan profundidad al patio y dejan entrever la arquitectura como parte de un entorno agreste, etc.

Las especies arbóreas previstas, absolutamente ligadas a la tierra, recrean una visión emocional de la naturaleza daimieleña, el paisaje de su infancia. Una sucesión de plátanos, olmos y chopos salpican diversas zonas delimitadas en una suerte de tablas sinuosas; y los sauces junto a la zona del estanque intensifica el carácter silvestre del borde del estanque y evoca la ribera de un río.

En el Centro de Formación del Profesorado también podemos apreciar el cuidado exquisito de las plantaciones. En este caso, esta cualidad nos acerca un poco más al Paraíso interior que se pretende crear como continuidad de la Creación, de la Naturaleza dada, al "Cielo en la Tierra", intensificando la conexión con La Alhambra.

Se crean dos espacios de pradera, uno junto al pabellón de las aulas pequeñas y otro junto a la zona de acceso. Un tercer espacio de jardín, más pequeño, se ubica en el lado Norte, entre las dos aulas mayores, introduciendo la vegetación y la luz a través de ella al espacio de circulación entre ellas. Por último, un seto dirige el itinerario de las personas, conduciéndolas intencionadamente.

Los dos primeros tratan de refrescar y humanizar los espacios de sombra y estancia creados por los umbrales, a la vez que dirigen el paseo entre los pabellones.

Sobre los mencionados espacios de pradera, encontramos las siguientes especies: 
En el primero, junto al estanque con surtidor, vinca, ciprés, paraíso, magnolio y grategus. Adosadas al pabellón de las aulas, piedras y planta de rocalla tocan el edificio.

En el segundo, un estanque de dimensiones parecidas, esta vez sin surtidor, se ve completado con madroños, retamas, una mahonia, forsitias, encinas y monte bajo.

Asimismo, en el citado jardín entre las aulas mayores, se dispone pradera, monte bajo, una encina, un pequeño estanque, rocas, y retamas "muy grandes".

En cuanto al seto existente junto al pabellón de oficinas, se disponen vinca, tojo, grategus y ampelosis.

Encontramos por tanto una intensa intencionalidad de realizar un jardín para los sentidos. Un espacio de texturas, colores y olores, una atmósfera que participa de la tradición hispanoárabe, en la que cobran protagonismo también el sonido -a través de los surtidores-, los reflejos de las láminas de agua, las sombras o el frescor.

Texturas, a través de los pavimentos, las rocas, los arbustos o las plantas de suelo como la vinca; pero también en la variedad de fondos de los estanques. Colores a través de las citados espacios de vinca, o los árboles como el magnolio o especies arbustivas la mahonia o las forsitias. Olores a través de las encinas, el tojo o las retamas...

Por otra parte, en el Patio de los Padres del Colegio Apostólico de Arcas Reales de Valladolid, se crea un sencillo y austero jardín, totalmente ligado al lugar, a las personas que lo van a utilizar y al uso de esparcimiento y meditación.

La sobriedad y parquedad de los fustes de los chopos generan un ambiente de meditación y trascendencia y conecta con los ideales de la orden dominica, además de generar amplias sombras en los meses cálidos. Como contrapunto, dispone una serie de pinos que enfatizan algunos espacios de la sinuosa pradera, y un sauce que aparece, al igual que en el citado edificio de Daimiel, ligado a un pequeño estanque.

Las dos viviendas gemelas de los hermanos Larragueta comparten un jardín que recrea la ribera de un río. Un río imaginario, fina acequia que divide el jardín en sendas propiedades pero que pretender establecer una conexión metafísica con el río Milanillos, muy próximo al conjunto.

La estrategia es, en esencia, parecida a los casos anteriores. Los chopos son utilizados en los perímetros, de forma que en la época estival filtre las vistas. Asimismo se utiliza como es costumbre en Fisac- sauces llorones vinculados a pequeños estanques que se pretenden enfatizar. Los árboles de gran porte, como los eucaliptos, generan agradables espacios de sombra y contrastan con otros menores como los castaños. 
Las especies arbustivas salpican el conjunto y potencian determinadas zonas, como el estanque-piscina.

En su vivienda del Cerro del Aire Fisac crea un rico jardín en la zona delantera de la vivienda, policromático y variopinto, que contrasta con el horizonte de líneas de alta tensión y lo delimita bellamente. Este acompañamiento vegetal -con relevante presencia de especies vinculadas al jardín hispanoárabe y al jardín oriental- forma parte del proyecto, ya que intensifica la variedad y matices del espacio. El patio interior, en contraste, tiene claras referencias orientales: la vegetación aparece como retorcida, como si se hubiera querido recrear una suerte de pequeño jardín japonés en el corazón de la casa.
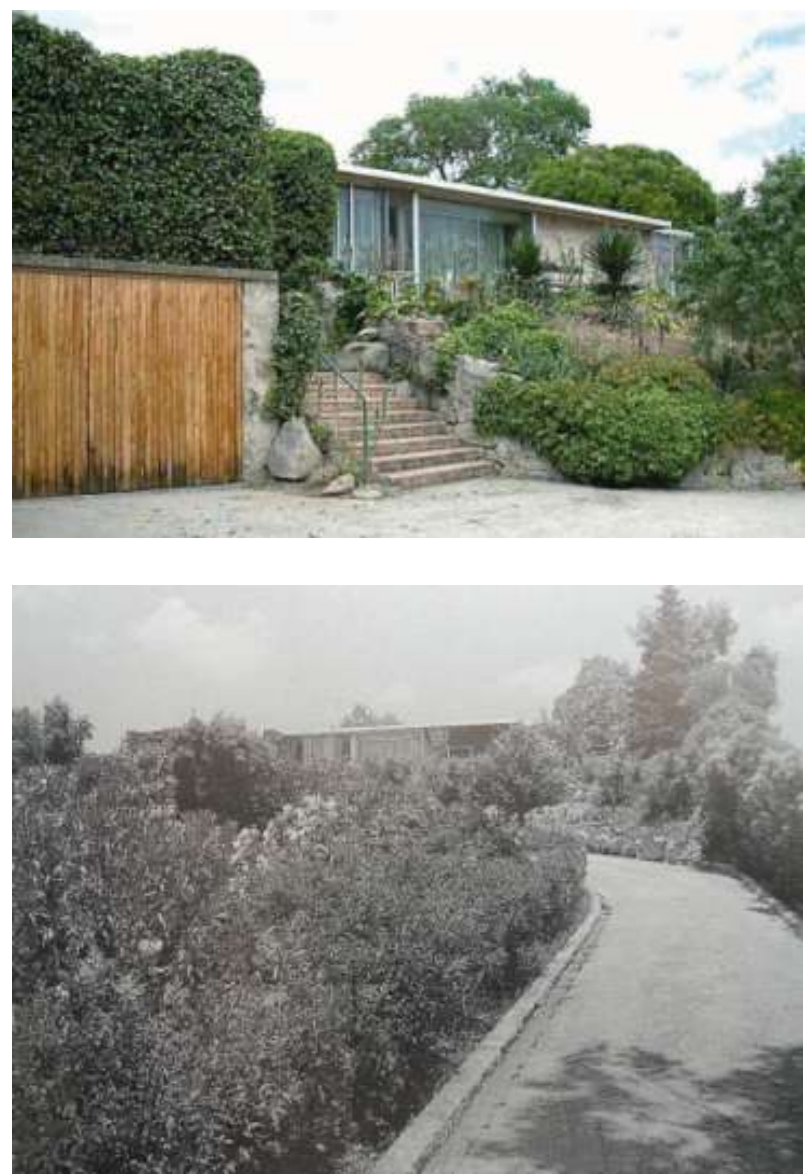

Miguel Fisac. Casa en el Cerro del Aire (1956). Fundación Fisac 
Como conclusión, podemos aventurar que para Fisac la vegetación y la jardinería es una material más de cada proyecto. Y como tal responde a un programa previo.

A través de ellos recrea la naturaleza circundante para intensificar la relación de la arquitectura con la naturaleza circundante, realizando una relectura emocional del entorno, inventando el paisaje. A través de las especies utilizadas, podemos ver las evocaciones de su infancia en cada especie colocada, con la intención de humanizar la arquitectura y a la vez propiciar la trascendencia del hombre desde la contemplación.

Una sensibilidad pareja a la mostrada por otros arquitectos españoles contemporáneos -si bien algunos años más joven- como Cano Lasso, para los que la vegetación forma parte inseparable de una arquitectura humana, para ser vivida: "Cuatro paredes blancas. Cancelas de hierro. Un patio en el que crece un álamo de hojas plateadas. Glicinias, lilos, parras, cipreses, espliego, violetas y romero. Desde mi mesa de trabajo se ve el jardín y se vive el paso de las estaciones: los días de invierno, la lluvia, el sol y los atardeceres; el otoño y el florecer de la primavera. Ahora estamos en abril: una mañana luminosa, y frente a mi ventana canta incesantemente un ruiseñor. Todos estos son deleites que la naturaleza ofrece sin pedirnos otro pago que un poco de sensibilidad y amor. Deleites al alcance de quien de verdad los busca, renunciando a otras cosas."223.

${ }^{223}$ Cano Lasso, J. (1980). Mi ambiente de trabajo. Julio Cano Lasso, Arquitecto, 35. Madrid: Xarait ediciones 


\section{Textura y materialidad}

La utilización certera de los materiales, muchos de ellos naturales, requieren una total comprensión de los mismos, así como de sus técnicas constructivas. Como el cocinero que, con modestia ensalza el producto y extrae de él sus cualidades más íntimas, minimizando con humildad la presencia de sí mismo como creador, la obra de Fisac es una continua celebración de la materia.

Todo ello se comenzó a forjar en Fisac con el estudio intenso de la arquitectura popular, destilando los íntimos porqués de las construcciones de muros de tapial -que es construir con la propia tierra- o de las cubiertas de rollizos, entendiendo que la forma de construir y la manera de tratar esos materiales intensifica la relación de la arquitectura con el paisaje, construyendo el lugar, y volviendo a la naturaleza.

"El tapial es tierra apisonada. Se obtiene compactando, a golpe de pisón de madera, tierra mojada -ligeramente arcillosa, o con alguna sustancia aglutinante: paja, estiércol, yesones, etc.- entre dos tableros verticales de madera separados unos cincuenta centímetros."224

Esta aparente descripción constructiva encierra una reflexión profunda con "resonancias prehistóricas"225 que acaba realizando sobre diversos materiales que utiliza, y que desemboca en la consideración del mismo como una manera de construir el paisaje.

Desde el proceso de enjabelgado con cal de los muros de tapial hasta el encofrado flexible de sus hormigones, Fisac recorre un camino en el que las texturas -verticales u horizontales, como ahora veremos- forman parte esencial de la conexión arquitecturapaisaje.

"La belleza de esa cal, unida a la preciosa textura que originan las sucesivas capas blancas al tirársela, generalmente con un cacillo o sartenilla atados a la punta de una caña de tortasol (girasol), es la propia estética de un perfecto planteamiento programático y constructivo.

\section{$(\ldots)$}

Esta preciosa textura así obtenida, con las suaves rugosidades resultantes de las sucesivas capas de cal caídas sobre la áspera superficie del tapial, es otra de las más bellas características de esta arquitectura."226

${ }^{224}$ Fisac, M. (1985). Op. cit. 225 Idem 
La textura que conforma la piel de su arquitectura, tersa o áspera, suave, estriada 0 rugosa, brillante o satinada; caracteriza de forma importante la interpretación que hace ella del lugar y del paisaje, utilizando el material como uno de los actores protagonistas.

El material no cumple en la obra de Fisac exclusivamente la misión de adaptación al medio y de protección de la climatología. Es utilizado como expresión de intenciones, de búsqueda de la esencialidad, de elemento sintético en la relación con el paisaje. La veracidad en la utilización del material -que no sólo es cerramiento sino que también tiene misión portante- está en conexión con las arquitecturas más ancestrales, de chozas de ramas entretejidas o de tiendas de esteras de palmas. En definitiva, la forma de usar el material es el soporte de la idea que nos traslada Fisac y que trasciende como en La Alhambra- la condición física del material.

En otro orden de cosas, es bien conocida la amplitud de estudios y experimentos realizados por Fisac con varios materiales. No en vano, varios de ellos, como el "nuevo ladrillo"227 desembocaron en patentes e innovaciones tecnológicas utilizadas también por otros arquitectos, como Luis Gutiérrez Soto o Alejandro de la Sota. Y en todo ello, destaca el hormigón, como material al que se le extrae un nuevo jugo desde la reflexión de su condición de material pastoso.

No nos detendremos, sin embargo a desarrollar estos temas, de sobra conocidos y que desvían el sentido de esta tesis. Interesa más bien centrar la atención sobre la utilización de dichos materiales para construir, para inventar el paisaje. Paisajes creados, caracterizados o redefinidos especialmente a través de la materialización de su piel.

Materiales en gran parte naturales, que devuelve de alguna manera al paisaje lo que es del paisaje; y sin disfraz ni artificio, mostrándose en toda su sinceridad: la textura es, en la arquitectura de Fisac, sensible a la naturaleza y al paisaje. En este sentido el uso de materiales naturales aporta a la arquitectura una especial atmósfera de serenidad fruto de haber convivido junto a los árboles; de alguna manera, el material sigue formando parte del lugar en esencia, aunque de otra manera o en otro estado. Esta concepción se extiende a elementos que se usan para apropiarse del lugar sin estridencias, para humanizarlo y hacerlo formar parte de la arquitectura. Un ejemplo de ello son los itinerarios realizados en Costa de los Pinos, en Mallorca (1968), realizados con la piedra del lugar, la piedra de marés, en un exquisito ejercicio de integración de un elemento de conexión de una vivienda unifamiliar con la playa.

${ }^{226}$ pg. 19 y 23

227 Cfr. Fisac, M. (1952). Un nuevo ladrillo. Revista Nacional de Arquitectura, 127, 40-42. Julio 
Memoria, Aprendizaje y Experimento. La invención del paisaje en Miguel Fisac Experimento. Gramática de un paisaje

Además, el uso frecuente de sistemas de construcción locales pone en armonía arquitectura y lugar, en combinación la arquitectura y el paisaje, y en paralelo el amor a la arquitectura tradicional y moderna.
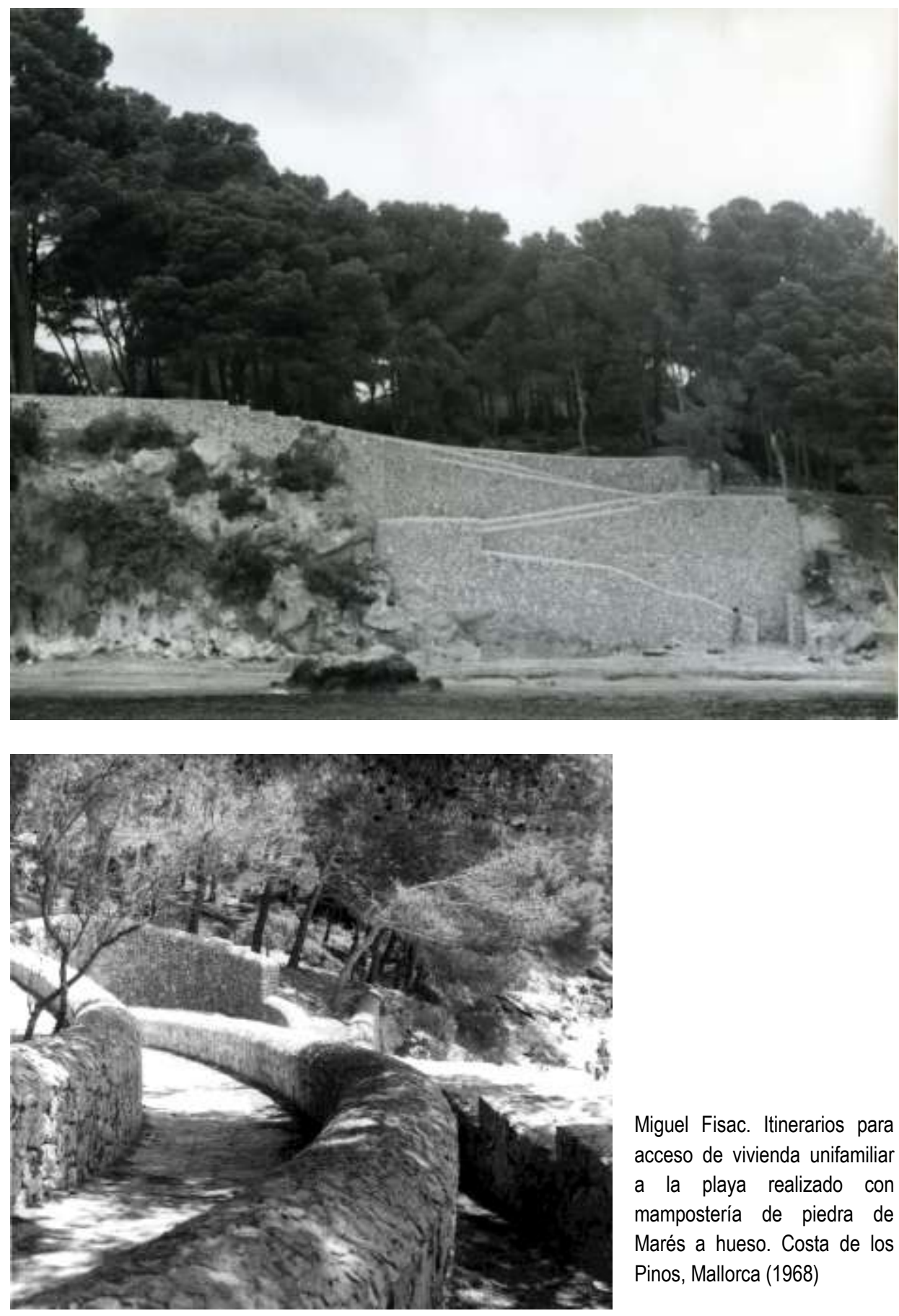

Miguel Fisac. Itinerarios para acceso de vivienda unifamiliar a la playa realizado con mampostería de piedra de Marés a hueso. Costa de los Pinos, Mallorca (1968) 
Podríamos ejemplificar lo dicho a través de muchas obras, pero nos centraremos en aquellas en las que la textura es esencial para caracterizar el paisaje: el Colegio Apostólico de los PP. Dominicos de Valladolid es uno de ellos.

En efecto, en dicho conjunto conocido como Arcas Reales (1952-1953), citado anteriormente, la textura de los materiales podría ser entendida como la resonancia del paisaje en la arquitectura para así, transformar dicho paisaje ${ }^{228}$.

El conjunto quiere pertenecer al paisaje, y la formalización material del mismo le ayuda definitivamente a ello.

Un lugar sin adornos, despojado, parafraseando a Unamuno, "monoteísta", compuesto de tierra parda, horizonte y cielo. Un lugar sin referencias, totalmente plano, adusto, casi sin árboles. En él, Fisac proyecta desde su Memoria, desde el conocimiento y las referencias de un paisaje agrario manchego con muchas similitudes con éste al que se enfrenta, para inventar un nuevo paisaje que no pierda la esencia de aquel paisaje ascético en el que sus admirados Teresa de Ávila y Juan de la Cruz aprendieran el renunciamiento.

En este contexto, la utilización del ladrillo caravista -no sólo como cerramiento, sino también como estructura- para los pabellones que conforman el conjunto facilita la adaptación y ajuste al lugar; y la piedra caliza de Campaspero es el contrapunto que insufla vida al conjunto.

Volúmenes texturados con aparejo inglés -alternando hiladas de sogas y tizones- que juegan con la luz y la sombra; pabellones que surgen de la misma tierra potenciando una cierta actitud de mimetismo, al igual que las aldeas y ciudades del entorno se confunden con el color del suelo.

$Y$ de entre ellos surge la tersura de un manto blanco que abraza el presbiterio de la iglesia, puro, abstracto, gigante, orientado hacia el sur, construido con piedra del propio lugar y dando por tanto vida al lugar, con la escultura oteizana cual reloj solar, en un ejercicio de despojamiento, de humildad, de lección cuasi-teológica a los residentes de la dualidad tierra (fábrica de ladrillo para los pabellones) - cielo (caliza para iglesia).

Así, la ascética desnudez del campo y la llanura, la metáfora del hombre frente a la inmensidad del horizonte, resuenan en la arquitectura como herramientas de exaltación espiritual y abnegación de sí mismo. $Y$ también en la misma línea reverberan un

${ }^{228}$ Este proyecto ha sido muy publicado, ya que fue merecedor de la Medalla de Oro de Arquitectura de la Exposición Internacional de Arte Sacro de Viena, en 1954. Para una descripción detallada del conjunto, véase Fisac, M. (1955). Colegio Apostólico de los PP. Dominicos en Valladolid. Revista Nacional de Arquitectura, 157, 3-9 y VV.AA. (1955). Sesión crítica de arquitectura dedicada a la iglesia de los PP. Dominicos de Valladolid. Revista Nacional de Arquitectura, 157, 10-19. 
conjunto de valores poéticos que atribuyera Unamuno a este paisaje castellano: austeridad, robusta fuerza interior, severidad, gravedad, carácter, etc...

Esta celebración de la materia, como hemos dicho, se puede contrastar en muchas otras obras de Fisac, como las citadas viviendas gemelas en Ortigosa del Monte, en las viviendas familiares de Canfranc o del Cerro del Aire; así como en las iglesias de Canfranc, Vitoria, Pumarejo de Tera y otras muchas. En todas ellas, el material y la intensificación de ciertas cualidades táctiles no se buscan de forma artificiosa, sino que son el propio fundamento de la arquitectura, el soporte, la estructura de la misma.

En Segovia -Ortigosa del Monte-, la utilización de gruesos muros portantes de mampostería de piedra natural no sólo facilitan la integración con el entorno, sino que ponen el conjunto en comunión con el mismo.

El profundo conocimiento de la arquitectura vernácula local permite a Fisac proyectar con elementos que trascienden lo puramente material, conectando la arquitectura con el espíritu del lugar. De esta forma, la piedra es el material óptimo para adecuar la arquitectura a un clima de inviernos muy fríos y veranos relativamente calurosos, con una oscilación térmica diaria bastante destacable, validando la inercia térmica del material. En este sentido, el medio geológico del lugar, con la presencia de granitos, recomienda la utilización de los mismos; y el medio social -fundamentalmente ganadero-, sugiere construcciones con materiales no sólo del medio natural, sino también existentes a pie de obra, y sin la utilización de grandes medios tecnológicos.

Además, existe una fidelidad constructiva respecto de este tipo de construcciones, labrando en sillares únicamente las aristas y bordes de la edificación, y en formas paralelepipédicas las jambas y dinteles -véase la celosía de granito para las estancias de leña y despensa-, dejando la realización del resto con mampuestos facetados de diversos tamaños.

El ligero enjabelgado de la piedra, crea sobre el material una atmósfera de sugerencias que recuerda a los parajes segovianos, en los que la nitidez se diluye a través de las brumas en determinadas horas del día.

La mampostería se mete hasta dentro de la casa, creando en las zonas comunes una continuidad con el exterior, y a través de ella con el lugar.

Parecen estas viviendas en cierto modo, precursoras de la casa del Cerro del Aire en la utilización del material, en la que los muros portantes de mampostería juegan un papel esencial en la definición del conjunto. En la casa madrileña, además, se introducen una serie de materiales que ayudan a la piedra a dialogar con el entorno. $Y$ es que la intensidad táctil en la obra de Fisac por tanto, no es exclusiva de exteriores. La elección 
material y su disposición interior también forma parte de un todo en la búsqueda de la conexión con el lugar.

En el Cerro del Aire destaca la utilización de la madera en el techo y en varios de los paramentos verticales interiores, aprovechando sus brillos y la disposición longitudinal de las tablas para reflejar la luz que entra a través de los grandes huecos, y avivar así su conexión con el paisaje. A ello colabora también el suelo continuo de sintasol , que discretamente cede el protagonismo al resto de los materiales.

La disposición de la madera no permite ver en ningún momento el canto delgado de sus tablas, como si quisiera semejar cierto estado natural, forrando -además del techo- la estantería que horada el grueso muro y evitando aparecer como marco en la hoja que comunica el estar con otro área de la casa.

En el espacio de estar conviven los materiales en una dicotomía rugoso-terso, destacando de ellos el valor y carácter propios, sin ocultar la naturaleza del propio material.

Los muros portantes de mampostería de granito, colocados en torno al patio -al vacíocomo los radios de la rueda en torno a un eje, se convierten en protagonistas del espacio evidenciando tanto su carácter natural como primigenio, con la presencia de importantes hilazas de argamasa.

La cubierta por su parte, una delgada losa de hormigón, apenas tiene la presencia imprescindible, desplazando igualmente la atención al elemento portante.

Fijemos ahora nuestra mirada en la iglesia de Canfranc, -anteriormente citada- en los muros de fábrica de piedra que delimitan la iglesia, y especialmente en los sinuosos muros de la parte frontal de la misma. La expresión de este material -que también nos envuelve en el interior, y casi nos traslada al interior de alguna de las montañas que nos rodean-, su ondulada presencia, y la aspereza del material suavizada por la sombra del propio muro y la cubierta, es igualmente la resonancia del paisaje oscense, -del entendimiento del lugar por Fisac- en la arquitectura. Un diálogo amable entre arquitectura y naturaleza, poniendo de manifiesto la actuación del hombre como artesano.

Un muro que nos vuelve a poner en paralelo la sensibilidad de Fisac con la arquitectura nórdica: la del diálogo de Aalto con la naturaleza a través de las ondulaciones de sus espacios, o la materialidad de las sugerentes texturas de Lewerentz. 
Memoria, Aprendizaje y Experimento. La invención del paisaje en Miguel Fisac Experimento. Gramática de un paisaje

La descripción de Luis Moreno Mansilla sobre la fotografía que toma Lewerentz en Villa Adriana parece describir el muro de esta iglesia: "Un muro con una textura hermosa, un plano patinado por el tiempo y oculto por los árboles hasta esconder su inmensa longitud, y un gran hueco, o, mejor, y sólo un gran hueco."229.
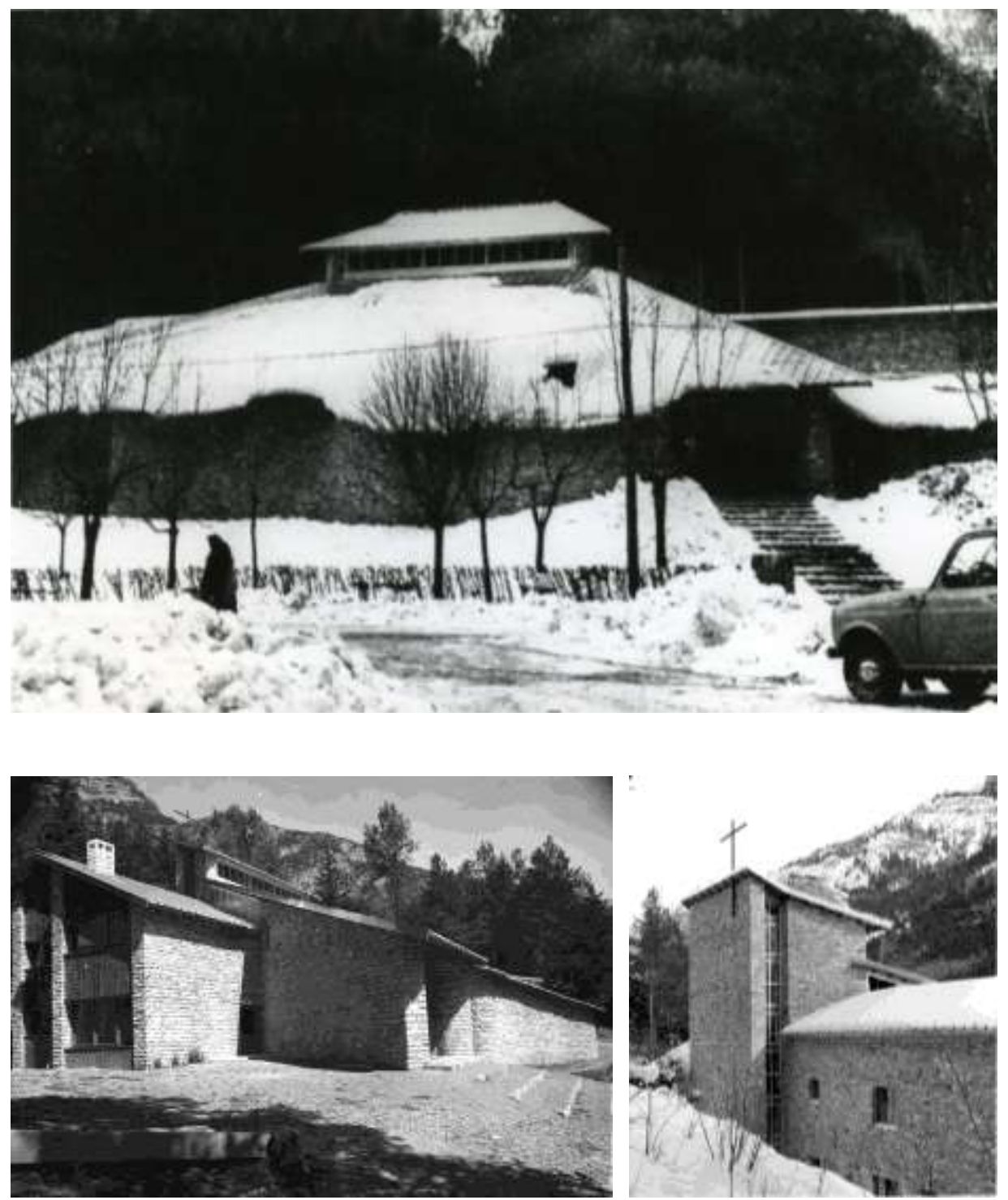

Miguel Fisac. Visiones de la iglesia de Canfranc (1965)

${ }^{229}$ Moreno Mansilla, L. (1994). Más allá del muro de Villa Adriana. El viaje de Lewerentz a Italia. Circo, 1994.12, 9 
De la cubierta, con una importante presencia en el conjunto y realizada en aluminio, resaltaremos su brillo y suavidad, que refleja la luz, aporta ligereza al conjunto, y sobre todo contrasta con la estereotomía de los muros portantes de piedra. La cara interior de la cubierta, realizada con tablas de madera tanto en la nave como en la capilla del Sagrario, siguen similar línea argumental de elemento natural básico, y conseguible a pie de obra -en contraste con la rudeza de la piedra-, mostrando ahora claramente la mano del hombre en la cubrición del espacio pero sin querer interferir más de lo necesario, lo que se manifiesta en los tableros veteados y sin pulir.

Las escaleras laterales por su parte también juegan su papel en la concepción de riqueza táctil del conjunto con sugerentes contrastes entre lo salvaje y lo domesticado en referencia al material. Las huellas de hierba, que se introducen en los grandes huecos de acceso permiten a la naturaleza agreste casi invadir el interior de la iglesia. También el suelo de lajas de piedra sin labrar dispuesto en el exterior y el presbiterio en contraste con el del resto de la iglesia, realizado de madera machihembrada-, acentúan la transición existente en el acto de entrar a la iglesia230.

La zona de vivienda del párroco, realizada fundamentalmente con madera, ayuda a caracterizar la zona, a potenciar el juego de contrastes con elementos naturales, y a diluir el carácter doméstico de esa zona de la edificación, integrándola con maestría en el conjunto parroquial.

Por último, es importante poner de manifiesto la influencia del paisaje también el ciertos elementos de la iglesia, como la mesa del altar, la sede, el ambón, la pila bautismal o la base de apoyo del sagrario; todas ellas realizadas con talla de piedra, lo cual potencia la coherencia material de todo el conjunto.

La textura y transiciones horizontales de diferentes pavimentos caracterizan también la interpretación que Fisac hace del paisaje y su resonancia en la arquitectura.

La utilización de varios materiales en los pavimentos que se entremezclan con especies vegetales -tapizantes o arbustivas-, la disposición de los mismos, etc... forman parte también de la búsqueda de un diálogo con el entorno que rodea la arquitectura. Se establece una conexión en dos niveles: entre lo creado y lo existente por un lado; y con los sistemas aprendidos de otras arquitecturas por otro.

La importancia de esa texturización de los elementos delimitadores del espacio, aprendida de La Alhambra, podemos verla reflejada como ejemplo en los estanques geométricos del Centro de Formación del Profesorado, con diferentes lechos en su fondo -canto rodado blanco, gris, u hormigón-, y que junto con la tierra compactada, la

230 El tipo de pavimento proyectado y construido en primera instancia, de madera machihembrada para el suelo de la zona de fieles, fue sustituido parcialmente en una de las obras de reforma. 
grama o los tapices vegetales crean un conjunto con una gran riqueza de matices que define las visiones de la Sierra de Guadarrama desde sus patios.

En definitiva, la humanización del espacio -interior o exterior- también precisa texturizar las superficies verticales $u$ horizontales que lo limitan de forma que interpelen a los sentidos y a la emoción.

En la conexión del objeto con el paisaje, al igual que en el refugio familiar construido en la misma localidad de Canfranc unos años antes, cobra especial protagonismo la materialización constructiva ${ }^{231}$, la elección del material.

${ }^{231}$ La elección de los materiales es importantísima en cuanto a la relación del conjunto parroquial con el entorno. En la Memoria del Proyecto -inédita-, firmada en Marzo de 1965 se indica: "El sistema constructivo se ha procurado (...) utilizar materiales locales más económicos y más conocidos en la localidad y de otra parte materiales ligeros, metálicos, que pueden transportarse fácilmente. Los muros perimetrales y estructurales del conjunto son de mampostería del país con mortero de cemento sobre el que se dispone una estructura metálica de cubierta tridimensional, tipo "ceno" o similar sobre la que se colocan placas aislantes de "Viroterm" de 2,35x 0,50x 0,05 m y cubierta de piezas de chapa de aluminio de perfiles adecuados, formando una cubierta a un agua con una pendiente del $50 \%$ (...) El pavimento es, exteriormente, de lajas de piedra sin labrar, así como también el del presbiterio, siendo el resto de madera machihembrada." 
Memoria, Aprendizaje y Experimento. La invención del paisaje en Miguel Fisac

La invención del paisaje

\section{5_ LA INVENCIÓN DEL PAISAJE EN LA ARQUITECTURA DE MIGUEL FISAC}

5.1_ Identidad y paisaje. El Instituto Laboral de Daimiel. Ciudad Real (1950-1953)

5.2_ El Objeto en el paisaje. El Tránsito de Arcas Reales a Alcobendas (1951-1955)

5.3_ El Hombre en el paisaje. El Centro de Formación del Profesorado de la Ciudad Universitaria. Madrid (1952-1957) 


\section{Introducción a la invención del paisaje}

Para explicar de forma aplicada el cuerpo teórico de la Tesis anteriormente desarrollado se ha seleccionado tres obras que, si bien muy próximas en el tiempo, son paradigmáticas de ciertas evoluciones trascendentales en la obra de Fisac en relación a la construcción del paisaje.

Las respuestas que se dan al paisaje desde el Instituto Laboral de Daimiel hasta el Teologado de Alcobendas, denotan un desplazamiento de sus ejes referenciales a través de la absorción de ciertas esencias en los mencionados viajes, en el descubrimiento de culturas del Lejano Oriente, o en el estudio de edificios de maestros indiscutibles de la modernidad, que enriquece su mirada.

De esta forma, veremos cómo se van desdibujando ciertos límites, y como el interior y el exterior comienzan a fluir con más intensidad, atrapando el aire que delimita la arquitectura.

También se alcanza la articulación de piezas con más libertad, en conjuntos en los que coexisten piezas más ligeras y abiertas, que dejan pasar el aire bajo ellas y que permiten relaciones visuales con el entorno, inventando un paisaje en el que lo de allá y lo de acá se funden en un único elemento y dejándose la arquitectura atravesar por él.

Se utilizan elementos de activación del paisaje, como hemos definido anteriormente en esta suerte de gramática experimental. En este sentido, es destacable la insistencia sobre algunos elementos comunes, como si se hubiera establecido un cierto léxico que actúa como campo semántico.

Todo ello se enfrenta -casi contradice- a la visión que tiene el propio Fisac sobre su arquitectura:

"Tengo que confesar que en aquella época -mediados de los años cincuenta- estaba tan obsesionado con la importancia del espacio interior y la veracidad de la calidad expresiva de los materiales, que dejé bastante olvidado el aspecto exterior de los edificios, la valoración de los volúmenes exteriores, y también los medios estructurales con los que se conseguían esos espacios." ${ }^{232}$

"Olvido" o no del exterior, qué duda cabe que Fisac se posiciona ante el paisaje. Su humanización del espacio contempla una expansión a lo no construido, a la

232 Documentos de arquitectura, n.10. Miguel Fisac. Delegación de Almería del Colegio Oficial de Arquitectos de Andalucía Oriental. p.24 
Memoria, Aprendizaje y Experimento. La invención del paisaje en Miguel Fisac

La invención del paisaje

exterioridad, potenciando la relación entre la arquitectura y su emplazamiento, construyendo un nuevo paisaje. Una manera propia de entender una suerte de organicismo -que él mismo afirma desconocer en principio-, en algunos momentos de adelantarse a él.

Este posicionamiento -que se inicia en el "dónde" de su conocido itinerario proyectual-, no implica necesariamente una actitud de sumisión ante él: no se trata de camuflarse como un camaleón. Se trata de valorar la relación con la naturaleza y adecuarse al lugar, siguiendo las coordenadas de su memoria y su aprendizaje, tal vez propiciando que su arquitectura parezca que se adelanta a la propia naturaleza.

Así integrar o dominar, esconderse o mostrarse, mirar o reservar...son actitudes que sólo al que es sensible al entorno de su arquitectura lo capacitan para establecer un diálogo certero entre el objeto y el paisaje, un diálogo de certera belleza. 


\section{1_ Identidad y paisaje. El instituto laboral de Daimiel. Ciudad Real (1950-1953)}

Como testigo de esa ligazón a La Mancha y a la estrecha unión entre la arquitectura y su paisaje, Fisac proyectó el Instituto Laboral de Daimiel (1950-1953). Uno de los primeros grandes proyectos de Fisac -junto con el Instituto de Microbiología Ramón y Cajal- en el que, fruto de sus aprendizajes, se intuye la inclusión de una serie de ideas renovadoras a su arquitectura ${ }^{233}$.

Un edificio sobre el que posteriormente Fisac, reflexionando sobre los puntos de partida previos al proyecto dirá:

"Ya tenía dos conceptos claros: el carácter sedentario, de circunstancia física, estática, de la arquitectura en su paisaje; y el espacial, de necesidad de creación de una ecología de la que el hombre no suele disponer en general en la naturaleza."

Y esa "arquitectura en su paisaje" será el núcleo de su propuesta, tanto en lo construido como en lo no construido, tanto hacia al parque que asoma -exterior- con esos huecos profundos cuyo tamaño responde a las necesidades del programa; como al jardín creado -interior-. Fisac cuidará desde la textura hasta el color o la volumetría, así como las articulaciones de los diferentes elementos, adelantándose intuitivamente a lo que posteriormente descubrirá como arquitectura orgánica -y que en el momento de proyectar el edificio Fisac afirmaba desconocer-.

Más que crear un objeto, pareciera que quiere crear un lugar: manchego, si, pero lejos de sentimentalismos o folclores. Una relectura emocional del paisaje de su niñez y su valor plástico.

"Me molesta referirme a mi propia experiencia, pero no tengo más remedio que constatar que he tenido que vivir en La Mancha los primeros años de mi vida $y$, después, alejarme durante cuarenta años, para darme consciente cuenta de esta realidad estilistica, aunque ya mucho antes hubiera captado de una forma más intuitiva no en profundidad- los valores plásticos que contenía esta arquitectura popular

${ }^{233}$ En el conjunto de Daimiel Fisac proyecta una capilla, no construida, en la que también existen una serie de conceptos renovadores (luz, muros convergentes, etc..) que, tras otro intento no construido en el Instituto Laboral de Almendralejo, finalmente conseguirá poner en práctica en el Colegio Apostólico de Arcas Reales de Valladolid. No abundaremos sobre ello para no desviar el objetivo de la investigación. 
manchega; por ejemplo, al redactar, en 1951, el Proyecto para el Instituto Laboral de Daimiel."234.

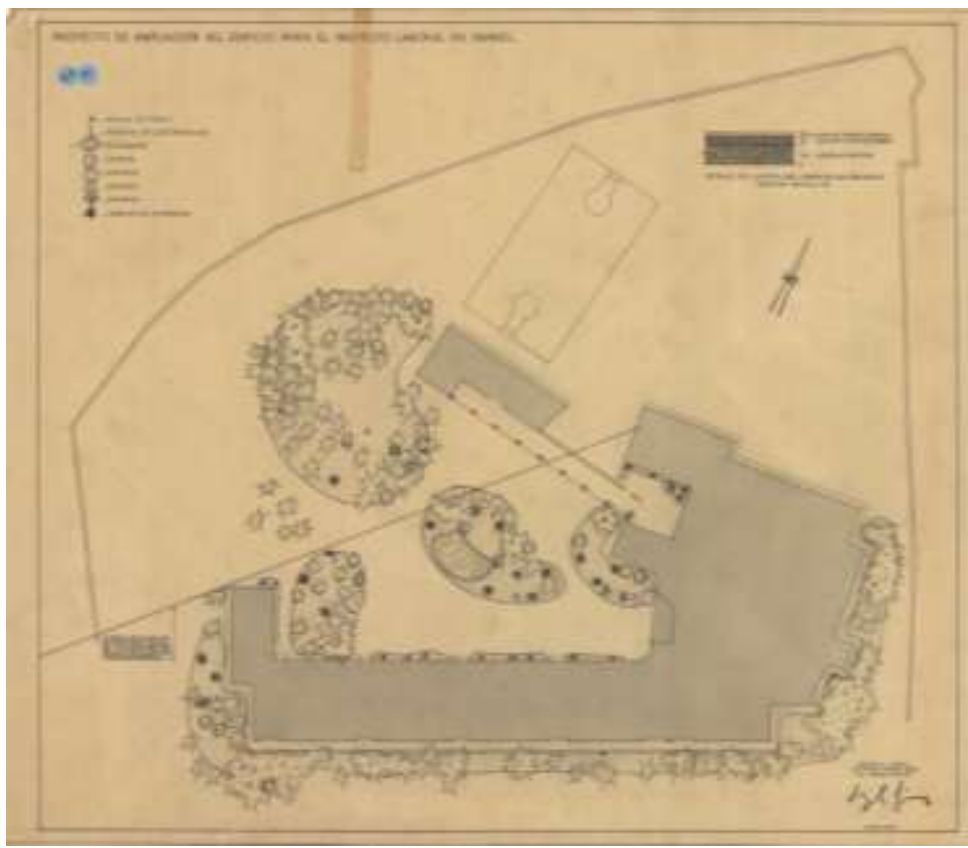

Instituto Laboral de Daimiel. Planta de jardinería del Proyecto de Ampliación. 1953

Se trataba de realizar un conjunto arquitectónico con un programa relativamente sencillo, en una sola planta, y en un solar "irregular de dieciséis lados".

Fisac optó entonces por disponer una serie de espacios, con el hombre -y su actividad allí- como centro fundacional, y se auto-impuso el ejercicio de jerarquizar el programa solicitado 235 .

El juego de volúmenes blancos crea una sinfonía interpretada por cada uno de los elementos, resultando un conjunto armónico, en absoluta comunión con el lugar. Destaca de entre ellos la sala de proyecciones, con un gran lienzo de azulete 0 añil236

234 Fisac, M. (1985). Op. Cit, 15.

235 Fisac inmortalizó este ejercicio de jerarquización en una serie de esquemas que posteriormente se publicaron (cfr. Instituto laboral de Daimiel. Revista nacional de Arquitectura, 139, 4-5. Julio) y que se convertirian en un auténtico sistema de trabajo que desembocaría en su conocido itinerario proyectual.

${ }^{236} \mathrm{El}$ añil, junto con el blanco, son los dos colores que más lucen las fachadas de los pueblos de La Mancha. Se trata de una pasta obtenida de los tallos y hojas de la planta del mismo nombre por maceración en agua. Su utilización se concentra especialmente en los zócalos para proteger éstos de las salpicarduras, etc.. y así evitar su rápido deterioro estético. También se usaba en puertas y ventanas para ahuyentar los 
oriundo de aquel entorno, quizás como insistencia de la vocación intrínsecamente manchega de esta arquitectura. Pero no lo utiliza aquí a la manera tradicional manchega; redefine su utilización y lo usa como textura para destacar tres grandes lienzos, abstractos, en los mayores volúmenes que emergen del conjunto horizontal. No se trata aquí de un simple color, sino de la redefinición de un concepto a través de un material. Su utilización lo libera asimismo de los lastres del pasado, pero con un asombroso respeto a lo esencialmente manchego.

La Sala de proyecciones es el elemento que genera el más destacado polo de atracción del conjunto, lugar de acceso y enlace, verdadera rótula en la que se apoyan las dos directrices convergentes sobre las que se construyen las piezas longitudinales que contienen el programa: uno de aulas y despachos, y el otro de talleres, laboratorio, aula de dibujo y almacén.

En la indicada segunda pieza existen tres elementos singulares que enriquecen el juego volumétrico del conjunto. Todos ellos se hilvanan mediante una galería abierta con soportes de madera que nos trasladan imaginariamente a ciertas plazas porticadas de La Mancha ${ }^{237}$, y que posteriormente inspirará los sinuosos umbrales de hormigón que realizará Fisac en la madrileña Ciudad Universitaria o en el conjunto dominico de Valladolid.

El primer elemento es el recoleto patio al que asoma la Sala de profesores. Este patio, que remata la citada galería al Este, propicia la desmaterialización de la misma en el encuentro entre la cubierta y el muro sobre el que apoya -que potencia su direccionalidad- a través de una serie de vigas de madera que actúan como soporte de una parra. Asimismo, destaca el hueco practicado en el muro, -el cual conserva un importante grosor en toda su longitud aunque se difumine su carácter portante-, que aporta bellas y profundas visiones desde el espacio central. El arco acarpanelado le confiere resonancias primitivas.

Uno de esos "recovecos" de los que tanto hablaba Luis Barragán: unos muros blancos, una higuera, el sonido de una fuente, la sombra de una parra, un banco..., capaces de evocar "nada menos que el Universo entero".

El segundo elemento, que se ubica en el extremo opuesto de la galería es el gimnasio, cuya pieza de vestuarios le sirve de remate.

$Y$ el tercer elemento es una ausencia. Se trata del espacio reservado para la construcción de una capilla que nunca se construyó, pero que crea un vacío tensionado

males; y en determinadas fechas para marcar las fachadas en las que vivían mozas solteras en edad de merecer. Fisac lo utilizará varias veces a lo largo de su carrera, como en el mencionado conjunto de Daimiel o en la casa familiar de Almagro (1978).

${ }^{237}$ Como la de Daimiel, erigida en el s. XVI. 
por dos muros convergentes que recuerdan dicha ausencia: un anuncio de lo que posteriormente se materializará en el conjunto dominico de Valladolid.

Por otra parte, en la pieza longitudinal que contiene las aulas, destaca el cuerpo de la biblioteca, que con un giro ortogonal define imaginariamente el límite espacial del jardín central a poniente. Se trata de un elemento que se ubica a la entrada del conjunto al funcionar como una biblioteca agropecuaria de uso público.

La formalización constructiva del conjunto -muros de carga de fábrica mixta de tapial y mampostería- enlaza con la tradición constructiva del lugar, esencializada y sin complejos, aceptando aquellos valores intemporales y adaptando las necesidades espaciales a los nuevos criterios absorbidos y validados a través de los aprendizajes. Así por ejemplo, los rítmicos contrafuertes que genera este sistema constructivo en la fachada sur, conforman una serie de grandes huecos -para aportar luz a las aulas- que aparentemente se contraponen a la arquitectura popular de la que nace, en la que predominaba el macizo sobre el hueco. Esta idea aparece reforzada cuando estudiamos el sistema de iluminación cenital de la Sala de proyecciones, dotado de un sistema de apertura con piezas de tablex, una novedosa tecnología para la época de la construcción.

En este proyecto, Fisac despliega una serie de intenciones de forma pedagógica, es decir, pretende que el proceso proyectual propuesto pueda servir de modelo para sus futuros proyectos. De esta forma, realiza una cristalina declaración de intenciones en la Memoria del Proyecto, haciendo especial hincapié en las circunstancias físicas y humanas:

"El procedimiento seguido para proyectar difiere, esencialmente, de los que ordinariamente se emplean, ya que se ha procurado jerarquizar y subordinar a lo propiamente esencial del edificio otras razones que suelen, por costumbre, tomarse como las más importantes. Este, como todos los edificios, tienen por objeto crear una serie de ambientes o recintos espaciales en donde sea posible realizar unas determinadas funciones humanas. Partiendo de esta base, se ha estudiado independientemente cada una de las funciones que han de vivirse en este edificio, estudiando la morfología en planta y en alzados: en volumen, del recinto; las propiedades óptimas de iluminación natural, teniendo en cuenta las condiciones climáticas locales y, también, las cualidades que ha de tener la luz artificial. La condiciones de aislamiento acústico e insonorización para los trabajos que se han de efectuar en él, teniendo en cuenta, también, las repercusiones acústicas que estos mismos trabajos originan. También las cualidades en los órganos del tacto en lo que se 
refiere a temperaturas, humedad, calidades de los materiales, etc. y, también, las cualidades de salubridad, de renovación de aire, etc, etc."238

Tomando como base las anteriores consideraciones, Fisac estudia cada uno de los elementos individualmente (evitaremos aquí este desarrollo para centrarnos en el objeto de la investigación), y suscita un sistema de agrupación elástica de las diferentes piezas del programa ${ }^{239}$, generando "un recinto abierto, a manera de jardín de recreo"240, que será el corazón del conjunto. En efecto, Fisac caracteriza así un lugar que remataba un parque sin ninguna singularidad espacial ni topográfica, justificando la pieza anteriormente referida de la galería porticada para hacer de ese jardín un lugar de estancia agradable, pues el elemento rompe los vientos más fríos de dirección Norte.
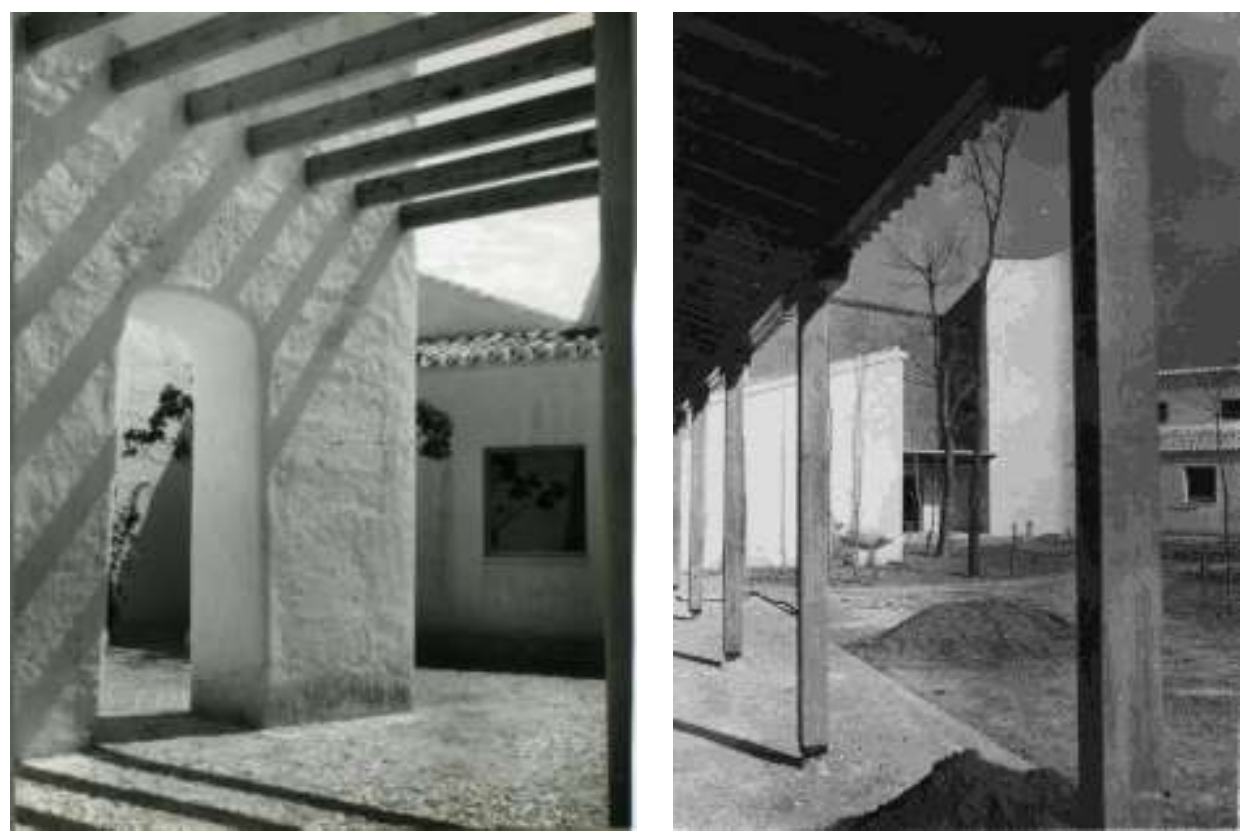

Vistas del pórtico de la parte Norte y del patio Noroeste, apreciándose la ligazón, también en el lenguaje, con el paisaje manchego.

${ }^{238}$ Fisac, M. (1951). Proyecto de edificio para Instituto Laboral en Daimiel. Memoria original, 1-2. Fundación Miguel Fisac.

${ }^{239}$ A partir de este proyecto y de los estudios realizados de agrupación elástica de las diferentes piezas del programa, Fisac genera una suerte de prototipo que utilizará como base para los Institutos Laborales de Hellín y Almendralejo, así como para el concurso de los Institutos Laborales.

240 Fisac, M. (1951). Proyecto de edificio para Instituto Laboral en Daimiel. Memoria original, 4. Fundación Miguel Fisac. 
En relación a los materiales con que se ejecuta el conjunto, la selección de aquellos existentes "a pie de obra", -como otras tantas veces hará Fisac-, intensifica la conexión del edificio con el lugar, ya que éste se conforma desde la propia tierra; así como desde la cultura, como veremos a continuación. Ejemplo de ello es la utilización de carrizos para la cubierta ${ }^{241}$ de este edificio. En esta misma línea, se constata como son precisamente los muros de tapial y su estructura los que posteriormente inspirarán a Fisac en el interés por traslucir de cada material su verdadera esencia.

También la especial sensibilidad demostrada en la búsqueda de la textura de los citados materiales juega un papel importante en el conjunto, como declaración de intenciones presente -conexión con el lugar y la cultura manchegas- e inspiración futura -cada material debe mostrar de forma veraz su carácter-, como el estudio de texturas del hormigón a través de los encofrados flexibles, etc. Un ejemplo de ello es el embelesamiento por la textura y la capacidad expresiva del enjabelgado de cal:

"La belleza de esa cal, unida a la preciosa textura que originan las sucesivas capas blancas al tirársela, generalmente con un cacillo o sartenilla atados a la punta de una caña de tortasol (girasol), es la propia estética de un perfecto planteamiento programático y constructivo."242

Una fascinación que le llevó a explicar personalmente a los operarios del conjunto daimieleño cómo debía aplicarse la cal para que su textura fuera similar a la conseguida en las arquitecturas populares de la zona. Ello se trasluce incluso en el diseño de este edificio. Existen una serie de curvas en el diseño como si de inicio quisiera huir de esquinas en arista viva, como si se deleitara en el acabado de las sucesivas capas de cal sobre los muros de tapial, que se recortan en el cielo y que producen "como un esfumato praxiteliano"243.

A través de estas operaciones introduce Fisac al hombre en un nuevo paisaje inventado, despojado de todo lo innecesario, que no tiene más ingredientes que la potenciación de la esencia de los valores plásticos de la arquitectura popular convenientemente destilados a través de su aprendizaje, visto desde un nuevo ángulo.

Podemos acordar pues, que la arquitectura popular manchega es un destacado patrón utilizado por Fisac para el diseño de los Institutos laborales. Encuentra en ella un haz de soluciones a los retos planteados por unos programas con ciertos elementos en común y su pretendida agrupación flexible, dejando espacios libres de forma que el lugar penetra en la arquitectura, definiéndose un nuevo paisaje. Y los valores plásticos de

241 En la citada Memoria del proyecto se escribe: "la cubierta se hace por el procedimiento local de correas de madera sobre la que se dispone una capa de carrizo (cañas delgadas existentes en la localidad) de alta calidad aislante, tanto térmica como acústica, sobre la que se coloca la teja árabe sentada con barro".

242 Fisac, M. (1985). Op. cit, 19

243 Idem, 23 
dicha arquitectura popular son, por tanto, tomados en esencia para definir una modernidad que se sacude el polvo en la misma medida en que se conecta metafóricamente con la esencia de una arquitectura ancestral. Como decía el propio Fisac parafraseando a Quatremere de Quincy, "nada en ningún género viene de la nada, y esto no puede dejar de aplicarse a todas las invenciones de los hombres", y continúa más adelante "una de las principales ocupaciones de la ciencia y la filosofía para captar su razón de ser es investigar su origen y su causa primitiva."244.

En este proyecto se erige como elemento destacado el vacío central; un jardín de morfología convergente que es materia del proyecto, activador y reminiscente del paisaje que interpreta.

Recrea allí la esencia de lo manchego a través de una aproximación a la esencia del paisaje, desde la construcción abstracta del mismo. Se trata de una suerte de canto poético cuya metáfora se materializa en la recuperación de unos elementos que le son propios y que están en vías de desaparición, como él mismo constata, evocadores a través de los cinco sentidos.

En efecto, el sonido la fuente "a dos voces" que ahora estudiaremos, realizada con fragmentos de unos elementos tan intrínsecamente manchegos como las tinajas de barro cocido -que también colocará, esta vez completas- en el acceso del Pabellón de Ciudad Real de la Feria del Campo (1953)-; la fragancia característica de la higuera y otras especies vegetales típicas del lugar; el rumor de los chopos; el uso del añil que contrasta sobre el blanco de la cal; el tacto -ya estudiado- a través de las texturas de lo edificado y de los diferentes pavimentos que recrean una suerte de tablas fluviales; el frescor de la sombra de un emparrado; el pórtico-galería, etc.. son el origen de una gramática muy bien hilvanada que dialoga con el paisaje y que poco a poco se irá destilando y depurando. Mención especial requiere la reverberación poética de las Tablas de Daimiel, a través de una serie de elementos vegetales que invaden la concavidad del patio, dilatándose los mismos hacia el exterior, y enlazando este patio con el paisaje en toda su magnitud -cultural, social y climatológico-.

$Y$ de esta forma, rememorar los mejores valores de aquel paisaje imaginario, que a su vez es real, para paliar la presentación que "de la forma más cruelmente genial y burlesca" realiza de su tierra Cervantes, quien, según Fisac: "posiblemente rebuscando en su memoria no encontró don Miguel paisaje y arquitectura -de los muchos que había conocido- que fueran para él más anodinos, más antipoéticos, memos proclives a la

244 Quatremere de Quincy, A. (1832). Dictionaire historique de I'Architecture. Paris. Citado en Fisac, M. (1985). Op. cit, 21 
idealización, que las resecas llanuras manchegas, los caminos polvorientos, las simplicísimas ventas y los fantasmales molinos de viento."245

El agua está presente en la relación del edificio con el paisaje. Es utilizada en estados distintos, y por tanto con distintas intenciones. La encontramos aquí en el momento de fluir, a través de la reinterpretación de un cántaro, cuya boca, encastrada en la arquitectura que no se agota nunca, y que produce un sonido que sabe a pueblo manchego en su caer sobre la cerámica del apoyo del mismo cántaro. Como hemos mencionado, Fisac llamará a esta fuente "fuente con ruido a dos voces", ya que al caer el agua sobre el pilón da una nota aguda y luego, al verterse ese agua en el suelo, da una nota grave de contrapunto ${ }^{246}$.

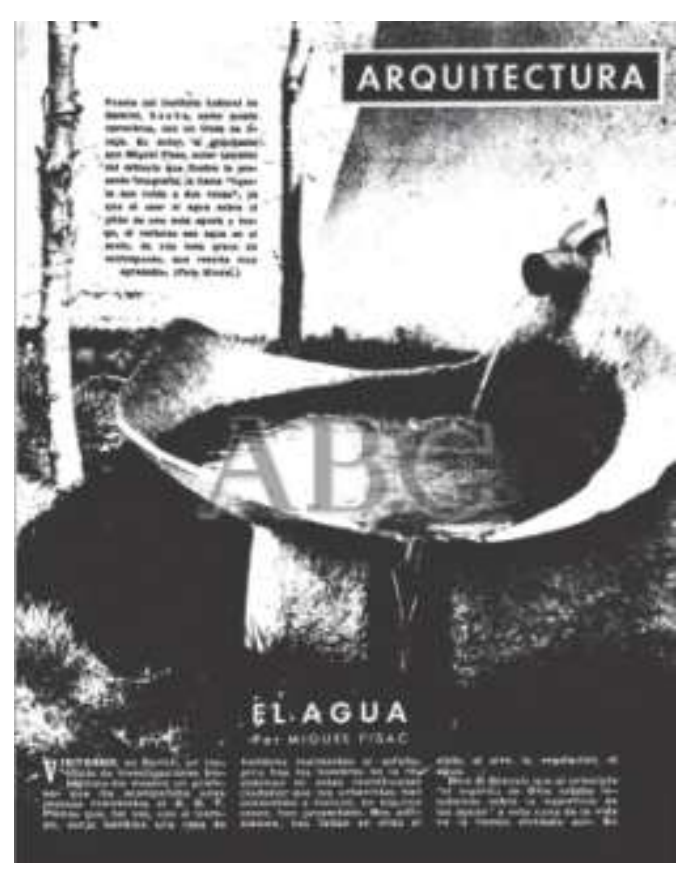

El Agua. Blanco y Negro 10 de agosto de 1957 Aparece la fuente del Instituto laboral de Daimiel

A diferencia del uso que del agua se hace en el Centro de formación del Profesorado, que posteriormente estudiaremos- donde el agua también juega un papel importante en la exterioridad del edificio y su relación con el paisaje, encontrándola domada y geometrizada; el estanque de Daimiel nos sugiere un elemento natural, conformado por la naturaleza.

245 Fisac, M. (1985). Op. cit, 23

246 Fisac, M. (1957). El Agua. Blanco y Negro 10 de agosto de 1957. 
No sólo su morfología, sino la vegetación que lo circunda, el límite aparentemente desdibujado, la fusión entre lo salvaje -el elemento vegetal- y lo domesticado -el murete de piedra desnuda que contiene al árbol-, etc., lo que nos acerca a un elemento que se mueve entre el orden de la arquitectura y los humedales próximos, entre lo estructurado y lo agreste.

Su borde indefinido, el verdor rebosante, o el surgir de las rocas desde el fondo del mismo crean un enlace emocional con el paisaje daimieleño, con los citados humedales, a lo que contribuye la disposición global del jardín interior, como si existieran desde siempre una serie de islas en una tabla fluvial. Islas que, además, crean un itinerario entre ellas que permite una gran riqueza de visiones.

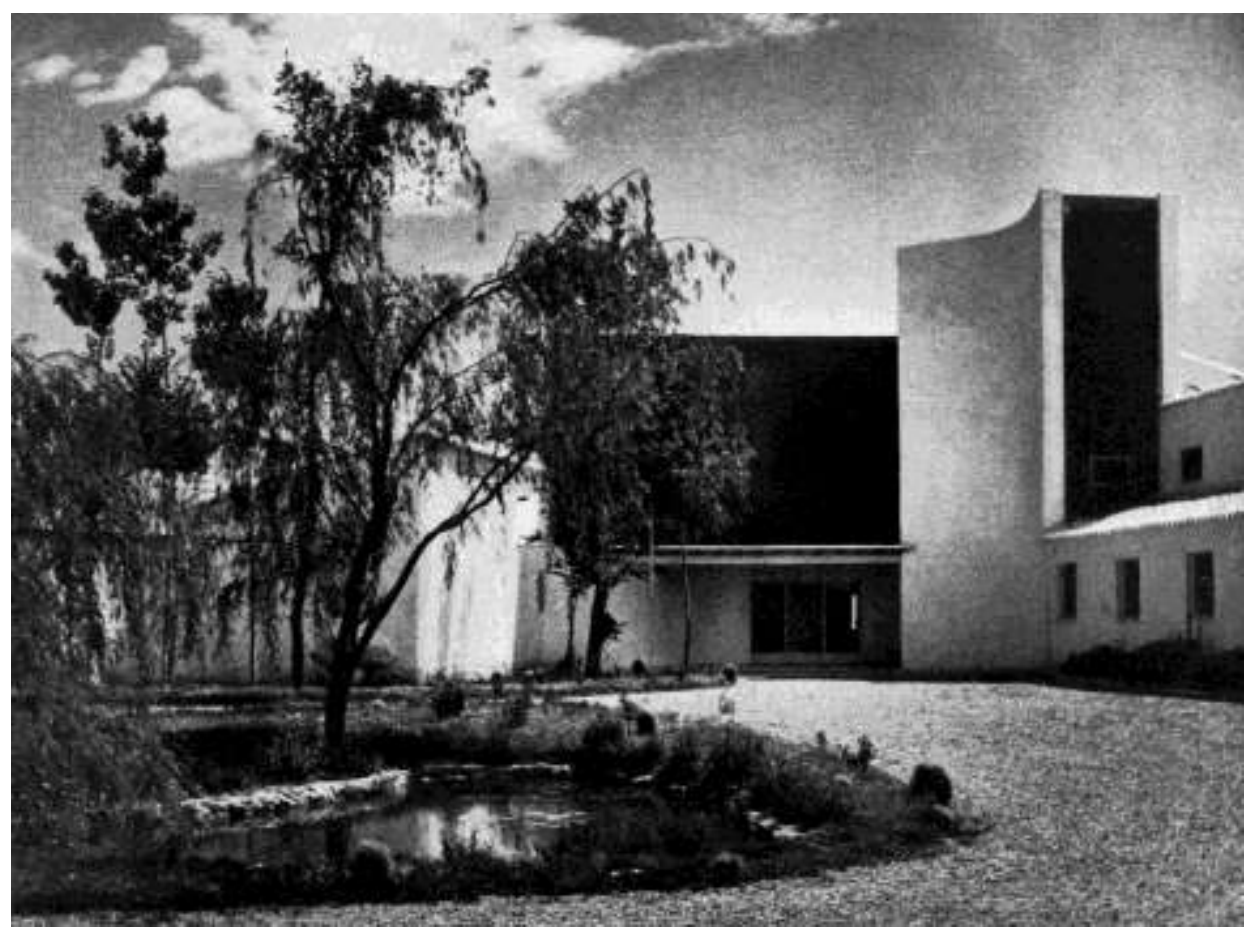

Estanque del jardín del Instituto Laboral de Daimiel. Fundación Miguel Fisac

Y siempre, el reflejo, que hace participar del jardín al cielo manchego, eterno, y a una re-elaboración culta y contemporánea de la arquitectura popular, como si el paisaje entero se encerrara en ese jardín para hacerse universal.

También el perfil de la arquitectura es resonante del lugar, sublimado en el cuerpo del salón de actos, creando una interesante tensión vertical que se contrapone a la horizontalidad del conjunto. 
La vegetación prevista es fundamental para realizar esa conexión, no sólo física sino también climática, psicológica y emocional -en palabras de Fisac-, con el paisaje de Daimiel. Plátanos, olmos, sauces y parras que abundan en la zona, y una serie de arbustos que crecen sobre la arquitectura y que la aferra a la tierra a la que pertenece. Destaca el uso de la higuera, que posteriormente repetirá en el Pabellón de la Feria del Campo de 1953. Un árbol que da intensidad a un pequeño patio recogido, de descanso, que remata el largo pórtico de sombra previsto, como expresión poética del paisaje manchego y del saber popular -curiosamente Alvar Aalto también repara en esta especie, en su viaje a España de 1951.-

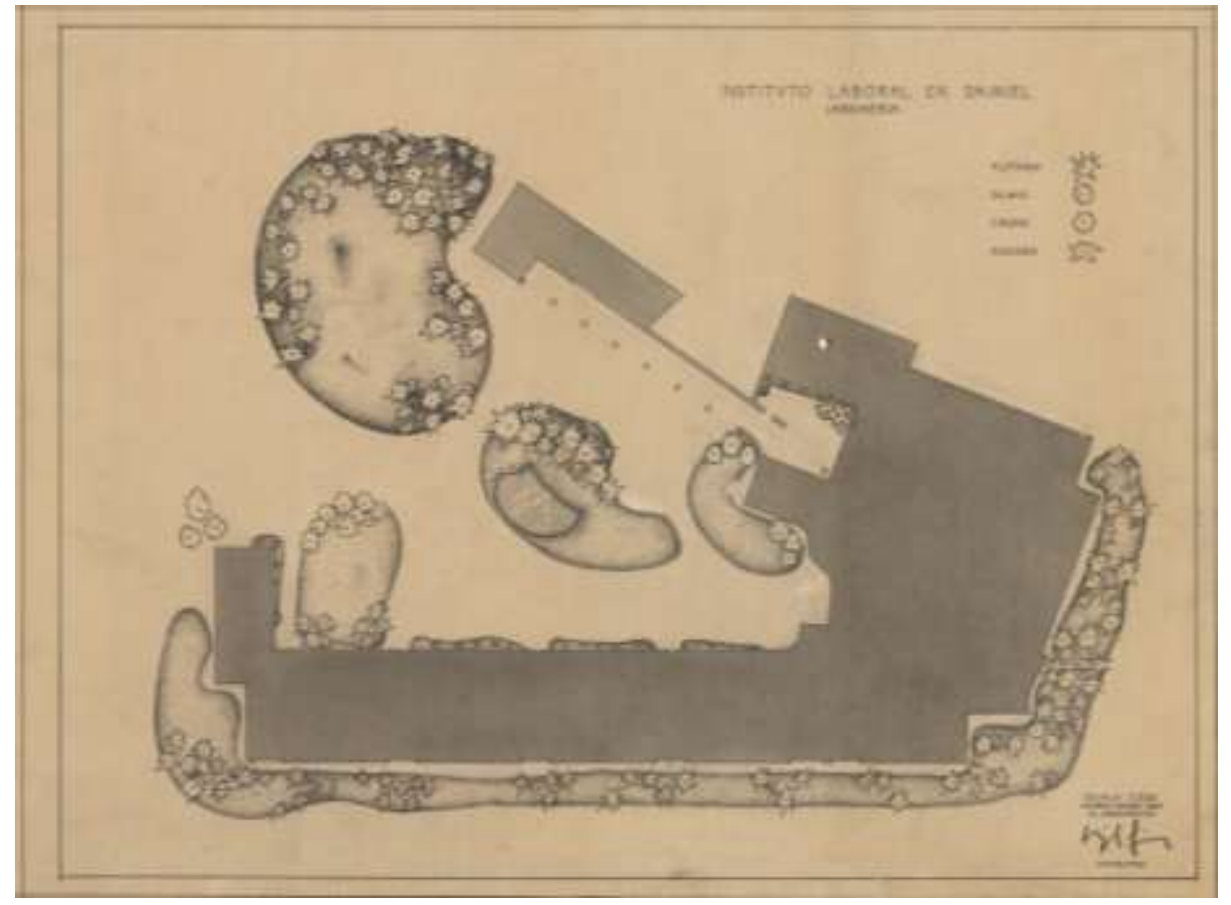

Instituto Laboral de Daimiel. Plano de jardinería del Proyecto original, fechado en 1952, en el que aparece la higuera en el patio existente al Noroeste (el plano está orientado Norte-Sur).

Por tanto, podemos concluir que el Instituto Laboral de Daimiel contiene la memoria del paisaje en toda su profundidad, ensamblando tradición y modernidad en una arquitectura que tiene una voluntad propia y singular.

Un quinto elemento -la memoria- que podríamos añadir a su conocido itinerario proyectual, citado como Programa, Técnica, Estética, Paisaje. Porque de acuerdo con las reflexiones del maestro portugués (Siza, 1998, 33) "El arquitecto trabaja 
manipulando la memoria, de eso no hay duda alguna, conscientemente a veces, y casi siempre subconscientemente."247

$Y$ es que al igual que ocurre en la Naturaleza, en el árbol de la emoción que conforma la arquitectura de Fisac, son más importantes las raíces que las ramas. Y es precisamente esto lo que hace que su arquitectura se conecte con la atemporalidad, más allá de los tiempos o de las modas.
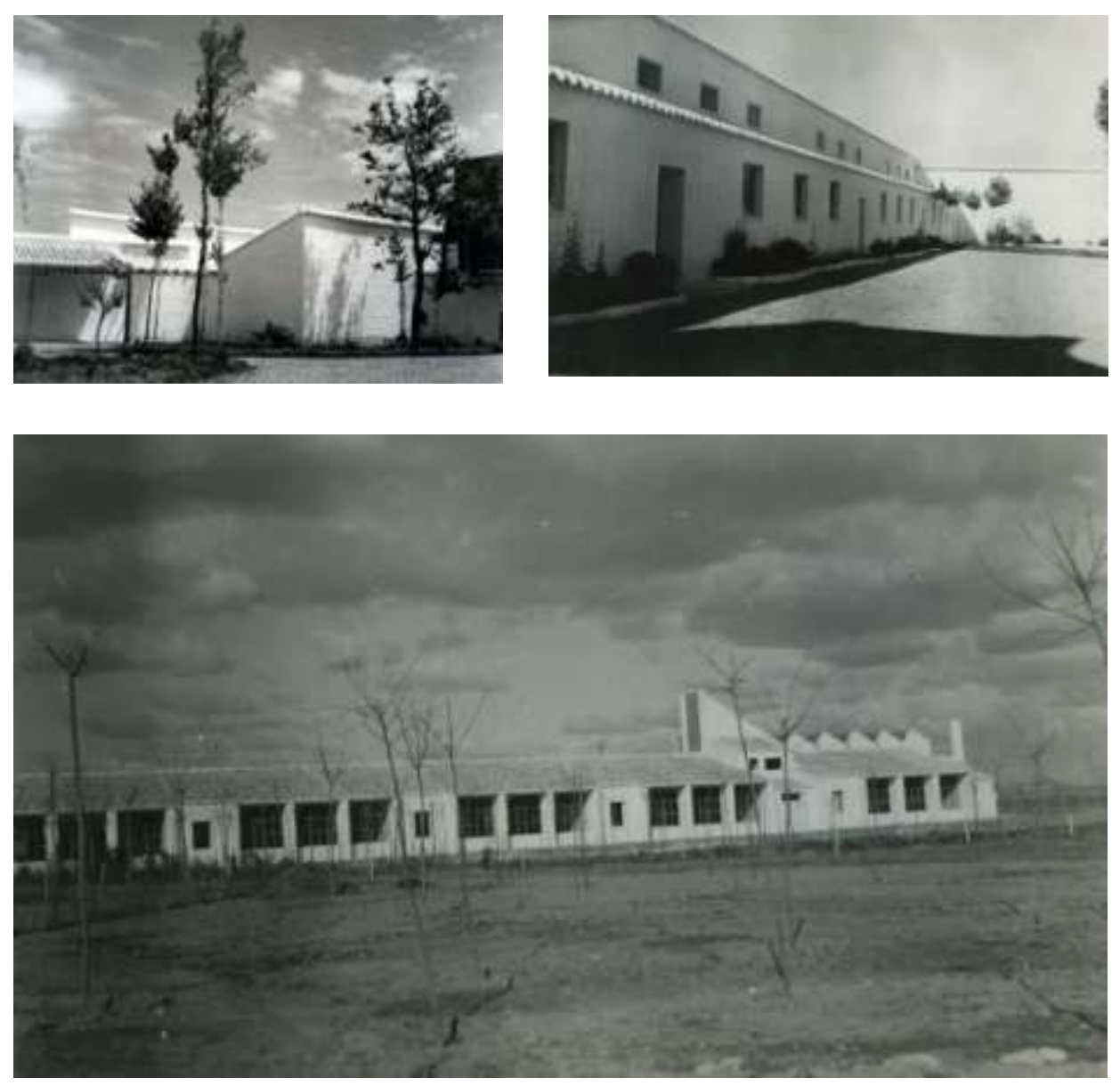

Juego de volúmenes blancos en el paisaje. Instituto Laboral de Daimiel. Fundación Miguel Fisac

247 Siza, A. (1998). Imaginar la evidencia. Primera edición española, 2003. Madrid: Abada editores, S.L. 


\section{Nota final}

La construcción de la casa familiar de la calle Las Cruces en Almagro (1978), podría suponer una síntesis de gran parte de las ideas expuestas anteriormente. La superposición de sus desarrollos experimentales de hormigón vertido en encofrados flexibles sobre la fachada de un antiguo molino de aceite expresa la firme intención más allá de lo gestual- de vincular Arquitectura y Memoria.

Una obra autobiográfica en la que vuelven a hacerse presentes en esencia ciertos elementos de su poética: la higuera, la alberca, la tapia blanca, el umbral, la noria construye sobre un viejo molino-, el añil, el vacío... pero sobre todo hay un elemento que destaca como culmen de un viaje de reencuentros: el artesonado de madera recuperado de su antigua casa, del "el agujero" en el que pasó oculto un año al comienzo de la Guerra Civil, que se apoya sobre los machones de hormigón. Como si llegara aquí al final de una peregrinación a través del tiempo en la que se hacen patentes los versos de Eliot: "Sólo a través del tiempo, el tiempo es conquistado": pasado y futuro conquistados y reconciliados. 


\section{2_ El Objeto en el paisaje. El Tránsito de Arcas Reales a Alcobendas (1951-1955)}

Los edificios del Colegio Apostólico de Arcas Reales en Valladolid y el Teologado de San Pedro Mártir en Alcobendas, ambos realizados para la congregación de los PP. Dominicos, son dos objetos rotundos, mediante los cuales Fisac da respuesta a sendos paisajes con pocas referencias. En los pocos años que transcurren entre uno y otro proyecto la evolución de pensamiento en Fisac es de una importante magnitud, de forma que a través de ellos podemos estudiar el posicionamiento del arquitecto ante el paisaje y de qué forma se desplazan los ejes referenciales que le llevan a ello.

El encargo del proyecto de Arcas Reales (1952-1953) le llegó a Fisac en 1951 a través del Padre Sancho ${ }^{248}$, en 1951, un momento de despegue de su trayectoria. En ese año se encontraba inmerso en las obras de varios Institutos Laborales (Daimiel, Hellín, Almendralejo), así como en las del Instituto de Microbiología Ramón y Cajal de Madrid; el viaje realizado a Europa estaba aún resonante en su pensamiento y su clara vocación transformadora de la arquitectura del momento se estaba consolidando.

El programa consistía en aulas, dormitorios, laboratorios, comedores y una iglesia; así como un teatro en pabellón independiente, instalaciones deportivas, etc...

En este contexto, Fisac se encuentra con la oportunidad de intervenir en un paisaje sin referencias, totalmente plano, adusto, sin árboles. Una llanura infinita conocida por él desde siempre, ya contemplada en su infancia manchega.

Así, realiza el arquitecto dos operaciones: La primera es potenciar el carácter del lugar, de forma que lo más íntimo del paisaje resuene en su arquitectura para inventar un paisaje nuevo que engloba lo anterior y lo nuevo.

Extrae del lugar su vigor para conseguir con él un diálogo profundo e intenso, y despliega para ello una estrategia que con recurrencia utilizará a lo largo de su vida en

248 El Padre Sancho, Provincial de los PP. Dominicos de la Provincia del Santo Rosario, conoció a Miguel Fisac a través de S. Josemaría Escrivá de Balaguer, del que era amigo personal y formador de los primeros sacerdotes del Opus Dei. A partir de esta intervención realizará Fisac varios trabajos para la citada Provincia de esta Orden, como el Teologado de San Pedro Mártir en Alcobendas, o un proyecto de iglesia en Taiwán (1966). En 1951 se unificaron dos colegiaturas de esta provincia en este lugar vallisoletano conocido como "Arcas Reales", por encontrarse en la zona los registros de la traida de aguas a Valladolid desde las fuentes de Argales en tiempos de Felipe II (con intervención del arquitecto Juan de Herrera en el trazado de la conducción). 
otras intervenciones en parajes agrestes: construir el paisaje desde la identidad del lugar. Desde la comunión con la tierra, y la confianza en la fuerza de lo ancestral, así como desde la idiosincrasia social y psicológica del lugar.

En efecto, desde sus primeras obras buscó con ahínco el arquitecto esa unión íntima con la tierra, encontrando uno de sus fundamentos en la arquitectura popular, esa que está hecha por el pueblo y el tiempo. Una arquitectura que "no es de antes ni de ahora, sencillamente es" 249 , y cuya esencia, basada en su condición artesana y su decantación lenta y sosegada son los elementos "que le proporcionan esa realidad de permanencia, de inmutabilidad, de intemporalidad."250.

Fisac conocía bien la arquitectura popular de aquella Castilla, con sus muros de adobe del color de la propia tierra, como pertenecientes a ella -como los bombos manchegos vistos en su infancia-, y los blancos y enormes palomares cilíndricos que se depositan sobre esos parajes: un juego de contrastes, el mimetismo frente a la contundencia elemental.
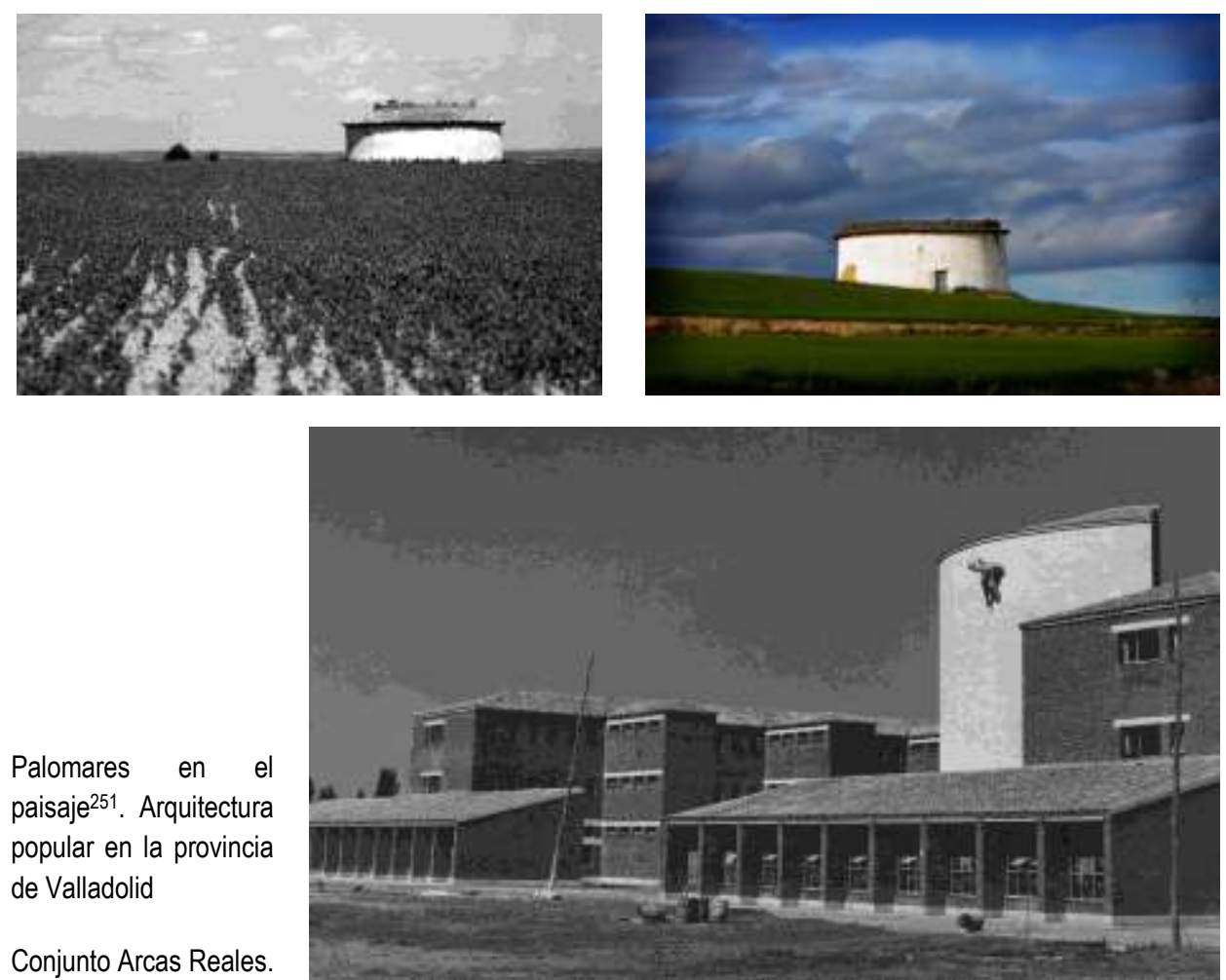

Miguel Fisac.

\footnotetext{
${ }^{249}$ Fisac, M. (1985). Arquitectura popular manchega, 11. Edición 2005. Ciudad Real. Colegio de Arquitectos 250 Idem

251 Fuente de las imágenes, tectonicablog.com
} 
$Y$ de esta forma, propone un conjunto que se contagia de la austeridad del entorno para acompañar la educación y canalizar las vocaciones de este "semillero" castellano. Los campos de juego y deporte filtran la presencia de los pabellones y diluyen sus volúmenes en la continuidad con la naturaleza, rodeándolos asimismo de árboles de gran porte en la orientación adecuada cuyas ramas tamizan la molestia del sol directo para los juegos.

La segunda operación es crear un jardín en el corazón del conjunto. Un lugar para contemplar la otra naturaleza, la creada por el hombre, una suerte de jardín claustral para los Padres residentes en el Colegio -espacios de paseo, de reflexión, de esparcimiento, de oración-, en claro contraste con la infinitud del páramo en el que se ubica. Un vergel de clara referencia hispanoárabe, tanto en la conceptualización del mismo, como en su formalización, con una serie de fuentes y albercas que evocan algunas de las existentes en los palacios nazaries de Granada.

El conjunto quiere, por tanto, pertenecer al lugar y a ello ayuda el predominio de lo estereotómico, como si los muros surgieran de la propia tierra. Pero a la vez, quiere ayudar al paisaje tradicional a transformarse en un nuevo paisaje, renovado y atemporal.

Un nuevo paisaje que potenciará la severidad y austeridad del lugar, a lo cual ayuda la lógica aplastante del conjunto.

En efecto, existen una serie de elementos concretos que denotan la sensibilidad y veracidad constructivas en la búsqueda de una sobria elegancia, con el objetivo de dar una respuesta global coherente al paisaje.

La propia disposición de los diferentes volúmenes ordenados sobre el terreno; sus diferencias de altura, rematando la composición los de una planta, con cubierta a un sólo agua, y grandes huecos, -ensayado en el instituto laboral de Daimiel-; sus patios 0 espacios intermedios; sus espacios de sombra compuestos por marquesinas ondulantes....Todo ello forma parte de este nuevo paisaje. Un conjunto de elementos que no quiere distorsionar la infinitud del paraje.

También contribuyen a ello la estructura de muros de carga de aparejo inglés, alternando por hiladas sogas y tizones para ejecutar muros de un pie o mayores -de gran altura en el caso de la iglesia-; así como los cargaderos de hormigón vistos unificando o separando huecos, poniéndolos en coherencia con la escala del conjunto.

En definitiva, la sencillez constructiva empleada conecta con la adustez del lugar, también la pone en paralelo con la modestia de la orden dominica-, y la totalidad del conjunto construye un nuevo paisaje moderno, pero coherente con la identidad del lugar. 
Y como no, la vegetación es utilizada de forma intencionadamente distinta en cada parte del perímetro del conjunto. El plano de emplazamiento nos sugiere plantaciones perfectamente ordenadas que rodean partes concretas del edificio, tratando de crear un colchón verde hacia la carretera (hoy calle Arca Real), y dejando libre la orientación de la iglesia. La realidad es que parte de la plantación no se ejecutó, si bien se puede intuir esa barrera verde hacia poniente, no pudiéndose decir lo mismo de la orientación norte.

De todo ello, destacaremos un elemento que conscientemente desea destacar del resto, y es el elemento iglesia. No sólo por la volumetría, que va decreciendo para hilvanar el conjunto, sino por el acento puesto por el arquitecto en el muro de caliza de Campaspero. Un acento realizado desde la sencillez, desde la humildad: como un manto blanco puro, enfatizado por la escultura de Oteiza. Un muro que contiene toda una declaración de intenciones, una aproximación hacia la esencia de las cosas, un "sacudirse el polvo", un canto a la libertad.

Los tanteos iniciales del proyecto (1951) contemplaban una serie de piezas y pabellones que se posan con cierta libertad dentro de un jardín más amplio, y cosidos entre ellos por una serie de umbrales. El programa final previsto, sin embargo, con elementos programáticos en idéntico número para las dos franjas de edad de los alumnos, llevó a Fisac a realizar un conjunto simétrico, que le conectaba con un tipo de arquitectura de la que pretendía huir. Para paliar esto, creó una serie de elementos que tensionan el espacio, como el acceso desde la carretera de Olmedo, la pieza de servicios y cocina, el espacio de la biblioteca de los Padres, o el Campanario de la iglesia. 


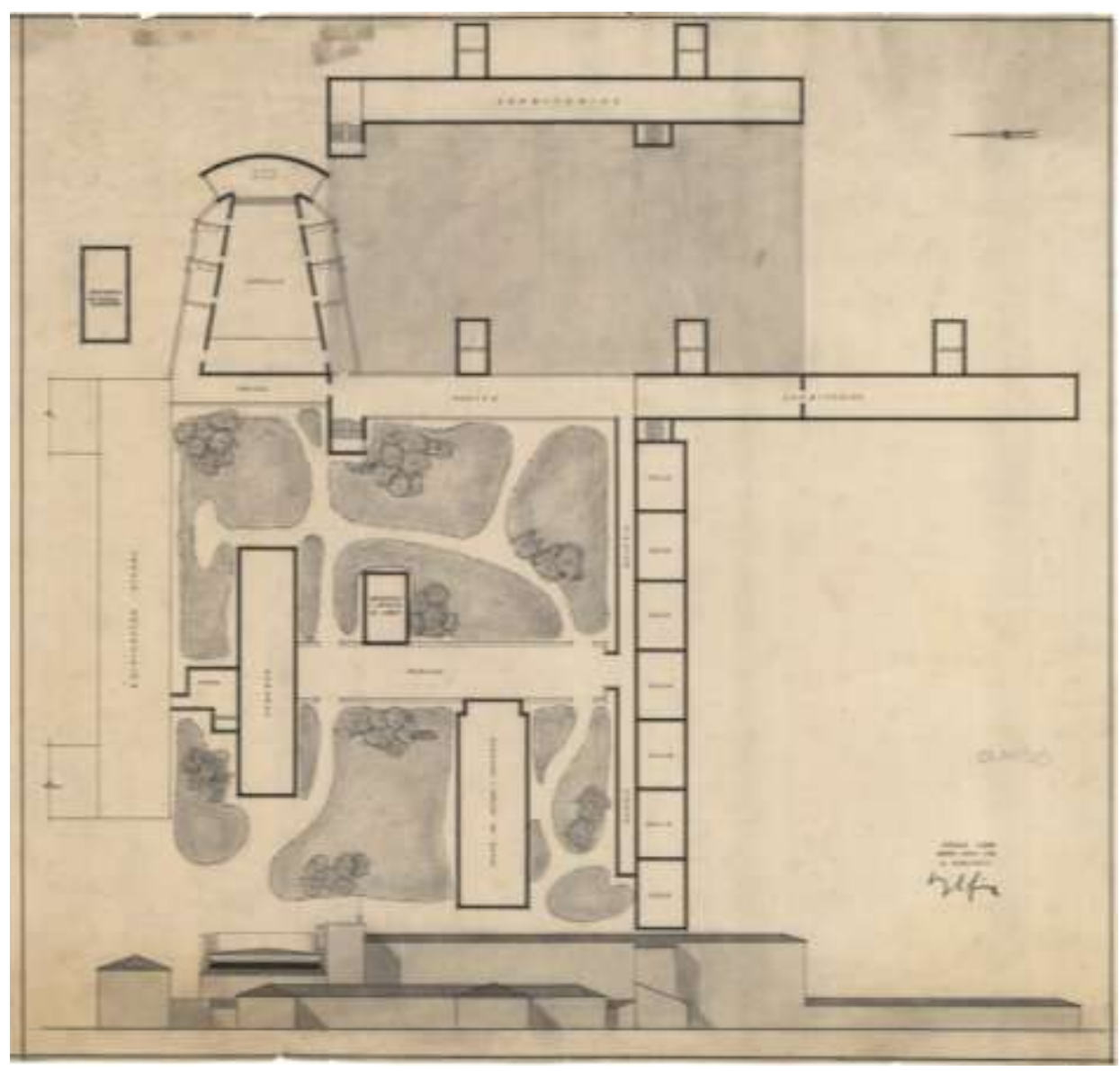

Propuesta previa para Arcas Reales (plano de 1951). Fundación Miguel Fisac. En él se observa una serie de pabellones que se posan en un jardín visualmente unitario, con una serie de umbrales que hilvanan los citados pabellones. El germen de unas ideas que posteriormente tendrá oportunidad de desarrollar en el Teologado de Alcobendas.

El lugar para erigir el Teologado de los PP. Dominicos en Alcobendas (1955-1958), por su parte, unos extensos terrenos junto al kilómetro 7 de la carretera de Alcobendas -la actual carretera de Burgos- se seleccionaron de entre varias opciones por la existencia de un pozo de agua. Un lugar totalmente agreste pero con alguna referencia más que la llanura vallisoletana, que presentaba una topografía con desniveles dignos de mención cercanos a los nueve metros-, en cota decreciente hacia el arroyo de Valdebebas. 
En este caso los distintos pabellones (padres profesores, padres jóvenes, coristas, hermanos y hermanas, etc.), cosidos a través de umbrales y pórticos, van articulando una serie de espacios abiertos adaptados a los distintos niveles de la topografía espacios claustrales, jardines, patios- con ciertas conexiones entre sí -físicas, visuales 0 presentidas-, que configuran un paisaje secuencial.

Como contaba el propio arquitecto, "se trataba de una vaguada bastante pronunciada, casi un hoyo hasta el arroyo de Valdebebas. Se tomó como nivel 0 el de la carretera Madrid-Burgos, y al extenderse el conjunto de edificios hacia el interior, se iba pasando de los primeros pabellones: iglesia, portería, edificio de profesores, salón de actos) que estaban en el nivel 0, a un nivel dos metros más bajo, por medio de escalones colocados en los lugares más adecuados; refectorio, clases, cocinas y sus anejos, asi como el pabellón de religiosas y enfermería. Un tercer nivel correspondía al de estudiantes. Como el terreno natural estaba unos nueve metros más abajo, era más económico realizar una estructura de varios niveles y cubrir después su contorno para destinarlo a jardín y zonas deportivas que rellenar y pilotar."252.

Una arquitectura introspectiva, pero con vocación de caracterizar un paisaje sin referencias. Quizás por ello hace participar al entorno de su fluencia, mediante la apertura de ciertas piezas o la gradación de los volúmenes que permiten rezumar el paisaje, o a través de la avenencia con las piezas construidas dispersas o los caminos existentes en el lugar.

De igual modo, el conjunto invoca las reminiscencias de los elementos definitorios del mismo: el agua, el relieve topográfico, la direccionalidad, etc.

252 Fisac, M. (1994). Miguel Fisac. Medalla de Oro de la Arquitectura, 86. Arquitectos, 135. Madrid: Consejo Superior de los Colegios de Arquitectos de España 

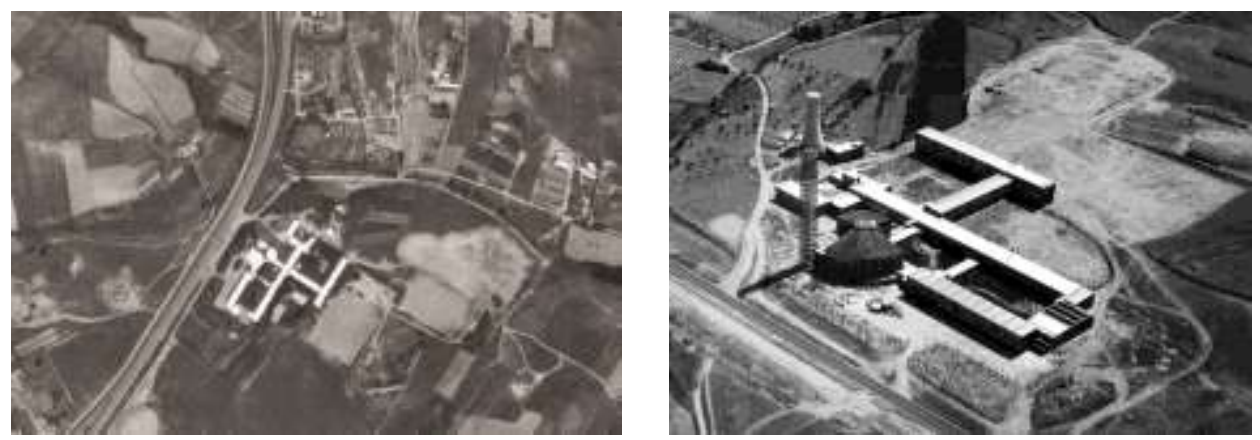

Sobre estas líneas, ortofoto de $1975^{253}$, en el que se observan todavía ciertos elementos de referencia del territorio encontrado por Fisac en 1955: la direccionalidad, los caminos, la dispersión de las piezas existentes y la ausencia de hitos.

A la derecha, imágenes aéreas tras la construcción del conjunto (1958). Fundación Miguel Fisac

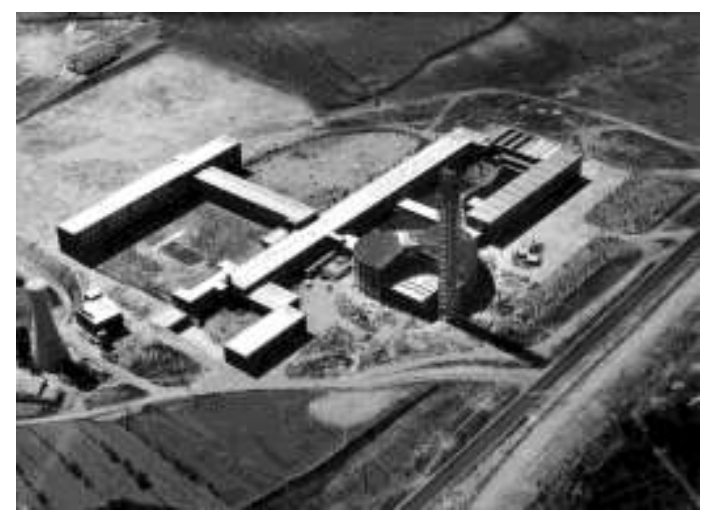

Asimismo, es destacable la creación de un hito en este lugar sin referencias reconocibles, y que aún hoy, sesenta años después, sigue teniendo la virtud de serlo: la torre-campanil. Con una operación de gran sencillez, Fisac dispone dieciséis soportes verticales cosidos por una rampa, rematando el cuerpo por una serie de elementos de acero girados entre los que se coloca una cruz de forma que parece flotar en el aire.

El jardín claustral se concibe como un lugar de meditación, de contemplación. Es el encuentro con Dios a través de una naturaleza manipulada, a través -por tanto- de una naturaleza trabajada por el hombre. Al igual que en el jardín de la casa japonesa, lo natural se domestica, aunque permanece un punto de reminiscencia de su procedencia salvaje. Un auténtico paisaje ancestral, que invoca cualidades anteriores al edificio, como si conectara con una naturaleza ajena al tiempo: las rocas, el agua que discurre por la ladera hasta el pequeño estanque, las sombras, la propia topografía, y como no, el ligero posar de los edificios sobre el terreno -incluso la escalera, como si no quisieran

253 Extraido del visor de ortofotos en línea de la Comunidad de Madrid http://www.madrid.org/cartografia_ambiental/html/visor.htm\# 
dañar algo anteriormente existente-, configuran un auténtico paisaje del pensamiento, el lugar idóneo para la trascendencia, la reunión o la convivencia.

El sentir de fusión y armonía creados entre naturaleza y arquitectura que aquí subyace, recuerda la historia que $L$. Kahn refirió al final de una de sus conferencias, procedente del poeta persa Rumí:

"Había una princesa que paseaba por el jardín en primavera y naturalmente hacía un día estupendo. Después de atravesar el jardín observando todas las cosas, llegó al umbral de la casa y allí se detuvo en atónita admiración; inmóvil en el umbral miraba adentro. Y su doncella se le acercó exclamando. «Señora, señora. Mirad afuera y verá qué maravilla ha creado Dios». Y la princesa respondió: «Si, si, pero mira adentro y verás a Dios.»"254.

Una armonía abrazada de tal modo que hace que incluso se tenga una visión más potente y límpida de la unidad que conforman aquí la arquitectura y la naturaleza, quintaesencia de la casa japonesa.

En el conjunto, de cuidado equilibrio volumétrico, existe también una búsqueda de la continuidad espacial, de la secuencialidad, en donde los diferentes patios y espacios abiertos quieren formar una única unidad, dejándose penetrar por la naturaleza circundante.

Esto se consigue en parte mediante la liberación de una parte de la planta baja del pabellón de los PP. jóvenes, utilizando unos pórticos de hormigón, estrategia que recuerda a la realizada por Gropius en el edificio de la Bauhaus de Dessau (1925), o las posteriores propuestas de Le Corbusier.

${ }^{254}$ Cita de L. Kahn a una conferencia a estudiantes de arquitectura de la ETH de Zurich. Cfr. NorbergSchulz, C. (1981). Louis I. Kahn, idea e imagen, 105. Madrid: Xarait 

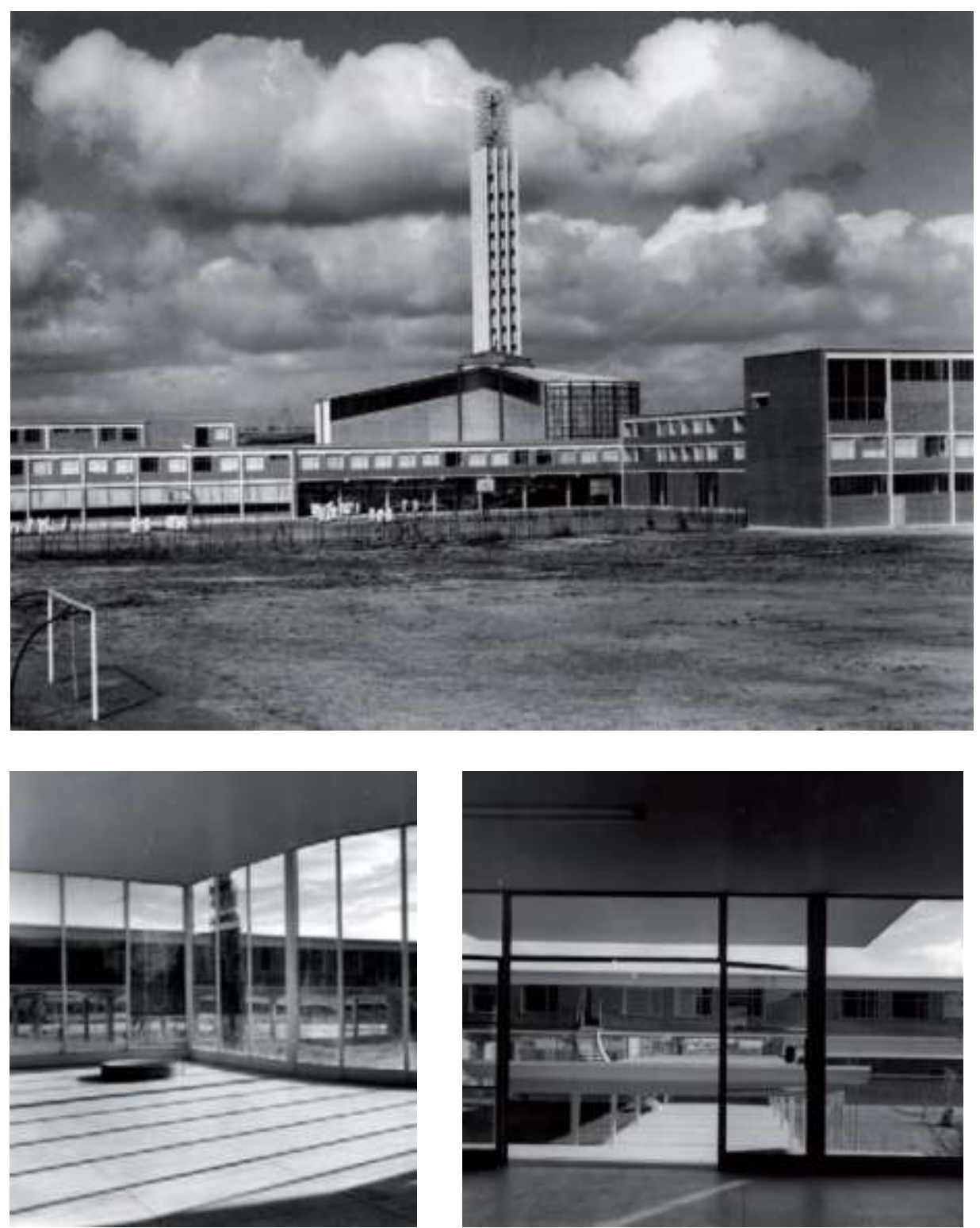

Desde el campo de deportes se puede apreciar la liberación de la planta baja del pabellón de los PP. jóvenes y la intención de un espacio exterior continuo y fluido, que se deja penetrar por la naturaleza circundante. En las imágenes inferiores se aprecia la secuencialidad de los espacios. Fotografías Fundación Miguel Fisac.

La vegetación de gran porte, ayuda de forma decisiva a la concepción unitaria de los distintos espacios abiertos: coníferas, sauces, y un gran ciprés que indica la zona junto a la que surge el agua para resbalar hasta el estanque del claustro; o plátanos, tilos y chopos en el patio de los estudiantes. 
En el citado claustro, que absorbe un desnivel de más de dos metros mediante un talud que lo atraviesa en diagonal, está delimitado por dos lados acristalados y dos abiertos. El primero de los lados abiertos es el que se encuentra bajo las celdas de los Padres Jóvenes, y el segundo es un ligerísimo umbral, que lo conecta con un jardín ataluzado, y lo hace partícipe de una misma unidad. Se trata de una finísima losa sobre unos finos pilares que recuerda la liviandad de la arquitectura doméstica japonesas, tanto en lo constructivo, como en la escala humana, permitiendo situaciones de visión por encima de ella. Todo ello contribuye de forma decisiva a la permeabilidad referida anteriormente.

Además del espacio claustral y del jardín, existen otra serie de espacios abiertos con conexiones entre ellos, y de ellos con el entorno. El espacio de acceso, que según lo previsto por Fisac -y podemos observar en el plano de jardinería- debía ser mucho más vegetal, actúa como elemento amortiguador con la carretera de Alcobendas. Por su parte, los campos de juegos se abren al entorno y a la propia parcela, como hemos visto; al igual que el patio de los estudiantes (coristas).

Por su parte, la torre de la iglesia representa un hito en el lugar. Su verticalidad es el contrapunto de la captura del horizonte, y su permeabilidad y ligereza representa una forma distinta de dialogar con él. 


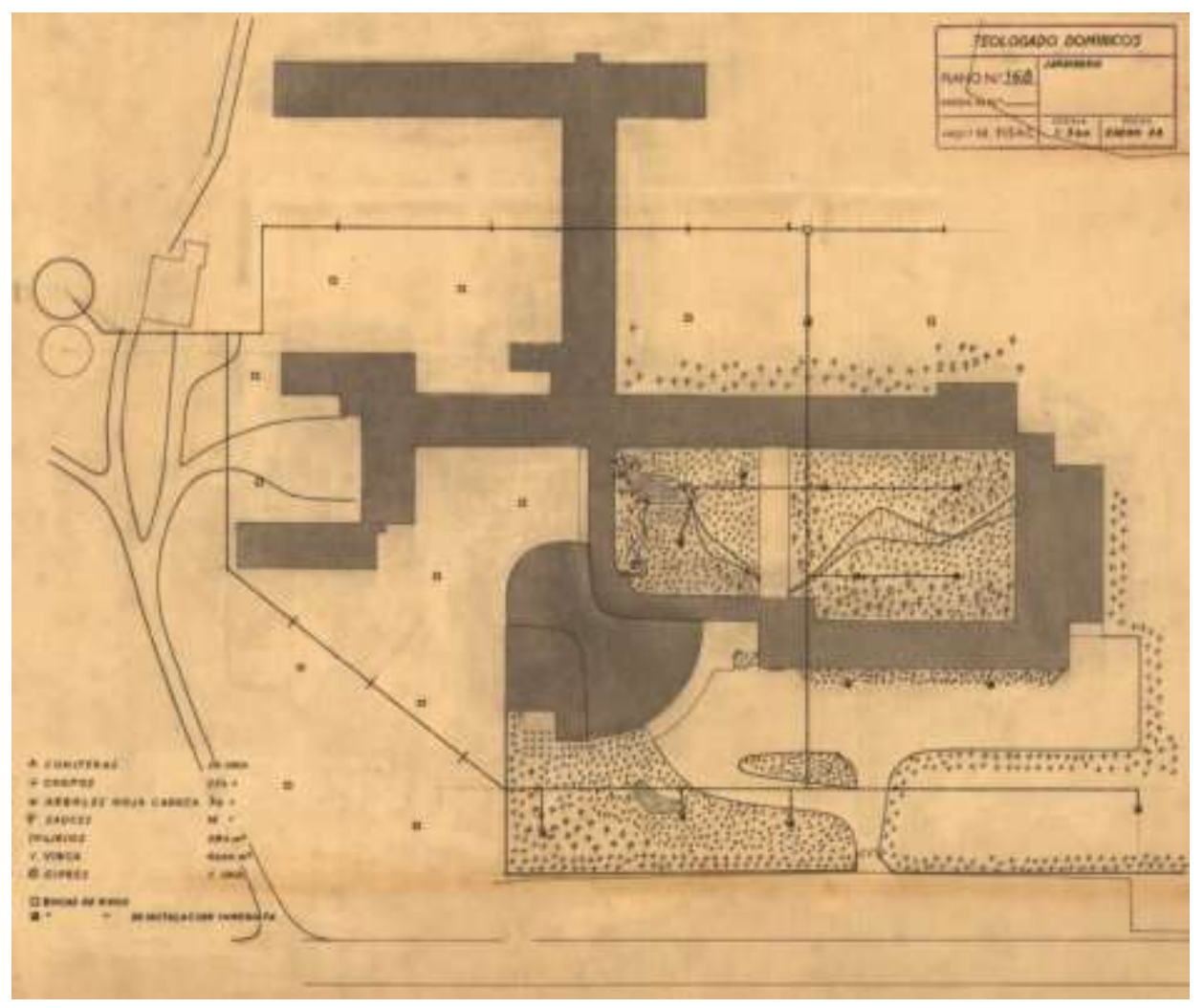

Plano de Jardinería (168). Proyecto para el Teologado de los PP. Dominicos en Alcobendas. Fundación Miguel Fisac

Podemos concluir, pues, que el tránsito entre estos dos elementos es paradigmático en la evolución de la consideración del paisaje para Fisac. Entre sendos conjuntos, a su vez, se sitúa el Centro de Formación del Profesorado, que a continuación estudiaremos. También entre uno y otro se sucede el Viaje alrededor del Mundo y una serie de reseñables episodios personales.

En este proceso se puede observar con claridad como en las "idas y regresos" oteizianas de la memoria al paisaje, se van sustituyendo ciertas referencias por las lecciones aprendidas en sus viajes, a través de los maestros de la modernidad estudiados y cuyos edificios son visitados.

El aspecto quizás más importante es el trasvase de la arquitectura de los volúmenes a la arquitectura del espacio; de la arquitectura corpórea, con delimitaciones algo rígidas, ligada a la tierra y de carácter estereotómico; a la arquitectura de la fluencia, en la que lo tectónico se hace presente. Desde esta óptica, comienza a ser factible la máxima fisacquiana de atrapar el aire como delimitación de la arquitectura, ya sea interior 0 
exterior. Estas ideas desarrolladas en Alcobendas enriquecen la mirada de Fisac sobre la construcción del paisaje, que comenzará a introducir nuevos elementos en su relación con el lugar y con la propia arquitectura.

En Alcobendas se supera la axialidad, la cuasi-simetría de Valladolid (aún justificada por la dualidad programática), y una cierta rigidez.

También existe un emergente interés por la continuidad espacial, por la fluidez del espacio exterior y por su secuencialidad, tomada de la casa tradicional japonesa. Esta es una de las claves que se superan desde el diseño del Centro de Formación del Profesorado, ya que en el proyecto de Arcas Reales los patios y espacios libres tenían límites más definidos y eran unitarios en sí mismos, sin vocación de fluencia.

En Alcobendas se vive desde más dentro de la naturaleza, existe una fusión más intensa con el medio; el conjunto bebe de la tradición japonesa en el sentido de que, en palabras de Fisac, "la arquitectura está para suplir a la naturaleza cuando no hay más remedio". En Valladolid, por otra parte, nos encontramos con un conjunto más cercano a la tradición hispanoárabe: desde el eje en el que se ubica la iglesia -el eje de Alá, el eje de Dios- hasta la delimitación espacial, pasando por la formalización de determinados elementos -la forma de tratar el agua, las texturas, etc.- nos confirman esto.

El estadio intermedio entre uno y otro conjunto, podría asimilarse a las operaciones realizadas en el proyecto del estudiado edificio de la Ciudad Universitaria, superando 0 redefiniendo las referencias de la tradición para alcanzar la innovación.

En éste, si bien las referencias a La Alhambra son claras, incluso en la geometrización de los estanques u otros elementos de los patios, comienza a existir un cierto interés por acercarse a la concatenación de espacios exteriores entre sí, y de ellos con la naturaleza circundante.

En el viaje evolutivo, es destacable el mantenimiento de ciertas piezas, como los pórticos, los umbrales de hormigón de formas sinuosas sobre finos pilares, etc. como si se hubiera establecido un cierto léxico que no se quiere perder, aunque la consideración del espacio sea diferente..

La apertura en "U" hacia el entorno circundante, a la penetración en estos espacios abiertos de la naturaleza circundante es algo común que se observan en sendos proyectos dominicos. Sin embargo, las longitudes diferenciales de los pabellones de Alcobendas acercan más este conjunto al diálogo con el entorno natural.

La jerarquización existe de forma relevante en ambos conjuntos. No obstante, Alcobendas supera el orden axial y cartesiano de Valladolid, en el que la iglesia es el colofón del mismo. En el conjunto madrileño, la iglesia actúa como un elemento 
polarizador, que es respondido en composición por un vacio -que por tanto cobra protagonismo-, el espacio claustral. La potencia de esta dualidad iglesia-claustro, -llenovacio-, en esencia aprendida en sus estudios y viajes orientales rebasa la composición especular del conjunto pucelano.

El elemento de la torre también es destacable desde el punto de vista evolutivo. Si en Valladolid el campanario se encuentra sobre el cuerpo de la iglesia, aquí aparece exento, libre, ligero. Como parte de un conjunto pero con su propia autonomía, reivindicando la suma a través del diálogo de las diferentes piezas, más que la compacidad de los volúmenes. Un elemento que se convertirá en una pieza recurrente, como reafirmación de elemento de invención en el paisaje. Así, podemos contemplar ejemplos en las iglesias de la Coronación en Vitoria o Santa Ana en Madrid, en los colegios de la Asunción en Madrid o Santa María del Mar en Coruña, etc.

El germen de esas ideas ya estaban en otros proyectos, así como en las propuestas previas de Arcas Reales. En el plano de 1951 se puede contrastar la intención de disponer una serie de pabellones en un jardín visualmente unitario, pero fragmentado por una serie de umbrales que hilvanan los citados pabellones.

Asimismo, aparece en Alcobendas la idea de continuidad de los espacios libres con el propio territorio, dejándose penetrar por la naturaleza circundante. 


\section{3_ El Hombre en el paisaje. El Centro de Formación del Profesorado de la Ciudad Universitaria. Madrid (1952-1957)}

"Era un edificio para profesores de instituto de enseñanza media y profesional que venían aquí quince días para renovar sus conocimientos; había clases teóricas, clases prácticas, y todo estaba muy estudiado."255

La simple descripción de estas arquitecturas por parte de Fisac nos dirige al concepto de escuela, y a su propia esencia.

De todas las definiciones de escuela que podemos conocer, la de Louis I. Kahn, (19011974), es especialmente sugerente (Kahn, 1975) "la escuela me sugiere una serie de espacios en los que se puede enseñar y aprender adecuadamente. La escuela se originó en el momento en que un hombre que no sabía que era maestro se sentó bajo un árbol a discutir sus conocimientos con otros hombres que ignoraban su condición de alumnos. Los alumnos aprendieron y desearon parecerse a su maestro. También querian instruir a sus hijos. A tal efecto se creó un espacio adecuado y surgió la escuela. Este hecho era inevitable, ya que era la consecuencia de las aspiraciones humanas.".

Esta definición nos aporta una característica importante que la diferencia de otras: el aprendizaje es una transferencia entre personas, para lo cual es necesario una serie de espacios adecuados; bien interiores -aulas, talleres, laboratorios, y otros espacios afines-, bien exteriores -intercambio y relación-. Sobre este segundo tipo nos centraremos especialmente.

Estos lugares exteriores, verdaderas aulas abiertas al cielo y a la naturaleza, son elementos esenciales en este proyecto por su importancia en dos vertientes: en la de relación con la naturaleza y en la de foro de intercambio y relación entre iguales, con interesantes conexiones con la Grecia Antigua ${ }^{256}$.

En este punto debemos aclarar una idea. La transferencia de conocimientos que estamos considerando en este conjunto de Fisac, no se concibe únicamente con la configuración de un maestro impartiendo clases a un grupo de alumnos. Se trata de una

255 Fisac, M. (2003). Centro de Formación del Profesorado. Madrid 1954-1957. AV Monografías, 101, 40-43. ${ }^{256}$ La escuela peripatética, que seguía las enseñanzas de Aristóteles -sobre el año 335 a.C.-, recibía ese nombre (cuya traducción del griego significa itinerante), por impartir el filósofo sus enseñanzas a los alumnos mientras paseaba por el jardín del Liceo, bajo los espacios cubiertos porticados y los enramados. 
visión más amplia, en la que la relación y el intercambio entre los propios alumnos en estos espacios, (alumnos que en este Centro de Formación de la Ciudad Universitaria son paradójicamente profesores), también es enseñanza y aprendizaje.

Son muchos los arquitectos que a lo largo del siglo XX han reflexionado sobre ideas cercanas a ésta, desde los más influyentes para Fisac, como Gunnar Asplund o Richard Neutra, hasta otros no menos importantes como el citado Kahn, pasando por Giuseppe Terragni, Aldo Van Eyck, Eugène Beaudouin y Marcel Lods, u otros, todos ellos con respuestas interesantísimas al intento de abrir los espacios de enseñanza al exteriori257 así como dar una certera respuesta al paisaje, cuya simple descripción nos desviaría del objetivo de esta investigación. Fisac sin embargo, -aún por exigencias del programava más allá.

En España, la primera experiencia que podemos considerar en esta línea fue la apertura de las aulas al exterior que con certeza realizaron en el Instituto-Escuela, de los arquitectos Carlos Arniches y Martín Domínguez, y en concreto su Pabellón de Enseñanza Primaria, construido en 1933 en la Colina de los Chopos, convirtiéndose en este caso la continuidad espacial como protagonista, pero abriendo nuevos caminos al desarrollo arquitectónico de esta idea de uso certero de la exterioridad:

"...donde los niños de corta edad pueden dedicarse a juegos o plantación de flores, con la singularidad de la existencia de una gran puerta de vidrio de cinco metros de longitud que se abre casi en su totalidad, que hará que el huerto sea una prolongación de la clase y puedan darse éstas al aire libre. Entre cada dos clases van dispuestos unos grandes voladizos, con bancos corridos que proporcionarán descanso, sombra y resguardo contra el viento.

\section{( ...)}

la estrecha colaboración entre los arquitectos y los elementos directores del InstitutoEscuela; llevados estos elementos por un deseo de superación, hace que estos edificios sean verdaderos laboratorios de ensayo de los más modernos y originales métodos de pedagogía."258

\footnotetext{
${ }^{257}$ Arquitectos con un interés especial en el desarrollo de ciertos conceptos que se trabajan en la presente investigación: Louis I. Kahn, con el Instituto Salk en La Jolla (California, Estados Unidos, 1959-1965); Gunnar Asplund, con la escuela de Karlshman en Blekinge, (Suecia, 1912); Giuseppe Terragni, con la escuela infantil Sant'Elia en Como (Italia, 1936-1937); Aldo Van Eyck, con el Orfanato de Amsterdam (Holanda, 1960) o la Escuela al Aire Libre en Amsterdam, (Holanda, 1955); Richard Neutra, con la Escuela Corona (California, Estados Unidos, 1935) y Eugène Beaudouin junto a Marcel Lods, con la Escuela al aire libre (Suresnes Hauts-de-Seine, Francia, 1932-1935).

258 Instituto-Escuela. Pabellón de Enseñanza Primaria. Arquitectura, 1983, 25.
} 
En la estrategia de proyecto, para algunos arquitectos lo importante será la disolución de los límites entre el interior y el exterior en los espacios de aula, la apertura de las mismas al exterior de un jardín o a la naturaleza; y para otros procurar espacios, patios, 0 exterioridades en los que relacionarse -ligados al concepto tradicional de plaza-, 0 bien a través de los cuales construir un paisaje interior más o menos cerrado al paisaje exterior.

En el caso de Fisac, los espacios no construidos de éste y otros edificios docentes, merecen ser estudiados pormenorizadamente no sólo por su especial interés espacial, 0 por haber sido punta de lanza en España en este aspecto; sino por los caminos que nos marca y las ventanas que abre.

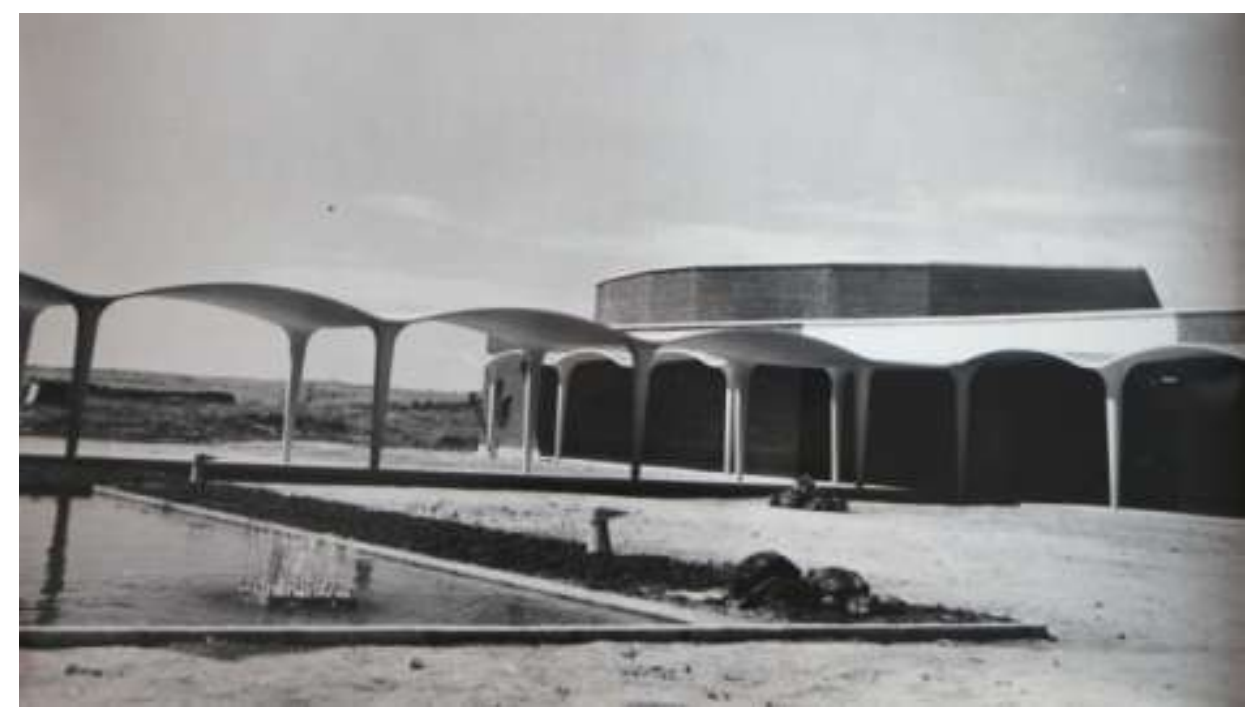

Centro de Formación del Profesorado de la Ciudad Universitaria (1952-1957)

El Centro de Formación del Profesorado, además de abrir en la obra de Fisac una etapa de intensa experimentación con el hormigón en la que no nos detendremos, abre una vía de diálogo íntimo con el paisaje a través de marcados contrastes entre presencias y ausencias, entre lo estereotómico y lo tectónico, entre naturaleza y arquitectura.

Asimismo, en este proyecto Fisac comienza a introducir en su arquitectura lo aprendido en sus viajes, reflexiones y estudios. Superadas quedan "intuiciones" organicistas ${ }^{259}$ para trasladarlas a la categoría de "certezas". Reconducidas quedan las referencias

259 Véase las experiencias en los Institutos Laborales de Daimiel, Almendralejo o Hellín, de los que se habla en apartados anteriores. 
vernáculas de cuyo halo estuvieron imbuidas sus obras durante una época, para convertirse ahora -sin prescindir de ellas-, en elementos de construcción del paisaje, universales.

En estos conceptos, si bien advirtiendo de la complejidad y la singularidad de cada proyecto, podemos ver que también trabaja Fisac en el Colegio Apostólico de los Padres Dominicos en Valladolid (1952-1953), o el Instituto de Enseñanza Media en Málaga (1953), cobrando un especial significado la búsqueda de una exterioridad en la que no sólo piensa el arquitecto en el esparcimiento, sino más bien en la convivencia de las personas, o la confrontación de aspiraciones, en un paisaje creado para ello.
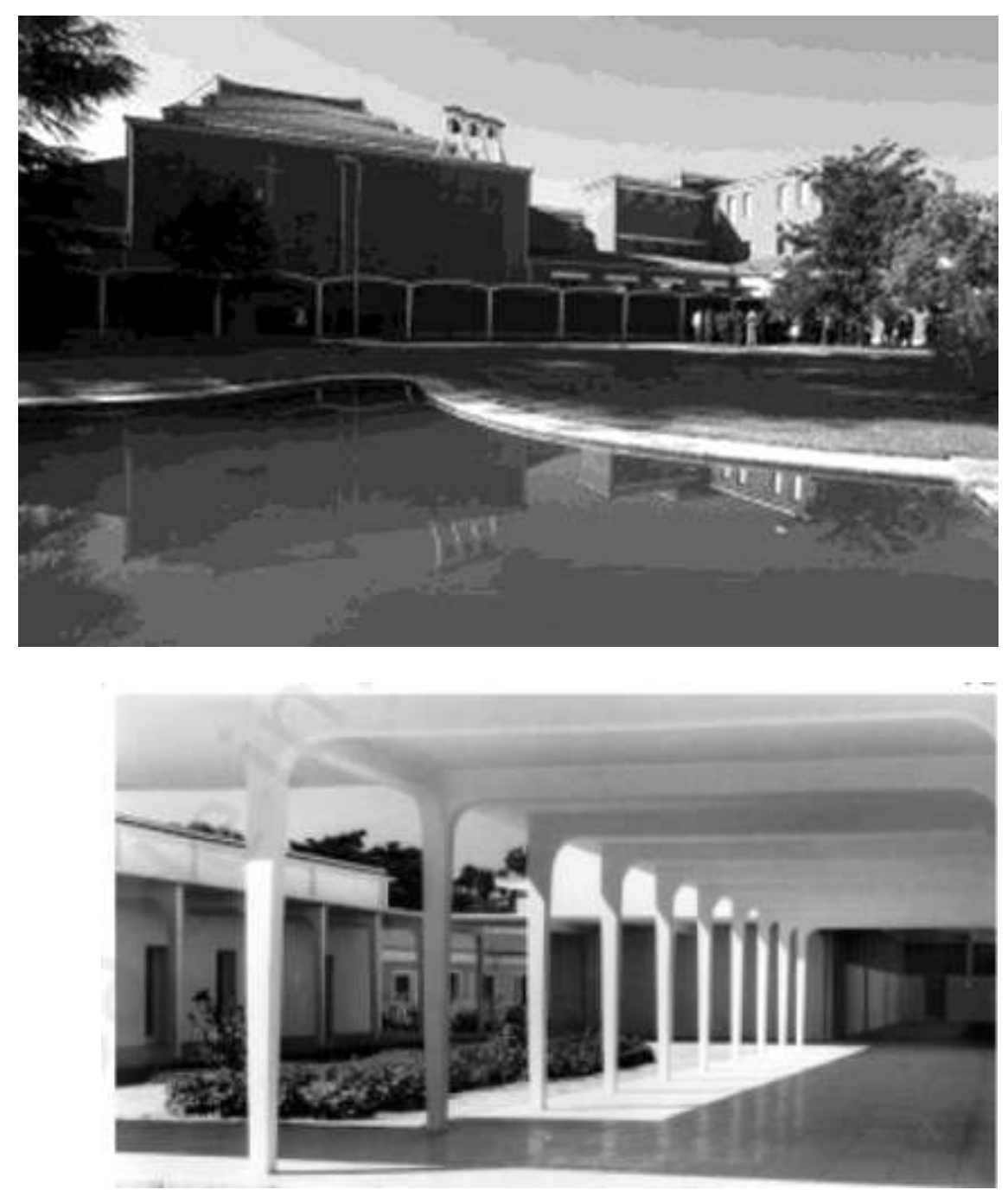

Colegio Apostólico de los PP. Dominicos de Valladolid (1952-1953) Instituto de Enseñanza Media de Málaga. 1953 
En el análisis de este conjunto podremos constatar los intereses de Fisac a la hora de enfrentarse a un proyecto, que van mucho más allá de los necesarios estudios sobre la luz en las aulas, la ventilación o el aislamiento; sobre la adecuación precisa del material, o las relaciones espaciales, cobrando una especial intensidad la búsqueda de un espacio auténticamente arquitectónico y humano en la exterioridad.

Ese "trozo de aire humanizado" al que con insistencia se refiere Fisac no es interior ni exterior, no es cubierto ni descubierto; se trata sencillamente de un espacio para que el hombre pueda ensanchar al máximo las capacidades para las que ha sido creado.

Empeñado en buscar la humanización de los espacios, en este conjunto aprovechará Fisac para engranar dos ideas y articularlas en el paisaje: la convivencia y el aprendizaje, ejes sobre los que se desarrollará el programa: espacios cuyo valor, como el de las artes, no reside en su mera utilidad.

Esa búsqueda de la humanización del aire en la exterioridad está llena de conexiones con sus experiencias vitales -anteriormente descritas-, con su Memoria y su Aprendizaje; ya procedan de vivencias de su infancia y su primer entorno, La Mancha, 0 bien hayan sido aprendidas posteriormente frutos de los intereses del mismo a través de viajes, del estudio de la historia y civilizaciones, o en el estudio de otros arquitectos que se convertirian en auténticas referencias para su obra.

En este caso destaca la consideración de La Alhambra, con esa dimensión -ya estudiada- del espacio que se humaniza mediante la limitación geométrica, independientemente de que disponga o no de techumbre, donde los patios, los espacios semiabiertos, las galerías, o los espacios de transición entre ellos, también son arquitectura. Espacios, como diría Fisac, que nos recuerdan que tenemos cinco sentidos, y que son el leitmotiv de la articulación del conjunto.

El resultado no puede ser más atractivo. Espacios que destilan atemporalidad y esencialidad. Espacios con conexiones ancestrales o primitivas, llenos de matices y referencias.

Pero centrémonos en el conjunto madrileño, construido en el borde de la madrileña Ciudad Universitaria.

Alí encontramos pocos ejemplos coetáneos similares, a pesar de los esfuerzos realizados por Modesto López Otero, director del proyecto para la citada Ciudad Universitaria, que se rodeó de arquitectos jóvenes y de espíritu más cercano a las corrientes modernas europeas. 
Los edificios de la Ciudad Universitaria que hacen girar el lenguaje hacia lo contemporáneo son posteriores, si bien se debe citar los concursos ganados por Moya, Aizpurúa y Aguinaga para sendos edificios en 1932, no construidos; así como la Facultad de Ciencias Físicas y Químicas de la Ciudad Universitaria de Madrid (19331936), obra de Miguel de los Santos, que mereció "los más encendidos elogios"260 por parte de Alvar Aalto en su visita a Madrid en 1951, con un lenguaje mucho más contemporáneo que la Facultad de Medicina (curiosamente también obra suya, de fecha posterior, 1949).

En la importante extensión de terreno baldío que era el solar donde había de ubicarse este Centro, las únicas referencias a las que podrá asirse Fisac son un gran eje al Este, la carretera de la Coruña, y la relación visual con la Sierra de Guadarrama y la Casa de Campo. Sin embargo, Fisac decide mirar hacia dentro, y ubicar una membrana permeable hacia la carretera, dibujando el borde de levante con una especial sensualidad, a través de unos umbrales de hormigón visto de formas sinuosas, como respuesta a la monotonía del tráfico.

Un conjunto destinado, no sólo a la ampliación de conocimientos de los profesores de enseñanza profesional de institutos laborales, sino también al contraste de sus experiencias, en un modelo que se estaba gestando en ese momento. Dichos profesores, se convertían en alumnos cada cierto tiempo, actualizando su formación en ciclos de corta duración.
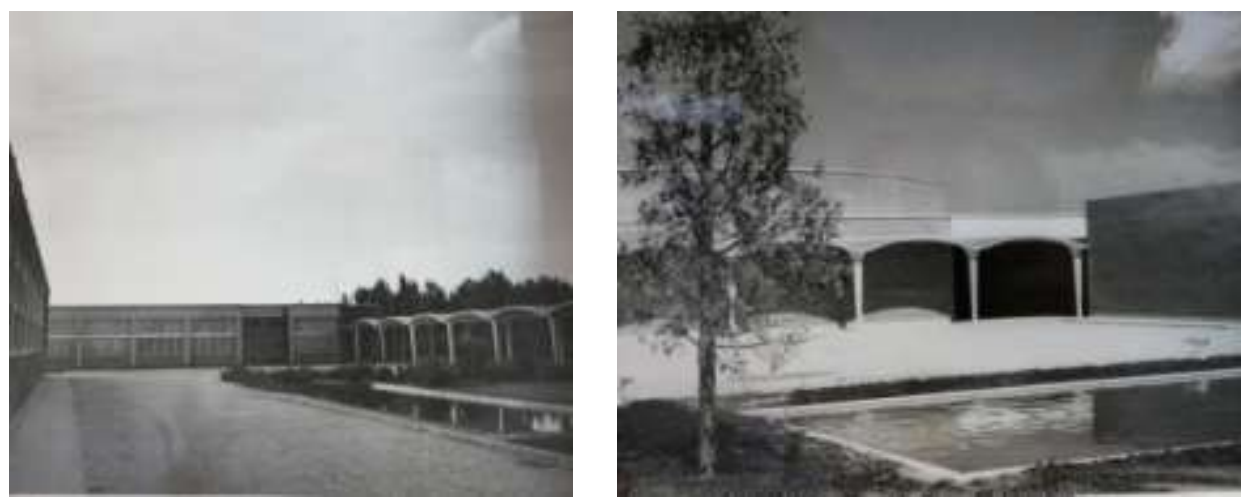

Centro de Formación del Profesorado de la Ciudad Universitaria (1952-1957) Fotografías Fundación Miguel Fisac

260 Campo Baeza, A. (1976). La Arquitectura Racionalista de Madrid (tesis doctoral), 212. Madrid: Universidad Politécnica de Madrid. Citado en San Antonio, C. de (2010). El viaje de Alvar Aalto a España en 1951: luces y sombras. Actas del Congreso Internacional Viajes en la transición de la arquitectura española hacia la modernidad, 363-370. 06/05/2010 - 07/05/2010, Pamplona. 
Como señala el propio arquitecto "Era importante favorecer el intercambio entre ellos y por eso se dio en el proyecto tanto protagonismo a los espacios abiertos. Se hizo en varias fases y yo iba añadiendo cosas conforme me iban diciendo, alrededor de patios que recordaban aquello que tanto me había gustado en La Alhambra, donde el palacio no se hizo de una vez, sino de forma aditiva.". De esta forma, como ahora constataremos, el espacio no construido se convertirá en un elemento esencial del proyecto.

Justificado proyectualmente como la articulación de las diferentes piezas del programa, con una diferenciación volumétrica según su destino (aulas, oficinas, talleres o salón de actos), y morfológicamente cercano a los conceptos del Instituto de Tecnología de Otaniemi de Alvar Aalto, Fisac crea un paisaje interior: una plataforma que se eleva sensiblemente sobre la carretera de La Coruña sobre la que se disponen una serie pabellones articulados en torno a espacios abiertos, hilvanados por los umbrales que invitan al paseo y que facilitan el contacto con la naturaleza, las vistas a la madrileña Casa de Campo y la Sierra de Guadarrama. Un campo de espacios entrelazados que consigue, además de desarrollar las actividades para las que ha sido proyectado, intensificar la visión del entorno y la naturaleza.

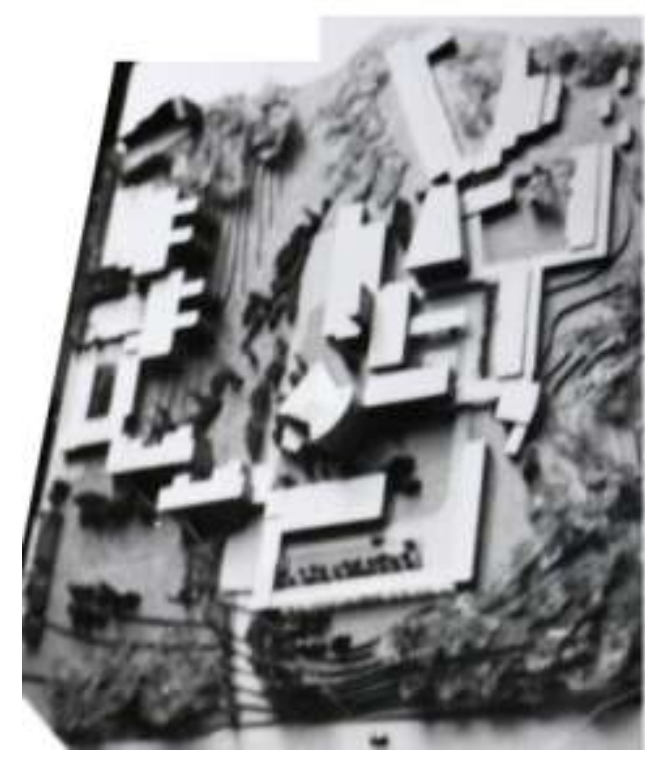

Centro de Formación del Profesorado de la Ciudad Universitaria. Maqueta de la primera propuesta (1952) Fotografías Fundación Miguel Fisac 

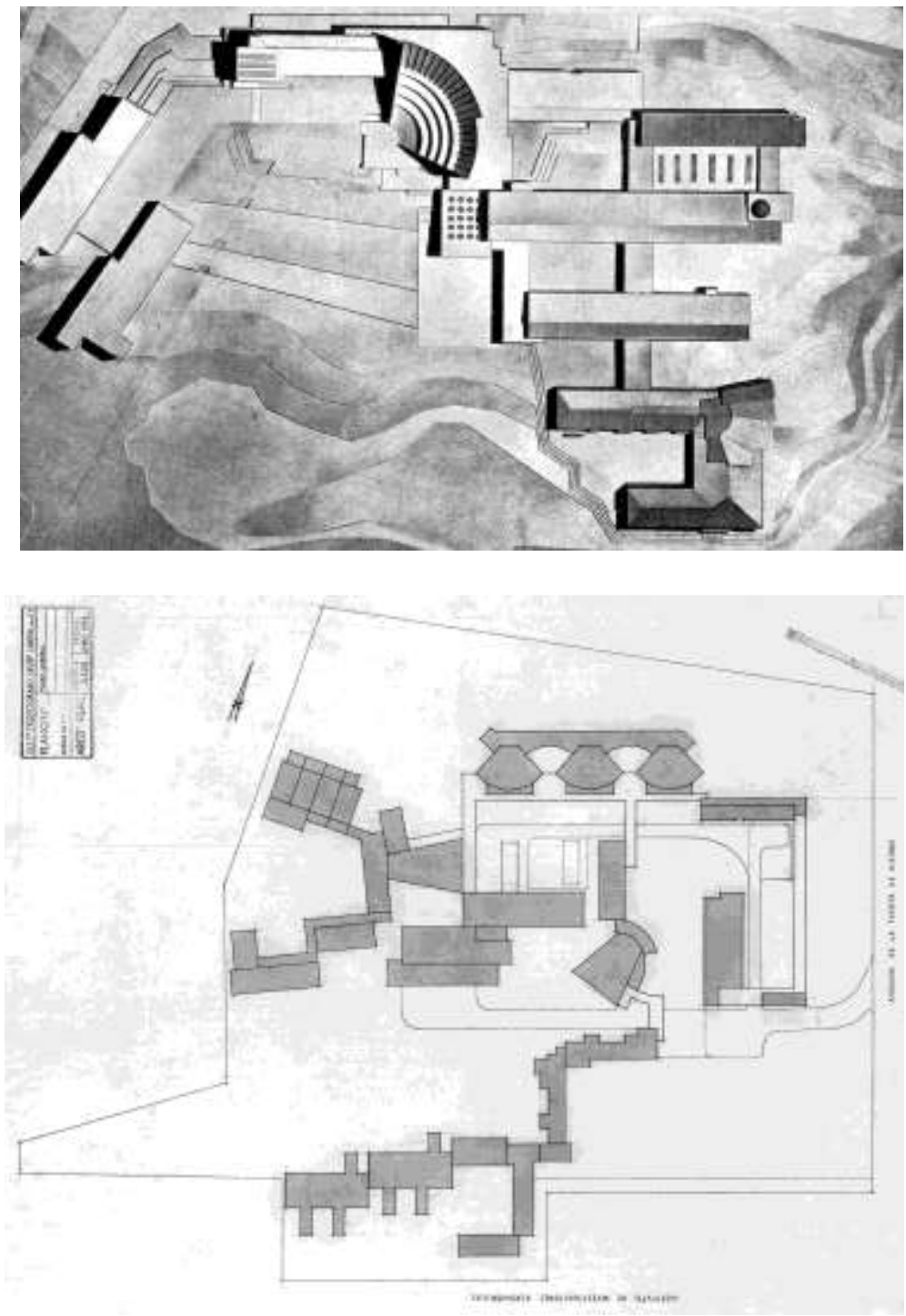

Paralelismos en su posicionamiento ante el paisaje de los proyectos de Otaniemi (Alvar Aalto, 1949) y Centro de formación del Profesorado (Miguel Fisac, propuesta de 1952)

De esta forma, crea un jardín. Plano, con poca vegetación y con láminas de agua estratégicamente ubicadas, en la misma orientación que las existentes en La Alhambra. Un espacio que invita al paseo (no se puede asimilar de un único golpe de vista); y a la relación entre los alumnos. Reflejos, texturas y pocos materiales -muy controlados-, hacen que se tenga la sensación de total equilibrio, sin ninguna estridencia. 
A este objetivo también responde la articulación y morfología de los edificios que cierran el jardín; edificios de altura única, entre los que destacan las piezas de los laboratorios, buscando la transparencia este-oeste, y con pabellones abiertos al jardín interior y cerrados a poniente. Todo ello aparece potenciado por los pórticos que hilvanan los distintos edificios. Marquesinas sinuosas y amables, de hormigón in situ, en situaciones perimetrales y permeables, o adosadas a determinados pabellones, indicándonos la direccionalidad de la circulación. Elementos que proporcionan sombra, y que dibujan trazos sensuales sobre los abstractos lienzos de fábrica de ladrillo: como "toldos al viento", se referirá el arquitecto a esos pórticos con apoyos esbeltos a través de los cuales se limitan patios y se enmarca el paisaje, o más propiamente se adueña del paisaje.

Esta articulación de volúmenes en torno a un jardín potencia la idea de una obra inacabada, que se puede prorrogar en el tiempo, sobre la que se puede seguir trabajando en el tiempo, -al igual que en el ámbito de la formación, que es una labor siempre continua e inacabada-, y con origen en la cultura hispano-árabe, se desarrollará también en otras obras posteriores, existiendo también esa conexión con los maestros nórdicos, -como con la casa experimental de Alvar Aalto, en la que también subyace esta idea de arquitectura aditiva-.

Un discurso coherente con una sensual narración espacial: sombras, recorridos y miradores, agua, umbrales, fronteras bien resueltas con la ciudad y con el ruido de la carretera de la Coruña, en definitiva un espacio, en palabras de María Zambrano, en los que el hombre, "más que alojarse, pueda albergarse"261.

Un único hueco-mirador abre el edificio al Norte, a Guadarrama. No es casual. Responde a la idea de enmarcar la naturaleza exterior, de adueñarnos de ella, de fusionar lo creado -paisaje interior-, con lo dado -paisaje exterior-, que también subyace en La Alhambra. De conseguir que el paisaje exterior se viva como una experiencia interior. De universalizar el edificio, como referencia intelectual Ortega (Ortega y Gasset, $1914,43)$ "mi salida natural hacia el universo se abre por los puertos del Guadarrama o el campo de Ontígola".

El hueco se realiza en un muro terso y largo, de ladrillo, sin ninguna otra referencia, potenciando su propia materialidad, como ahora veremos. Y una única curva al Este, que amablemente ayuda a la conexión de este lado opaco con la Naturaleza. Formalmente, como si de un homenaje a la fábrica de Racine de Wright se tratara; una referencia que era más clara, si cabe, en las primeras propuestas, -incluso existía un contrapunto vertical a la horizontalidad del conjunto-.

261 Zambrano, M. (1964) 
Memoria, Aprendizaje y Experimento. La invención del paisaje en Miguel Fisac

La invención del paisaje. El hombre en el paisaje. El Centro de Formación del Profesorado
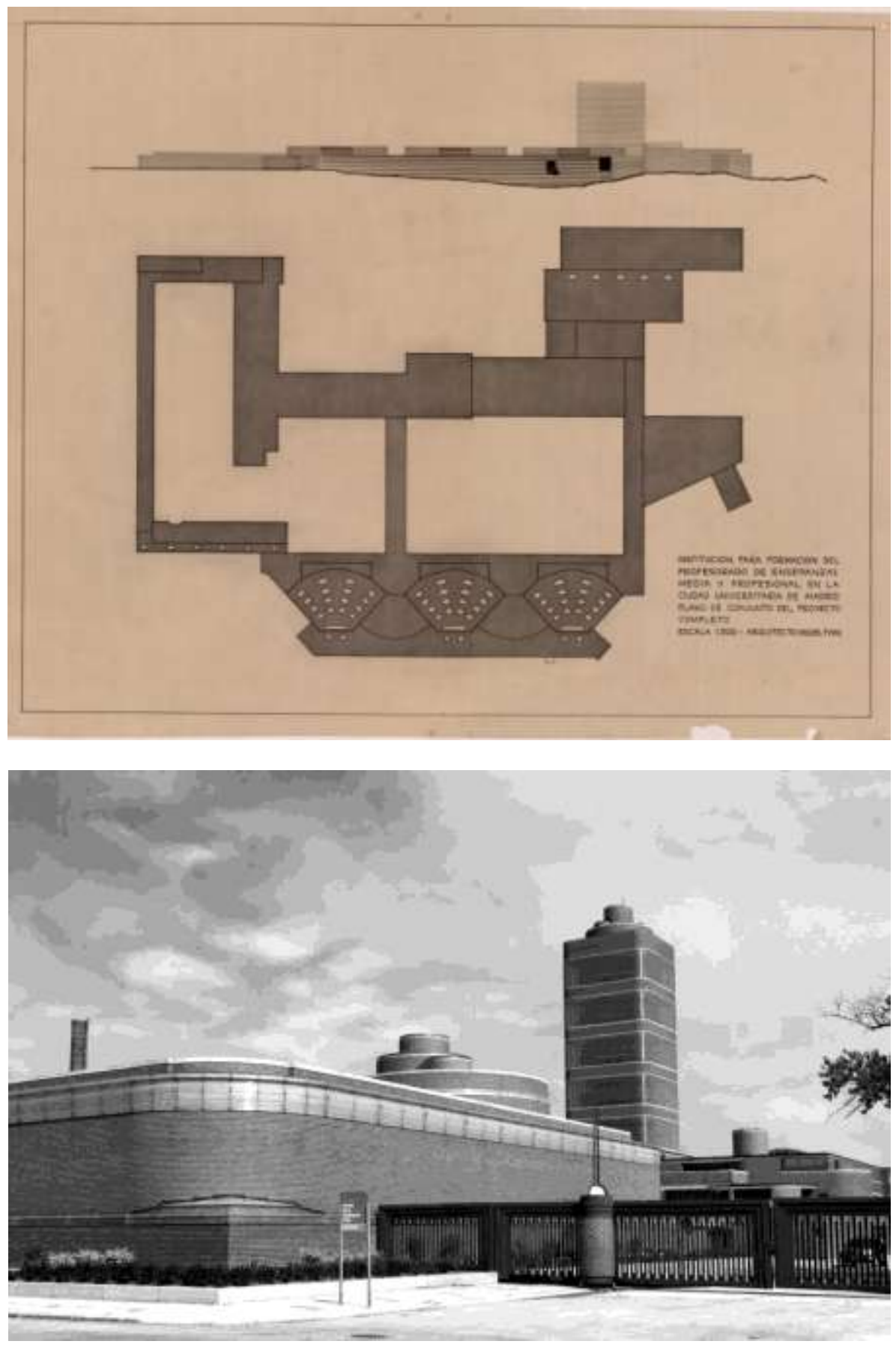

Miguel Fisac. Centro de Formación del Profesorado. Ciudad Universitaria, Madrid. 1952-1957 Frank Lloyd Wright. Oficinas y laboratorios Johnson. Racine, Wisconsin. 1936-1939 
Ya que por indicaciones del cliente este proyecto debía realizarse por fases, Fisac diseñó un sistema elástico -en palabras del propio arquitecto-, que permitiera enlazar las diferentes piezas como si de los engranajes de un reloj suizo se tratara. La constatación del éxito de este sistema de pabellones y galerías abiertas es que la ejecución de la Segunda Fase quedó perfectamente integrada con la primera, incluso habiendo cambiado de estrategia totalmente con respecto al Anteproyecto, como se explica en la Memoria de la citada Segunda Fase escribe: "la experiencia de estas enseñanzas en el tiempo transcurrido, obliga a que esta segunda fase no coincida con las características que se presumía en el principio que habian de tener, y que gracias a esa concepción elástica de que ya hemos hablado, hace posible que esta segunda fase quede perfectamente enlazada en el conjunto aun cuando sus funciones sean muy distintas de las que se presumieron en origen."262

Y continúa posteriormente, sobre el pabellón que se realiza esta fase y que articula los dos patios, insistiendo en la búsqueda de la homogeneidad del conjunto: "Las edificaciones de este proyecto forman una $T$ de brazos desiguales que acoplada perfectamente con la entrada y portería de la primera fase y con una galería de enlace con las aulas teórico-prácticas también de la primera fase, forman un conjunto homogéneo de dos plazas armónicamente enlazadas y homogéneamente dispuestos en su funcionamiento interno"263.

Esta forma de considerar el conjunto mediante la articulación de diversas partes que se construyen en el tiempo, en torno a una serie de jardines, y "que van enlazándose unos a otros de forma orgánica"264 es también un punto de conexión con La Alhambra.

Y la utilización de la luz, el ritmo de sombras y penumbras, así como el uso de luces cenitales en las aulas de planta curvilínea, también dirigen la mirada hacia la cultura hispano-árabe.

La oportunidad de trabajar de forma prácticamente simultánea con el conjunto de Enseñanza Media de Málaga hizo que existieran una importante transferencia de conceptos entre ambos. Lo anecdótico de este conjunto es que existen una serie de propuestas previas, proyectadas entre 1944 y 1948 (junto con Fernández-Vallespín), con unos diseños más cercanos a otros regímenes y estilos arquitectónicos pretéritos. Diferentes circunstancias propiciaron que este proyecto nunca se ejecutara y que el propio Fisac redactara otro proyecto en 1953.

262 Fisac, M. (1955). Proyecto de edificios de la Institución para la Formación del profesorado de enseñanza media y profesional en la Ciudad Universitaria de Madrid. Memoria. Inédita. Fundación Miguel Fisac.

263 Idem

264 Ibidem 


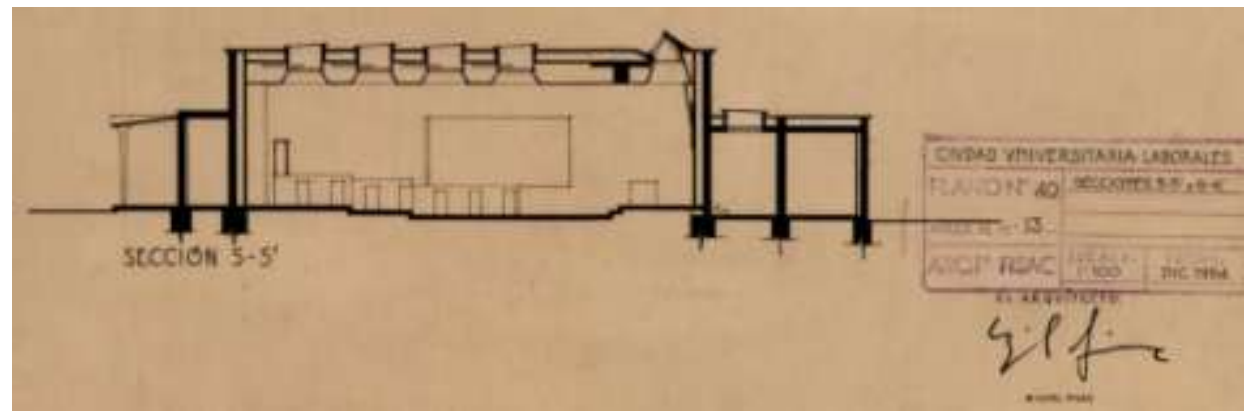

Luces cenitales en las aulas de planta curvilínea. Plano de 1954. Fundación Miguel Fisac.

Se vuelve a crear un universo interior, un espacio humanizado mediante una precisa limitación geométrica. Los volúmenes arquitectónicos se articulan a través de los umbrales, definiendo espacios exteriores -esta vez para la estancia y el esparcimiento de unos alumnos de enseñanza media-, con pequeños estanques de agua y una estudiada vegetación. Elementos similares, pero conjugados de otra manera, con umbrales más generosos que en el edificio de Madrid, con otro tipo de aperturas y veladuras hacia el entorno -urbano-, otras alturas en los pabellones -estos disponen de dos alturas-, y otros materiales, jugando con el reflejo de la luz sobre la blancura de la materia. En definitiva, un intento de arraigar el edificio a su paisaje, de desarrollar con la arquitectura el concepto de ser-ahí de Heidegger.

En el Proyecto ${ }^{265}$, aparecen reflexiones del propio arquitecto sobre estos espacios, en las que justifica la importante anchura de los umbrales, de forma que se convierten, como en Madrid, en auténticos espacios de relación y estancia, más allá del tránsito y la conexión entre pabellones, actuando además de filtro térmico.

"Así como se ha considerado innecesario el cerrar las galerías de acceso, se considera, sin embargo, muy útil tener grandes superficies abiertas pero cubiertas, que protejan del Sol dando al conjunto una agradable variación de zonas abiertas, zonas abiertas pero cubiertas y recintos cerrados"

265 Citado en Loren-Méndez, M. (2012). Tecnología, materia y lugar: Procesos de modernización en la obra española de la posguerra. Instituto de enseñanza media, Málaga. Arquitecto: Miguel Fisac. Informes de la Construcción, 64, 526, 167-177. 

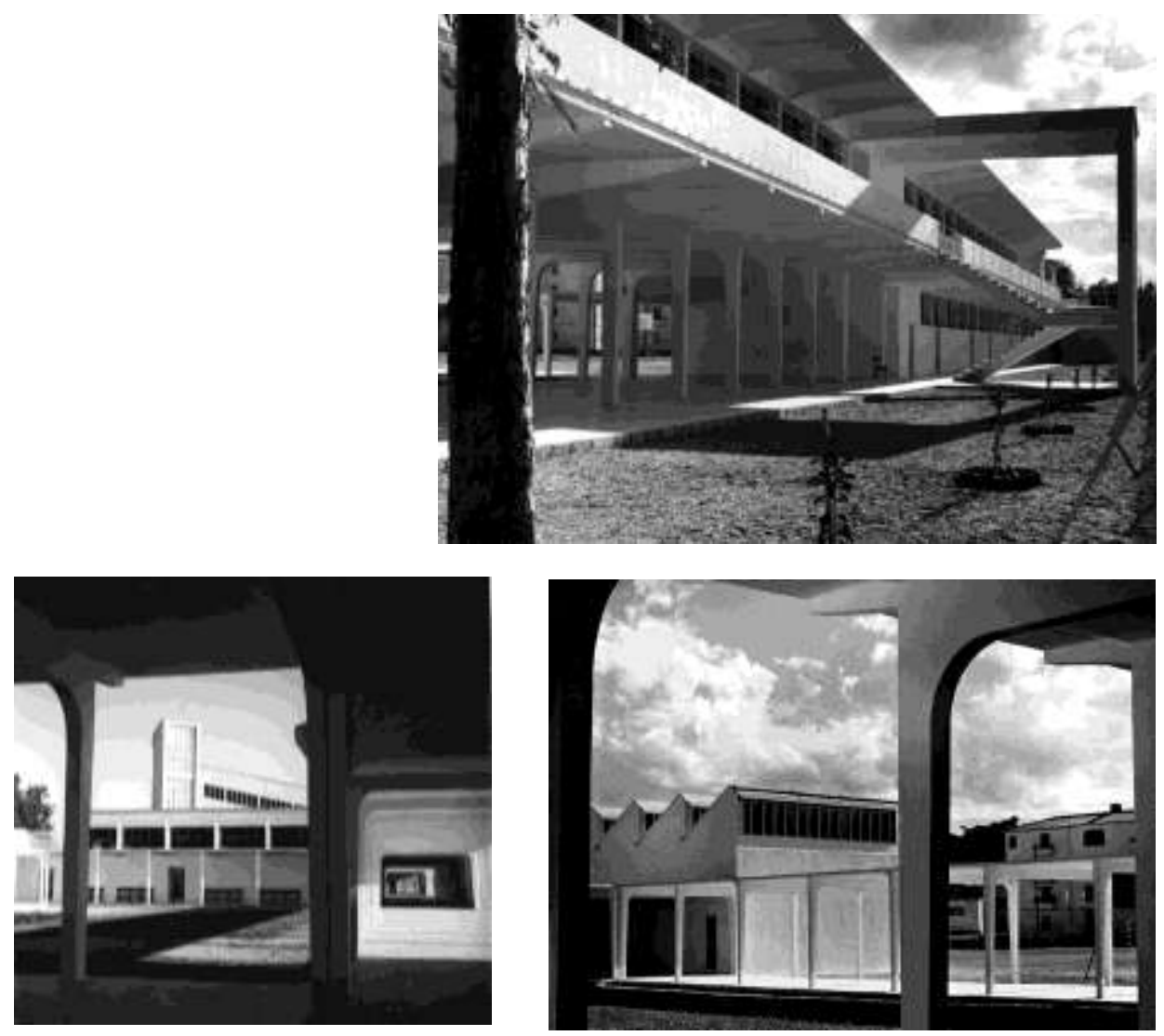

Instituto de Enseñanza media de Málaga. Miguel Fisac. (1953).

El propio lenguaje del proyecto ya denota una sensibilidad especial hacia la arquitectura hispano-árabe:

"Se ha procurado también, jugando con las orientaciones más convenientes de todas las partes del edificio, formar conjuntos gratos de patios, estudiando las diferentes jardinerías, estanques y surtidores, que sin plagiar las formas arquitectónicas locales, recogen el espiritu de lo que entendemos más acertado de ellas"

Se crean sensuales espacios de inspiración hispano-árabe que permiten la convivencia y estancia de los alumnos que niega en este segundo proyecto la edificación en torno a una gran plaza monumental que se había propuesto en 1944. 
Un auténtico paisaje interior lleno de experiencias espaciales para los alumnos que combina recorrido, atmósferas, puntos focales; como una ciudad combina calles, plazas, puertas...

Se vuelve a trabajar para hacer una arquitectura de cinco sentidos, aprendida de La Alhambra, en la que texturas, olores, sombras y umbrales, patios y jardines se funden con las aulas para crear una intensa experiencia espacial en los usuarios, además de ayudar a que las relaciones fluyan. Transiciones espaciales aparentemente impensadas, que generan riqueza en esa exterioridad que busca ser espacio de relación. Al igual que en el edificio madrileño, los muros que acogen una función estudiada y atravesados por la luz, con una gran veracidad constructiva y con la fuerza de la expresión del material son capaces de delimitar, junto con los umbrales, unos espacios exteriores de una riqueza merecida, que expresan con la arquitectura -de la que también forma parte la exterioridad- lo que el edificio es, y lo que significa.

También aquí los umbrales son protagonistas y actúan hilvanando los diferentes pabellones, apoyados sobre pilares con secciones variables y crecientes desde la base, pero morfológicamente diferentes a los madrileños.

Volviendo a Madrid, es importante mencionar dos aspectos.

El primero, es que la primera propuesta, de 1952 era mucho más ambiciosa que la que finalmente se construyó, ya que por diversos motivos hubo de reducirse el programa.

"...un edificio que tenía muchas reminiscencias de La Alhambra en un sitio pues... la Ciudad Universitaria de Madrid... que se empezó a hacer... tenía siete patios...porque eran unas uniones por patios... y quedaron en dos..."266

La segunda, es el carácter de obra inacabada inherente a las circunstancias, ya que el conjunto primeramente construido se fue ampliando sin saber exactamente cuál sería el estado final de la actuación.

\section{$\underline{\text { Lo estereotómico y lo tectónico en el Centro de Formación del Profesorado }}$}

En el contexto de las investigaciones sobre La Alhambra realizadas por Jesús Aparicio, y encontrándose este conjunto madrileño tan en conexión con el nazarí, parece oportuno siquiera realizar un acercamiento desde estas dos formas de ver la arquitectura que son lo estereotómico y lo tectónico 267 .

266 Fisac, M. (1995). Conferencia dictada en la ETS de Arquitectura de Valencia. Véase Apéndice 1.

267 Un estudio completo sobre estos términos acuñados por Gottfried Semper y su desarrollo en el edificio de la Alhambra lo encontramos en Aparicio, J. (2000). El Muro. Palermo: Universidad de Palermo 
No en vano, este acercamiento nos ayudará a intensificar la relación íntima del Centro de Formación del Profesorado con el paisaje.

Lo estereotómico, los pabellones, ligados a la tierra, como el pódium del Partenón. Y lo tectónico, los umbrales o marquesinas, como la ausencia de la materia, para "dejar que la Naturaleza se incorpore a la Arquitectura".

En el edificio fisacquiano, como en La Alhambra, podemos encontrar ambas, pero es mediante la existencia del concepto de tectónico a través del cual el espacio se abre al paisaje: a su propia exterioridad y al exterior dado.

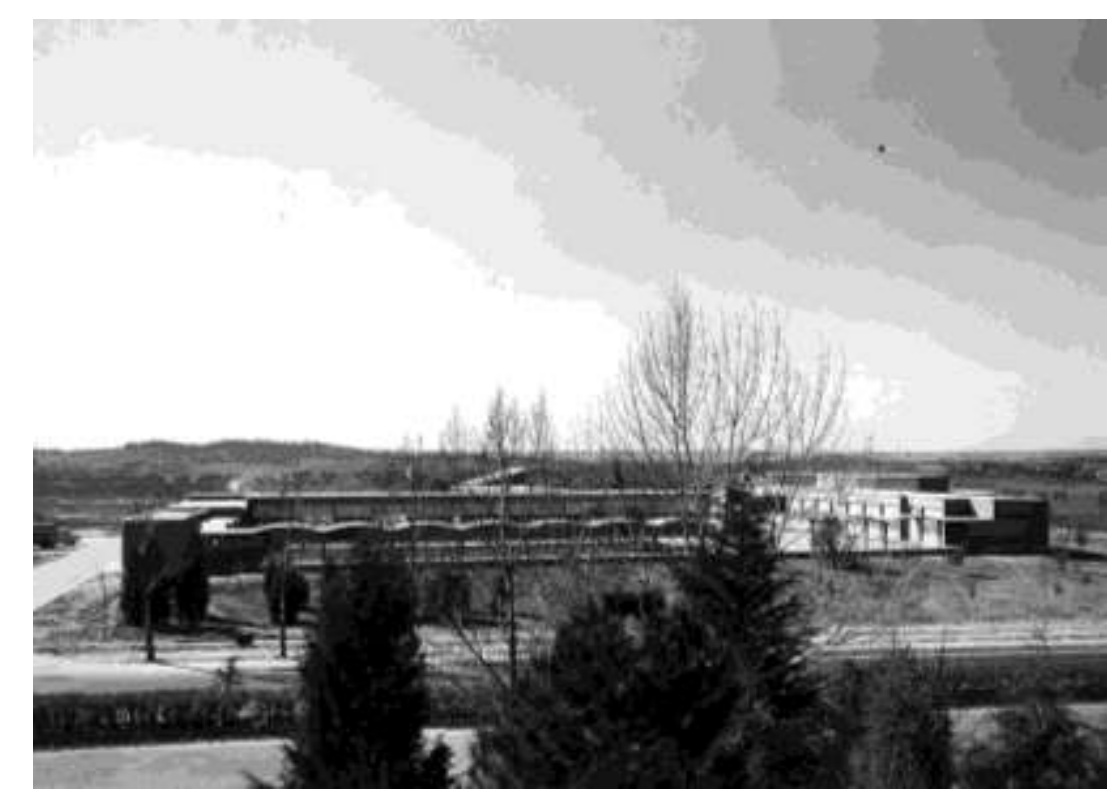

Miguel Fisac. Centro de Formación del Profesorado. Ciudad Universitaria, Madrid. 1952-1957. Vista desde el extremo de la actual carretera de La Coruña

El elemento estereotómico, por su parte, quiere ser muy potente, marcando un claro contraste con lo tectónico, de forma que los umbrales realzan su característica de delicadeza.

Esta potencia de lo estereotómico se realza en el pabellón de las aulas con la apertura de un mirador, un único hueco de todo el muro, reafirmando la materialidad del mismo, huyendo -sin embargo- de posicionarse en el eje visual.

Una conexión la del mirador que es únicamente visual, al igual que el muro de la torre de Comares en La Alhambra, de forma que se enfatiza el paisaje interior creado. 
En este edificio existe un fuerte contraste en la relación con el paisaje, ya que igual que hacia el Norte podemos entender el conjunto como atalaya muy cerrado, hacia el Oeste se abre a través de los pórticos, que enmarcan el paisaje de la Casa de campo y la Sierra, convirtiendo así en parte del paisaje interior la naturaleza universal.

Y esta doble lectura no hace sino potenciar el carácter de invención del paisaje que tratamos de investigar aquí, uniendo finalmente lo universal y lo particular.

\section{La escala humana}

Contaba Fisac en su primera visita a la Acrópolis, que tiene uno la sensación cuando llega de que aquello es pequeño, y enseguida rectificaba: no es pequeño, está hecho a escala humana.

El Centro de Formación del Profesorado, como la Acrópolis, y como La Alhambra, tiene escala humana.

Y de esta forma, la relación del hombre con el paisaje es más intensa; aunque la visión sea lejana, a través de los huecos -que sólo se traspasan visualmente- se hace cercana.

Asimismo, a través de las compresiones y dilataciones que se establecen -talleres, aulas, umbrales, jardín-, se hace discontinuo el espacio aunque sea continuo el plano del suelo. De esta forma el hombre se mueve entre dos mundos, el continuo estereotómico del suelo y el discontinuo creado por la propia arquitectura. "La escala del hombre define la separación física entre lo tectónico y lo estereotómico en La Alhambra"268, y podríamos añadir, y en el Centro de Formación del Profesorado de Fisac.

${ }^{268}$ Aparicio, J. (2000), 81. Op. cit. 
Memoria, Aprendizaje y Experimento. La invención del paisaje en Miguel Fisac

La invención del paisaje. El hombre en el paisaje. El Centro de Formación del Profesorado

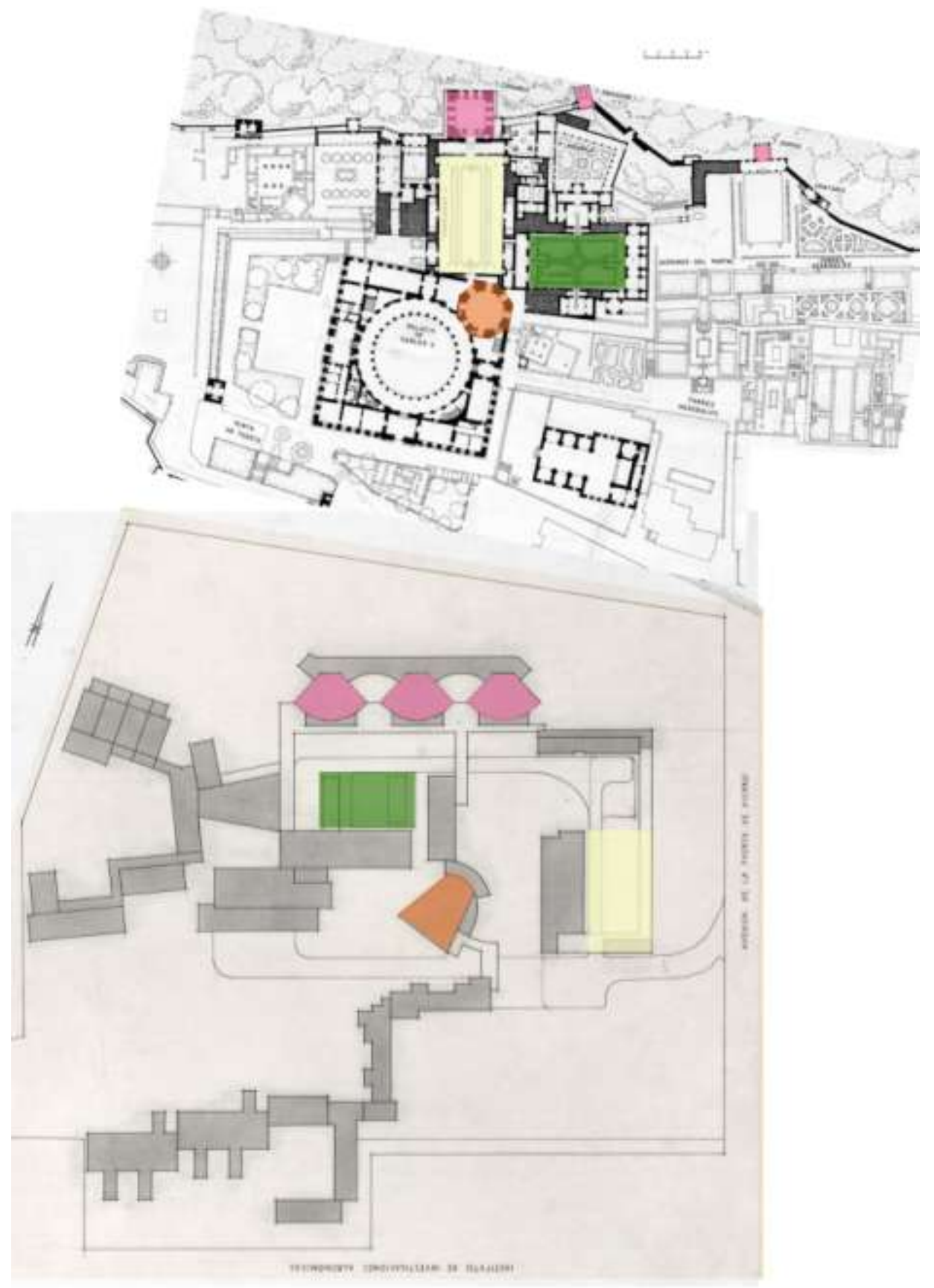

Estudio comparativo Centro de Formación del Profesorado y La Alhambra. Se pueden observar piezas comunes en ambos conjuntos, así como relaciones entre las proporciones de determinados patios. 


\section{El jardín}

El cuidado exquisito de las plantaciones es un valor que cuidará Fisac en toda su obra, como ya hemos visto en algún ejemplo.

En este caso, esta cualidad nos acerca un poco más al Paraíso interior que se pretende crear como continuidad de la Creación, de la Naturaleza dada, al "Cielo en la Tierra", intensificando la conexión con La Alhambra.

Señala Fisac en la Memoria de este proyecto: "Se estudia minuciosamente la jardinería en disposición de agua, mosaico sumergido, y disposiciones arbóreas, de acuerdo con los jardines ya realizados y del paisaje que lo encuadra".

Se crean dos espacios de pradera, uno junto al pabellón de las aulas pequeñas y otro junto a la zona de acceso.

Un tercer espacio de jardín, más pequeño, se ubica en el lado Norte, entre las dos aulas mayores, introduciendo la vegetación y la luz a través de ella al espacio de circulación entre ellas.

Por último, un seto dirige el itinerario de las personas, conduciéndolas intencionadamente.

Los dos primeros tratan de refrescar y humanizar los espacios de sombra y estancia creados por los umbrales, a la vez que dirigen el paseo entre los pabellones.

Sobre los mencionados espacios de pradera, encontramos:

En el primero, un estanque con surtidor, vinca, ciprés, paraíso, magnolio y grategus. Adosadas al pabellón de las aulas, piedras y planta de rocalla tocan el edificio. 
Memoria, Aprendizaje y Experimento. La invención del paisaje en Miguel Fisac

La invención del paisaje. El hombre en el paisaje. El Centro de Formación del Profesorado
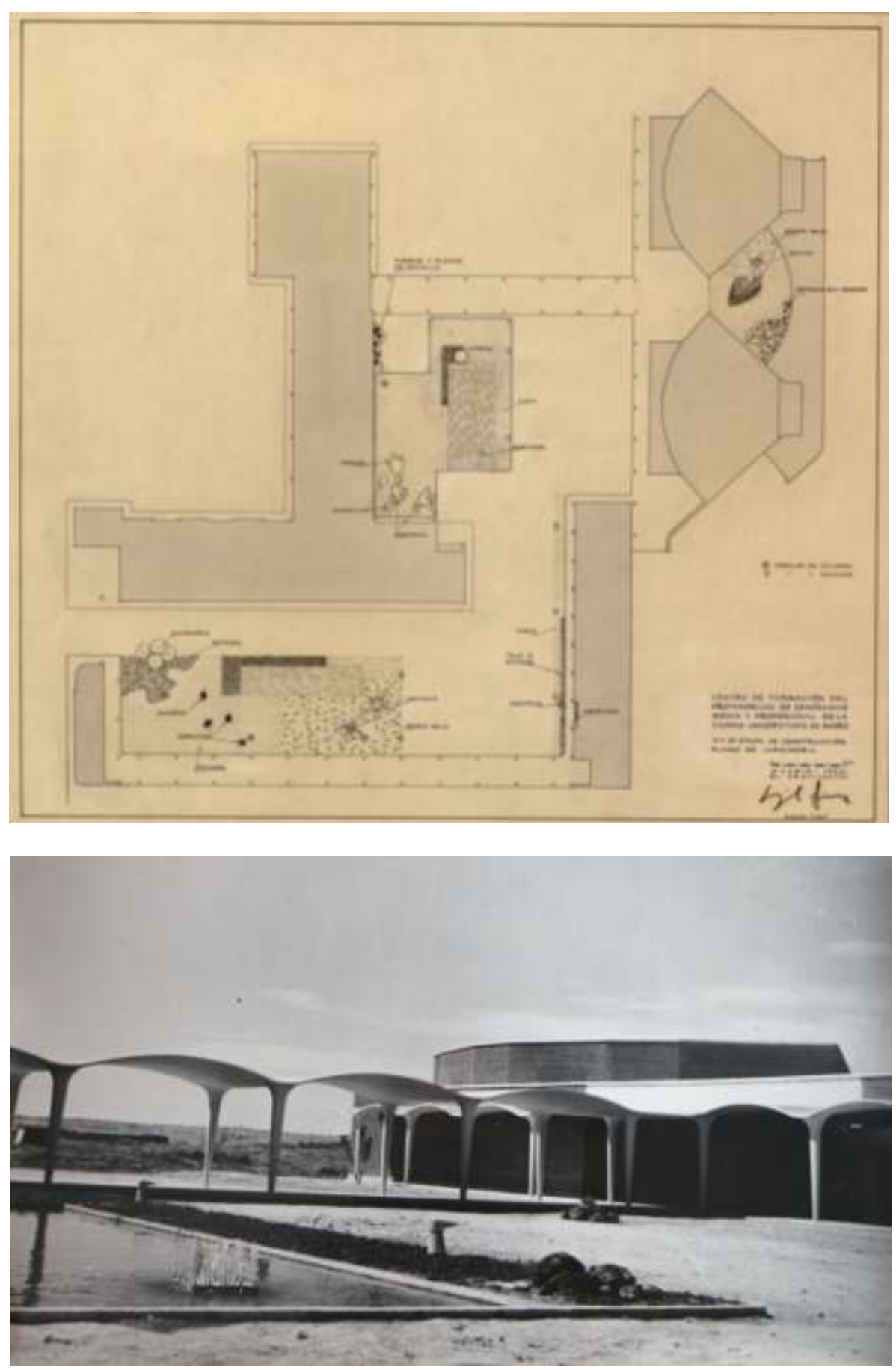

Centro de Formación del profesorado. Planta de Jardinería (1953).

Centro de Formación del Profesorado. Primer estanque y surtidor, zona Oeste 
En el segundo, un estanque de dimensiones parecidas, esta vez sin surtidor, se ve completado con madroños, retamas, una mahonia, forsitias, encinas y monte bajo.

Asimismo, en el citado jardín entre las aulas mayores, se dispone pradera, monte bajo, una encina, un pequeño estanque, rocas, y retamas "muy grandes".

En cuanto al seto existente junto al pabellón de oficinas, se disponen vinca, tojo, grategus y ampelosis.

Encontramos por tanto una intensa intencionalidad de realizar un jardín para los sentidos. Un espacio de texturas, colores y olores, una atmósfera que participa de la tradición hispanoárabe, en la que cobran protagonismo también el sonido -a través de los surtidores-, los reflejos de las láminas de agua, las sombras o el frescor.

Texturas, a través de los pavimentos, las rocas, los arbustos o las plantas de suelo como la vinca; pero también en la variedad de fondos de los estanques. Colores a través de las citados espacios de vinca, o los árboles como el magnolio o especies arbustivas la mahonia 0 las forsitias. Olores a través de las encinas, el tojo o las retamas...
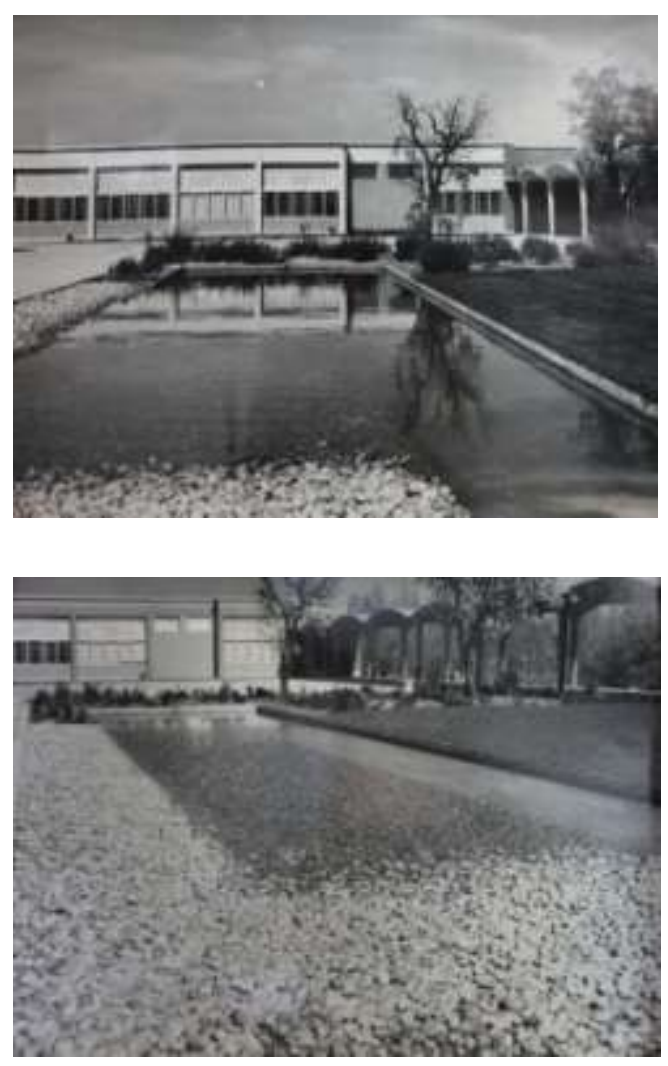

Centro de Formación del Profesorado. Segundo Estanque, zona Este. Fotografía Fundación Miguel Fisac 
Memoria, Aprendizaje y Experimento. La invención del paisaje en Miguel Fisac

La invención del paisaje. El hombre en el paisaje. El Centro de Formación del Profesorado
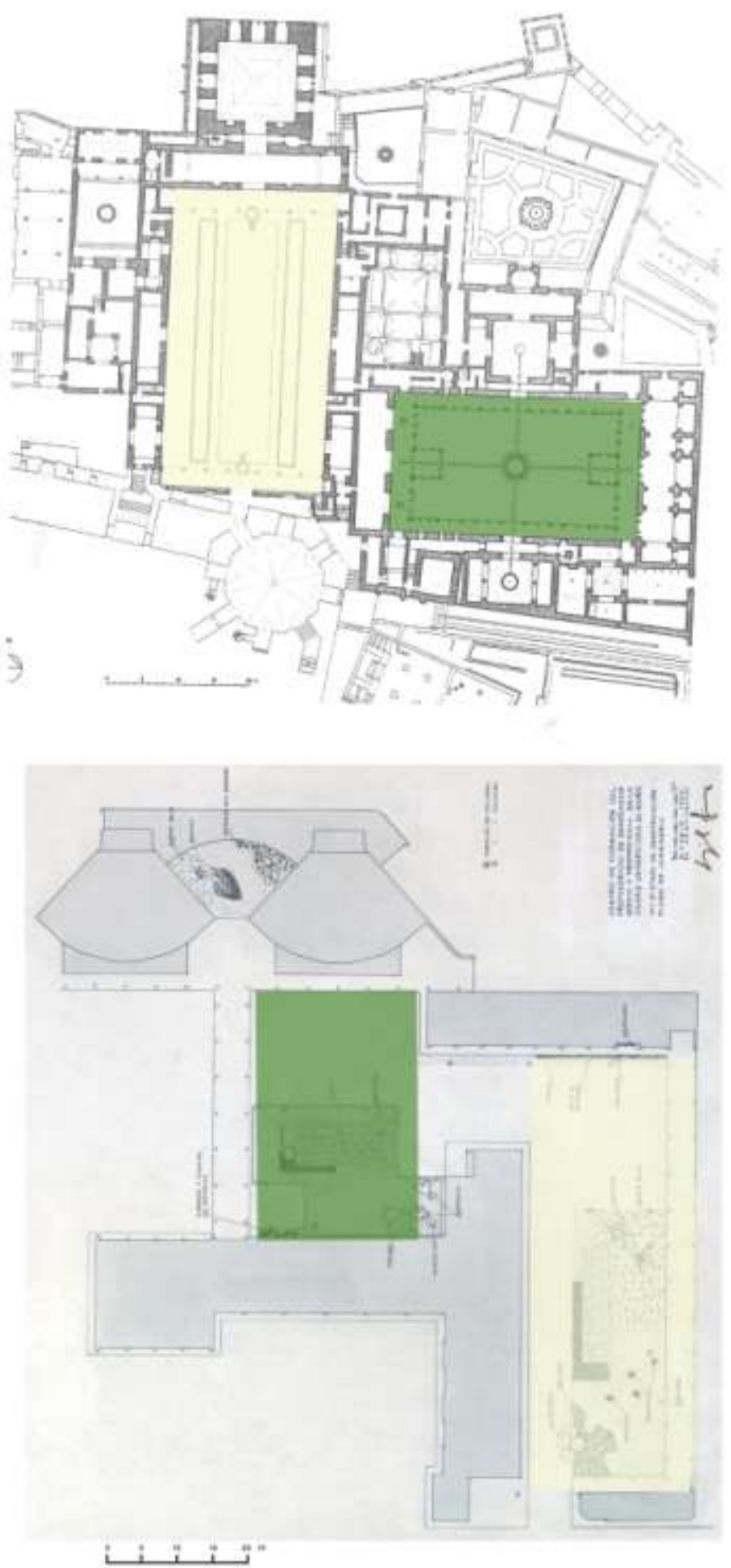

Estudio comparativo Centro de Formación del Profesorado y La Alhambra. Proporcionalidad de los patios del primer conjunto con el Patio de los Arrayanes (amarillo) y el Patio de los Leones (verde). 
Memoria, Aprendizaje y Experimento. La invención del paisaje en Miguel Fisac

La invención del paisaje. El hombre en el paisaje. El Centro de Formación del Profesorado
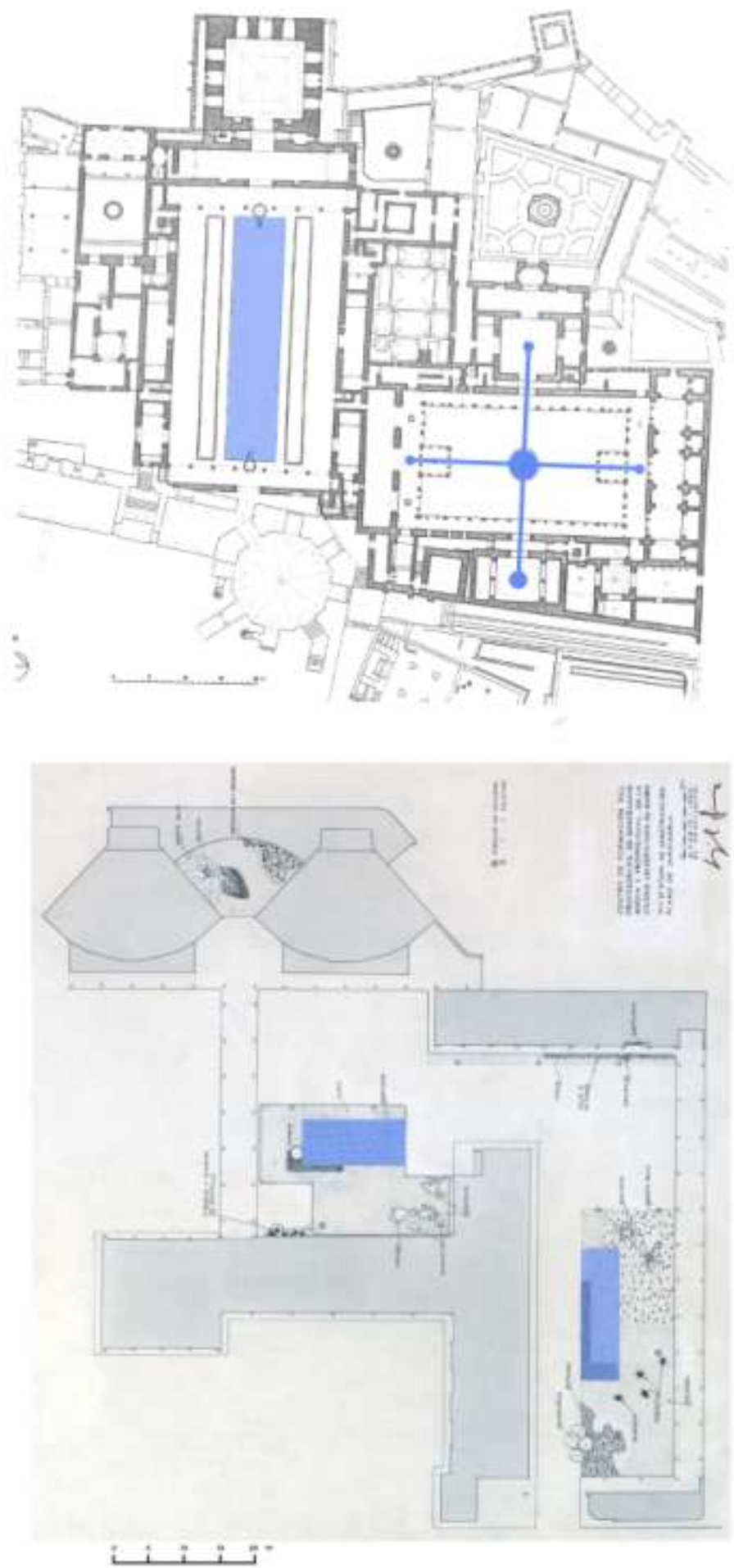

Estudio comparativo Centro de Formación del Profesorado y La Alhambra. Esquema comparativo de la articulación de estanques en ambos conjuntos. 
Memoria, Aprendizaje y Experimento. La invención del paisaje en Miguel Fisac

La invención del paisaje. El hombre en el paisaje. El Centro de Formación del Profesorado
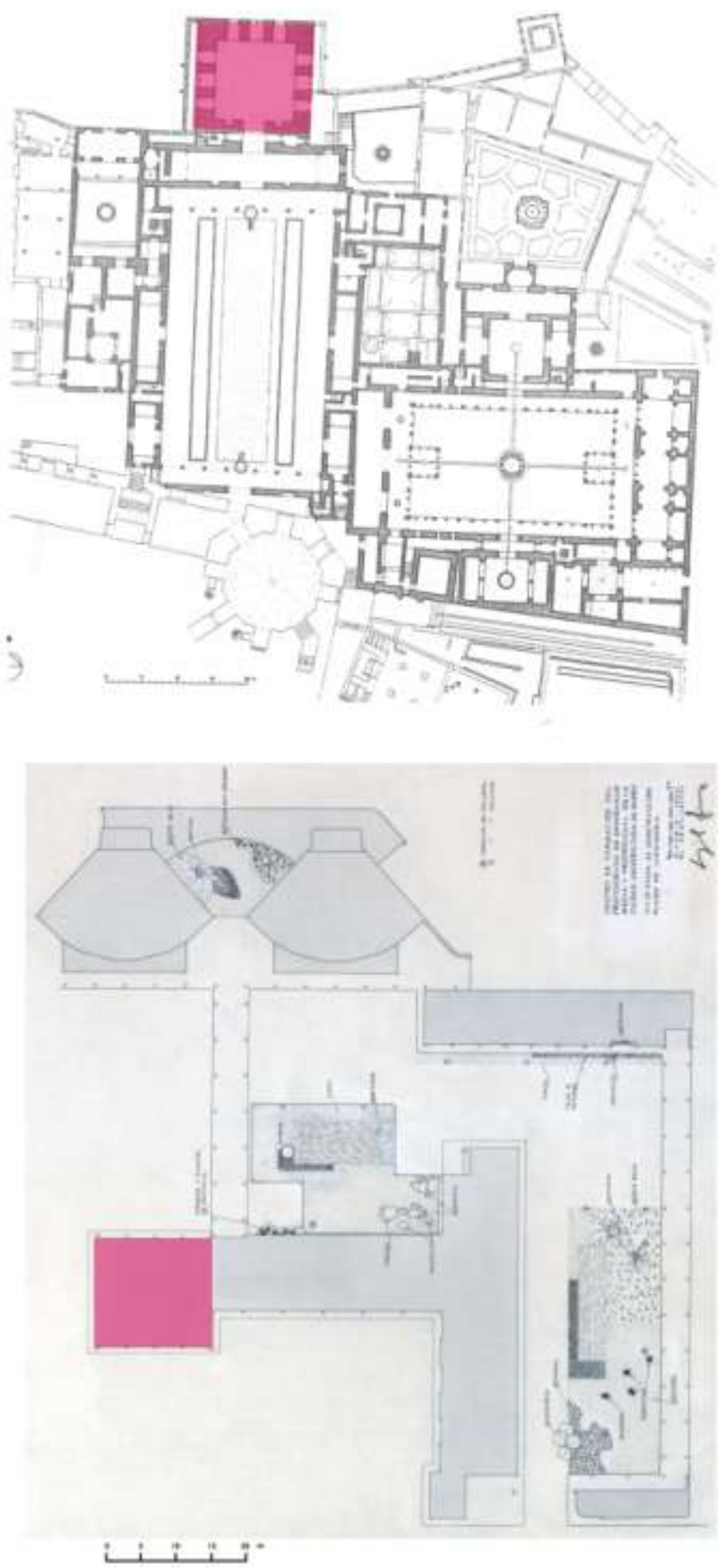

Estudio comparativo Centro de Formación del Profesorado y La Alhambra. Las proporciones de la Torre de Comares son exactas a las del cuerpo de aulas de dibujo del edificio de Fisac. 


\section{Epílogo}

Esta actuación es pionera en su ámbito. En este conjunto, Fisac redefine en clave de modernidad una serie de cualidades de La Alhambra, convirtiendo en cuerpo nuevo el alma del pasado. De todo su aprendizaje, destacaremos la creación de un jardín paraíso- interior que se adueña de la Naturaleza circundante, la delimita y la hace cercana.

Ello influirá de forma importante en posteriores proyectos con programa docente, ya sean propios -Málaga, ó Núñez de Arce en Valladolid por citar dos ejemplos-, como de otros arquitectos. Y no sólo en la forma de entender la arquitectura, también en la frescura de tratar la articulación de las diferentes piezas y la exterioridad, así como de la utilización de elementos activadores del paisaje, como el agua, los umbrales, la apropiación del horizonte, las texturas, la vegetación o la luz.

Cabe citar como ejemplo la relación cercana con proyectos como el del Colegio Guadalaviar en Valencia (1958), de Fernando Martínez García-Ordóñez, amigo y antiguo colaborador de Fisac, proyectado como una escuela-jardín, con piezas articuladas en torno a patios, umbrales, y estanques.

Esta suerte de paisaje que se dibuja en los edificios de Miguel Fisac tiene una importante dimensión trascendente para el hombre. Igual que en sus propuestas de ciudad, Fisac insiste en la búsqueda incansable de la convivencia socializada y trata de proponer espacios en los que esto sea posible, volviendo al concepto de Plaza en su sentido más amplio, aquí se trata de busca de otra forma esa Plaza, donde los iguales (estudiantes) se relacionen entre sí, paseen, compartan experiencias, o confronten sus aspiraciones con las de sus compañeros. 
Memoria, Aprendizaje y Experimento. La invención del paisaje en Miguel Fisac Conclusión. Constelaciones en el paisaje

\section{6_CONCLUSIÓN.}

CONSTELACIONES EN EL PAISAJE 
La construcción del paisaje con una singular sensibilidad al lugar en el que se asienta la arquitectura, a su cultura, historia, clima e idiosincrasia propia, con el hombre como actor principal, forma parte esencial del universo conceptual y arquitectónico de Miguel Fisac.

Las aproximaciones realizadas a su obra hasta el momento, realizadas de forma lineal, biográfica, o con criterios de orden tipológico, de investigación estructural, o a través de alguna de sus innovaciones, -si bien igualmente necesarias-, nos habían velado la mirada hacia el paisaje como hilo conductor que sustancia el entendimiento de su mensaje.

Mediante el desarrollo de esta idea a través de los dos grandes ejes que nos han conducido en esta investigación, los conceptos Memoria y Aprendizaje, así como el acercamiento a posturas filosóficas contemporáneas, como el "ser-ahi" de Heidegger, hemos podido analizar en profundidad cómo resuena en su arquitectura la máxima que con insistencia repetía Fisac, convertido en auténtico leitmotiv de la misma: "La arquitectura, como el árbol, está plantada en el paisaje".

Como hemos visto, en la obra de Fisac la Memoria se erige como un instrumento de trabajo. Es paradójico poder llegar a esto cuando el propio arquitecto defendía que él trataba de "dejar la mente en blanco" al inicio de cada proyecto. Sin embargo, hemos visto que utilizando el paisaje como instrumento de análisis, lejos de ello, la Memoria podría constituirse como el quinto elemento del itinerario proyectual tan conocido, mediante el cual se tamiza sus "para qué, dónde, cómo y no sé qué". Como si se tratara de un proceso de ósmosis, en el que a través de una suerte de membrana semipermeable, -que es su Memoria-, son decantados los diferentes elementos de Aprendizaje para volcar su perfume en el territorio y así reelaborar el paisaje. Podríamos incluso aventurar que en esa membrana van quedando huellas de lo aprendido, convirtiéndose en un cuerpo múltiple, un palimpsesto de memorias superpuestas, destiladas, que devienen en esa invención -adelantada- del paisaje a través de su arquitectura.

El paisaje contiene historia, a la vez que contiene la propia historia de Fisac-Memoria-; y esto determina su manera de hacer arquitectura. En un primer momento el intenso contacto con la Naturaleza procede de una cierta celebración de la vida como anestesia ante la muerte que acecha a la familia; pero el descubrimiento de la luz, los aromas, los colores, los reflejos y veladuras de Las Tablas y del horizonte de La Mancha lo vinculan 
al lugar. Su relación con la tierra de su infancia queda almacenada en su interior y por tanto en el paisaje. Y preparan sus sentidos para recibir las enseñanzas posteriores.

El Aprendizaje, por su parte, se constituye en un sólido elemento con capacidad para mover los ejes referenciales de Fisac en relación a la articulación de la arquitectura en el paisaje. Adelantándose a otros coetáneos, intensifica Fisac el estudio de los límites entre lo construido y el paisaje para tomar una posición adecuada en cada caso: cerrando, abriendo, o diluyendo, pero siempre flexibilizando estos límites y tratando el espacio como un elemento fluido; lecciones aprendidas en La Alhambra, en la Casa tradicional japonesa, 0 a través del acercamiento a maestros indiscutibles de la modernidad.

Estos límites se producen a veces dentro de la propia arquitectura, con mayor clausura o apertura al entorno, de forma que la creación de jardines y patios que dialogan con la edificación y a través de los cuales se filtra la luz, se escuchan los sonidos del agua, 0 se sienten las texturas del pavimento nos hacen trascender del propio edificio, intensifican la relación de la arquitectura con el lugar, haciéndola pertenecer a él desde siempre, como si consiguiera Fisac que el medio se adaptara al cuerpo. En la línea de lo escrito por Ortega en sus Meditaciones del Quijote:

"La ciencia biológica más reciente estudia el organismo vivo como una unidad compuesta del cuerpo y su medio particular: de modo que el proceso vital no consiste sólo en una adaptación del cuerpo a su medio, sino también en la adaptación del medio a su cuerpo. La mano procura amoldarse al objeto material a fin de apresarlo bien; pero, a la vez, cada objeto material oculta una previa afinidad con una mano determinada".

La aproximación fenomenológica a los paisajes construidos, inventados, conforma un proceso de investigación y experimentación en la obra de Fisac, a través de secuencias, umbrales, articulaciones, estratos, atmósferas, texturas, estanques o miradores, que hilvanan con maestría edificio y territorio, así como jardín y Naturaleza. Son elementos configuradores de una suerte de gramática que el arquitecto utiliza para modificar el paisaje, transformarlo o reinterpretarlo; en una palabra, para activarlo. Elementos de experimentación a través de los cuales se habita el paisaje, y por lo tanto, de acuerdo con Heidegger, se construye.

Su arquitectura por tanto, responde a un posicionamiento dinámico ante el paisaje, que como no puede ser de otra manera deviene en una reelaboración del mismo, una invención, de forma que el nuevo paisaje brilla con mayor luz.

Este posicionamiento es épico en la época vivida, y más concretamente en la estudiada (1951-1978), adelantado como se ha dicho, moviéndose con la seguridad y destreza de quien maneja la esencia de las cosas de lo popular a lo culto, de lo tradicional a lo 
experimental, de lo local a lo universal, como reacción a la deshumanización y negación del paisaje que Fisac atribuía al Movimiento Moderno y que siempre reprobó.

El siguiente texto de Miguel Fisac sintetiza en sus propias palabras una idea que hemos tratado de desarrollar utilizando como instrumento de análisis su propia obra:

"Cuando leo, ahora, en la Revista "The Architectural Review" (mayo 1988) un documentado estudio de Juhani Pallasmaa, que llega a la conclusión de que la sociedad postmoderna trata de humanizar con "flexibilidades regionales" las rigideces abstractas del Movimiento Moderno, y en el número monográfico de viviendas unifamiliares de "Architectural Record" (abril 1988) valoradas por su "local colour", me sonrío pensando que fue precisamente ese plasticismo abstracto, sin ninguna referencia al paisaje físico, cultural y social, la primera causa que -allá por el año 1948- me descalificó al Movimiento Moderno. Por reacción, yo había sentido la necesidad de incorporar, como hice en 1950 en el Proyecto del Instituto Laboral de Daimiel, el primer factor a tener en cuenta en toda arquitectura, la tierra en la que el edificio se asienta. Un edificio es como un árbol, está plantado en su paisaje"269

II

Fisac se aproxima al paisaje de una forma estética y sensitiva, y por tanto puramente humana. Una de sus primeras aproximaciones al paisaje, y quizás ello es lo que le aporta una profunda y certera belleza, surge de la vinculación, con mayor o menor consciencia, con el paisaje cultural tradicional, con aquellos que -a través de lo que llamamos arquitectura popular- han tratado el suelo con sabiduría, conectando con belleza la obra del hombre y la naturaleza.

Fisac tiene enorme respeto por el suelo sobre el que construye, como hemos visto en varias obras comentadas como el Teologado de Alcobendas o la iglesia de Canfranc. Siempre existe una primera reflexión sobre la topografía y la estructura de sus formas, y se esfuerza en transmitir -incluso posteriormente a través de elementos de jardinería como rocas, etc.- que la arquitectura surgió a la par que el lugar, que está allí desde siempre. Las montañas, los ríos, las ondulaciones de una pradera o unas rocas que emergen, son elementos de la Naturaleza que trata de apropiarse para la arquitectura, afianzando la pertenencia al sitio.

Asimismo, hemos visto la importancia que el material, su textura, y la forma de construir tienen para Fisac, de manera que se relacione con el lugar y encaje con lo sustancial del paisaje formado a lo largo de la historia. En muchas ocasiones Fisac utiliza

${ }^{269}$ Fisac, M. (1989). Documentos de arquitectura, 10. Almería: Colegio Oficial de Arquitectos de Andalucía Oriental. 
materiales existentes, como él mismo llama, "a pie de obra", materiales que proceden directamente del lugar y que así facilitan que el lugar los acepte, potenciando su autenticidad y consiguiendo que el paso del tiempo por ellos vaya en paralelo con el tiempo del lugar.

La claridad y la esencialidad en la arquitectura es también un elemento importante para la comprensión de la misma. La arquitectura de Fisac se configura desde esquemas sencillos, sintéticos y precisos, que dan lugar a volúmenes claros, aun teniendo en algún caso una geometría alejada de formas elementales.

En otro orden de cosas, independientemente de la estrategia proyectual, la arquitectura de Fisac parece surgir del paisaje. Como las aldeas o los castillos que se alzan en lo alto de las montañas y que él mismo tantas veces representó en sus apuntes y acuarelas, desdibujando los límites entre lo natural y lo construido. $Y$ esta arquitectura celebra la belleza del paisaje sobre el que se erige, hace más visible su grandeza, establece un nuevo lugar de enfoque, crecen juntos e inventan un nuevo paisaje.

III

Al estudiar la obra de Fisac utilizando la construcción del paisaje como herramienta de análisis, hemos encontrado y desarrollado tres estadios entre los que oscila su mirada al paisaje: la Identidad, el Objeto, y el Hombre. Tras realizar el ejercicio a lo largo de la presente investigación, bien nos podrían servir ahora para realizar una relectura transversal de su obra, a modo de recapitulación sintética de las ideas vertidas; y no sólo como categorías puras, siendo muy interesante la consideración de las intersecciones o superposiciones entre ellas, como se muestra en la sinopsis gráfica adjunta. Esta construcción facilita una lectura de la obra de Fisac que no es lineal, ni biográfica, ni determinada por alguna de sus innovaciones estructurales o materiales.

Por tanto, la investigación realizada se constituye en una suerte de herramienta para la interpretación y revisión de la obra de Fisac.

Es paradójico que la variedad y dispersión de enfoques, -todos ellos interesantes-, desde los que se ha estudiado la obra de Fisac contraste de una forma tan decisiva con la contemplación de su obra desde esta óptica que ilumina una unidad de intención, y por tanto un entendimiento mucho más claro y esencial de su mensaje.

La gran amalgama heterogénea que conforma su producción arquitectónica se hilvana a través de la construcción del paisaje, y genera gran cantidad de referencias y conexiones a través de determinados rasgos característicos, presentes o evocados, de las arquitecturas, conformándose lo que se ha denominado constelaciones dentro de lo que podríamos llamar un mapa del cielo. De esta forma, las conexiones entre sus obras 
manchegas, las existentes en las viviendas, en sus iglesias, o incluso en las casas familiares; las más tempranas, o las realizadas después de determinado viaje, pueden mostrarnos nuevas vías de entendimiento de su obra.

Cada obra de Fisac genera un polo dentro de una suerte de mecánica de fuerzas que atrae 0 repele, ilumina 0 deja en penumbra, determinadas constelaciones arquitectónicas, vivencias, etc. las reverberaciones, resonancias y reflejos forman como una bóveda donde el equilibrio y la armonía no excluyen las necesarias tensiones. Es la construcción del paisaje la que crea y atrae, jilumina! determinados elementos que, una vez evocados, son aceptados o rechazados por la arquitectura, los irisa o los refracta.

Las citadas superposiciones nos muestran un evolución de los acuerdos personales sobre el lugar, la materia, la geometría, el espacio, la topografía, los límites, etc. obteniendo así información muy valiosa de los posicionamientos ante el paisaje que mantiene Fisac a lo largo de su vida, en función de los retos a los que se enfrenta.

Identidad, Objeto y Hombre son tres aproximaciones a la obra del maestro manchego desde el paisaje. Y es precisamente este análisis el que, además de posibilitarnos una lectura singular y diferente de su obra, nos conduce al descubrimiento de que el conjunto de su arquitectura podría constituirse como un proyecto único.

La Identidad emerge mediante el encuentro de la esencia de los rasgos subyacentes a la Memoria y sus raíces con el paisaje sobre el que se interviene. La Identidad surge de la contemplación del paisaje que le es propio: el horizonte manchego, el agua, Las Tablas fluviales de Daimiel, la superficie viva de la tierra, los árboles, la hierba; y del desarrollo de un sentimiento de amor por lo que contempla. Esto deviene en una actitud que no trata únicamente de no dañar, -pues nadie hace daño a lo que ama-, sino de potenciar al máximo las cualidades de lo amado. Y llega a su máximo embelesamiento en el reconocimiento de la arquitectura popular no ya como patrimonio del paisaje, sino como paisaje mismo.

El arquitecto procede de la forma más cuidadosa posible. Como el viticultor que labra una viña y que ama la tierra. Y se generan habitaciones abiertas al cielo en las que el espacio fluye, interacciones con la topografía, capturas del horizonte, etc. Se reafirma de este modo la consideración fisacquiana del posicionamiento del hombre ante el paisaje, así como la emoción inherente a la contemplación de la naturaleza desde un nuevo jardín -el cielo en la tierra-, creando un nuevo paisaje.

Esta idea no sólo recoge la arquitectura, también otras intervenciones en el paisaje como terrazas, miradores o caminos realizados por Fisac generan una bella invención del paisaje, producida por el cuidado con el que se trata a la tierra, la vegetación, etc, en definitiva a la naturaleza, ya que manifiestan un pacto de respeto, la vinculación que tiene el hombre del suelo, porque de él depende su sustento. 
La constatación de estos fundamentos en el estudio realizado sobre el Instituto Laboral de Daimiel nos hace ver que este posicionamiento ante el paisaje no es estático: Fisac camina el paisaje, no sólo lo contempla. Va y viene continuamente, hilvanando una trayectoria a través de sus Aprendizajes, sin soltarse del cordón umbilical que lo une a su Memoria, y esencialmente al paisaje. Fisac redefine el paisaje tradicional mediante una serie de elementos de una gramática propia con capacidad de activar el lugar, de inyectarle una energía que permite entender su identidad de forma diferente. Esos elementos proceden, como explicaba Dimitris Pikionis parafraseando a Aristófanes del hálito que emerge de lo más profundo de la tierra ${ }^{270}$.

Por su parte, el Objeto encuentra la medida, la forma y la geometría adecuados, de manera que fluye en él la armonía de articularse en el paisaje, la concordancia que emana de la aceptación del mismo, y también la tensión adecuada a esos acuerdos. El Objeto, materia de experimentación en sí misma y en sus relaciones con el lugar en el que se asienta, recoge una evolución en la que la arquitectura corpórea, con delimitaciones algo rígidas, ligada a la tierra y de carácter estereotómico; va dejando paso a una cierta arquitectura de la fluencia, en la que lo tectónico se hace presente, dejándose penetrar por la Naturaleza.

Los Objetos construidos por Fisac en el paisaje tratan siempre de entablar una relación con el lugar, con la tierra, con la cultura e idiosincrasia de las gentes que allí habitan, manifestando así su propio valor y haciendo que el lugar brille con una nueva luz. Surge así un elemento que no sólo impide la desaparición del paisaje, sino más bien mantiene la esperanza de su permanencia en el tiempo.

Estas ideas afloran en el tránsito intelectual -si se permite la expresión- que existe entre los proyectos de Valladolid y Alcobendas, ambos para la Orden de los Dominicos.

La última aproximación a la obra de Fisac desde el paisaje como herramienta de análisis es la del Hombre. El Hombre se erige como centro de la arquitectura de Fisac, pero proponemos aquí que también es el centro de la construcción del paisaje. De esta forma, a través de los Aprendizajes sobre los que se ha profundizado, y de la utilización de una determinada gramática, se vincula el hombre al lugar y se le hace partícipe de la emoción de un nuevo paisaje. Fisac hace que el paisaje suene en la arquitectura; un nuevo delante y detrás, un nuevo arriba y abajo se adueña de él para que un nuevo todo se adueñe de nosotros con renovado aura.

Con este proceder, el paisaje brilla con una nueva luz después de la arquitectura. Arquitectura que es el paisaje mismo.

270 Cfr. Pikionis, D. (1966) In a waste place. Discurso de ingreso a la Academia de Atenas, que nunca fue

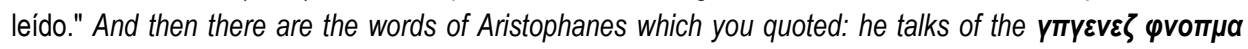
which means the breath that emerges from the soil of the earth". 
Si continuamos transitando sobre estas constelaciones que a la luz del paisaje nos permiten considerar de forma distinta la vida y obra de Fisac, parece ésta un viaje circular, con salida y regreso a La Mancha. La humanización y universalidad buscada siempre encuentra conexiones en los conceptos y esencias del paisaje manchego. Así, Fisac convierte en cuerpo nuevo el alma del pasado, a través de una visión global y universalizadora de las tradiciones y de su interpretación de la Naturaleza. De esta forma, se convierte en relevante aquello que no cambia.

El análisis de ciertas obras eleva decididamente los planteamientos e intuiciones que nos hacíamos con carácter previo a esta investigación. No esperábamos encontrar tal cantidad de referencias pedagógicas en la defensa del entendimiento de la arquitectura "con humanidad y con paisaje". Una obra -la de Fisac-, que por su complejidad y por la manera tradicional de abordarse su estudio, nos estaba ocultando un valioso tesoro en su interior, adelantado a su tiempo en sensibilidad. En palabras de Ortega, los árboles nos impedían ver el bosque.

Si la arquitectura orgánica en la que se ha tratado de etiquetar a Fisac es una arquitectura adecuada al tiempo, adecuada al lugar, y adecuada al hombre; aquí hemos visto como el maestro daimieleño va más allá: no se adecúa al lugar, va en busca del lugar, no se adecúa al hombre, va en busca del hombre, y no se adecúa a su tiempo, porque al filtrarse a través de la Memoria -como hemos visto- absorbe un carácter universal y adelantado a su tiempo.

IV

No podíamos finalizar este texto sin introducir un elemento muy relevante para el entendimiento de la arquitectura de Fisac, y en concreto para la construcción del paisaje: la concepción trascendente de la vida humana y su arraigada espiritualidad. En este sentido, el arquitecto tenía especial inclinación hacia la obra del místico San Juan de la Cruz, -de quién originariamente procede el conocido "no sé qué" de su itinerario proyectual-.

Atreviéndonos a traslucir ciertas valencias aquí enunciadas a la luz del pensamiento de San Juan de la Cruz, con el cuidado de quien prueba fruta del cercado ajeno, descubrimos que se podrían tender puentes entre las tres aproximaciones propuestas en esta investigación para el análisis de la construcción del paisaje -Identidad, Objeto y Hombre- y las dimensiones constitutivas del alma -las potencias- que el santo de Ontiveros propone en su Antropología: Memoria, Entendimiento y Voluntad; aquellas que han de vaciarse primero para llenarse de las tres principales virtudes y así poder acercarse -dice el místico- a la contemplación de Dios. 
Así, la Identidad se conecta con la Memoria, y traza un camino hacia la innovación en el que se despoja de ciertos apegos a referencias tradicionales para quedarse con la esencia de las cosas.

El Objeto, ensambla con el Entendimiento. Desde este foco, el arquitecto concibe las cosas, las compara, experimenta sobre ellas e induce otras distintas a las que ya conoce.

Y el Hombre, relacionado con la Voluntad, se reafirma en su libertad activa y positiva al permitir que el paisaje penetre la arquitectura, y ésta lo acepte, de forma que el nuevo todo brille con mayor luz.

Fisac no tiene un posicionamiento pasivo ante el paisaje, de exclusiva contemplación. Su posicionamiento es activo, recorre el paisaje ${ }^{271}$, asciende el camino. En este sentido, la construcción del paisaje en Fisac oscila en ascensión zigzagueante hacia una búsqueda -no lo llamaremos Monte Carmelo-, que se mueve entre el Aprendizaje y el Experimento. Él necesitó construir las bases de su arquitectura "desde cero", definiendo sus propios ejes de referencia, y se aupó para ello en la Memoria. Sería interesante pensar que los versos de San Juan hubieran tenido para Fisac un significado especial, un cierto carácter de guía biográfica respecto de su arquitectura en el contexto aquí estudiado:

Para venir a gustarlo todo, no quieras tener gusto en nada.

Para venir a saberlo todo, no quieras saber algo en nada.

Para venir a poseerlo todo, no quieras poseer algo en nada.

Para venir a serlo todo, no quieras ser algo en nada. Para venir a lo que no gustas, has de ir por donde no gustas. Para venir a lo que no sabes, has de ir por donde no sabes Para venir a poseer lo que no posees, has de ir por donde no posees.

271 Se trata de una referencia a Kessler, para quien la percepción visual es apenas un componente más de las formas que tiene una persona de relacionarse con el paisaje. En su estética del paisaje, involucra al resto de los sentidos. Cfr. Kessler, M. (2000) El paisaje y su sombra. Barcelona: Idea Books. 


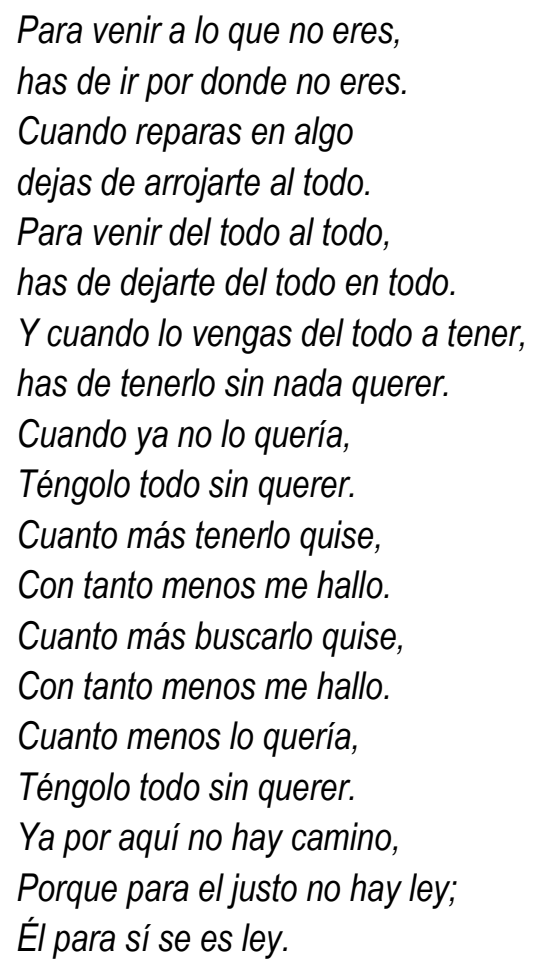

Si aceptamos que el hombre está compuesto de cuerpo y alma, y realizamos el ejercicio de trascender ahora de lo propiamente físico de aquel "trozo de aire humanizado" que proponía Fisac, podemos encontrar conexiones con la vertiente espiritual de lo humano.

Porque a través de la construcción del paisaje conecta Fisac la arquitectura y la naturaleza, el tiempo con lo intemporal, lo finito con lo infinito. $Y$ nos gustaría pensar que, quizás, la búsqueda del arquitecto se encuentra con las respuestas del místico. Porque en el camino recorrido a través de la construcción del paisaje, si podemos ver en la Naturaleza la creación de Dios, a través de la Arquitectura en la Naturaleza, por la intervención del hombre, podemos experimentar a Dios mismo ${ }^{272}$.

Madrid, otoño de 2015

272 Nos referimos aquí al texto del poeta persa del s. XIII Rumí referido por L. Kahn en la Conferencia a estudiantes de arquitectura de la ETH de Zurich. Cfr. Norberg-Schulz, C. (1981). Louis I. Kahn, idea e imagen, 105. Madrid: Xarait 


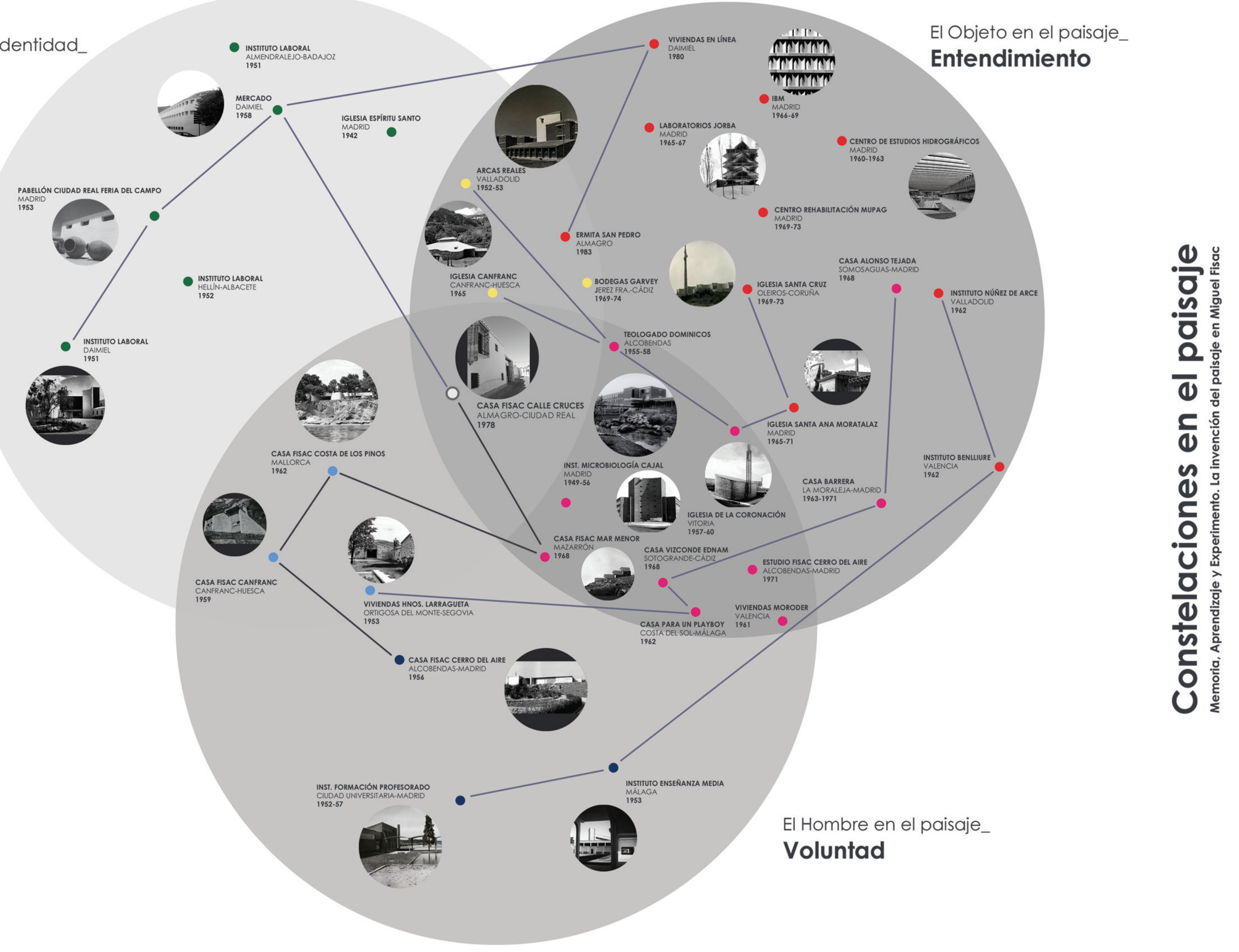


Memoria, Aprendizaje y Experimento. La invención del paisaje en Miguel Fisac Bibliografía

\section{7_BIBLIOGRAFÍA}

[Redactadas según normas APA, 6 a edición]

\section{1_ Bibliografía específica Miguel Fisac}

Libros como autor

Libros y publicaciones monográficas

Artículos como autor o participante

Artículos de investigación o divulgación sobre Miguel Fisac

Prensa, magazines y dominicales

\section{2_ Bibliografía específica paisaje}

Libros

Artículos de investigación y publicaciones en revistas especializadas

\section{3_Bibliografía general}

Libros

Artículos de investigación y publicaciones en revistas especializadas

Páginas web y hemerotecas digitales

Redes Sociales

Tesis doctorales de interés

Bibliografía literaria 


\section{1_ Bibliografía específica Miguel Fisac}

\section{Libros como autor}

Fisac, M. (1969a). La molécula urbana: una propuesta para la ciudad del futuro. Madrid: Ediciones y Publicaciones Españolas (Epesa).

Fisac, M. (1985). Arquitectura popular manchega. Discurso de ingreso en el instituto de Estudios Manchegos. Edición 2005. Ciudad Real: Colegio de Arquitectos.

Fisac, M. (1982a). Carta a mis sobrinos (estudiantes de arquitectura). Edición 2007. Ciudad Real: Fundación Miguel Fisac y Lampreave y Millán editorial.

Fisac, M. (1982b). Mi estética es mi ética. Ciudad Real: Museo de Ciudad Real.

\section{Libros y publicaciones monográficas}

Arqués, F. (1996). Miguel Fisac, Arquitecto. Madrid. Pronaos

Asensio-Wandosell, C. (2004). Miguel Fisac. Ensamblaje con vacíos. 1959-68. Colección Arquitecturas ausentes del siglo XX, 7. Ministerio de Vivienda. Madrid: Editorial Rueda, S.L.

Cortés, J.A. (2001). Miguel Fisac, el último pionero. Valladolid: Colegio Oficial de Arquitectos de Castilla y León Este.

Delgado Orusco, E. (2007). Santa Ana de Moratalaz 1965-1971. Miguel Fisac. Archivos de Arquitectura. España Siglo XX. Almería: Colegio Oficial de Arquitectos

Morales, F. (1960). Arquitectura religiosa de Miguel Fisac. Madrid: Distribuidora Librería Europa.

Morales Saro, M.C. (1979). La arquitectura de Miguel Fisac. Ciudad Real: Colegio de Arquitectos. 
Morell, A. (2005). Miguel Fisac. El espacio dinámico. Guadalajara: Colegio Oficial de Arquitectos de Castilla La Mancha.

Fullaondo, J.D. (1972). Miguel Fisac. Colección Artistas Españoles Contemporáneos. Madrid: Ministerio de Educación y Ciencia, Servicio de Publicaciones.

Peris, D. (2014). El espacio religioso de Miguel Fisac. Ciudad Real: Serendipia editorial.

Peris, D. (2015). Miguel Fisac. Arquitecturas para la investigación y la industria. Madrid: Bubok

Roda Lamfus, P. de (2007). Miguel Fisac apuntes y viajes. Madrid: Scriptum.

W.AA. (2007). Miguel Fisac. Huesos varios. Catálogo de la exposición al cuidado de Fermín González Blanco. Madrid: Fundación COAM

\section{Artículos como autor o participante}

Fisac, M. (1958). Arquitectura y Urbanismo. Hogar y Arquitectura, 15, 44-67.

Fisac, M. (1981). Asplund en el recuerdo. Quaderns de arquitectura i urbanisme, 147, 32-33. Octubre

Fisac, M. (1953). Cartas al Director. Revista Nacional de Arquitectura, 138, 9-11. Junio.

Fisac, M. (1958). Centro de formación del profesorado: Enseñanza laboral. Ciudad Universitaria, Madrid. Informes de la construcción, 106. Diciembre

Fisac, M. (1956). Centro de investigaciones biológicas. Informes de la construcción, 184. Octubre.

Fisac, M. (1955). Colegio Apostólico de los PP. Dominicos en Valladolid. Revista nacional de Arquitectura, 157, 3-9. Enero.

Fisac, M. (1961). Comentarios a los Artículos de Reyner Bahnam. Arquitectura, 26, 2728. Febrero.

Fisac, M. (1958). Conjunto de edificios para formación del profesorado de enseñanza laboral en la Ciudad Universitaria, Madrid. Revista Nacional de Arquitectura, 203, 3-10. Noviembre

Fisac, M. (1969). El hormigón pretensado. Arquitectura, 127, 2. Madrid. 
Fisac, M. (1963). Futuro, hombre y arquitectura. Cuadernos hispanoamericanos.

Fisac, M. (1967). Iglesia de Santa Ana. Breves reflexiones de Miguel Fisac. Arquitectura, 99. Marzo.

Fisac, M. (1954). Iglesia del Colegio Apostólico de los Padres Dominicos, Valladolid. Miguel Fisac. Informes de la Construcción, 66.

Fisac, M. (1960). Iglesia parroquial de la Coronación de Nuestra Señora en Vitoria. Arquitectura, 17, 36-40. Mayo.

Fisac, M. (1953). Instituto laboral de Daimiel. Revista nacional de Arquitectura, 139, 314. Julio.

Fisac, M. (1954). Institutos laborales (concurso). Revista nacional de Arquitectura, 153, 1-44. Septiembre.

Fisac, M. (1951). Intervención sobre Alvar Aalto. Boletín de la Dirección General de Arquitectura, 18, 17. Segundo trimestre.

Fisac, M. (1948a). Las tendencias estéticas actuales. Boletín de la Dirección General de Arquitectura, 9. Diciembre.

Fisac, M. (1948b). Lo Clásico y lo Español. Revista Nacional de Arquitectura, 78, 197198. Junio. Madrid.

Fisac, M. (1989). Miguel Fisac Serna. Colección Documentos de Arquitectura 10. Almería: Colegio Oficial de Arquitectos de Andalucía Oriental.

Fisac, M. (1950b). Notas sobre la Arquitectura Sueca. Boletín de la Dirección General de Arquitectura, 14. Abril.

Fisac, M. (1971). Problemas actuales del urbanismo. Arbor, 79, 21. Retrieved from http://search.proquest.com/docview/1301384078?accountid=14712

Fisac, M. (1950a). Sobre la manera de ver el arte. Arbor, 49, 57-63. Enero-abril.

Fisac, M. (1960). Teologado de San Pedro Mártir para los PP. Dominicos en Madrid. Arquitectura, 17, 9-19

Fisac, M. (1952). Un nuevo ladrillo. Revista Nacional de Arquitectura, 127, 40-42. Julio

Fisac, M. (1953). Valor actual de las arquitecturas populares. Intervención en las Sesiones de Crítica de Arquitectura de Madrid. Revista Nacional de Arquitectura, 137. Mayo. 
Fisac, M. (1951). Viviendas en cadena.

Fisac, M. (1957). Vivienda unifamiliar, Madrid. Revista Nacional de Arquitectura, 186, 59. Junio

\section{Artículos de investigación o divulgación sobre Miguel Fisac}

Arqués, F. (2006). Miguel Fisac (1913-2006). Un propósito experimental. Informes de la Construcción, 58, 503, 5-9.

Ballesteros, J. y Barahona, M. (1998). Entrevista a Miguel Fisac. Pasajes de Arquitectura y Crítica, 1, 36. Madrid.

Campo Baeza, A. (1994). La belleza rebelde. Arquitectos, 135, 83-84.

Casa Fisac en Costa de los Pinos, Son Cervera. Mallorca. (1964). Hogar y Arquitectura, 51, 23-27. Marzo-Abril

Casa-refugio en Canfranc, Huesca. (1962). Hogar y Arquitectura, 41, 33-35. JulioAgosto

Castro, C. (1971). Los arquitectos critican sus propias obras: Miguel Fisac, Edificio I.B.M. y Laboratorio Jorba en Madrid. Arquitectura, 151, 44.

Centro de Formación del Profesorado (2003). Revista AV Monografías, 101, 40-43.

Delgado Orusco, E. (2007). Las iglesias de Miguel Fisac. Actas del Congreso Internacional de Arquitectura Religiosa Contemporánea, 1, 130-168. A Coruña: Escuela Técnica Superior de Arquitectura.

Fernández-Galiano, L. (2003). Laboratorios Jorba: 1965-1967, Madrid. AV monografías, 101, 78-83. Madrid.

Fernández Isla, J.M. (1997). Miguel Fisac, vivienda en el Cerro del Aire: Madrid, 1956. Arquitectura, 309, 61-63. Primer trimestre.

García-Gutiérrez Mosteiro, J. (2000). Un trozo de aire humanizado. conversación con Miguel Fisac. Cuadernos Hispanoamericanos, 606, 95-104.

González Amezqueta, A. (1965). Las Iglesias de Fisac. Hogar y Arquitectura, 59, 49-53.

González Blanco, F. (2006). Razón y ser de los tipos. Informes de la Construcción, 58, $503,41-48$. 
González Calero, A. (1998). Miguel Fisac: la arquitectura es un trozo de aire humanizado. Añil: Cuadernos de Castilla - La Mancha, 14, 42-46. Ciudad Real.

Iglesia parroquial, Canfranc, Huesca. (1965). Hogar y Arquitectura, 57, 46-49. MarzoAbril.

Instituto de Óptica Daza de Valdés de Miguel Fisac, 1948, c/ Serrano 115, Madrid (1983). Arquitectura, 241, 32-33. Marzo-Abril

Laboratorios Made, S.A., en el km. 5.800 de la carretera Madrid-Alcobendas. (1966). Hogar y Arquitectura, 64, 16-21. Mayo-Junio

López-Peláez, J.M. (1983). Innovación y tradición en la obra de Fisac. Arquitectura, 241, 47-50. Marzo-Abril.

Loren-Méndez, M. (2012). Tecnología, materia y lugar: Procesos de modernización en la obra española de la posguerra. Instituto de enseñanza media, Málaga. Arquitecto: Miguel Fisac. Informes de la Construcción, 64, 526, 167-177.

Navarro, M.I. (2003). Miguel Fisac 2003. Basa, 27, 5-39. La Palmas: Colegio Oficial de Arquitectos de Gran Canaria.

Oteiza, I. (2006). Dos obras de Miguel Fisac. Informes de la Construcción, 503, 65-87. Madrid

Sentieri Omarrementería, C. y Castellanos, R. (2010). Más vueltas. Erick Gunnar Asplund, Miguel Fisac, Alejandro de la Sota... y Carlos Puente. En VV.AA. Viajes en la transición de la arquitectura española hacia la modernidad. Pamplona: Escuela Técnica Superior de Arquitectura Universidad de Navarra.

Sesión Crítica de Arquitectura dedicada a la iglesia de los PP. Dominicos de Valladolid. Revista nacional de Arquitectura, 157, 10-19. Enero.

VV.AA. (1969). Nueva Forma, 39, 3-64.

VV.AA. (1969). Nueva Forma, 41, 3-65.

\section{Prensa, magazines y dominicales}

Fisac, M. (1956). Bangkok. La Actualidad Española, 209. 5 de enero.

Fisac, M. (1955). Calcuta. La Actualidad Española, 207. 23 de diciembre. 
Memoria, Aprendizaje y Experimento. La invención del paisaje en Miguel Fisac

Bibliografía

Fisac, M. (1957). Día mundial del urbanismo. Blanco y Negro, 2375. Noviembre

Fisac, M. (1957). El paisaje. Blanco y Negro, 2349. Mayo.

Fisac, M. (1960). Enseñanzas de una exposición de arquitectura finlandesa. Blanco y Negro, 2495, 50-53. 27 de Febrero

Fisac, M. (1955). Jerusalén. La Actualidad Española, 205. 8 de diciembre.

Fisac, M. (1957). La calle. Blanco y Negro, 2373. Octubre.

Fisac, M. (1954). Leyes para hacer belleza. ABC, 21-22. Edición 14 de febrero. Madrid

Fisac, M. (1956). Manila. La Actualidad Española, 211. 19 de enero.

Fisac, M. (1956). Nueva York. La Actualidad Española, 219. 15 de marzo.

Fisac, M. (1956). Tokio. La Actualidad Española, 213. 2 de febrero.

Fisac, M. (1959). Salvemos las zonas verdes. Blanco y Negro, 2450. 18 de Abril

Fisac, M. (1956). San Francisco, Los Ángeles, Hollywood. La Actualidad Española, 215. 16 de febrero.

\section{2_ Bibliografía específica sobre el paisaje}

\section{Libros}

Appleton, J. (1975). The Experience of Landscape. Segunda edición revisada. 1996. London-New York: John Wiley \& Sons Ltd.

Assunto, R. (1973). Il paesaggio e l'estetica. Segunda edición, 1994. Palermo: Novecento.

Berque, A. (1994). Cinq propositions pour une théorie du paysage. Seyssel: Editions Champ Vallon.

Berque, A. (2009). El pensamiento paisajero. Madrid: Editorial Biblioteca Nueva.

Berque, A. (1995). Les raisons du paysage, de la Chine antique aux environnements de synthèse. Paris: Hazan. 
Careri, F. (2002). El andar como práctica estética. Barcelona: Gustavo Gili

Cauquelin, A. (2002). L'invention du paysage. Collection Quadrige. Paris: Presses Universitaires de France (PUF).

Clark, K. (1971). El arte del paisaje. Barcelona: Seix Barral.

Emerson, R.W. El espíritu de la naturaleza. Edición 1998. Buenos Aires: Errepar.

Gómez de Liaño, I. (1990). Paisajes del placer y de la culpa. Madrid: Tecnos

Gregotti, V. (1966). El territorio de la arquitectura. Edición 1974. Barcelona: Gustavo Gili.

Hernández de León, J.M. (2007). La resonancia del lugar. Arquitectura contemporánea y contexto. En WV.AA. Arquitectura y ciudad. La tradición moderna entre la continuidad y la ruptura. Madrid. Editorial Círculo de Bellas Artes.

Humboldt, A. von (1858). Cosmos. Ensayo de una descripción física del mundo por Alejandro de Humboldt. Edición 2011. Madrid: Consejo Superior de Investigaciones Científicas (CSIC)

Jellicoe, G. (1975). El paisaje del hombre, La conformación del entorno desde la Prehistoria hasta nuestros días. Edición 1995. Barcelona: Gustavo Gili.

Kessler, M. (1999). El paisaje y su sombra. Barcelona: Idea Books.

Laffón, C. (2000). Visión de un paisaje. Discurso de ingreso en la Real Academia de Bellas Artes de San Fernando. Madrid.

Maderuelo, J. (2005). El paisaje. Génesis de un concepto. Madrid: Abada Editores.

Maderuelo, J. (1996). Nuevas visiones de lo pintoresco: El paisaje como arte. Lanzarote: Fundación Cesar Manrique.

Maderuelo, J. (2010). Paisaje y patrimonio. Madrid: Abada Editores.

Mcharg, I (1967). Proyectar con la naturaleza. Edición, 2000. Barcelona: Gustavo Gili. .

Milani, R. (2007). El arte del paisaje. Madrid: Biblioteca Nueva.

Norberg-Schulz, C. (1976). Genius Loci. Edición 2003. Milán: Electa

Ritter, J. (1963). Paesaggio. Uomo e natura nell'età moderna. Edición 2001. Mlián: Guerini e Associati. 
Rubió y Tudurí, N. (1953). Del paraíso al jardín latino. Edición 1981. Barcelona: Tusquets.

W.AA. (2005). Paisaje de los paisajes. Edición al cuidado de José Manuel Vidal. Valencia: Asociación Arquitectes pel paisatge del Collegi de Arquitèctes de la Comunitat Valenciana.

Watsuji, T.(1935). Antropología del paisaje: climas, culturas y religiones. Edición 2006. (Primera edición española 1973). Salamanca: Ediciones Sígueme.

Zimmer, J. (2008). La dimensión ética de la estética del paisaje. En Nogué, J.(ed.). El paisaje en la cultura contemporánea, 27-44. Madrid: Biblioteca Nueva.

\section{Artículos de investigación y otros documentos}

Ando, T. (1990a). Composición espacial y Naturaleza. El Croquis, 44. El Escorial: Editorial El Croquis.

Ando, T. (1990b). Naturaleza hecha abstracción. El Croquis, 44. El Escorial: Editorial El Croquis.

Ando, T. (1993). Pensando en el Ma, entrando en el Ma. El Croquis, 58. El Escorial: Editorial El Croquis.

Assunto, R. (1980). Paesaggio, ambiente, territorio: un tentativo di precisazione concettuale. Rassegna di architettura e urbanistica, 47-48. Milán.

Barba i Casanovas, R. (1982). El proyecto de lugar. Quaderns d'Arquitectura i Urbanisme, 153. Barcelona: Col-legi de Arquitectes de Catalunya.

Berque, A. (2008). El amor al paisaje destruye el campo. Le Monde Diplomatique, 18 (edición española), febrero.

Berque, A. (1990). En el origen del paisaje. Revista de Occidente, 189. Madrid.

Bretagnolle, A. (1990). El mensaje intemporal de la Naturaleza. El Croquis, 44. El Escorial: Editorial El Croquis.

Convenio Europeo del Paisaje (2000). Boletín oficial del Estado (BOE), 31, 6259-6263. 5 de febrero de 2008. Estrasburgo: Consejo de Europa.

Corajoud, M. (1989). Le paysage est l'endroit. L'Architecture d'Aujourd'hui, 262. Paris. 
Criado-Boado, F. (1999). Del terreno al espacio: planteamientos y perspectivas para la arqueología del paisaje. Santiago de Compostela: Universidad de Santiago, 1999.

Farinelli, F. (1991). L'arguzia del paesaggio. Casabella, 575-576. Milán.

Farinelli, F. (2003). La Natura del Paesaggio. Parametro, 245. Faenza.

Frampton, K. (1990). En busca del Paisaje Moderno. Arquitectura, 285, 52-73

Gregotti, V. (1965). La forma del territorio. Edilizia Moderna, 87-88. Milán.

Gregotti, V. (1993). La realidad sentida. El padre de un nuevo minimalismo. A\&V, 40. Madrid

Gregotti, V. (1991). Progetto di paesaggio. Casabella, 575-576. Milán.

López Ontiveros, A. (2009). Valor, significado e identidad del campo y de los paisajes rurales españoles según Unamuno. Boletín de la Asociación de Geógrafos Españoles, 51, 127-152.

Maderuelo, J. (1995). Arte y naturaleza. Actas: Arte y Naturaleza, Huesca: Diputación Provincial.

Maderuelo, J. (1997). El Paisaje. Actas: Arte y Naturaleza, Huesca: Diputación Provincial.

Nogué, J. (2009). El valor de la contemplación. La Vanguardia, 22. Edición 14 de octubre. Barcelona.

Norberg-Schulz, C. (1966). Il paesaggio e l'opera dell'uomo. Edilizia Moderna, 87-88. Milano.

Ortega Cantero, N. (2004). Naturaleza y cultura en la visión geográfica moderna del paisaje. En ORTEGA CANTERO (coord.). Naturaleza y cultura del paisaje, 939. Madrid: Universidad Autónoma y Fundación Duques de Soria.

Zoido, F. (2012). El paisaje un concepto útil para relacionar estética, ética y política. Scripta Nova. Revista Electrónica de Geografía y Ciencias Sociales. [En línea]. Barcelona: Universidad de Barcelona, 10 de julio de 2012, vol. XVI, n ${ }^{0}$ 407. <http://www.ub.es/geocrit/sn/sn-407.htm>. 


\section{3_Bibliografía General}

\section{Libros}

Aparicio Guisado, J. (2000). El muro. Colección Textos de Arquitectura y Diseño. Palermo: Universidad de Palermo.

Bachelard, G. (1942). El agua y los sueños. ensayo sobre la imaginación de la materia. México, D.F.: Fondo de Cultura Económica.

Bachelard, G. (1957). La poética del espacio. Segunda edición, 1975. Madrid: Fondo de Cultura Económica.

Benévolo, L. (1974). Historia de la Arquitectura Moderna (6 $6^{\mathrm{a}}$ ed. ampliada). Barcelona: Gustavo Gili.

Berger, J. (1997). Algunos pasos hacia una pequeña teoría de lo visible. $6^{\text {a }}$ reimpresión, 2009. Madrid: Ardora ediciones.

Brooks Pfeiffer, B. (1998). Frank Lloyd Wright. Barcelona: Gustavo Gili.

Campo Baeza, A. (2008). Aprendiendo a pensar. Madrid: Nobuko

Campo Baeza, A. (1996). La idea construida. Colección Textos dispersos. Madrid: Colegio Oficial de Arquitectos.

Cheng, F. (2006). Cinco meditaciones sobre la belleza. $2^{a}$ Edición, 2012. Madrid: Siruela.

Climent, F. (2000). Jørn Utzon. Dos casas en Mallorca. Palma de Mallorca: Consellería de Turismo. Govern de les Illes Balears.

Deleuze, G. (2000). Francis Bacon. Lógica de la sensación. Madrid: Arena libros, S.L.

Delgado Orusco, E. (2013). Alvar Aalto en España. Madrid: Casimiro.

Delgado Orusco, E. (2006). Entre el cielo y el suelo. Madrid: Fundación Institución Educativa SEK

Eliade, M. (1956). Lo sagrado y lo profano. Edición 1998. Barcelona: Paidós.

Fernández Alba, A. (1997). Esplendor y fragmento. Escritos sobre la ciudad y la arquitectura europea 1945-1995. Madrid: Biblioteca Nueva. 
Frampton, K. (1981). Historia Crítica de la Arquitectura Moderna. Séptima edición, 1994. Barcelona: Gustavo Gili.

Frampton, K. (1995). Studies in Tectonic Culture: The Poetics of Construction in Nineteenth and Twentieth Century Architecture. Editado por John Cava. Edición 2001. MIT University Press Group, Ltd.

García Mercadal, F. (1930). La casa popular en España. Madrid. Espasa Calpe.

Gazapo, D. y Lapayese, C. (2000). Oteiza: Paisaje...Dimensiones. Madrid: Fundación Capa.

Giedion, S. (1941). Espacio, tiempo y arquitectura. Origen y desarrollo de una nueva tradición. Colección Estudios Universitarios de Arquitectura, 17. Traducción: Jorge Sáinz. Edición 2009. Barcelona. Editorial Reverté, S.A.

Heidegger, M. (1927). El Ser y el Tiempo. (Rivera, J.E., traductor). Edición 2003. Madrid: Trotta.

Hertzberg, M. (2004). Wright in Racine. The architect's vision for one American City. Portland, US: Pomegranate Communications Inc.

Jeanneret, C.E. (1966). El viaje de Oriente. Edición 1984. Valencia: Colegio Oficial de Aparejadores y Arquitectos Técnicos de Murcia y otros.

Le Corbusier (1923). Hacia una arquitectura. Edición 1977. Barcelona: Ediciones Apóstrofe, S.L.

Le Corbusier (1957). Ronchamp. Stuttgart: Verlag Gerd Hatje.

Linazasoro, J.I. (2011). Otras vías: Pikionis, Lewerentz y Van der Laan. Buenos Aires: Nobuko

Kurokawa, K. (1991). Intercultural Architecture. The philoshophy of symbiosis. London: Academy Editions

López- Peláez, J.M. (2002). La arquitectura de Gunnar Asplund. Colección Arquithesis, 11. Barcelona: Fundación Caja de Arquitectos.

López-Peláez, J.M. (2007). Maestros cercanos. Barcelona: Fundación Caja de Arquitectos

Llobet, X. (2007). Hilberseimer y Mies. La metrópoli como ciudad jardín. Colección Arquithesis, 24. Barcelona: Fundación Caja de Arquitectos. 
Lynch, K. (1960). La imagen de la ciudad. Tercera edición, 1998. Colección GG Reprints. Barcelona. gustavo Gili.

Martínez Santa-María, L. (2004). El árbol, el camino, el estanque, ante la casa. Colección Arquithesis, 15. Barcelona: Fundación Caja de Arquitectos.

Merleau-Ponty, M. (1945). Fenomenología de la Percepción. Edición 1975. Barcelona: Península.

Moneo, R. (2004). Inquietud teórica y estrategia proyectual. Barcelona: Actar.

Moreno Mansilla, L. (2002). Apuntes de viaje al interior del tiempo. Colección Arquithesis, 10. Barcelona: Fundación Caja de Arquitectos.

Navarro Baldeweg, J. (1999). La habitación vacante. Colección Pre-textos de Arquitectura. Segunda Edición, 2001. Barcelona: Editorial Pre-textos y Colegio de Arquitectos de Catauña. Demarcación de Gerona.

Neumeyer, F. (1986). Mies Van Der Rohe. La palabra sin artificio. Edición 1995. El Escorial: El Croquis Editorial.

Nute, K. (1993). Frank Lloyd Wright and Japan. The Role of Traditional Japanese Art and Architecture in the Work of Frank Lloyd Wright. London and New York: Routledge.

Oteiza, J. (1943). Interpretación estética de la estatuaria megalítica americana. Edición al cuidado de María Teresa Muñoz, 2007. Navarra: Fundación Museo Oteiza.

Pallasmaa, J. (2006). Los ojos de la piel. La arquitectura y los sentidos. Barcelona: Gustavo Gili.

Pérez, F. (1958). Daimiel. Geografía de un pueblecito manchego. Ciudad Real: Publicaciones del Instituto de Estudios Manchegos.

Puente, M. (2010). Jorn Utzon. Conversaciones y otros escritos. Barcelona: Gustavo Gili.

Riggen, A. (2000). Luis Barragán. Escritos y conversaciones. El Escorial: El Croquis Editorial.

Siza, A. (2003). Imaginar la evidencia. Madrid. Abada editores, S.L.

Taut, B. La casa y la vida japonesas. Colección Arquitemas, 19. Barcelona: Fundación Caja de Arquitectos. 
Tuset, Juan J. (2011). Encerrar la exterioridad. Avances en la arquitectura y el jardín en Europa. Valencia: General de ediciones de Arquitectura TC Cuadernos.

Venturi, R. (1966). Complejidad y contradicción en arquitectura. Barcelona: Gustavo Gili.

VV.AA. (1993). Manifiesto de la Alhambra. Dirección General de Arquitectura del Ministerio de la Gobernación. Edición Fundación Rodríguez Acosta, 1993. Granada: Colegio Oficial de Arquitectos de Andalucía Oriental

VV.AA. (2005). Robert Smithson. Spyral Jetty. California: University of California Press.

Wrede, S. (1985). Paisaje y arquitectura: clásico y vernáculo en Asplund. En Asplund, 41-46. Edición 1988. Barcelona: Gustavo Gili

Wright, F. LI. (1961). La Ciudad Viviente. Traducción Aníbal Leal. Buenos Aires: Compañía General Fabril Editora.

Yoshida, T. (1969). The Japanese House and garden. Londres: Pall Mall.

Zumthor, P. (2004). Atmósferas. Entornos arquitectónicos. Las cosas de mi alrededor. Barcelona: Gustavo Gili.

Zumthor, P. (2010). Pensar la Arquitectura. Tercera edición ampliada, 2014. Barcelona: Gustavo Gili.

\section{Artículos de investigación y publicaciones en revistas especializadas}

Cagijas, Y. (2010). Cartas de Josemaría Escrivá de Balaguer a Dolores Fisac (21 de mayo de 1937 - 16 de noviembre de 1937). Studia et Documenta, 4, 375-409. Roma: Instituto Histórico San Josemaría Escrivá.

Castro Morales, F. (2005): "Teoría y momentos del paisaje. Segundo momento: Sur, Paisaje Nativo. Miguel de Unamuno en Fuerteventura: una poética del paisaje antihumboldtiana", en Castro Morales, F. y Otros: Islas Raíces. Visiones insulares en la vanguardia de Canarias. Santa Cruz de Tenerife: Viceconsejería de Cultura y Deportes, y Fundación Pedro García Cabrera.

Coca Leicher, J. de. (2010). Fragmentos de paisaje y arquitectura. El pabellón de Ciudad Real en la II F.I.C., 1953. Revista Proyecto, Progreso, Arquitectura, 2, 34-45. Superposiciones en el territorio. Sevilla: Universidad de Sevilla. 
Curtis, W. (2000). Notas sobre la invención: Álvaro Siza. El Croquis, 68/69+95. El Escorial: El Croquis Editorial.

Curtis, W. (1995). Paisajes míticos. AV Monografias, 54: Frank Lloyd Wright, 16-19. Madrid: Arquitectura Viva.

Delgado Orusco, E. (2002). Alvar Aalto en El Escorial. Actas del Simposium El Monasterio de El Escorial y la arquitectura, 8/11-9-2002, 437-460. San Lorenzo de El Escorial: Real Centro Universitario Escorial-Maria Cristina.

Economaki-Brunner, Y. (1991). Dimitris Pikionis: la trasformazione di un sito. Casabella, 585. Milán.

Esteban Maluenda, A. (2008). El papel de Informes de la Construcción en la difusión de la arquitectura moderna extranjera (1948-1968). Actas de las II Jornadas de investigación en construcción. Madrid: Instituto Ciencias de la Construcción Eduardo Torroja.

Frampton, K. (1986). Modernidad y Tradición en la Obra de Mies van der Rohe. En W.AA. Mies van der Rohe: Su Arquitectura y Sus Discípulos. Edición 1987. Madrid: MOPU.

Instituto-Escuela. Pabellón de Enseñanza Primaria (1983). Arquitectura, 241, 25.

Instituto de óptica Daza de Valdés (1950). Revista Nacional de Arquitectura, 102, 253260. Junio. Madrid

Marcel Breuer construye su casa (1949). Informes de la Construcción, 12. Junio-Julio.

Moreno Mansilla, L. (1994). Más allá del muro de Villa Adriana. El viaje de Lewerentz a Italia. Circo, 1994.12, 9

Navarro, M.I. (2001). Desde el origen: La arquitectura de Fernando Higueras. Basa, 24 . La Palmas: Colegio Oficial de Arquitectos de Gran Canaria.

Navarro, M.I. (2004). La crítica italiana y la arquitectura española de los años 50 . Pasajes de la arquitectura española en la segunda modernidad. Actas del Congreso Internacional Modelos alemanes e italianos para España en los años de la postguerra, 99. Pamplona: Universidad de Navarra.

Sambricio, C. (1999). En torno a 1949: Gardella, del Msa y la reconstrucción, a la moderna arquitectura. En: Ignazio Gardella, [1905-1999]. Arquitectura a través de un siglo, 13-14. Madrid: Ministerio de Fomento. 
San Antonio Gómez, C. de (2010). El viaje de Alvar Aalto a España en 1951: luces y sombras. En: "Actas del Congreso Internacional Viajes en la transición de la arquitectura española hacia la modernidad", 06/05/2010 - 07/05/2010, Pamplona, España. pp. 363-370.

San Antonio Gómez, C. de (2010). El viaje desconocido de un arquitecto olvidado. Revista De Arquitectura, 12, 25-36. Retrieved from http://search.proquest.com/docview/1243335949?accountid=14712

Trabajos recientes de Marcel Breuer. Casa del Arquitecto, Connecticut. (1953). Informes de la Construcción, 51. Mayo.

Thorne, M. (1983). Miguel Fisac. Entrevista. Quaderns d'Arquitectura i Urbanisme, 157, 100-101. Barcelona: Col-legi de Arquitectes de Catalunya.

VV.AA. (1997). Erik Gunnar Asplund. 1895-1940. Madrid. Ministerio de Obras Públicas y Urbanismo.

VV.AA. (2009). Tectónica, 30. Espacios exteriores. Octubre 2009. Madrid: ATC ediciones, S.L.

Zambrano, M. (1964) La ciudad, creación histórica. Semana (San Juan de Puerto Rico), vol. X, $n^{0} 304$. Artículo inédito en España publicado en Contrastes, 23 (2002, 73-75).

\section{Páginas web y hemerotecas digitales}

Fundación Fisac. http://www.fundacionfisac.org

Hemeroteca digital ABC. http://hemeroteca.abc.es/nav/Navigate.exe/hemeroteca

Hemeroteca Digital Biblioteca Nacional de España. http://hemerotecadigital.bne.es/index.vm

López Reche, M. (1957). Alhambra. Casa Real (Palacios Nazaríes y de Carlos V). Planta con itinerario. Original, Papel vegetal, Tinta y lápiz, $37 \times 60 \mathrm{~cm}$., 1/200, 0 . Numero de plano de la oficina técnica del servicio de conservación: 3298 , Restitución de Jesús Bermúdez Pareja sobre datos de Leopoldo Torres Balbás (1926). URI http://hdl.handle.net/10514/3223 
Marías, J. (1933). Notas de un viaje a Oriente. Diario El Sol. Domingo, 27 de agosto de 1933. Año XVIL, $\quad n^{0} \quad 5006 \quad$ Madrid. http://hemerotecadigital.bne.es/issue.vm?id=0000508696\&page=10\&search $=\& 1$ ang=es

Plataforma educativa del centro IES Nuestra Señora de la Victoria de Málaga. http://www.juntadeandalucia.es/averroes/centrostic/29005928/helvia/sitio/index.cgi?wid_seccion=12\&wid_item=83

Prieto-Moreno, F. (1945). Palacio de Carlos V. Planta baja. Proyecto de ángulo Suroeste. Original, Papel vegetal, Lápiz, tinta negra y roja, $79 \times 76 \mathrm{~cm} ., 1 / 100$, 6.1. Numero de plano de la oficina técnica del servicio de conservación: 2397. Recursos de investigación de La Alhambra. URI http://hdl.handle.net/10514/2394

\section{Redes sociales}

Para ciertos datos han sido útiles los siguientes perfiles de la red social Facebook:

\begin{tabular}{|c|c|c|c|c|c|c|}
\hline Perfil & $\begin{array}{l}\text { de } \\
\text { ps:// }\end{array}$ & $\begin{array}{l}\text { personaje } \\
\text { acebook.cc }\end{array}$ & $\begin{array}{l}\text { público } \\
\text { guel.fisa }\end{array}$ & Miguel & Fisac & Serna: \\
\hline Perfil & del & Colegio & Arcas & Reales & de & Valladolid: \\
\hline
\end{tabular}

\section{Tesis Doctorales de interés}

Alarcón, C. (1999). La Arquitectura en España a través de las revistas especializadas 1950-1970. El caso de Hogar y Arquitectura (tesis doctoral). Madrid: Universidad Politécnica de Madrid.

Arqués, F. (2003). La forma y el ordenamiento en la obra arquitectónica. El Centro de Estudios Hidrográficos de Miguel Fisac. Un para qué, un cómo y un no sé qué (tesis doctoral). Madrid: Universidad Politécnica de Madrid. 
Cabañas, N. (2014). Convento Dominico de Miguel Fisac en Madrid. El acento de los objetos. (tesis doctoral). Madrid: Universidad Politécnica de Madrid.

Campo Baeza, A. (1976). La arquitectura racionalista en Madrid (tesis doctoral). Madrid: Universidad Politécnica de Madrid.

Delgado Orusco, E. (1999). Arquitectura sacra española, 1939-1975: de la posguerra al posconcilio (tesis doctoral). Madrid: Universidad Politécnica de Madrid.

González Blanco, F. (2010). Los huesos de Fisac. La búsqueda de la pieza ideal. (tesis doctoral). Madrid: Universidad Politécnica de Madrid.

Martínez Santa-María. L. (2000). Tierra espaciada. El árbol, el camino, el estanque: ante la casa. (tesis doctoral). Madrid: Universidad Politécnica de Madrid.

Morales Saro, M.C. (1974). La arquitectura de Miguel Fisac. (tesis doctoral). Oviedo: Universidad de Oviedo. Departamento de Historia del Arte

Morell, A. (1998). Forma, espacio y construcción en la arquitectura de Miguel Fisac (tesis doctoral). Madrid: Universidad Politécnica de Madrid.

Muñoz, M. J. (1988). El minimalismo en arquitectura y el precedente de Jorge Oteiza (tesis doctoral). Madrid: Universidad Politécnica de Madrid.

Tomás Gabarrón, L. (2014). Idas y venidas. Los viajes de arquitectura en España entre 1920 y 1960 (tesis doctoral). Madrid: Universidad Politécnica de Madrid.

Quesada, S. (2006). Imitatio Naturae. El paisaje como referente en la arquitectura contemporánea (tesis doctoral). Sevilla: Escuela Técnica Superior de Arquitectura de Sevilla. Universidad de Sevilla.

\section{Bibliografía Literaria}

Casciaro, P. (1994). Soñad y os quedaréis cortos. Madrid: Rialp.

Cernuda, L. (1942). Ocnos. Edición 2009. Madrid: Turner.

Delibes, M. (1950). El camino. Edición 2006. Madrid: Destino.

Eliot, T.S.(1922). The waste land. (La tierra baldía). Edición 2015, al cuidado de Andreu Jaume. Barcelona: Lumen. 
Memoria, Aprendizaje y Experimento. La invención del paisaje en Miguel Fisac

Bibliografía

Kipling, R. (1920). Viaje al Japón. Edición 2004, al cuidado de Emili Olcina. Madrid: Editorial ABC, S.L.

Muñoz Rojas, J.A. (1999). Las cosas del campo. Madrid: Editorial Pretextos.

Ortega y Gasset, J. (1914). Meditaciones del Quijote. Madrid: Publicaciones de la Residencia de Estudiantes.

Petrarca, F. (1336). Carta a Dioni da Borgo San Sepolcro. En Francesco Petrarca. La ascensión al Mont Ventoux. Edición 2002. Vitoria-Gasteiz: Apuntes de Estética Artium

Sánchez Ferlosio, R. (1954). El jarama. Edición 2004. Madrid: Destino.

Tanizaki, J. (1933). El elogio de la sombra. Biblioteca de ensayo Siruela, I. 6ª Edición, Noviembre 1997. Madrid: Ediciones Siruela, S.A.

Unamuno, M. de (1966). Paisajes. Edición al cuidado de Manuel Alvar. Madrid: Ediciones Alcalá.

Unamuno, M. de (1983). Paisajes del alma. Segunda edición. Madrid: Alianza Editorial.

Valente, J.A. (1995). Hermenéutica y mística. San Juan de la Cruz. Madrid. Tecnos.

Ynduráin, D. (1990). Aproximación a San Juan de la Cruz. Madrid: Cátedra. 
Memoria, Aprendizaje y Experimento. La invención del paisaje en Miguel Fisac Bibliografía 
Memoria, Aprendizaje y Experimento. La invención del paisaje en Miguel Fisac

\section{8_APÉNDICES}

Apéndice 1_ Miguel Fisac a los estudiantes de arquitectura. Conferencia dictada en la Escuela Técnica Superior de Arquitectura de Valencia como clausura del curso académico, el día 31 de mayo de 1995.

Apéndice 2_Cuadernos de Viaje.

2.1_ Facsímiles del Cuaderno de Viaje a Europa

2.2_ Facsímiles del Cuaderno de Viaje alrededor del mundo [inédito]

2.3_ Transcripciones de varios cuadernos de viaje [inédito] 


\section{Apéndice 1_ Miguel Fisac a los estudiantes de arquitectura. Conferencia dictada en la Escuela Técnica Superior de Arquitectura de Valencia como clausura del curso académico, el día 31 de mayo de 1995.}

En la Escuela Técnica Superior de Arquitectura de Valencia, tras las correspondientes presentaciones y la semblanza profesional a cargo de Carmen Jordá Such, profesora del Departamento de Proyectos de la Escuela Técnica Superior de Arquitectura de Valencia, comienza la conferencia de Miguel Fisac:

Yo soy el conferenciante de esta conferencia, que no quiero que sea conferencia porque yo no he sido nunca conferenciante.

He hablado mucho de arquitectura y ahora, últimamente, sigo hablando en otro sentido, y es en poder ser útil. Y esto que yo os voy a decir, y algunas cosas os van a chocar, parecen un poco raras, pero os pueden servir en vuestra vida profesional. Me quedaré contentísimo de que a uno solo le sirva para algo. Y si no, es vanidad y es humo. Es decir que yo vengo a explicaros lo que yo he entendido por arquitectura, que ha sido bastante distinto de lo que se suele entender por arquitectura, la manera de cómo he concebido esa manera de entenderla y si os puede servir para aclararos un poco esta confusión terrible que hay en el mundo actual de la arquitectura, que es la expresión de la situación de confusión que tiene la sociedad.

Voy a empezar por pediros dos cosas. Una, igualdad de oportunidades. Vosotros estáis ahí tan fresquitos y yo estoy metido en esto. Me vais a permitir que os pida que me quite la chaqueta. Yo empiezo y luego, que cada uno haga lo que le parezca, pero es que si no voy a sudar una barbaridad y estoy ya muy viejo. En segundo lugar, que puede que algunas de las razones que yo os diga os choquen, por bien o por mal, y querríais, de alguna manera, dejar esto un poco claro. $Y$ entonces, en vez de que al final se diga "si alguno quiere decir algo"... en general no quieren decir nada y lo que dicen ya está un poco pasado. 0 sea, como yo realmente tengo aquí unos papelitos para disimular un poco, sino que yo voy sobre la marcha... quiere decir que no me molesta en absoluto 
que me interrumpan...y entonces cuando yo estoy hablando de una cosa con mucho entusiasmo (porque, eso sí, yo siempre le echo a todas las cosas mucho entusiasmo), pues me paran y me dicen "un momento, querríamos saber...", pues muy bien... vamos a saberlo. Yo voy a decir lo que siento, pero sin ninguna preocupación de querer llevar el agua a mi molino, sino sencillamente porque he entendido a lo largo de mi vida profesional lo que creo que debe ser la Arquitectura. No estoy en posesión de la verdad, pero tampoco admito que estén en posesión de la verdad otros señores muy puestos. 0 sea que vamos a aclarar y vamos a desmitificar tanto mito, que algunos de ellos son unos mitos inadmisibles. Otros tienen alguna razón para serlos... pero, en fin...

Yo he seguido un procedimiento de aprender Arquitectura bastante heterodoxo. Estuve en la Escuela, me aburrí bastante, me enseñaron cosas... pero no me enseñaron a ser arquitecto, porque creo que a ser arquitecto no se puede enseñar. Se pueden dar las herramientas suficientes y la manera de trabajar con esas herramientas para llegar a ser arquitecto. Pero cada uno tiene que formar la conciencia de que tiene uno que hacerse arquitecto. Entonces, para eso conviene tener una idea clara de lo que es ser arquitecto. Yo salí de la Escuela, había estado allí funcionando y tal... y, de pronto, a los 2 meses de terminar (porque entonces había muy pocos arquitectos y muchas obras, ¡que envidia hoy! ¿verdad? Porque ahora pasa todo lo contrario) dije ¡Bueno! ¿qué hago yo aquí con esto? Entonces, se me ocurrió que en la poquísima información que teníamos (era malo porque no sabíamos lo que se estaba haciendo en el mundo; en el mundo se estaba deshaciendo la Arquitectura, que es lo contrario de hacerla), pero, en fin, de todas maneras vi que en las poquísimas cosas que yo había visto en alguna revista, en una que se llamaba Architettura, que era una revista italiana que ponía las cosas que se estaban haciendo para una Exposición que Mussolini iba a hacer en el año 42, y que luego llegó a realizarse las obras pero no llegó a inaugurarse la Exposición. Pero eso mantenía una posición un poco clásica, bastante actual, limpia, muy bien proporcionada... Me gustó y dije: "pues no sé"... Por otra parte el Movimiento Moderno que ya había aceptado cosas anteriores que habían hecho, el resultado práctico de llevar edificios a la realidad, no nos había convencido tampoco. Entonces, aparte de que el ambiente nacional, muy patriotero, no se prestaba a hacer una arquitectura internacional muy limpia y muy estricta, tampoco había motivos para tener entusiasmo por todo aquello.

Entonces, yo me tiré al agua y dije: "Bueno, vamos a hacer esto". O sea, que la arquitectura clásica se puede decir que es la arquitectura eterna. De ahí que contextualizarla con la situación que cada país y que cada tiempo tiene para ponerla al día... Eso es así. Se me presentó la ocasión de, primero sobre un pequeño edificio de un salón de actos y sin tirar nada, sino sencillamente sobre esos mismos muros de carga, hacer una iglesia al Espíritu Santo... y, después como parece que funcionaba un poco... pues me encargaron ya el edificio central del Consejo de Investigaciones. Entonces, una columnata corintia que yo llevaba un poco "in mente", la solté allí y me 
quedé tan tranquilo. Cosa que agradezco mucho, porque si no hubiera llevado atragantada esa columnata corintia... La solté, me quedé tan tranquilo... y se acabó.

¿Qué pasó? pues que, efectivamente, tuve un gran éxito de público y de crítica. A todo el mundo le pareció bien. $Y$ con cuatro cosas, me llevé en el año 48... no, antes, en el año $46 . .$. pues yo ya estaba bien conceptuado y había hecho una obra que estaba allí, con su eje principal y su...lo hice todo pues como no había nada tuve que inventarme todas las lámparas, todos los muebles y todos los picaportes y todo lo habido y por haber. Trabajé como un energúmeno. Entonces estaban prohibidos los concursos y, por lo tanto había que hacerlo por administración directa. Yo me encontré con que el primer día lo que tuve que hacer es buscarme a un encargado de obra, que me encontré que ya había tenido relación con él en unas obras de Fernández Vallespín, y dije pues este Vasco y tal, Ángel Salaverría.. ¿quiere Vd. venirse conmigo de encargado y tal y cual ...? Le pago su sueldo y tal... Luego tuvimos allí a un señor que llevaba las nóminas y tal. Y así empecé. Tirarme al agua como suelo decir, sin saber nadar y tapándome el agua, o sea a punto de ahogarme. Aprendí bastantes cosas, esa es la verdad, trabajé muchísimo y me divertí, porque aquello era divertido. Tuve que cambiar la estructura que ya había hecho en metálica, porque no había hierro, tuve que hacer unas bóvedas baídas, de rejillas... y fui saliendo. Nadando "a lo perro" pero sin ahogarme. Y cuando terminé todo eso y tuve, como digo, ese éxito de público y de crítica... los mejores críticos escribieron artículos en sitios importantes..y tal y cual... me dije: "No quiero ni pensarlo, pero por aquí no se va a ninguna parte. Esto no es".

Yo había tenido un choque porque en el año 43 (y esto lo voy a desarrollar mejor esta tarde, porque como tengo que dar dos conferencias en el mismo sitio, quiero que sean distintas). El caso es que en al año 43, para ver unas humedades que había en la casa del Chapíz, me mandaron el Consejo de Investigaciones a Granada. Y me encontré allí dos cosas, dos entes distintas: Una el Palacio de Carlos V. El Palacio de Carlos V yo lo entendía perfectamente. Me había empollado el Cinquecento y el Quattrocento sobretodo italianos. Tenía un libro hecho por un inglés en el siglo XVIII, que era el Letarouilly273 y luego yo había estado en Roma y en Florencia viendo todo como era y cómo funcionaban. Recuerdo que me bajé desde Roma en la estación de Florencia, me fui andando sin preguntar a nadie, y por los sitios por donde iba pasando iba conociendo quienes eran los arquitectos de todas aquellas casas que estaban allí. Cuando llegué a la Plaza de la Signoria (iba yo solo y no era por teatro ni nada) me mareé de la emoción que me produjo. Procuré no perder el sentido porque si no allí me quedaba. Quiero decir que yo tenía un gran entusiasmo por aquello.

${ }^{273}$ Letarouilly, P. M. (1944) Edifices de Rome Moderne. The Renaissance and Buildings of Rome. Londres: John Tiranti, Ltd. 
Vi aquello que había terminado yo y dije: "Por aquí no se va a ninguna parte". Por otra parte, también me encontré con que... dije : "a lo mejor el movimiento moderno tenía algo de real".

Una oyente le interpela: Estabas hablando de lo de Granada.

Esto es una continuación. Es que contar el detalle de lo de Granada es una historia muy larga y yo quiero abreviar un poco esta historia.

Esa es mi mujer, que es mi mentor...

Bien, es que no..., para el caso no hace falta más que concretar que realmente aquello no iba a ninguna parte. Así fomento el que haya publico esta tarde.

El caso es que yo estaba allí viendo esta cosa y viendo otra cosa que vi allí, que era La Alhambra...a mí no me dijo nada aquello. Pero seguí despistado. Luego ojeando un libro de Frank Lloyd Wright, encontré una cita de Lao-Tsé, el filósofo chino 600 años antes de Jesucristo, que decía: "cuatro paredes y un techo no son arquitectura, sino el aire que queda dentro" (gesticula y produce risas). Esto me interesó bastante.

Por otra parte, me dieron una bolsa de viaje, 8.000 pts., de las de entonces... y me recorrí Europa, porque entonces con 8.000 pts. se podía recorrer Europa de una manera modesta, pero se podía. Y vi mucha obra. Entonces empecé a seguir el sistema de formarme de la siguiente forma, y es una cosa muy contradictoria. Consistía en ver los edificios que me interesaban, que creía que eran interesantes para verlos, analizarlos yo solo, sin preguntar nada, ni leer nada, sino viendo a ver si a mí me gustaba aquello, y si me gustaba por qué me gustaba, y si no me gustaba por qué no me gustaba y nada más. 0 sea que realmente mi formación arquitectónica ha sido $2.000 \mathrm{~h}$. de vuelo en DS4 y pensando mucho sobre el asunto, porque cuando veía alguna cosa de arquitectura, y no digamos de los últimos tiempos, eran tan subidas y tan sublimes y una palabras tan incongruentes unas con otras, que se queda uno sin saber qué es lo que dicen... pero nada más. Yo dije, bueno yo lo que quiero es ver arquitectos y funcionar... estas cosas que me han encargado o que me encargan... saber por dónde tirar.

Entonces, hubo dos años, el 47 y el 48 que no sabía por dónde tirar... incluso se me quitó un poco el entusiasmo que yo he tenido siempre y sigo teniendo. $Y$ en ese viaje que digo, porque el viaje me lo hicieron para que yo visitara sitios donde había animales de experimentación (cobayas, ratones y ratas) en los Institutos porque yo lo que iba a hacer era el Cajal y el Instituto de Microbiología. Y en ese Instituto fundamentalmente lo que hay son animales de experimentación, primero limpios y luego inoculados para ver cómo había que tratarlos y las cosas que había que hacer. Entonces, estuve por ejemplo en Basilea viendo los 3 grandes Institutos, Hoffmann-La Roche, Sandoz y Ciba, 
la cual tenía unas instalaciones de gatos como no he visto ninguna más... y luego, fui a Estocolmo, estuve viendo el Nobel Institute, en fin, una serie de cosas.

Y al pasar, bajando hacia Copenhague quise pararme en Göteborg, que había una ampliación de la Rathause, dell Ayuntamiento de un edificio neoclásico y me interesaba mucho porque yo había visto cosas que me interesaban. Y allí me encontré con lo que yo buscaba, que era una arquitectura humana, que tenía relación con el pasado pero no copiándolo ni nada, sino uniéndose de una manera amigable pero nada más. Y luego, con un sistema espacial que me recordó mucho lo que yo había leído de Lao-Tsé sobre "el aire que queda dentro". Entonces empecé a coger un poco la posibilidad de cómo seguir un itinerario mental para hacer la arquitectura.

Entonces, al encargarme el Instituto Laboral de Daimiel yo hice ese proyecto por ese sistema. $Y$ ese sistema me dio unos resultados que me agradaron. $Y$ esos resultados los he ido siguiendo durante 45 años. $Y$ a mí me han ido bien. No tienen nada que ver con los demás. Tienen algunos inconvenientes con vistas a la galería. $Y$ es que el que quiera coger un edificio mío y decir, bueno como esto... enseguida que aparezca esto... esto: la repetición del modelo... que es la manía que han cogido ciertos pintores y ciertos escultores y ciertos arquitectos. Pues bueno. Hay, un edificio que yo hice por ejemplo en Mallorca, que era una casa unifamiliar que ahora veréis, del Sr. Fanjul, que se parece bastante a esta cosas que hace Meier, pero Meier hizo una y luego ha hecho todas las demás igual, de forma que cuando ve uno... pues dice: "de Meier". Y eso ha pasado con Miró y ha pasado con una serie de gente que yo respeto, pero no admiro. Entonces, ¿qué pasa? pues que la arquitectura formalmente no puedes encasillarla. Esencialmente sí.

Por eso una de las cosas que puede despistar en esta exposición mía que hicieron en Múnich es que no se parecen unas cosas a otras. En la misma época hago cosas que parece que no se parecen. Se parecen en esencia, pero no se parecen en lo demás. La esencia entonces, es una cosa distinta completamente de lo que pensamos en la arquitectura. Por ejemplo, nosotros estamos en esta sala. ¿Qué vemos? Vemos este techo, estas paredes, la vemos de esta manera o de la otra, más grata o menos grata, pueden ser mejores o peores, pero realmente la arquitectura es la que hace posible este ambiente esté cortado por esa superficie... ¿Son importantes esas superficies? Son importantes, en tanto en cuanto sirven para de una manera grata y buena y adecuada limiten ese espacio. Pero si eso no tiene el interés fundamental no es arquitectura. Entonces, a mi me entró un vértigo muy grande sobre ese tema y dije: las fachadas... cuadradas... y me equivoqué. $Y$ en ese periodo, así un poco entusiasta de aquel tema...las fachadas mías son muy poco visibles.

Luego me di cuenta de que las fachas limitaban también el espacio social y que, por tanto también tenían derecho a su corazoncito, a que tuvieran una estética y un aspecto 
agradable y he procurado.... pero en ese sentido, o sea... a mi modo de ver hay que ver como arquitecto con unas gafas que nos den los negativos. Cuando yo después de muchos años fui a La Alhambra y al Palacio de Carlos $V$ y los miré con esas gafas, vi que los espacios eran bellísimos en La Alhambra y que los espacios en el Palacio de Carlos $\mathrm{V}$ no tienen ningún interés. Entonces, ¿qué pasa? Pues que la Arquitectura como en la espiritualidad (que también he cogido yo por otro lado) hay dos partes importantísimas: una es la esencia, el por qué de aquello, lo que vale realmente: y otra es unas estructuras que son necesarias en tanto en cuanto sirven para ese espíritu, pero que no sirven para nada como tales. $O$ sea que cuando nosotros cogemos el Vitrubio o los renacentistas posteriores, Palladio y todos estos, estamos estudiando estructuras, pero los volúmenes nada, los espacios nada. Los volúmenes sí, pero los espacios nada.

Entonces empecé a hacer un análisis de los edificios buenos y me encontré con que, por ejemplo, un edificio bueno lo vi con idea de que era malo: el Partenón, porque el Partenón está hecho con la idea de la casa del dios, de un supergigante, Athenea Promakhos o Zeus olímpico, pero es una casa y la estructura de esa casa es la que ha creado unas armonías completamente compatibles, pero en tanto en cuanto son estructuras. $O$ sea que yo lo que creo es que en esta situación de desbarajuste, de que uno llega y dice: ahora voy a hacer una estructura más difícil todavía, ahora voy a romperla (las modas actuales del Ghery y de todas estas gentes)vamos a hacer unas cosas extrañas que no sirven para nada...Hombre, un poco de respeto... y además hay que tener en cuenta otra cosa que es gravísima: cada vez la arquitectura es peor pero los fotógrafos son mejores (risas).

Yo veo algunas revistas que recibo y digo iqué maravilla de fotógrafo y qué porquería de arquitectura! Porque los tíos cogen un primer término, lo ponen en un anochecer y hacen no sé qué y no sé cuánto y te queda una cosa preciosa. Son más fotografía, pero luego lo demás no.

Entonces vosotros que ya vais a pasar de eso, de lo postmoderno y de lo otro y de la deconstrucción y de todos estos señores, tenéis que pensar en algo... y entonces yo digo ¿por qué no pensáis en hacer arquitectura?. Porque yo lo he pasado estupendamente haciendo arquitectura. Porque he tenido un sistema clarísimo. Primero: te encargan una cosa y a lo mejor he hecho otras de eso mismo, una iglesia, un laboratorio farmacéutico, unas oficinas o lo que sea. Procedo a hacer el esfuerzo de dejar la mente en blanco y decir: "ni lo que yo he hecho, ni lo que han hecho los demás me interesa". ¿qué es lo que va a salir? No sé lo que va a salir. Lo que quiero es contestarme a la pregunta clarísima de para qué se hace esto. Todavía no he cogido el lápiz, ni he pensado en la forma que va a tener aquello, en nada de nada. 
¿Para qué se utiliza? Hay una serie de espacios, la relación de esos espacios y una serie de cosas que, primero no lo piensas delante del tablero (yo delante del tablero estoy poquísimo)pero lo piensas delante del semáforo esperando que se ponga en verde... lo vas pensando y al final ¿qué obtienes?. Pues obtienes un organigrama, unas cositas un día, unas más grandes, otras más pequeñas que vas enlazando,... un organigrama.

Vamos a pasar a una segunda etapa. Todavía no hemos pensado en nada más que en eso, tengo un organigrama y tengo que hacer ese edificio. ¿Dónde? Esa pregunta para mi es clave porque me desencajó totalmente el Movimiento Moderno. El Movimiento Moderno prescinde en absoluto del dónde está hecho esto. El para qué, dicen que es funcional... que habría que verlo, pero en fin, por lo menos lo dicen, pero el dónde, nada.

Yo me encontré con que un arquitecto por el que tengo un gran respeto y que he visto casi toda su obra, incluso algunas a medio hacer, como es la Escuela de Arquitectura de Chicago o el Museo de Arte Contemporáneo de Berlín, y resulta que en unas oficinas que le encargan en Santiago de Cuba, tiene la misma forma y las mismas características que el Museo de Arte Contemporáneo de Berlín. Es un poco fuerte... Ni el paisaje de Cuba, ni la sociedad, ni los cubanos, ni el Berlín, ni la sociedad berlinesa tienen nada que ver. ¿Cómo puede ser que esto resulte ser un cubo con 8 columnas? ¿Qué es esto? A mí me descolocó totalmente. Todos los respetos para Mies van der Rohe, pero desde luego seguirlo, "ni atao", así de claro.

Luego, tú tienes que darle un valor al dónde está eso, porque la Arquitectura es como un árbol que está en un paisaje, y nosotros ahora correremos e iremos de un lado para otro, pero la Arquitectura está ahí, está en el paisaje, como el árbol, y por lo tanto con ese paisaje tiene una serie de relaciones físicas y sociales. No se puede construir la misma cosa para unos señores que tienen una manera de ser y una mentalidad y una idiosincrasia determinada, que para otros de otra manera y de otra forma de pensar. Total, que había que ver el dónde está eso, con qué posibilidades económicas juegas, con qué materiales puedes disponer para eso...

Cuando ya tienes esas dos cosas, entonces pasas a otra pregunta, sin solución de continuidad, radicalmente separada. Con los conocimientos técnicos que yo dispongo y que me ha proporcionado la Escuela... cómo puedo yo ejecutar esto. Entonces ya tenemos las estructuras y esas estructuras te hacen posible que puedas coger el lápiz y hacer algo y ver si realmente aquello puede ser visible y ese inconveniente en aquel caso concreto. Cuando ya has pasado de eso (vamos un poco más de prisa) te encuentras con que ya puedes materializar un Proyecto que lo has visto tu primero y que luego lo has llevado a los planos para que se enteren los demás e incluso para tu comprobar ciertas cosas, pero no inventarte cosas. Yo tenía un profesor que nos decía : 
"una cosa es conveniente... es coger un papel y un lápiz y se empieza así, así, así, así.... y a lo mejor salen cosas... a él le salieron dos Ministerios, el de Educación y el de Marina... pero allá películas. 0 sea que el procedimiento ese sale, ya creo que sale, pero no coinciden los pisos con las ventanas... y, en fin. Salen cosas.

Ahí está la primera solución. Yo suelo decirle a los propietarios honradamente, que yo creo que la 14 solución es mejor que la 13. Quiero decir, que hay que darle vueltas. Entonces viene ya una parte final, no primitiva, no previa sino final: que aquello que haga...que aquello pueda ser una obra de arte. Y eso es una formación estética que tienes, que incluso eres un artista sin saberlo, porque si lo sabes... malo, porque entonces no lo eres. 0 sea que sale aquello de una forma bastante inconsciente, porque en el arte hay un factor de inconsciencia tremenda. Si Velázquez o Rembrandt oyeran las cosas que han dicho de ellos los que lo han dicho porque saben juzgar aquello... pero ellos no se han dado cuenta, ellos han hecho aquello (aparte de ser unos artistas de primerísima categoría)... pero quiero decir que eso viene por añadidura.

O sea que... entonces ¿qué pasa? pues yo me lo he pasado bomba, como en una película de Hitchcock... a ver, a ver, a ver y ver.. con suspense y tal, y al final jhombre! Me sale esto....j $Y$ me sale una planta hiperbólica! (risas) Pues sí, me sale una planta hiperbólica. $Y$ entonces, el dominico aquel al que le enseño la planta hiperbólica y me dice: ¡Qué planta más rara! Y digo ¡Rarísima! (risas) Y ¿cómo? Pues mire Vd. Ha salido así, porque he hecho esto y he hecho esto y he hecho esto...y como ustedes quiere valorizar esto y esto otro y tal y cual... pues ha salido así.

- Le interpela Carmen Jordá: Perdona. ¿Es el mismo que dijo que era moderna y nueva?

- No. No. Era más elemental. Era el Padre Ortega

- Una asistente: "Cuando alguien encarga algo y dice a mí lo que me gusta es una casita tipo inglés..."

- Pues le dices que se lo encargue a otro (risas)

- La misma asistente: "Pero, claro, hay que comer. Quiero que me hagas una cosa parecida a esto...."

- Si, si hay que comer. yo he podido decir que no a las 5 cosas más importantes que me han encargado. He podido decir que sí y que no... pero, bueno podía. No era rico, ni soy rico y me conformo con eso sencillamente, y ahora mas sencillamente todavía, pero por otras razones. Pero bueno, vamos a seguir porque es que si no...

- Una interpelación que no se oye bien, pero que parece referirse a cuestiones de presupuesto... 
- Carta blanca en mis 53 años de ejercicio profesional no la he tenido nunca, pero además, he tenido la suerte de no tenerla. He visto mucha mala Arquitectura por sobrar dinero que por faltar, que conste. Eso lo digo con toda seriedad. No puedes pedir que las cosas sean... si tu vas a hacerlo lo más barato posible no tiene ningún inconveniente. Un edificio que para mi desde el punto de vista internacional ha sido bastante emblemático, el de IBM en la Castellana de Madrid, lo que me dijo a mí los propietarios de IBM fue: "nosotros queremos el edificio más barato que se pueda conseguir y por lo tanto, tenemos que desechar el Proyecto que había anterior a comprar nosotros esto, que era un muro cortina al poniente. 0 sea que lo primero que $V d$. tiene que hacer es proponernos soluciones para que no tengamos que poner una instalación de aire acondicionado con una cantidad de frigorías desorbitada para poder vivir de una manera correcta". O sea que no solamente no me sirve, sino que no vale. En la mayoría de los casos se hace mucha peor Arquitectura por mucho dinero que por poco. Y el desafío de hacerlo con poco dinero es un desafío precioso y culturalmente estupendo. Que conste. $Y$ he hecho algunas cosas que son mucho más baratas que las que hacen otros. Y ahí están.

- Interpelación inaudible

- Pues eso está en el "Cómo". ¿Cómo se hace esto? Pues con las estructuras más baratas que había.

Si yo, por ejemplo, hubiera hecho lo que ha hecho (y tiro a matar) el fulano este... esto que ha hecho un japonés en Barcelona con un arco de tres articulaciones... ¡Dios mío! si esa es una solución del siglo XIX. Bueno, pues es carísima. La solución postesada hubiera resultado cinco veces más barata. $Y$ hubiera enseñado algo. $O$ sea, que aquí las cosas claras. Mis huesos, famosos más o menos, son más baratos que en ninguna parte. Yo he hecho soluciones que han costado la mitad y la tercera parte que esas cosas que hay por ahí ahora con esas cosas trianguladas que están más pasadas que la Pepa... ¿Ustedes saben lo que cuesta eso, la solución que tiene?... Yo tengo a mi mujer que es muy crítica, y cuando hago una cosa lo primero que me dice es ¿y cómo la limpias? (risas) La preguntita se las trae.... Pues pregunten Vds. cómo se limpia todo esto. Ahora han querido limpiar el Pompidou y han tenido que hacer un Pompidou nuevo (risas). No, no... las cosas como son... y ha costado más que ninguna cosa, pero que ahora ha costado miles y miles de millones... porque lo van a hacer nuevo, porque no hay solución. Si, si, la economía por delante... Generalmente lo que quiere la gente que pide cosas absurdas, con falta de cultura, no es que cueste menos, sino que parezca más importante. Estamos en un país todavía tristemente... como somos tan pobres pues vamos siempre de nuevos ricos. Por eso, se encuentra uno más satisfecho cuando va a Alemania o a Suecia , o a Italia y se encuentra con que la gente vive con mucha más modestia, sin todos estos lujos. Los lujos son del Tercer Mundo al lado del 
que se muere de hambre... esos son los nuevos ricos. Por eso digo, que no....lo que pasa es que es muy difícil educar a la gente...

Bueno vamos a hacer esto... porque es que si no... No sé si alguno quería intentar alguna cosa mas...

Vamos muy mal ya. Bueno voy a ir muy rápido (comienza a pasar diapositivas):

- Esta es la Iglesia que organicé yo allí. Bueno aquí como veréis está la famosa columnata corintia. (se refiere a la iglesia del Espíritu Santo, Madrid, 1942).

- Este edifico que es el de Óptica. Ya había un problema de unir con un edifico que había anterior, que era de Sánchez Arcas, que era muy bueno. Yo busqué unos ladrillos que tuvieran gres, me costó trabajo encontrarlos (es una historia que sería divertido contar, pero que hoy no...)... bueno, total que... en medio de... estando este edificio por aquí pues fue cuando hice yo el viaje ese a Europa en el año 48.

- Esta es la planta del Instituto Laboral de Daimiel. Daimiel es mi pueblo, nadie es profeta en su tierra...menos todavía queriendo hacer una cosa que tuviera relación con La Mancha...porque los manchegos adoran La Mancha y...que no se parezca a La Mancha... y como esto se parecía a La Mancha... hasta que no lo han "tirao" no han "parao".

- Aquí había una cosa que actualizar con materiales locales... esto les molestaba mucho... porque en España se está haciendo un regionalismo muy curioso que consiste en inventarse un regionalismo falso y decir que eso es un regionalismo de... Cuando dices: "Los muebles castellanos"... y no sé qué no sé cuantos... que tiene un gran éxito por ahí y tal.... Y es mentira todo. Pero bueno, siguen con ello.

- Esto era un edificio que tenía muchas reminiscencias de La Alhambra en un sitio pues... la Ciudad Universitaria de Madrid... que se empezó a hacer... tenía siete patios...porque eran unas uniones por patios... y quedaron en dos, y luego ya... lo dedicaron a otra cosa y... no funcionó, jelaro!

- Esto es los Dominicos de Valladolid, el Colegio Apostólico de los dominicos de Valladolid, que tenia... ya estaba yo siguiendo mi marcha mental de hacer el proyecto. Era un proyecto simétrico. En realidad eran dos programas simétricos completamente, de los chicos de 10 a 14 años y de los chicos de 15 a 18, que no tenían que verse más que en la iglesia. Y entonces, me presentaba un problema de crear... y, claro, a mi me han molestado siempre un poco, y ahora más cada vez, la simetría esa rígida. Porque me parece deshumanizada. $O$ sea, nosotros somos unas figuras simétricas, pero menos. Tenemos el corazón a este lado, tenemos el hígado a este... y tenemos una serie de cosas que crean tensión, que crean vida... y una simetría a lo Palacio de Versalles (que yo lo tomo como arquetipo de lo que no se debe hacer), pues me parece 
que es bastante repugnante. Yo aquí hice la entrada por el sitio más conveniente, en este lado... y entonces me crea una serie de tensiones que son interesantes.... Por otra parte, tiene un muro emblemático, que es el ábside de la Iglesia con una figura de Oteiza y una relación de cartas divertidas que me escribía Oteiza y yo le contestaba y a partir de eso pues la estatua es muy bonita.

- Aquí se ve, por ejemplo, que una iglesia simétrica con esta disposición y tal... pues yo hago por una parte lo que puede ser el campanario y por otra... o sea crear una tensiones y crear unos equilibrios para que de esa forma, pues las cosas tengan una cierta vitalidad.

- Aquí está la famosa planta hiperbólica, que esta es una parte de coro muy importante y una parte de fieles corrientes, que tiene unas entradas y unas posibilidades bastante distintas...y que no importa nada, no pasa nada.... Ahí están.

- Aquí esto, conocido, un señor metió unos azules (se refiere a las vidrieras del Teologado de San Pedro Mártir en Alcobendas), que las hicieron en Suiza y que cuando vinieron ya estaban puestos, que es lo único que veo yo. Porque no me divierte generalmente el ir a ver obras mías, porque no veo más que los defectos, que son siempre bastantes, porque las equivocaciones que uno pueda haber tenido, las equivocaciones de los que los que lo han ejecutado y las equivocaciones de los que los conservan, pues resulta que no es fácil generalmente verlo allí.

- Esta es la Capilla del Santísimo, que tiene un grupo escultórico como es obligatorio en la Orden de Santo Domingo, de que haya un grupo de la Virgen entregando el Rosario a Santo Domingo. En la Iglesia de los dominicos de Valladolid me la hizo Capuz, precioso grupo y aquí me la hizo otro distinto completamente pero buenísimo también. He tenido mucha relación con pintores y escultores y cuanto mejores son mejor me entiendo con ellos. Eso es indudable. Esto es de Pablo Serrano...

- Esto es una iglesia preconciliar que tenía intención de crearle un dinamismo hacia el altar. $O$ sea, ante la cosa un poco absurda de un sacerdote que se pone de espaldas a nosotros (ahora nos choca ya, pero antes no chocaba), no se le podía buscar más posibilidad que aquel señor iba andando y nosotros íbamos siguiéndolo. Entonces, había un movimiento dinámico hacia el altar. $Y$ yo procuré en todas las iglesias que hice preconciliares, el crear ese movimiento dinámico hacia el altar. $Y$ la idea del dinamismo...en el tren la da por ejemplo, el del paso de los palos del telégrafo. Si no ves los palos de telégrafo pasar, parece que no vas andando. Yo pensé en la posibilidad de que hubiera palos de telégrafo en este muro que tiene unas ventanas y tiene un muro de mampostería vista...y otro muro envolvente que no tuviera ningún obstáculo. Aquí a esta foto, le falta otro tanto de blanco, porque es un muro enorme que envuelve. Entonces, de alguna manera, resbala la vista hasta llegar al altar. Era mi procedimiento dinámico. 
- Cuando viene el Concilio Vaticano II y vuelve el sacerdote hacia los fieles, aquello se reduce. Y aquello que era dinámico ha dejado de serlo, puesto que lo que se forma es un corro y lo que interesa es la relación de unos con otros, que es la verdadera Iglesia. 0 sea que en ese sentido, esto tiene mucho más sentido. Entonces, yo hago esta Iglesia de Santa Ana, que es el mismo año que termina el Concilio Vaticano II, entonces procuro primero quitarle el efecto de polo que tenía el altar. Aquí no es un punto. Aquí es un itinerario que hace de las Liturgia de la Palabra que pasa luego a la explicación de esa Palabra en la Presidencia de la Asamblea y que luego se termina en el rito de la Consagración y que luego se hace por ultimo guardarlo en el Sagrario. $O$ sea que hay un itinerario completo y se crea un espacio estático. Es lo contrario exactamente. ¡Claro! Si tú tienes unas cosas formales de lo que es la Iglesia, vamos a poner por caso el caso ese de la Cruz Griega o la Cruz Latina que tiene San Pedro y todos los demás... pues resulta que seguirías funcionando con eso... pues jno señor! Hay que hacer una cosa completamente distinta, porque el espacio que es lo que vale, tienes que limitarlo de una forma distinta, con unas tendencias y con unas tensiones distintas a las que has hecho de otra manera. Entonces ¿en qué se parece esto a lo otro? Pues en nada. Lo ha hecho el mismo, pero no tiene formalmente un aspecto de todo eso. ¿Qué inconveniente tiene eso? Pues que no tienes unas cosas especiales para ti; pero sin embargo tienes mucha más amplitud de llegar a esto. La idea de que cuando te encargan una cosa difícil o fácil, lo primero que tienes que hacer es ¿qué hago yo de esto? Pues la idea es decir "no sé lo que voy a hacer de esto, ni me importa", Voy a estudiar el tema y luego veremos a ver qué sale. Eso es mucho más divertido y es mucho más lógico y necesitarás herramientas de conocimiento, de cultura, de sensibilidad que tendrás que ir mejorándolas. $Y$ otras cosas no. Cada vez te sirven menos las Revistas y cada vez te importa un rábano lo que hace el señor fulanito 0 menganito, que está de moda. Ese señor que está de moda a lo mejor no termina siquiera las obras estando de moda.

- Esta es una Iglesia completamente distinta. Esta es una iglesia que he hecho hace unos años. Es la Iglesia de Torre del Carmelo cerca de Moratalaz, digo de Moratalaz... del Barrio del Pilar. Pues allí los Carmelitas me dieron un programa y el programa que me dieron era distinto completamente a todos lo que yo había tenido. Entonces, me tuve que guardar todo lo que yo pudiera saber de todo eso, sin estar convencido de que aquello era lo que debía hacerse, pero era lo que querían ellos y ellos son unos señores que habían estado ya durante 18 años metidos en una especie de sótano en el Barrio este que se llama de Altamira, en la calle Fernández de Almagro. Pues bien... "queremos mucha luz, queremos que se vea todo. No queremos ningún signo.... la Cruz es respetabilísima, pero no ha de presidir la Cruz... tiene que ser un Resucitado". Yo dije ¡Dios mío! Un Señor "en camisón"... pues estamos hundidos. Bueno, pues luego, nos encontramos con que unos santeros que eran muy buenos escultores aunque ellos no lo sepan... me hicieron unos bocetos que no se ven ahí muy bien, pero que 
realmente tienen dignidad. $Y$ en la Iglesia que tiene una cantidad de luz tremenda y empezaron a llegar los parroquianos, jóvenes y viejos, y empezaron a entusiasmarse. Recuerdo a un viejecito que me decía igracias! igracias! Estamos emocionados... Bueno, con decir que creían que iba a venir tanta gente...y ahora de tres Parroquias que hay alrededor se quedan solas las Parroquias porque vienen aquí... No lo entiendo muy bien, pero creo que estaban en lo cierto los que tenían ese concepto de la Pastoral, porque realmente aquí se encuentran muchas gentes, y están viviendo de una manera espiritual, pero viviendo todos. No tiene recogimiento... pues porque a lo mejor no es el sitio más a propósito el ir a un sitio más o menos destinado a Dios "para recogerse", sino al contrario, para volcarse a los demás. Y es que estábamos equivocados, es que teníamos un cristianismo al revés de la realidad. Quizás lo que teníamos eran unas estructuras. $Y$ esto es un sentido espiritual mucho más profundo. No lo sé. Yo lo que digo es que aquello salió y no tengo más que la ventaja de que he sido obediente a unas cosas que me pedían y que yo no terminaba de entender. Creo que en ese sentido hay que ceder un poco. Si nosotros ahora en vez de escudarnos en un titulo que hace posible que lo que podíamos llamar el Impuesto de arquitecto...¿en qué consiste? Hay que presentar unos papeles firmados por un señor... Y eso es lo que más les interesa a la gente que nos encargan cosas... que necesitan esos papeles para que la Administración pueda admitir eso. Y a cambio de eso tienes que pagar el Impuesto de arquitecto. Aunque el arquitecto sea un señor que hace una sustantiva actitud a la propiedad y a que las gentes vean que tener un arquitecto es tener una persona que le va a procurar un ahorro económico, un cumplimiento de aquello, una cosa que sirva para algo... Nosotros no servimos más que para estorbar un poco al contratista... i las cosas como son!... porque los contratistas dicen. jhombre, si viene un arquitecto, mejor! Y tienen razón. En este momento tienen razón. Hay que tomar conciencia. Vosotros que tenéis un toro por delante que, no te digo nada...de la profesión, en donde se han enriquecido gente por firmar unos papeles que ni han visto siquiera... Eso sí, han "firmao" papeles... A mí me agobian tantos papeles... pero porque cada vez es más complicado... y hay que pasar por el aro... O servimos para la sociedad o no servimos "pa ná"... jlas cosas como son! Hay que puntualizarlo así, hay que decirlo así y hay que pensarlo así... y llegar a la conclusión de que podemos ser una aportación a la sociedad...y si no, terminaremos por desaparecer. En este momento hay grandes movimientos europeos, principalmente en Inglaterra y en Austria, que quieren hasta suprimir (y lo digo porque lo ha dicho Rafael de la Hoz, que es el que está más enterado en España de esta cuestión) la palabra, porque dicen que estorba. $O$ sea, que tenemos que ganárnoslo a pulso... el que no estorbamos.

- Esto es una casita con tres muros y unos rollizos... para que la pudiera hacer un albañil que no supiera casi nada... y la hizo. Ahí está. Ahí está pero rodeada de una naturaleza preciosa y rodeada de unos mamotretos espantosos...pero, en fin. 
Esta la ponía, porque esto es en el Pirineo y esto es precisamente Costa de los Pinos en Mallorca, en donde vemos que el formalismo de aquello y de esto no tiene nada que ver. ¿por qué? Pues porque ha primado fundamentalmente la palabra "Dónde". "Dónde" es donde más ha primado esto ¿dónde?... Allí. Es un cortado, en donde por la parte de detrás está la carretera en la planta de arriba y luego va bajando porque va bajando el terreno.

- Esta es una iglesia también de Canfranc en que el espacio que hay allí y los materiales que se pueden utilizar priman sobre todo lo demás. Priman en el sentido formal. Esto no se puede poner en un sitio que no tenga esas características.

- Aquí pasa lo mismo. Esto es terreno extraordinariamente violento en que están organizado...Esto es un chalé, pero un chalé en que cada pieza está un poco en escalón. Es un poco lio, pero no más que un dúplex.

- Esto es un edificio que se hizo para un terreno que era un montículo, pero se tardó un poco en los trámites administrativos con la Casa de la Cultura en Cuenca y que cuando fui a hacerlo me encontré con que habían quitado el montículo. $Y$ ahí queda ese voladizo como referencia a las casas colgadas y un recuerdo al montículo y...

- Esto es una iglesia en Santa Cruz, en La Coruña, curiosísima. Me la encargó una señora "que quería ver empezar la obra"... Estaba enferma. Yo le dije "y terminar". No, no, empezar. Cuando llevábamos metro y medio de altura, murió. Una cosa bastante bonita. Había un albañil bueno en el pueblo, en Santa Cruz. Hablé con él, era un chico joven. ¿Está dispuesto a hacer exactamente todo que yo le diga, y las proporciones, las cosas donde yo le diga y las proporciones de hormigón y tal? Sí, señor, todo lo que usted me mande, y tal... Empezó a hacer la obra (era prefabricada) y, realmente cuando paso por allí un compañero mío, me dijo ¿Qué casa alemana está haciendo esto? -El albañil del pueblo...

...Y es una cosa maravillosa, lo bien hecha que está... con el cariño con que lo hizo.

- Este es el interior.

- Esto es para decir que esto que era un edificio en triangulo, el edificio Vega, de oficinas... pues era un triángulo... y entonces eso nos creó las tres patas esas, que son conocidas, con los servicios en medio, con la zona de escaleras y todo esto, que ya condiciona el terreno y condiciona las características que ha de tener el edificio.

- Esto es el hotel Tres Islas. El hotel Tres Islas está en una playa preciosa, que a mí me daba miedo...cogí un poco la silueta de Lobos, porque esa es la Isla de Lobos y luego está Lanzarote, por eso se llama Tres Islas...y recuerda un poco las dunas que hay en esta playa de 25 kilómetros... no sé. Me pareció que no estropeaba mucho el paisaje... no lo sé. 
- Esto es el problema del "Cómo". Había que hacer los Laboratorios Made, había que unir de alguna manera... con una galería.. pues la parte de fabricación y la parte de dirección y laboratorios y oficinas y entonces hice esta marquesina que estaba abierta para que en caso de.... en caso de... estas marquesinas completamente cerradas, en verano son bastante inhabitables porque se condensa el calor allí en el fondo.. y queda muy mal. Entonces si le da uno alguna posibilidad de salir... pues entonces se crea un circulo... un movimiento de aire que es bastante agradable y resulta bien. Aquello me pareció demasiado...demasiado pesado para hormigón armado corriente... y entonces empecé a estudiar los problemas de pretensado y allí creé esta figura parecida a aquella pero que tenía las posibilidades de pesar mucho menos y de ser mucho más fácil. Tuve la grandísima suerte de encontrar una persona idónea que me pudiera hacer esto, que supiera hacerlo y que le gustara hacerlo... que es un valenciano... que es Vicente Peiró... que tienen arrozales por aquí, y que el hombre ha colaborado conmigo con gran entusiasmo. Quiero decirlo porque además a lo mejor los valencianos no lo conocen.... pero yo sí lo conozco y muy bien, y sé que ha hecho cosas inverosímiles... como por ejemplo hacer algunas cosas que ahora veremos, de 20 metros de luz y centímetro y medio de espesor... que ya está bien... pretensadas.

- Bueno, esto es un chalet que tiene las mismas características de los...estos salientes... estas viseras...

- Aquí se ve mejor... Es que esto, no solamente queda bien, sino que crea un movimiento de aire muy claro... y... incluso como ese que está en segundo término, que está encajonado un poco... pues más todavía crea ese movimiento...

Esto es de un valenciano, el propietario, que es este.... Vicente Barrera, que está en Madrid.... vamos que es un chalet que tiene él en Madrid.

- Esto es una pieza, también postesada que luego he utilizado bastante. Hoy he visto que quería ver el Museo... digo el Instituto este Benlliure y algunas partes de ese Instituto tienen estas piezas. No todas, porque hubo una razón muy complicada de cómo tuvo que hacerse aquello y la ultima parte... pues se hicieron con unas piezas rectangulares también de Vicente Peiró. Esta es una historia que...

Interviene Carmen Jordá:

- Perdona Miguel, es que yo no he comentado antes en la selección de las obras que Miguel Fisac tiene obras en Valencia. Muchos de vosotros las conocéis... Pero como ha citado ahora el Instituto y algunos no sabéis de qué se trata; es el instituto Benlliure que está en la calle Alboraya. Otro edificio emblemático suyo que antes no he citado, en la selección que he hecho de obras -no he citado las de Valencia- es el edificio de viviendas de la plaza de Tetuán. 
- Bueno, lo que pasa es que yo esta tarde... yo quería ampliaros todos estos detalles de los edificios míos de aquí. De unos estoy satisfecho y de otros un poco menos...y de otros nada; pero, en fin, bueno, bien. Ese es un tema un poco más largo.

- Esto quiere decir que con una pieza, como veis aquí de 12 metros y con una pluma de 700 kilos en punta, que es una grúa completamente ordinaria, pues se mueve perfectamente, y se coloca simplemente apoyada y es una estructura muy clara.... Esto es un colegio de los jesuitas en La Coruña, que se hizo en el año.... no recuerdo, 610 62.

- Aquí vemos también los laboratorios Jorba, que también todas las piezas esas funcionan perfectamente y llevan ya más de 20 años. No han tenido problemas. El pretensado es un tema que no me explico, cómo los arquitectos lo han desprestigiado, vamos lo han desprestigiado no, no lo han utilizado nada, hasta el punto de que cuando a mi me invitaron para que fuera ponente en una reunión de la FIP, de la Federación Internacional de Pretensado...yo era el único arquitecto que había hecho pretensado. No lo entiendo, porque es la técnica más adecuada para hacer arquitectura. Se puede decir jhombre! es una técnica que está pasada. No está pasada. En este momento, toda la ingeniería que se está haciendo en el mundo se está haciendo con hormigón pretensado. No sé por qué ese dejar de hacer cosas de pretensado. En este momento se está haciendo lo que podría ser un record de luz, de casi 1 kilómetro (ochocientos noventa y tantos metros) de hormigón pretensado. ¿No se puede hacer grandes edificios en donde haya 150-200 metros de luz con toda facilidad y tres veces más barato que las soluciones estas del siglo XIX?

- Aquí tenemos una iglesia, la iglesia de Santa Ana por fuera, donde se ve también toda esta disposición de las piezas de hormigón pretensado.

-Este es el Colegio de la Asunción, que también tiene ese aspecto. Claro, yo no tengo parecidos... lo que pasa es que donde están esas cosas... pues estoy interviniendo yo...eso sí... Pero es una solución que busqué, que da muy buenos resultados, que se ha demostrado con los años que son de muy bien resultado y que a nadie les interesa...por lo visto. Es una cosa que no entiendo...pero, en fin.

- Aquí vemos el interior de la iglesia, donde he querido buscar el efecto de luz en la zona principal del ábside...y lo que he hecho ha sido quitar los trozos de piezas que no tienen una labor completamente estructural, puesto que la labor estructural la tiene el anillo. Realmente las patas esas es para poder cubrir más espacios, pero en realidad se pueden quitar en un momento determinado, que es lo que quería hacer en esta zona de aquí.

- Aquí es una exposición de cómo me surge una pieza, que luego he utilizado bastante, de postesado, que es el Centro de Estudios Hidrográficos. Me piden una nave de $80 \mathrm{x}$ 
22 que tenga luz completamente uniforme, puesto que van a hacer maquetas, va a ser un lugar donde tienen que tomar fotografías que tienen que tener una luz totalmente uniforme. Entonces yo, organizo en las pantallas para que no tengan más iluminación que de bóveda celeste..osea busco los sitios extremos y la inclinación que deben tener esas pantallas y la separación que han de tener... y cuando tengo esto entonces busco una manera de recoger el agua que pueda llover y dejar las partes claves transparentes. Esto lo doy al proyectista, al calculista, que es José $\mathrm{M}^{\mathrm{a}}$ Priego, un gran ingeniero, que me dice: Miguel, 22 metros, yo esto así esto abierto no lo puedo hacer. Me tienes que buscar una solución que puedas crear unos momentos que yo pueda defenderme con los 22 metros. Entonces... y creo que esta es la voz conjunta de uno y otro... o sea, yo creo que el arquitecto tiene la obligación de saber cómo funcionan los elementos y qué cosas pueden llegar a hacer... y luego hay un especialista que es que debe poner los cálculos y ver las estructuras que tienen que ser para poder realizar aquello. Pero son dos cosas completamente distintas. Yo he sabido... porque estudié con cierta facilidad, las formas de cálculo...(a mí de joven me gustaban las matemáticas), pero luego, me ha servido para tener un cierto olfato cosas que se pueden sostener y cosas que no se pueden sostener... y por donde van las tensiones de aquellas piezas. Entonces, yo busco una tensión aquí y digo: yo creo que con este triángulo puedo mantener esto. Entonces queda la ultima parte..., aquí está desarrollado todo mi itinerario mental: ¿Para qué sirve esto? Primero. Unas pantallas que me quiten el sol. Segundo. ¿Dónde? Bueno, pues en un sitio, que era bastante libre porque era al lado del Manzanares, no tenía ninguna cosa alrededor...en este caso el "dónde" tenía menos importancia. Pero el "¿Cómo?", es ya cuando tienes que ver qué estructura. Y para eso es para, fundamentalmente, para lo que sirve el conocimiento estructural que debemos tener.; ¿cómo funciona esto? Entonces yo llego a la última etapa de decir: todo esto que ya sirve, ¿cómo hacerlo en una pieza que armónicamente pueda resultar grata? Eso ya es un problema de sensibilidad, de arte, podemos decir. Pero es un subproducto, es la consecuencia de. No empieza: "yo soy un artista y todo lo que hago es un arte" jnarices! Tú tienes que hacer unas cosas que te han mandado, lo mismo si es un templo para Atenea Promacos que si es un almacén de lo que sea. Pero luego hay posibilidad de hacer algo parecido a eso.

- Entonces le doy esta pieza a Priego, y Priego lo primero que hace es calcular el centro de gravedad...y precisamente esta lámina es la expresión gráfica de cómo calcula él el centro de gravedad para que esas piezas no tengan torsiones y para que esas piezas funcionen bien. Una vez hecha esa verificación, hace ya las estructuras. En este caso es una estructura pesada que tiene forma de catenaria, porque no puede hacerla recta. En otras ocasiones de menos luz, 16 metros de luz, en Vic y en Montmeló yo hago 35.000 metros cuadrados de piezas de estas, pero ya de cable recto, porque tiene $16 \mathrm{y}$ hay que evitar... porque esto trae bastantes complicaciones en la construcción. Y esta es la nave, que ahora está en pleno funcionamiento, porque la utilizan mucho. 
- Bueno... y entonces queda la posibilidad de que esto tenga un reflejo externo y que, incluso esa marquesina pudiera tener algo parecido, postesado también para que de alguna manera la Nave de Ensayos y el Centro de Estudios Hidrográficos tenga una cierta relación. Ahí está el "no sé qué", el hacer una zona que sea realmente un poco grata.

- Y esto es la consecuencia plástica del tema, que tiene un cierto parecido con nuestro Plateresco, que tiene pues unas cosas muy menudas y una cosa muy planas, muy lisa, muy limpia, que es el muro de hormigón.

- Estas son las fabricas estas que hice de cueros, que se hicieron porque todas las estructuras que hacían de hierro, los gases del tratamiento de estos cueros las corroían. Entonces, se hicieron estas y llevan ya veintitantos años, y funcionan muy bien sin ninguna corrosión.

- Esto es, diferentes tipos, porque tuve que hacer también unos forjados que ya se eligieron para 2.000 kilos de sobrecarga y también funcionan muy bien.

- Esto es un Anteproyecto que me encargó Samaranch para unas cosas de Granada, donde yo hacía aquí una zona de patinaje y tal y cual, cubierta, con 150 metros de luz, y con unas piezas que tenían alrededor de 3 metros de altura, no llegaban a 3 metros de altura, y que se colocaban sencillamente, antes pieza a pieza; ahora casi de una sola vez, si no, por lo menos de dos o tres. 0 sea una solución de lo más sencilla y muchísimo más económica que eso...porque si vamos a sumar ahora las posibilidades de transporte y todo esto, y la colocación, con grúas de 400 y 500 toneladas, pues es bastante fácil.

-Esta es lo que ya os he hablado de IBM, para quitar el sol sencillamente y... no sé. Esto, ha funcionado bien, vamos.

- Yo tenía la manía que, utilizando mucho el hormigón, era un material que tenía que tener la cualidad expresiva...¿Qué cualidad tiene el hormigón que no tengan los demás materiales? Pues yo me figuré...es una suposición mía, dándole vueltas...que es el único material que llega a obra en un estado distinto del que va a tener, que ha sido blando, ha sido pastoso...Entonces yo quería dejar una huella genética de que aquello ha sido blando. $Y$ entonces, empecé a darle vueltas y a redondear los moldes... pero eran moldes rígidos, de escayola y tal... y ya por fin llegué a la solución de que podían ser unos moldes flexibles. Y la primera obra que realicé con esos moldes flexibles fue esta de la Mutua del Papel, Prensa y Artes Gráficas que está en Madrid, y que me dio unos resultados, que me dio unas texturas que no me figuraba siquiera, brillante y estupendas, como si fueran de granito pulimentado, y quedaba muy bien y que todavía siguen con brillo, después de más de 20 años que tiene esto... 
- Esto es de eso que hemos visto del hotel Tres Islas, que hice con piezas de $3 \times 4$ que se fueron colocando y formando una relación...

- Esto es una cosa en Ciempozuelos que, no es para locos pero en fin, recuerdo de las primeras fundadoras y tal...Había un escudo que yo quise repetirlo y lo hice demasiado grande para que no se viera...porque el escudo era un poco difícil. Era un corazón con una cruz, y lo hice bastante abultado...

- Esto es un chalé de La Moraleja, que quería que entonara con esas encinas y que cumpliera exactamente las características que tenia este caso concreto...y es que pasaban unos aviones por encima y había que aislar totalmente la cosa acústica... doble pared y separar la iluminación de la ventilación...Bueno es una cosa muy larga...

- Esto es un edificio que hice con dos moldes exclusivamente. Resulta baratísimo.

- Esto es...cuando te permitan hacer una cosa que llame la atención...pues es un poco fuerte, pero es el programa. Entonces ya tienes que jugar un poco a hacer una cosa un poco extraña, y agarrarte a un clavo ardiendo. En este caso había un triangulo allí casi inedificable, rodeado de edificios altísimos. Y me tomaron unas fotos y como el fotógrafo no quería sacar los otros edificios, terminó por no sacar este tampoco y, claro porque es que es muy difícil sacarlo del contexto de los rascacielos aquellos... y como había una cosa curva pues hice una curva en la parte baja, luego una contracurva, y luego otra...y salió una cosa extraña, no tan extraña como esas que hace Ghery.... pero extraña.

- Y esta también tiene su objeto...cuando yo terminé y entregué la primera solución que le entregué al señor Jorba, me dijo: ${ }_{H} H o m b r e$, sí, pero yo he comprado un solar en un sitio que se ve mucho... quería que me sirviera un poco de propaganda!...y entonces aquí tenemos un cuadrao de $17 \times 17$, démosle $45^{\circ}$ de giro en cada planta, obtendremos ahí unas formas de paraboloides hiperbólicos, que serán divertidos. Luego, el remate no sabía cómo hacerlo. Probé muchos. Si lo sacaba de punta parecía una pagoda, si no lo hacía de punta me resultaba una cosa bastante feilla... pero como tuve un buen fotógrafo en esa foto...pues me lo quitó. Y quedó muy bien.

Y nada más. Muchas gracias. 
Memoria, Aprendizaje y Experimento. La invención del paisaje en Miguel Fisac Apéndices

\section{Apéndice 2_Cuadernos de Viaje}

2.1_ Facsímiles del Cuaderno de Viaje a Europa

2.2_Facsímiles del Cuaderno de Viaje alrededor del mundo [inédito]

2.3_ Transcripciones de varios cuadernos de viaje [inédito] 
A lo largo de sus múltiples viajes, Fisac toma notas y apuntes en diversos Cuadernos de viaje. Existen dos tipos de cuaderno: aquellos en los que vierte ideas, notas o intereses por escrito, en muchas ocasiones como base para posteriores artículos de prensa 0 magazines $^{274}$-de los que era asiduo colaborador-; y por otra parte, cuadernos en los que dibuja o realiza croquis de paisajes, lugares, edificios o fragmentos de ciudad.

La mayor parte de los apuntes y croquis del segundo tipo de cuadernos fue recogido en 2007 por Paloma de Roda en el libro Miguel Fisac. Apuntes y viajes (Scriptum). Por el contrario, la mayor parte del contenido de los cuadernos escritos, se encuentran inéditos en la actualidad.

274 Se ha comprobado como una gran parte de los textos e ideas que aparecen en los artículos publicados en La Actualidad Española, correspondientes al conjunto "Viaje alrededor del mundo parando en nueve ciudades", proceden casi textualmente de su Cuaderno de Viaje. 
2.1_Facsímiles del Cuaderno de Viaje a Europa

327 
VIAJE A SUIZA, FRANCIA, SUECIA, DINAMARCA, HOLANDA

OCTUBRE-NOVIEMBRE 1949 


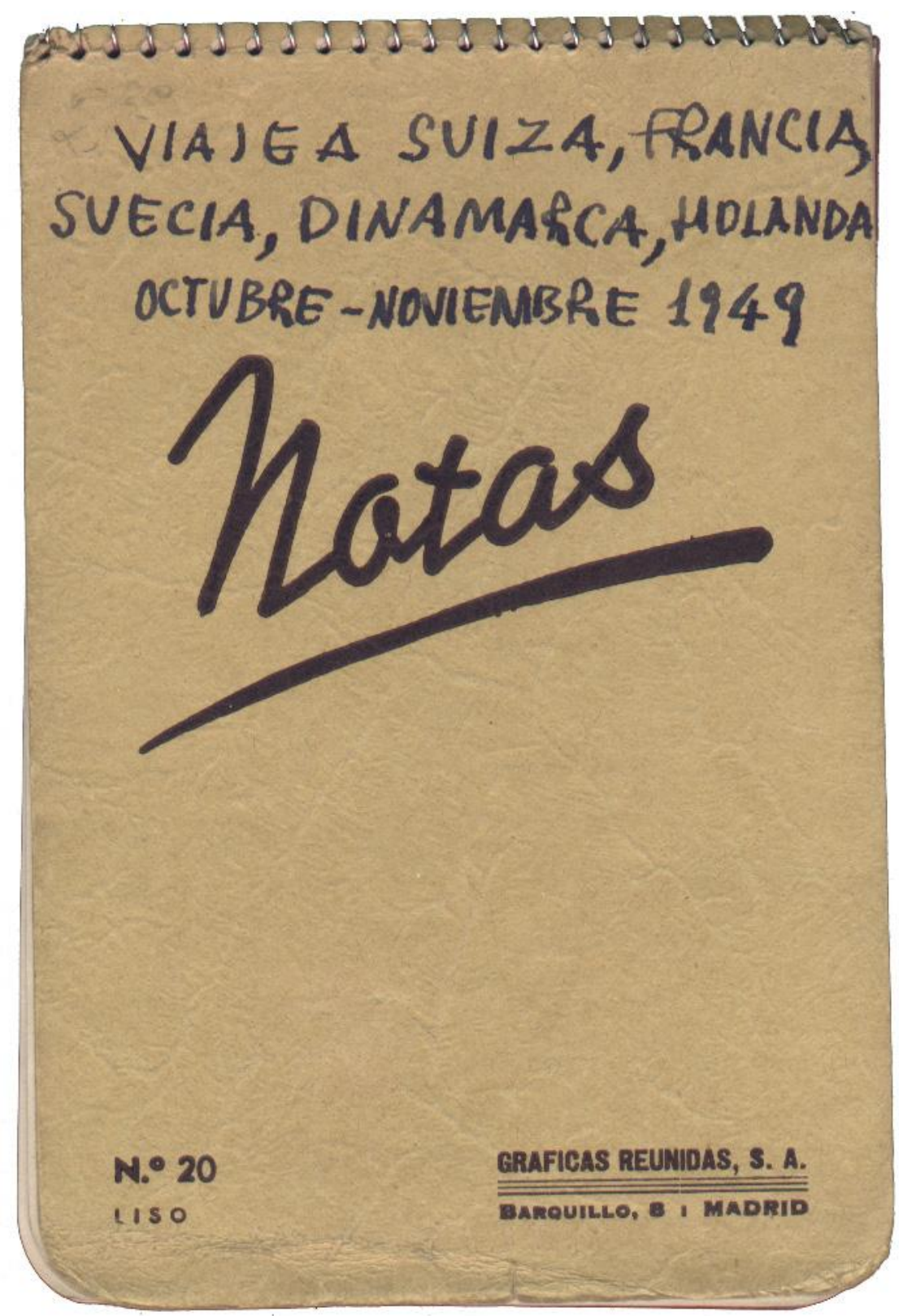

329 


\section{Página 1}

19 Ginebra

20 Berna

21 y 22 Zurich

23 y 24 Basel

25 Viaje a París

26, 27, 28 París

29, 30 Viaje a Stockholm

31, 1, 2, 3 Stockholm

4 Uppsala y Ultuna Göteborg

5 Lund1 Göteborg

6 Göteborg Lund y Malmö

7 Viaje

8, 9 Copenhagen

10 Viaje

11 Amsterdam

12 La Haya

13 Bruselas

1415 Viaje de regreso

${ }^{1}$ Tachadura del propio arquitecto; parece una corrección sobre la marcha del itinerario del viaje. 


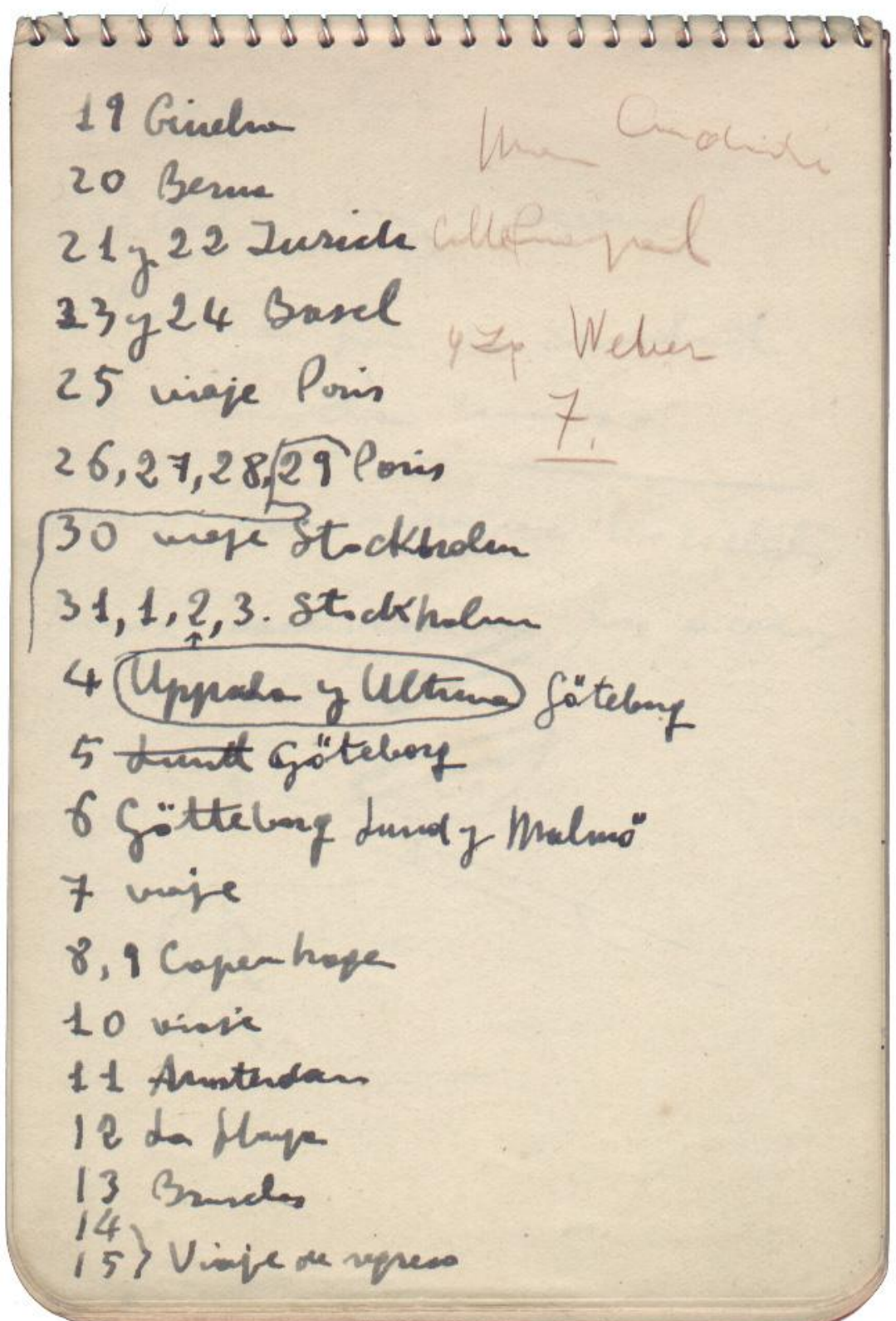




\section{Página 2}

19 miércoles

Viaje y bueno

Visita por la ciudad.

Y nada más

Si, para dejar bicicletas

Unos ranuras en las aceras

Dibujo 


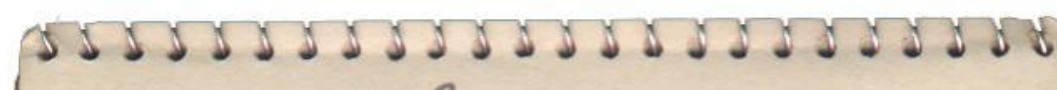
19 mincales

Viain y lavene.

Visit te he cander.

fi, pace defier bividety

thos sacuasos is los ecers

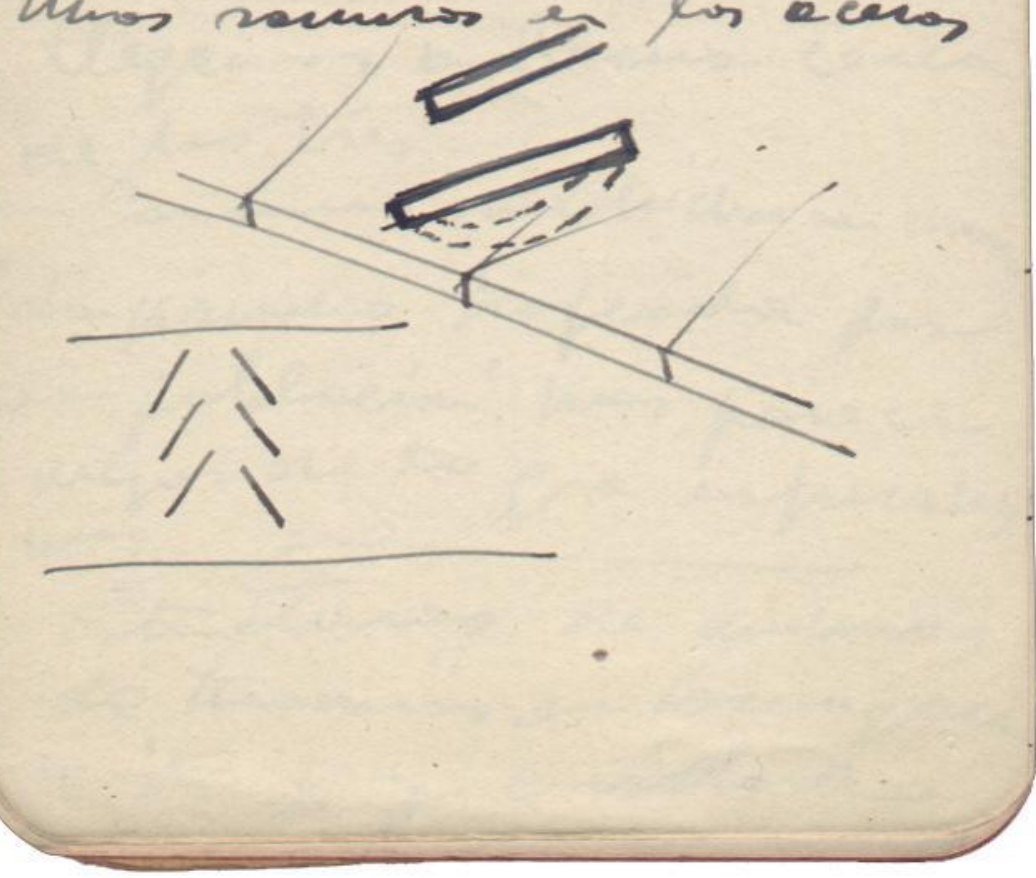

333 
Página 3

20 jueves

Lausanne

Llegamos a las 10 (aprox)

Nos recibe cariñosísimo el Prof. Hardiuroy

Seguimos a Berna

Llegamos a Berna cerca de las tres

Comemos salchichas con cerveza

La primera hojeada por la población nos parece mejor de los que esperábamos

Estructuras de andenes de tranvías en hormigón visto muy cuidado 


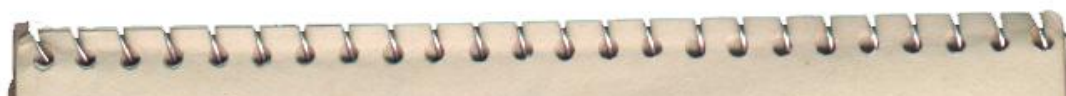

20

jurees

dausampe

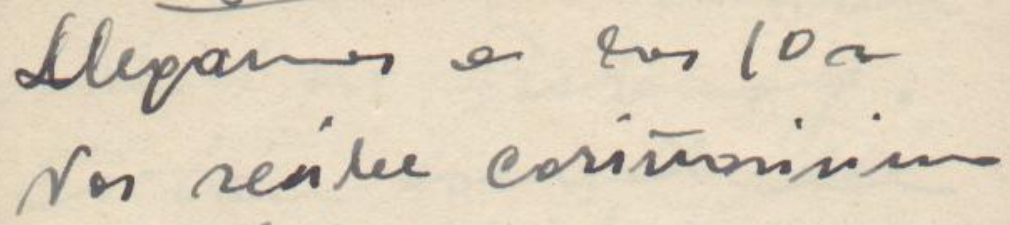

al Prof. Hondeuroy

repinimas a BescueLlequmos a Bema carca ole los thes

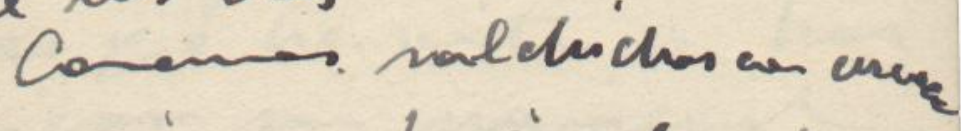
da primene hajeada for la pablación has parece mevor oce lo pre espreselea un

Estictins de anderes

de tansess en hocusipa erito un cuidoro

335 
Página 4

de encofrado.

En el viaje he visto de refilón la universidad de Friburg: es tan lamentable como me la figuraba el hormigón visto es horrible. La orientación general de las cosas que he visto en hormigón son siguiendo a Perret. 


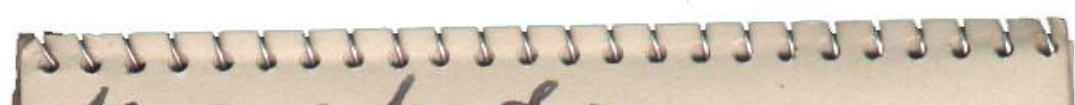
de encapado.

Es vioie he wits de refila la niber. sithod de firbury: Es tan fomentaler camo me ha fipinaba el hosmigu vito es hassible. La ovén tocin' peneal oce lor ao was pe he vito en hos mipor sa squienas ce ersat.

337 
Página 5

Dibujo de una estabulación de caballos 


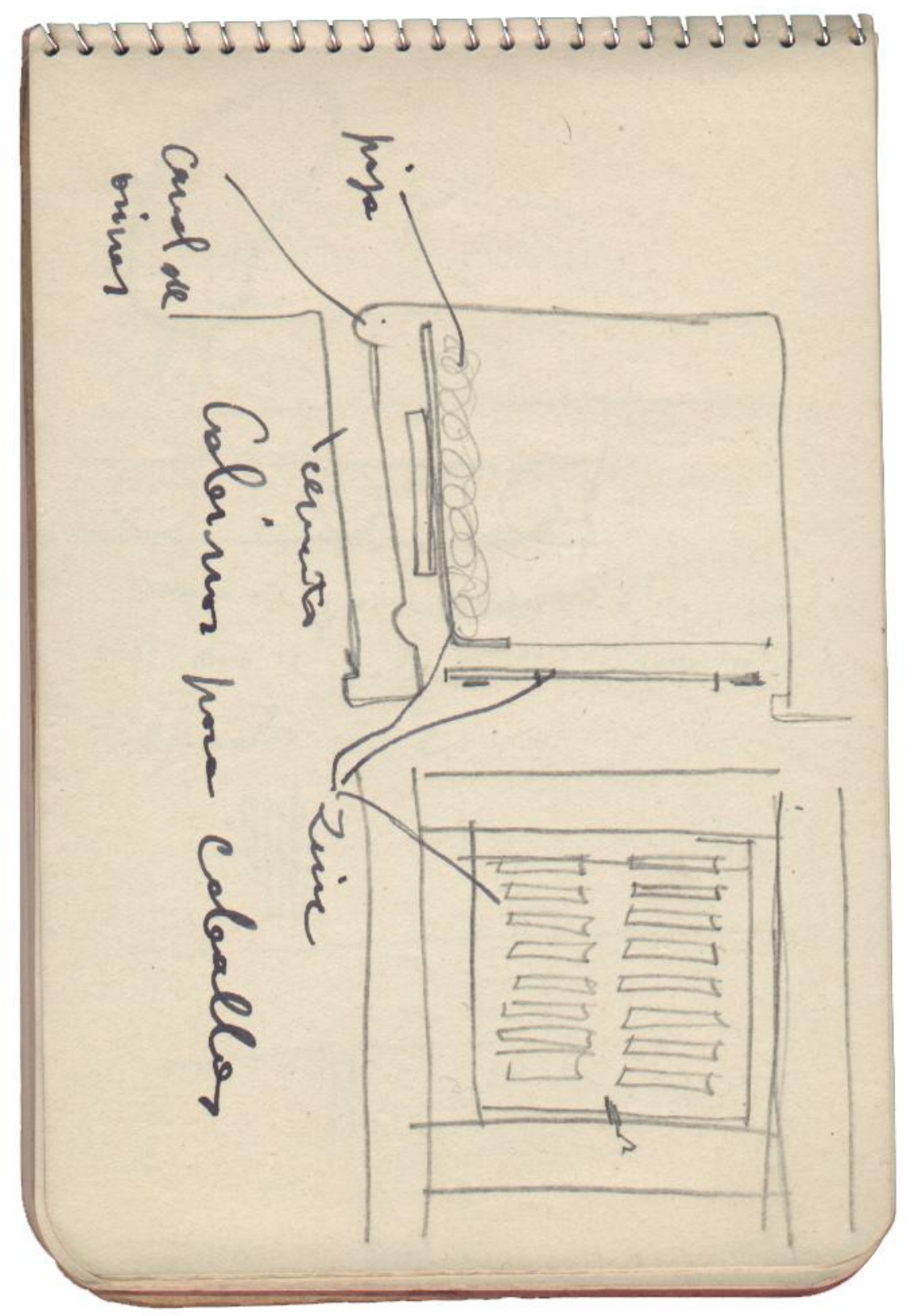




\section{Página 6}

Dibujo de detalle de una sección de pasamanos

$Y$ de un felpudo de goma

presas de goma como de cubiertas de coche que sustituye al felpudo de coco 


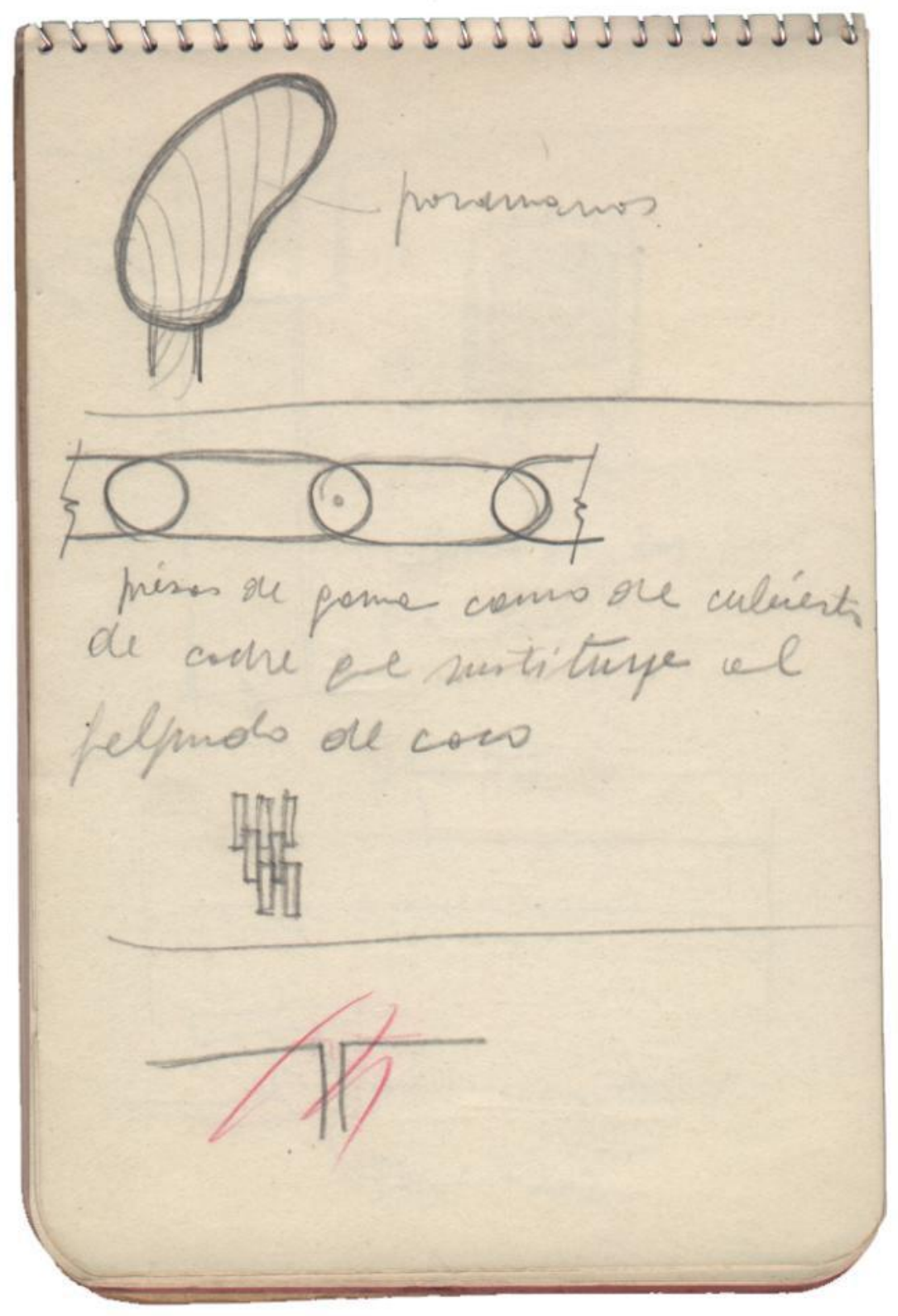


Página 7

Dibujos varios, parecen de una escalera 


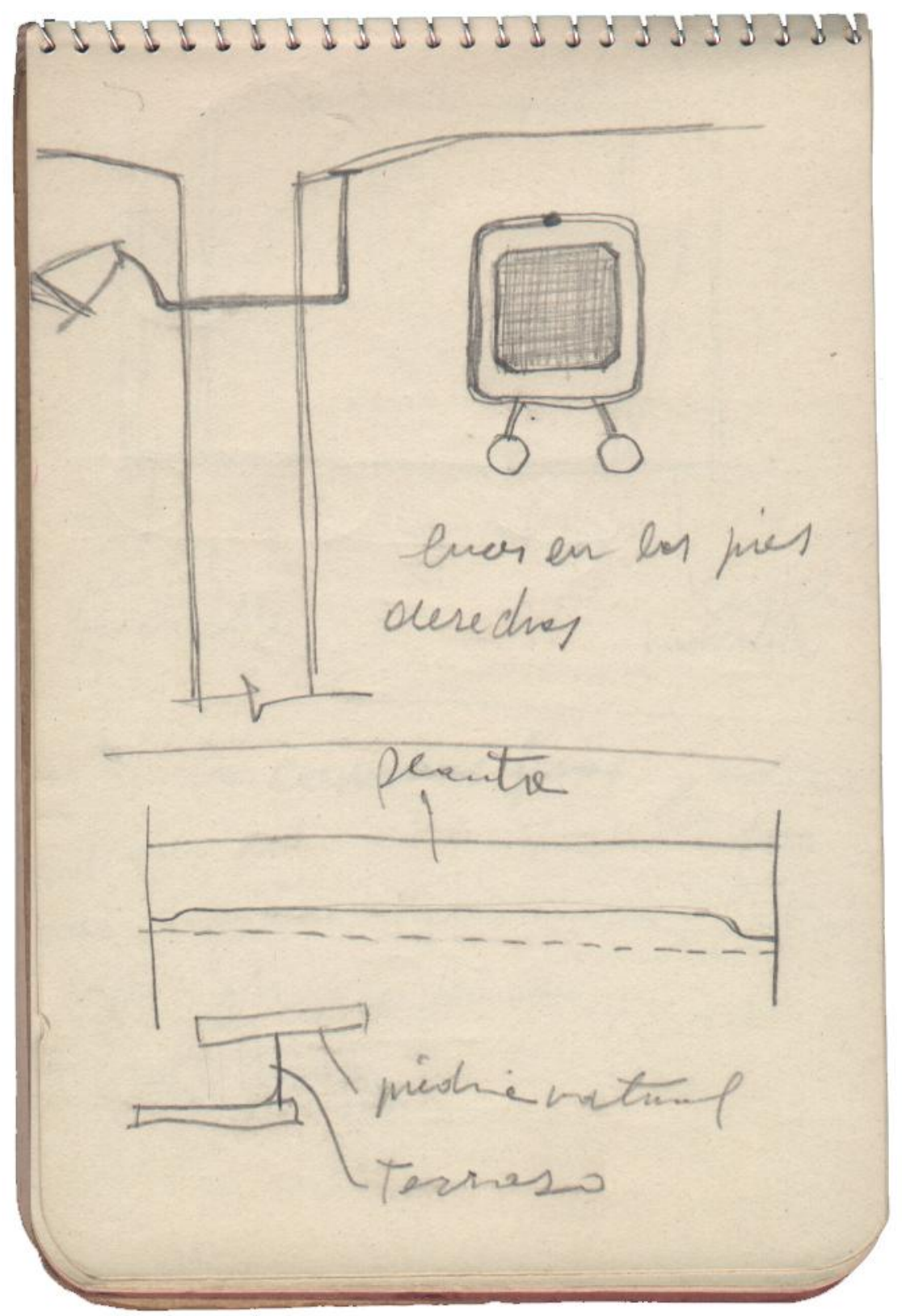




\section{Página 8}

Dibujo de un ventanal grande partido en tres con los dos extremos practicables y el central fijo.

Visto cámaras frias y calientes

Todo esto de los Institutos de Higiene, Policlínica, Patología, etc. Enseñado por el Prof. Mooser 


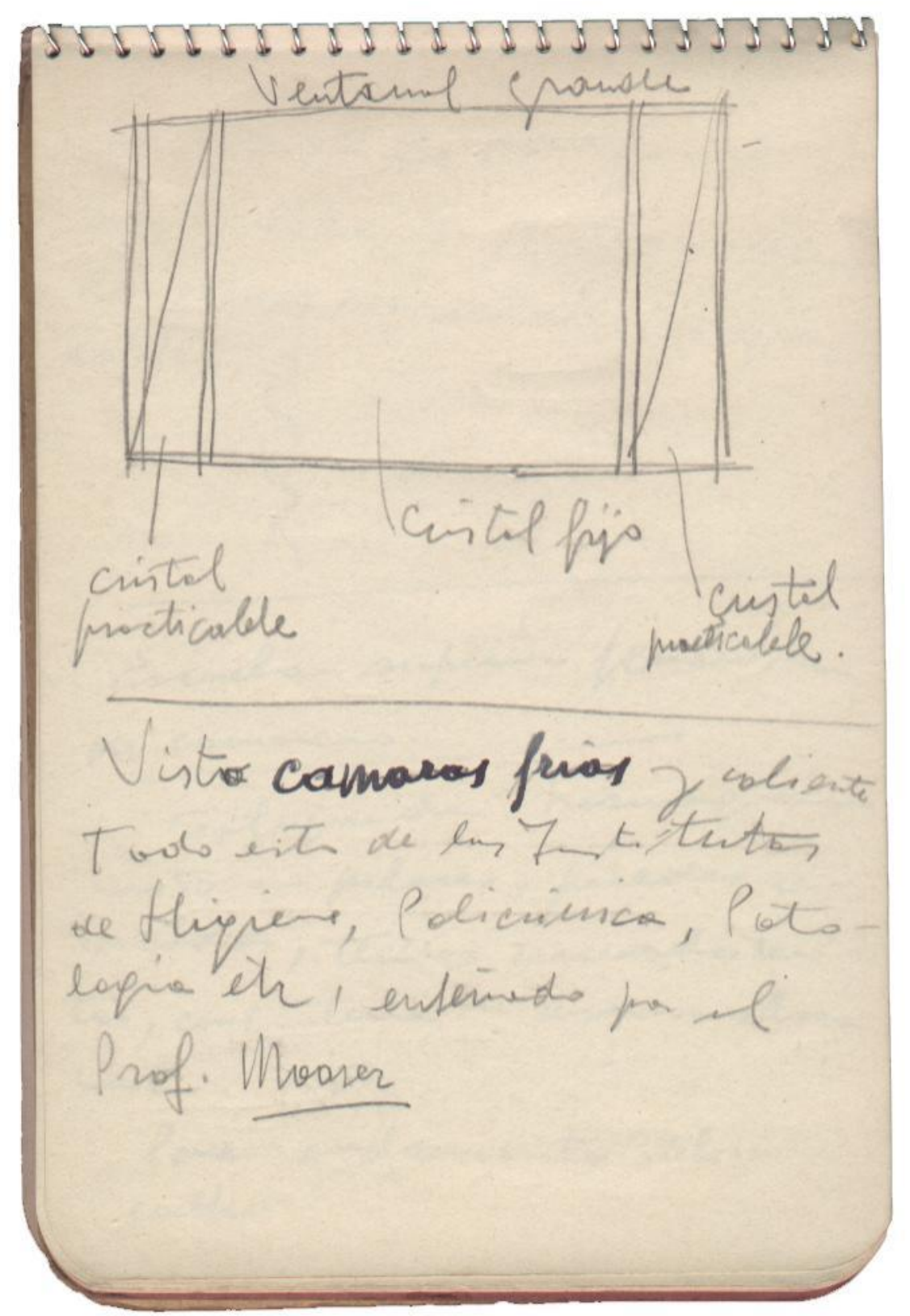

345 


\section{Página 9}

En muros de hormigón en masa labra a puntero haciendo estrías horizontales (es agradable)

Dibujo

Escuela Superior femenina de Comercio

Estupenda: hormigón visto en pilares, paredes revocadas, techos nervados vistos, carpintería de madera clara vista.

Para aislamiento utilizan corcho 
Sun monos de hamig en mava balva a puntas hacica do estuos howizatales (es apra. dolele

\{

Escuela superion fensersinole comerein.

sotupeda: hosmereror nito - pilsces, paseder veweads, tecks newards bistos, concittenis de madese doca linte.

Por indoceriento vtilica conlses

347 


\section{Página 10}

Pavimentos de linoleum, gres y baldosa cerámica

Chalet particular del Prof. Dunkel²

Lunas fijas en paredes.

Algunas ventanas y una luna con contrapeso para el enlace del cuarto de estar con el jardín.

Separaciones con cortinas dentro de una misma habitación

He visto vibrar hormigón

Dibujo del vibrador

\footnotetext{
2 El profesor William Dunkel era el encargado de la sección de Proyectos Arquitectónicos en el Politécnico de Zurich. Según Fisac -con quien estableció una relación de sincera amistad que duraría muchos años-, Dunkel, a pesar de su exigüa obra, era un excelente arquitecto aunque centrado en su trabajo universitario. Fisac cuenta que cuando Richard Neutra quiso que su hijo estudiase arquitectura le envió junto al Profesor Dunkel. Nota extraida del archivo personal de Eduardo Delgado Orusco.
} 


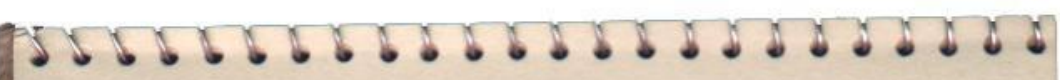
Poviuntas de limalinary y baldosa de cenamia.

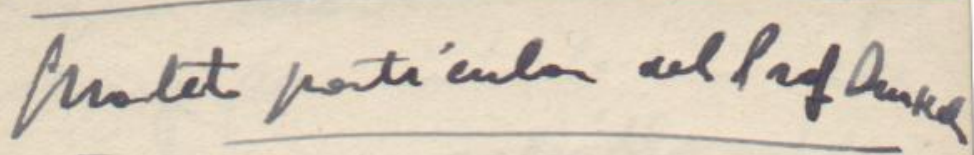
duares fijos en poseder. Hepurs leentans 7 una lum can estropesto pae el enese bel cuetto de ext ca el jach i.

Sefuncianes en cations

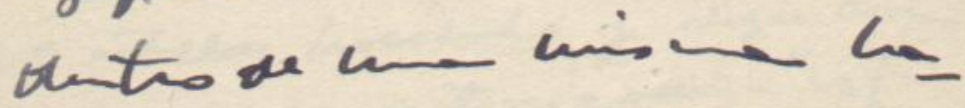
witacion du vit

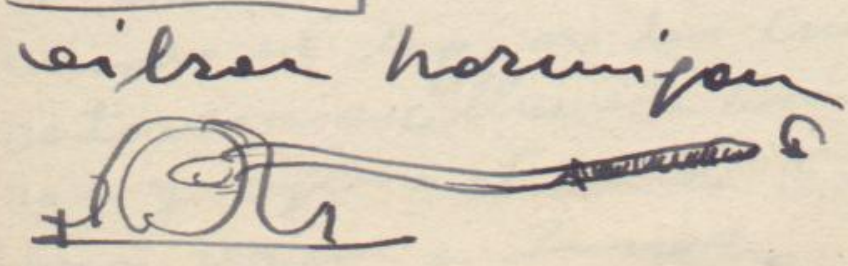

349 


\section{Página 11}

\section{Domingo 23-X-49}

Viaje a Zug, visita del Colegio Montana en Zugslach ${ }^{3}$ (una instalación mala en un lugar maravilloso) después continuamos viaje a Lucerna visita a la Catedral de Lucerna.

"Has producido una emoción estética en un niño suizo" frase de José Antonio ${ }^{4}$ después que un niño se me acercó a ver una acuarela que estaba haciendo y dijo con cara de entusiasmo "ist so reizend"5. Después hemos atravesado el lago de los Cuatro Cantones -sencillamente maravilloso-y cogemos el tren en Berna para regresar a Zurich.

\footnotetext{
${ }^{3}$ Ubicada en los alrededores de Zug

4 José Antonio Balcells, joven arquitecto barcelonés que acompañó a Miguel Fisac en este viaje, recomendado al arquitecto manchego por su hermano el médico Alfonso Balcells.

${ }^{5}$ ¡es tan bonito!...[traducción del alemán] 
Dam $23-x-45$

Viojic a Zug, wimite del colevis Mantana en Zuge-

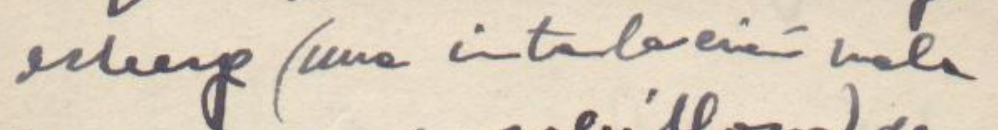
en un knger anvalu'llow) des

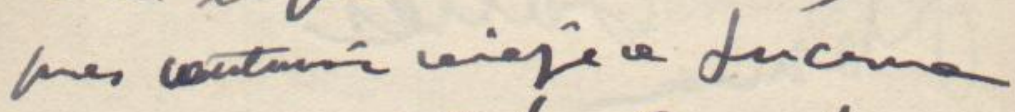
visite a bo cacerdun se ducena "has pad duenies lua ecmacinextetica a c viño miso"fose ore friéfuton: deperes be an limi se we ececese wer uns a currel re strue hocient. 7 digi an - cosa de enturiasmo-" it s schánen "Despres haves thaverade cl hap or les cuato contoves-rencllameite wovobills. so-y exjersos ef ter en bsume bro requer a Zncidh.

351 


\section{$\underline{\text { Página } 11 \text { (por la parte de detrás) }}$}

\section{Arquitecto}

Herman Baur ${ }^{6}$

${ }^{6}$ Del arquitecto Herman Baur, arquitecto de por entonces mediana edad, años después recordará Fisac una iglesia que les impresionó; no así sin embargo las escuelas visitadas y referidas en este diario. 


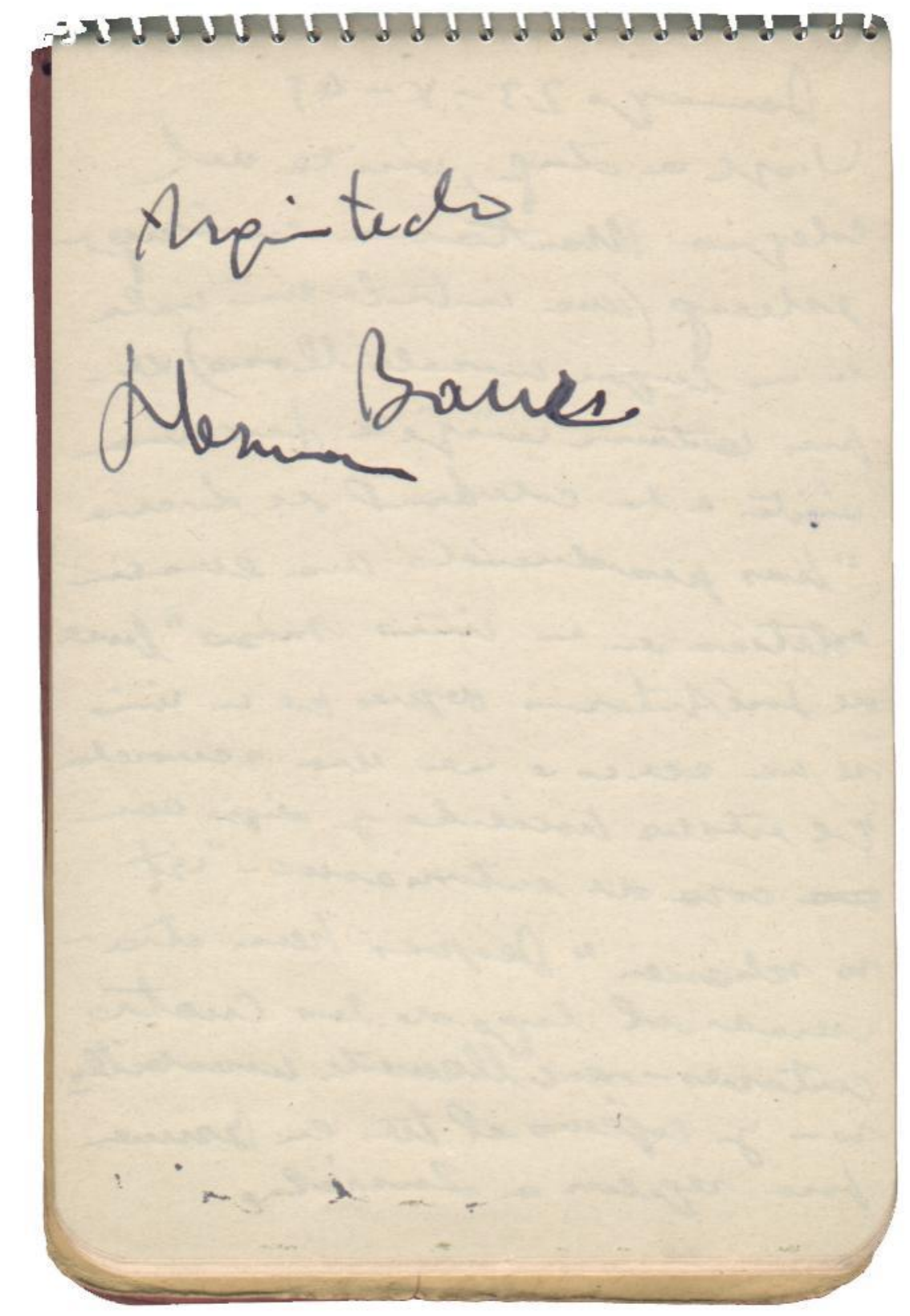

353 


\section{Página 12}

Dibujo de una fuente en un estanque

\section{Dia 24.}

Salimos de Zurich y llegamos a Basel

El Sr. Prikli al que íbamos recomendados de Rafael ${ }^{7}$ nos recibe muy bien y nos da un largo paseo en coche por toda Basilea. Vemos las escuelas hechas por el arquitecto

\footnotetext{
${ }^{7}$ Se refiere a Rafael Calvo Serer (1916-1988), conocido de Miguel Fisac. Fue el primer catedrático de Historia de la Filosofía española y Filosofía de la Historia en España, así como uno de los primeros miembros del Opus Dei. Entre 1943 y 1945 se trasladó a Suiza, donde formó parte del grupo de Consejeros políticos de Don Juan de Borbón. Destaca su labor en la revista Arbor -órgano generalista del CSIC- , en la que Fisac publicó en repetidas ocasiones
} 


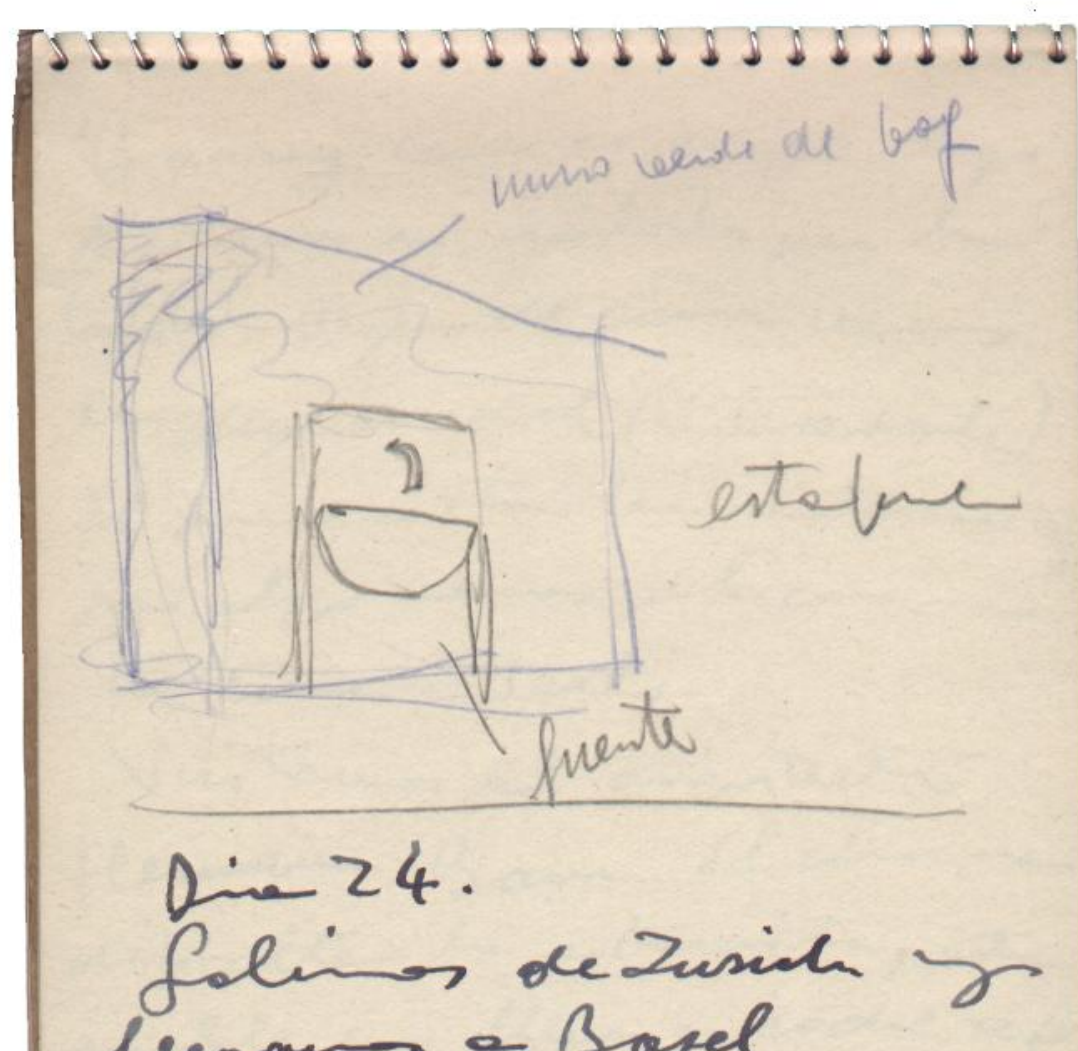
levan a Bard

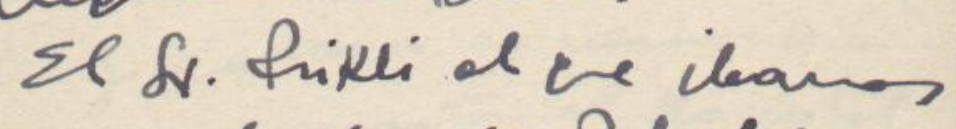
recoundade ore frobel has reciber or bieng hos de wo lapp poseose m cade pare tade Bonilea. Veus ror excuelos hechor mod venteds

355 


\section{Página 13}

Baur y como es amigo suyo quedamos en visitarlo por la tarde. Después de comer vemos la Universidad (interesante). El museo también interesante; pero algo menos, el casino no tiene interés.

Visitamos al arquitecto Herman Baur. El idioma dificulta la entrevista, esta amable nos lleva en coche al hotel y quedamos en vernos mañana para visitar el hospital. Llueve un poco.

Basilea nos ha producido buena impresión. 


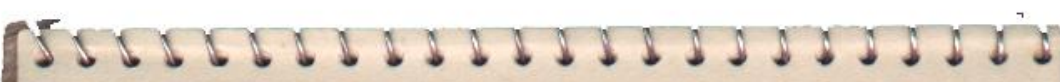
Baury cour es anife says pestams a visitosh ver ha tonse. Deppes oce camen weurs en Miviensidool (iteresanth) sl huses, the bi iterent to hes hep cew, il canis u treic iteres. Vinitanos al arenitedo Hesmana Baun. El ishir dificulta lo etreraita, esta andble un ther. coche ef bately eedonor a vennor ma mane posa cinta el taypital. Llueve 4 paco.

Basiles un ha prodratio vuen -viená

357 
Página 14

Dibujo de la sección de una puerta que dejaba un pequeño canal perimetral.

Puerta enmarcada

Basel

Casa Hoffman La Roche 


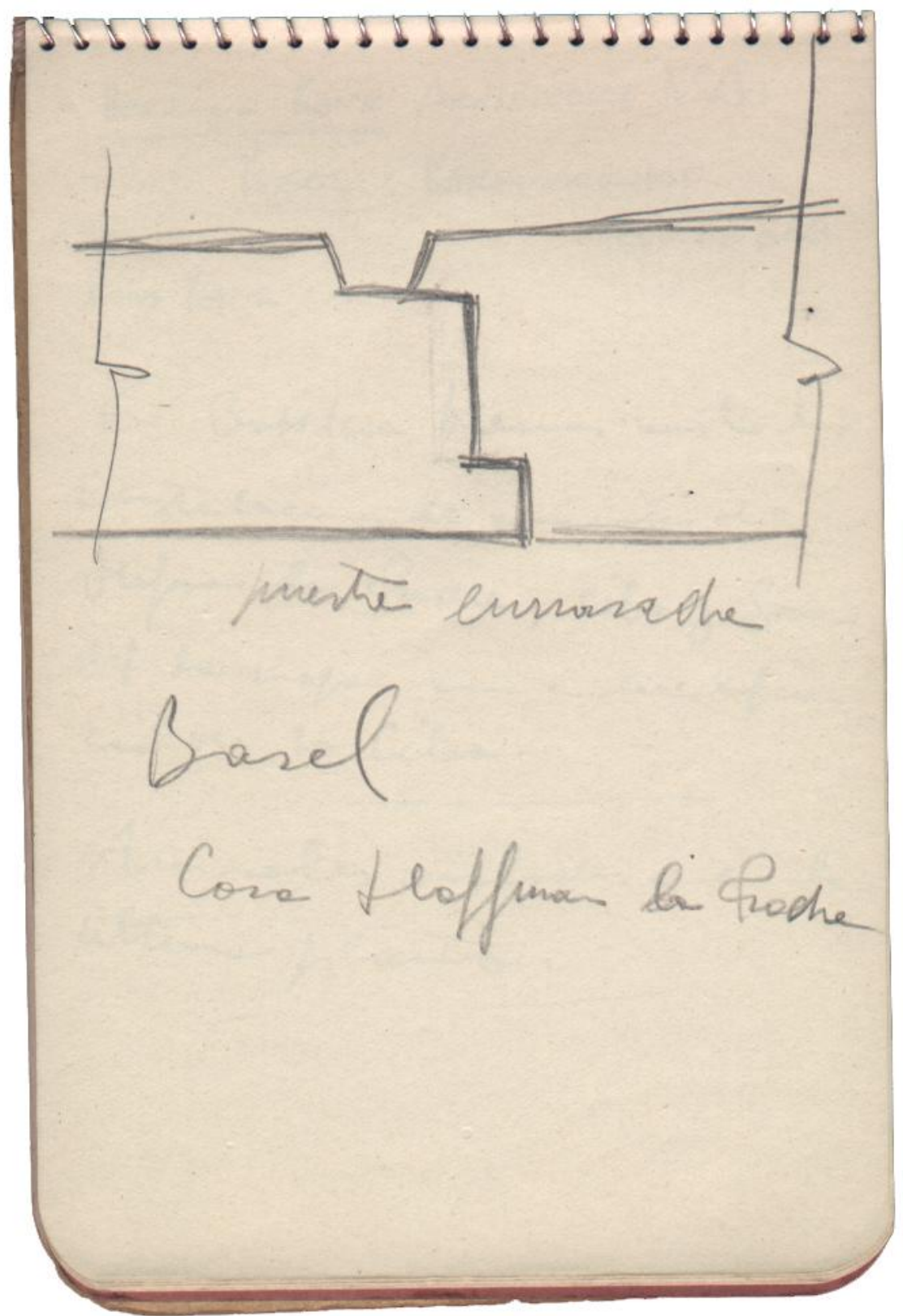

359 
Página 15

HERMANN BAÜR ARCHITEKT BSA

BASEL BARFÜSSERHOFF

TEL. 28066

HANS PETER

En Basilea hemos visto las instalaciones de animales de Hoffman La Roche, Ciba y Sandoz. La mejor con diferencia la de Ciba

Animales aislados o en la última planta 


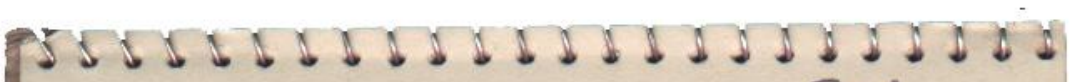
Herratar baúr Architekt BSA, Basec Barfússeritof Re. 28066

Haws Reer

E Basilera blewes visto hos instalacins de emindes de Hopmer he Frocke, cibary foun-

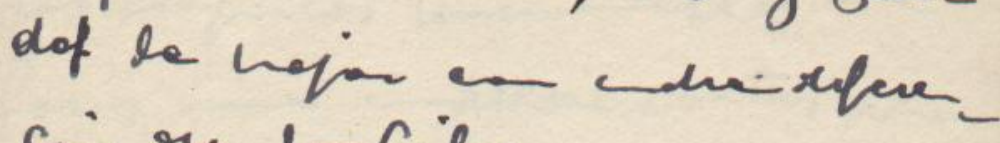
cin re le Cilas.

Anireles vishasoe h uttina placto.

361 


\section{Página 16}

París El contraste desagradable del paso de la pequeña población moderna, limpia, cómoda a la gran ciudad gigantesca, vieja, sucia.

¿Para qué negar lo innegable?

Los conjuntos monumentales de París son impresionantes pero nada más.

La visita al Museo del Louvre una decepción ¡Qué poca pintura!

$Y$ que pocas cosas de calidad.

El Instituto Pasteur es muy viejo: vistas jaulas de monos.

Lamentable fuera de to- 


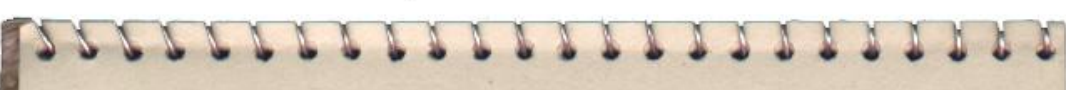
Paris el contraste deceve dolele del ta pas de lo pereañ poldeción unedense, hit pin, cace da. a la pran cinded jupaesterce, viepe, sucie.

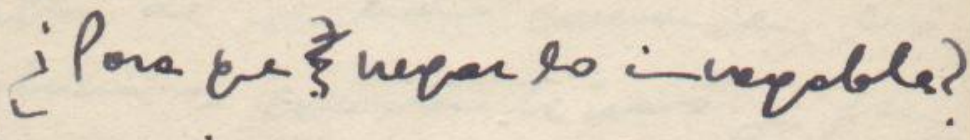
des astitos unumatales de Poin ma i presionates pao under mas.

to winta el musen xedoucre

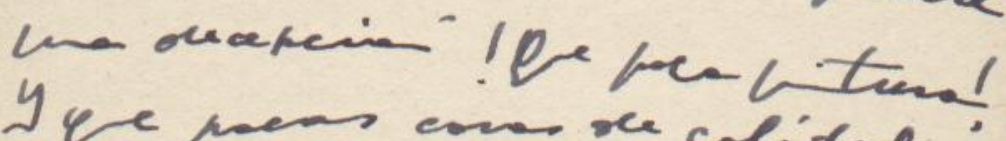
yee neas cons be calided. 51 7-litut Pesteocen is $o$ viesis. Vistos faulos te mavas.

damentable fuen se $t$ -

363 


\section{Página 17}

-da ponderación el pabellón suizo de la ciudad universitaria de Le Corbusier. Tiene todos los latiguillos plásticos de la peor arquitectura cubista. No cabe una mayor falta de sentido común en las soluciones constructivas y funcionales. Las calidades no pueden ser peores. En resumen: una porquería. 


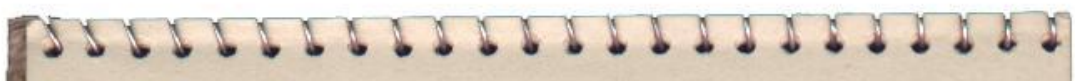

do prenderacier el polellen

mins de la cundorl Univeritasie de de Corlewaic. Tiène tados los estienillos hlast. cos de la peas arenitectura culeista. No calee we urea bulta de suntide esura en les uluevios coust te iad $2 \mathrm{fm}$ ciamales. Las calidader mo prue dur ver pesses. E senuc: ba horecis.

365 


\section{Página 18}

Upsala es un buen escenario para pasar el día de difuntos. Hemos visto al profesor Swetbert? ${ }^{8}$ Premio Nobel, y, nos ha enseñado un ciclotrón(. $)^{9}$ Cualquiera de las dos cosas es un plato fuerte para una conversación de sociedad.

Más tarde visitamos la Catedral

${ }^{8}$ La interrogación en el del propio Fisac. Se refiere a Theodor Svedberg, quísmo sueco ganador del Premio Nóbel de Química en 1926.

${ }_{9}^{9}$ Acelerador de partículas construido para la comprobación de las teorías del Profesor Svedberg. 


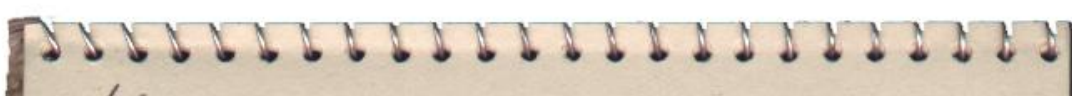
Hppede es un Gecen excen in para varer af dia ace oifunats. Hecum visto al prof. Suenterax? preinis movel, f, mos ham ever mads un ciclstren curburande las des cover es un ploc furte pona una comeresein, the saciedad.

Mńs taner visitamosla catedual

367 


\section{Página 19}

Dos dibujos:

Uno de un Limpiabarros (felpudo) con marco de madera y bandas onduladas de goma Parece que en Stockholm

Y otro de una luminaria de luz fluorescente con cristal opal, registrable 


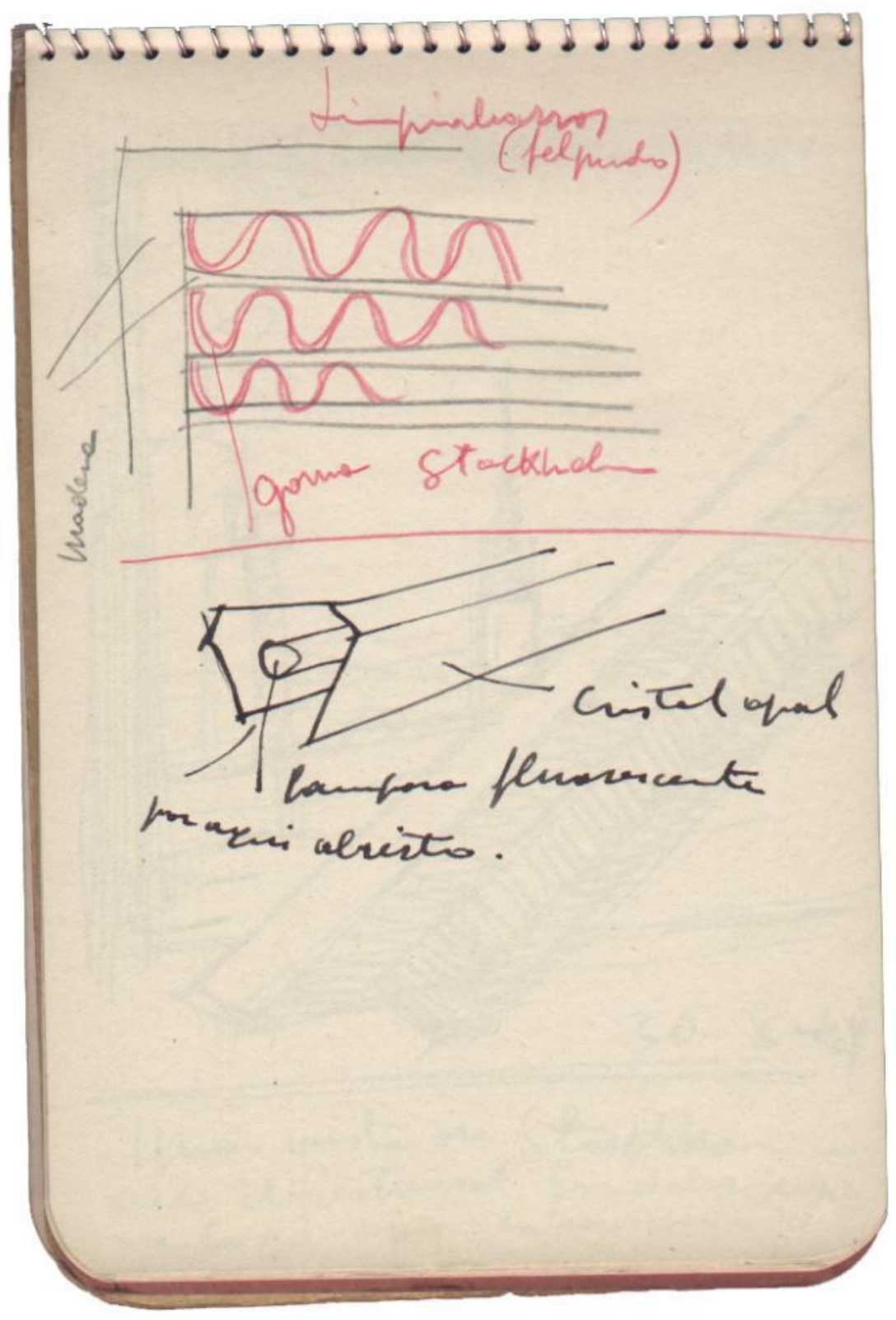




\section{Página 20}

Dibujo con una anotación:

$30-X-49$

Una vista de Stockholm desde el Restaurant Gondolar esperando que sirvan la comida 


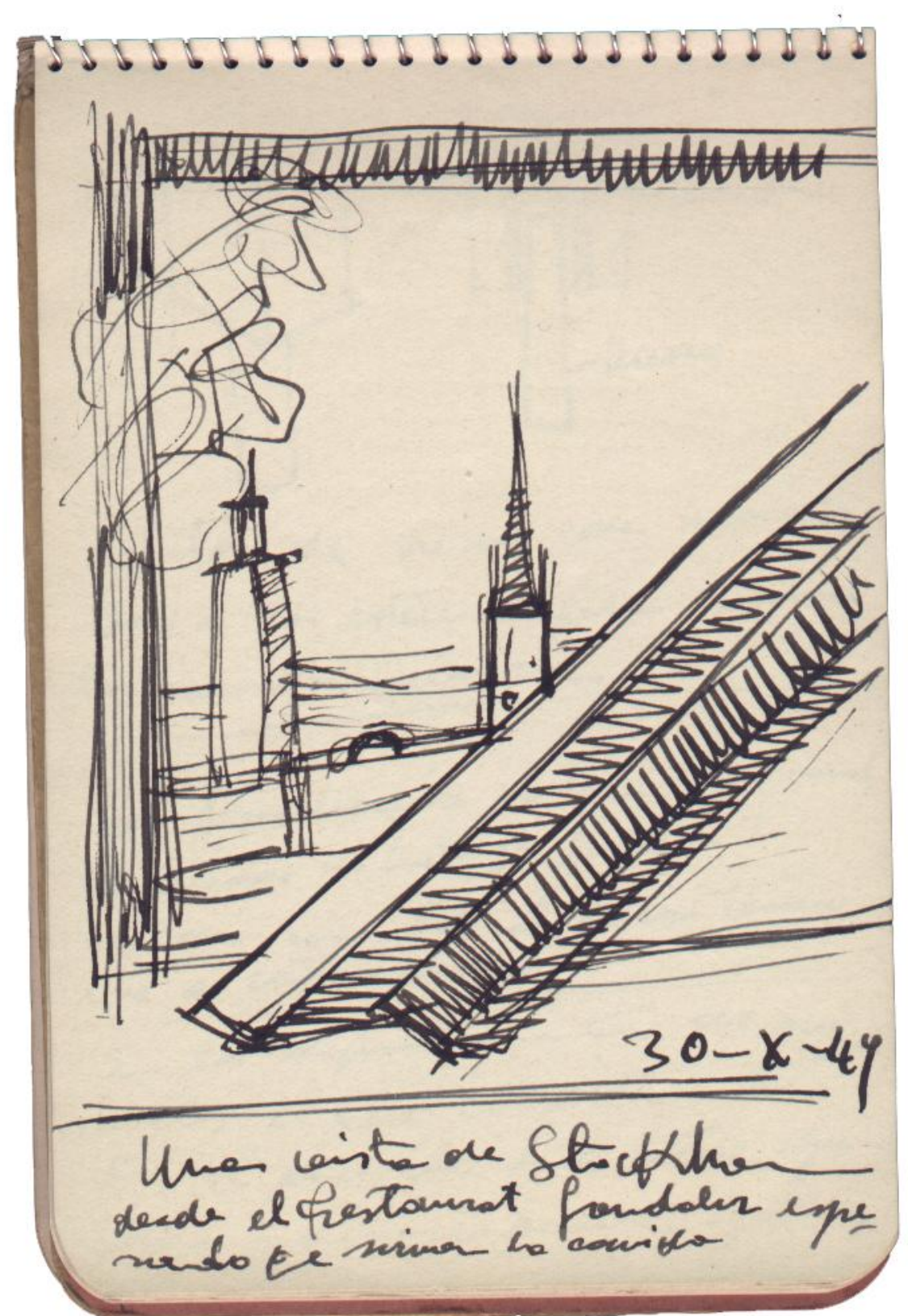




\section{Página 21}

Dos dibujos (sección y vista) de:

Patas de mesa con hierro (tubo?) en los extremos para graduarlas como una balanza.

Los laboratorios no tienen en general los lugares de trabajo frente a la ventana sino lateral para tener a izquierdas

En los departamentos de animales el aire caliente entra por el pasillo que tiene agujeros ordinariamente y a las 


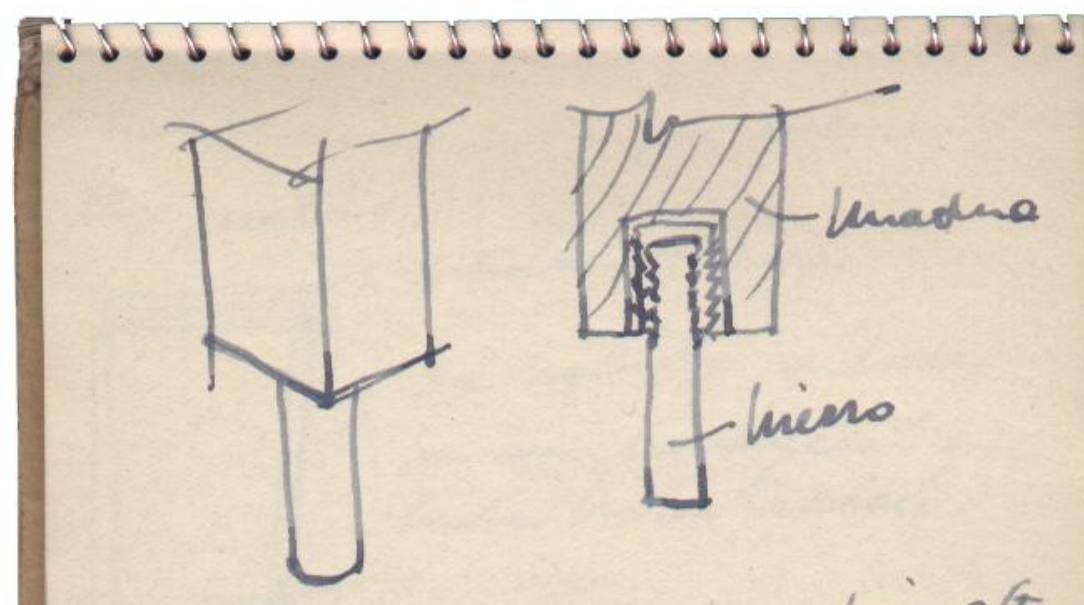

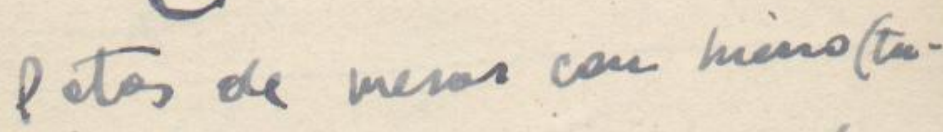
bo?) E los extremos para Vodusa by cons une balouses

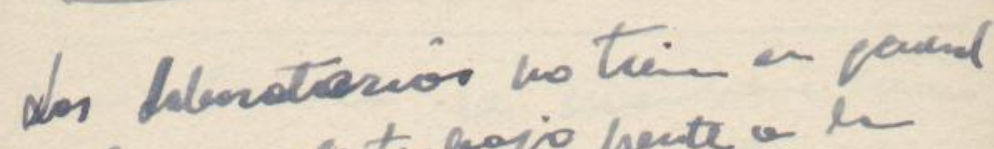

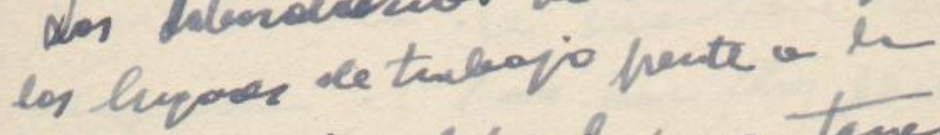
weitam sins loted pose teres lus e vivisecde

$\sum$ en epptrat ts or evimales al aire coliente the ha el parileo pre tîne aqu. firas adinociamente $y^{a}$ ly

373 


\section{Página 22}

habitaciones entra por encima de las puertas.

Dibujo Indicando la entrada de aire

La salida se hace por una conducción en cada habitación

La calefacción es por paneles radiantes tiene la ventaja de no tener movimiento de aire Generalmente se mantiene una sobrepresión en los pasillos para que no salga el aire a ellos de las habitaciones

Paredes pintadas en distintos colores, más claro la pared que tiene la ventana y más oscuro la de enfrente. 


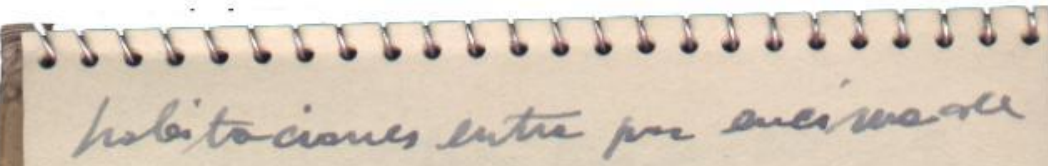
las pirtos.

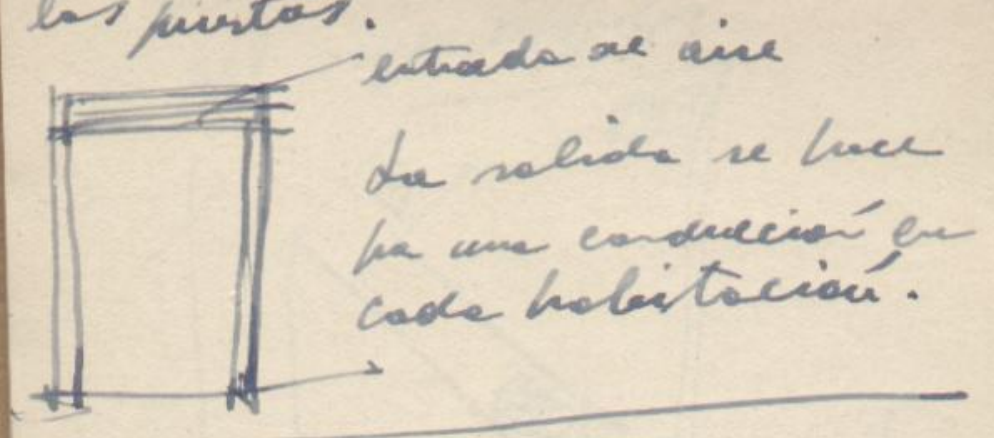

da colefecciar es fion paucles sodiantes tivie la ventigi de mo tener movicusento se avie yeveralente re mantión cura soheprecina to los pasillos pase Le no sera d acie a ellos de rasholitaciones. Pucdes pintsoles vi dishi tos celves, mad loce la pased cetine is ventane of mos oseare ra de entrenta.

375 


\section{Página 23}

Dibujo de elementos para la red del espectógrafo

Croquis de una pieza, parece de hormigón, con unos puntos de fijación. Fisac no recuerda de qué pieza se trataba.

elementos de hormigón con tres puntos de apoyo pero sin fijar en el suelo. Suelo de cemento 


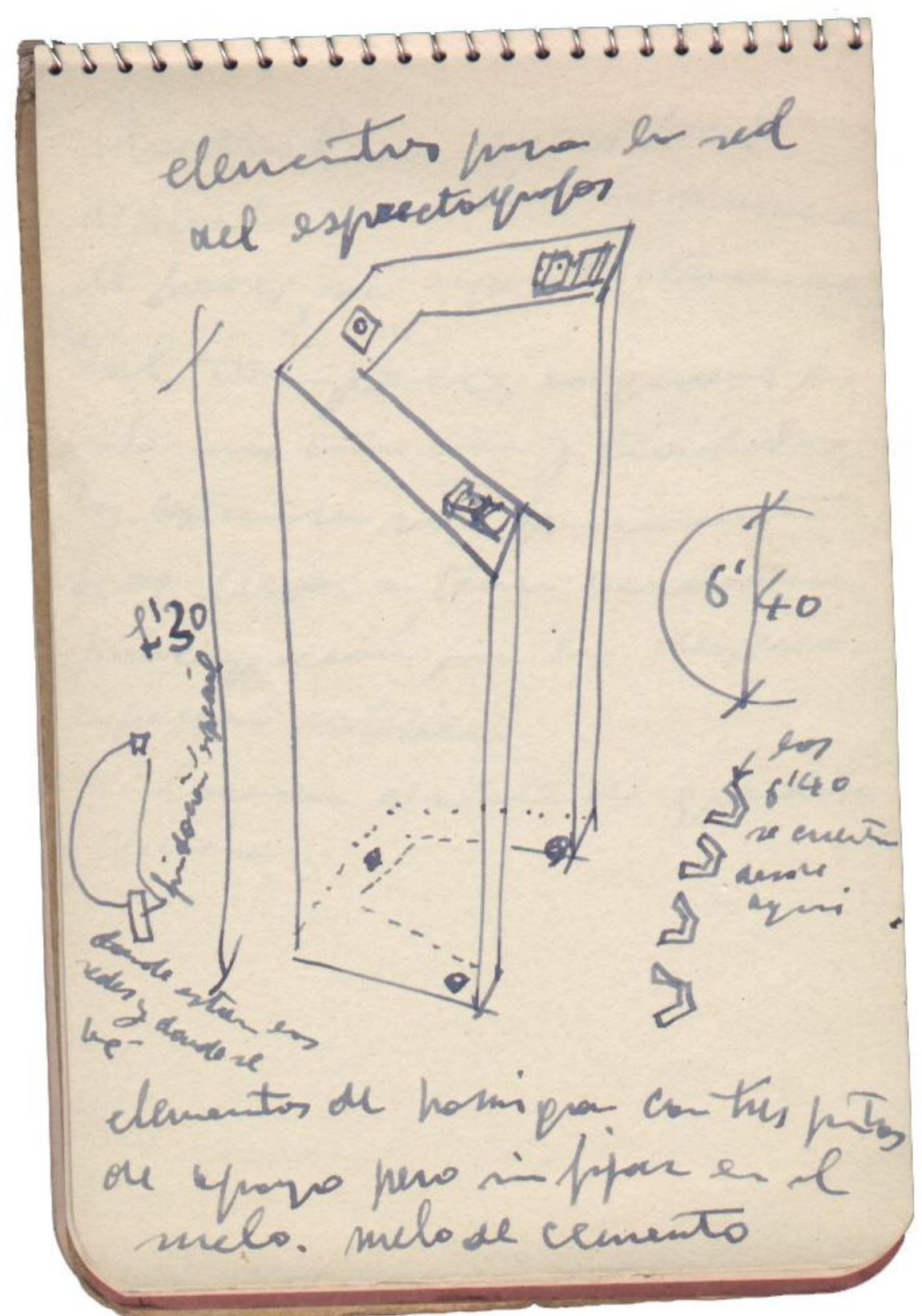


Página 24

Stockholm no es fácil definirlo con media docena de frases, su arquitectura actual tampoco, en general los interiores están bien cuidados, los exteriores son francamente feos llegan a tener verdadera preocupación por la despreocupación estética.

Carencia absoluta de grandilocuencia. 


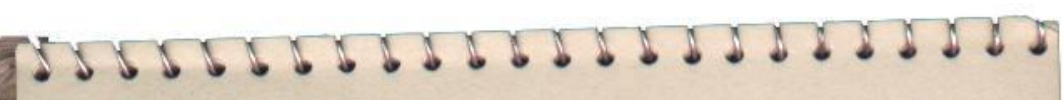
ftockhalm no es bacil definirls can medie secena

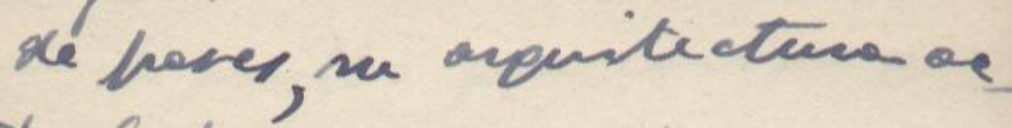
thal to poco, en ycuent los interines ext bien o cuidodor, los extevines san ben come te feos llevan a tewer vesdodena prevenfucián pos lo deques. copación estefica

Coremcie alsoluta de quadils cuencines.

379 


\section{Página 25}

Instituto nuevo de Macrobiología de Ultuna (Uppsala) ducha en el pasillo para caso de quemaduras

Dibujo en planta de la ducha

Muy interesante la manera de cerrarse las puertas unos ganchos fijos y un aparato arriba

Dibujo 


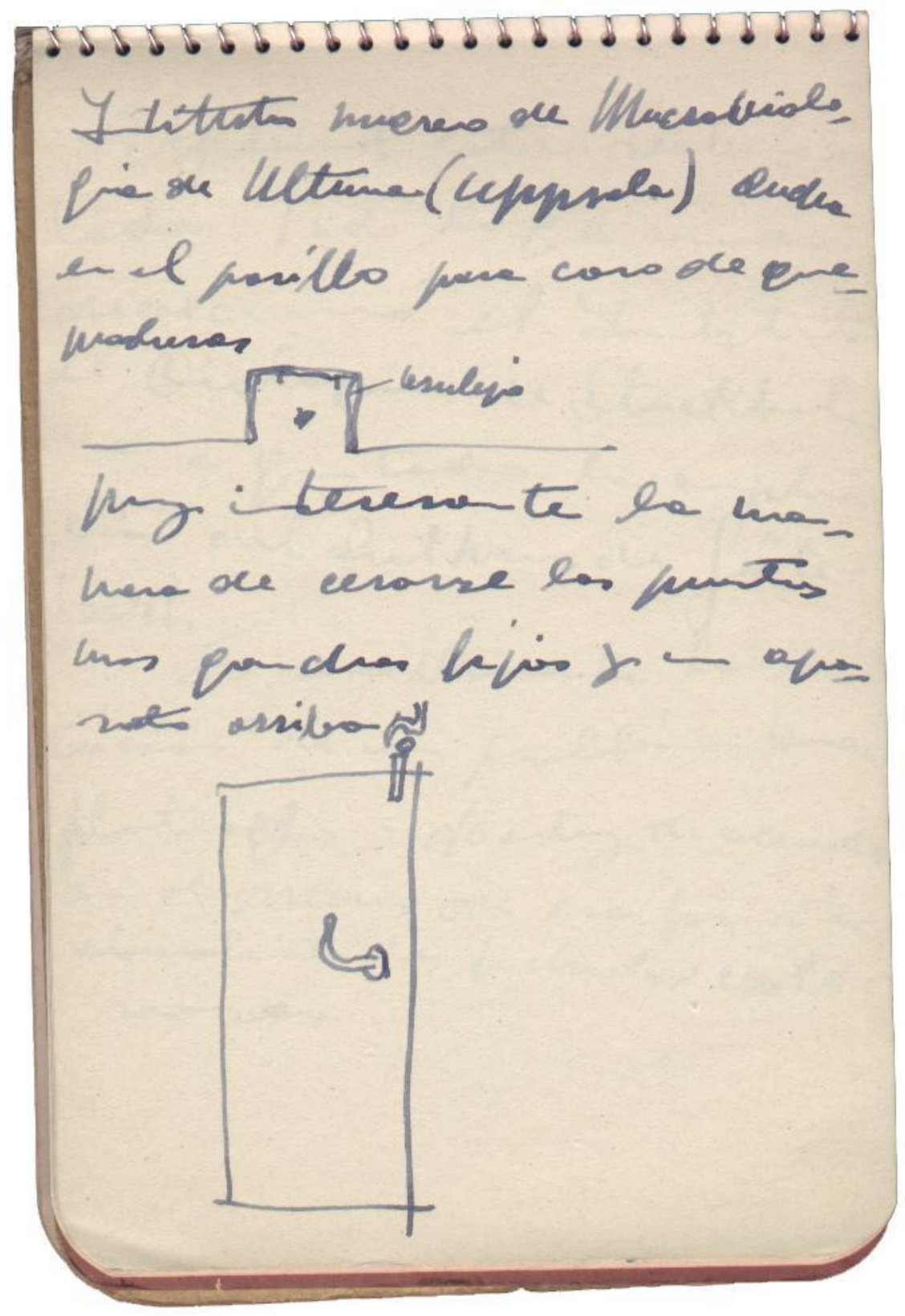




\section{Página 26}

Asplund está rehabilitado. Todo lo que me decepcionó el Instituto de Biología de Stockholm ${ }^{10}$ me ha gustado la ampliación del Rathaus (supongo que será la palabra sueca para ayuntamiento o tribunal) de Goteborg. Es sencillamente la solución de un problema bien planteado. No estoy de acuerdo en despreciar de esa forma tan absoluta las fachadas exteriores.

10 Se refiere a los Laboratorios Bacteriológicos del Estado, obra de Asplund, ganada en concurso en 1933 y que, como se desprende del texto del diario, causaron una pobre impresión al arquitecto manchego. 
Asplund ista seceilis tado. Tod la ce un a deaccions' el y titht de Biabeia de Stactehal ue retar h a phi. cin' oul hat ham ol fäte-

Es seraibernante lo nos

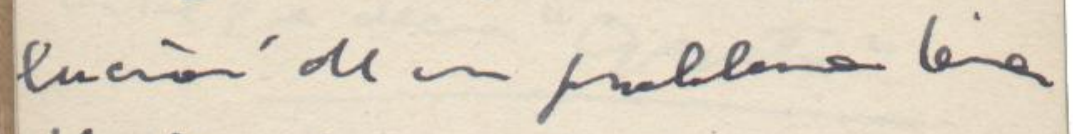
plateoges. Nostrg on ocurado en denpecis ore ena ponat absole to los frchados eate. nives

383 


\section{Página 27}

Si una palabra sueca no se pronuncia exactamente como debe ser la gente no la entiende por esto bien se podría decir como dicho: "Tienes menos imaginación que un sueco".

Ves, dice José Antonio, aquí dejas estos libros en la calle y nadie se los lleva y debajo de esos libros, más bien folletos había un cartel que decía "Gratis".

En Goteborg hemos visto muchas más cosas interesantes de las que esperábamos.

La sala de conciertos es realmente buenísima toda forrada de madera de abedul y con una acústica per- 
fi une palales suecen as re prom

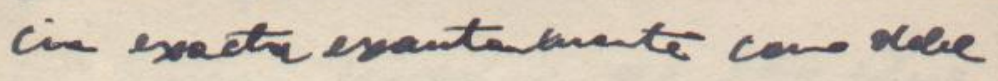

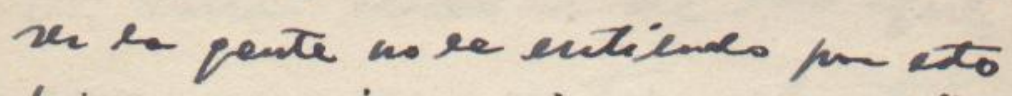

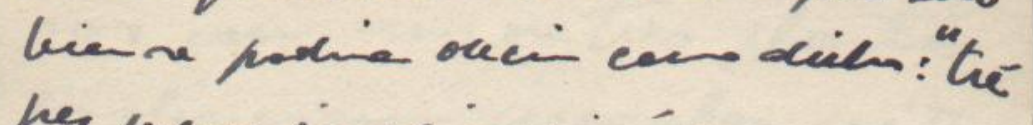

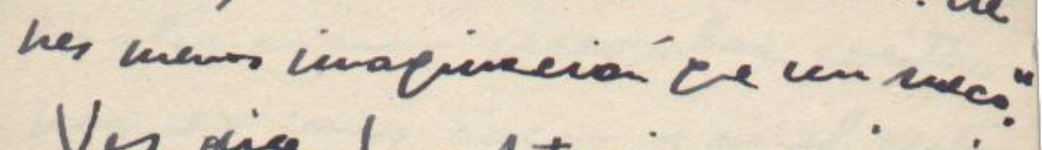
Ves acia dose futais on aria

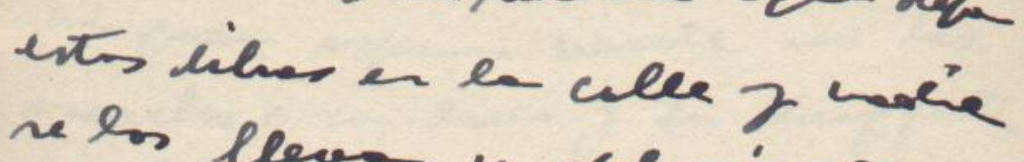
rebos leven y oblenis de as liks, und bin fallets Mobia a atelle deia "Qpate"

En pitelery heme bist hohare uns cons itterests oh ha ce rpenderens.

La salo de carciestos es realuate buenivive toda lorradade undena the cledul Y cen una acustica rea-

385 


\section{Página 28}

-fecta. Hemos visto también un barrio nuevo de las afueras con casas de tres plantas en alineación irregular contrapeando unas rocas y en el centro un gran espacio verde con las escuelas a un lado y un Kindergarten en el centro.

Con el arquitecto jefe de urbanismo hemos visitado otra colonia de casas elefantes en donde él vive. Dice que está bien pero que es solución desechada por la necesidad de instalaciones más caras, etc.

La solución ideal, según él, es la que están haciendo de casas de tres plan- 
fector. Hewne witis th les ¿ bover unews dee bes ofue sos cen cans detes plants en hiverin isepulo couterheands uns sacos yex el certo

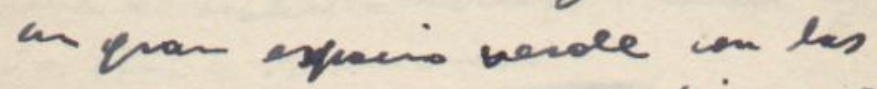
esacts a car hace of en kingtode in centi.

Can menityts jefe are ubainons hen visitions otro colanie el cosos eleforts - donde ol vine Dice e. esto hi penceres soluciebuschada for re neceridul oce initaluciares mar coner ete.

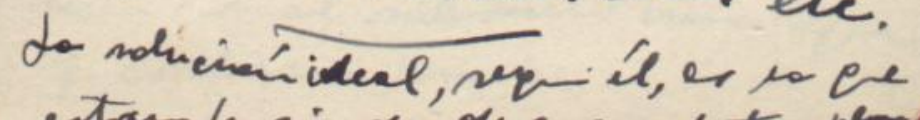
estan hacien or cosas de tras wh

387 


\section{Página 29}

-tas en línea adaptándose al terreno. La orientación dice que no tiene importancia porque como son casas de solo dos crujías la que tiene mejor orientación se destina a habitaciones de vivir y la otra a servicios.

En Malmö el teatro está bien resuelto técnicamente el escenario es enorme tiene $18 \mathrm{~m}$ de embocadura, treinta metros de fondo y 25 de alto las decoraciones se transforman trasladándolos por carriles pero sin variar de plano. No tiene foso...

dicen que el subsuelo tiene agua y costaría mucho. 
tos en limcre odaptandose ${ }^{2}$ tersens, ha sientacin' avice ce wo the inatancia prese cano

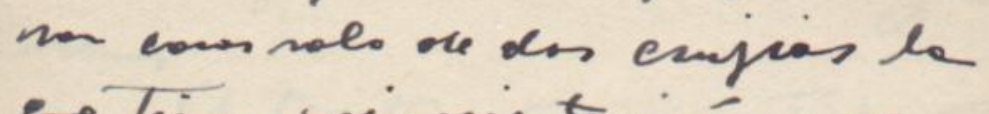

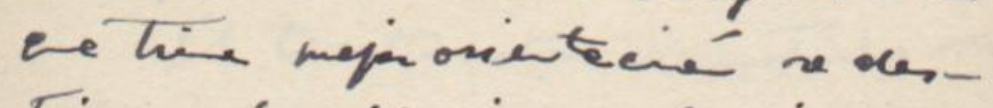
tine le halitacinuester vivin $y$ the thase servicinis.

En Malminad teatho ext leir semelts teminan el excentio es enome the

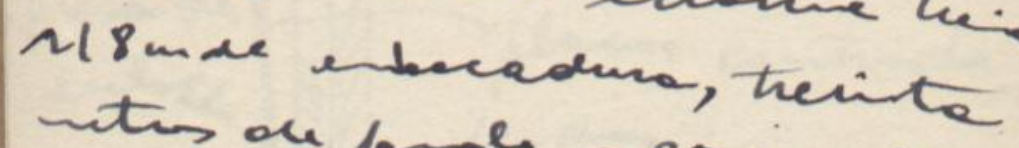
utis ou buce 225 ou alto en olecineives 24 tansforman toshada eseos mo covider nas ni unsion ore plans. Notiene foso arie ce ol mesuelo tien ave y costaria mueho.

389 


\title{
Página 30
}

La sala tiene unos cortes en el techo y se puede dividir reduciendo la capacidad de 1700 a 1100 y a menos.

El teatro está revestido de aplacados de madera clara creo que es fresno. Las placas se cogen así:

Dibujo con indicación de los componentes en sección

\author{
Unos bastidores fijos sobre nudillos
}

Pieza de enlace

Placas contrachapadas 


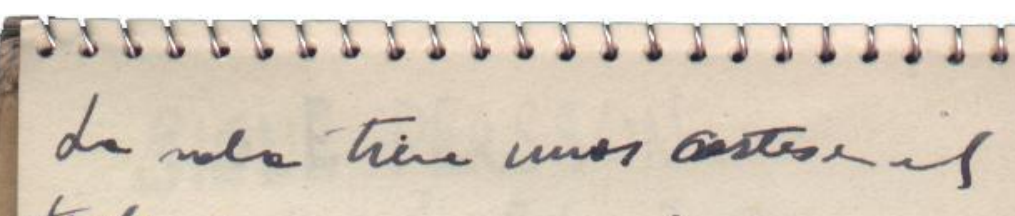

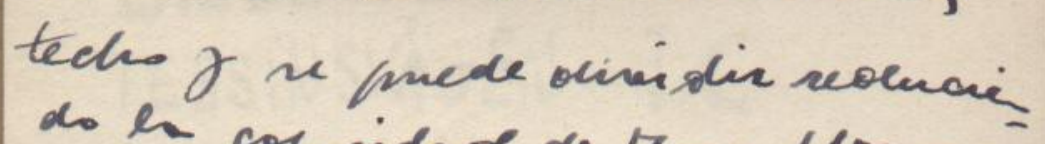
do ha copacidad de 1700 a $1100 \mathrm{~g} e^{-}$ menos.

Ir terth ist sevestide on eplacoses de undereches crenge prene. los places se coje ex:

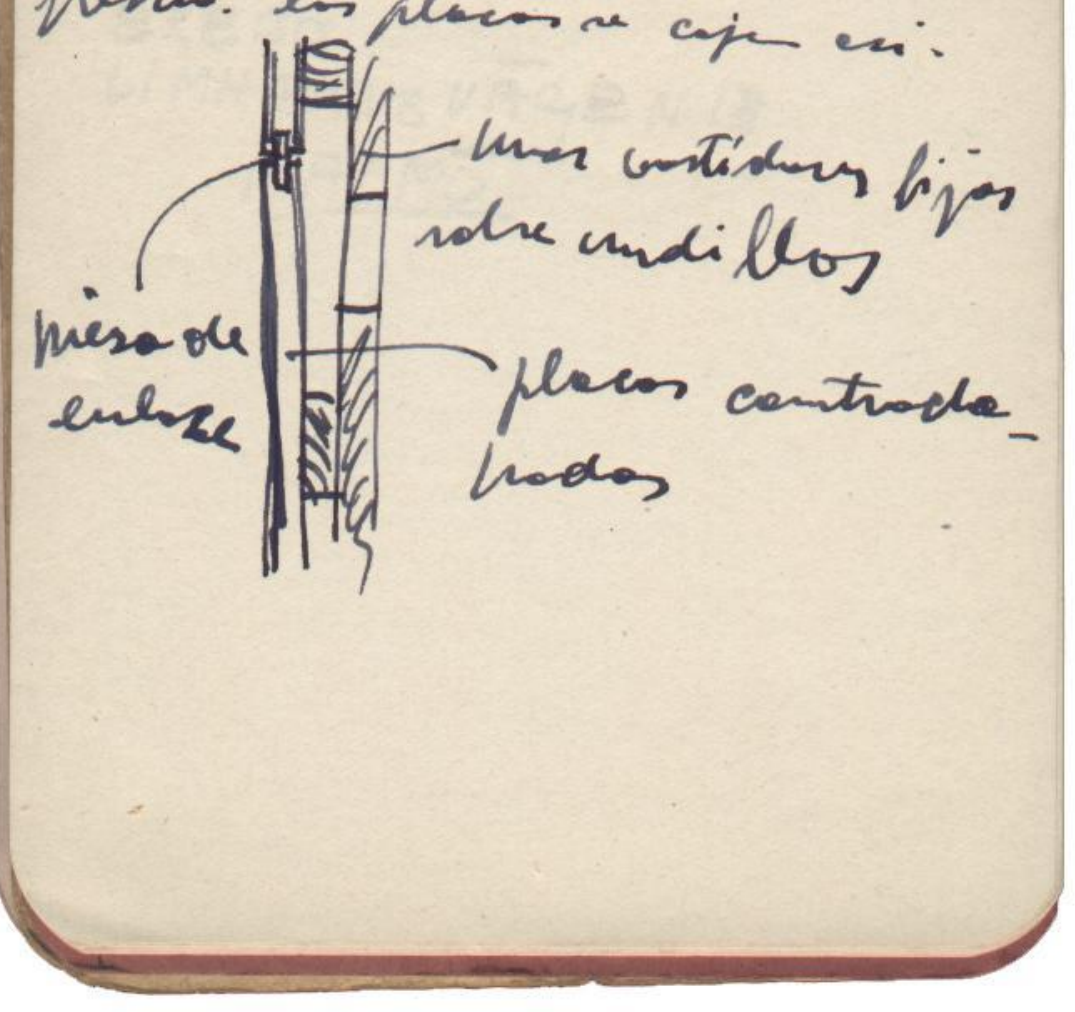

391 


\title{
Página 31
}

\author{
SIGNE PERSSON ${ }^{11}$ \\ TESSINSVÄGEN 1.C \\ MALMÖ
}

\section{SWEDEN}

Lena Möller

\section{EKEBO}

LIMHAMNSVÄGEN 18

MALMÖ

\footnotetext{
${ }^{11}$ Arquitecto sueco que les enseñó un barrio que había hecho con 15 ó 20 casitas individuales, unidas por un túnel subterráneo recorrido por una motocicleta de tres ruedas que llevaba la basura a un quemador que servía para calefactar el conjunto. La chimenea del calefactor recordaba la torre de una iglesia y el arquitecto había fijado allí unas campanas que sonaban con el movimiento del aire. Nota extraida del archivo personal de Eduardo Delgado Orusco.
} 


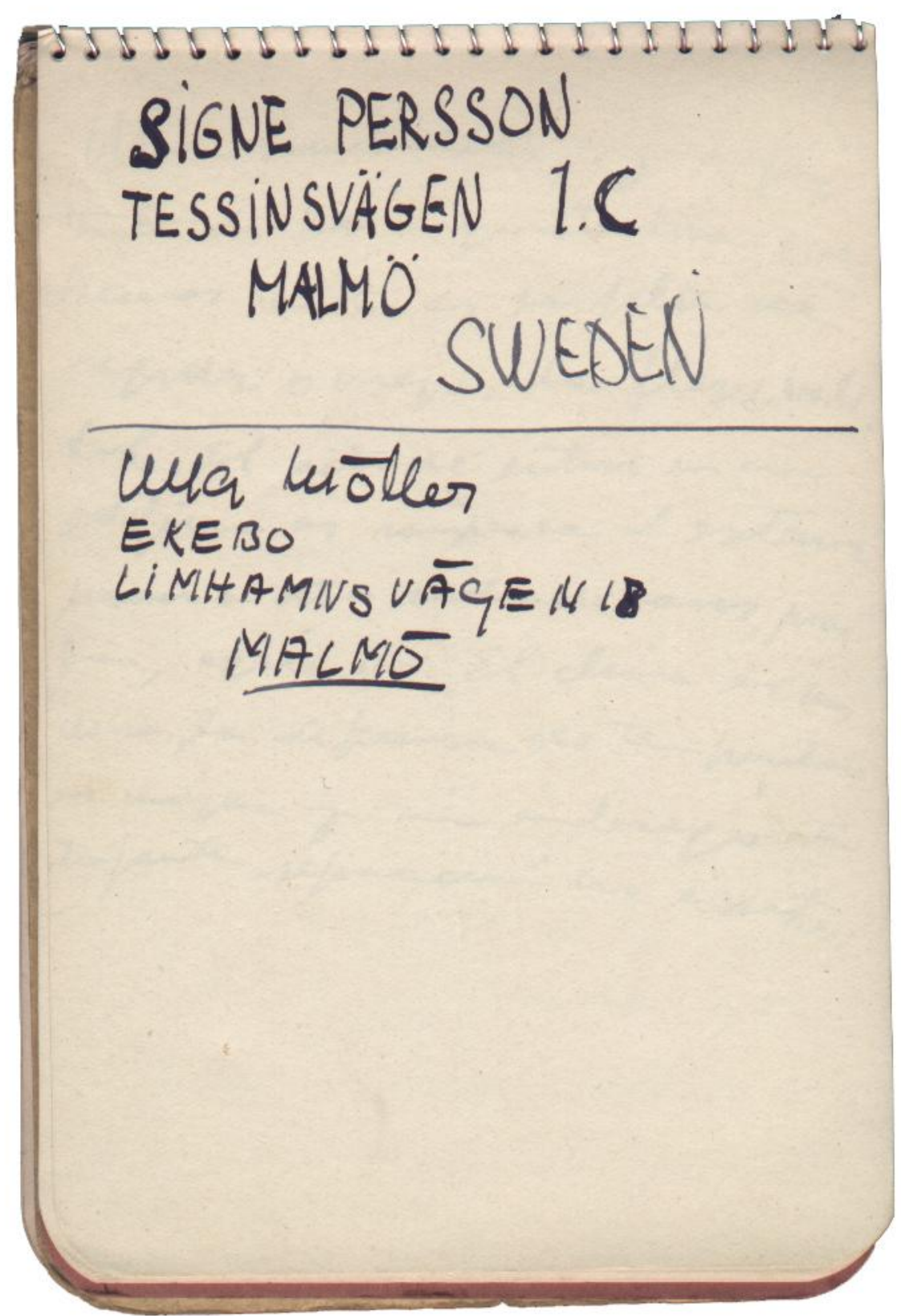




\section{Página 32}

Una característica muy importante de la arquitectura que hemos visto es la falta de rigidez o mejor la flexibilidad. El acto de entrar en un edificio es romper con el exterior pasar a otros orden de cosas, pues bien, aquí no. El clima es muy duro, la diferencia de temperaturas es mayor y sin embargo esta tajante separación no existe. 


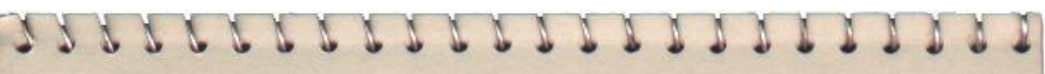

the conctenticice orye bibo de es areritache ere heuns lecito es en Wlt de repides o mejor la flessibili dod. El actore entras in w exificios sanper ex exteniz parno tho asde decaros pus lin, revis no. Sl cline er my durs, la diferencie ole te hestun

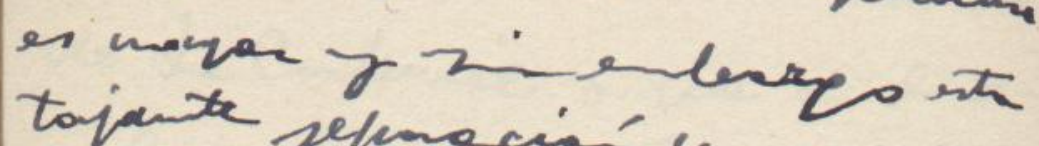
tajante sefaracior us escite.

395 


\section{Página 33}

Dinamarca es una nación menos exótica que Suecia para nosotros. Tiene más arquitectura antigua y popular que Suecia y una arquitectura moderna menos definida.

Hay alguna tendencia al funcionalismo a la manera de Le Corbusier o sea a lo malo, más decorativismo que en Suecia, peor gusto.

El edificio de la radio tiene interés pero tiene preocupaciones de casa moderna 


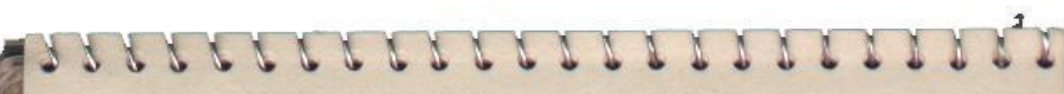

Dimanasere es una noción mems sectica cre fueens pace mosotras. Tiene mál asenitecture antifue of populos be sicke y une erpiritecture maderma nems delinide Hog alenne terolencie el funciandians a la unarea de de Cadencie o sca a ho unalo, má olloosativioms ere el riecia, pear pust.

El colificio de la redio tien. itores pero teire preace pacioner ole eara undeccra

397 


\section{Página 34}

que no suele tener lo sueco.

Realmente la arquitectura sueca lleva la modernidad con una naturalidad subyugadora.

Los grandes bloques de viviendas populares de Copenhagen son plúmbeos, el mueble, el aseo personal y de la vivienda etc. Es bastante inferior.

Las instalaciones en los institutos científicos es en general del Estado-edificio antiguo y el de odontología modernísimo son deficientes. 


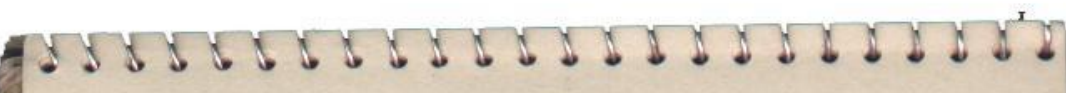
Ue no mele terer eo sues. freslmente la esquitectran sueca llese la marlescides can una naturalided sub_ Hugfadeka.

Las grandes beoparoce sina das propulaces en Copendopen

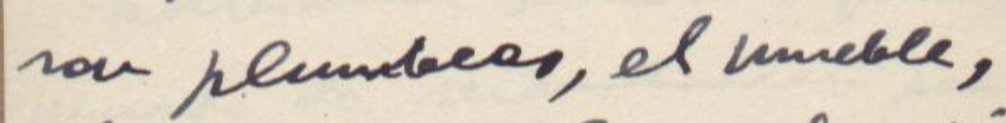
el eseo pessonal $y$ de lo vinis. de ete. os lestante ifferis das instabidiner en las insti: tubs cientificas a de fuery oul Estado-edificin, axtépsy el de odastilyia mader minimo san deficiestes.

399 


\section{Página 35}

La impresión primera de Ámsterdam es de ciudad hecha en 1910. Cosas de ladrillo modernas entonces. Una ojeada posterior confirma la primera impresión.

Rotterdam está en franco período de reconstrucción pero las construcciones no tienen gracia, son modernas algunas con decidida preocupación moderna pero le falta la proporción en unos, la falta de esos detalles de arquitecto en otros, los reducen 


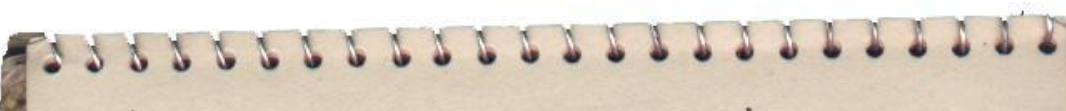
da imeiná mincusa de Amiterdan as de ciidnd hedue en 1910. Cosas gre hadillo modrunaroce eutances. How hoje de fusteris confina la primere ivacień.

Puttroscan est en panc feciads de secanst ciom fero

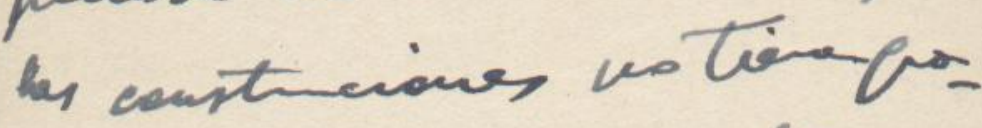

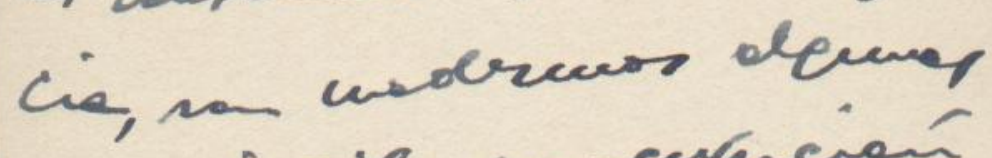
con decidide peedecuciań modrune vero la plata popazción en was, to bl. te be ros etalle the revi: tets en thr, by reshon

401 


\section{Página 36}

En unos mamotretos viejos antes de nacer.

Hay 8 páginas más prácticamente en blanco salvo dos de ellas. Una presenta lo que parece un horario de trenes:

Y en otra un par de dibujos distraídos e ininteligibles y algunos números. 


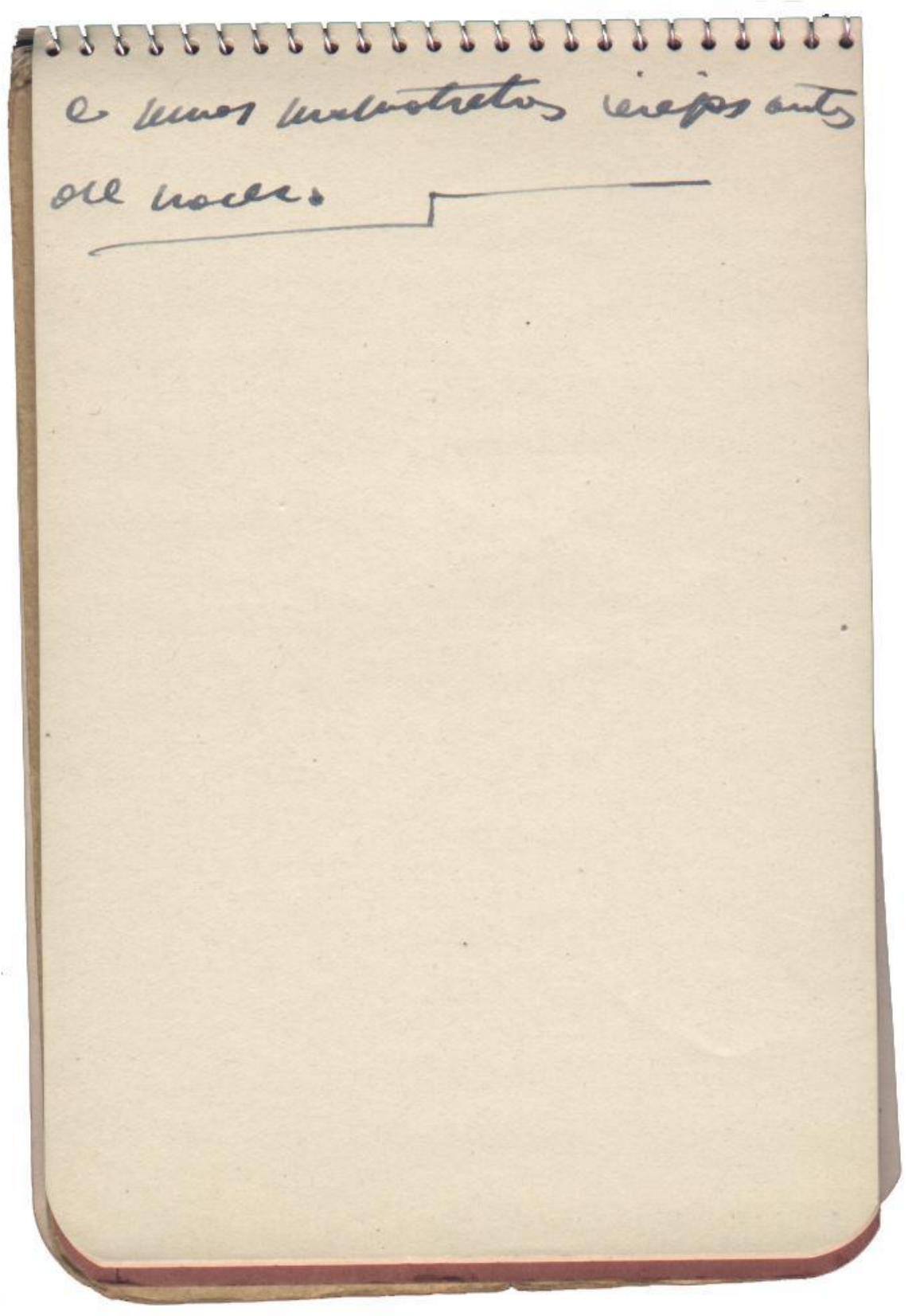


Página 37 


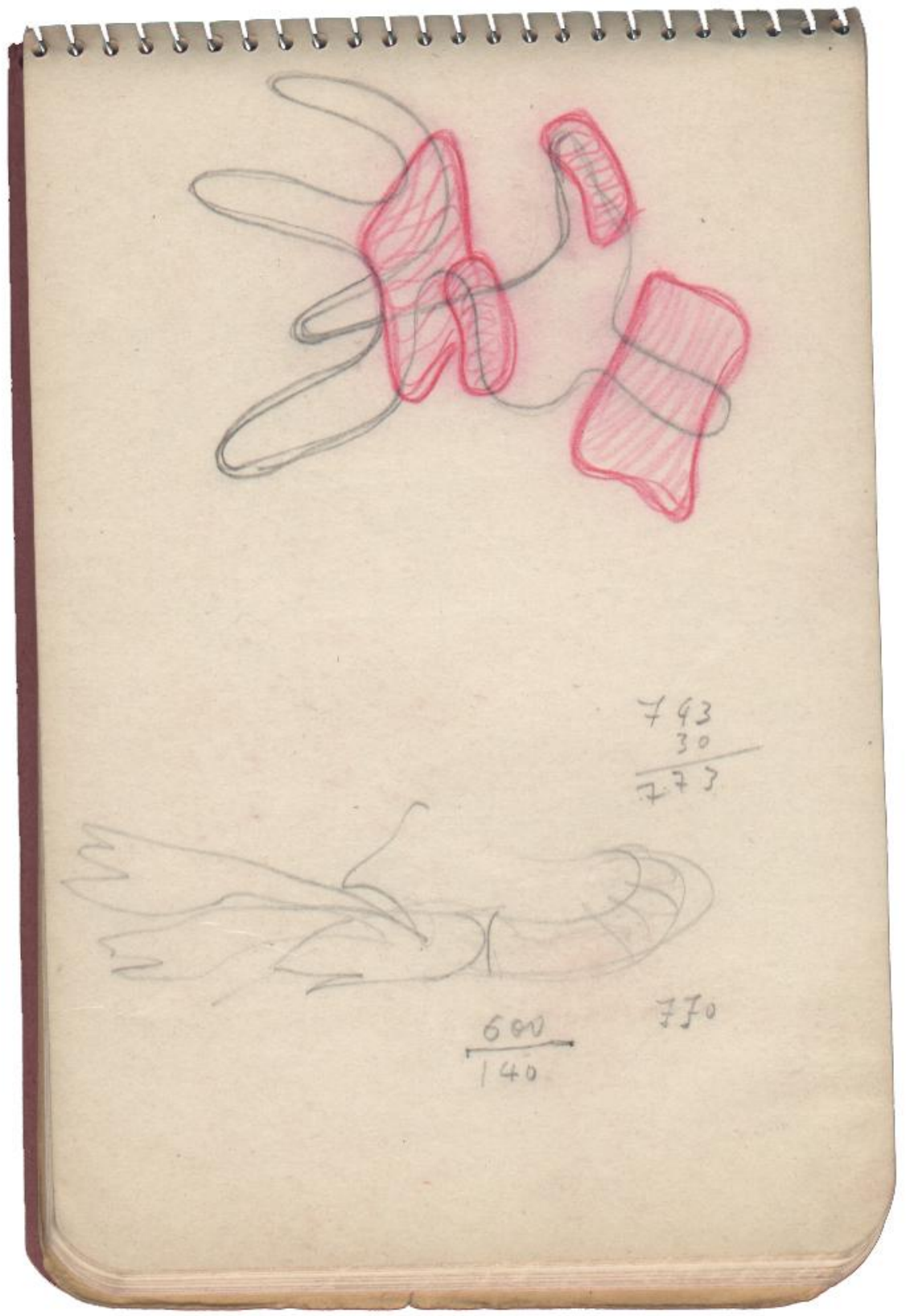

405 
Página 38 


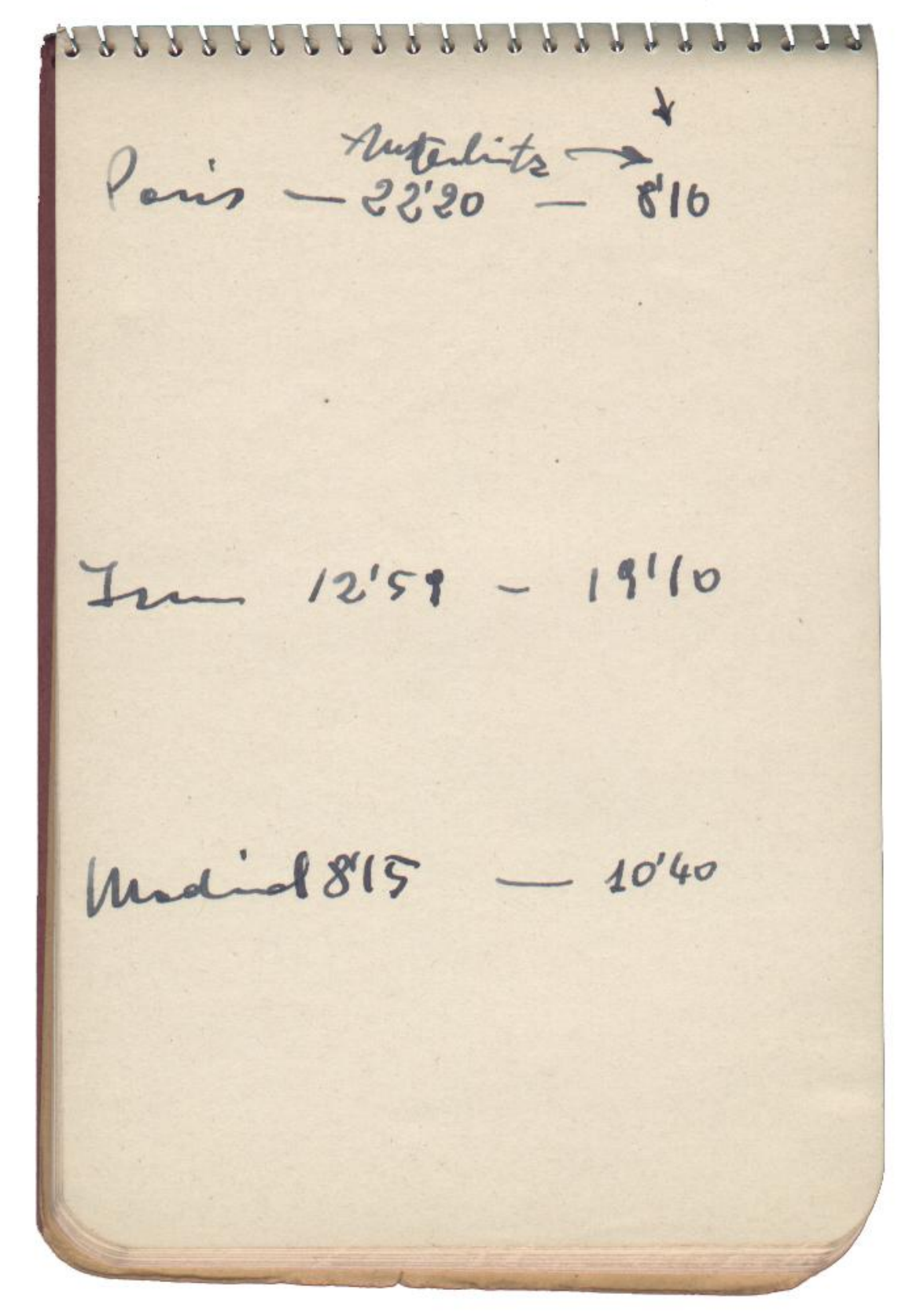

407 
2.2_ Facsímiles del Cuaderno de Viaje alrededor del mundo [inédito]

409 
VIAJE ALREDEDOR DEL MUNDO

DEL 17 DE AGOSTO DE 1955

AL 28 DE SEPTIEMBRE 


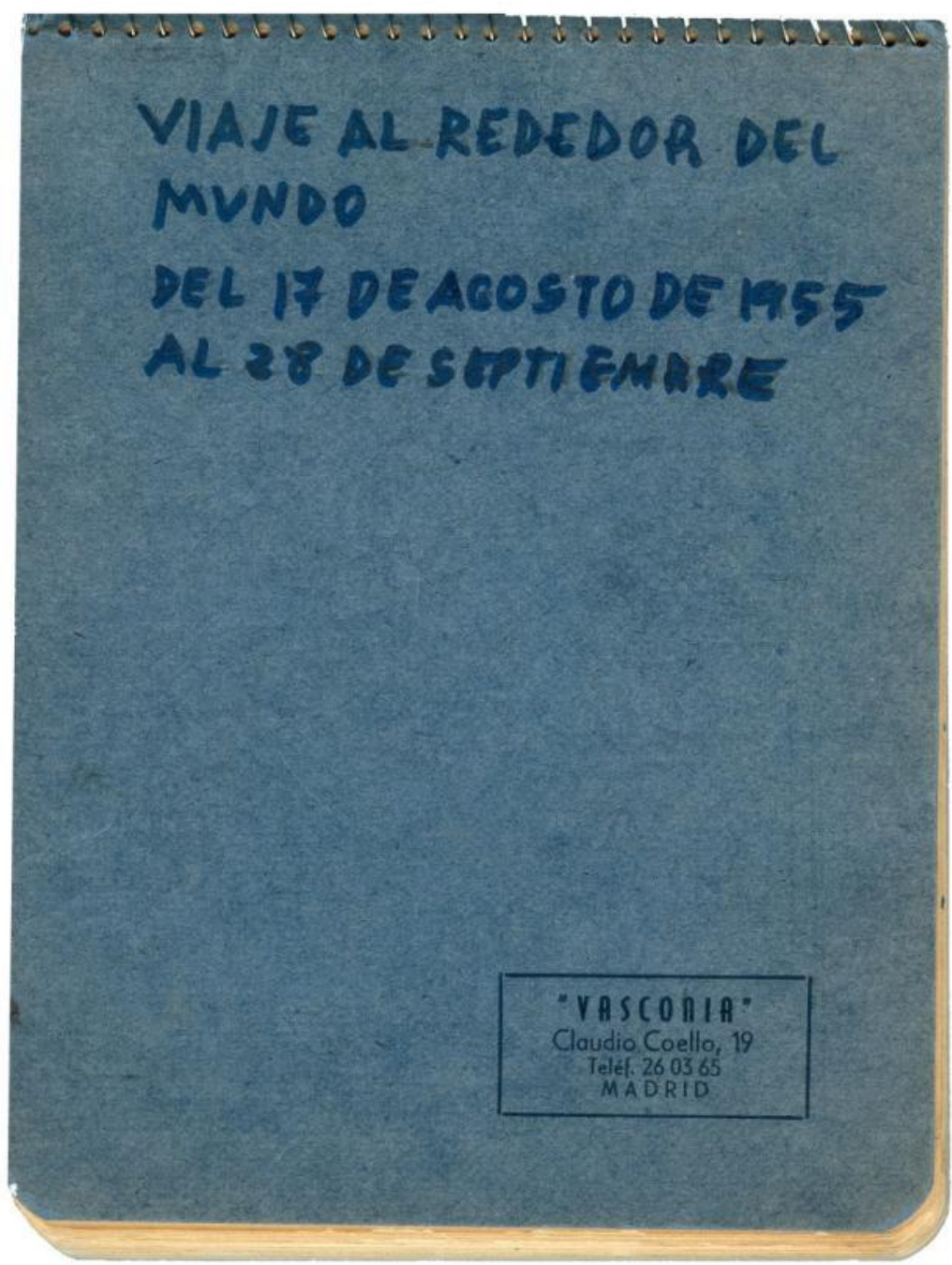




\section{Página 1 (delante)}

\section{VIAJE ALREDEDOR DEL MUNDO}

17 agosto 1955 Salgo a las 9'05 de Barajas en Iberia para Ginebra

Cambio de avión de la SWISSE a Zurich y de allí en TWA a Roma y Atenas.

Llego a Atenas a las 9,30 de la noche

18 agosto Salgo de Atenas a las 5 del día 18.

Después de parar en Chipre llego a Beyrouth a las 10 1/2 de la noche.

19 agosto Salgo de Beyrouth a las 3 parada en Amán y llegada a Jerusalem a las 6

$\underline{27 \text { agosto }}$ Salgo de Jerusalén a las $41 / 2$ y llego a las $51 / 2$ a Beirut

28 agosto Salgo de Beirut a las $21 / 2$ de la madrugada y llego a Bangkok a las 5 de la madrugada después de haber hecho un viaje de unas 22 horas. 


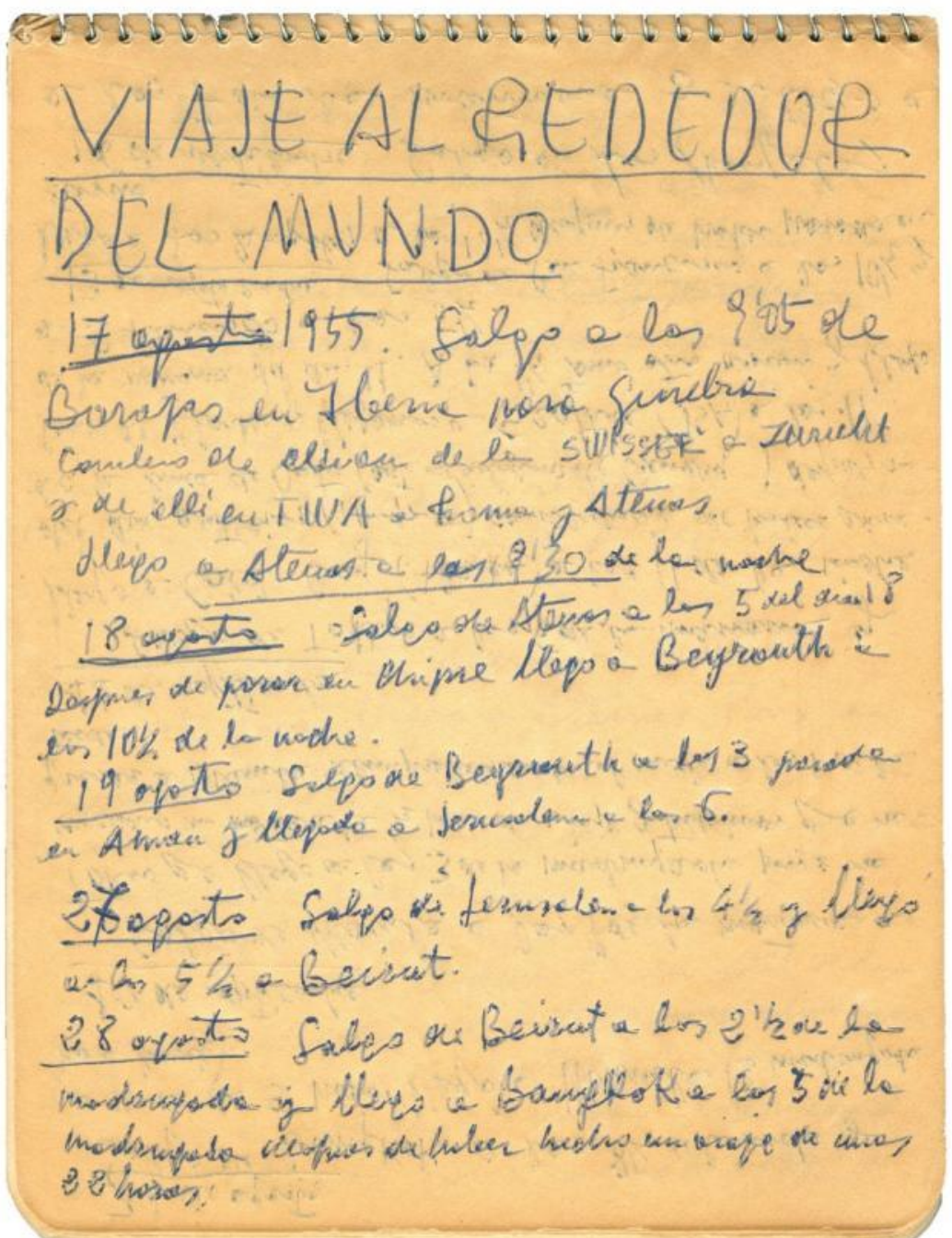




\section{Página 1 (detrás)}

31 de agosto

Salgo de Bangkok a las $81 / 2$ de la noche y después de 5 horas llego a Manila ( 3 madrugada hora local).

\section{0 de Septiembre}

Salgo de Manila a las 9 de la mañana Tokio que llego a las 3 de la madrugada porque se incendió un motor a la $1 / 2$ hora de viaje y tuvimos que regresar a Manila reemprendiendo el vuelo a las 4 de la tarde.

\section{1 de Septiembre}

Salgo de Tokio a las 6 de la mañana y llego a Cold-Bay (Alaska) a las 11 de la noche del dia anterior (10-9-55) consecuencia de haber pasado la línea de Barrow (antimeridiano de Greenwich) después salimos de Alaska y llegamos a Seattle (USA) a las 11 de la mañana del día 11. A la 1 1/2 tomo otro avión y llego a S. Francisco a las 5 1/2

13 de Septiembre

Salgo de San Francisco a las 10 1/2 y llego a Los Angeles a las 12 1/2 después de haber parado en Fresno

16 de Septiembre

Salgo de Los Ángeles a las 7 de la mañana y llego a 
3) di apesto

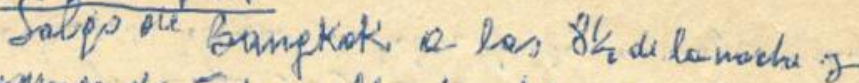

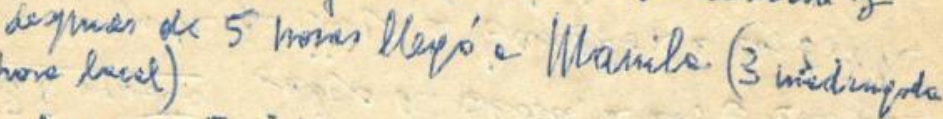
10 de ngricinitue

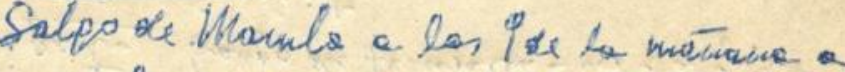

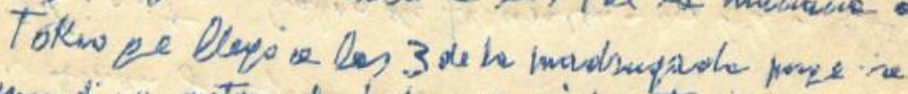

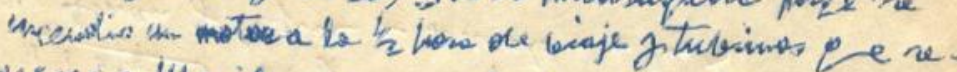

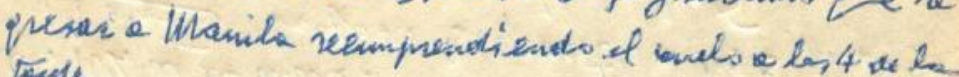
toule.

11 su noptisenthe,

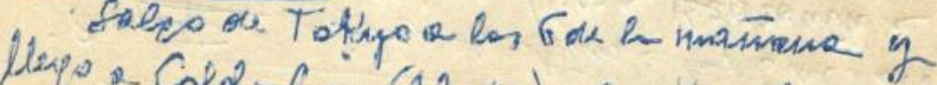

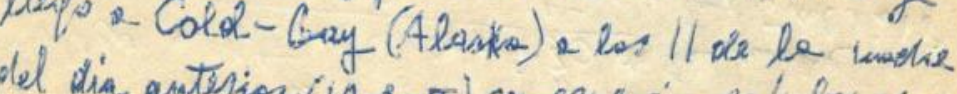

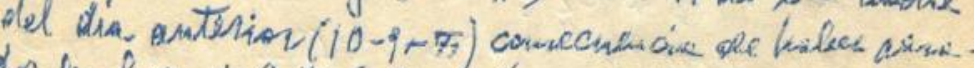

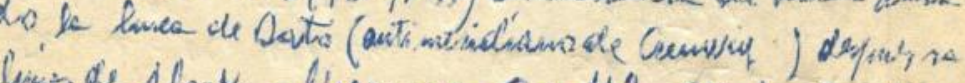

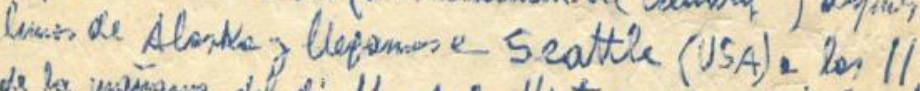

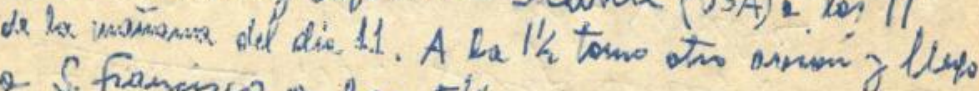
2 S. Framiniso a tas $5 \%$.

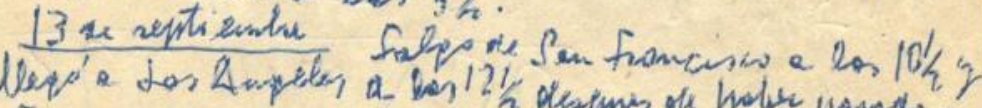
fiesno.

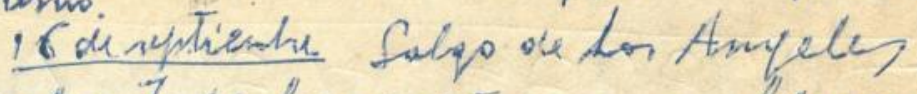
a la, 7 die la mañana a llegoe

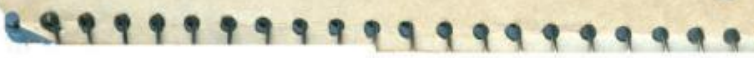




\section{Pg.2 (Detrás)}

Chicago a las 4 1/2 de la tarde (hora local) después de un viaje de 7 horas.

21 Septiembre Salgo de Chicago para Madison

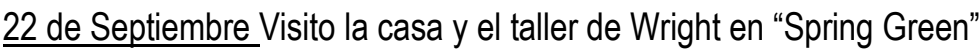

22 por la noche veo la fábrica de Racine

23 de Septiembre Salgo para New York y llego hacia las 5 de la tarde

25 de Septiembre Salgo de New York para Boston

27 salgo de Boston para Madrid llegando a Madrid a las $21 / 2$ de la tarde (hora local) del 28 de Septiembre 


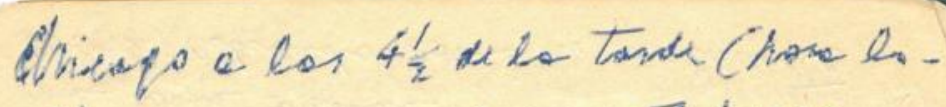

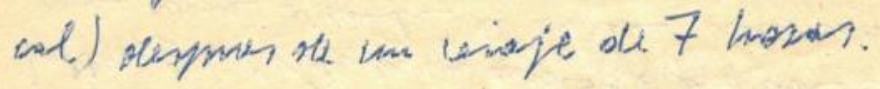

21 Septiende Salp de chicope pase Madiceas

22 sptienhe visito la cose g el Tolla de Wright en "Ipring Green"

22 por bo nodhe ves sen palrica of hacime 23 septiende saleo paes New Kork 2 llepe hacia les 5 dec la torde.

25 Septin he solep de New bate pase Batan.

27 saleo de Battan asen Mndind Mle pando a Madind a tor $2 \frac{1}{2}$ ob ho torde (how locel) del 28 sae septisiake.

417 


\section{Pg. 2 (Delante)}

Este estragamiento de cuerpo y de alma que producen los viajes en avión al pasar todo el día con ruido y comiendo o chupando comestibles con celofán y viendo por ejemplo como un joven "yankee" tiene ante la ventanilla de su asiento todo el macizo montañoso de los Alpes y no se molesta en levantar la vista de una revista de deportes que está leyendo.

Ese estragamiento, decía, no es el más a propósito para llegar a Atenas. Porque Atenas, hasta para los que creemos que ha pesado excesivamente en la cultura occidental, tiene mucho peso.

Tampoco resulta agradable a las 11 de la noche no encontrar alojamiento en hotel de ninguna categoría y tener, y como gran favor, que dormir en un cuarto de limpieza con una cama armada de manera provisional, eso sí, cobrando como si realmente 


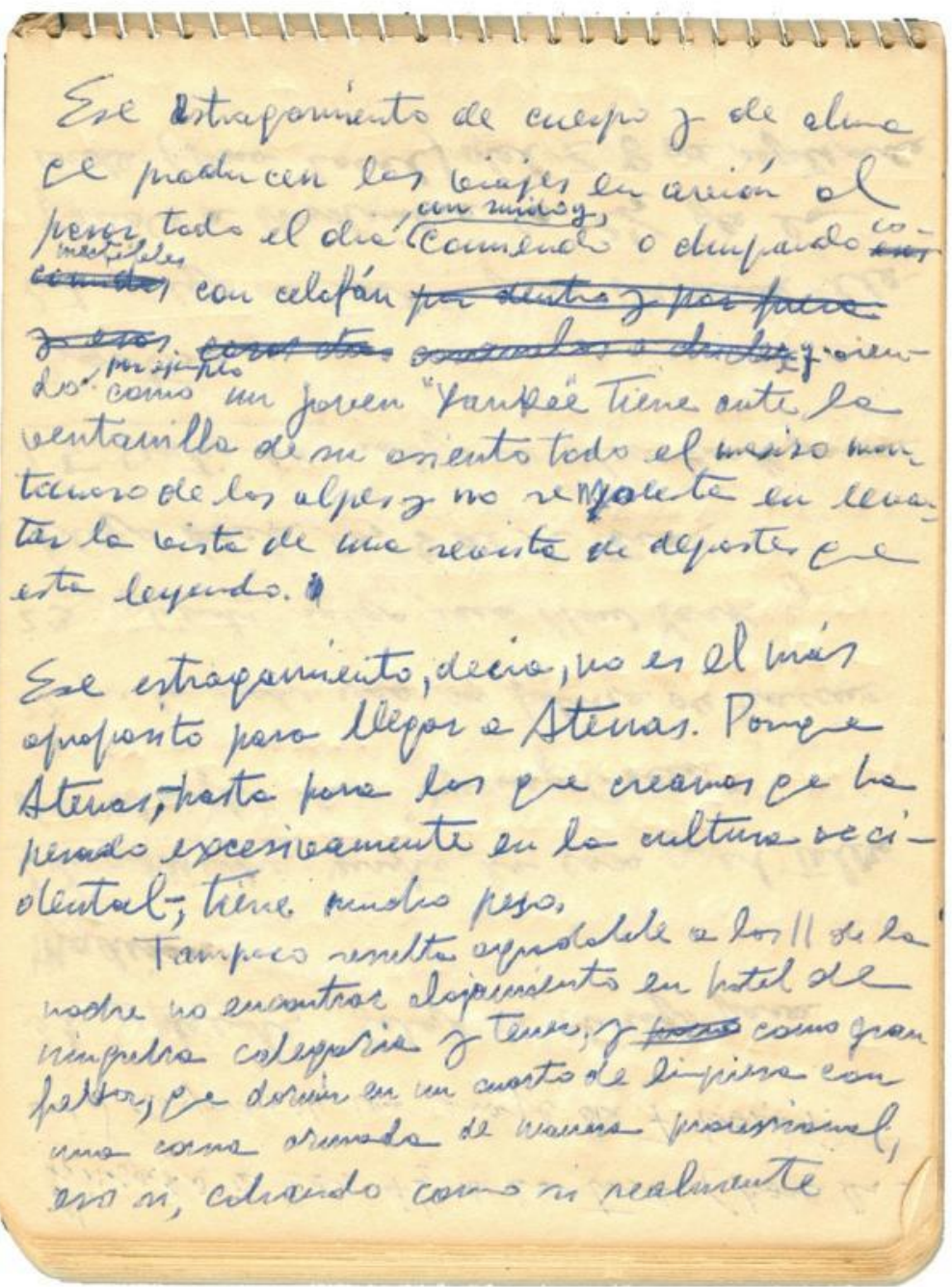




\section{Pg. 3 (Delante)}

la cama y la habitación fueran definitivas

Después de todo esto queda "el interrogante de la Acrópolis".

Este interrogante se despeja por la mañana temprano. Un taxi me lleva allí y ya estoy frente a una primera puerta provisional que da acceso a la entrada de los Propíleos. Miro la deliciosa disposición y tamaño de los Propíleos, la Victoria Aptera, de la NIKE pero en este momento unos aviones de reacción que cruzan el cielo me distraen.

Para el visitante que llega sabiendo Lo que va a ver con todos los detalles el interés es mucho mayor que para el que mascando chicles y tirando fotos pasa por allí para darse importancia con las visitas cuando regrese de Europa, aunque estos se encuentren en una proporción de uno a mil o tal vez mayor.

La primera impresión que produce el enfrentarse con la entrada de la Acrópolis es de pequeña, o mejor humana.

El hombre en esta entrada es un

\section{Pg.3 (Detrás)}

En blanco 


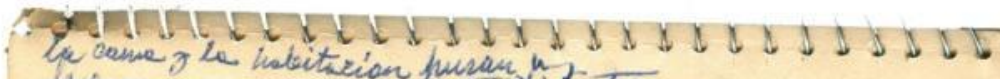

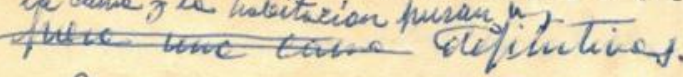

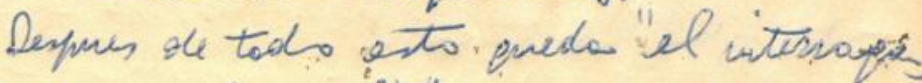
to de la Anapalin".

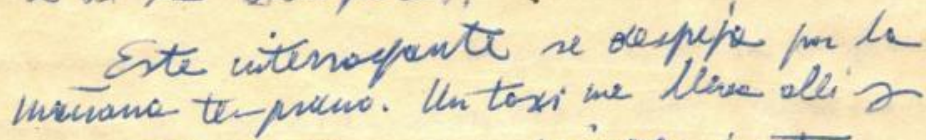
vo extoj hente a una primere mesta noovimand os de eceepo a la entrode

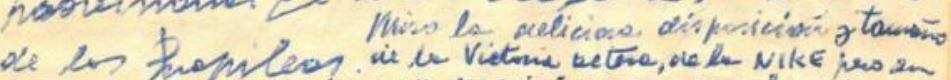

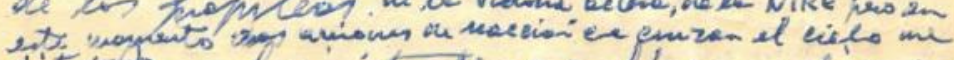

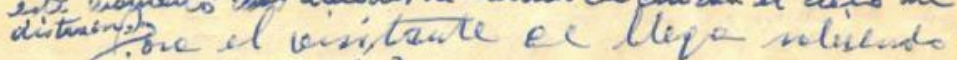

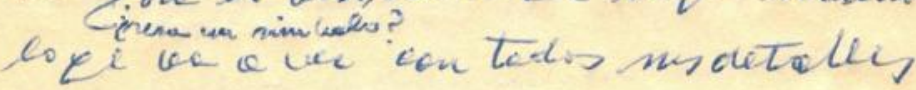

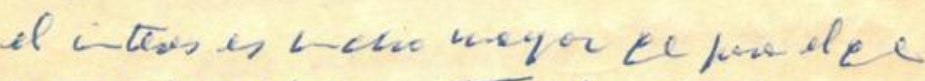
maxando olvielexy tivindo litos pase has elli prose dorse inportanere en los bisitos cuado requese she Eusapa, are

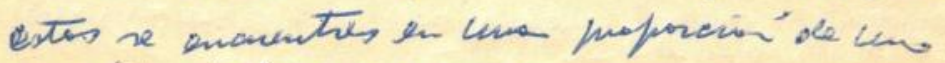
- nil tol vir nagor.

do piness i puesion pe pudace $l$ - funtare a to entrad de $l$

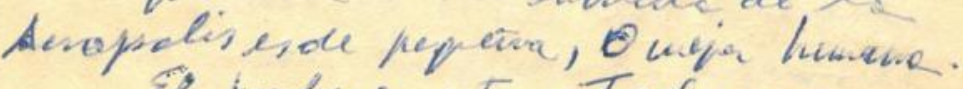

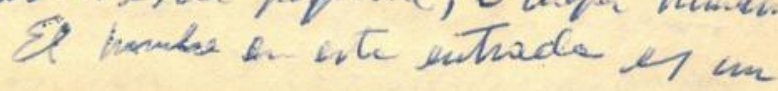




\section{Pg. 4 (Delante)}

factor, aun cuando ni el módulo ni la intención sean humanos del todo. Es curioso comparar que cuando los monumentos de la antigüedad se deshumanizan adrede, resultan más humanos o menos deshumanizados que los actuales, incluso de aquellos que hemos querido humanizar. La cosa es que antes lo humano era una realidad vivida y hoy la deshumanización es también vivida también y por mucho que mande la cabeza se imponen las realidades de los hechos.

Este montón de bloques de mármol balbuciendo con su osatura de sujeto que desapareció tiene aún muchas lecciones que dar.

La primera la del urbanismo. Urbanismo que es en primer lugar topografía de situación. La colina rocosa de la Acrópolis dejando siempre el cielo como telón de fondo es el más bello contraste que se puede imaginar y después la disposición de los edificios es

Pg. 4 (Detrás)

En blanco 
lactor, ann emando hi el kuedulo un la untencioin scan hamanos del tools. Es curions compareser ex anando los

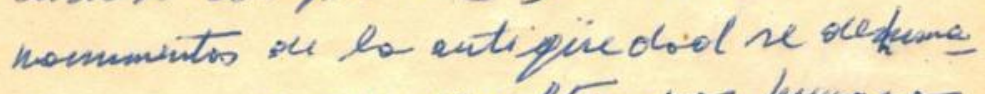
nism a drede, seniltan was huvanas - menas destumaniodo ee las ectaves,

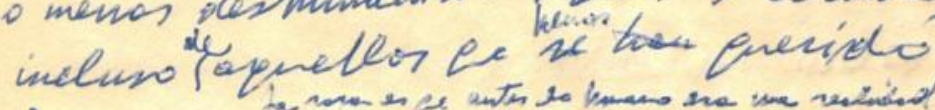

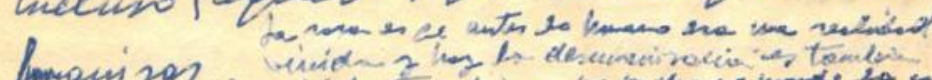
lowansar.

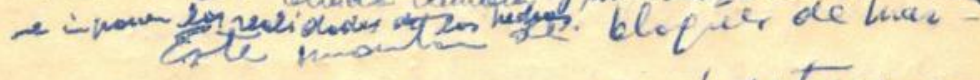
wel ballenciendo can min hasatura an sujeto fuie derapacecio tome aum nay beciones de dar.

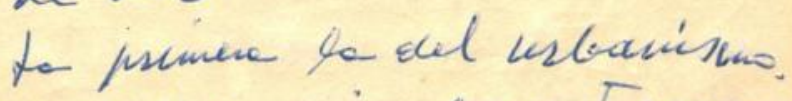

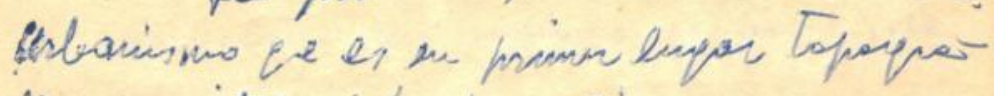
fir de sitrascion. to coline sacen de be Acropalis defiands nimpe et cielo cano telow ole fundo $\rightarrow$ al mas bello eartiarte oque se puede inapivar 7 olespues la desporicuin de los edificiopes es

423 


\section{Pg. 5 (Delante)}

de una audaz lógica maravillosa.

Si hoy se hiciera algo semejante o mejor se pretendiera algo semejante no creo que habría un país lo suficientemente cultivado estéticamente para que diese su consentimiento a esta empresa.

Edificios para verlos y además para verlos desde puntos determinados o mejor con corrientes de puntos de vista determinados es afinar tanto que después no extraña que se afine en las correcciones ópticas del grueso de las columnas, de la horizontalidad de las líneas del "podium", de las correcciones del éntasis...

Hoy todo esto es un montón de huesos de arquitectura pero rodeado de vida, de la vida de hoy.

Creo que es tan interesante lo uno como lo otro en la Acrópolis.

Es extraordinario el poder catalizador que tienen estas ruinas para estudiar la psicología actual de las

\section{Pg. 5 (Detrás)}

En blanco 
de ane andar leyie mazaleillone.

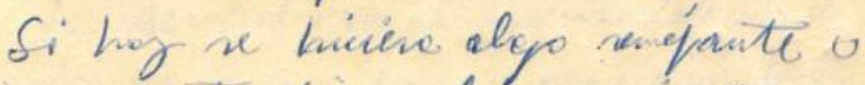
mejor ge pretentiens elpo remequate vo cespe fratio mif pios os mivien tamente cultieaso esteticamantipedre ve mincentimieito e. ath enparo.

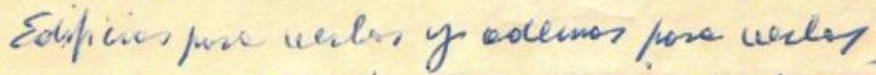
viesde funtos determinados o unejor cancouncia

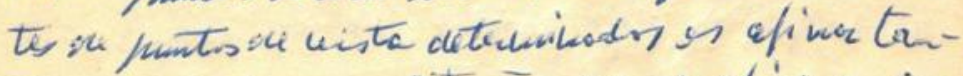

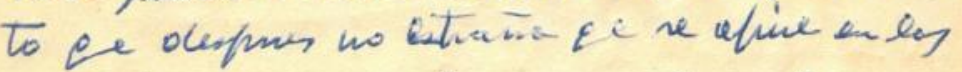

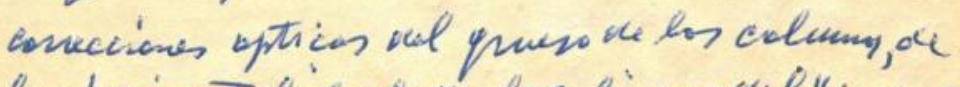
lo hosirantalidsol de for livess del "podiun" pe tor concecisine sell entrans.

$$
\text { thrg tad isto es un mantan ne luvieas }
$$

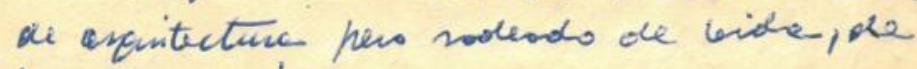

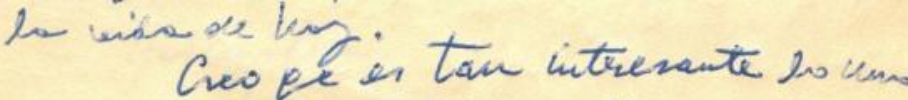
coms ho tho a be Andpolis.

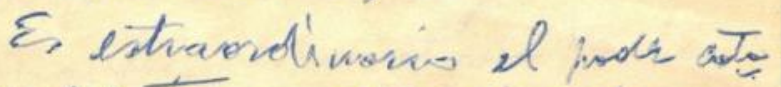
lisenere pe teren exter sminer frovo

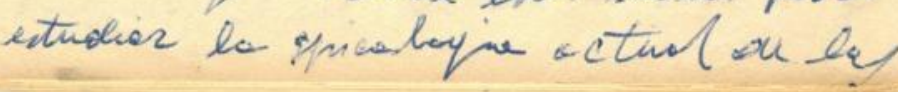




\section{$\underline{\text { Pg.6 (Delante) }}$}

gentes.

La Acrópolis se podría definir diciendo que es una gran exposición internacional de imágenes fotográficas y también un gran estudio de fotografía.

Las gentes entran allí con una verdadera gula fotográfica, no les interesa nada más, les interesa la fotografía bien es verdad que no creo que exista ningún otro lugar en la tierra más fotogénico.

Esta ingenua vanidad de enseñar a los amigos la foto propia en este marco se puede asegurar que ocupa el primer motivo turístico.

Norteamericanos, ingleses, franceses italianos todos ellos vienen con la obsesión fotográfica.

Algunas muestras: Estoy haciendo una fotografía de la entrada de la Acrópolis. El sol todavía no está muy

\section{Pg. 6 (Detrás)}

En blanco 


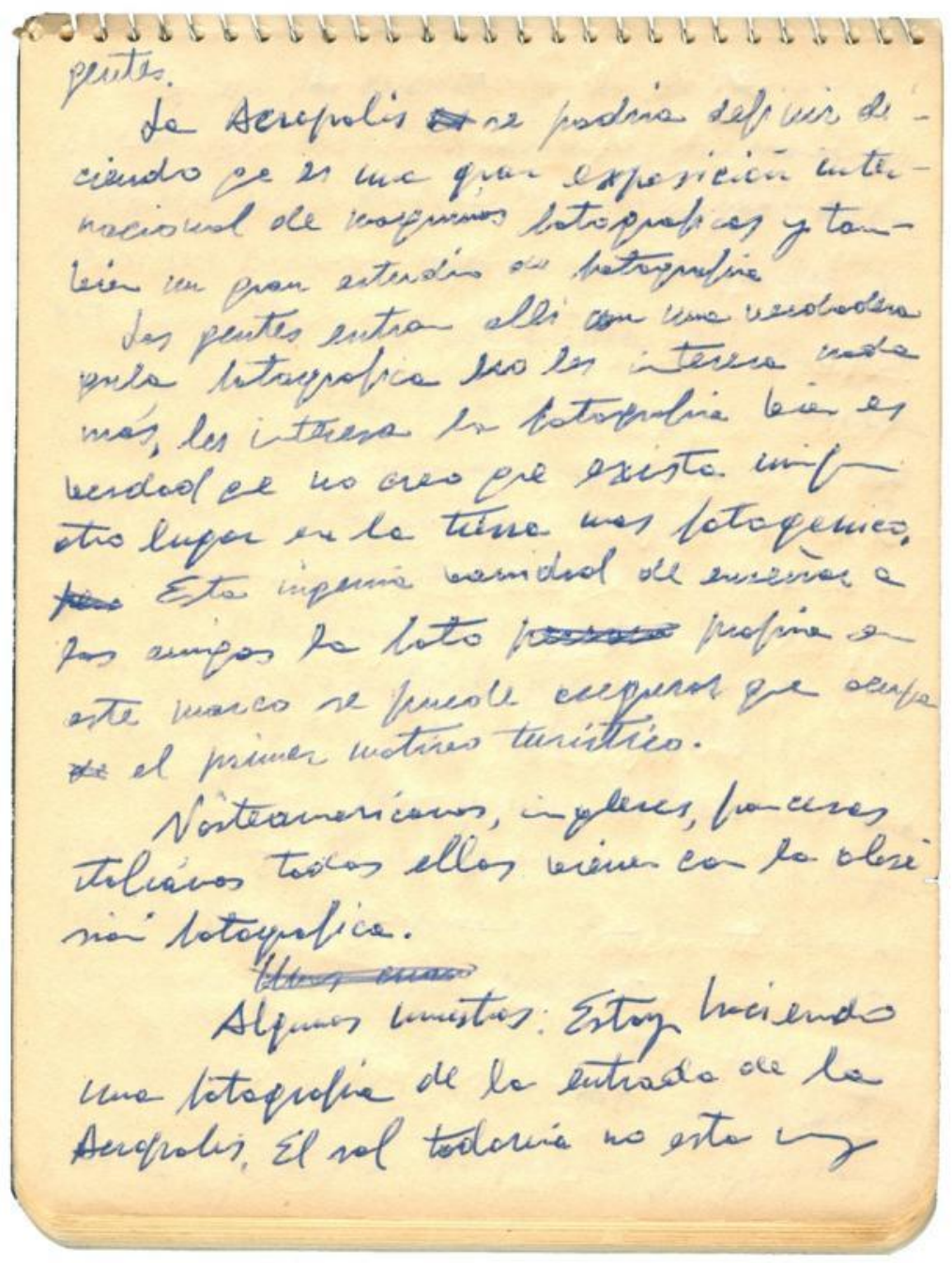




\section{Pg. 7 (Delante)}

alto y con el descuido y la falta de pericia que caracterizan mis actuaciones como fotógrafo estoy haciendo estas fotos cuando se me acerca un francés joven y me pregunta con extrañeza ¿V. cree que es posible sacar esta foto? Yo no lo creía posible y acto seguido coge el sitio que yo ocupaba y dispara su máquina. Tal vez cuando reciba los trabajos realizados en el laboratorio comprenderá de que es posible hacerlo lo que es más problemático en el éxito del resultado.

Otra: Una joven italiana se me acerca angustiada y me pregunta qué máquina tengo. Al comprobar que no es como la suya se aleja preguntando a todos los que se encuentra a su paso para ver si alguien le podría indicar la características justas de diafragma y exposición

Pg. 7 (Detrás)

En blanco 


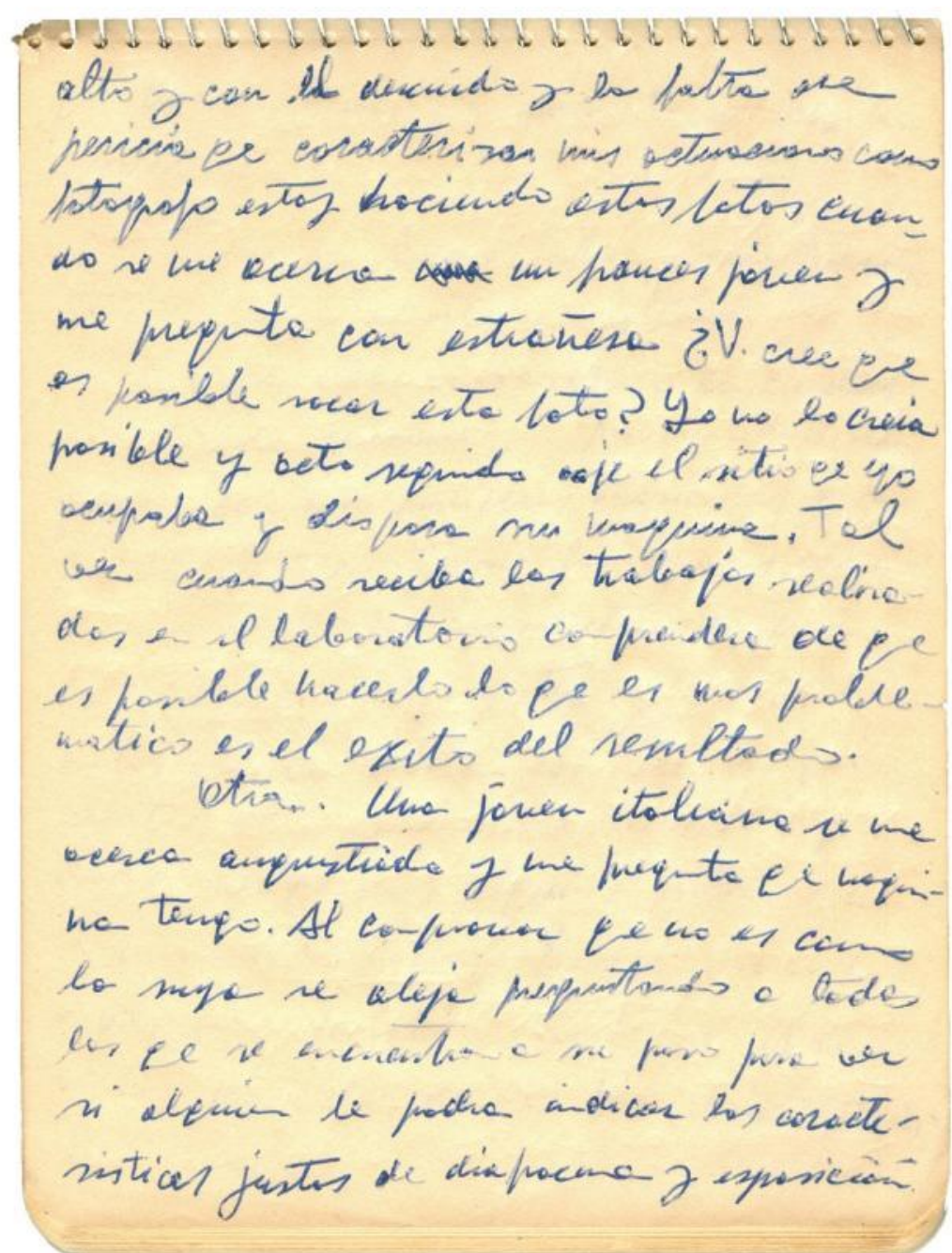




\section{Pg. 8 (Delante)}

que tendrá que dar que garanticen un buen resultado.

Pero la Acrópolis y sus turistas es un mundo aparte en Atenas.

Queda allá arriba, abajo la ciudad se extiende anodina, sin personalidad, sin gracia, con unos pastiches clasicistas que por lo visto en todas las épocas recientes han creído los arquitectos que tenían la obligación de repetir y sin otras notas que la distingan de cualquier capital de provincia que habérsele quedado rezagadas algunas piedras como el monumento coreográfico a Sófocles o alguna palabra como le llaman a las paradas de los tranvías: "éxtasis"

\section{$\underline{\text { Pg. } 8 \text { (Detrás) }}$}

En blanco

\section{Pg. 9 (Delante)}

En blanco

Pg. 9 (Detrás)

En blanco 


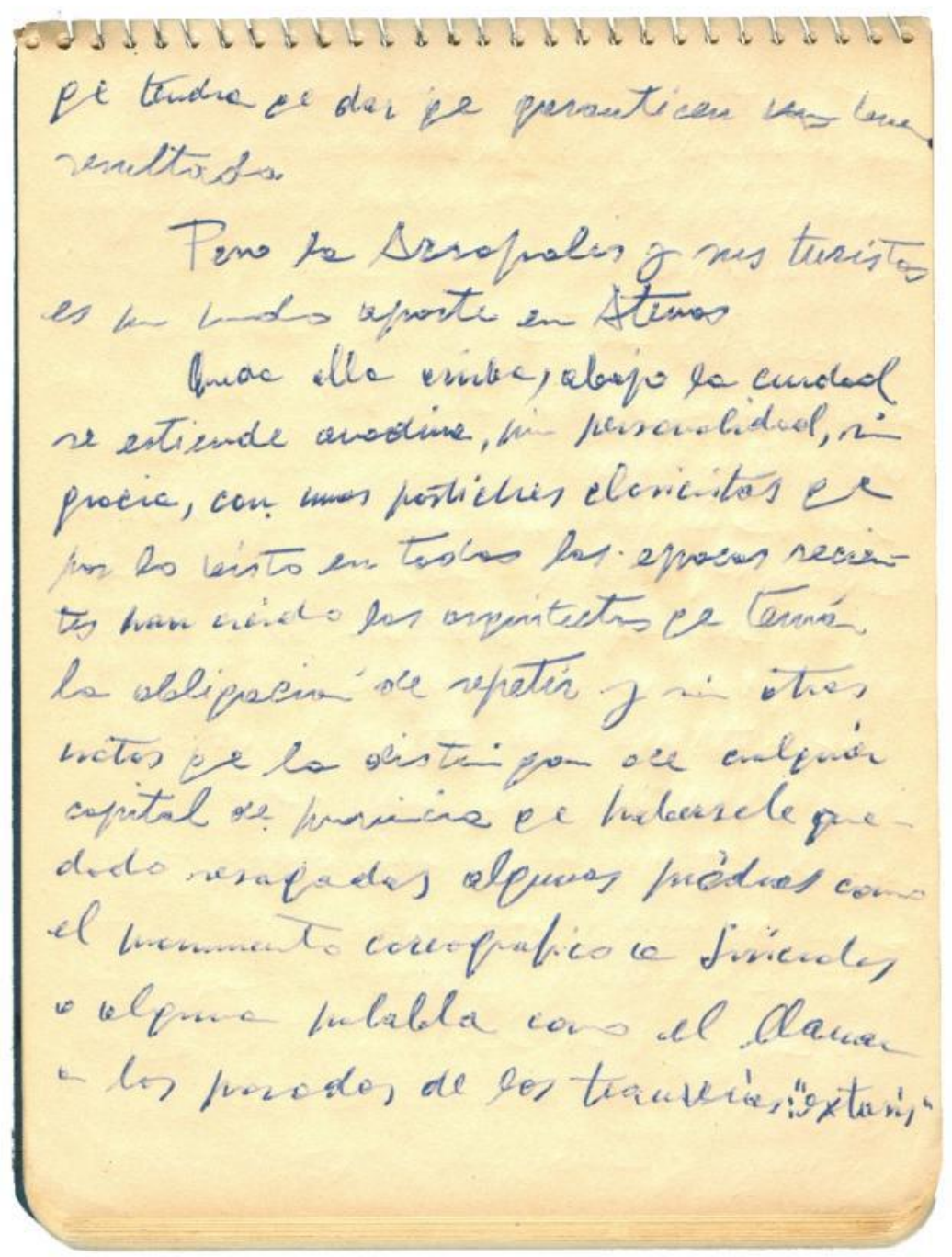




\section{Pg. 10 (Delante)}

Al subir en Beyrouth al avión que me transportaría a Jerusalén sentí una reacción que no había sentido nunca al subir en esta clase de vehículos: la desazón de pensar que tal vez en aquellos asientos hubiera piojos. No era muy descabellada la idea, porque transportando estos aviones peregrinos musulmanes a La Meca, la suposición era muy probable y el aspecto de la tapicería y, en general, de toda la ornamentación del interior del aparato predisponía a suponerlo.

Al pasar por encima de Damasco, la azafata nos ofreció unas botellas de Coca-Cola. Pensé que, tal vez, en castigo a no querer la Humanidad llegar a un acuerdo en asuntos esenciales transcendentes: Fé, Justicia... Dios consentía que nos esclavizara esta es-

\section{Pg. 10 (Detrás)}

En blanco 


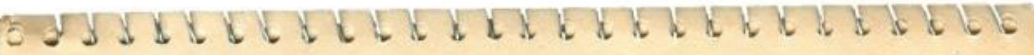

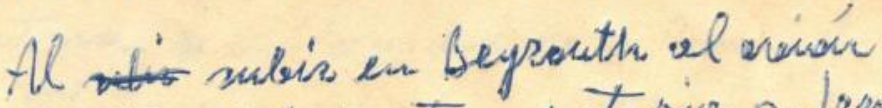

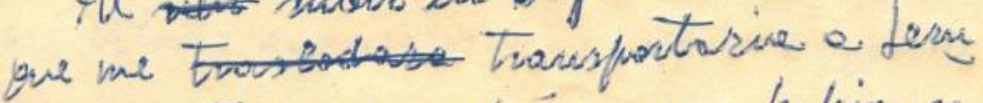

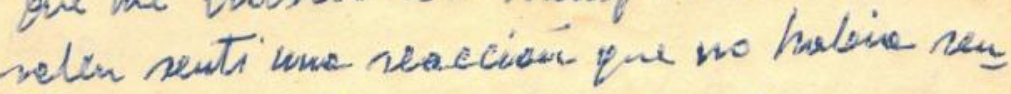

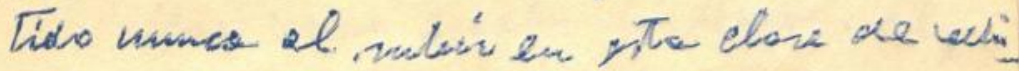
culos: bo desasan de purar pre tal ver en aquellos esientos hubiese priojas. No gne

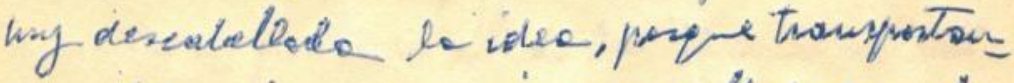

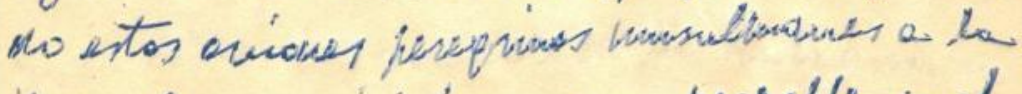

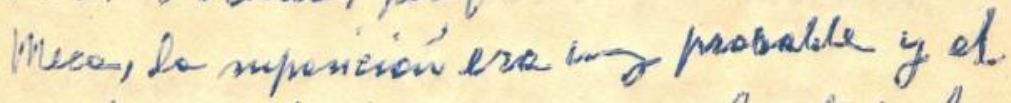

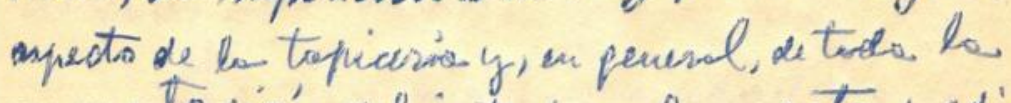

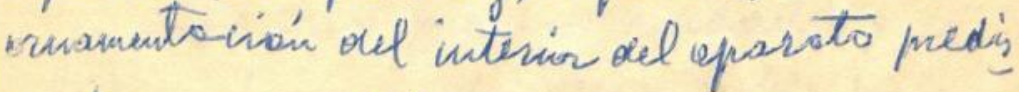
jomia a mpanesto.

Al parar has encina de Lanases, h asafata nos opecio unar leotellos de Cara-eals. Perare pue tolver be en castify a ho queser la thrmainda of leques a un cacuesdo en pun tos esenciales transeendentes i $F e$, Justicia... lias courentio of nos exlavizare esto es 


\section{Pg. 11 (Delante)}

pantosa (tachón) uniformidad de la Coca-Cola, del tabaco americano...jde la arquitectura!

Una breve escala en Aman, el paso por el desierto de Judea, dejando a la izquierda la rápida bajada al mar Muerto y junto a él a la Jericó actual y, al lado, las ruinas de la antigua y después Jerusalén.

Yo creo que las ciudades que fueron hermosas deberían haber muerto como murió Pompeya: instantáneamente. Transformándose en un monumento, de ser una ciudad llena de vida, de gentes, de poder cultural, religioso, etc, en....recuerdo.

Atenas, Jerusalen... se parecen

Pg. 11 (Detrás)

En blanco 
prantsona uniformódod de lo Coca colo, ael tabaco amesicano.... i de ha erquinter tara!

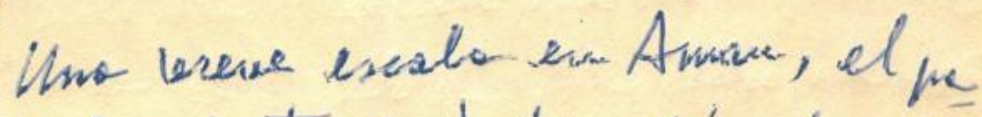
nopar el desierto ale fadea, objando ve la isemierda la rápinda leajada al mar mento y junto il a ba terwá vetual

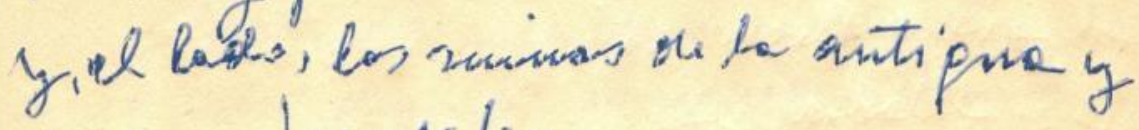
derpourer besusialen.

Ho cuo pe las ciandader be

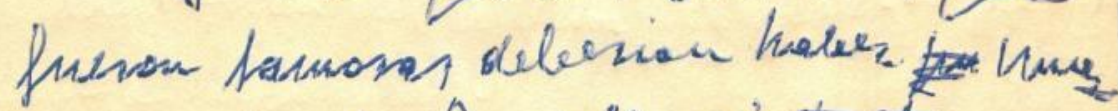

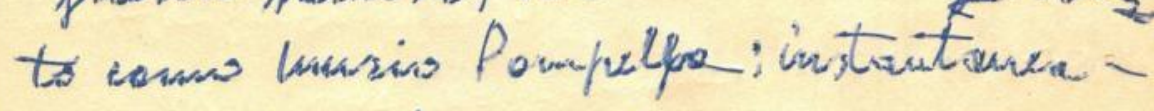

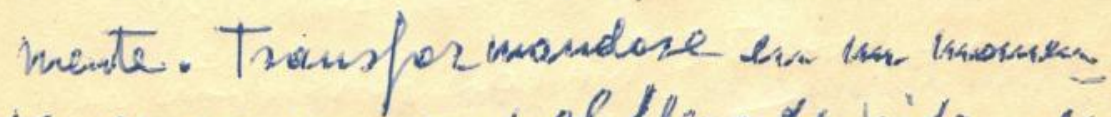

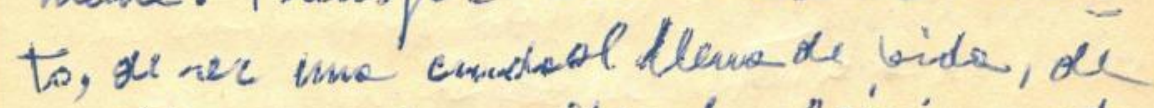
yentes, ar proder culfunal, neldiquaro bte lin.... recuesong:

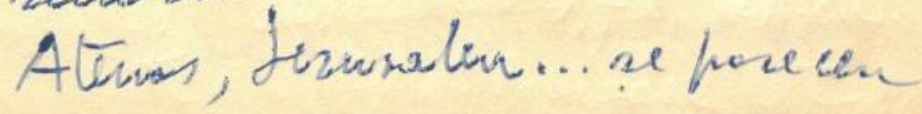

435 


\section{Pg. 12 (Delante)}

a esas señoras hijas de un magistrado que, venidas a menos, han tenido que recibir huéspedes, y su posición social es heredada pero incómoda. De todas formas cuando el coche que me transladaba (sic) del pequeño aeropuerto que como el de Vitoria la pista corta la carretera y tienen que poner pasos a nivel, cuando el coche digo que me lleva a Jerusalén alcanza una loma desde la que se presenta a nuestra vista toda la ciudad, no se puede reprimir la emoción de sentirse -aunque sea ahora- ante ¡Jerusalen!

No es posible para el creyente alejado de estas tierras, poderse dar una idea de la tristísima situación actual de los Santos Lugares. La iglesia del Santo Sepulcro creo que se puede decir sin miedo a equivocarme

Pg. 12 (Detrás)

En blanco 


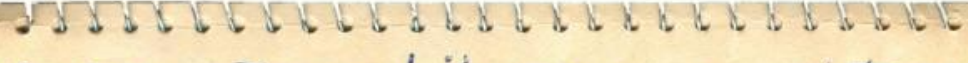
- evar neñosas hijás de un unapintrado yne, levindes 10 menos, han teindo que veilein huespedes, of m poricion social es haverada peno uacamado. De Tadas parmas cinando al coche pe une tiang

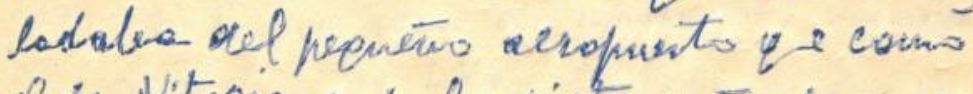

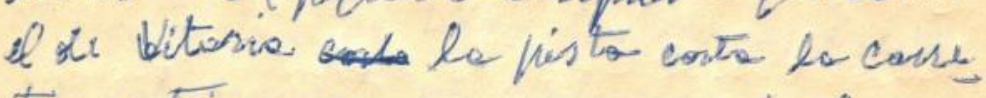

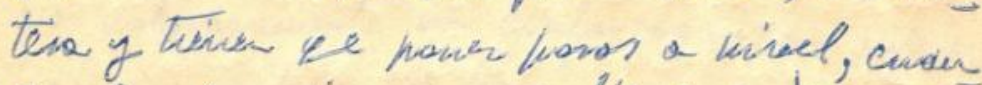
do el cache dip. pe me llevere desura len alcanso una lamo desde be ve presente a muestre visto tode lo eurded

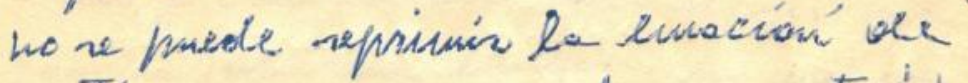
sentina- anume nea alvora-aute i de nowalen,

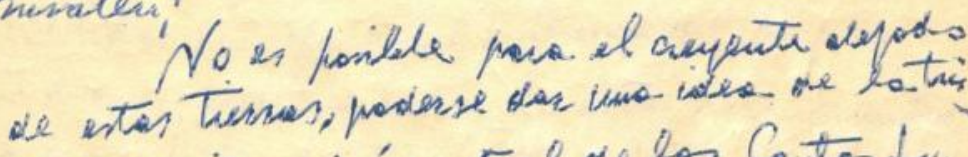
tinime nituresion atuol de las fantes tas -

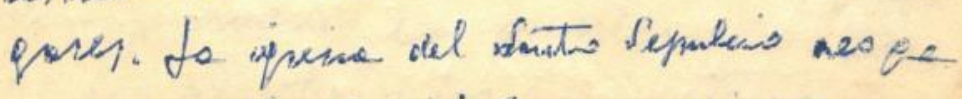

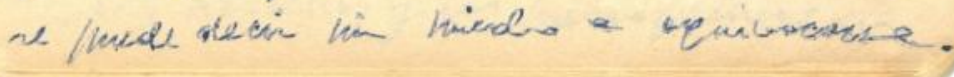




\section{Pg. 13 (Delante)}

que es el lugar de la tierra donde existe mayor confusionismo humano.

Prescindiendo de los terremotos, las guerras y los incendios que ininterrumpidamente se han ido sucediendo y que lo han dejado reducido a una serie de muñones inconexos de arquitectura de todas las épocas. Existe más dolorosamente un confusionismo intelectual y volitivo que hace que cada mañana un musulmán abra la única puerta que ha quedado para todo el servicio del templo y continúa allí todo el día una guardia jordana tumbada en una especie de mugrientos camastros situados a la entrada pero ya en el interior del templo.

Y después prescindiendo de esta servidumbre a los infieles, dentro entre cristianos, griegos, latinos y armenios los departamentos estancos, los derechos y las prerrogativas se

\section{Pg. 13 (Detrás)}

En blanco 


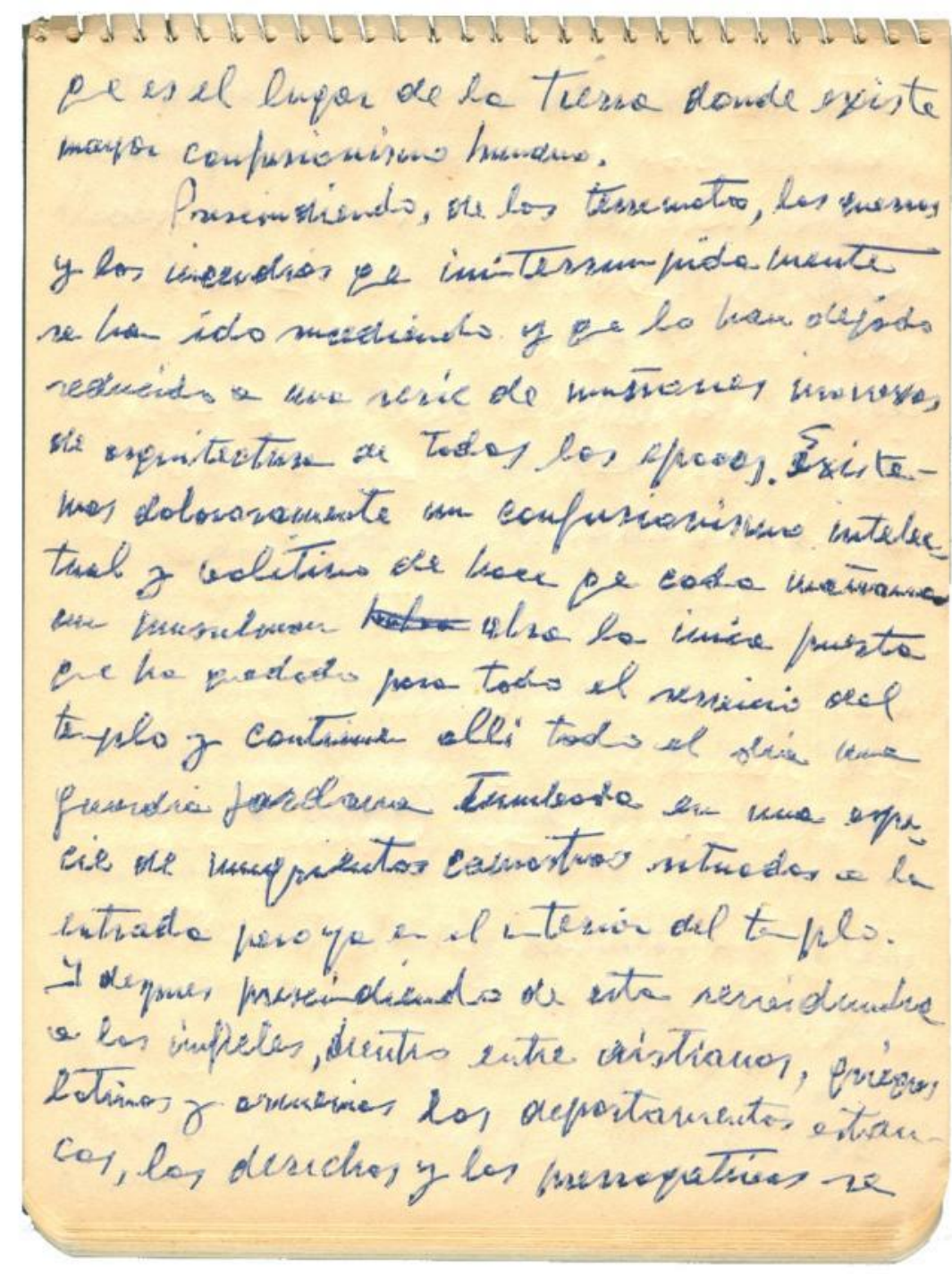




\section{Pg. 14 (Delante)}

multiplican en una inexplicable complicación formando repugnantes cobachas (sic) llenas de lobreguez y de suciedad.

Al salir de allí ante este dantesco espectáculo uno piensa con dolor lo bien que estarían estos santos lugares al aire libre, sin piedras milenarias, sin desechos, ni suciedad donde crecieran al sol florecillas que peinara el viento.

Pero el Santo Sepulcro es un enclave extraño en una ciudad que lo inquina en una ciudad sucia, maloliente, chillona y mendicante que se desparrama por calles estrechas y cubiertas con toldos o bóvedas de fábrica que de trecho en trecho dejan un hueco cuadrado cenital por donde entre la luz y salga algo del edor ambiente.

Pg. 14 (Detrás)

En blanco 
mattiplican en una insosplicable coungeli-

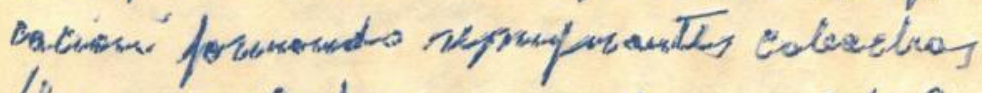

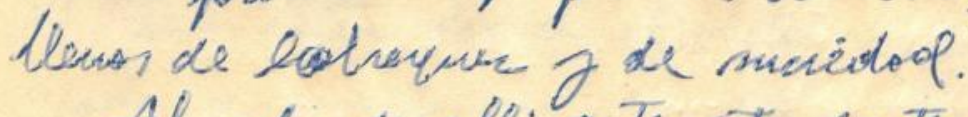

Al ndu di elli aute este sranterco espectaculs uno preure con debo lobien ye estrisian estos saitos engase, el ovic

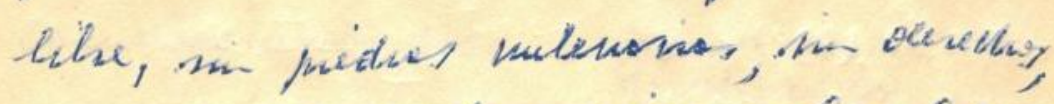

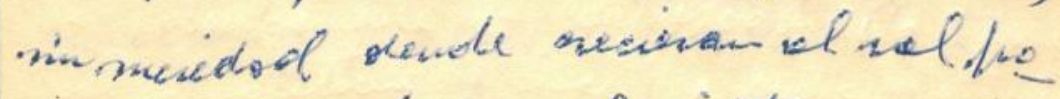
seisles ge perinoma el visinto.

Paroel dianto fefpulorio es un ende we estrains en cuna evidost pe lo ingins

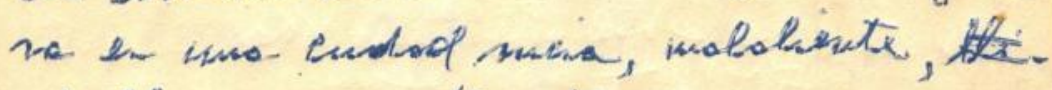

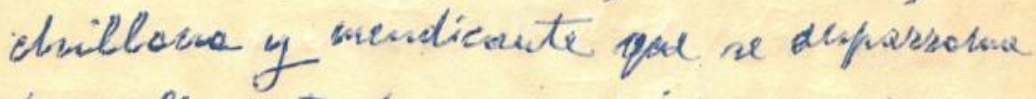

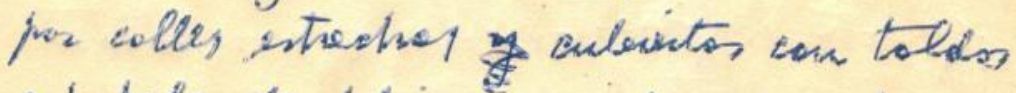

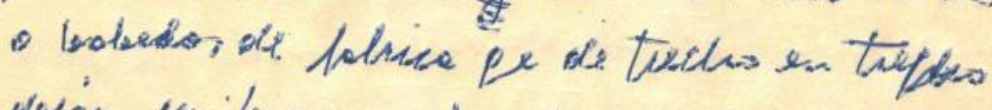
arjar vn Inces cuodrado enital por do

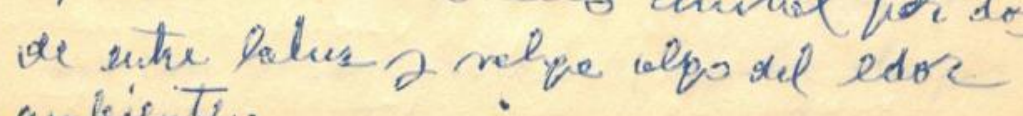
amisiente.

441 


\section{Pg. 15 (Delante)}

En una recepción que la Custodia de Tierra Santa dió en el Hotel Embassador recientemente inaugurado en honor de los arquitectos que como expertos hemos asistido a una serie de conversaciones para informar sobre la situación y posibilidades de restauración del Santo Sepulcro vimos llegar los más extraños personajes de toda la Tierra. Jefes religiosos de varias sectas autóctonas, ortodoxos griegos, Armenios, Coptos, etc etc. Jefes religiosos de religiones casi tan antiguas como el Cristianismo y que creemos que sólo quedan en las reseñas de los libros de historia de la Iglesia. Negros abisinios con barbas rizadas, sagrados obispos de coptos orientales, con indumenarias

\section{Pg. 15 (Detrás)}

En blanco 


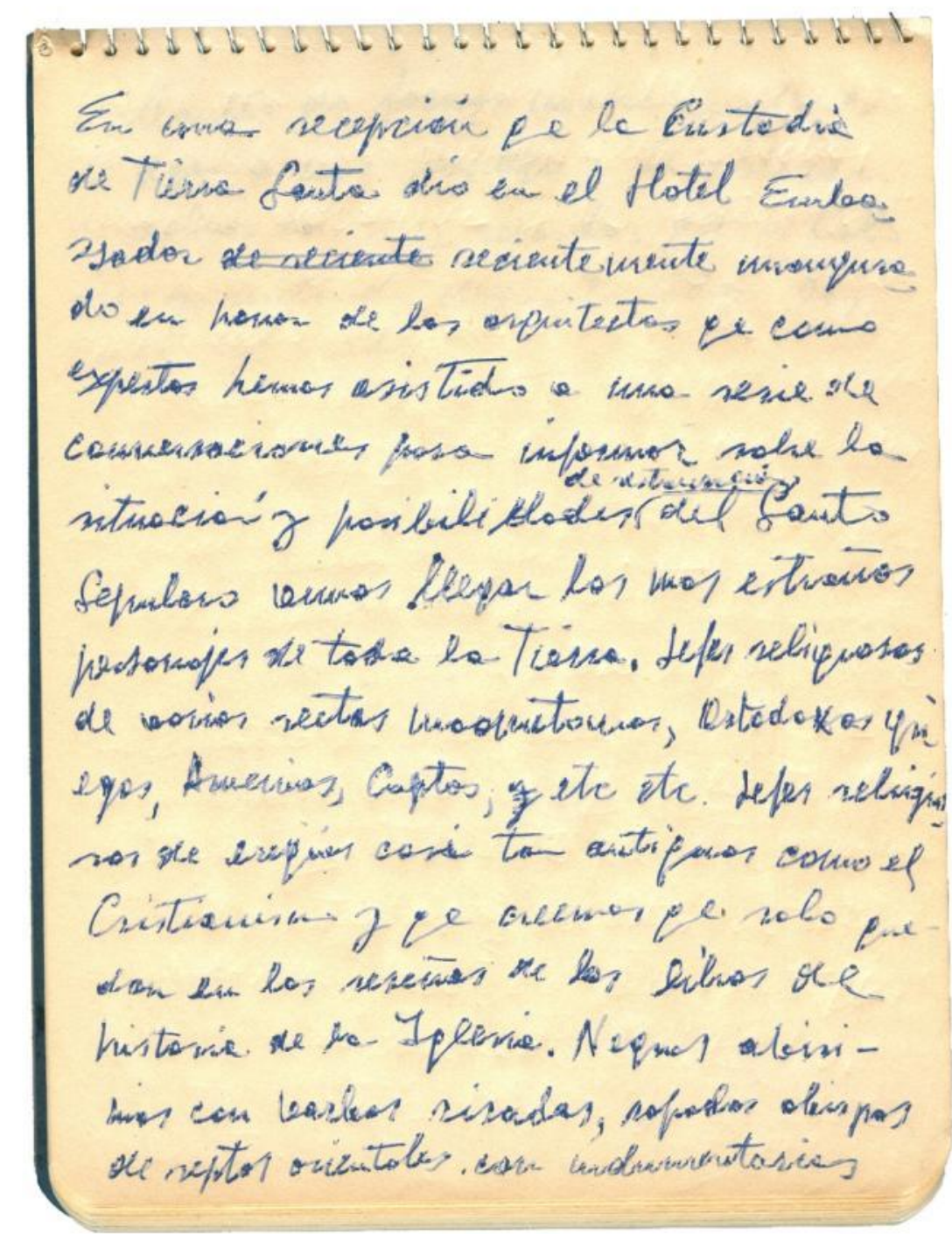




\section{Pg. 16 (Delante)}

brillantes de formas inverosímiles que le dejan a uno perplejo y le obligan a volver en sí y recordar que es Católico recitando despacito todos los puntos del credo.

(línea)

\section{Pg. 16 (Detrás)}

\section{En blanco}




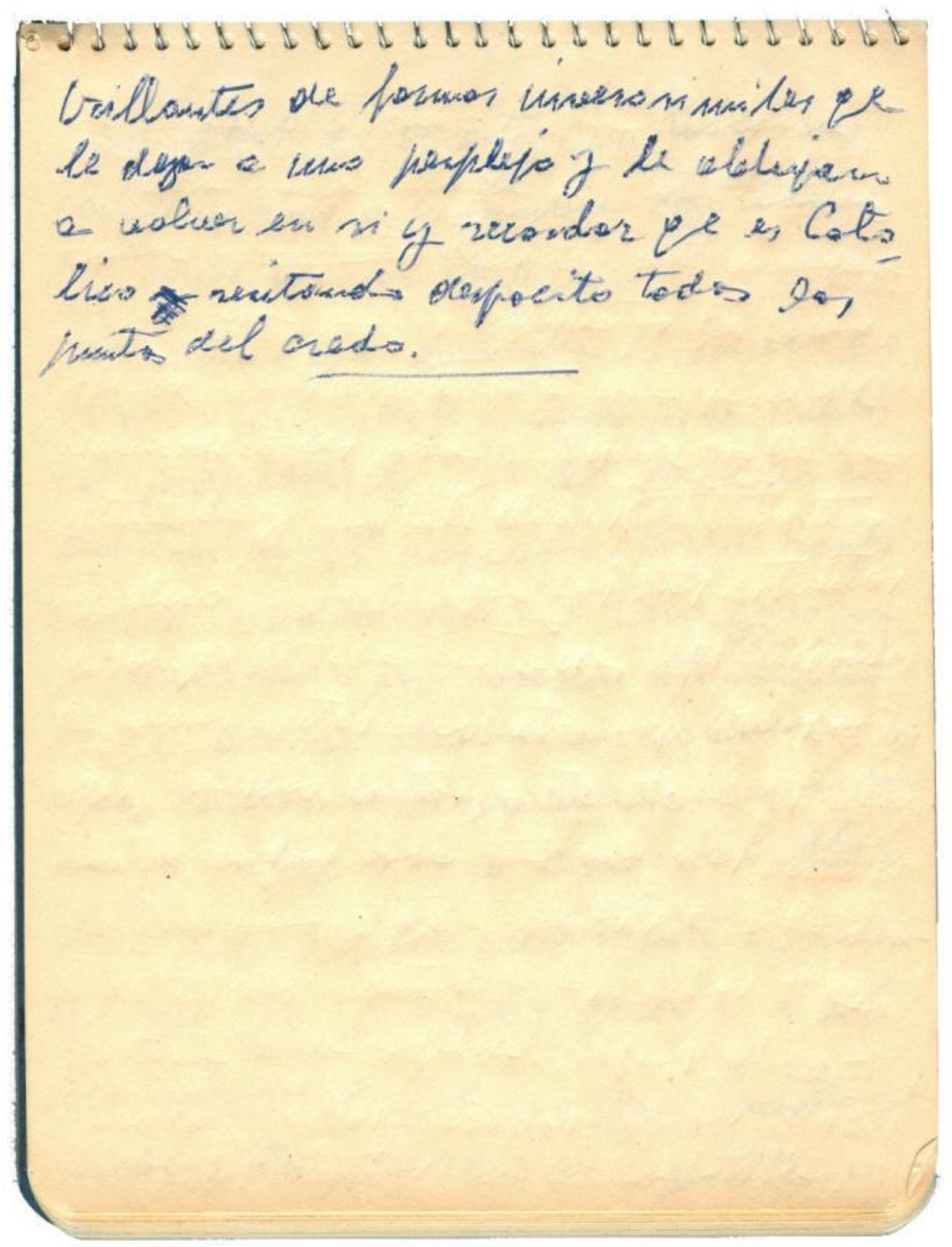




\section{Pg. 17 (Delante)}

Bangkok es oriente con todas sus consecuencias y es también con todas sus consecuencias trópico.

Lo primero que encuentra el viajero que llega a Bangkok o, para hablar con propiedad, lo que al final no encuentra es el corazón, porque Bangkok es una ciudad que no tiene corazón. Entendiendo por corazón, claro está, lo que así se llama en urbanismo, o creo, centros de convivencia ciudadana, o religiosa, o comercial etc, etc. Este núcleo netamente occidental que es la polis griega o el foro romano y que es en nuestros núcleos la plaza, no existe 0

\section{Pg. 17 (Detrás)}

En blanco 
Bangentert es oriente can today mey conrecuenicias y es toumberie con todo sus consecuencios twopico.

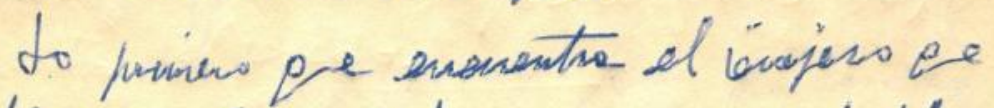

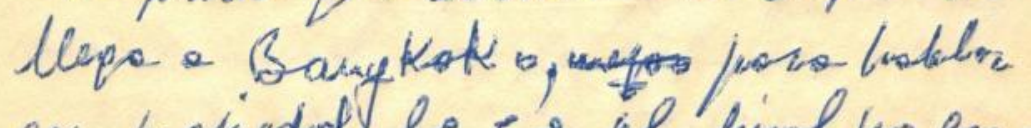
con propuedual, to to ial pinal us en.

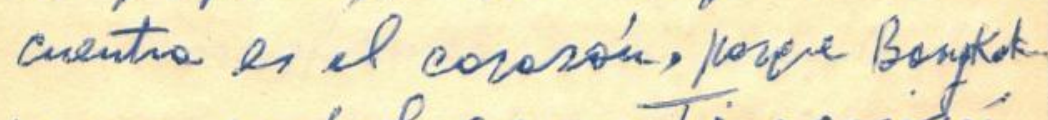

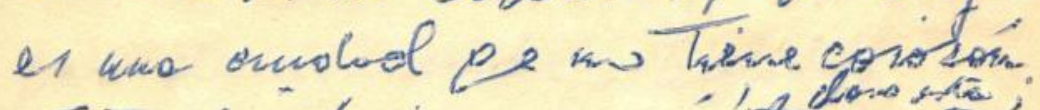

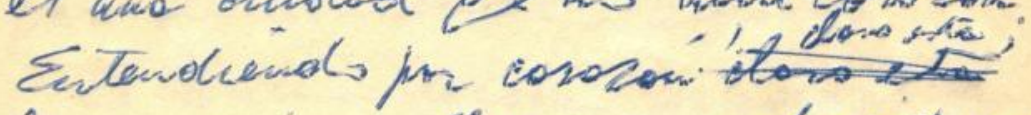

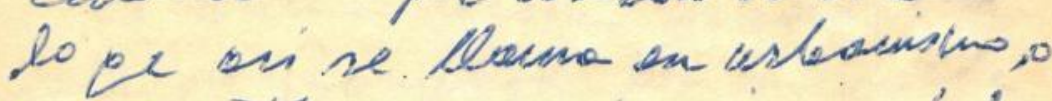
Greo, centrot sh comnivensire cendodoma, silupiose, comerisel the ete. Ste meleo netrannente sccidemtal ce es la polis prieqe o frso somano of pl es en unistros uncelos la plasa, no esiste

447 


\section{Pg. 18 (Delante)}

queda sedimentariamente expresado en las ciudades de oriente. Este corazón es el que preclaramente no existe en Bangkok.

$Y$ es curioso pero entonces una ciudad ha perdido su más noble expresión: la convivencia, para transformarse en un simple lugar de viviendas aisladas.

Es buena lección urbanística esta de Bangkok por su doble enseñanza de lugar disperso de cómoda habitabilidad y de equivocada carencia de convivencia ciudadana.

El día que los urbanistas consigan la ciudad

\section{Pg. 18 (Detrás)}

En blanco 


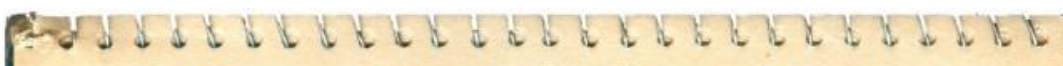

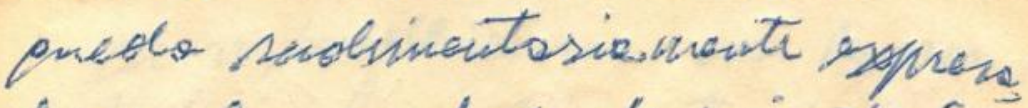

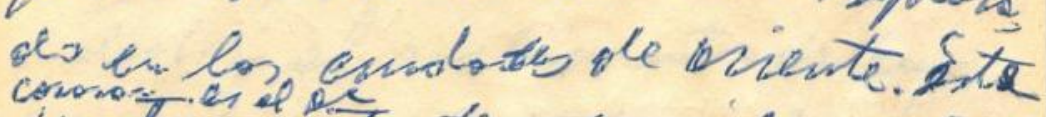

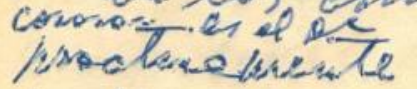
kot in sxiste

en bang Yes curiosa pera entonces

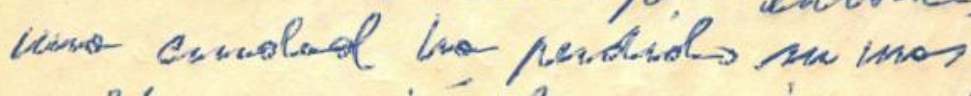

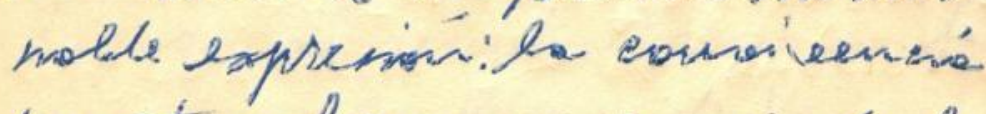
provo tramaformasse en si-ple law pas de cuiremendas aighodor.

$\sum$ bavera heccine uslesnistria

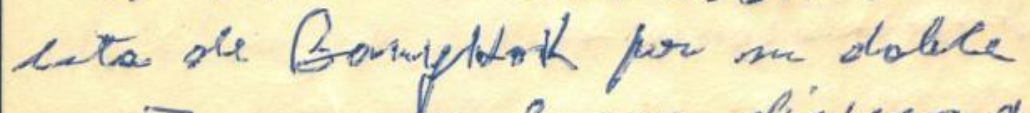
enseñansa de luger dispess dx comado enarkabitalailindod 7.

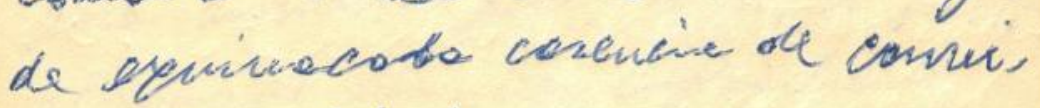
uensine exideshoro.

It olve pe los ushomis tas consipas la cunplool -

449 


\section{Pg. 19 (Delante)}

en que se pueda vivir con la comodidad y el aislamiento de los bungalok (sic) de Bangkok, la facilidad de circulación rodada de las autobank (sic, es autobahn) alemanas y los lugares de reunión como en la Plaza de San Marcos de Venecia o para poner un ejemplo más modesto; como la plaza de Chinchón, habremos construido la ciudad ideal para hoy y tal vez para mañana pero eso sí, si falta alguno de estos tres ingredientes, reunión, habitabilidad, circulación la ciudad será incomple-

\section{Pg. 19 (Detrás)}

\section{En blanco}


ew pire meda leinizi cose bo come

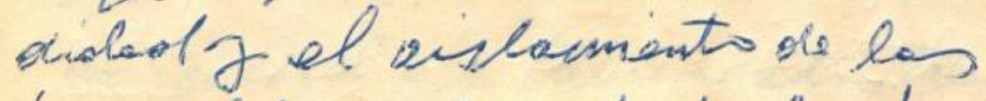
lempelok ol bangtrok, las poen. bidual de aicularión radada a los antobank almanasy hos lupars de seunion como a la ploso de fan llinoreas de Veneané o poser promer una spaplo inar modesto; cam ta pose of

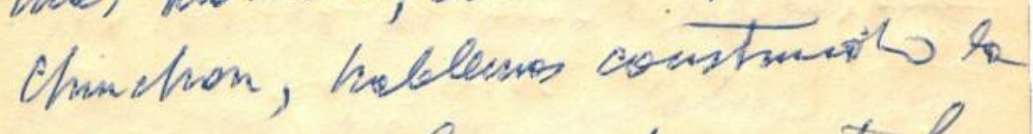
cundod weteal paso hy $y$ te lue poso unañme peco eso $n$, ni fola alprumo de estos thes inprediente:

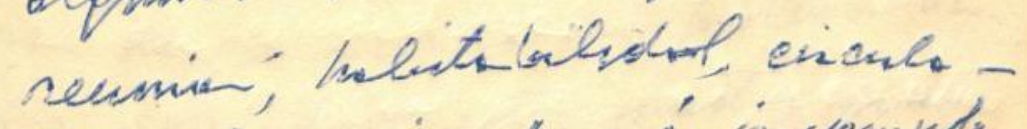
cion be curdod nemé incomple.

451 


\section{Pg. 20 (Delante)}

ta, defectuosa.

La ciudad que tuviera estos tres ingredientes sería perfecta pero para ello es necesario que tenga estos tres ingredientes armónica y proporcionadamente desarrollados en la relación justa que exige la idiosincrasia de sus habitantes.

No necesita un inglés la misma proporción que un andaluz para los lugares de reunión ni necesita un oriental (del trópico) las arterias de circulación que necesita un norteamericano. Variedad, este nuestro gran slogan que es necesario gritar

\section{Pg. 20 (Detrás)}

En blanco 
to, defietinare.

da cundod pe tubiene extos tro impredi nutes sise porfecte peso pone.

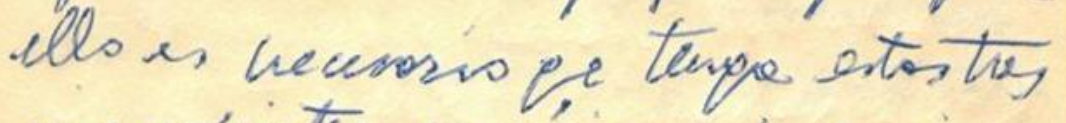

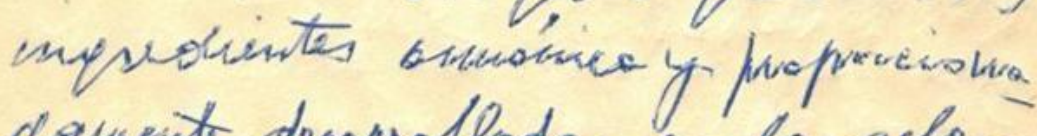
damenste desomalbodog en la relemon juste pe rovipe fa covisu$\rightarrow$ ovine de mis habitorstes. No neverita un ciriples lo wisiswe froporasión qe ene andalar posa los empases ole seumini un kecen.

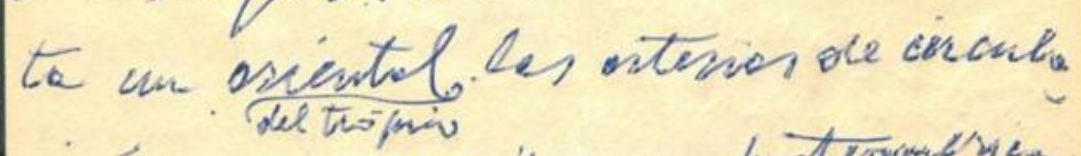

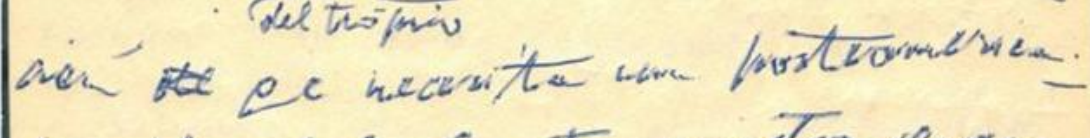
wo. Voridool este mista Gram slopan ere es recernaino quitor.

453 


\section{Pg. 21 (Delante)}

ante este mundo que se uniformiza en lo accesorio.

Es natural que en una ciudad como Bangkok tan exótica para cientos, seamos nosotros y nuestras cosas tan exóticas para ella en justa reciprocidad. $Y$ así resulta paradójicamente ejemplar que mientras está enjaulada como especie rara una vulgar urraca (y un borrico, nota posterior en negro) en el parque zoológico, fuera en libertad estén alrededor de su jaula mil especies distintas de pájaros de colores y una serpiente verde persiga también en libertad, y ante la indiferencia de los

\section{Pg. 21 (Detrás)}

En blanco 
ounte site unud to ve su uniformi. ra en lo occesago.

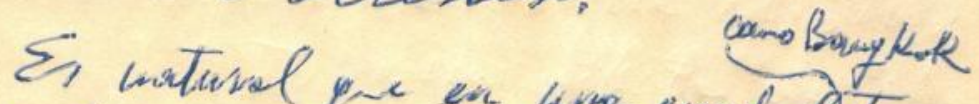

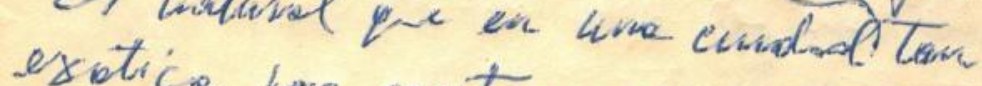
exitic a pune constios seamas mosotios $y$. mustros cosas tam exaticas posa elle

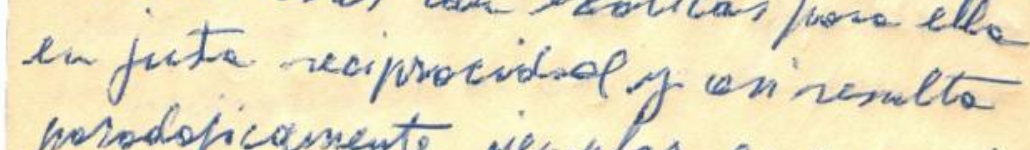
poindoficamente jexplar en y men-

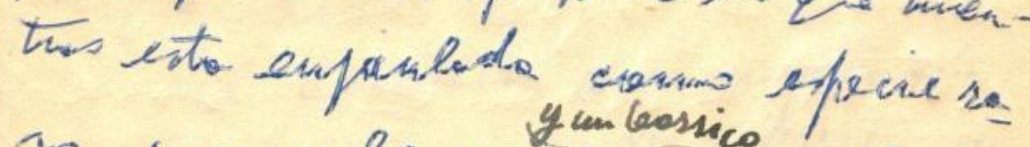

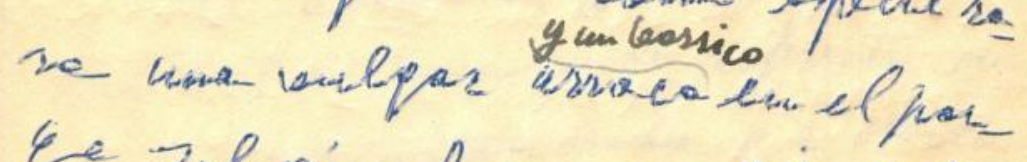
Ee zobopiro friewe en libutale Tow al-cacestor de ter jaubre mil

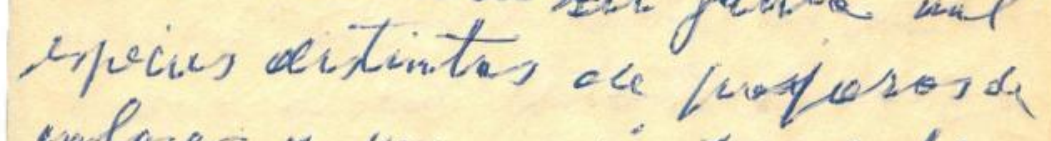
whore, y una serpiente uecole hersige tandain en hilar tool, y ante lo inobferencia die lag

455 


\section{Pg. 22 (Delante)}

visitantes a una especie de ratones blancos.

Pero oculta a una visión superficial de la ciudad, Bangkok tiene una intensa vida fluvial que es necesario ir a buscarla para saber que existe.

Al amanecer una incontable cantidad de canoas de diferentes anchuras que desembarcan en un como "Gran canal de Venecia" adquieren vida. Es una verdadera ciudad flotante en la que se compra y se vende toda la variadísima gama de productos que va desde flores a bisutería

\section{Pg. 22 (Detrás)}

En blanco 
cinitarites a una exparia oll natows blameas.

Pewo acubta ce una vision sa hecficial an es aindool, Brngetiok Thine una intense vide flubire 2 mecendion in a lenscrasta para sa ler que existe:

Al amancer vana inontable cantrideol ole carnotes of diferentes on clunas vidue ele olvenbacan en un cows" Gnon arrual de Uenecia" adevieren wide. St uma we

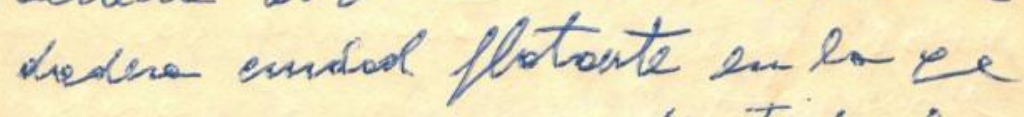
se couphe of re wande tode be

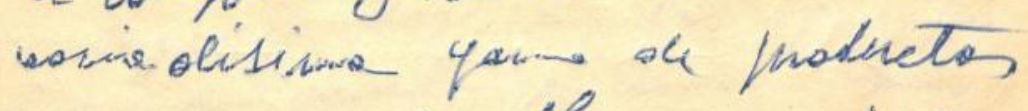
ve ve dende flove cusiterne

457 


\section{Pg. 23 (Delante)}

pasando, claro está, por todos los variadísimos alimentos tropicales, frutas, verduras, carnes, pescados...

El habitante de estas casas fluviales de Bangkok que en algunos casos tienen una calle de tierra firme al otro lado de la casa pero que otras veces tiene solamente un trozo de terreno agrícola sin salida a la ciudad, hace toda su vida en el canal que es para él desde su baño de lavarse los dientes, cuantos he visto a estas horas del amanecer en cuclillas lavándose los dientes y enjuagándose en las aguas pordioseras del canal - es también baño, camino y diversión y es que

\section{Pg. 23 (Detrás)}

En blanco 
parando, clovo este, par toxs los

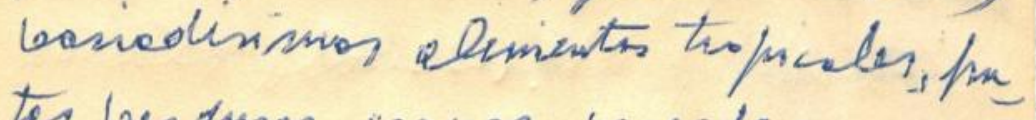
tes, leerdinas, cosmes, perredos...

Il habitante de estes ceral flarenales de Bamptok ve en alpanas ceros tione uno dolle di tiésa firine al otwo lado de lo casa fieno

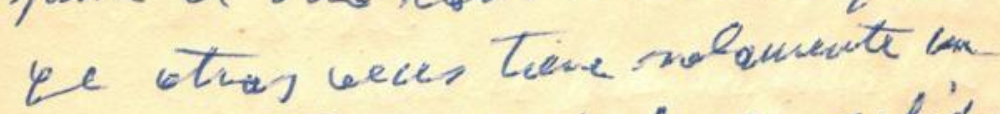

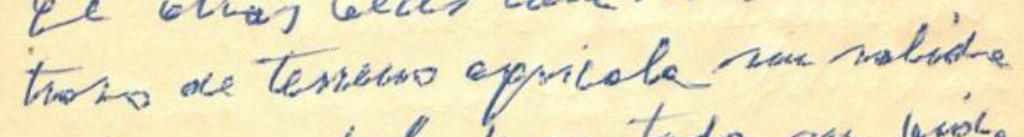
a la cusadad, have tade ma lavisa - al canal el es paso íl iesoa

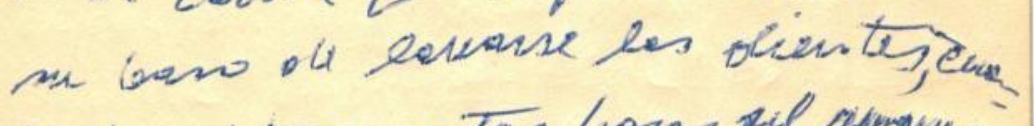
tos he visto astos hosas ril cumanuia en cuclillos labandare los diantes o cugurepandose en ens ofures par

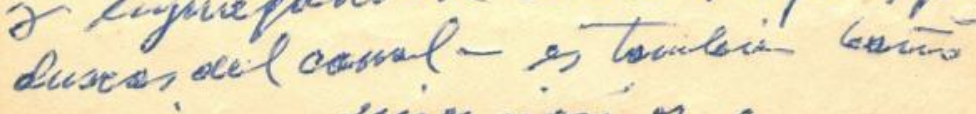

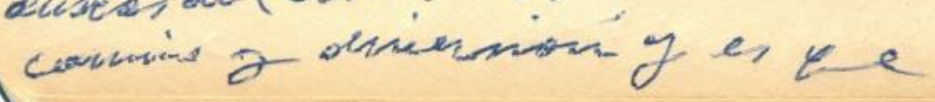

459 
Pg. 24 (Delante)

el agua es el origen de la vida y su más estimado elemento

Pg. 24 (Detrás)

En blanco 


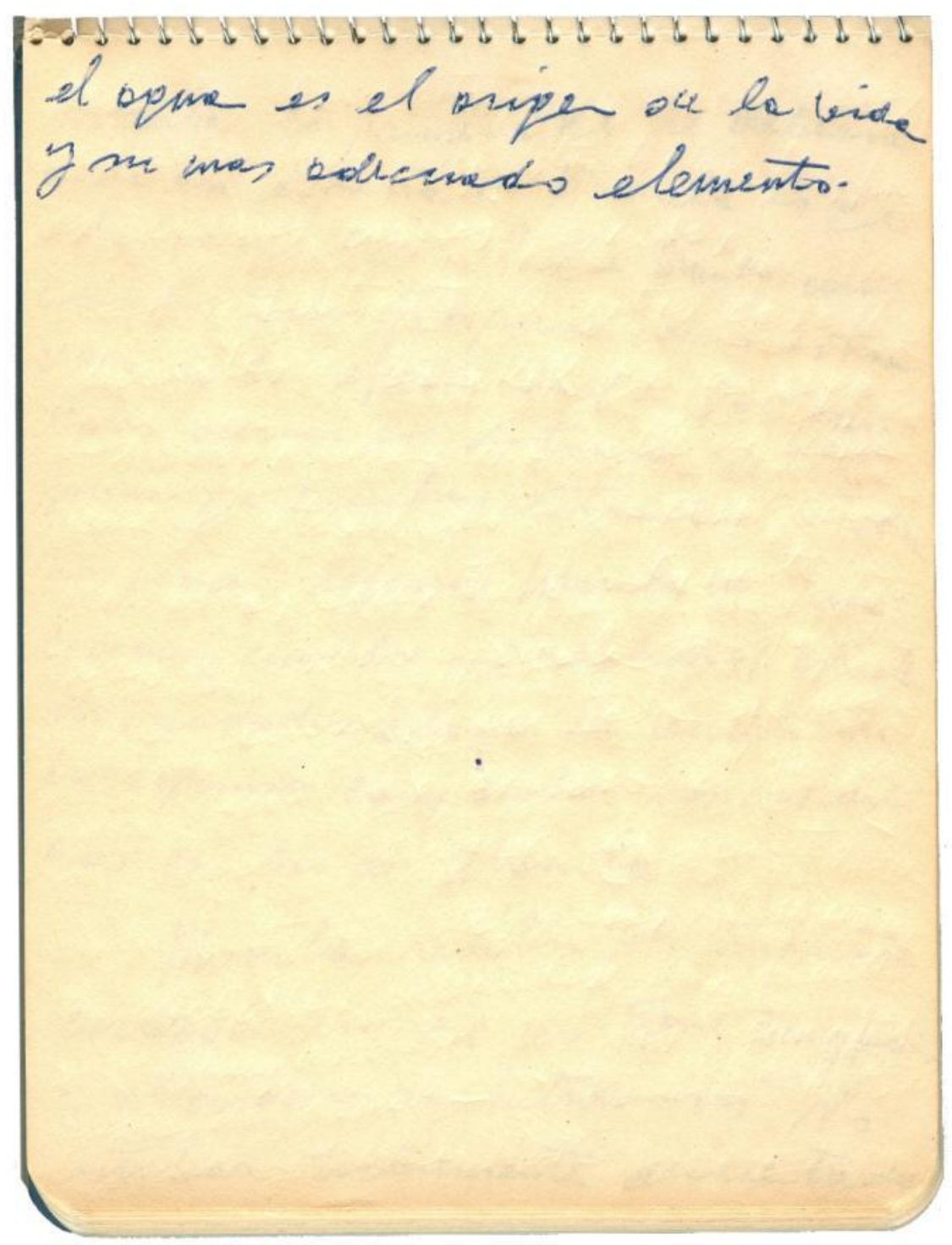




\section{Pg. 25 (Delante)}

Lo primero que se debería decir en España de Manila es que está muy lejos. Porque Manila como todas las Islas Filipinas como están cerca en la afectividad de los españoles acerca las distancias de tal forma que mientras Estambul o Teherán nos parecen lejanos Manila nos parece cercana cuando en realidad aquellas otras ciudades están a la vuelta de la esquina comparadas sus distancias con las de Manila.

Manila recibió de España corazón, eso que no tiene Bangkok, y el corazón es intramuros. No estaban totalmente desacertados

\section{Pg. 25 (Detrás)}

En blanco 


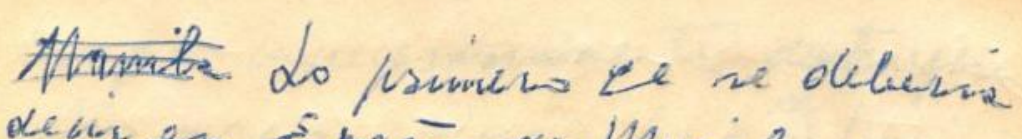

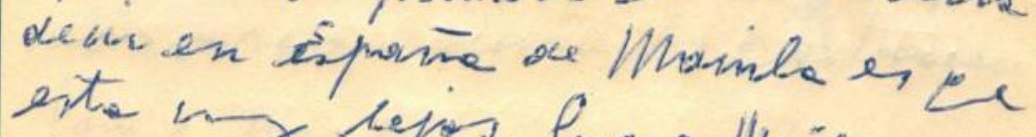

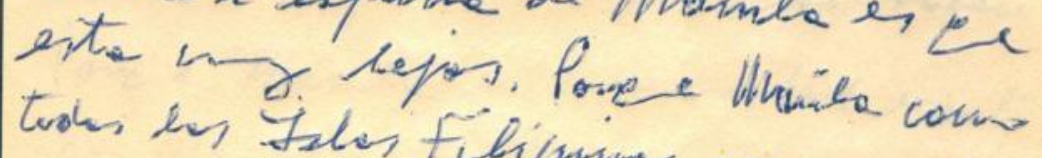

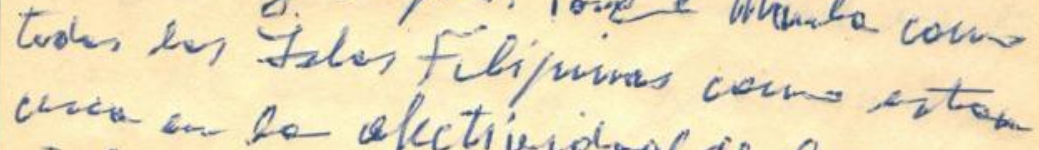
wara an be efectividinol al bos splue-

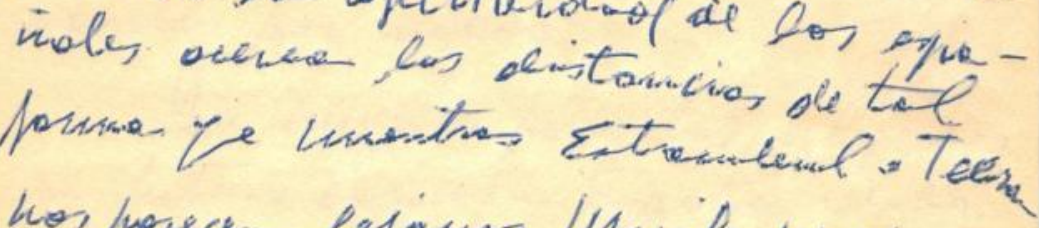

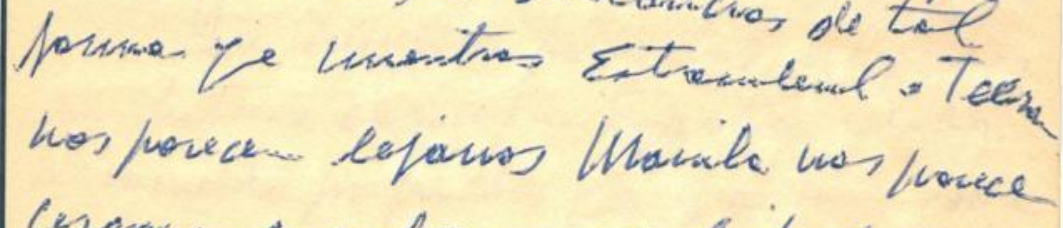

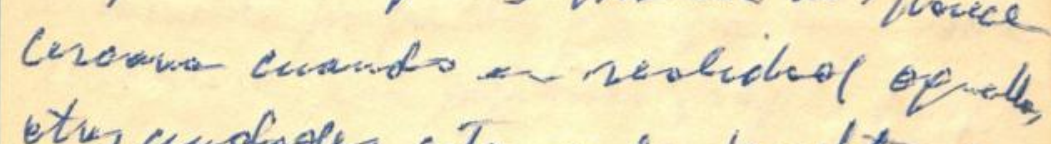

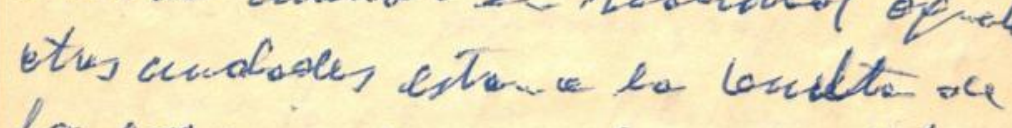

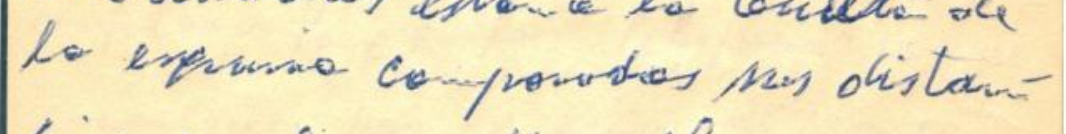
vios co las a Monila

thanila reaibio ar Eaprañe coswson eno el wo time banuftols 7 el cosasón sa intrianmas. No estoban toslexmente deace to

463 


\section{Pg. 26 (Delante)}

los que innecesariamente destruyeron intramuros, sabían lo que se hacían.

Porque Manila es una ciudad exótica de oriente con casticismos españoles por medio.

Yo auguro para la Filipinas un futuro cariño a España verdaderamente profundo, que ya hoy son levadura los pequeños grupos hispanófilos. Porque la filipinas nos reconocerán, por encima de pequeños incidentes esporádicos, una rectitud colonizadora única.

España dió a Filipinas lo mejor que tenía, su Fé, su

\section{Pg. 26 (Detrás)}

En blanco 


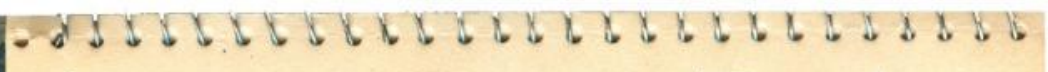

los ge inpecesosidumsinte destruyera

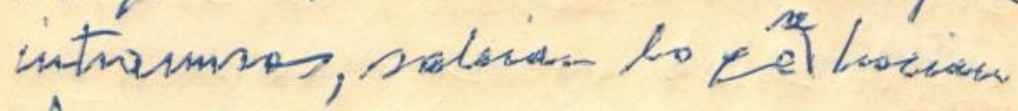
Ponpe thumbe es una cundeal waeti. cie de cercinte can cardicistrums os miniondes for medio.

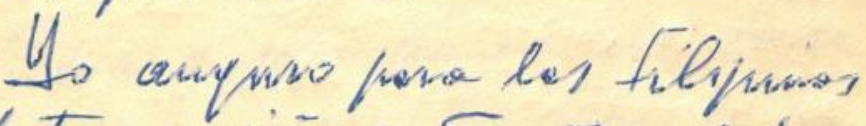

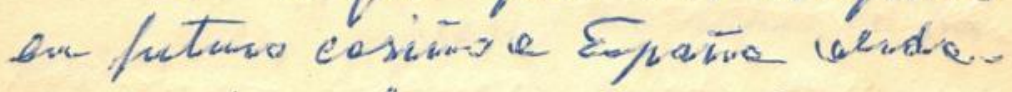
decomente profunato ye vo harg son

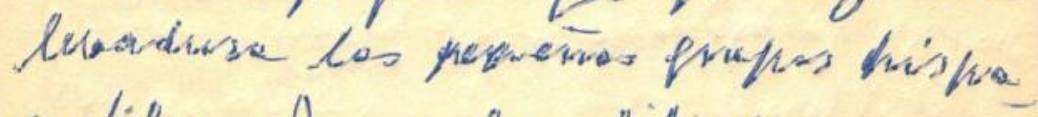
wafiltas. Paree los filipinimas vas ze. comocesara, fios susiune de fiepuestos inisidentes esposodicos, cura resti: tind colominadosa úrica.

Eppañe dio e Filiminas lo mepre to terine, su fe', sm

465 


\section{Pg. 27 (Delante)}

sangre y hasta los héroes de su independencia. Y así mientras los hijos de españoles es la nobleza filipina, las hijas de los ingleses son las prostitutas de la India y esto no es una frase porque los ingleses no tienen la hombría de casarse con las indias y los hijos de estas se encuentran desamparados de unos cortos indígenas que les aborrecen y de una sociedad inglesa que los desprecia.

Hay una realidad en Manila que descorazona a los españoles que la visitan por primera

Pg. 27 (Detrás)

En blanco 


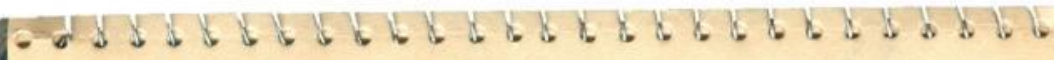
sanigere y. haste las hesour sell

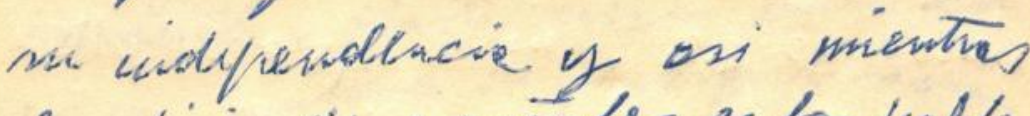

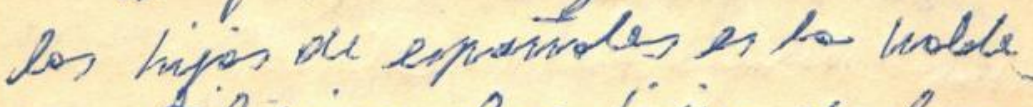
sa filipina las hipas ot los uipleses som has prostitustos oce fo Indire $y$ exto wo es lemo prase paspe los uipleses no tience ha lna

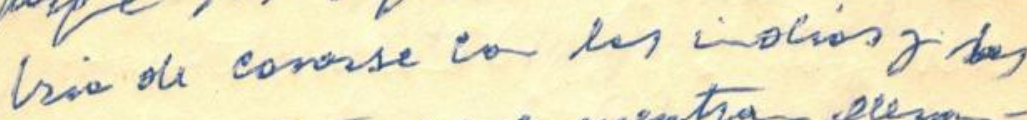
hipas ole estas se enenentra elesom-

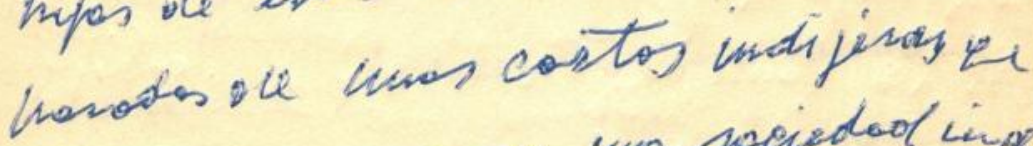
les aboween of una sociedod in se or los oleprevia:

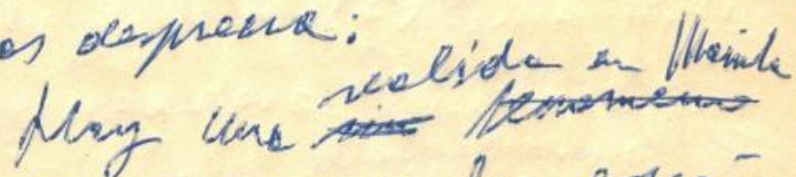
De desiasosuca ce los eqrañ les pe lo vintan por primera

467 


\section{Pg. 28 (Delante)}

vez y es, lo poco que se habla el español. Hasta cierto punto esto es un síntoma de jerarquización y de generosidad porque España se preocupó en Filipinas de lo importante y descuidó lo secundario. Y otros impusieron la Coca-cola y el idioma porque les convenía pero no he visto ningún símbolo de su generosidad por esto comparando presiento un acercamiento del pueblo filipino hacia los que le quieren de verdad, hacia los que le dieron lo mejor que tenían sin hacer distinciones de raza y sin dejar en su interior ningún desprecio ocul-

\section{Pg. 28 (Detrás)}

\section{En blanco}




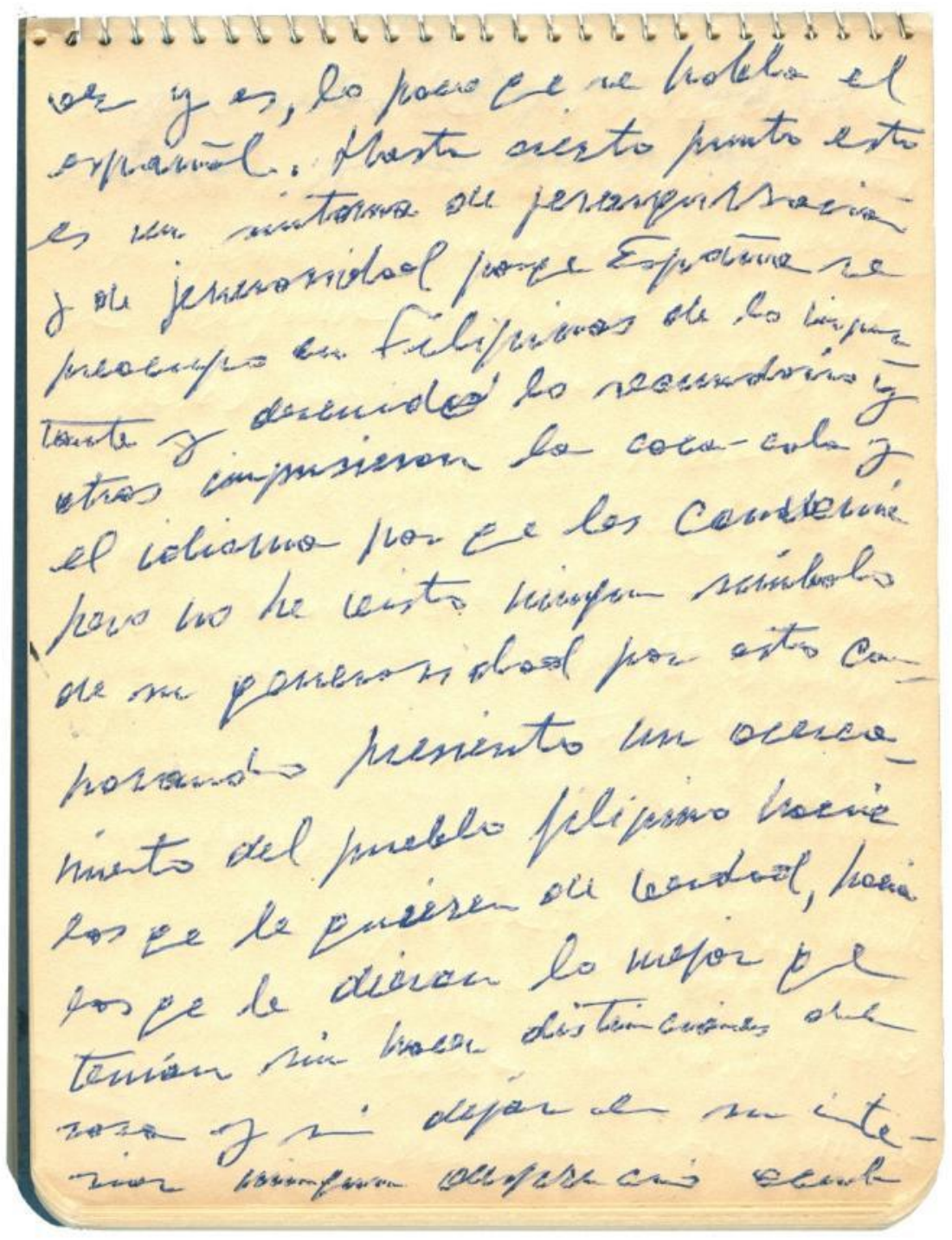




\section{Pg. 29 (Delante)}

to que antes o después sale al exterior y da sus frutos.

\section{Pg. 29 (Detrás)}

\section{En blanco}




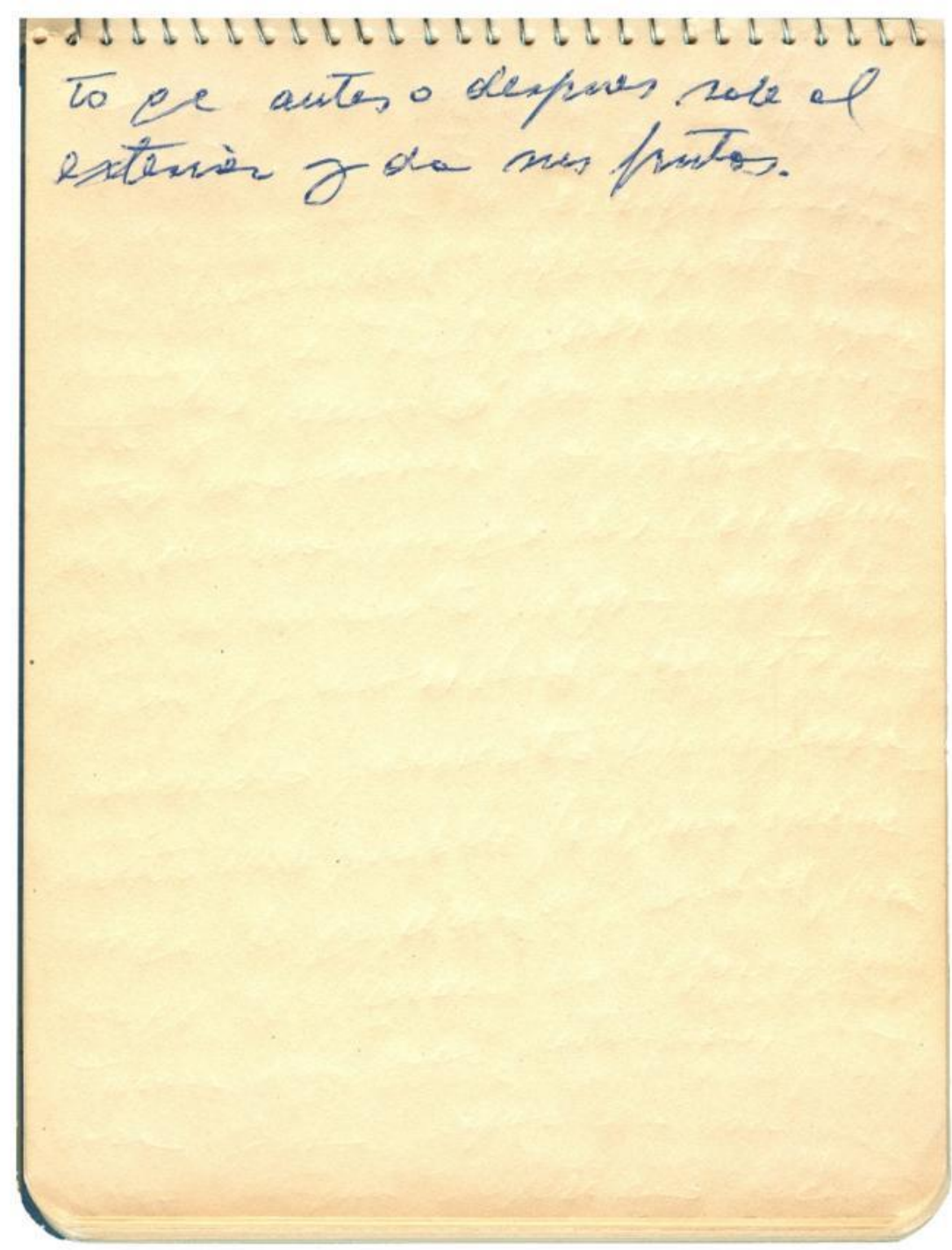




\section{Pg. 30 (Delante)}

Reconozco que es un poco singular para un español llegar a América por Alaska. El primer sitio de Amércia donde puse el pie fue en Cold-Bay. Fué solo una hora, pero lo suficientemente helada, fría e inóspita (sic) para darse uno cuenta por donde andaba.

\section{Pg. 30 (Detrás)}

En blanco 
Fecomoseope es lem poer semolo perat un esprañal lexpos a Amari ine por

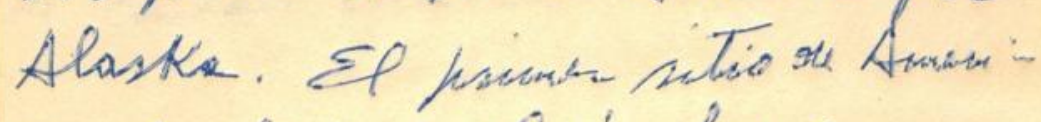
ca dounde purse el pine fare en

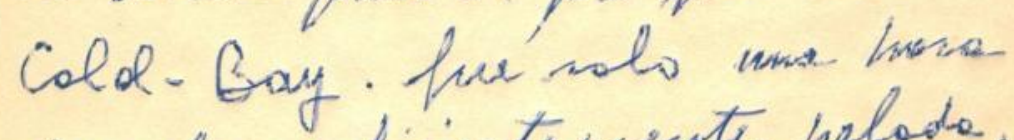
pero lo suficiente merste pelodo, pire e unospita paro dos ine cuenta por danda austaba. 


\section{Pg. 31 (Delante)}

Seattle está en un lugar estupendo entre bahías con una impresión de ciudad apacible.

Pg. 31 (Detrás)

\section{En blanco}




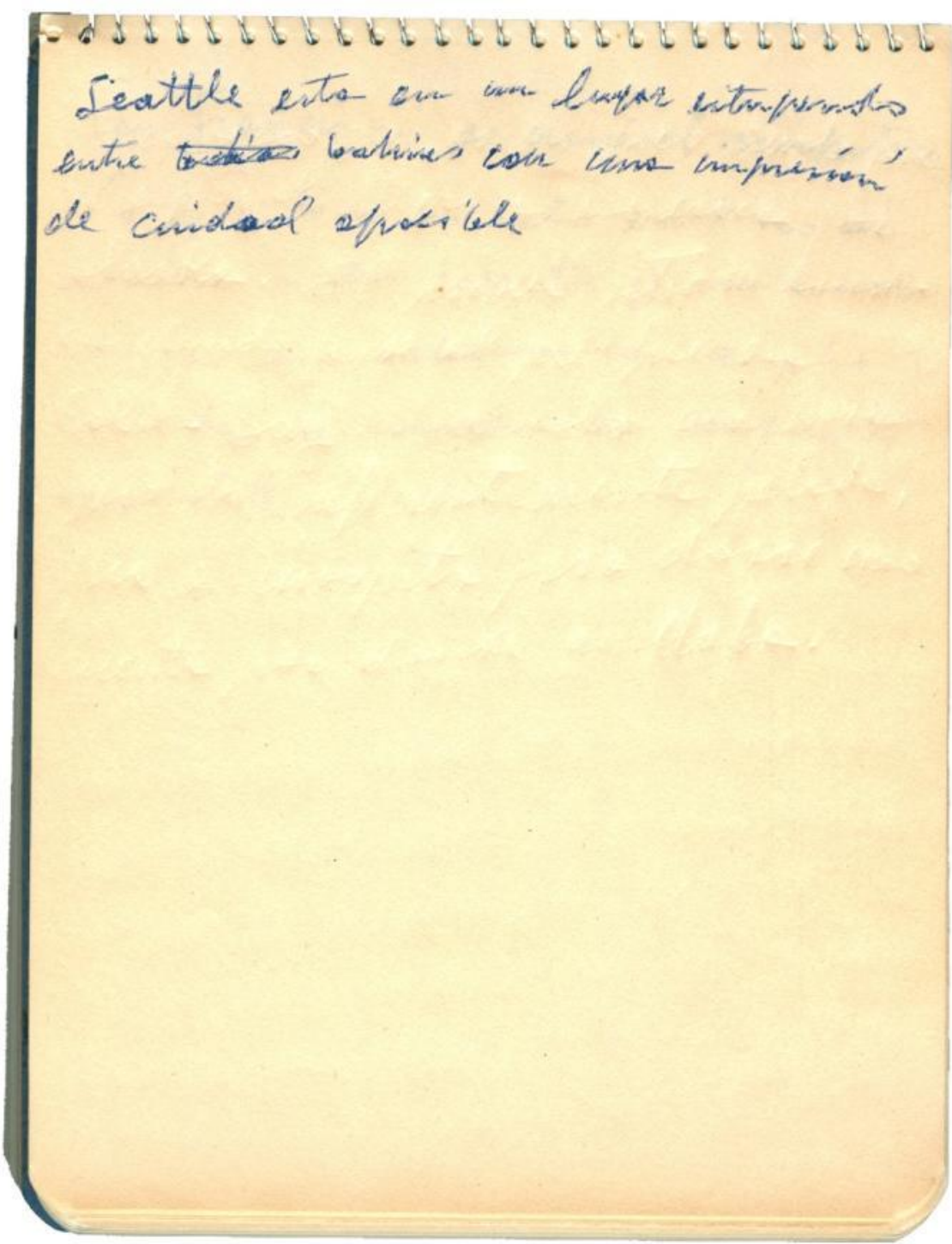




\section{Pg. 32 (Delante)}

San Francisco es una ciudad simpática. No he visto ni un solo edificio ni siquiera medio correcto y sin embargo sólo con una urbanización amplia y soleada se consigue un conjunto agradable.

Pg. 32 (Detrás)

En blanco

Pgs. 33, 34 (Completa)

En blanco 


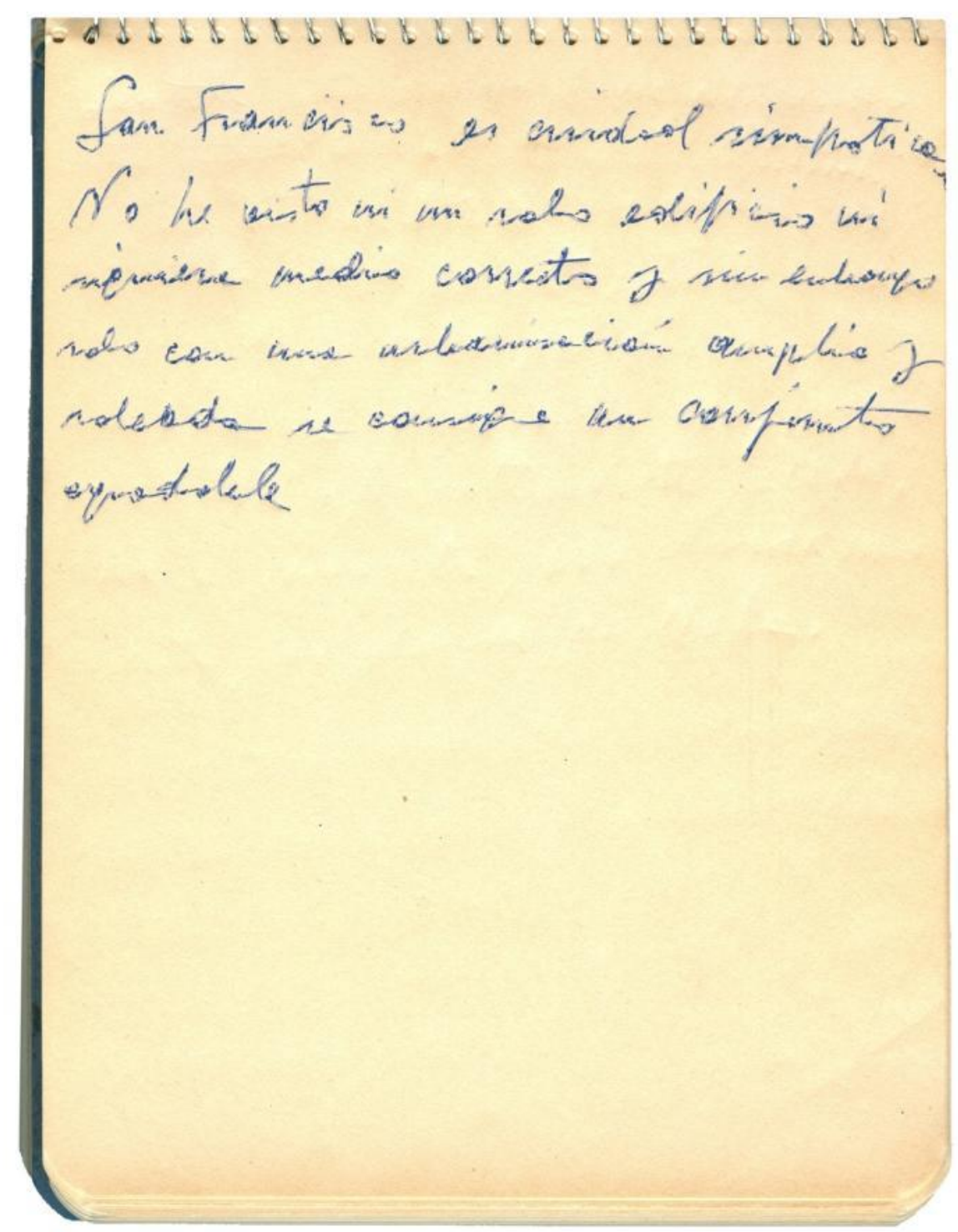




\section{Pg. 35 (Delante)}

Los Ángeles es una ciudad, -la única ciudad que yo conozco-, que tiene por módulo el automóvil. Si un hombre, yo por ejemplo, intenta olvidar esta realidad métrica termina por la noche con ampoyas (sic) en las plantas de los pies y con el cuerpo molido.

Porque lo peor, es que ese módulo automóvil hay que añadir que es automóvil particular porque ni

\section{Pg. 35 (Detrás)}

\section{En blanco}


Las Arugely es una cuandoal ; la

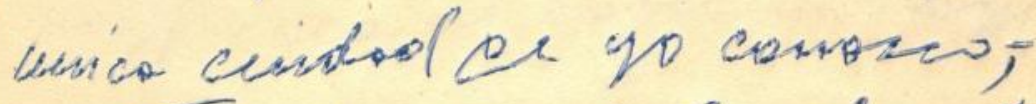
be Tizma ha unosubs el anto movil. fi un hombe: yo por apinlo intenta olvidar esta nealideof un'tuica tocmsina jus lo wathe can amprayas en exs plantos ove los pies y con el carestos molido.

Povere lo heos, es eqe ese modulo wistanoriol bug H a añodir eles autas vil postianlor pospe un

479 
Pg. 36 (Delante)

hay posibilidad económica ni física de coger un taxi.

Pgs. 3738 (Completa)

En blanco 


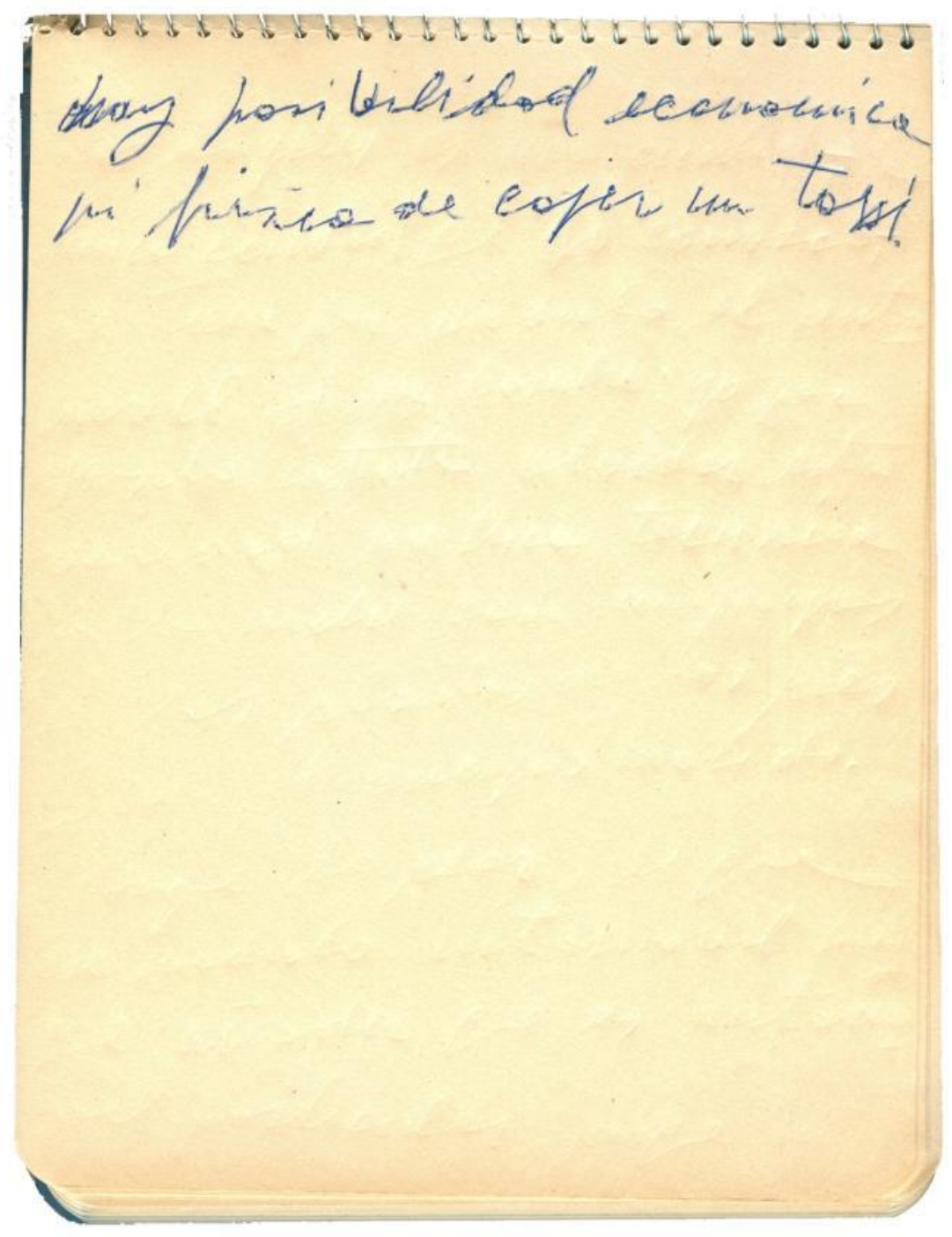

481 


\section{Pg. 39 (Delante)}

\section{Chicago}

Los aparcamientos. Los camiones grúas de la policia para llevarse los coches mal aparcados.

La piña de América y la lechuga (comidas absurdas, el sentido de lo dulce y lo salado)

La circulación.-

La falta de corazón

No se nota trepidación los americanos viven pacíficamente 0 al menos producen esa impresión

El resto de la libreta está en blanco.

Última página

APXITEKTON APXITEKTSN

TWA

984 a las 2,20 el 28 


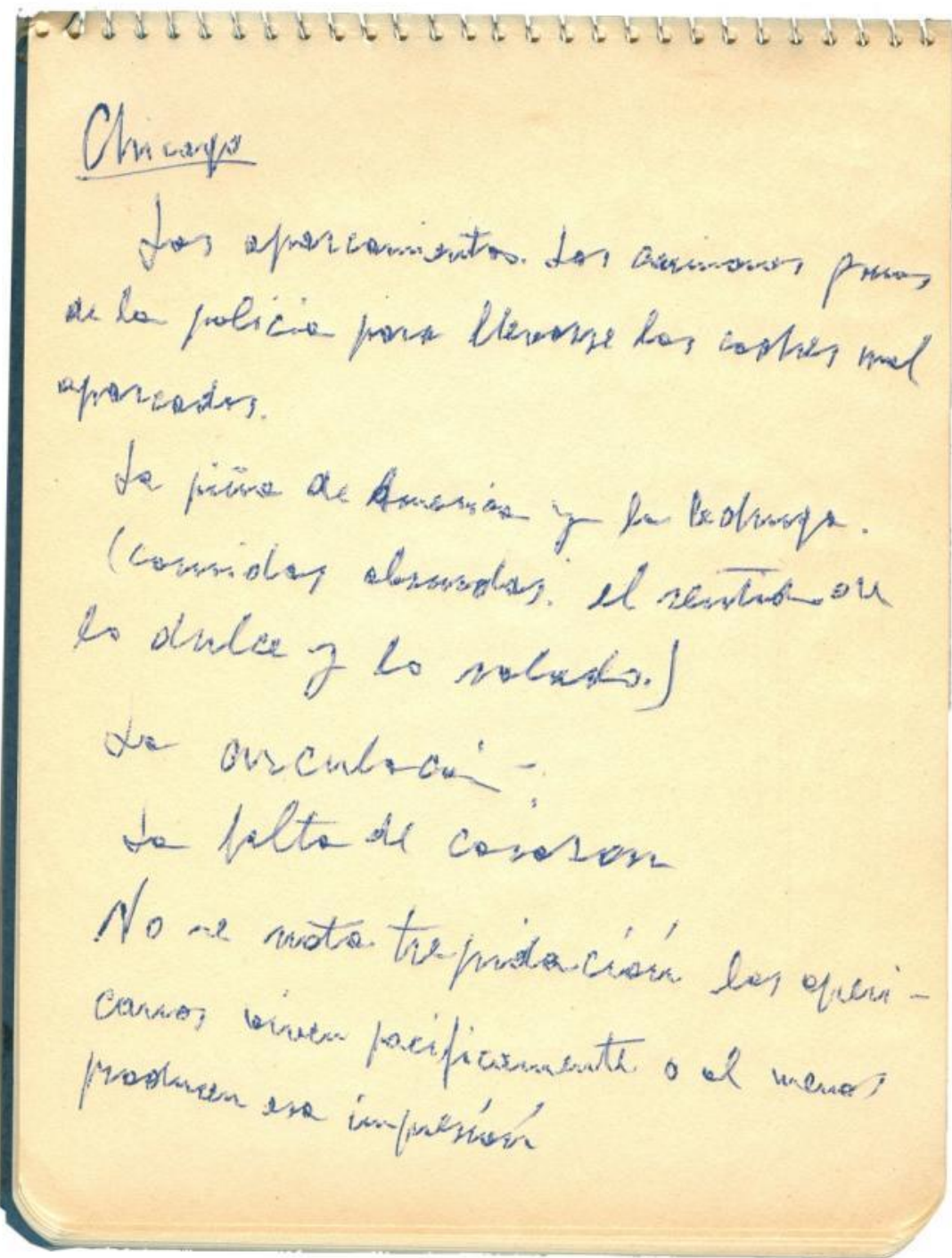




\section{3_ Transcripciones de varios cuadernos de viaje [inédito]}

Viaje a Suiza. 8 al 12 de marzo de 1954

Viaje a Viena. 10 al 26 de octubre de 1954

Viaje a Moscú, Leningrado, Berlín Oriental, Berlín Occidental. 8 al 19 de abril de 1967 


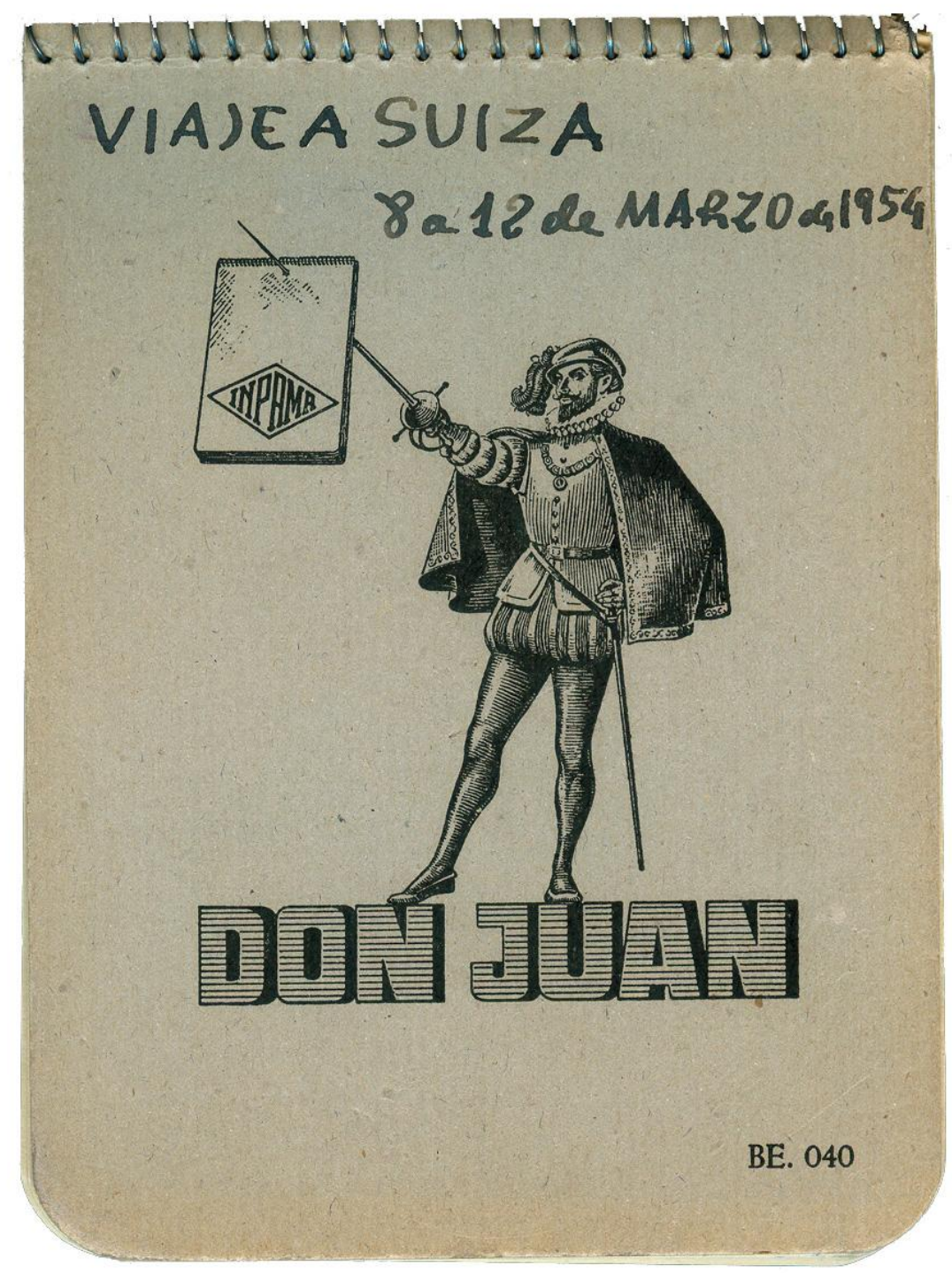

Sólo se escribe por la parte delantera de las páginas, por lo que se omite la distinción Delante-Detrás, excepto en la página 4. 


\section{Página 1}

En blanco

\section{Página 2}

Salimos de Madrid y llegamos a Ginebra sin novedad.

Paseos, visita a nuestro Consul Sr. Erice que está muy simpático y al día siguiente, 9 de marzo, visita al edificio en construcción

\section{Página 3}

de la Battelle. Por la mañana hemos estado dando vueltas por todos sitios por Ginebra. Muy pocos edificios nuevos y los pocos de tipo entre Perret y Le Corbusier con ventanas de aluminio cristal mate??

Una lápida inte-

\section{Página 4 (Delante)}

resante a Miguel Servet en que los calvinistas dicen que considerando a Calvino como su fundador etc, como calló (sic) en los errores de su siglo ellos reparan con esa lápida el incidente ${ }^{12}$. Es muy

\section{Página 4 (Detrás)}

\section{W.J. Kappeyne}

Battelle Memorial Institute

3 Rue de Mont Blanc

Geneve Suisse

12 En 1902, tras un congreso internacional de librepensadores en Ginebra, de decidió construir un monumento como homenaje a Miguel Servet. Se trata de una sencilla pieza de granito con acabado abujardado pero sin buscar la planeidad de la pieza. Un grupo de personas muy influyentes dentro de la comisión internacional que se constituyó a tal efecto, consiguió que el texto de la lápida, más que recordar el trágico final de Servet en la hoguera, disculpar a Calvino: "Hijos respetuosos y reconocedores de Calvino, nuestro gran reformador, pero condenando un error, que fue el de su siglo..." 
Página 5 (Delante)

curioso eso de encajarle al siglo los errores. ¿qué dirían si eso lo hicieran los católicos? (Raya)

La visita a la Battelle la iniciamos después de las 2 1/2 nos acompaña el Sr. Kappeyne

\section{Página 6 (Delante)}

los módulos son de $4 \times 7$.

El pasillo central 3m.

Todos los servicios, todos, vistas bajadas etc.

Total de caveas por pabellón 500 cav.

Agua caliente, fria, gas,

las instalaciones en anillo en sótano y columna verticales. El edificio es rectangular con las estructura vista

\section{Página 7}

Pavimento de cemento rodillado y dos manos de pintura verde antiácido.

Los tabiques de bloques de cemento sin guarnecer y pintados todos al temple verde claro, el resultado de estas econo-

\section{Página 8}

mías es que realmente les resulta un tercio más económico que un edificio corriente.

Las escaleras al final de los pasillos, metálicas y huella de madera. Una planta piloto (adornada?) al edificio que ocupa la altura de las tres plantas. La

\section{Página 9}

calefacción por radiadores

[Dibujo de planta y alzado] 
Después de esta visita el Sr. Erice nos recoge y vamos a visitar

\section{Página 10}

el palacio de la Sociedad de Naciones hoy ONU.

Es, como me figuraba por las fotografías, muy caro y lujoso pero ni un solo detalle de verdadero buen gusto.

Algunas cosas de colores agradables y una desorganización de edi-

\section{Página 11}

ficios verdaderamente tremendos.

Después nos marchamos al hotel, recogemos los equipajes y nos marchamos a Zurich.

Llegamos a las 11 de la noche. Es una población mucho más interesante desde todos los puntos de vista.

\section{Página 12}

Por la mañana visitamos al Sr. Palman, Presidente del Politécnico y después, allí mismo, a Dunkel. A primera hora de la tarde visitamos el aula del profesor Scherrer (?, signo de MF) es estupenda en cuanto a instalaciones. Arquitectónicamente no tie-

\section{Página 13}

ne nada de particular y como todo lo de Suiza exangüe, sin color blanco, completamente blanco.

Por la tarde nos recoge Dunkel y cenamos en su casa y después asistimos con él y su señora a una conferencia en el "aula" del Prof. Scherrer.

\section{Página 14}


Es algo muy parecido a una sesión de juegos malabares.

El jueves por la mañana visitamos con Dunkel la ampliación de la escuela de Agronomía y las instalaciones de invernaderos etc.

Vemos unos proyectos interesantes pero sin nada patentado

\section{Página 15}

Por la tarde visitamos una nueva escuela, como todas las suizas, sin color, sin doble ventilación e iluminación etc.

Las casas torres en tres viajes y alguna otra cosa por el estilo.

Al regresar al centro conduciendo, presencia-

\section{Página 16}

mos un choque de un coche y una moto, sin consecuencias grandes pero que pudimos ver prácticamente la anécdota que el Sr. Erice nos contó de un hombre muriendo y que nadie le auxilia y al querer levantarlo impedirlo el guardia diciendo:

\section{Página 17}

"Vd. conoce la técnica de levantar heridos?"

En el caso nuestro también hizo falta un "técnico" de levantar motos.

Por la mañana del dia siguiente visitamos las casas de Breuer. Las conocidas y como

\section{Página 18}

en casas semejantes no tienen ni comodidad, ni calidad, ni honradez, ni utilidad; una fotografía saqué en que se puede apreciar que la azotea se inunda cuando llueve. 


\section{Página 19}

Regresamos a Barcelona y Madrid sin novedad.

Un viaje interesante, en que se ve que está uno por buen camino y que se puede tutear perfectamente con los de fuera 
Viaje a Viena . $10-X-54$ a 26-X-54

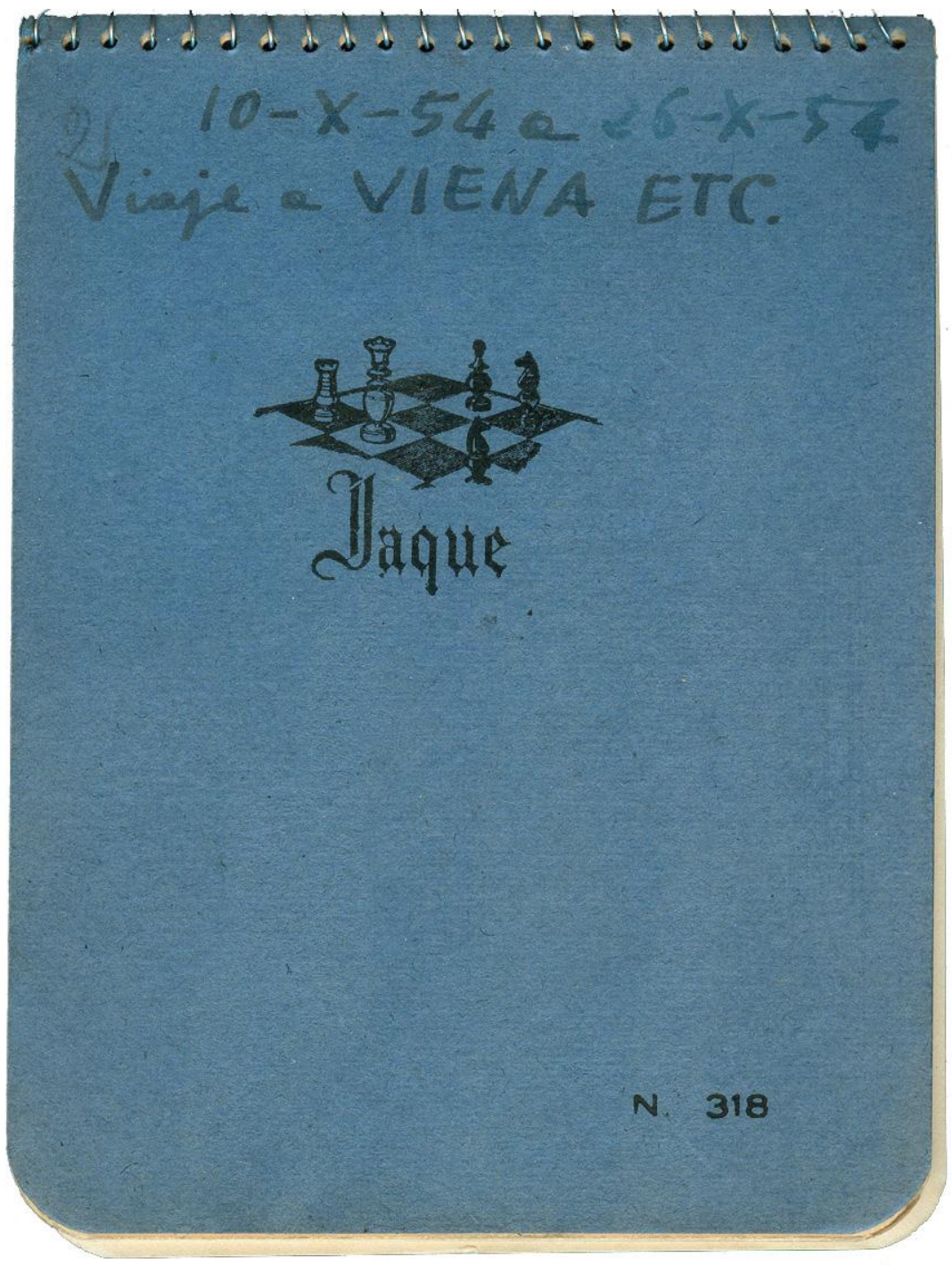

Se trata del viaje que realizó para recoger la Medalla de oro de Arte Sacro concedida por el Colegio Apostólico para los Dominicos en Valladolid (Arcas Reales).

Sólo se escribe por la parte delantera de las páginas, por lo que se omite la distinción Delante-Detrás, excepto en las páginas indicadas. 


\section{Página 1}

Salimos el dia 10 de octubre y dormimos en Pou. Y el día siguiente en Aix. Sin novedades dignas de mención.

Hacia las 12 del dia 12 llegamos a Vence para ver la capilla que ha pintado Matisse ${ }^{13}$.

Nos cuesta trabajo encontrarla porque estando en la carretera pasa bastante inadvertida por estar en la parte baja de

\section{Página 2}

la pendiente a media ladera sin que esté la carretera.

Los días de visita son sólo los martes y jueves. Hemos tenido suerte porque es martes. Nos parece exagerado esta restricción de visitas en un lugar apartado de la línea turísitica Niza-Monte Carlo.

Comemos cerca de allí y después marchamos hacia la capilla. Allí encontramos

\section{Página 3}

en la carretera dos autobuses grandes y varios coches.

A la hora señalada, en punto.-

$* * *$

El resto de la libreta está en blanco.

Última página

14 Milán Jueves

15 Ven Viaje viernes

16 Venecia Sábado

17 Viena Domingo

${ }^{13}$ Se refiere a la Capilla del Rosario, cerca de Niza 
19 Viena Martes

20

Miércoles

$\star * *$

Alberto da Guirano

$\underline{\text { Penúltima página }}$

Verona Piazza Brá e Arena Romana

Piazza delle Ebe a Arche degli Scaligere 
Viaje a Moscú, Leningrado, Berlín Oriental, Berlín Occidental. Del 8 al 19 de Abril DE 1967

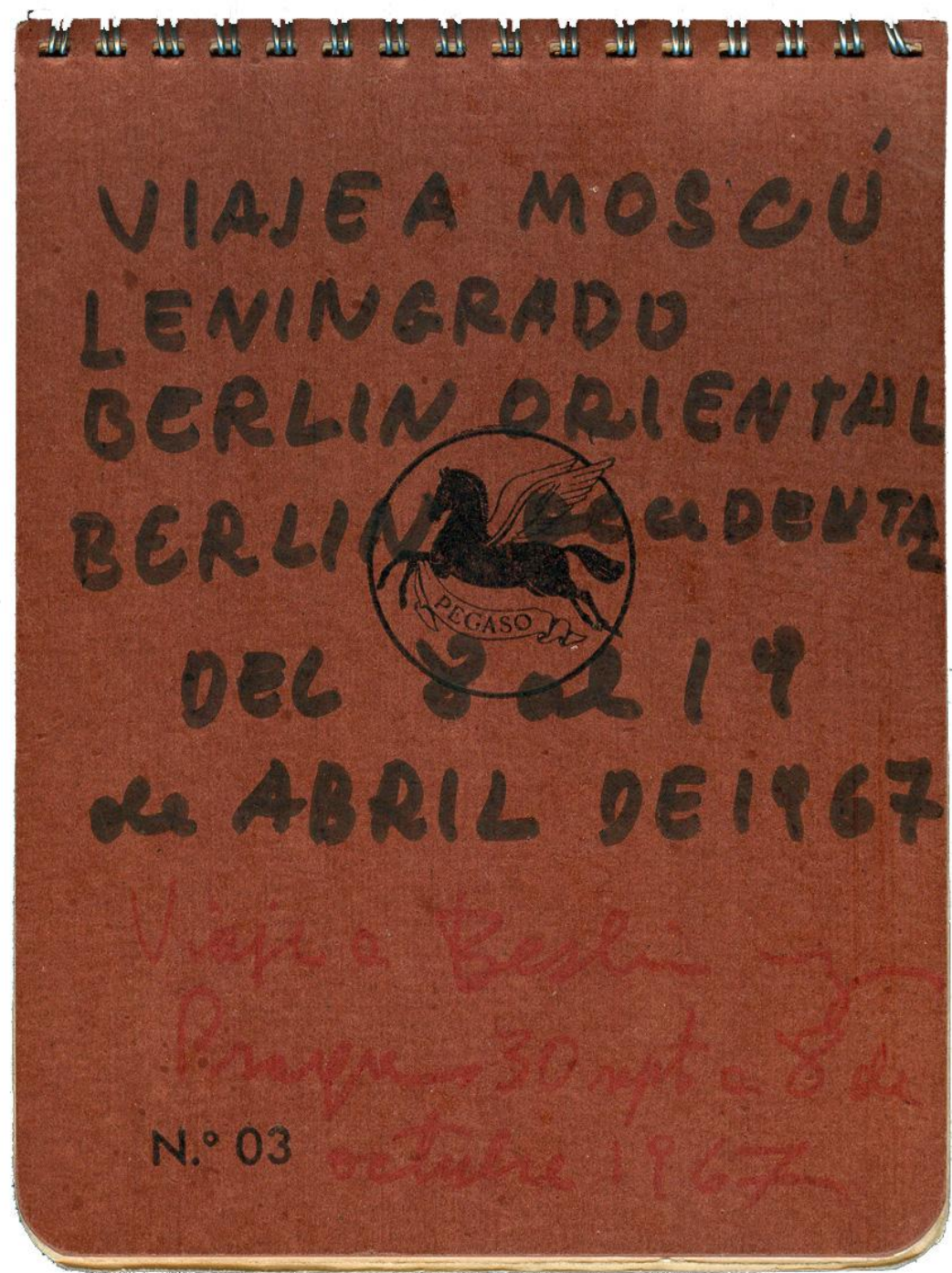

Sólo se escribe por la parte delantera de las páginas, por lo que se omite la distinción Delante-Detrás, excepto en las páginas indicadas. 


\section{Página 1}

Dia 8 de abril de 1967

Salida a las 11 menos 1/4 de Barajas.

Llegamos a París a las 12 1/2

París limpio pierde empaque. Ya me lo había parecido cuando ví por primera vez los edificios limpios. Se nota que en estos años últimos Paris ha quedado anticuado.

Por la tarde intentamos ver la comedia de Arrabal "El Arquitecto y el Emperador de Asiria" pero no la vimos hasta la noche.

Es una obra confusa muy farragosa con un sentido simbólico servido con un lenguaje desgarrado anti-

\section{Página 2}

clerical y a veces blasfemo.

Plásticamente no tiene ninguna novedad. La música concreta de acompañamiento buena.

\section{Día 9}

Salimos en un Carabell (sic) de Air France camino de Moscú a la hora prevista.

A las 2 1/2 horas llegamos a Varsovia. La impresión del aeropuerto y de sus alrededores es de mucha pobreza. Solo estuvimos en una sala para pasajeros en tránsito sin ningún interés con "souvenir" sin ningún interés. Dos horas y cuarto de vuelo de un viaje total $\sin$

\section{Página 3}

un solo bache y llegamos a Moscú a la hora prevista.

Los alrededores de Moscú están nevados, no completamente y en gran parte cubiertos de bosques de cedros y abedules. 
El aeropuerto de Moscú es importante pero no mucho de una arquitectura muy comercial y mal acabada.

El primer impacto de nuestra llegada, después de pasar los primeros trámites burocráticos completamente normales, y con toda amabilidad por parte de los empleados, fue la vista de un pope obispo o (tachón) patriarca con traje talar impecable y un gran pectoral que venía a despedir a un señor vestido de "cleriman" no sé si católico

\section{Página 4}

y ambos con muy buena pinta.

La INTOURIST compañía de turismo soviética nos llevó al hotel Metropol, un hotel viejo y sucio.

Moscú tiene un trazado a escala gigante en plazas calles etc.

La arquitectura no tiene ningún interés. Lo más moderno no llega a la altura normal de un país medio, como España.

No se ve ningún signo de arquitectura personal ni regional.

Los acabados están totalmente descuidados.

No se nota ni en la arquitectura (tachón) ni en el diseño industrial

\section{$\underline{\text { Página } 5}$}

trajes ni maquinaria ninguna nota estética propia ni buena ni mala.

La gentes visten todos dignamente y sin estar uniformados presentan todos muy análogo nivel económico, cosa que resulta muy agradable.

Moscú es una ciudad muy tranquila y normal con muchas gentes a pie y pocos coches muy segmentados de circulación complicada e innecesaria desde la escasa densidad de tráfico.

\section{Página 6}


El miércoles dia 12 visitamos Antonio García y yo una fábrica de metales pesados que se llaman laminados de Kasloff (tachón).

Es una instalación importante no muy grande para hacer paneles de una forma continua.

Son muy toscos pero eficaces.

Pesan unas $8 \mathrm{~T}$ cada pieza.

\section{Página 7}

Viaje a leningrado el 13 (nota JAF, Leningrado es San Petesburgo actual).

Estancia en Leningrado el 14 y viaje Leningrado Moscú el 15.

Salida de Moscú a Berlín el domingo 16.

Parada en Varsovia.

\section{Página 8}

Leningrado es una ciudad con una concepción típica del siglo XVIII

Grandes avenidas, edificios importantes en finales de perspectiva etc.

El Ermitif (Hermitage) es un museo eterogéneo (sic), destartalado sin la más remota idea de museografía actual.

La colección Rembrandt es realmente excepcional

\section{Página 9}

después de la de Amsterdam creo que es la mejor del mundo.

La Dánae es un cuadro importante ${ }^{14}$. A mi me gusta más el David y Ansola ${ }^{15}$ y "el hijo pródigo".

\footnotetext{
${ }^{14}$ Se refiere al cuadro de Rembrandt

${ }^{15}$ Se refiere a David y Saúl, de Rembrandt
} 
La colección de impresionistas franceses es importante y sobre todo los Gauguin y los Matisse.

\section{Página 10}

Los barrios nuevos de Moscú y Leningrado son barrios típicos de la Carta de Atenas con generosidad espacial.

\section{Página 11}

Kirosteatro

\section{Página 12}

He visitado el Barrio Hansa ${ }^{16}$ de Berlín y he visto a medio hacer el Museo de Arte de Mies van der Rohe.

He visto también en Berlín un sanatorio para 1800 camas.

No he visto ninguna arquitectura que me interese de verdad y que la considere de auténtica calidad actual.

\section{Página 13}

En blanco

${ }^{16}$ Se refiere al Hansaviertel, en el que a final de la década de los 50, realizaron obras los arquitectos más sobresalientes del momento: Le Corbusier, Alvar Aalto, Bakema, Gropius, etc... 


\section{Página 14}

\section{Croquis}

Leningrado 13-IV-67

Fortaleza de Pedro y Pablo

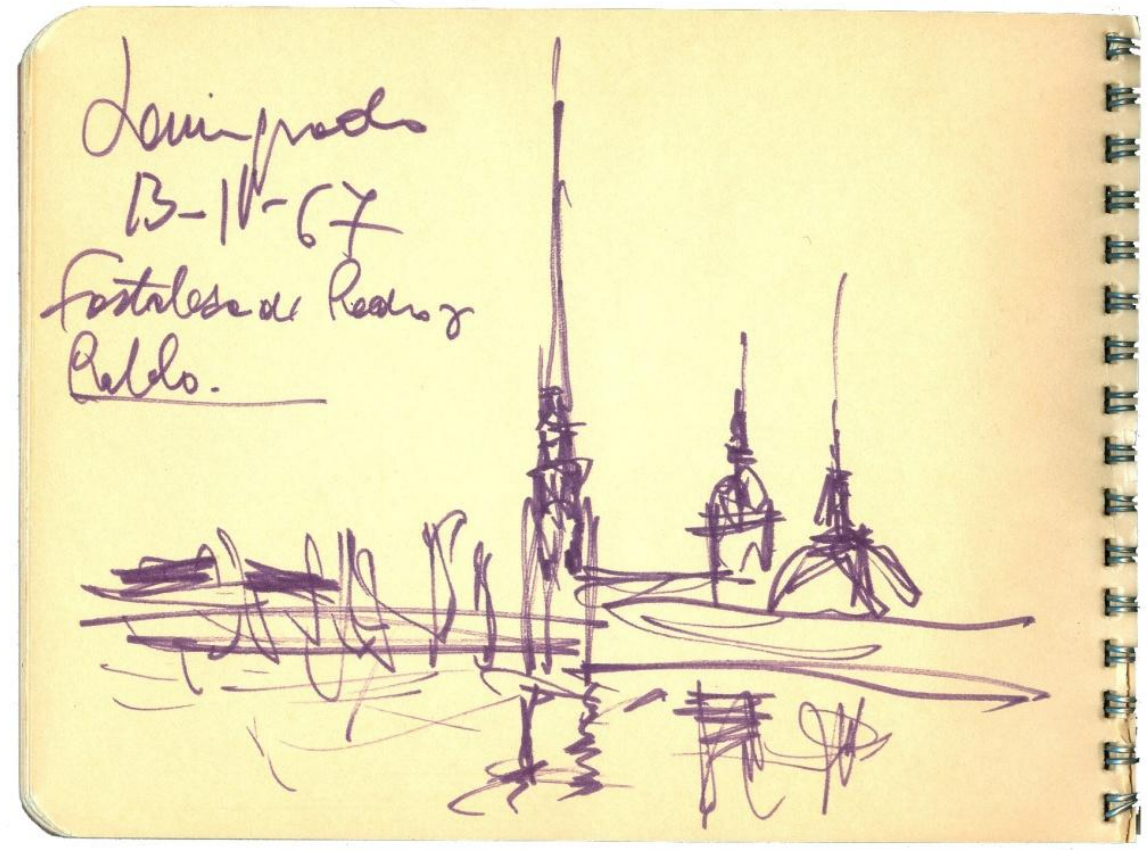

12 páginas en blanco 
Página 27

Croquis

Leningrado 13 - abril 67

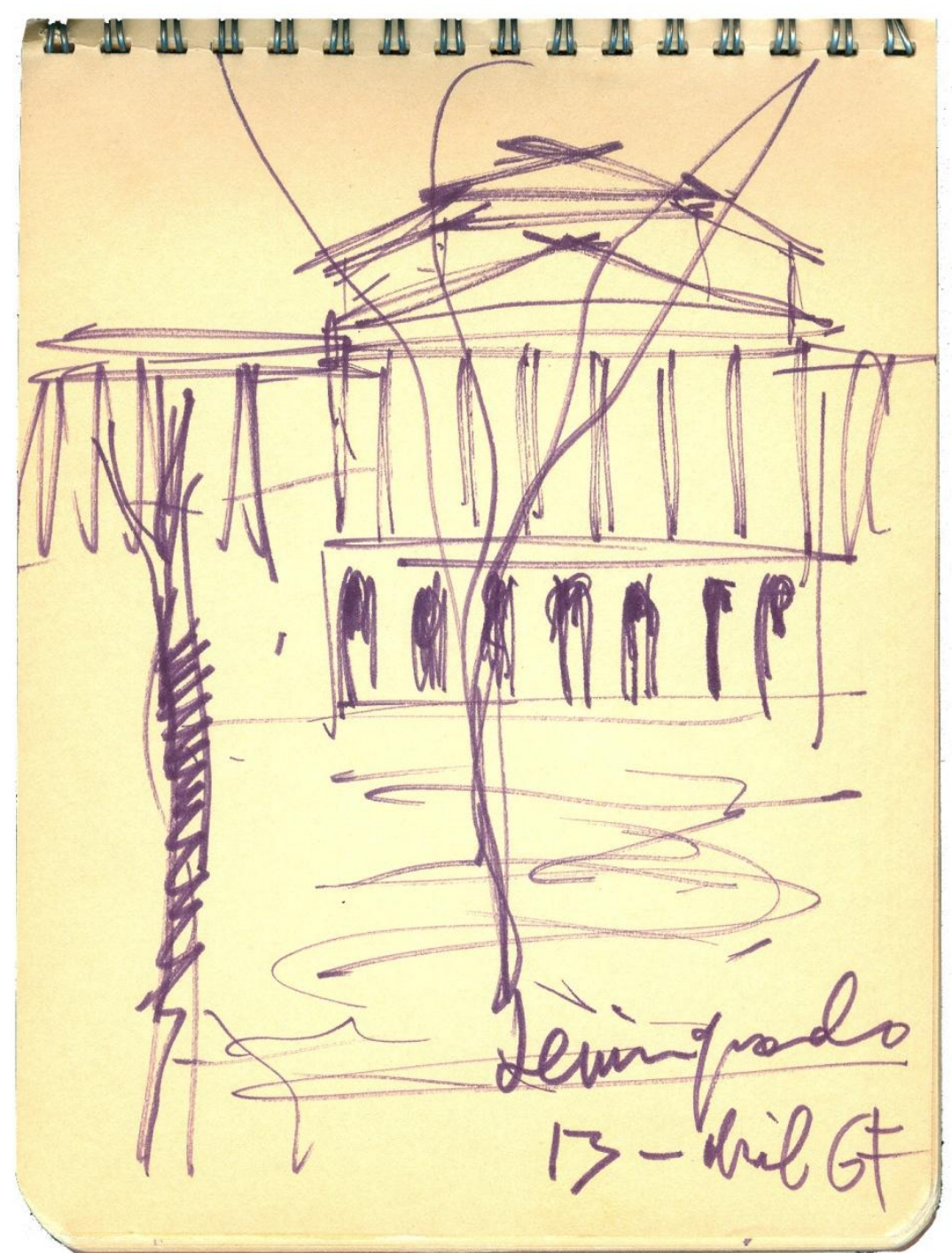

5 páginas en blanco 
Página 33

Croquis

Leningrado 13 - I. Plaza de Pedro el Grande

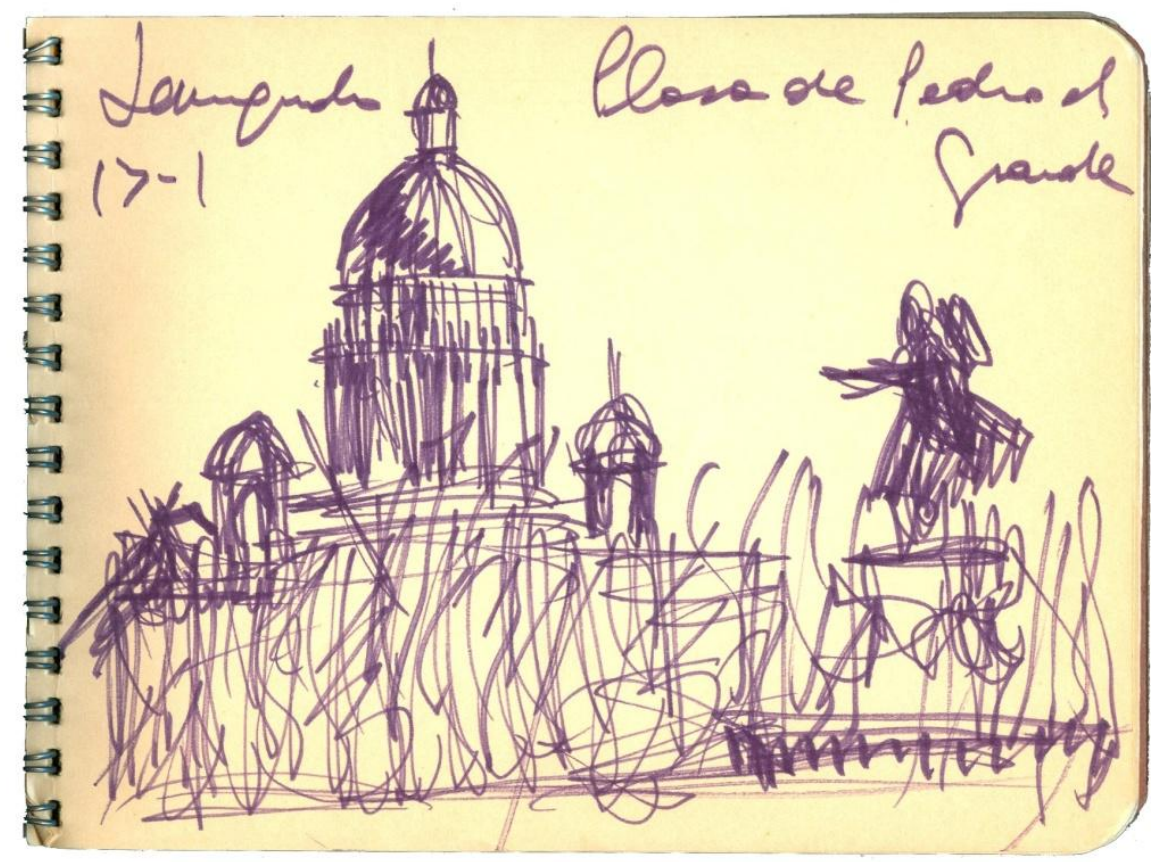

Resto del Cuaderno en blanco

***

Última pg.

PARKHOTEL ZELLERMAYER

Notas de telegramas y gastos del hotel en hojas aparte 